The Look of Lyric: Greek Song and the Visual 


\section{Mnemosyne Supplements}

MONOGRAPHS ON GREEK AND

LATIN LANGUAGE AND LITERATURE

Executive Editor

G.J. Boter (VU University Amsterdam)

Editorial Board

A. Chaniotis (Oxford)

K.M. Coleman (Harvard)

I.J.F. de Jong (University of Amsterdam)

T. Reinhardt (Oxford)

VOLUME 391

The titles published in this series are listed at brill.com/mns 


\title{
The Look of Lyric: \\ Greek Song and the Visual
}

Studies in Archaic and Classical Greek Song, vol. 1

\author{
Edited by
}

Vanessa Cazzato

André Lardinois

With an Introduction by

Anastasia-Erasmia Peponi

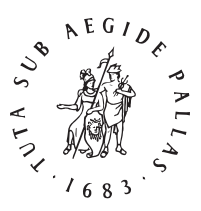

B R I L L 
B R I L L OPE N

This is an open access title distributed under the terms of the Creative Commons Attribution-Noncommercial 3.0 Unported (CC-BY-NC 3.0) License, which permits any non-commercial use, distribution, and reproduction in any medium, provided the original author(s) and source are credited.

Library of Congress Cataloging-in-Publication Data

Names: Cazzato, Vanessa, 1977- editor. | Lardinois, A. P. M. H., editor.

Title: The look of lyric : Greek song and the visual. Studies in archaic and classical Greek song / edited by

Vanessa Cazzato, Andre Lardinois ; with an introduction by Anastasia-Erasmia Peponi.

Other titles: Mnemosyne, bibliotheca classica Batava. Supplementum ; v. 391.

Description: Leiden ; Boston : BRILL, 2016- | Series: Mnemosyne. Supplements ; volume 391 | Includes bibliographical references and index.

Identifiers: LCCN 2016004344 (print) | LCCN 2016005703 (ebook) | ISBN 9789004311633 ((hardback) : alk. paper) | ISBN 9789004314849 ((e-book))

Subjects: LCSH: Greek poetry-History and criticism. | Greek drama-History and criticism.

Classification: LCC PA3110 .L66 2016 (print) | LCC PA3110 (ebook) | DDC 884/.0109-dc23

LC record available at http://lccn.loc.gov/2016004344

Want or need Open Access? Brill Open offers you the choice to make your research freely accessible online in exchange for a publication charge. Review your various options on brill.com/brill-open.

Typeface for the Latin, Greek, and Cyrillic scripts: "Brill”. See and download: brill.com/brill-typeface.

ISSN 0169-8958

ISBN 978-90-04-31163-3 (hardback)

ISBN 978-90-04-31484-9 (e-book)

Copyright 2016 by the Editors and Authors.

This work is published by Koninklijke Brill NV. Koninklijke Brill NV incorporates the imprints Brill, Brill Hes \& De Graaf, Brill Nijhoff, Brill Rodopi and Hotei Publishing.

Koninklijke Brill NV reserves the right to protect the publication against unauthorized use and to authorize dissemination by means of offprints, legitimate photocopies, microform editions, reprints, translations, and secondary information sources, such as abstracting and indexing services including databases. Requests for commercial re-use, use of parts of the publication, and/or translations must be addressed to Koninklijke Brill NV.

This book is printed on acid-free paper and produced in a sustainable manner. 


\section{Contents}

Preface VII

List of Figures VIII

List of Contributors $\mathrm{X}$

1 Lyric Vision: An Introduction 1

Anastasia-Erasmia Peponi

2 Political and Dramatic Perspectives on Archaic Sculptures:

Bacchylides' Fourth Dithyramb (Ode 18) and the Treasury of the Athenians in Delphi 16

Lucia Athanassaki

3 The Fight of Telephus: Poetic Visions behind the Pergamon

Frieze $5^{0}$

Laura Lulli

4 Choral Performance and Geometric Patterns in Epic Poetry and Iconographic Representations 69

Jesús Carruesco

5 Making Monkeys: Archilochus frr. $185^{-187}$ w. in Performance 108 Deborah Steiner

6 Observing Genre in Archaic Greek Skolia and Vase-Painting 146 Gregory S. Jones

7 'Glancing Seductively through Windows': The Look of Praxilla fr. 8 (PMG 754) 185

Vanessa Cazzato

8 How to Construct a Sympotic Space with Words 204 Jenny Strauss Clay

9 Turning Sound into Sight in the Chorus' Entrance Song of Aeschylus' Seven against Thebes 217

Caroline Trieschnigg 
10 Light and Vision in Pindar's Olympian Odes: Interplays of Imagination and Performance 238

Michel Briand

11 Visual Imagery in Parthenaic Song 255

Laura Swift

12 The Amorous Gaze: A Poetic and Pragmatic Koinê for Erotic

Melos? 288

Claude Calame

13 Visualizing the Cologne Sappho: Mental Imagery through Chorality, the Sun, and Orpheus 307

Anton Bierl

14 Female Choruses and Gardens of Nymphs: Visualizing Chorality in Sappho 343

Katerina Ladianou

15 Imagining Images: Anacreontea 16 and $17 \quad 370$ Ippokratis Kantzios

Index $\quad 387$ 


\section{Preface}

This volume inaugurates a series within Brill's Mnemosyne Supplements which records the proceedings of the conferences of the Network for the Study of Archaic and Classical Greek Song (http://greeksong.ruhosting.nl/). Three further volumes in the series are in preparation: on authorship and authority in Greek lyric poetry, on the reception and transmission of Greek lyric poetry from $600 \mathrm{BC}$ to $400 \mathrm{AD}$, and on the newest Sappho fragments published in 2014 (P. Sapph. Obbink and P. GC inv. 105). The Network was founded in 2007 as a means of facilitating interaction between scholars interested in the study of archaic and classical lyric, elegiac, and iambic poetry. Most of the papers included here were originally presented at the first open conference of the Network, held on 17th-2oth July 2009 at the European Cultural Centre of Delphi. This was funded by the Netherlands Organization for Scientific Research (NWo) and Stanford University, and organised by Anastasia-Erasmia Peponi and Richard Martin. Theirs was the choice of theme, the formulation of the call for papers, and the initial selection of abstracts. The publication of the volume was then planned by them jointly with André Lardinois and the papers underwent a process of peer reviewing at the hands of the 'core members' of the network as well as an anonymous reviewer for the Press. The final process of shaping the volume and editing the typescript for submission was undertaken by Vanessa Cazzato and André Lardinois, one of the network's founders and the initiator of the series. Two students, Hendri Dekker and Marieke Graumans, helped with the preparation of the index. We would like to thank the Faculty of Arts of Radboud University for providing the funds which enabled this volume to be made available through Open Access.

V.C.

A.L. 


\section{List of Figures}

2.1 Reconstruction of the Athenian Treasury by A. Tournaire (1902) 21

2.2 Theseus and Procrustes or Sciron. Metope from the Athenian Treasury at Delphi, South Side, Archaeological Museum of Delphi $\quad 25$

2.3 Theseus and Cercyon. Metope from the Athenian Treasury at Delphi, South Side, Archaeological Museum of Delphi $\quad 26$

2.4 Athena and Theseus. Metope from the Athenian Treasury at Delphi. South Side, Archaeological Museum of Delphi 27

2.5 Display of the Metopes in the Delphi Archaeological Museum 28

2.6 Display of the Metopes in the Delphi Archaeological Museum, detail 29

3.1 Hiera, Telephus' wife, against the Greek warriors, from the Pergamon Great Altar 61

3.2 Hiera's funeral, from the Pergamon Great Altar 62

3.3 The death of two warriors, from the Pergamon Great Altar 63

3.4 The death of Aktaios, from the Pergamon Great Altar 64

3.5 The wounding of Telephus by Achilles, from the Pergamon Great Altar 65

4.1A Attic oinochoe, c. 740 BC, from Dipylon 85

4.1B Inscription on Attic oinochoe, c. 740 BC, from Dipylon 86

4.2 Corinthian aryballos, with representation of dance and inscription. c. $590-58$ в в 87

4.3 Argive crater (Late Geometric), from grave T45 in Argos 88

4.4 Attic crater (LG1b), c. 740 BC, from Kerameikos 91

4.5 Attic chest (MG I) with model granaries 92

4.6 Attic pyxis (MG II), c. $760-50$ вС 93

4.7 Late Geometric oinochoe, c. 75 о в 94

4.8 Euboean LG crater from Cyprus by the Cesnola Painter 95

4.9 Attic crater (LGIb), c. 740b, from Dipylon 97

4.10 Oinochoe, c. 735-720 в . Boston 25.42, Richard Norton Memorial Fund 98

4.11 Kantharos. Boiotian. Late 8th century B.C. 99

4.12 Dancing warriors. LG cup 101

4.13 Boeotian LG pythoid jar, from Thebes 102

4.14 Couples dancing. Neck of Attic (EPA) loutrophoros, by the Analatos Painter 103

4.15 Heracles and Triton. Attic Black figure kylix 104

4.16 Attic Red figure kylix 105

5.1 Terracotta kantharos with monkey face 129

5.2A Cup dated to circa $520 \quad 130$

5.2B Cup dated to circa $520 \quad 131$ 
$5 \cdot 3$ Terracotta figure vase of a monkey, ca $5^{6} 5^{-55^{0}} \quad 13^{2}$

5.4A Corinthian oil flask 133

5.4B Corinthian oil flask 134

5.4C Corinthian oil flask 134

5.5 Red-figure hydria 135

5.6A Hydria depicting the Calydonian boar hunt 139

5.6B Hydria depicting the Calydonian boar hunt 140

6.1A Red-figure krater by Euphronios 171

6.1 B Detail of red-figure krater by Euphronios $\quad 172$

6.2A Red-figure kylix by the Epeleios Painter 176

6.2B Tondo of red-figure kylix by the Epeleios Painter (tondo) $\quad 178$

7.1A Side A of unattributed red-figure kylix $\quad 189$

7.1 B Side в of unattributed red-figure kylix 190

7.1C Tondo of unattributed red-figure kylix 191 


\section{List of Contributors}

\section{Lucia Athanassaki}

is Professor of Classical Philology at the University of Crete, Rethymnon. Her research interests focus on choral performance, its artistic context and its ideological and political agenda.

\section{Anton Bierl}

is Professor of Greek Literature at the University of Basel. His research interests include Homeric epic, drama, song and performance culture, and the ancient novel. His books include Dionysos und die griechische Tragödie (1991); Die Orestie des Aischylos auf der modernen Bühne (1996); Der Chor in der Alten Komödie (2001; English second ed. Ritual and Performativity 2009).

\section{Michel Briand}

is Professor of Ancient Greek Language and Literature at the University of Poitiers. His research activities focus on archaic (especially melic) poetry, narrative fiction (the ancient novel and Lucian), and cultural and aesthetical issues such as the role of dance or the relation of text and image. His latest publication is Pindare. Olympiques, Les Belles Lettres, Paris, 2014.

\section{Claude Calame}

is Director of Studies Emeritus at the École des Hautes Études en Sciences Sociales in Paris (Centre AnHiMA: Anthropologie et Histoire des Mondes Antiques). His publications include The Craft of Poetic Speech in Ancient Greece (1995), The Poetics of Eros in Ancient Greece (1999), Choruses of Young Women in Ancient Greece (2001 ${ }^{2}$ ), Masks of Authority. Fiction and Pragmatics in Ancient Greek Poetics (2005), Poetic and Performative Memory in Ancient Greece (2009), Greek Mythology. Poetics, Pragmatics and Fiction (2009).

\section{Jesús Carruesco}

is Associate Professor at the University Rovira i Virgili (Tarragona) and Researcher at the Catalan Institute of Classical Archaeology. He has published extensively on Archaic Greek epic and lyric poetry, Greek religion, and classical reception.

\section{Vanessa Cazzato}

is a postdoctoral researcher at Radboud University, Nijmegen. Her research interests have so far focused on Greek lyric poetry, especially monody. She has 
co-edited The Cup of Song. Studies on Poetry and the Symposion (OUP, 2016) and is completing a monograph stemming from her Oxford DPhil on poetic imagery.

\section{Gregory S. Jones}

is an independent scholar. He received his $\mathrm{PhD}$ from Johns Hopkins University and has taught at George Washington University and Indiana University. He has been a Regular Member of the American School of Classical Studies at Athens and has published on skolia and Greek drama.

\section{Ippokratis Kantzios}

is Associate Professor of Classics at the University of South Florida. He has published articles on archaic and Hellenistic poetry as well as Greek drama. His monograph, The Trajectory of Archaic Greek Trimeters, appeared in 2005.

\section{Katerina Ladianou}

received her PhD from the Ohio State University in 2009. She has taught at the University of Patras and the University of Crete. Her academic interests include archaic Greek poetry (lyric and epic), Greek and Roman poetics, and literary theory.

\section{André Lardinois}

is Professor of Greek Language and Literature at Radboud University, Nijmegen. His research interests centre on Greek lyric poetry and Greek drama. He is also the academic director of OIKOs, the national research school of classical studies in the Netherlands.

\section{Laura Lulli}

is a temporary lecturer in Greek Language and Literature at the University of L'Aquila. She has authored a number of papers on Greek epic and lyric poetry. Her monograph on Greek historical elegy, Narrare in distici. L'elegia greca arcaica e classica di argomento storico-mitico, was published in 2011.

\section{Anastasia-Erasmia Peponi}

is Professor of Classics at Stanford University. She works on aesthetic thought in the classical world; lyric poetry, ancient and modern; the relationship between the visual and the verbal in ancient and modern thought; and dance and aesthetic perception in ancient and modern times. She has published numerous articles as well as Frontiers of Pleasure: Models of Aesthetic Response in Archaic and Classical Greek Thought (Oxford UP, 2012) and has edited Performance and Culture in Plato's Laws (Cambridge UP, 2013). 


\section{Deborah Steiner}

is the John Jay Professor of Greek at Columbia University. Among her publications are discussions of archaic iambos and animal fables that draw on both verbal and visual sources; a forthcoming book treats archetypal choral ensembles and exchanges between choreia and other institutions and practices in late archaic and early classical Greek culture.

\section{Jenny Strauss Clay}

is William R. Kenan Jr. Professor of Classics at the University of Virginia. She is the author of The Wrath of Athena (1983), The Politics of Olympus (1989), Hesiod's Cosmos (2003), and Homer's Trojan Theater (2011) as well as numerous articles on Greek and Roman poetry.

\section{Laura Swift}

is Lecturer in Classical Studies at the Open University, UK. Her research interests range across archaic and classical Greek poetry and drama. Her publications include The Hidden Chorus (2010) and a book on Euripides' Ion (2008).

\section{Caroline Trieschnigg}

obtained her PhD in Classics from Radboud University Nijmegen in 2009. Her dissertation is entitled Dances with Girls: The Identity of the Chorus in Aeschylus'Seven against Thebes. She teaches Classics at a secondary school in the Netherlands. 


\title{
Lyric Vision: An Introduction
}

\author{
Anastasia-Erasmia Peponi
}

'Do I paint it natural, Susie, so you think how it looks?' Dickinson, a defiant and uncanny poet of the modern era, referring to her own verbal skills. Quintessentially lyric, especially if one admits that lyric thrives in the gaps and breaches of conventional generic taxonomies, Dickinson was repeatedly testing the boundaries between the verbal and the visual in her own recalcitrant manner. Neither the first nor the last among modern poets to approach such issues, the inventiveness and unpredictability of Dickinson's experimentations are yet particularly telling instances of the way in which modern lyric has always reached out for the world of the visual when exploring the flexibility of its own frontiers.

Was this the case in ancient lyric poetry as well? We will probably never learn in what context Simonides of Keos, one of the nine lyric poets of the Alexandrian canon, articulated the famous statement attributed to him by Plutarch: 'Simonides calls painting silent poetry and poetry painting that speaks.' ${ }^{2}$ It is worth tackling at some length this sweeping utterance about the relationship between the verbal and the visual as it seems to touch upon key aspects of the ways lyric poetry engaged with vision and visuality in antiquity. Before doing so, however, I would like to bring up - if briefly - two sets of broader considerations regarding ancient lyric poetry and its visual demeanor.

The first set of considerations relates to broader questions pertaining to the role of lyric poetry in the development of visual sensibilities and practices in Greek cultures. To what extent can the various Greek lyric genres, with their powerful soundscapes generated by verbal or musical components, be considered an important part of Greek discourses about the visual? Indeed, the rich area of lyric production (understood here inclusively, as the totality of melic, elegiac and iambic genres) did reflect, shape, and interact with dominant modalities of viewing in Greek cultures. To put it in a different way, lyric production created its own diverse and manifold spectatorships.

1 Dickinson (1958) 85.

2 De glor. Ath. $346 \mathrm{f}$.

(C) ANASTASIA-ERASMIA PEPONI, 2016 | DOI: 10.1163/9789004314849_002

This is an open access chapter distributed under the terms of the Creative Commons AttributionNoncommercial 3.o Unported (CC-BY-NC 3.0) License. 
By using the term spectatorship I refer to at least three viewing practices associated with Greek lyric poetry.

First of all, I refer to the wide range of its actual performative aspects, an essential part of which was meant to address sight in its purely sensory impact. One should include here not only the evidently visual aspect of Greek chorality, namely the dance component in all of its many instantiations, but also the visual force of solo performances, for instance the kitharodic, where the performer's apparel along with his kinetic apparatus created a powerful and affective optical nexus. ${ }^{3}$ In this broader category I would also include the public display of inscribed poetry, the various genres of which were integral parts of lyric traditions. In Greek cultures inscribed poetry was conceptualized as a distinct mode of performance that engineered its own spectatorships. ${ }^{4}$

Next, I refer to the various ways in which lyric genres responded and contributed to, or even generated their own, modes of visual imagination. How cultures shape and manipulate imagination is an essential part of their visual sensibilities: the various ways in which Greek lyric poets handled visual representation revealed exciting potentials for imaginary envisioning. From the wide range of verbal representations of colors, hues, shades of light and darkness, shapes, objects, faces, bodies, to larger-scale interior settings and all sorts of topographies and landscapes, lyric poetry created, within its verbal fabric, a visual world to be accessed and enjoyed through intense imaginative activity.

Finally, I refer to the critical junction of vision, on the one hand, and visualization, on the other, in other words to the intersection-and indeed interaction - of what can actually be seen with what can be visually imagined. The juxtaposition of, or osmosis between, these two visual modalities, vision and visualization, is of paramount importance for our understanding of Greek visuality. Lyric poets played a key role in promoting ways of bringing them together. In fact, strategies of handling vision and visualization may illuminate selective affinities among seemingly disparate areas such as dramatic productions, lyric performances, and ekphrastic discourses.

That is to say that the Athenian theater was not just the locus par excellence for seeing but, perhaps even more importantly, it was where actual seeing, as a sensory activity, was mixed with modes of visualizing the unseeable. The muchdiscussed case of the messengers' speeches in tragedy, with their dense optical references inaccessible to the audience, is a typical but far from exclusive

3 On the visual perception of dance see Peponi (2015) 204-217 with further bibliography. On kitharôidia as spectacle see Power (2010) 11-27 and passim.

4 On various aspects of this issue see Svenbro (1993); Day (2010); LeVen (2014) 283-329. 
instance of this practice. Interestingly, techniques of apposing, correlating, and at times fusing actual and virtual vision are a quintessential part of the rhetoric we encounter in the oldest surviving sample of Greek choral lyric from the seventh century BC, Alcman's first Partheneion ( $P M G F$ 1). In a section of the partheneion that is densely packed with visual references, Alcman's chorus of young women refers to their chorus leaders in this way: 'Don't you see? This race horse / is Enetic; but the hair / of my cousin / Hagesichora has the bloom / of undefiled gold. / And that silver face of hers! / But why am I talking to you with full clarity? / Here she is: Hagesichora!' (vv. 50-57). ${ }^{5}$ Even if the simulated second-person addressee, who is urged to look at what the song describes, is the chorus members themselves addressing each other, there should be no question that the targeted and ultimate addressee of this animated rhetoric is the audience watching the choral performance. Yet the repeated encouragement to behold, and even more the rhetoric of admonition to look at details supposedly obvious and in front of one's eyes (for instance, the silvery face of Hagesichora) was in fact much more artful, especially if one takes into account not only the restrictions on optical access for an audience watching the performance but, even more, the time of the actual performance which, as has been repeatedly suggested, was probably before sunrise. More importantly, one realizes that these optical incentives are in flux as they are part of a continual flow of changing metaphors. In other words, a series of visual stimuli is indeed displayed in front of the audience's eyes, but it is mainly with their imaginative power that the audience can interpret and enjoy them, prompted by the intricate verbal nexus of the chorus' song. ${ }^{6}$

This deep-seated cultural practice of enriching the visual by emancipating it from actual sight while, at the same time, rhetorically appealing to this very sight, was significantly advanced by Greek lyric traditions in numerous ways. Once described this way, this practice helps us realize the existence of a common attitude towards visuality in verbal samples of very different provenance. It is because of this well-established cultural stance, for instance, that the ancient commentator Heraclitus could contend that Archilochus' poem impelling Glaucus to look at the threatening signs of a storm is part of an elaborate allegory. ${ }^{7}$ Regardless of whether or not these lines were meant

5 The translation here as in Peponi (2004) 297-298 and n. 3.

6 For an extensive discussion of the way visual perception operates in this poem along with a discussion of the relevant literature (including Calame's seminal work) see Peponi (2004). See more recently Budelmann (2013) 81-98, esp. 81-93.

7 Fr. 105 w. ap. Heraclit. All. 5·3. 
as an allegory by the poet himself, the speaker's urging that Glaukos look $(\not \circ p \alpha$, v. 1) as 'already waves are disturbing the deep sea and a cloud stands straight round about the heights of Gyrae, a sign of storm' is clearly yet another instantiation of a rhetorical appeal to pure sight designed to stir imaginary envisioning. ${ }^{8}$ The trope is still flourishing in ekphrastic literature of a much

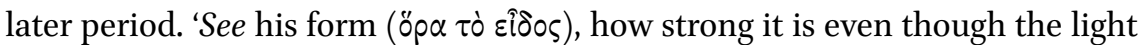
has gone from his eyes; see (öp $\alpha$ ) his downy beard, how it matches his age with that of his youthful slayer.' ${ }^{9}$ This is Philostratus the Elder, in the third century AD, encouraging his internal addressee, a ten-year-old boy, to look at details of a painting representing the death of Memnon. In the first book of his Imagines there are about two dozen instances where the verb ópâv is used as an admonition to his addressee to look at the parts of the painting the speaker is in the process of describing and interpreting. In ways not dissimilar to early lyric poetry, this intratextual viewer-Philostratus' constructed witness-functions as a trope, a way for the speaker to rouse and empower the visualizing potential of his readers' imagination.

The second set of questions relates to the political aspects of lyric visuality. Was there-or could there ever be-a politics of viewing in the case of archaic and classical lyric production? The question is prompted by compelling and influential suggestions, made over the last twenty years in classical scholarship. Such approaches usually focus on Athenian visual culture and more specifically on Athenian theater. 'The act of looking, central to any discussion of word and image,' Simon Goldhill wrote, 'must be comprehended in the broadest possible way as a culturally and historically specific performance, and if we are to understand how word and image are conceptualised in ancient democratic Athens, then the construction of the democratic subject as viewer is a necessary project.' ${ }^{\prime 10}$

Comprehending mentalities of viewing as generated and practiced within 'culturally and historically specific performance' entails performance genres originating from and fastened to a specific cultural and political environment, and this was indeed how classical Athenian drama, for instance, operated by and large. It is reasonable to think that when Euripides was composing his tragedies he was principally elaborating on or challenging Athenian modes of looking at a tragic production, while addressing visual sensibilities that had

\footnotetext{
8 Translation by Gerber (1999) 145. On this poem see recently Bowie (2009) 109-110.

9 Philostr. Imag.1.7.2; translation by Fairbanks (1931).

10 Goldhill (2000) 165 .
} 
been molded by the totality of Athenian democratic institutions. How he may have thought about the viewing practices and sensibilities of a Macedonian audience, if we ponder the possibility that he composed the Bacchae in the court of Archelaus with the prospect of a production in the area, is an intriguing question. ${ }^{11}$ In other words, should we think that an Athenian 'democratic subject as viewer' had its equivalent in a Macedonian 'monarchical subject as viewer'? What would monarchy and its institutions entail for an audience's visual psychology?

To return to our subject, the usefulness of such highly speculative questions is that they make one realize how challenging it is to conceive of a politics of viewing in the case of lyric genres, even though most of them employed significant visual components. Contrary to the fixity of Athenian drama, which was wholly centralized inasmuch as it was produced and originally meant to be consumed by Athenians (or by visitors joining an Athenian audience in an Athenian theater), a very considerable part of the archaic and classical lyric production was generally itinerant and centrifugal. ${ }^{12}$

This typical mobility of lyric production and performance complicates the relationship between the dynamics of spectatorship, on the one hand, and political structures, on the other. The plurality, diversity, and transformability of ancient lyric genres do not allow for an exhaustive discussion of this issue, yet a couple of examples can highlight different aspects of it. The political issues deriving from the programmatic transportability and adjustability of epinician poetry, along with some of their visual implications, have been addressed effectively in scholarship. ${ }^{13}$ Here I would like to offer examples from a different area. The New Musical scene, for instance, has primarily been discussed in connection with Athenian theatrical culture and as an emblematic case of its decaying democratic ideologies, as these were seen by certain aristocratic circles. ${ }^{14}$ Yet most influential representatives of the profoundly lyric new waves were composers and performers visiting democratic Athens from all over the Hellenic world. To single out only some representatives of this stylistically

11 On this possibility see for instance Seaford (1996) 184.

12 For different aspects of this issue see for instance Nagy (1990) 82-115, in regards to the 'panhellenization of song; Kowalzig (2007) in relation to choral rituals and locality; Hunter and Rutherford (2009) on travelling poets, with a focus on lyric poets in several excellent chapters; Rutherford (2013) in relation to the cultural practice of theoria, part of which was attached to lyric production and performance; LeVen (2014) esp. 134-148 on traveling poets in later classical lyric.

13 See for instance Kurke (1991); Athanassaki (2009); Morgan (2015).

14 See for instance Csapo (2004) 207-248. 
diverse but nevertheless consistently innovative group: Melanippides was from Melos, Philoxenus from Cythera, Timotheus from Miletus, Phrynis from Lesbos, Telestes from Selinous, and Polyidus from Selymbria. ${ }^{15}$ Even if we assume that the Athenian musical-and-theatrical scene along with its audiences created the ideal pool for musical advances and experimentations, it is still important to think about the many and quite different cultural and political environments that generated such musicians in the first place. What were the dynamics of spectatorship in their own, quite divergent, poleis? And did these in any way trigger such novel (as it turned out) musical impulses?

Questions regarding lyric production in relation to the political infrastructures of its consumption become even more complex if we take into account data indicating how welcomed the musical vanguard seems to have been in the monarchic environment of Macedonia. Unlike those with oligarchic inclinations in Athens who found all sorts of flaws in modernizing experimentations, for which they blamed democracy, the monarchic establishment in Macedonia sought to embrace them. The Macedonian hospitableness, not only to experimental tragedians such as Agathon and Euripides, but apparently to at least two lyric representatives of musical innovation as well (Melanippides and Timotheus) indicates that the political underpinnings of taste were malleable enough to allow for a smooth shift from a radical democracy to an ambitious monarchy. In other words, along with the traveling lyric poets and their audiovisual productions, the political dynamics of spectatorship could swerve in quite oblique ways. ${ }^{16}$

These two, briefly discussed, sets of considerations regarding the ways in which lyric production challenged, complicated, or contributed to visual sensibilities in Greek cultures, provide an illuminating context for a lengthier exploration of the famous Simonidean statement regarding the relationship between poetry and painting. The quotation, with nearly identical wording and unequivocal attribution to Simonides, appears twice in Plutarch's works. The authoritative style of the phrase, along with its symmetrical wording, fits nicely the profile of a poet who was indeed well known in antiquity for his broader intellectual allure, but it also encourages generalizing interpretations. According to the

15 For a geocultural mapping of lyric production in the archaic and classical periods see Driscoll et al. (2015).

16 For Melanippides in Macedonia see Sud. $\mu 454$ Adler. See also LeVen (2014) $115^{-118}$ for the problems of his identity. For Timotheus in Macedonia see for instance Plut. Mor. 177b and 334 b; on the possibility that he died there see Steph. Byz. $\mu 184$ Billerbeck. 
predominant approaches it is the totality of poetry, regardless of genre, that is said to be speaking painting. But was this Simonides' original intention? Or was the statement part of a poetic manifesto meant to explain his own lyric art?

Although we cannot exclude the possibility that Simonides' statement was meant to be heard as a sweeping pronouncement about poetry as a whole, such a formulation must have been elicited primarily by his own experience of, and experimentation with, the wide range of the poetry that he himself was composing, namely melic. Thus the phrase, uttered by one of the most sought-after and well-traveled lyric poets of the late archaic and early classical Greek world, is emblematic for the broader subject of this volume: The Look of Lyric, Greek Song and the Visual. Certainly, in the volume as a whole it will be clear that painting was far from the sole visual art with which Greek lyric poetry engaged. On the contrary, over the last years there has been some excellent work on the diverse channels through which lyric poetry, and especially choral song, addressed yet another visual art, sculpture, to mention just one other example. ${ }^{17}$ My focus on painting as an emblematic instance of lyric poetry's relationship with the visual is due to three factors: first, to the fascinating influence that the Simonidean statement exercised over the centuries; second, to the curious fact that scholarship tends to be oblivious of the lyric identity of its creator; and, third, to the fact that painting is the art that played a consistently decisive role in Greek critical thought throughout antiquity, whenever philosophers, critics, or poets commented on, or theorized, the verbal arts. This trend, conceivably originating with, or at least advanced by, the lyric poet Simonides can be traced in major authors, for instance Plato, Aristotle, Demetrius, Dionysius of Halicarnassus, and Longinus-not to mention Horace's notorious and perhaps already clichéd ut pictura poesis in his Ars Poetica.

Whether or not the two different but equally thought-provoking contexts in which Plutarch quotes the Simonidean phrase are close to the original context in which the poet might have employed it will remain unknown, yet both instances are suggestive of the complexity that may have underlain the statement's deceptive simplicity. In his epideictic oration In what were the Athenians famous, Plutarch makes a peculiar argument for the primacy of the city's excellence in military affairs over cultural matters. ${ }^{18}$ His line of reasoning might strike one as convoluted yet several of his specific references to cultural pro-

\footnotetext{
17 See for instance Steiner (1993) 159-180; Athanassaki (2009), (2012) 134-157; Kurke (2013) 123-170.

18 De glor. Ath.346-347.
} 
duction, and especially to the verbal and visual arts, are particularly interesting. After a rather lengthy description of the battle of Mantineia and the critical role of the Athenians in its outcome, Plutarch comments on the masterful way in which the painter Euphranor captured the fervor and vehemence of this famous battle. It is in this context that the Simonidean statement is brought up. 'Simonides calls painting silent poetry and poetry painting that speaks', Plutarch says. ${ }^{19}$ Two sets of loosely interrelated comments follow. The first refers to the different temporal registers in pictorial and verbal narratives, for painters demonstrate actions as taking place at present while verbal arts narrate them as having taken place in the past. The second, somewhat lengthier, distinguishes the different media of the two arts (colors and shapes as opposed to words and phrasing) but nonetheless ends up emphasizing their ultimate shared aim: vividness, enargeia, a key concept in Greek critical thought, now explicitly attributed to Thucydides as Plutarch shifts his focus onto the historian's ability to turn listeners into viewers. Detailed examples from Thucydides' vivid descriptions of the battle of Pylos and of the Sicilian expedition bring this section of Plutarch's epideixis full circle.

Interestingly, the almost symmetrical arrangement of the passage, with the battles at the outer rims and with Euphranor and Thucydides praised respectively for their pictorial and verbal vividness in the two inner ones, puts the Simonidean statement regarding the relationship between painting and poetry right at the center of this section. This neat concentric structure makes clearer the underlying associations between center and inner rims on either side. On the one side visual virtuosity, that of Euphranor, is praised for capturing mental states that are primarily the domain of discursive modes; on the other side verbal virtuosity, that of Thucydides, is praised for triggering human faculties that are primarily the domain of sense perception. If our reading between the lines is fair, the deep structure of this section reveals implicit and far more interesting aspects concerning the relationship between poetry and painting than those explicitly mentioned by Plutarch in his rather perfunctory exegesis of the Simonidean phrase.

We will probably never learn whether, when articulating his famous statement about the two arts, Simonides indeed had in mind their different ways of developing synergies between sense perception and mental function. Yet the possibility that this statement had roots in the poet's deeper involvement with the arts and their experiential potential fits well the wide-ranging intellectual profile that was attributed to him in antiquity, for he was identified 
and acknowledged as sophos. ${ }^{20}$ Furthermore, it is important to consider the possible relationship between this statement and the specific type of poetry Simonides was actually composing. How would the various lyric genres in which he was engaged prompt such a statement about the relationship between poetry and painting?

One aspect that arises immediately is the way in which the finite space of a painting and the limited length of a melic poem urge both painter and lyric poet to zoom in on individual scenes that are carefully selected from a much longer narrative sequence of the type found in epic-style accounts. In other words, provided that such endeavors in painting are meant to-or can-be enjoyed as self-standing images (i.e. either they are not physically juxtaposed with other paintings with which they are supposed to form a narrative cluster or they can nevertheless be appreciated as independent wholes), painters and melic poets stand on common ground when considering their otherwise diverse media. ${ }^{21}$

Once this common ground is established, Simonides' extant poetry can indeed provide some insights into the manner in which the lyric poet might have been contemplating and experimenting with the interrelation between mental and sensory channels in the apprehension of verbal and visual arts. The twenty-seven-line segment of the Simonidean poem quoted by Dionysius of Halicarnassus and often identified as 'Danae's lament' is a particularly interesting instance of the way in which sensory, and especially visual, markers are ingrained in the remarkably affective language of Danae's words while her infant, Perseus, is sleeping. ${ }^{22}$ Staged by the poet as she is being tossed about in a chest on the rough sea, Danae utters a monologue dense with descriptive terms that would sound unsuitable in the mouth of a horrified mother doomed to death, were they not so intricately woven into the texture of the poem. While addressing the sleeping infant she refers to the darkness of the night and to the dark-blue murk into which they were forced while a hint of glowing light is suggested by her reference to the brazen bolts of the chest. ${ }^{23}$ Two additional sensory registers, touch and hearing, are subtly elicited in the next four lines, while Danae comments on Perseus' lack of awareness: he does not sense the sea-spray tossed over his hair by the waves and he does not hear

\footnotetext{
$20 \quad$ For this aspect of Simonides' profile see especially Xenophon's Hiero.

21 For painted scenes juxtaposed to one another in a narrative sequence see for instance Pausanias' descriptions of the paintings of Polygnotus in the Cnidian Lesche in Delphi $(10.25-31)$.

$22 \quad P M G 543$.

23 On the diction and dramatic effect of the poem see Rosenmeyer (1991). On other aspects of the poem's visual references see for instance the insights in Carson (1999) 45-62.
} 
the sound of the wind. A reference to the purple blanket covering the infant and to his beautiful face completes her description while, at the same time, spotlighting Simonides' complete lack of interest in a realistic portrayal of a frightened mother enclosed in a dark chest in the middle of the sea. For how would she see the purple color and the beauty of the infant's face in the gloomy dark, let alone comment on them while on the verge of sinking?

In other words, Danae's emotive yet highly artificial first-person lament-like lullaby is an outstanding instantiation of a speaking painting. The carefully distributed tonalities of darkness, brightness, and color in her speech, her comment on the beauty of sleeping Perseus' face, her references to the saltspray of the waves over his hair and to the sound of the wind are all typical examples of a successful ekphrastic discourse that centers on vision while synaesthetically awakening the totality of the senses, in this case touch and hearing. A number of surviving vase paintings indicate that Danae with Perseus in the wooden chest was a favorite pictorial subject and it is therefore most probable that it was also depicted in wall-painting-or else that it could be easily imagined as such - where the potential for nuanced shading and color was considerably greater. ${ }^{24}$

Ekphrasis, more or less defined as 'descriptive language that brings what is portrayed clearly before the sight' does not seem to appear as a term before the first century $\mathrm{AD}$, and it does so then in the quite restrictive educational context of the progymnasmata, rhetorical textbooks for schoolboys. ${ }^{25}$ Yet the fundamental attributes of ekphrasis are present throughout archaic, classical, Hellenistic, and certainly imperial, literature and the models of its descriptive strategies and ramifications too many and too diverse to be put into a brief definition. By using the term ekphrastic discourse instead of ekphrasis I wish to refer to the widest possible range of verbal manipulations of the visual, which would include varying modes and ratios of descriptive and interpretive elements, in or outside longer narratives. If ekphrastic occurrences are considered this way, then lyric poetry has much to offer to its study and the present volume makes several suggestions in this direction.

Our approach so far indicates that Simonides might have been instrumental in thinking about, and experimenting with, the multiple ways in which descriptive language can enhance the emotional impact of lyric while at the same time enriching the visual imaginary of an audience that was probably encouraged to recall or imagine a painted image of Danae while listening to her words.

24 See LIMC vol. III.2 s.v. Danae.

25 Theon, Prog. p. 118 Spengel $=66$ Patillon. See Kennedy (2003) 45. 
The other context in which Plutarch quotes the Simonidean statement is in the last section of his Table-Talk (747-748) where two boys, among a group of several, excel in their dance performance and are asked by the sympotic participants to perform a pas de deux with alternating movements, for which

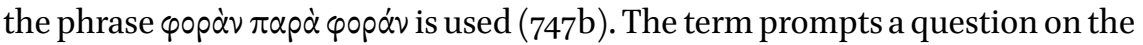
part of Thrasybulus and a long answer by the Athenian philosopher Ammonius, who undertakes to clarify the relationship between dancing movement (phora) and dancing posture (schêma) as well as the role of a third component in dance, that of pointing (deixis). It is in this broader context that the Simonidean statement concerning the relationship between poetry and painting is brought up: 'One can transfer Simonides' saying from painting to dancing' Ammonius says. 'For dance can rightly be called silent poetry and poetry speaking dance whereas there seems to be nothing from painting in poetry or from poetry in painting, nor does either art make any use whatsoever of the other; on the contrary, dancing and poetry are fully associated and the one involves the other.'26 Thus in Table-Talk the Simonidean statement is brought up only to be dismissed, yet the example Ammonius provides in order to demonstrate the deeper synergy between poetry and dance comes from another lyric poet, possibly Pindar. $^{27}$

One might want to question Ammonius' (or Plutarch's own) understanding of the Simonidean phrase. For instance, his assertion that there is nothing in poetry from painting or in painting from poetry appears to be quite tenuous if one considers the vast array of themes that have been the common property of both poetry and painting throughout the Greek world and that must have cross-fertilized both the shaping and re-shaping of verbal and pictorial narratives respectively and the audiences' perception and imagination. This serious pitfall aside, however, Ammonius' juxtaposition and contrasting of two major visual arts, painting and dance, is too suggestive to pass over. Given Ammonius' (and, of course, Plutarch's) most likely familiarity with earlier discourses of verbal and art criticism lost to us, one is prompted to wonder if the otherwise awkwardly articulated comparison between the two visual arts in their relationship to poetry, with its clearly agonistic overtone, is in fact echoing views that were originally expressed by, and perhaps exchanged between, first-rate lyric poets of the late archaic and early classical period.

26 Quaest. conv. 748a. Many thanks to Anastasios Nikolaidis for his comments on Plutarch's insights.

27 See fr. 107a Sn.-M. 
Nevertheless, the famous Simonidean statement served here as an emblematic instance of the multifaceted visuality of Greek lyric poetry. This volume offers a wide range of approaches to many aspects of this rich subject that have not thus far been explored systematically.

Lyric poetry in its relation to sculpture is extensively discussed by Lucia Athanassaki, who proposes a much deeper understanding of Bacchylides' eighteenth ode, if the dithyramb that was performed in Athens is envisioned in the imaginary foreground of the south metopes of the Athenian Treasury in Delphi. Not only do the distant metopes and the Bacchylidean poem share the same narrative sequence regarding Theseus' deeds on his way from Troizen to Athens but, according to Athanassaki, because of this specific interrelation between song and monument one can better understand the political and cultural ambience surrounding the performance of this quite distinctive dithyramb. Laura Lulli also discusses sculptural scenes, the so-called 'smaller frieze' of the altar at Pergamon, where episodes of the life of Telephus are depicted. Here as well lyric poetry proves to co-operate with sculpture, but in an almost reverse manner. Whereas Athanassaki examines the pathways through which the choral song can be envisioned as interacting with, or even enacting, the metopes in Delphi, Lulli discusses the possibility that the Pergamon altar, commissioned in later times by the Attalids, is very likely to have drawn its inspiration from a long elegy attributed to Archilochus and published by Dirk Obbink in 2005 .

Another set of contributions discusses the ways in which lyric language manipulates the visual in cases where the plastic arts do not seem to play a central role in the apprehension of the lyric composition. How does a lyric poem act upon an audience's sensory perception and cultural imaginary in such cases? Michel Briand explores the manner in which Pindar's epinician odes, especially the Olympians, activate visual imagination through strategically placed stress on a wide range of terms evoking sparkle and luminosity. Thus, according to Briand, the epinician performance is amplified and irradiated in the audience's synaesthetic apprehension of the audio-visual verbal medium. Katerina Ladianou, too, discusses the sensory network of Greek chorality as formed primarily by visual associations that are eventually enhanced synaesthetically. Her focus is on the synaesthetic potential of vision in Sappho's poetry as well as on later ekphrastic literature that elaborated on its rich sensory apparatus. Caroline Trieschnigg as well explores the dynamics of synaesthesia and especially the way acoustic stimuli enhance visualization in the parodos of Seven Against Thebes. Finally, Anton Bierl examines the complex visual network of the Cologne Sappho fragment in both its verbal texture and its ritual context while underlining the fact that lyric poetry in general, and Sappho's poetry in particular, rely heavily on visual images and 
tableaux but, unlike other genres, tend to provide a rough visual outline that audiences are prompted to fill out by means of their cultural imaginary.

The importance of the visual for a key aspect of Greek lyricism, namely its erotic subjects, is discussed by Claude Calame, Laura Swift, Vanessa Cazzato and Ippokratis Kantzios. Calame explores the way in which the amorous gaze is embedded in the verbal texture of poems by Sappho, Anacreon, and Pindar and discusses extensively its complex function and dramatic enactment in Alcman's partheneia, where visual exchanges not only among choral performers but also between the chorus and its audience intensify the seductive aspects of the performance. Swift examines the unique emphasis of parthenaic songs on the visual allure of their female performers as well as on the visual aspects of their dramatic action, a feature that she considers intrinsically connected with the genre's cultural function and with Greek attitudes towards the parthenos. Vanessa Cazzato reinterprets a fragment attributed to Praxilla ( $P M G$ 754), where the suppressed eroticism of a young woman's gaze is opposed to her erotically experienced 'down-below'. The fragment is usually associated with the figure of a hetaira in a sympotic context but Cazzato, relying partially on vase painting, proposes that we understand it as part of a wedding song. Finally, Kantzios discusses two later Anacreontic compositions that are likely to belong to the Imperial period, where the erotic gaze is mediated through two particularly stimulating ekphrastic instances, in which the speaker directs an imaginary painter on how to paint a detailed portrait of the absent beloved.

The broader field of lyric production is approached in its relationship to painting in several other contributions as well, albeit from different angles. Jesús Carruesco explores the ways in which pictorial and choreographic patterns seem to be in creative and mutually interpretive dialogue in the iconography of the Geometric (and particularly of the Late Geometric) period, on the one hand, and in archaic poetic representations of choral practices, on the other. He focuses on three types of patterns especially, which he considers fundamental to both painting and choral dance: linear, circular, and whirling. The long ekphrastic archetype of the Shield of Achilles in the eighteenth book of the Iliad with its carefully arranged descriptions of dance is key to his analysis.

Despite differences in their methods and angles, Deborah Steiner's and Gregory Jones' contributions as well highlight the importance of vase painting for the interpretation of lyric poetry, while underlining the co-operation of verbal and visual practices in the Greek cultural imaginary. Steiner discusses Archilochus frr. ${ }^{185^{-1}} 187 \mathrm{~W}$. and their reference to an animal fable. While focusing especially on the role of the monkey in the poem, Steiner examines pictorial representations of simians in Greek vases that corroborate, but also enrich, the 
understanding of the poem as a comment on sympotic decorum. Gregory Jones examines lyric skolia (songs attached to actual sympotic action) inscribed on, or simply relevant to, vase-paintings depicting sympotic scenes and sheds light on the origins and the imaginary of this under-examined but culturally vital lyric genre. The symposium is also central in the contribution of Jenny Strauss Clay who examines three compositions of the archaic period, by Alcaeus, Xenophanes and (perhaps) Theognis, and comments on their diverse verbal and visual strategies in constructing the sympotic space as the locus of material and human co-existence.

By focusing on the relationship between the visual and the verbal as well as the sensory and the mental, the present volume raises a wide range of questions concerning human perception and cultural practices. As the contributions included here indicate, Greek lyric poetry played a decisive role in the shaping of both. In that respect, the volume offers an exciting stimulus for further contemplation.

\section{Works Cited}

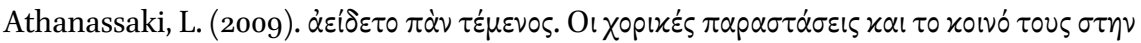

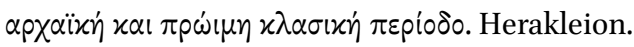

- (2012). 'Performance and reperformance: The Siphnian Treasury evoked', in P. Agócs, C. Carey, and R. Rawles (eds), Reading the Victory Ode. Cambridge: 134-157. Bowie, E. (2009). 'Wandering poets, archaic style' in Hunter and Rutherford (eds) (2009): 105-136.

Budelmann, F. (2013). 'Greek festival choruses in and out of context' in J. Billings, F. Budelmann and F. Macintosh (eds), Choruses Ancient and Modern. Oxford: 81-98. Carson, A. (1999). Economy of the Unlost. Princeton.

Csapo, E. (2004). 'The politics of the New Music', in P. Murray and P. Wilson (eds), Music and the Muses: The Culture of Mousike in the Classical Athenian City. Oxford: 207-248.

Day, J.W. (2010). Archaic Greek Epigram and Dedication: Representation and Reperformance. Cambridge and New York.

Dickinson, E. (1958). Selected Letters: edited by T.H. Johnson. Cambridge, Mass.

Driscoll, D. et al. (2015) Mapping Greek Lyric: Places, Travel, Geographical Imaginary. (http://web.stanford.edu/group/lyricmapping/linemap.html)

Fairbanks, A. (1931). Elder Philostratus, Younger Philostratus, Callistratus. Cambridge, Mass.

Gerber, D. (1999). Greek Iambic Poetry. Cambridge, Mass.

Goldhill, S. (2000). 'Placing theatre in the history of vision' in N.K. Rutter and B.A. Sparkes (eds), Word and Image in Ancient Greece. Edinburgh: 161-179. 
Hunter, R. and Rutherford, I. (2009). Wandering Poets in Ancient Greek Culture: Travel, Locality and Pan-Hellenism. Cambridge.

Kennedy, G.A. (2003). Progymnasmata: Greek Textbooks of Prose Composition and Rhetoric. Atlanta.

Kowalzig, B. (2007). Singing for the Gods: Performances of Myth and Ritual in Archaic and Classical Greece. Oxford.

Kurke, L. (1991). The Traffic in Praise: Pindar and the Poetics of Social Economy. Ithaca and London.

- (2013). 'Imagining chorality: Wonder, Plato's puppets, and moving statues' in A.-E. Peponi (ed.) Performance and Culture in Plato's Laws. Cambridge: 123-170.

LeVen, P. (2014). The Many-headed Muse: Tradition and Innovation in Late Classical Greek Lyric Poetry. Cambridge.

Morgan, K. (2015). Pindar and the Construction of Syracusan Monarchy in the Fifth Century B.c. Oxford.

Nagy, G. (1990). Pindar's Homer: The Lyric Possession of an Epic Past. Baltimore and London.

Peponi, A.-E. (2004). 'Initiating the viewer: Deixis and visual perception in Alcman's lyric drama'. Arethusa 37-3: 295-316.

— (2015). 'Dance and aesthetic perception' in P. Destrée and P. Murray (eds), $A$ Companion to Ancient Aesthetics. Malden, Mass.: 204-217.

Power, T. (2010). The Culture of Kitharôidia. Washington, DC.

Rosenmeyer, P. (1991) 'Simonides' Danae fragment reconsidered'. Arethusa 24.1: 5-29.

Rutherford, I. (2013). State Pilgrims and Sacred Observers in Ancient Greece. A Study of Theôria and Theôroi. Cambridge.

Seaford, R. (1996). Euripides' Bacchae with an Introduction, Translation and Commentary. Warminster.

Steiner, D. (1993). 'Pindar's "oggetti parlanti”'. HSCPh 95: 159-180.

Svenbro, J. (1993) Phrasikleia: An Anthropology of Reading in Ancient Greece. Trans. J. Lloyd. Ithaca and London. 


\title{
Political and Dramatic Perspectives on Archaic Sculptures: Bacchylides' Fourth Dithyramb (Ode 18) and the Treasury of the Athenians in Delphi*
}

\author{
Lucia Athanassaki
}

Bacchylides' Fourth Dithyramb dramatizes the dialogue between Aegeus and a group of Athenian youths which is prompted by the news of the imminent arrival of a hero whose outstanding bravery causes them fear and awe, as his identity and intentions are as yet unknown to them. Aegeus enumerates the unknown hero's amazing feats, reported by a messenger who has just come from the Isthmus: the prodigiously strong hero has overcome Sinis, the sow of Cremmyon, Sciron, Cercyon, and Procoptas/Procrustes (16-30). The Athenian youths express the view that a god must drive him on so that he can punish the unjust, thus alluding to his future accomplishments.

The deeds of Theseus had long been a favorite subject of story-tellers, poets, painters and sculptors. The Bacchylidean dithyramb, however, is our earliest extant literary source for the deeds of Theseus on his way from Troezen to Athens. ${ }^{1}$ In what follows I discuss the points of contact and contrast between

* This is a bibliographically updated version, at many points condensed, at other points expanded with further documentation, of sections of a book written in Greek (Athanassaki [2009]). Oral versions have been delivered at the first Network conference held at Corpus Christi College, Oxford (2008), at the University of Texas at Austin (2009) and at Reed College (2009), and at the summer seminars of the European Centre of Delphi for Argentinian and Brazilian classicists $(2010,2011)$. I am grateful to the audiences of all those occasions for stimulating discussions, helpful comments and suggestions and in particular to Rosina Colonia, Thomas Hubbard, Richard Martin, Ellen Millender, Anastasia-Erasmia Peponi, Ian Rutherford and Oliver Taplin; to Ewen Bowie, Vanessa Cazzato, John Marincola and H. Alan Shapiro for comments and suggestions on this version. Finally, many thanks to Ms. Calliope Christophi of the École française d'Athènes for photographs and permissions (figs 2, 3, and 4) and to the 1oth Ephorate of Prehistorical and Classical Antiquities for their permission to take photographs of the current exhibit of the metopes of the Athenian Treasury in the Delphi Museum (figs 5 and 6 ) at a time when it was not open to the general public.

1 Simonides sang of Theseus too. The few lines that have survived relate his voyage to Crete (Plutarch, Theseus $17=P M G 55^{\circ}$ ), but he may have sung of Theseus' early deeds as well. Aristotle in the Poetics (8) and Plutarch in the Life of Theseus mention an epic Theseis. Some

(C) LUCIA ATHANASSAKI, 2016 | DOI: 10.1163/9789004314849_003

This is an open access chapter distributed under the terms of the Creative Commons AttributionNoncommercial 3.o Unported (CC-BY-NC 3.0) License. 
Bacchylides' song-dance and the sculptural theme of the south metopes of the Athenian Treasury in Delphi which, like the dithyramb, focus on Theseus' arrival in Athens and feature an almost identical sequence of Theseus' deeds on his way from Troezen. I argue that Bacchylides consciously evokes the metopes of the Athenian Treasury and offers a new perspective on the monument through a song that draws its inspiration from Athenian politics, tragedy, and the ambitious architectural program of Cimonian Athens.

In Section 1.1 I set out my approach to the interaction of song and image which is based on evidence showing (a) the poets as engaged and creative viewers, (b) the fascination that Delphic architectural sculpture exercised on melic poets and dramatists throughout the fifth century, and (c) viewers'/listeners' tendency to correlate verbal and visual representations. In 1.2 I compare the Bacchylidean composition with the iconography of the Athenian Treasury in terms of theme and narrative style from a listener's/viewer's point of view, with emphasis on the contrast between the human and the divine perspective that differentiate the focal scenes of the verbal and sculptural narrative. Through further comparison of the dithyramb with vases from Attic workshops I argue that the most significant departure of the Bacchylidean dithyramb from visual representations is its dramatization of human alarm and fear at the advent of the prodigiously strong hero. In Section 2 I discuss (a) Bacchylides' evocation of the Athenian Treasury in the light of Theseus' prominence in the art, cult and politics of Cimonian Athens, and (b) the political significance of ignorance and fear of the motives and intentions of the outstanding individual in the democratic polis. In Section 3 I bring the strands of my argument together and I suggest that artistically and politically the Bacchylidean dithyramb played to Athenian tastes, sensitivities and preoccupations: the evocation of the faraway monument in dramatic form draws its inspiration from tragedy and the monumental architecture which dominated the Athenian cultural scene in Cimonian Athens; the problematization of the reception of an outstanding individual in the polis is a political statement which, while relevant to Cimon, transcends the man and his time.

scholars thought that it was a sixth-century or even earlier epic that provided the inspiration for the sculptural representations of the Athenian Treasury and, possibly, for Bacchylides' dithyramb. See e.g. Schefold (1946), Schefold (1992) 175-183; tentatively Maehler (2004) 191193. Others have challenged the existence of an early epic and proposed instead that Aristotle and Plutarch were thinking of a later poem or poems. See in particular Francis (1990) 43-46, Walker (1995) 38-39 and 46. Whether such an epic existed or not, there can be no doubt that there were non-literary tales about Theseus' deeds. 
1.1 The Poet and His Audience(s) as Viewers of Architectural Sculpture The existence, the nature, and the degree of interaction between visual and literary representations have been subjects of intense debate. Studies that posit the dependence of the visual arts on literature occupy one end of the spectrum, whereas studies that espouse the total independence of literary and visual mediums represent the other extreme. ${ }^{2}$ In a recent discussion of the two opposing approaches to the relationship of drama with visual representations, Oliver Taplin offers a new angle. Taplin accepts the view that visual arts build their own vocabulary and that the signification of visual representations is on the whole self-sufficient. Contrary to the 'iconocentrists', however, Taplin puts forward the idea of 'enrichment', which has to do more with the experience of the viewer and less with the artistic vocabulary of the painter. On this view a visual representation means more to a viewer who knows and can therefore recall the corresponding tragic scene:

Whatever it was that the viewers wanted from mythological paintings, it was clearly not pictures of plays and not pictures of tragic performances. But, given the presence of tragic theatre in their lives, there was no reason for them to keep these two art-forms running separately along parallel lines. ${ }^{3}$

The 'enriched' experience of the viewer is the angle I adopt in my discussion of the interaction of Bacchylides' dithyrambic composition for the Athenians and the metopes of the south side of the Athenian Treasury in Delphi. Bacchylides' dithyrambs cannot be dated safely, but a number of indications point to the 470 s or the 460 s for the composition and performance of this dithyramb as well as the thematically akin ode 17 . I will discuss briefly the date of the monument in the next section, but if mid-470s is a terminus post quem for the composition and performance of the dithyramb, it is certain that Bacchylides had plenty of opportunity to see the sculptural décor of the Athenian Treasury during his visits to Delphi before its composition. ${ }^{4}$ Thus I include him among the viewers,

2 For the controversy see Taplin (2007) 22-26; for the debate on viewers' attitudes to architectural sculpture see Marconi (2009). For the growing interest in the relationship between melic poetry and architectural sculpture see Marconi (2009); Athanassaki (2011) 254 with references in n. 53; Power (2011).

3 Taplin (2007) 26.

4 For an early date of composition, i.e. around 475, see e.g. Zimmermann (1989) 99 n. 27; Francis (1990) 58; Calame (1996) 153-156. 
but I consider him a special viewer who-as I will suggest—was inspired by the monument but cast his experience in a tragic mould. ${ }^{5}$

There is reason to believe that Bacchylides was an engaged viewer. His overt reference to Hieron's dedicatory offerings to the Delphic sanctuary in the epinician song that he composed for Hieron's chariot victory at Olympia in 468 (ode 3.17-22) offers such an indication:

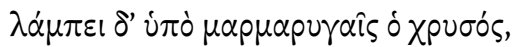

$$
\begin{aligned}
& \dot{u} \psi 1 \delta \alpha 1 \delta \dot{\alpha} \lambda \tau \omega \nu \tau \tau \mid \pi \delta \delta \delta \omega \nu \sigma \tau \alpha \theta \dot{\varepsilon} v \tau \omega \nu
\end{aligned}
$$

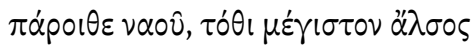

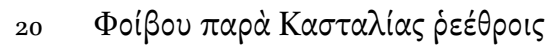

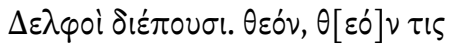

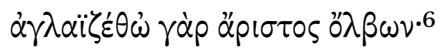

and gold shines with flashing light from the high elaborate tripods standing in front of the temple, where the Delphians tend the great sanctuary of Phoebus by the waters of Castalia. Let God, God be glorified: that is the best of prosperities.

In this instance, Bacchylides focuses on the visual effect of the ornate golden tripods on the viewer. Through the spatial specification $(\pi \dot{\alpha} \rho \circ \theta \varepsilon \nu \alpha \circ \hat{v})$, he orients his audience's mind to the particular locale in the sanctuary where Gelon's and Hieron's tripods were placed. Those who were already familiar with the temple of Apollo from previous theoric visits would recall the glittering tripods. Those who were not could easily imagine them and possibly keep a mental note to look out for them on a future visit.

The Fourth Dithyramb was composed for performance in Athens. Bacchylides could count on his Athenian audience's interest in, and familiarity with, Apollo's sanctuary. The Athenians had old and strong ties with Delphi. Their Treasury was in the immediate vicinity of the temple of Apollo, which had been brilliantly restored by the Alcmaeonids at the end of the sixth century. Athenians who visited the temple on official or private theoriai would have every reason to pay special attention to their city's Treasury. The deeds of Theseus in the metopes of the south side were their first sight of their Treasury

5 For the different responses of different viewers to monumental sculpture and vases see now Von den Hoff (2010) 162-164 and passim.

6 The Bacchylidean quotations are taken from Maehler (2004). The translations are those of Campbell (1992). 
(fig. 2.1)..$^{7}$ Not all of them, of course, would have been engaged viewers, but there is evidence showing that some of them at least would look carefully and contemplate the sights.

Two Euripidean plays, the Andromache and the Ion, offer precious glimpses into sight-seeing in Delphi. In the Andromache the messenger explains to Peleus how Orestes succeeded in convincing the Delphians that Neoptolemus came to sack the temple of Apollo. Neoptolemus' extensive and intensive sightseeing caused suspicion: the Delphians gathered to watch Neoptolemus and his retinue who were looking at the buildings and the valuable dedications of the sanctuary; his activity gave Orestes the opportunity to convince the already suspicious Delphians that the purpose of his second visit was the same as that of his first $\left(1085^{-1095)}\right)^{8}$

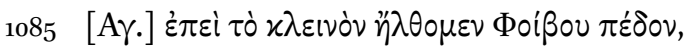

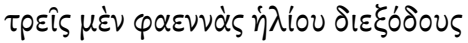

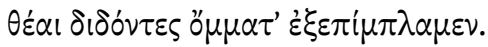

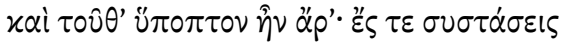

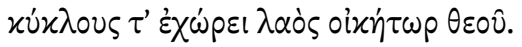

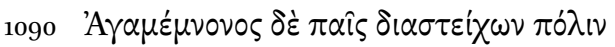

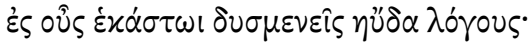

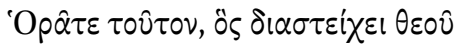

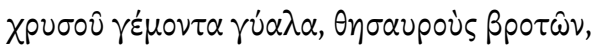

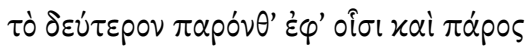

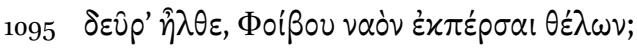

When we had come to Phoebus' glorious land, we spent three days in gazing our fill. This, it seems, caused suspicion: the people who dwell in the god's land gathered in knots and circles. The son of Agamemnon went through the city and spoke in each man's ear these hostile words: 'Do you see this man, who makes his way through the god's gold-laden precincts and the treasuries given by mortals? He has come here a second time for the same purpose as his earlier visit and means to sack the temple of Phoebus.'

7 Reconstruction of the Athenian Treasury by Tournaire (1902).

8 The text of Euripides is that of Diggle (1984) for the Andromache and Diggle (1981) for the Ion; the translations are those of Kovacs (1995) (Andromache) and Potter (1938) (Ion); they are taken from the $T L G$ and Perseus databases. 


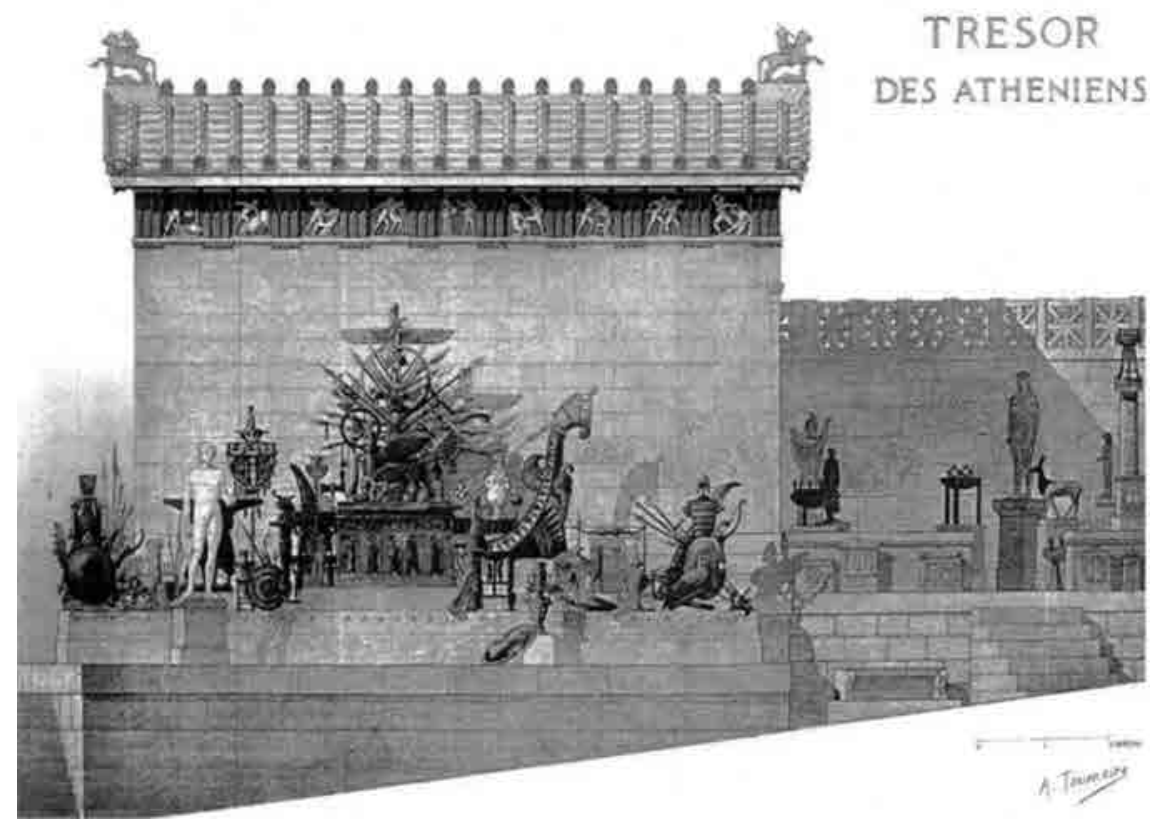

FIG 2.1 Reconstruction of the Athenian Treasury by A. Tournaire (1902)

The Athenian chorus' reaction to the sculptural decoration of the temple of Apollo in the Ion complements the picture by showing individual viewers' responses to specific representations. The fact that the chorus describes scenes that decorated the west pediment, which they could not have seen from the East side where they stood, has been pointed out and variously explained. ${ }^{9}$ Whatever explanation one gives, however, the members of the chorus are represented as engaged viewers. One viewer's response is of particular interest for our discussion (190-200):

$190-i \delta 0^{\prime}, \tau \hat{\alpha} \mathrm{l} \delta^{\prime} \ddot{\alpha} \theta p \eta \sigma o v^{\circ}$

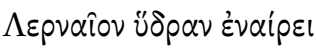

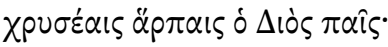

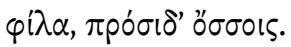

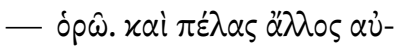

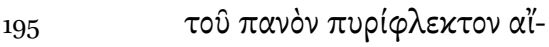

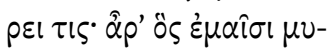

$\theta \varepsilon \dot{\varepsilon} \varepsilon \alpha \mathrm{l} \pi \alpha \rho \dot{\alpha} \pi \dot{\eta} v \alpha l \varsigma$,

9 See Zeitlin (1994) 151 and Athanassaki (2010) with the references in n. 5 . 


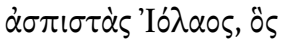

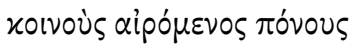 \\ 200

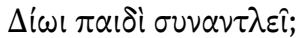

Look, look at this: Zeus' son is killing the Lernaean Hydra with a golden sickle, look there my dear. Yes - and near him another is raising on high a flaming torch. Can it be he whose story I hear as I sit at my weaving, Iolaus the shield-bearer companion of Heracles, whom he helped to endure his labors?

Stories told or sung during weaving time enable this particular viewer to venture an identification of the sculpted figure as Iolaus. The speaker does not make clear whether the story of Iolaus was simply a pastime narrative or also a theme she had woven..$^{10}$ In the latter case the tentative identification implies certain differences between the sculptural representation and her own woven version. But in either case, it is clear that the sight of the sculptural representation activates an association process whereby the viewer correlates visual and verbal variations on the same theme.

Bacchylides' mention of the effect of Hieron's golden tripods, the messenger's report in the Andromache and the chorus' vivid response to individual sculptural representations in the Ion illustrate different aspects of the viewers' intense engagement with the sights of the Apollo sanctuary. ${ }^{11}$ These are not the only overt references to the sculptural decorations and dedications at Delphi. Pindar's imaginative reconstruction of the mythical temple of Apollo featuring

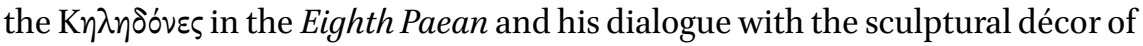
the east pediment of the temple of Apollo in the Seventh Pythian show similar engagement on the part of the viewer. ${ }^{12}$ But there are also veiled references to the sculptural themes of the Delphic temple and its treasuries. I have discussed elsewhere Pindar's variations on the sculptural theme of the Siphnian Treasury in the Sixth Pythian, the Second Olympian and the Second Isthmian. ${ }^{13}$ The Pythia's allusion to the representations of the east pediment of Apollo's temple in Aeschylus' Eumenides is yet another example of the fascination that the

\footnotetext{
$10 \quad$ For the ambiguity see Lee (1997) 180.

11 For the theoria in the Ion and the Andromache see also Rutherford (1998). On theoria in general see now Rutherford (2013).

12 For Pindar's imaginative reconstruction of the mythical temple see Marconi (2009) and Power (2011); for Pindar as a viewer of the Alcmaeonid temple see Athanassaki (2011).

13 Athanassaki (2009) 132-146, 32-37 and Athanassaki (2012).
} 
Apolline sanctuary exercised on its visitors and on the range of their engagement with its architectural sculptures. ${ }^{14}$

It goes without saying that fifth-century poets did not and need not expect every single member in their audience to be as fascinated by the sights of the temple as Neoptolemus or as excited and observant as Creusa's servants. But they could count on the fact that architectural sculpture of the Delphic sanctuary or any other Panhellenic center was a fixed and common point of reference. In Pindar's famous evaluation, song was superior to monuments and statues because, unlike sculpture, it could travel everywhere and could not be destroyed by the natural elements. ${ }^{15}$ Poets may have thought their art superior to architectural sculpture, but they engaged in dialogue with it. Its fixity may have been a disadvantage in comparison to song, but as common points of reference fixity and conspicuousness had a clear advantage over less stable, conspicuous and enduring visual representations such as those on everyday ceramic vessels.

\subsection{Theseus' Deeds: Viewing and Listening in Delphi and Athens}

The date of the monument and the date of the dithyramb have been debated, but both the high and the low dates proposed for each one do not affect their temporal relation. The monument antedates the dithyramb. The archaic style of the metopes of the south side has led a number of scholars to date the monument no later than the first decade of the fifth century, but Pausanias tells us that the Athenians built their Treasury in Delphi after the battle of Marathon from the spoils they took from the Persian army (10.11.5). The post-490 date has long been defended by the French excavators and recent finds seem to corroborate it. ${ }^{16}$ In this case the archaic style of the sculptures is explained as the old-fashioned work of a sculptor (or sculptors) of the previous generation. ${ }^{17}$ As has already been mentioned, the date of the Bacchylidean composition is unknown. Most scholars date it to the mid- or late $470 \mathrm{os}$, but a date as late as 458 has also been proposed. ${ }^{18}$ The high date brings the dithyrambic performance

\footnotetext{
14 Plassart (1940); Athanassaki (2011) 249-252 with references.

15 For the mobility of song vs. the immobility of statues see Nem. 5.1-5 and Isthm. 2.43-46; for its greater endurance see Pyth. 6.1-17.

16 See Amandry (1998), Neer (2002) and Neer (2004). For new arguments in favor of the earlier date see now Von den Hoff (2009) and (2010).

17 See Maaß (1993) 174.

18 Post-459: Merkelbach (1973); 458 at the Panathenaea: Maehler (2004) 189-191; see also the discussion in Section 2.
} 
in Athens closer in time to the completion of the monument in Delphi, the low date brings it closer to the inception of the Hephaisteion which, like the Athenian Treasury, was also decorated with metopes representing the deeds of Theseus and Heracles. ${ }^{19}$

Song and monument tell the same story from a different perspective. To start with the monument, eight of the nine metopes of the south side of the Athenian Treasury each illustrate one famous deed in Theseus' impressive curriculum, whereas one depicts Athena welcoming him. ${ }^{20}$ According to the widely accepted reconstruction of Pierre de la Coste-Messelière the sequence from West to East is: (1) Theseus and Sinis; (2) Theseus and Procrustes or Sciron (figs 2.2 and 2.5); (3) Theseus and Cercyon (figs 2.3 and 2.5); (4) Theseus and Sciron or Procrustes; (5) Athena and Theseus (figs 2.4 and 2.5); (6) Pallas; (7) Theseus and the bull of Marathon; (8) Theseus and Minotaur; (9) Theseus and Antiope (figs 2.1 and 2.6). ${ }^{21}$

The metope featuring Theseus with Athena, which according to the reconstructed sequence separates the deeds before his arrival to Athens from his later deeds, is the only moment of relief for the young hero, the only representation that does not show him engaging with an opponent. The scene has been interpreted as Theseus' arrival in Athens and, as Jenifer Neils suggests, it forms the climax of his deeds on his way from Troezen:

19 For the Hephaisteion see below, Section 2.

20 This representation is unique in contemporary art. Elsewhere Athena is included in scenes depicting Theseus' engagement with opponents, but only here does she appear alone with Theseus. As a rule Athena appears alone only with Heracles. See Brommer (1982) 69, who suggests Theseus' status is thus elevated to that of Heracles. Morris (1992) 343 observes: 'On the Athenian treasury she represents the blessings of the city of Athens, duplicated below the building where she appears in the line-up of gods and heroes dedicated after Marathon'.

21 La Coste-Messelière (1957) 37-81. Brommer (1982) 69 proposes a slightly different order: (1) Sinis; (2) Sciron; (3) Cercyon; (4) Procrustes; (5) Athena and Theseus; (6) the Sow; (7) the Marathon Bull; (8) Minotaur; (9) Antiope; cf. Von den Hoff (2009) 99-100 and Von den Hoff (2010) 167-170, who argues in favor of Periphetes in metope 4. In the current display of the metopes at the Delphi Museum (figures 5 and 6) only the best-preserved are displayed; for the various practical considerations that led to this particular display see Colonia (2003). 


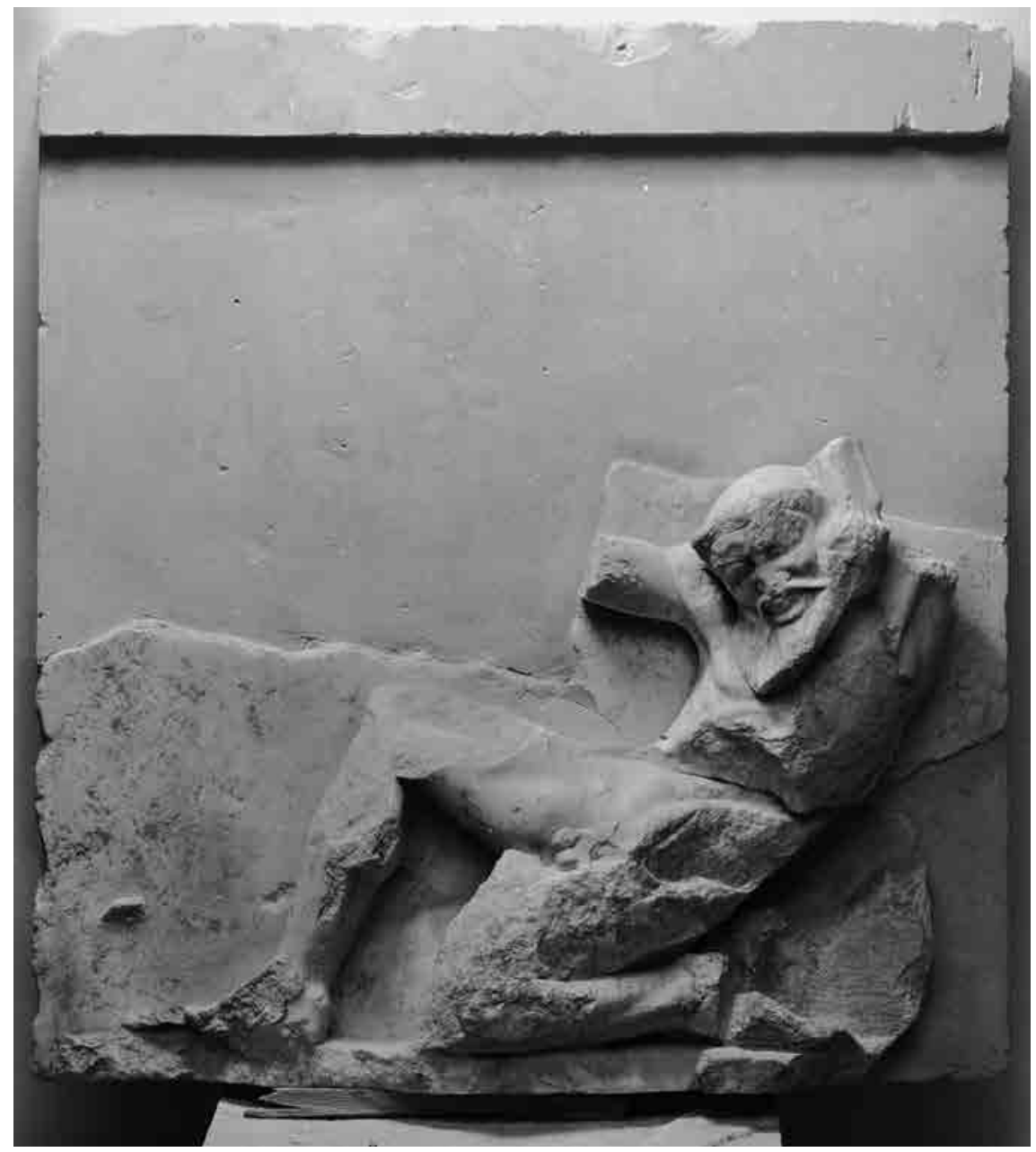

FIG. 2.2 Theseus and Procrustes or Sciron. Metope from the Athenian Treasury at Delphi, South Side, Archaeological Museum of Delphi. PHOTO 22364: ÉCOLE FRANÇAISE D'ATHÈNES/ G. DE MIRÉ 


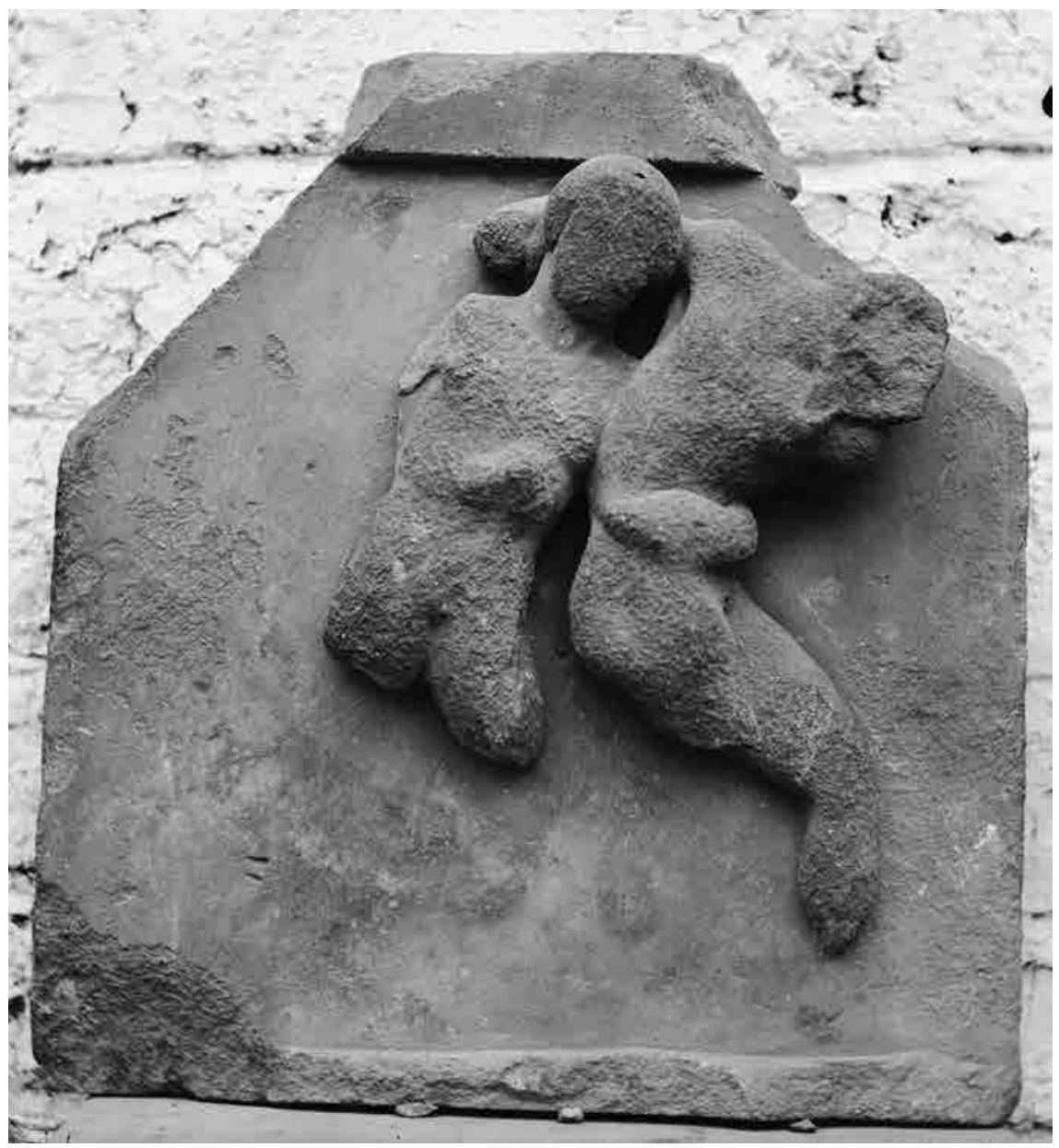

FIG. 2.3 Theseus and Cercyon. Metope from the Athenian Treasury at Delphi, South Side, Archaeological Museum of Delphi.

PHOTO CO92: ÉCOLE FRANÇAISE D'ATHÈNES 


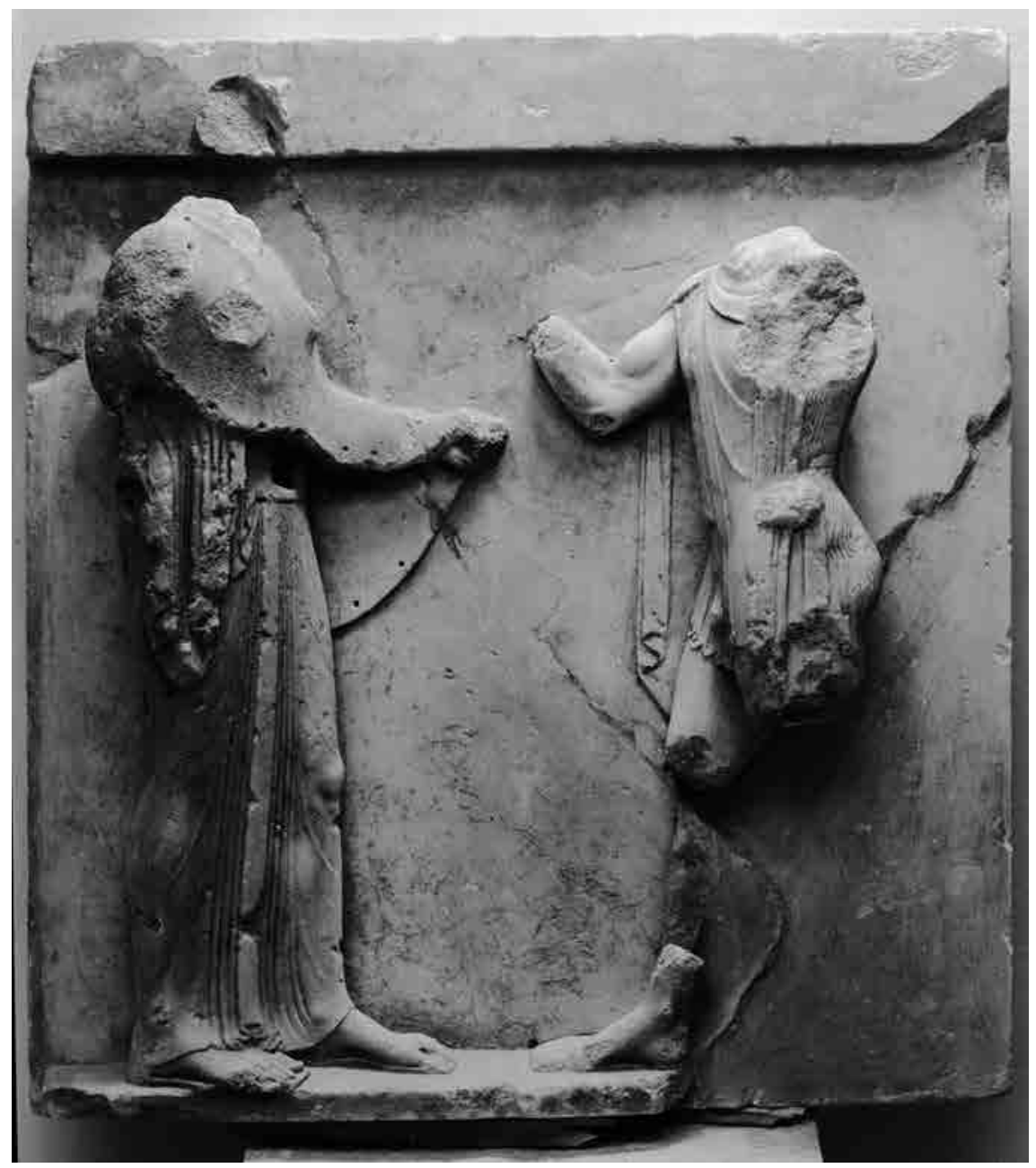

FIG. 2.4 Athena and Theseus. Metope from the Athenian Treasury at Delphi. South Side, Archaeological Museum of Delphi. PHOTO 22356: ÉCOLE FRANÇAISE D'ATHÈNES/ G. DE MIRÉ 


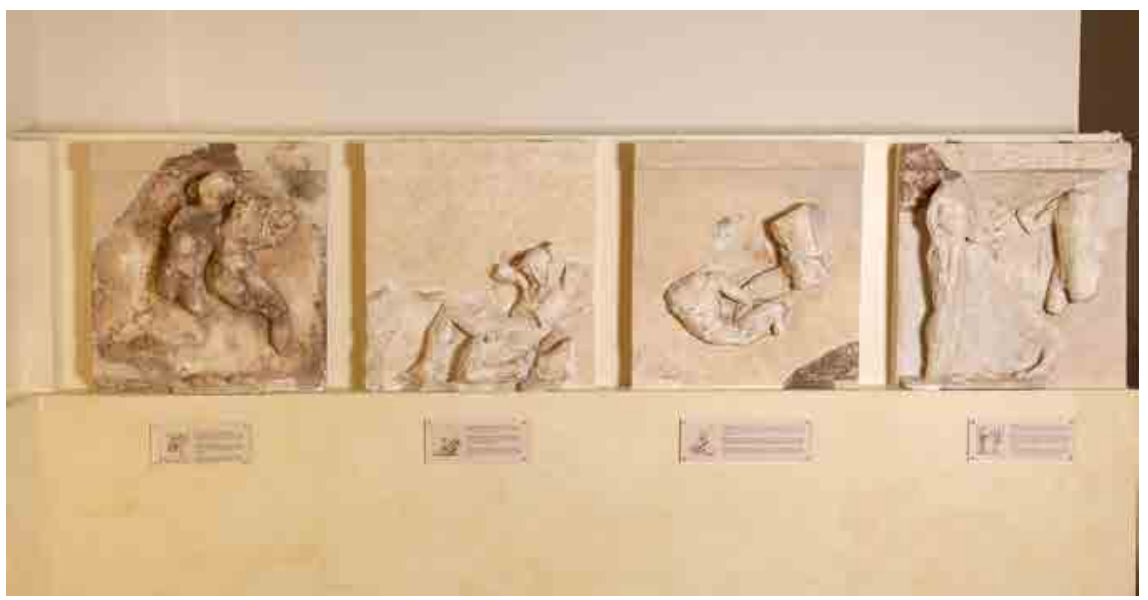

FIG. 2.5 Display of the Metopes in the Delphi Archaeological Museum PHOTO: AUTHOR's ARCHIVE

The series culminates as it does in Bacchylides' ode in the triumphant arrival of the hero into Athens, and this is precisely the subject of the fifth and central metope (...) Dubbed a 'sacra conversazione', the scene shows the goddess Athena standing immobile at the left confronting a youth who is arriving from the right. He is wearing a short chiton, traveling cloak and sandals, and rests his left hand on his hip. (...) Athena, whose Attic helmet overlaps the metope border, is no doubt holding her spear and making a welcoming gesture. ${ }^{22}$

Theseus' imminent arrival at Athens is the moment that Bacchylides chose to dramatize. Unlike the sculptor, however, who depicted the hero's meeting with the omniscient goddess, Bacchylides opted for the limited human perspective of king Aegeus and a group of young Athenians:
$\mathrm{A}^{\prime}\langle\mathrm{XOPO} \Sigma\rangle$

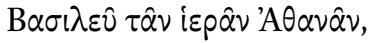

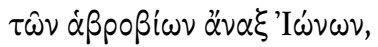

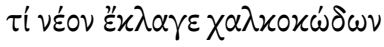 $\sigma \dot{\alpha} \lambda \pi \nu \xi \xi \pi \lambda \varepsilon \mu \eta \ddot{\alpha} \alpha \nu \dot{\alpha} \circ \delta \delta \dot{\alpha} \nu ;$

22 Neils (1987) 49. Cf. Von den Hoff (2009) 100, who argues that Athena held the helmet in her right hand. 


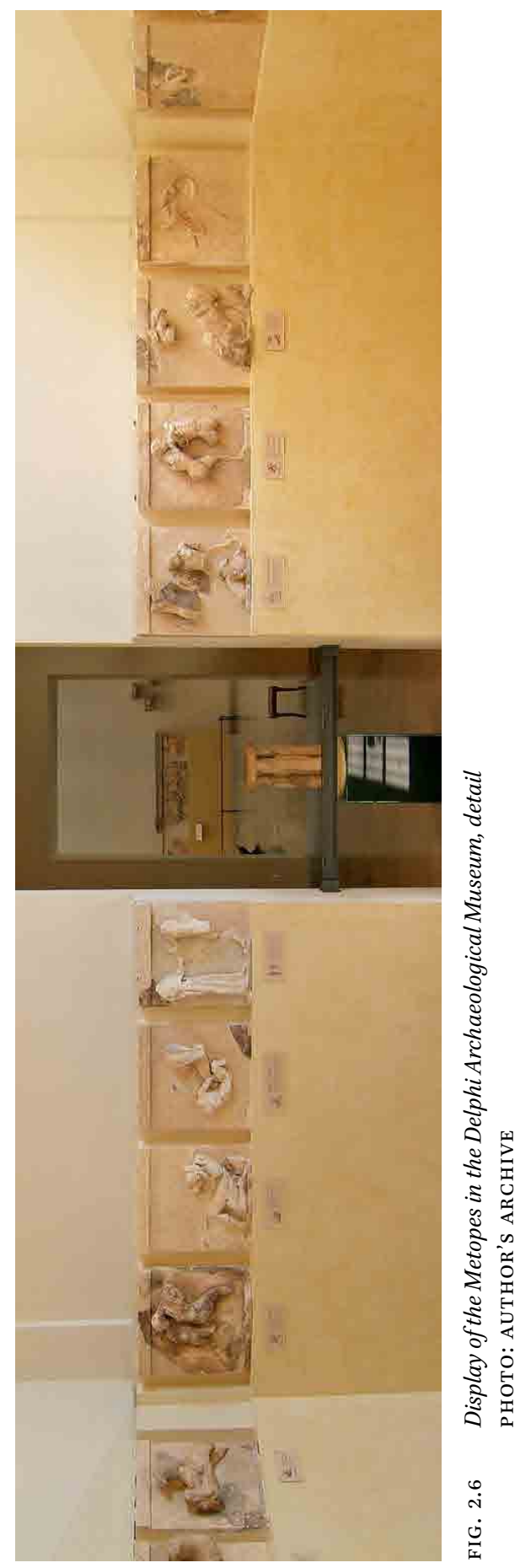


$5 \quad \hat{\eta} \tau ı \varsigma \dot{\alpha} \mu \varepsilon \tau \varepsilon \dot{\rho} \rho \varsigma \chi$ Өovò

$\delta v \sigma \mu \varepsilon v \eta \dot{s}$ öpl' $\alpha \mu \varphi$ i $\beta \alpha \lambda \lambda \varepsilon l$

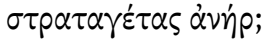

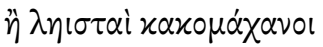

$\pi 01 \mu \varepsilon^{\prime} \nu \omega \nu \alpha \dot{\alpha} x \alpha \tau \iota \mu \eta^{\prime} \lambda \omega \nu$

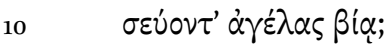

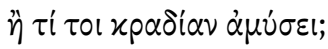

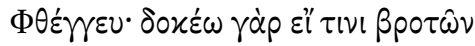

$\alpha \lambda x i \mu \omega \nu$ ह่ $\pi$ เxoupi $\alpha \nu$

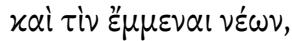

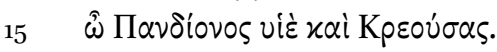

$\mathrm{B}^{\prime}\langle$ AIГEY $\Sigma\rangle$

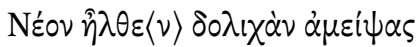

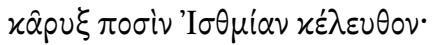

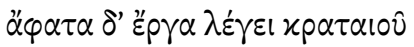

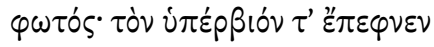

$20 \quad \sum i v i v$, ös i

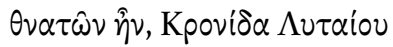

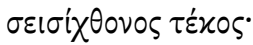

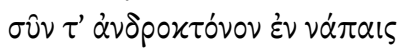

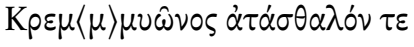

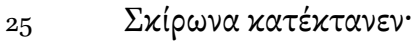

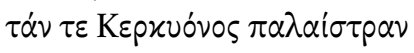

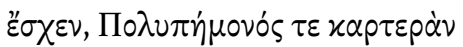

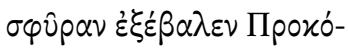

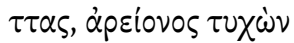

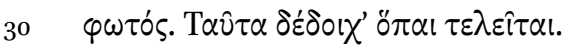

$\left.\Gamma^{\prime}\langle\mathrm{XOPO}\rangle\right\rangle$

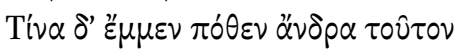

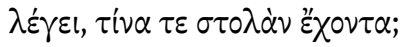

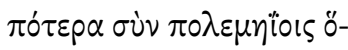

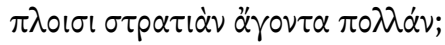

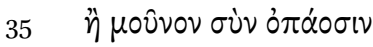

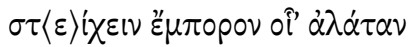

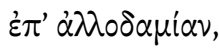

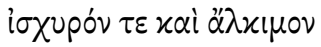

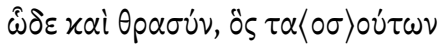

$40 \quad \alpha$ ¿ 
[Chorus:]

Who does he say that this man is? From where? How equipped? Does he bring a large force armed for war or travel alone with his attendants like a wanderer journeying to foreign parts, so strong, valiant and bold that he has overcome the powerful might of such great men? Truly a god must be driving him on to contrive just punishments for the unjust; for it is not easy to perform deed after deed without meeting disaster. All things come to an end in the long course of time.

\section{[Aegeus:]}

He says that only two men accompany him; he has a sword with ivory hilt slung from his bright shoulders; two polished spears in his hands, a wellmade Laconian cap about his fire-red hair, a purple tunic over his chest and a wooly Thessalian cloak; from his eyes flashes red Lemnian flame; he is a youth in his earliest manhood, and his thoughts are of the pastimes of Ares, war and the clashing bronze of battle; and he seeks splendour-loving Athens.

The most significant difference between the sculptural and the poetic narrative lies in the different perspective which the poet adopts. Unlike the sculptor who foregrounds the omniscient perspective of Athena, Bacchylides opts for the limited perspective of Aegeus and the Athenian youths who, unlike the welcoming goddess, experience fear and hope. The differences resulting from the different perspective of the dithyramb and the sculptures notwithstanding, sculptor and poet tell a strikingly similar story in terms of content and narrative manner. ${ }^{23}$ With the exception of the episode of Theseus' encounter with the sow of Crommyon, which the sculptor probably did not include in the sequence, Theseus' encounters with Sinis, Sciron, Cercyon and Procrustes are verbal and visual miniatures in paratactic sequence. ${ }^{24}$ The limited perspective that the Athenian king and youths adopt excludes the narration of Theseus' deeds after his arrival in Athens, but the chorus clearly alludes to them in

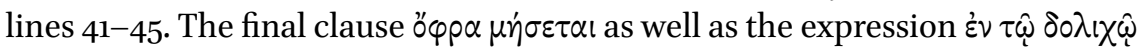
$\chi p o ́ v \omega \tau \tau \varepsilon \lambda \varepsilon i \tau \alpha l$ add a future dimension to the series of the wondrous deeds of the unknown hero, thus alluding to his future feats.

23 For Bacchylides' narrative art in general see Rengakos (2000).

24 Cf. Von den Hoff (2009) 100 with n. 41, who, like others, entertains the possibility of a metope representating the slaying of the sow of Crommyon. 
If the metope depicting Theseus' reception by Athena was originally placed in the middle of the sequence, the dialogue between song and monument is indeed most powerful. Just as in the sculptural representation, so too in the poetic version Theseus' arrival in Athens serves as the central scene from which one can look back or forward. Through the king's revelation of the messenger's report Bacchylides' audience is invited to look back. Through the young Athenians' hypothesis concerning the divine sanction of Theseus' initiatives, they are encouraged to think of those that will follow. The chorus does not know the identity of the deity that drives Theseus to punish the unjust, but as is obvious from ode 17.7 , Bacchylides, like the sculptor, is thinking of Athena.

But even if the metope was placed elsewhere in the original sequence points of contact between poem and monument would still exist, for, as Robin Osborne observes, the metopes encourage the viewer to look at them both individually and as a sequence:

Metopes are different. They are the most ambiguous of all the sculpted surfaces of a building, for they exist both individually and as a sequence. They are heavily framed by triglyphs, whose insistent vertical lines resist the motion of the eye laterally, yet their size is such that the viewers on the ground will always have more than one metope in their field of vision, always be conscious that the one metope on which they are focusing is but part of a set and requires to be compared and contrasted with its neighbours. That process of comparison establishes the expectation of links, of continuities: viewers expect to find that what is shown in one metope is, in one way or another, comparable with what is shown in the next. $^{25}$

The metope depicting Theseus' reception by Athena is a thematic variation in a sequence of eight scenes that show the hero overcoming an opponent. Osborne's observation concerning the effect of the typological repetition of the Parthenon metopes is applicable here as well:

One of the effects of having a sequence of actions by the same hero, rather than a series of episodes in a single struggle, is that the nature of the comparability between the successive scenes is quite different. For the viewer taking these in as a group, typological repetition is stressed 
much more heavily than contrast, and interest centres on the varied challenges posed to the hero. ${ }^{26}$

The typological repetition is also evident in the verbal miniatures. In each case the poet uses a variant expression denoting either the amazing strength of Theseus' opponents or the nature of their crimes, thus emphasizing his superior strength and the range of his feats. The paratactic style of the account of Theseus' deeds evokes the similarly paratactic sculptural narrative and would therefore trigger the memory of those in the audience who had seen and admired the small metopes and invite them to correlate the poetic with the sculptural version. In view of the temporal and spatial focus of the Fourth Dithyramb, an overt reference to a fairly recent building would be an anachronism, but given the importance of the Treasury for the Athenians, it is a fair assumption that Bacchylides could reasonably expect some at least, if not most, in his audience to make the association.

Visual representations of Theseus' deeds were certainly not lacking in Athens, as is evident from a great number of vases that have survived and are dated to the last quarter of the sixth and first quarter of the fifth centuries. Some of these vases represent a selective cycle of Theseus' deeds and come from Attic workshops. What has survived is presumably a minimal fraction of what was on offer. As Robert Connor observes, 'the common utensils of the dining room and kitchen bore images of his great deeds'. ${ }^{27}$ Like the metopes of the Athenian Treasury and the dithyrambic narrative, vase representations are also paratactic miniatures. ${ }^{28}$ Yet there are reasons to think that the Athenian monument in Delphi was Bacchylides' main source of inspiration and point of reference.

The most important reason has already been mentioned. The Delphic monument was a fixed and common point of reference for the poet and his audience. Whereas it is virtually certain that Bacchylides, like his audience, was familiar with various versions of the cycle of Theseus' deeds on drinking cups, amphoras, etc., such household utensils could not form the basis of a shared visual experience that the poet could take for granted. Unlike the metopes, which were a fixed sight anyone would see any time they were on their way to the Treasury or to the Temple, pots had unpredictable ownership and circulation, not to mention of course their fragility.

26 Osborne (2000) 239-240.

27 Connor (1970) 143. For the ideology of vase representations of Theseus see Shapiro (1992) and Neer (2002) 154-168.

28 For the differences between monumental and vase representations see Von den Hoff (2010). 
But there are other considerations as well. Of the extant earlier and contemporary representations only the metopes of the Athenian Treasury and the Bacchylidean dithyramb feature a sequence of deeds before and after Theseus' arrival in Athens. Bacchylides' choice to dramatize Theseus' arrival from the limited human perspective precluded of course the narration of the hero's future deeds, but, as has already been mentioned, the chorus' gnomic statement invites the audience to think of the feats that lie in store. This is not to deny, of course, that there may have been pots depicting this sequence which may have inspired the poet and/or triggered his audience's associations. Such representations, however, if they existed, could not outweigh the advantages of the Athenian Treasury as a fixed and common point of reference.

Vase representations depicting Theseus' arrival in Athens fall thematically into three categories: (a) a meeting of Theseus with Aegeus with no other figures involved; (b) a meeting of Theseus with Aegeus in the presence of other male and female figures; and (c) a meeting of Theseus with Athena either alone or with others. ${ }^{29}$ Comparison of the Bacchylidean dithyramb with all representations of Theseus' arrival in Athens falls outside the scope of this paper, but I wish to draw attention to an important difference in the representation of the human perspective by the poet and the vase painters respectively. Unlike Bacchylides, the vase painters opt on the whole for the moment of recognition and joyous reception. For instance, an amphora at the Fitzwilliam Museum in Cambridge (37.21) shows a draped man and a woman holding a phiale greeting Theseus, while a draped youth stands behind Theseus. ${ }^{30}$

The closest parallel is offered by a skyphos at the Louvre (G. 195), attributed to the Brygos painter. ${ }^{31}$ It is a cycle cup that has been interpreted by David Francis as an illustration of the very occasion for which Bacchylides composed his dithyramb. ${ }^{32}$ On the one side of the skyphos we see Theseus shaking hands with Aegeus and two women. One woman is about to crown the hero, the other holds a phiale. On the other side, which is badly preserved, art critics have identified three of Theseus' deeds on his way to Athens, namely Sinis, the Sow with Phaea, and Cercyon. Thematically the skyphos is closely related to the dithyramb and

29 LIMC s.vv. Aigeus D (Aigeus bei der Begrüßung des Theseus) and Theseus v (Theseus in Athens): A (Arrival and reception by king Aigeus).

$30 \quad A R V^{2} 580.2$, LIMC s.v. Theseus 157 with photograph.

$31 \quad A R V^{2} 381.174$, LIMC Aigeus 27, Theseus 156; see also Strawczynski (2003).

32 Francis (1990) 58. According to Francis the occasion for which Bacchylides composed this dithyramb was the Return of the bones of Theseus, or alternatively the dithyramb commemorated this event. 
Francis may be right in associating it with the occasion of the Bacchylidean performance. Yet the important difference is that the Brygos painter opted for the moment of recognition. This is the characteristic that the Brygos cup shares with other visual representations of the human reception of Theseus in Athens. The vase painters depict the welcome reception of the hero in Athens showing Aegeus shaking hands with Theseus and women crowning or embracing him. Thus, like Bacchylides, these representations foreground the human perspective on Theseus' arrival, but unlike him they do not problematize it. ${ }^{33}$

By foregrounding limited human knowledge and by dramatizing the moment before the recognition and joyful reception, the Bacchylidean dithyramb offers a different perspective by posing a different question: how would the Athenians feel if they knew only of Theseus' formidable power but not of his identity and intentions? The enriching experience that the dithyrambic songdance offers to viewers of artifacts of all forms is precisely the problematization of the cheerful and insouciant reception of the young hero that the sculptor of the Athenian Treasury and the vase-painters depict. This is a song-dance composed under the influence of the 'tragic Muse.. ${ }^{34}$

We do not know if the whole chorus impersonated in turn Aegeus and the Athenian youths, or if they conversed with one choreut who played the role of the king, or if two semi-choruses sang and danced the two parts. ${ }^{35}$ Whatever the mode of performance was, this miniature drama offered its audience dialogue, an embedded messenger-speech, re-enactment of ignorance, fear and hope,

33 Very interesting, but disputed, is the scene of the beautiful red-figure kylix of the Briseis painter in the Metropolitan Museum of Art (53.11.4, ARV 206.7, LIMC Theseus 219, 309). Heide Froning, followed by Jenifer Neils, ascribe the reception of Theseus by Athena and his crowning by Athenian women to his arrival in Athens from Troezen (Froning [1971] 4649, Neils [1987] 96-98) whereas others opt for his victorious return from Crete. See also Francis (1990) 6o, who interprets the scene as Theseus' departure for Crete with the twice seven and associates the cup with Bacchylides 17. In a recent article, Claude Calame opts for Athens and interprets the three related scenes on the sides and the tondo as the double legitimization of Theseus: a terrestrial legitimization by Athena which happens right after his arrival from Troezen and a maritime legitimization by Poseidon and Amphitrite on his way to Crete (Calame [2009a]). If the cup illustrates Theseus' initial arrival in Athens, it is an interesting thematic expansion of the sculptural theme. The young hero is received not only by the omniscient goddess, but also by a group of mortal Athenian women who already know who he is and therefore, unlike the dithyrambic chorus, do not experience fear and anxiety at the prospect of his arrival.

For the modes of performance see Zimmermann (1989) 96 with references in n. 5 . 
and irony. ${ }^{36}$ But unlike in tragic theatre, the audience did not experience either pity or fear but relief, because unlike their mythical ancestors, they knew that Theseus would save them from many more criminals.

\section{The Fourth Dithyramb in Context: The Athenian Political and Cultural Scene}

Like the date, the occasion of composition and performance are not known. The high date, i.e. mid- or late 470 , places the performance at the time of Cimon's rising political power and military successes, whereas the low date 458 , tentatively proposed by some scholars, places the performance at the period after Cimon's ostracism. ${ }^{37}$ The dramatic form of this unique song-dance has led some scholars to the hypothesis of composition for performance at the Great Dionysia, whereas the prominent role of the Athenian youths has suggested to others a festival associated with ephebes, such as the Great Panathenaea, the Hephaesteia or the Theseia. ${ }^{38}$

The political aim of the composition has also been given various interpretations. In an ingenious if controversial article John Barron has argued that the diction of odes 17 and 18 is carefully chosen so as to invest Theseus with the characteristics of Cimon and thus highlight the similarities between the hero and the statesman who brought back Theseus' bones to Athens. According to Barron, Theseus' Laconian helmet and his Thessalian woolly cloak (oن̉ $\lambda$ ı० $\Theta \varepsilon \sigma-$ $\left.\sigma \alpha \lambda \dot{\alpha} \nu \chi \lambda \alpha \mu u^{\prime} \delta^{\prime} 53-54\right)$ echo the names of Cimon's sons Lacedaemonius, Ulius and Thessalus, the Lemnian fire in his eyes alludes to the annexation of Lemnos to Athens by Miltiades, whereas the hero's red hair may point to Cimon's Thracian origin through his mother Hegesipyle. ${ }^{39}$ Bernhard Zimmermann, who saw the ode as an encomium of Athenian power and splendor sung for the Atheni-

36 Burnett (1985) 117-123; Zimmermann (1989) 95-100.

37 According to Plutarch (Pericles 10) Cimon was recalled to Athens in 457 in acknowledgement of his good services during the Athenians' negotiations with the Spartans after the battle of Tanagra. Plutarch's testimony has met with scepticism, because Cimon did not hold any public office in Athens until the expiration of his ten-year term in 451. In an effort to make sense out of conflicting evidence, Ernst Badian, who, like others, expressed scepticism about Plutarch's testimony, raised the possibility of Cimon's recall under the condition not to stand for any public office until 451: Badian (1992) 17-19, 101-103. See also Stadter (1989) 124-125 with further references; and below p. 38 with n. 42.

38 For the various proposals see Zimmermann (1989) 99 with references.

39 Barron (1980) $1-2$. 
ans and their allies at one of the great festivals, probably the Panathenaea, felt that Barron went a little too far. ${ }^{40}$ On the contrary, Maehler conceded that the choice of Theseus' attributes may have been 'a string of strange coincidences', but entertained the idea that they may not have been. Building on Merkelbach's and Barron's insights Maehler put forward the hypothesis that the ode celebrated the victory of Athenian youths and veterans over the Corinthians at Geraneia under the command of Myronides and was performed at the Panathenaea of 458. On this view, Cimon's three sons were among the youths of Myronides' force. ${ }^{41}$

Bacchylides' evocation of the metopes of the Athenian Treasury tells us nothing about the date of performance. In the 470 s or 460 s Bacchylides may have been inspired by Cimon's impressive architectural program, in the early 450 s he may have wished to remind his audience of a monument associated with the victory at Marathon and therefore with the Philaids and create a favorable climate for Cimon's recall to Athens. ${ }^{42}$ Although neither alternative can be excluded, the evocation of the Athenian Treasury is more meaningful in the 470 s or the 460 s, when the figure of Theseus was an endless source of artistic inspiration in Athens. But regardless of the date of composition, as long as Cimon was alive his association with Theseus on the part of Bacchylides' audience seems to me inescapable, even if the echoes that Barron identified are due to a strange coincidence.

There are certainly more links between Cimon's effort to associate himself with Theseus and Bacchylides' 'Theseus' dithyrambs. Thanks to Pausanias we

\footnotetext{
$40 \quad$ Zimmermann (1989) 99 n. 27.

41 Maehler (2004) 189-191.

42 Since ostracism was an ad hominem penalty it would not affect Cimon's sons. The low date for the composition is therefore not impossible. But a 'Theseus' ode honoring Cimon's sons through the evocation of Theseus could not but honor Cimon himself and therefore create a favorable climate that would facilitate his recall. Cole (1977) has argued for a political message in the reconciliation of Orestes with the Erinyes in the Eumenides, performed in 458 , i.e. the wished-for reconciliation of Pericles with Cimon. If the Fourth Dithyramb was composed in the same year with a similar purpose, who would be the choregos? I am tempted to think of Cimon's brother-in-law Callias (II), who had good relations with Pericles during Cimon's ostracism and after his death; for Callias' relations with Pericles see Davies (1971) 258-261 and Badian (1992) 17-26. For the recall of Cimon see Stadter (1989) 124-125 with bibliographical references. In what follows I argue for an earlier date and a broader political statement and therefore against a very specific political agenda, but since a song about Theseus' arrival could certainly acquire a new meaning and purpose after Cimon's ostracism, I cannot resist the temptation to consider it an ideal song for the symposia of his friends and relatives.
} 
know that there was some thematic overlap between the mythical narrative of the Third Dithyramb (ode 17) and Micon's painting representing an episode of Theseus' voyage to Crete on one of the walls of the Theseion which was erected to house the hero's bones. Pausanias' account leaves unclear which episode Micon chose to paint. ${ }^{43}$ Thus the thematic overlap between song and painting cannot be precisely established. The temporal relation of the Bacchylidean composition and Micon's painting is also unknown. With regard to their relationship, there are three scenarios: (a) if song and painting are roughly contemporaneous, it is possible that Bacchylides had already seen the painting, in which case we have another instance of the poet drawing his inspiration from a civic monument; alternatively, he might have heard of it when he composed his song for the performance of the Ceian chorus on Delos; (b) if the painting was not yet realized, he may have heard of the theme that Cimon and the painters planned either through his own or Simonides' connexions in Athens; (c) if, finally, poet and painter worked in ignorance of each other's work and plans, it must be yet another coincidence. Even in this case, however, it is certain that they both chose a topic that was popular at the time both in Cimon's inner circle and in Athens at large.

We may now turn to the significance of the evocation of the sculptural theme of the Athenian Treasury in Cimonian Athens. ${ }^{44}$ The Athenian Treasury, built or at least lavishly decorated with the spoils that the Athenian took from the Persians, was closely associated with victory at Marathon and with its architect, Miltiades. Theseus was also associated with the battle of Marathon, for as Plutarch reports he appeared at Marathon and led the Athenians against the

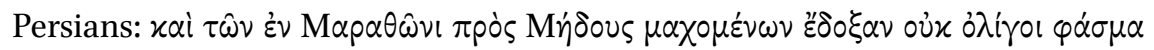

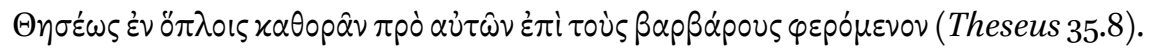
The legend was popular in Cimonian Athens and was commemorated in the Stoa Poikile:

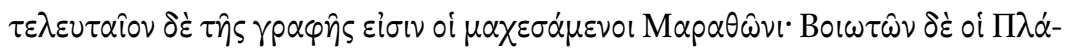

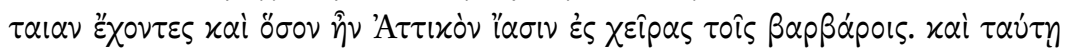

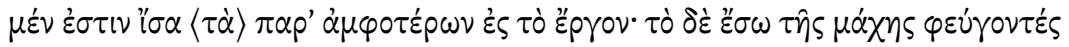

43 Pausanias reconstructs the scene on the basis of his own knowledge of the story, because time had worn the painting and Micon did not paint the whole story ( $\tau 0 \hat{v} \delta \dot{\varepsilon} \tau p i \tau o v \tau \hat{\omega} \nu$

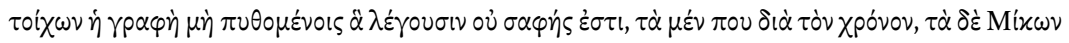

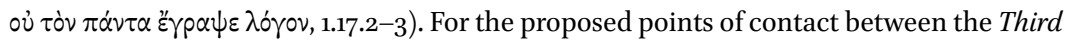
Dithyramb and Micon's painting see Athanassaki (2009) 301-304 with references.

44 For the ambitious architectural program in Cimonian Athens see Francis (1990) 43-90; Castriota (1992) 33-133. 


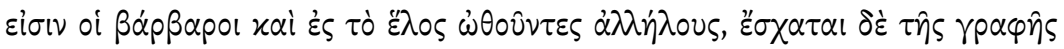

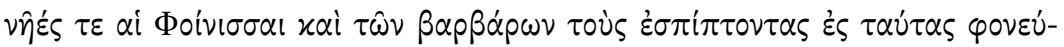

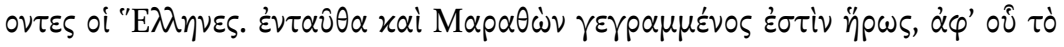

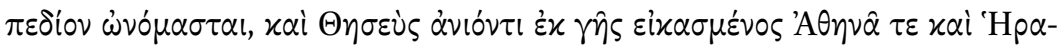

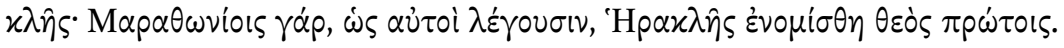

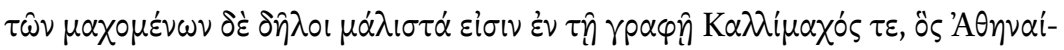

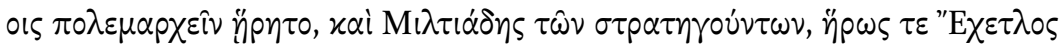

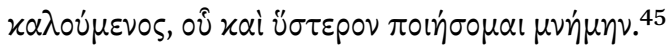

PAUSANIAS 1. $15 \cdot 3$

At the end of the painting are those who fought at Marathon; the Boeotians of Plataea and the Attic contingent are coming to blows with the foreigners. In this place neither side has the better, but the center of the fighting shows the foreigners in flight and pushing one another into the morass, while at the end of the painting are the Phoenician ships, and the Greeks killing the foreigners who are scrambling into them. Here is also a portrait of the hero Marathon, after whom the plain is named, of Theseus represented as coming up from the underworld, of Athena and of Heracles. The Marathonians, according to their own account, were the first to regard Heracles as a god. Of the fighters the most conspicuous figures in the painting are Callimachus, who had been elected commander-inchief by the Athenians, Miltiades, one of the generals, and a hero called Echetlus, of whom I shall make mention later.

The erection of the Stoa, which was funded by Peisianax, probably Cimon's brother-in-law, is dated to $475^{-45^{\circ}}$ on the basis of the pottery found at the foundation of the building. ${ }^{46}$ Once again, there is no way to establish the relation of the Bacchylidean composition with the painting. Yet the decorative program of the Stoa, like that of the Theseion, shows the Athenian interest in the monumental commemoration of Theseus' deeds and explains, in my view, why Bacchylides chose to evoke the sculptural theme and style of the faraway monument in Delphi and thus bring it to life through the chorus who sang and danced his dithyramb in Athens. ${ }^{47}$

Before turning to Bacchylides' creative dialogue with drama, it is worth bringing into the picture the similar sculptural theme and style of yet another

\footnotetext{
45 The text and translation are Spiro (1903) and Jones and Ormerod (1918).

$46 \quad$ Camp (1992) 66.

47 For the close relationship between mythical and historical past in the paintings of the Stoa Poikile see Castriota (1992) with references.
} 
Athenian building, the Hephaisteion, which is probably too late to account for Bacchylides' evocation of the Athenian Treasury, but illustrates the Athenians' admiration of and sustained interest in the Delphic monument. The metopes of the Hephaisteion evoke the metopes of the Athenian Treasury in terms of both theme and style. ${ }^{48}$ Theseus' encounter probably with Procrustes, Cercyon and the sow of Crommyon featured on the north side, Sinis, the Bull of Marathon and the Minotaur on the south side. Of course we do not know if Bacchylides knew of the intended decorative programme of the Hephaisteion. We do not know, either, if the Bacchylidean dithyramb was ever reperformed in Athens. If its premiere was successful, however, the sculptural décor of the Hephaisteion could in theory renew Athenian interest in it and enhance its chances of survival through reperformance. On the present state of the evidence, all we can say is that the Ceian poet will have been fully aware of Athenian predilection for visual representations of Theseus' deeds in Athens and Delphi. For this reason the evocation of the sculptures of the Athenian Treasury both in terms of theme and narrative style cannot but have been conscious.

The reinterpretation of the sculptural narrative in the dramatic idiom was clearly meant to heighten the popularity of the poet and his songs in a city where dramatic performances and monumental structures were at the heart of civic activity and religious life. As has already been mentioned, Cimon and his circle did not spare any effort to foreground the multiple ties of the Philaids with Theseus in Athenian art and cult. For this reason, the association of Theseus with Cimon on the part of Bacchylides' Athenian audience in the $470 \mathrm{~s}$ or the 460 os was inevitable, but it was not the only message of the dithyrambic performance.

In the Fourth Dithyramb Theseus mirrors Cimon, but I suggest that through the adoption of a dramatic, almost tragic, perspective Bacchylides formulated a far more interesting question that at once reflected contemporary politics and transcended them. Unlike sculptors and painters, Bacchylides brought out the uncertainties and the anxieties involved in the reception and accommodation of an outstanding individual in the polis. This was a question that had preoccupied Athenian politics ever since the implementation of ostracism and

48 Those who opt for inception around 460 date the metopes to the 450 ; see e.g. Neils (1987) 127 who thinks that its location in the Agora and subject matter are better suited to Cimon's than Pericles' interests. Others date the monument to 449; see e.g. Dinsmoor (1975) 179181; Boardman (1985) 146-148. For the influence of the Treasury on the Hephaisteion see e.g. Boardman (1985) 146-148, 170; Barringer (2008) 116-122 and Von den Hoff (2010), who offer comparative discussions of the metopes of the two monuments. 
which would occupy the tragic stage for many years to come. ${ }^{49}$ Sophocles, for instance, tackled the issue from different viewpoints several times in the Ajax, Trachiniae, Oedipus Rex and Oedipus Coloneus. Theseus, the archetypical Athenian statesman, could mirror more than one outstanding Athenian politician and we know that Cimon was certainly not the first Athenian leader who sought to appropriate Theseus' legacy. ${ }^{50}$ In this respect, Bacchylides' audience could associate Theseus with other prominent political figures of the present or the past. Through the dramatization of the Athenian people's ignorance and fear of the intentions of this outstanding individual Bacchylides thus made a much broader political statement. The Athenian choreuts reenacting their mythical king and ancestors legitimatized in effect the alarm and fear that citizens experience as a rule at the excessive power of individuals such as Theseus when they are either unaware or unsure of their motives and intentions. The audience's knowledge that there was no reason for fear in this case did not undermine the legitimacy of fear-it simply qualified it. The political message of the dithyramb is that people are justified in fearing immense power, but in the right hands such power can benefit the community.

As a statement on people's attitudes to outstanding individuals the Bacchylidean dithyramb offered a different perspective on the Athenians' fear and suspicion of excessive power. According to Aristotle, ostracism was first enacted because the people were suspicious that those in power might attempt to establish tyranny, as Peisistratus had done in the past. Thus in the first three years after the battle of Marathon they ostracized friends of the tyrants, but immediately afterwards they turned against anybody who was too powerful (Ath.Pol. 22. 3, 6):51

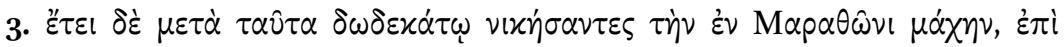

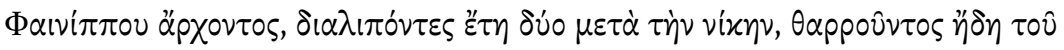

49 Recent discussion of ostracism in Forsdyke (2005) 144-177.

5o For Cleisthenes' attempt see Schefold (1946); Sourvinou-Inwood (1971) and SourvinouInwood (1979) with further documentation. See also Morris (1992) 338-341; Francis (1990) 65 , who does not deny the association of Cleisthenes with Theseus, but suggests that it 'can be most readily understood in the period immediately postdating Cimon's death, when new claims arise for the inheritance of Theseus' mantle and mythological revisionists once again set to work to rewrite history'. Shapiro (1989) 143-149 shifts the focus from the differences between the art of Cleisthenic and the Cimonian period to the similarities and argues that Theseus transcends the disputes of tyrants, oligarchs and democrats. In his view the essential difference lies in the growing interest in Theseus in Athens. Text and translation are those of Oppermann (1928) and Rackham (1952) respectively. 


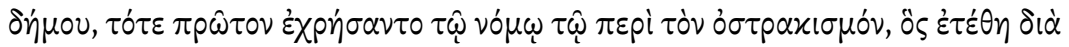

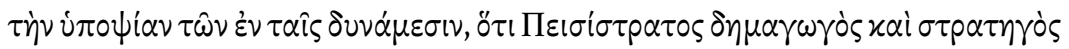

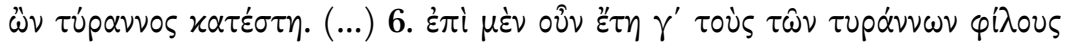

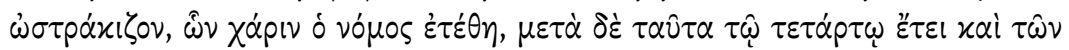

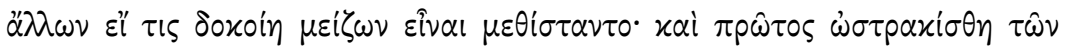

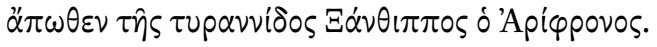

Eleven years afterwards came their victory in the battle of Marathon; and in the archonship of Phaenippus, two years after the victory, the people being now in high courage, they put in force for the first time the law about ostracism, which had been enacted owing to the suspicion felt against the men in the positions of power because Peisistratus when leader of the people and general set himself up as tyrant. (...) For three years they went on ostracizing the friends of the tyrants, at whom the legislation had been aimed, but afterwards in the fourth year it was also used to remove any other person who seemed to be too great; the first person unconnected with the tyranny to be ostracized was Xanthippus son of Ariphron.

The Bacchylidean dithyramb hit out against Athenian fear by shifting the perspective. It brought out the beneficial aspect of immense power, but significantly it did not overlook or discredit the suspicion and fear it could cause. By problematizing the representation of the welcoming reception of Theseus by sculptors and painters, Bacchylides projected contemporary issues to an idealized past, thus rendering it more complex than was hitherto represented. Seen from this new angle the past could serve in turn as a mirror of the present. Like those of contemporary leaders, Theseus' outstanding accomplishments could now be thought to have caused consternation too once upon a time, but with regard to Theseus the audience of the song-dance had the privilege of hindsight. To the extent that Theseus' attributes, deeds and reception mirrored the present, the audience was encouraged to draw analogies. Comparison of Theseus' portrayal in the song that Bacchylides composed for performance in Athens with Theseus' portrait in the Third Dithyramb, composed for the Panionian audience on Delos, to which we shall briefly turn, shows that the Fourth Dithyramb was playing to Athenian tastes, sensitivities and preoccupations.

In the Third Dithyramb Bacchylides also draws attention to the limited human perspective, but the chorus of the Ceians does not enact ignorance and fear. Minos clearly misjudges Theseus' leadership and resolution, his divine origin and Athena's favor, and sets a task for the Athenian hero that proves how 
wrong his judgment was. Like Minos, the young Ionians do not know that Theseus will accomplish the task that seems at first impossible. The Ceian choreuts, who adopt an omniscient point of view, sing of the fear which Theseus' companions experience and of the tears they shed once Theseus leaps into the sea. They also sing of their cries of joy and their paean song once he resurfaces. Unlike Aegeus and the Athenian youths, however, the sons and daughters of the Ionians are not unsure about Theseus' intentions, because in this songdance Bacchylides presents a moment after Theseus' recognition in Athens. What Theseus' companions do not know is the magnitude of his resolution and the divine favor he enjoys. Because they know his intentions, they do not fear his power, they only fear that it may not be sufficient. In this song Bacchylides chose to highlight people's anxiety and fear at the prospect of losing an outstanding leader and their joy and relief at seeing him coming back safe and triumphant. Obviously, the poet did not deem it proper to explore the dangerous side of immense power at a Panionian celebration in the first years of the Delian league. ${ }^{52} \mathrm{He}$ foregrounded its positive side and the strong emotional attachment of the Ionians to Theseus. In Athens, on the other hand, where he could take the Athenians' emotional attachment to Theseus for granted, he could afford an approach more in tune with Athenian politics, concerns and sensitivities.

\section{3}

\section{The Look of the Dithyrambic Song-Dance}

The similarity of the Fourth Dithyramb to tragedy was not only thematic but also visual and acoustic. Ignorance, hope and fear were enacted by choreuts in dialogical form. In terms of mimesis the affinities would have been greater if one choreut had enacted Aegeus and the rest the Athenian ephebes, but in any performance scenario the look of this song-dance was clearly dramatic.

I have argued that this melic drama offered a new, almost tragic, perspective on the sequence of the deeds of Theseus before and after his arrival in Athens as depicted on the metopes of the Athenian Treasury, which the choreuts brought to life through their song-dance. Bacchylides' familiarity with the temple of Apollo and the adjacent Athenian Treasury, the similarities of the visual and verbal representations in theme and narrative style, the advantages of the

$5^{2} \quad$ For the sociopolitical background of the ode see Severyns (1933) 56-59; Scodel (1984); Zimmermann (1989) 77-94; Francis (1990) 43-66; Käppel (1992) 178-189; van Overen (1999); Fearn (2007) 242; Calame (2009b); Tsagalis (2009). 
Delphic monument as a point of reference, the vested interest of the Athenians in their Treasury, and the ambitious architectural program in Athens after the Persian Wars all point to conscious evocation on the part of the poet who was a frequent visitor to Delphi and Athens. In view of the strong ties of Athens with Delphi Bacchylides could count on the familiarity of some at least in his audience with the sculptural décor of the Treasury. In the Seventh Pythian Pindar claims that in every city people talk about the Athenian restoration of the temple of Apollo. Even if we allow for encomiastic hyperbole, the assertion calls attention to what must have been a favorite pastime. Upon their return home, visitors to Panhellenic sanctuaries would describe the sights they had seen to their townsmen. ${ }^{53}$ Euripides' Ion sheds precious light on the keen interest of the theoroi in architectural sculpture. From the point of view of our discussion the identification of Iolaus by one choreut on the basis of stories she had heard at home is particularly interesting, for it shows the viewers' tendency to correlate stories they knew with visual representations and compare them, as is evident from this choreut's tentative identification of the sculpted figure.

It is therefore reasonable to assume that Bacchylides expected his audience to compare the dithyrambic version of Theseus' deeds with the sculptural version upon a future visit. If we use the chorus of the Ion as a paradigm, a viewer of the metopes who had also seen the dithyrambic performance in Athens would correlate and compare song and image and notice their main difference, namely the wholehearted reception of Theseus by Athena vs. the alarm and fear that his imminent arrival had caused Aegeus and the Athenians. I have suggested that the different perspective of the dithyrambic composition would enrich the experience of the viewer, who, like the poet, would be encouraged to ponder the complications of great power when human ignorance is factored into the picture of divine omniscience. Those who associated Theseus with Cimon would think that Athena's favor did not always guarantee smooth sailing. Such thoughts could come to one's mind both at the time of his rising power, for there were many such precedents in Athenian politics, and even more so at the time of his ostracism. Despite the inescapable association of Theseus with Cimon, however, Bacchylides' main focus was not on Cimon but on Theseus, the archetypical Athenian statesman. By projecting contemporary concerns onto the archetypical statesman, the poet had composed a song that offered the human perspective on the reception and integration of any outstanding individual in the past, the present, and the future. 
The viewer of the metopes focusing on the reception of Theseus by Athena was invited to look back at Theseus' feats on his way to Athens from Troezen and forward to what lay in store for the young hero. Like the sculptor, Bacchylides used Theseus' arrival in Athens as his focal point, thus enabling his audience to think that with Athena's favor Theseus had still many deeds to accomplish. For this reason, despite its dramatic look and tragic outlook, the Bacchylidean song-dance remained melic at its core.

\section{Works Cited}

Amandry, P. (1998). 'Notes de topographie et d'architecture delphiques. x. Le 'socle marathonien' et le trésor des Athéniens', $B C H$ 122: 75-90.

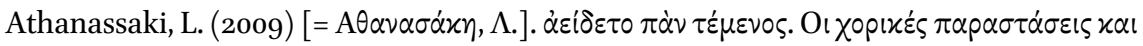

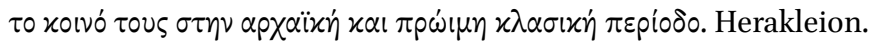

(2010). 'Performing myth through word, deed, and image: The Gigantomachy in Euripides' Ion', in A.M. Gonzalez de Tobia (ed.), Mito y Performance. De Grecia a la Modernidad. Quinto Coloquio Internacional. Acta. La Plata: 199-242.

- (2011). 'Pindar's Seventh Pythian, the Alcmaeonid Temple, and the politics of performance', in L. Athanassaki and E. Bowie (eds), Archaic and Classical Choral Song: Performance, Politics \& Dissemination. Berlin: 221-254.

- (2012). 'Performance and reperformance: The Siphnian Treasury evoked', in P. Agócs, C. Carey and R. Rawles (eds), Reading the Victory Ode. Cambridge: 134157 .

Badian, E. (1992). From Plataea to Potidea. Studies in the History and Historiography of the Pentecontaetia. Baltimore.

Barringer, J.M. (2008). Art, Myth, and Ritual in Classical Greece. Cambridge.

Barron, J.P. (1980). 'Bakchylides, Theseus and a woolly cloak', BICs 27: 1-8.

Boardman, J. (1985). Greek Sculpture. The Classical Period. London.

Brommer, F. (1982). Theseus. Die Taten des griechischen Helden in der antiken Kunst und Literatur. Darmstadt.

Burnett, A.P. (1985). The Art of Bacchylides. Cambridge, MA.

Calame, C. (1996). Thésée et l'imaginaire athénien. Lausanne.

- (2009a). 'Thésée l'Athénien au Metropolitan Museum of Art de New York: scènes étiologiques de légitimation et questions de méthode', in D. Yatromanolakis (ed.), An Archaeology of Representations: Ancient Greek Vase-Painting and Contemporary Methodologies. Athens: 98-127.

(2009b). 'Apollo in Delphi and in Delos. Poetic performances between paean and dithyramb', in L. Athanassaki, R.P. Martin and J.F. Miller (eds), Apolline Politics and Poetics. Athens: 169-197. 
Camp, J.M. (1992). The Athenian Agora. Excavations in the Heart of Classical Athens. London

Campbell, D.A. (1992). Greek Lyric, IV: Bacchylides, Corinna, and Others (Loeb Classical Library). Cambridge, MA.

Castriota, D. (1992). Myth, Ethos, and Actuality. Official Art in Fifth-Century B. c. Athens. Wisconsin.

Chaniotis, A. (2006). 'Rituals between norms and emotions: Rituals as shared experience and memory', in E. Stavrianopoulou (ed.), Ritual and Communication in the Greco-Roman World. Kernos supplément 16. Liège: 211-238.

Cole, J.R. (1977). 'The Oresteia and Cimon'. HSCPh 81: 99-111.

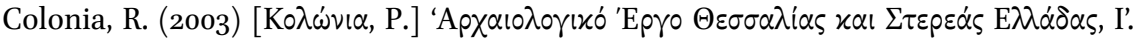

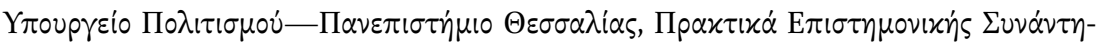
ons. Bó̀os

Connor, W.R. (1970). 'Theseus in Classical Athens', in A.G. Ward (ed.) The Quest for Theseus. London: 143-174.

Davies, J.K. (1971). Athenian Propertied Families. 6oo-30o B.c. Oxford.

Diggle, J. (1981) Euripidis fabulae, vol. 2. Oxford.

- (1984). Euripidis fabulae, vol. 1. Oxford.

Dinsmoor, W.B. (1975). The Architecture of Ancient Greece. London.

Fearn, D.W. (2007). Bacchylides. Politics, Performance, Poetic Tradition. Oxford.

Forsdyke, S. (2005). Exile, Ostracism, and Democracy. Princeton.

Francis, E.D. (1990). Image and Idea in Fifth-Century Greece. London.

Froning, H. (1991). Dithyrambos und Vasenmalerei in Athen. Würzburg.

Jones, W.H.S., and Ormerod H.A. (1918). Pausanias. Pausanias' Description of Greece, IIV. Cambridge, MA.

Käppel, L. (1992). Paian. Studien zur Geschichte einer Gattung. Berlin.

Kovacs, D. (1995). Euripides, II: Children of Heracles. Hippolytus. Andromache. Hecuba. Cambridge, MA.

La Coste-Messelière, P. de (1957). Fouilles de Delphes, IV/4: Sculptures du Trésor des Athéniens. Paris.

Lee, K.H. (1997). Euripides. Ion. Warminster.

Maaß, M. (1993). Das Antike Delphi. Orakel, Schätze und Monumente. Darmstadt.

Maehler, H. (2004). Bacchylides. A Selection. Cambridge.

Marconi, C. (2009). 'Early Greek architectural decoration in function', in D.B. Counts and A.S. Tuck (eds), Koine. Mediterranean Studies in Honor of R. Ross Holloway. Oxford: 4-17.

Merkelbach, R. (1973). 'Der Theseus des Bakchylides', ZPE 12: 56-62.

Morris, S.P. (1992). Daidalos and the Origins of Greek Art. Princeton.

Neer, R.T. (2002). Style and Politics in Athenian Vase-Painting. Cambridge.

Neer, R.T. (2004). 'The Athenian Treasury in Delphi and the material of politics', ClAnt 23: 63-93. 
Neils, J. (1987). The Youthful Deeds of Theseus. Rome.

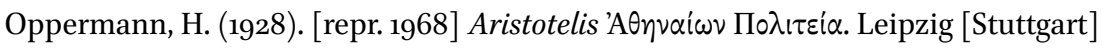

Osborne, R. (2000). 'Archaic and classical Greek sculpture and the viewer', in N.K. Rutter and B.A. Sparkes (eds), Word and Image in Ancient Greece. Edinburgh: 228-246.

Plassart, A. (1940). 'Eschyle et le temple delphique des Alcméonides', REA 42: 293-299.

Potter, R. (1938). Euripides. The Complete Greek Drama, edited in two volumes by W.J.

Oates and E. O'Neill, Jr. vol. ı. Ion, translated by Robert Potter. New York.

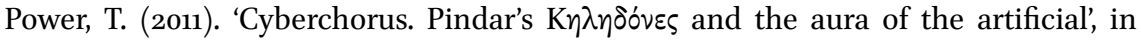
L. Athanassaki and E. Bowie (eds) Archaic and Classical Choral Song: Performance, Politics \& Dissemination. Berlin: 67-113.

Rackham, H. (1952). Aristotle in 23 Volumes, xx. Cambridge, MA.

Rengakos, A. (2000). 'Zu Bakchylides' Erzähltechnik', in B. Zimmermann (ed.), Bakchylides. 10o Jahre nach seiner Wiederentdeckung. Munich: 101-112.

Rutherford, I.C. (1998). 'Theoria as theater: Pilgrimage in Greek drama', Leeds Latin Seminar 10: 131-156.

- (2013). State Pilgrims and Sacred Observers in Ancient Greece: A Study of Theoria and Theoroi. Cambridge.

Schefold, K. (1946). 'Kleisthenes', $M$ H 3: 59-93.

- (1992). Gods and Heroes in Late Archaic Greek Art. Engl. transl. A. Griffiths. Cambridge.

Scodel, R. (1984). 'The irony of fate in Bacchylides 17', Hermes 112: 137-143.

Severyns, A. (1933). Bacchylide. Essai biographique. Paris.

Shapiro, H.A. (1989). Art and Cult under the Tyrants in Athens. Mainz.

_ (1992). 'Theseus in Kimonian Athens: The iconography of empire', Mediterranean Historical Review 7: 29-49.

Sourvinou-Inwood, C. (1971) [= Sourvinou, C.] 'Theseus lifting the rock and a cup near the Pithos Painter', JHS 91: 94-109.

- (1979). Theseus as Son and Stepson. A Tentative Illustration of GreekMythological Mentality (BICs Supplement, 40). London.

Spiro, F. 1903. Pausaniae Graeciae descriptio, 3 vols. (Teubner) Leipzig.

Stadter, P. (1989). A Commentary on Plutarch's Pericles. Chapel Hill.

Strawczynski, N. (2003). 'Artémis et Thésée sur le skyphos du peintre de Brygos (Louvre G 195)'. RA 35: 3-23.

Taplin, O. (2007). Pots and Plays. Interactions between Tragedy and Greek Vase-Painting of the Fourth Century B.c. Los Angeles.

Tournaire, A. (1902). Fouilles de Delphes, II: Topographie et architecture. Relevés et restaurations. Paris.

Tsagalis, C. (2009). 'Blurring the boundaries: Dionysus, Apollo and Bacchylides 17', in L. Athanassaki, R.P. Martin and J.F. Miller (eds), Apolline Politics and Poetics. Athens: 199-215. 
van Overen, C.D.P. (1999). 'Bacchylides Ode 17: Theseus and the Delian League', in I.L. Pfeijffer and S. Slings (eds), One Hundred Years of Bacchylides. Amsterdam: 31-42. Von den Hoff, R. (2009). 'Herakles, Theseus and the Athenian Treasury at Delphi', in P. Schultz and R. von den Hoff (eds), Structure, Image, Ornament: Architectural Sculpture in the Greek World. Proceedings of an International Conference held at the American School of Classical Studies, 27-28 November 2004. Oxford and Oakville: 96104.

Von den Hoff, R. (2010). 'Media for Theseus, or: the different images of the Athenian polis-hero', in L. Foxhall, H.-J. Gehrke and N. Luraghi (eds), Intentional History. Spinning Time in Ancient Greece. Stuttagart: 161-188.

Walker H.J. (1995). Theseus and Athens. Oxford.

Zeitlin, F.I. (1994). 'The Artful Eye: Vision ecphrasis and spectacle in Euripidean theatre', in S. Goldhill and R. Osborne (eds), Art and Text in Ancient Greek Culture. Cambridge: 138-196

Zimmermann, B. (1989). Dithyrambos. Die Geschichte einer Gattung. Gōttingen 


\title{
The Fight of Telephus: Poetic Visions behind the Pergamon Frieze
}

\author{
Laura Lulli
}

Tracing the possible reciprocal influences between the visual arts and literary works is always an interesting challenge, since it enables one to highlight the huge variety of suggestions, influences, tendencies, and aims that lie behind a work of art. ${ }^{1}$ This process is even more complex when it is applied to the ancient world: in this case it is essential to exercise caution, since the scholarly tradition often has to deal with influences which are neither immediately explicit nor hardly ever documented by 'statements of intent' on the part of the artists. However, even if it may not be possible to pinpoint in a figurative work an explicit allusion to a literary work, nevertheless it is worthwhile to try to compare the two art forms. ${ }^{2}$ In doing so it is important to regard them not as two distinct objects connected merely by the attempt at comparison proposed by the scholar, but rather as two interconnected spheres, sometimes moving in parallel and sometimes intersecting with a lesser or greater degree of selfconsciousness. ${ }^{3}$

With this in mind I have tried to read afresh some scenes of the so-called 'smaller frieze' of the altar at Pergamon, that is the frieze in which the life and exploits of the hero Telephus are represented. ${ }^{4}$ The standard interpretation of

* For suggestions received I would like to thank Luca Bettarini, Ewen Bowie, Michele Napolitano, Bruna Marilena Palumbo Stracca, Massimiliano Papini, and Livio Sbardella. Translations from Greek are my own where not otherwise stated.

1 This topic has been dealt with from many angles in a massive bibliography referring to different historical periods. I here limit myself to mentioning only a few towering works such as those of Gombrich (1966) on the Renaissance, and Ginzburg (1981) on Piero della Francesca.

2 For a broader perspective on the possible relationships between Greek choral song in particular and the iconographical evidence see Athanassaki's chapter in this volume.

3 There is a huge bibliography on the influences between poetry and figurative art in the ancient world; I mention here only Shapiro (1994), Snodgrass (1998), and Vetta (2001), which pay special attention to epic and lyric poetry; cf. also Taplin (2007) on the relationship between tragedy and vase-painting.

4 For an overall analysis of the Telephus frieze on the Pergamene altar see Dreyfus and Schraudolf (1996).

(C) LAURA LULLI, 2016 | DOI: 10.1163/9789004314849_004

This is an open access chapter distributed under the terms of the Creative Commons Attribution- 
the frieze is based on identifying the influence on the myth's representation of two main genres of the Greek literary experience: archaic epic on the one hand, and tragedy on the other. ${ }^{5}$ At any rate, a closer look at some details of the frieze, and in particular at the scenes dealing with the Mysian battle (fig. 3.1), enables a reappraisal of the possible literary influences behind this representation of the Telephus myth on the Pergamon frieze.

The Mysian battle is an episode from the central period of Telephus' life, soon after the adventures of his early years and before his involvement in the events of the Trojan war, when, following the instructions of an oracle, he helped the Achaeans to land at Ilium. Our knowledge of this section of the Telephus myth is due for the most part to the evidence of the cyclic epic poems, Hesiodic poetry, tragedy, and the erudition of Philostratus and Pausanias. ${ }^{6}$ It will be helpful in the first instance to examine this evidence in order to understand its value; I will discuss later the handling of the Telephus myth in lyric and elegiac poetry, since this shows features which are peculiar compared to other literary testimonies of the same myth.

Among our earliest sources for the Mysian battle is the cyclic epic Cypria, which narrates the events leading up to the Trojan war. Althought the date of the poem is controversial, most scholars would agree that the Cypria, like other cyclic epics, originates in the diffusion of rhapsodic activity between the late eighth and the early sixth centuries BC. ${ }^{7}$ Thanks to the summary in Proclus' Chrestomathia, we know that the Cypria also mentioned the Mysian battle, in which Telephus was wounded in a duel with Achilles while repelling the attack of the Achaeans, who had mistaken his land for Troy.

Cypr. Argumentum Procl. Chrest. 80 Severyns (= pp. 38-43 Bernabé $=$ pp. 30-33 Davies)

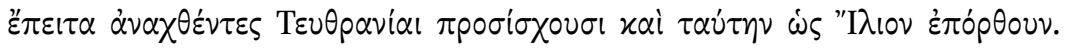

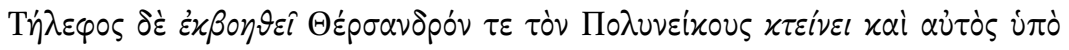

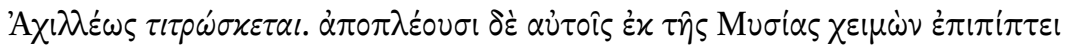

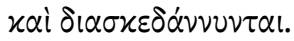

5 The first attempt at a comparison between the literary tradition and the scenes of the Telephus frieze can be read in Robert (1887), especially pp. 254-259 (on the Mysian battle), Robert (1888a), and Robert (1888b), whose work is still the starting point of the majority of the interpretations of the frieze.

6 See, in particular, Paus. 8.4.9, 8.47.4, 8.48.7, 8.54.6.

7 On the chronology of the Cypria see Burgess (1996) 77 n. 2, West (1995) 204, and West (2013) $63-65$. 
Then they put to sea and land at Teuthrania, and they were setting out to sack it thinking it was Ilion. Telephus comes out to defend it, kills Polynices' son Thersander, and is himself wounded by Achilles. As they are sailing away from Mysia, a storm catches them and they become dispersed.

trans. M.L. WEST

From this brief summary only the fundamental details of the episode emerge: the intervention of Telephus in defence of his own city, besieged by the Achaeans, the killing of Thersander, son of Polynices, and, finally, the wounding of Telephus by Achilles. It is difficult to infer from this outline which thematic and verbal formulae were used in the epic poem for the description of this battle scene.

In the Epitome of Apollodorus' Bibliotheca we find a more detailed account of the events, though they still correspond to the scheme found in the summary of the Cypria just mentioned (invasion of Mysia by the Achaeans / resistance and reaction on the part of Telephus / killing of Thersander / wounding of Telephus):

Apollod. Epit. 3.17

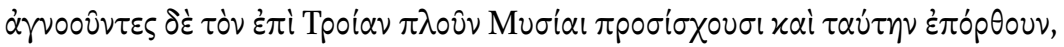

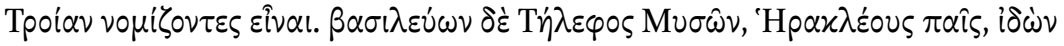

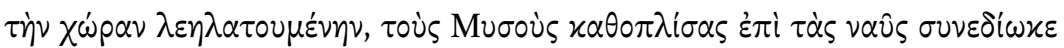

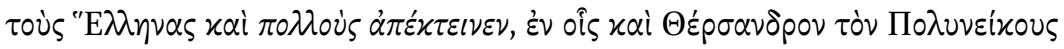

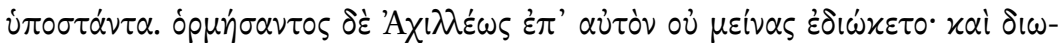

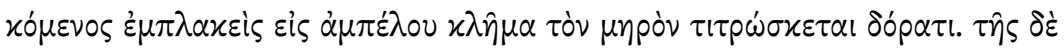

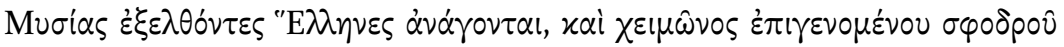

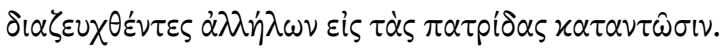

But not knowing the course to steer for Troy, they put in to Mysia and ravaged it, supposing it to be Troy. Now Telephus, son of Hercules, was king of the Mysians, and seeing the country pillaged, he armed the Mysians, chased the Greeks in a crowd to the ships, and killed many, among them Thersander, son of Polynices, who had made a stand. But when Achilles rushed at him, Telephus did not abide the onset and was pursued, and in the pursuit he was entangled in a vine-branch and wounded with a spear in the thigh. Departing from Mysia, the Greeks put to sea, and a violent storm coming on, they were separated from each other and landed in their own countries.

trans. J.G. FRAZER 
When we compare Apollodorus' account with the information given in the summary of the Cypria we find one additional detail: Telephus killed many soldiers ( $\pi \circ \lambda$ ov่ $\dot{\alpha} \pi \varepsilon \dot{\varepsilon} \tau \varepsilon i v \varepsilon v)$. Although at first sight this might seem insignificant and even banal, it should be kept in mind, since it suggests an attempt to describe the extreme brutality of the battle, and not just the main elements of Telephus' clashes with individual heroes, in primis Thersander and Achilles. It cannot be excluded that Apollodorus relied upon Alexandrian scholarship for this account of the Mysian battle. In this connection it is worth examining a scholium to line 59 of the first book of the Iliad:

\section{Cypr. fr. 20 (I) Bernabé = schol. D Il. 1.59 van Thiel}

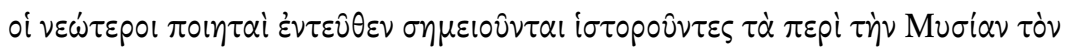

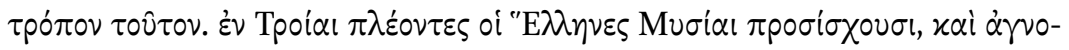

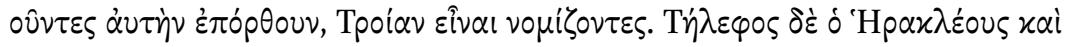

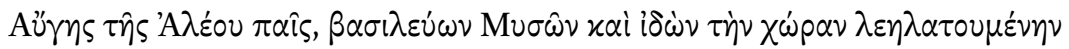

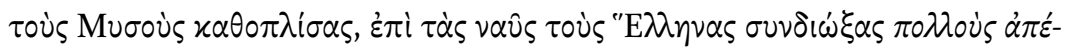

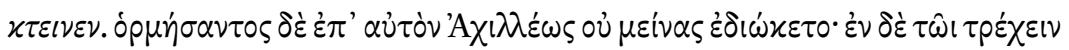

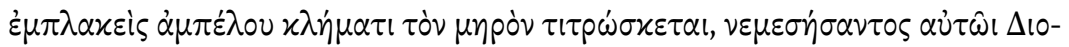

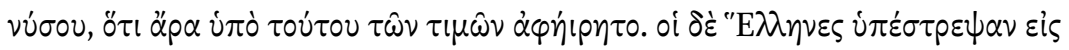

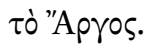

The younger poets are distinguished because they recount the events concerning Mysia in the following way. The Greeks, sailing to Troy, landed in Mysia and, not recognizing it, plundered it thinking that it was Troy. Then Telephus, son of Herakles and Auge, the daughter of Aleos, being king of the Mysians and seeing that his land was plundered, armed the Mysians and chased the Greeks back to their ships killing many. But when Achilles rushed headlong at him he did not stand fast and was pursued: while running, entangled by a vine branch, he is wounded on the leg, for Dionysus was angry with him for depriving him of his honours. Then the Greeks turned back toward Argos.

Here the scholiast, while giving the main outlines of the Mysian battle, stresses that Telephus 'killed many' Greeks. It is clear that Alexandrian scholars, in

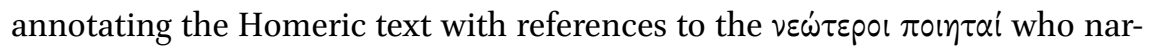
rated the Mysian battle, ${ }^{8}$ considered it important not only to give a report of

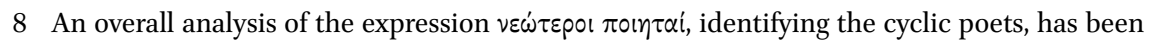
done by Severyns (1928) 31-101. 
the sequence of events, but also to specify the bloodiness of the battle, adding the significant detail of the killing of many Greeks at the hands of Telephus.

Another well known archaic source for the Telephus myth is Hes. fr. 117 Most (= fr. 165 M.-W. = P. Oxy. 11. 1359 fr. 1) of Hesiod's Catalogue of Women. ${ }^{9}$ After a section of the poem concerning the birth of Telephus from Auge and Heracles, at lines 12-25 it is possible to see the traces of a reference to his Mysian adventures:

Hes. fr. 117.12-25 Most

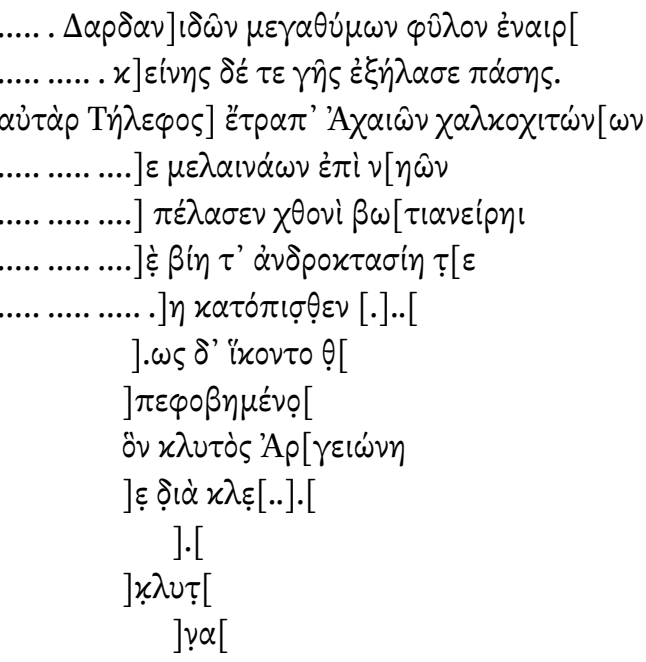

] slew the tribe of great-spirited [Dardanians

] and drove them out from the whole country.

Then Telephus] fled from the Achaeans with their bronze tunics

15

] on black ships

] he brought down to the man-feeding land ] force and slaughter ] in later times [ ] they came [

20 ] frightened [ whom] glorious [Argea bore

trans. G.W. MOST

9 For the collocation of this fragment in the Arcadian stemma of the Catalogue see West (1985) 42-43, 90-91. See also Haubold (2005) 89 n. 22. 
In these very fragmentary lines (especially $14 \mathrm{ff}$.) the narrative of the Mysian battle focuses on Telephus, who tries to defeat the Greeks and turn them away from his kingdom but is wounded by Achilles. However, it does not set out to describe the bloody scene of the battle in vivid terms. This fragment of the Catalogue of Women, then, depicts the Mysian battle in the same terms and following the same narrative scheme as that we have seen in the Cypria.

Similarly to what happens in the hexametric poetry of the archaic periodof which we have seen two examples in the Cypria and the Catalogue of Women - the Telephus myth also receives a detailed treatment in Attic drama of the fifth century вс. ${ }^{10}$ However, the extreme fragmentariness of the plays in which the hero appeared does not allow us to reach a complete understanding of their handling of the myth. This is the case, for example, for the Mysians $^{11}$ and the Telephus ${ }^{12}$ attributed to Aeschylus, of which we know little more than the title and some sporadic quotations from lexicographers, and for Sophocles' Mysians. ${ }^{13}$ Euripides' Telephus, known only through fragments, is thought to be the third play of a tetralogy consisting of The Cretan Women, Alcmaeon in Psophis, and Alcestis. ${ }^{14}$ Based on the sections of the play that we can reconstruct from the surviving papyrus fragments ${ }^{15}$ it is possible to say that the Mysian battle was narrated in the prologue, which can be read in a papyrus from the Milanese collection (P. Mil. I.2 15) $\cdot{ }^{16}$ Moreover, in the extant lines there is no reference to the bloody and violent aspects of the action. ${ }^{17}$ In short, the

10 A useful analysis of the handling of the Telephus myth in fifth-century drama can be found in Platter (2007) 143-175.

11 See Aesch. frr. ${ }^{143^{-145}}$ Radt. The most important source for this drama is Arist. Poet. 1460a.27, where Telephus is defined $\delta \ddot{\alpha} \varphi \omega \nu$ os. For this appellative of Telephus see Alex. fr. 183.3-4. Kassel-Austin, Amphis fr. 30.5-14 Kassel-Austin. To the Mysians have been attributed dubiously also frr. * $239,354,379$ Radt.

12 See Aesch. frr. 238-240 Radt.

13 See Soph. frr. 409-418 Radt. According to a fourth-century inscription $\left(\right.$ IG II $^{2} 3091.8=\operatorname{Tr} G F$ I 39), this drama was part of a Telepheia, which would have included also a Telephos (fr. 580 Radt). On the inscription see Pickard-Cambridge (1933) and Ghiron-Bistagne (1976) 9597. On the controversial nature of the Sophoclean Telephus, regarded by some critics as a satyr play, see $\operatorname{Tr} G F$ IV 434 and Sutton (1974).

14 This information is known from one of the two hypotheseis of the Alcestis: see Del Freo (1996) 198, 204-209, with an analysis of the evidence for Euripides' Telephus.

15 P. Mil. I.2 15 = Eur. fr. 696 Kannicht; P. Oxy. XxviI 2460 = fr. 727 a Kannicht; P. Ryl. III $482=$ fr. ${ }^{* *} 727$ b Kannicht; BKT 5.2 pp. 64-72 n. XVI = fr. 727c Kannicht.

16 The standard reconstruction of the sections of the drama is in Handley and Rea (1957), with a discussion of the fragments. For an analysis of the whole tetralogy see Del Freo (1996).

17 It should be added that, as suggested by Handley and Rea (1957) 28-29, Accius' lost 
fragmentary state of the plays of the three Attic tragedians dealing with the Telephus myth does not allow us to reach any firm conclusions; however, on the basis of what survives, it does not seem that in those tragedies the violent aspects of the Mysian battle received special emphasis.

There is evidence for the literary use of the myth of Telephus also in the Hellenistic period. In particular, P. Oxy. II 214, published in 1899 by Bernard P. Grenfell and Arthur S. Hunt, ${ }^{18}$ is of great interest. It contains an anonymous poetic fragment, with parts of forty-three hexameter lines written on the remains of a leaf from a third-century papyrus codex. ${ }^{19}$ On the verso, it is possible to read a very lacunose group of verses devoted to a description of the dangers of travelling by sea. On the recto there is a speech, probably spoken by a woman, ${ }^{20}$ about Telephus' adventures and, in particular, the very first part of his story in Mysia: lines 2-5 deal with the defeat of the Greeks at the hands of our hero. ${ }^{21}$ Another indication of the probable use of the Telephus myth in the Hellenistic age has been found in a scholium to Apollonius Rhodius, where it seems to be said that Philitas of Cos was the author of a poem entitled Telephus. ${ }^{22}$

At any rate, in order to find some clear traces of a vivid representation of the bloodiness of the Mysian battle, we must turn our gaze to archaic lyric and elegiac poetry. Here the most interesting item is the well known P. Oxy. LXIX 4708, published by Dirk Obbink in $2005,{ }^{23}$ thanks to which it has

drama about Telephus may have been modelled on Euripides'. For a useful analysis of the influence of Telephus' myth on Latin literature see Fantham (2009).

18 A further edition of the text is in Heitsch (1963) $5^{8} \mathrm{n}$. XVIII. A literary study of the fragment is in Pellin (2010).

19 To be more precise, the editors state that this papyrus fragment is 'presumably a leaf out of a book' (P. Oxy. II, p. 27).

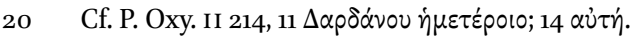

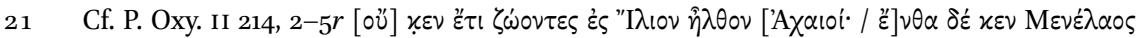

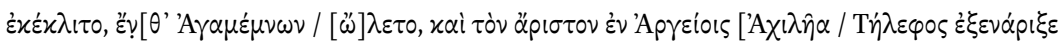

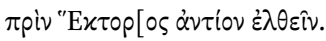

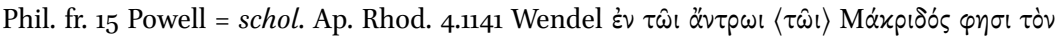

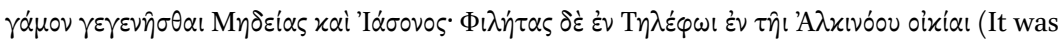
in the cave of Macris that he [scil. Apollonius] says that the wedding of Jason and Medea took place, whereas Philitas in the Telephus said it was in the palace of Alcinous. [trans. J.L. Lightfoot]). It should be noted that the text of the scholium is far from unproblematic and there are some, such as Bach (1829) 6o, who try to correct it in order to read $\delta$ T $\eta \lambda \dot{\varepsilon} \varphi \circ v$, i.e. a reference to Philitas' father instead of a title. On the Telephus attributed to Philitas of Cos see Sbardella (2000) 41-44, with a reconstruction of the debate and further bibliography, and Spanoudakis (2002) 92, 309-311. 
been possible to recover a long elegy by Archilochus concerning the myth of Telephus. It is worthwhile to look especially at the following verses:

P. Oxy. LXIX 4708 fr. $1.5^{-15}$

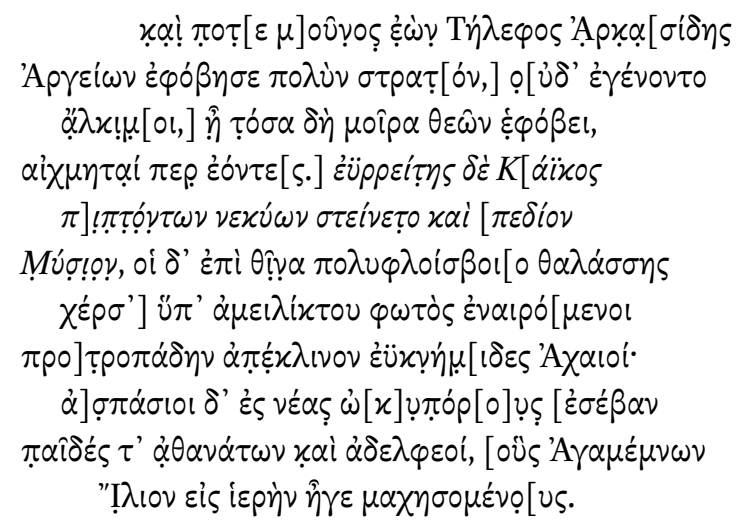

Even once Telephus, descendant of Arkasos, by himself put to flight the great army of Argives, and they were not brave-indeed, so greatly was the fate of the gods routing them-powerful spear-men though they were. The fair-flowing river Kaikos and the plain of Mysia were stuffed with the falling corpses, while the well-greaved Acheans, being slain at the hands of the relentless man (Telephus), turned-off with headlong speed to the shore of much-resounding sea. Gladly did they embark on their swift ships, the sons of the immortals and brothers, whom Agamemnon was leading to holy Ilios to wage war.

trans. D. овВINK, with modifications

In these lines, which seem to have followed immediately after the now lost opening section of the elegy, much space is given to the narration of the myth of Telephus and, more specifically, to the landing of the Achaeans in Mysia and their consequent fight with the local population led by their king Telephus. What is striking in these elegiac distichs is the description of the violence of the war action, which involves both the river Kaikos and the Mysian plain being filled with the corpses of the fallen (ll. 8-10): to depict this, the poet uses the

and D'Alessio (2006). For a useful synthesis of the debate about the new Archilochus elegy on Telephus see Nicolosi (2005) 80-87, Nicolosi (2006), Nicolosi (2007) 279-333, and Lulli (2011) 87-105. 
expression $\nu \varepsilon x u ́ \omega \nu ~ \sigma \tau \varepsilon i v \varepsilon \tau 0$, which has its roots already in $\mathrm{Homer}^{24}$ and can be found in the same form much later in Quintus Smyrnaeus. ${ }^{25}$

A similar grim image can be seen in Pindar's eighth Isthmian ode, where the poet makes an explicit, if brief, reference to the Telephus myth.

Pind. Isthm. 8.49-50

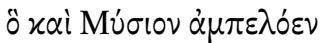

50

$\alpha i \mu \alpha \xi \varepsilon \mathrm{T} \eta \lambda \varepsilon \dot{\varepsilon} \varphi 0 \nu \mu \varepsilon \dot{\varepsilon} \lambda \alpha \nu$

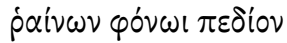

He also bloodied the vine-clad

5o plain of Mysia

with the dark drops of Telephos' gore

trans. W.H. RACE

In this section of the ode the poet lists all of Achilles' military achievements, including the wounding of Telephus during the fight between the Achaeans and the Mysians. In this case, too, the bloodiness of the fight between the two demigods is a striking feature: ${ }^{26}$ Achilles is said to stain with blood the Mysian plain, soaking it with the dark blood of Telephus. ${ }^{27}$

After Pindar we must wait until the age of the Second Sophistic to find another literary representation of the vivid bloodiness of the Mysian battle. The section of Philostratus' Heroicus ${ }^{28}$ devoted to the life and exploits of Telephus includes a description of the Mysian battle:

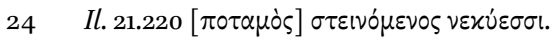

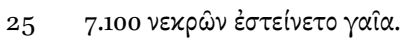

26 The particularly grim tone of this battle scene description is noted also by Privitera (1982) ad loc.: 'Pindaro amplifica e carica le tinte'.

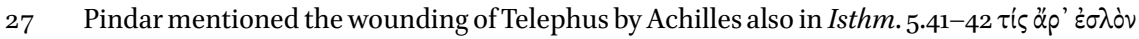

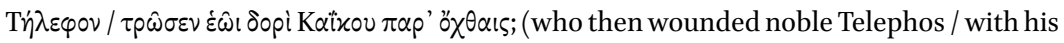

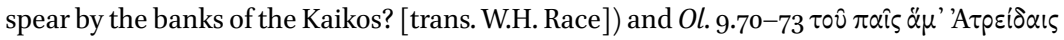

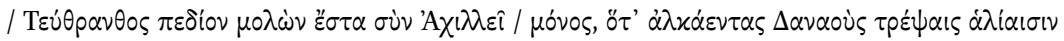

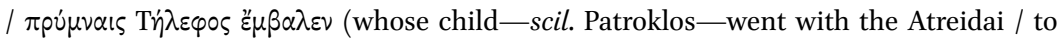
the plain of Teuthras and stood by Achilles / all alone, when Telephos routed the valiant Danaans / and attacked their seaworthy sterns [trans. W.H. Race]).

28 On Philostratus' Heroicus see Kim (2010) $175^{-215}$, with further bibliography; Bowie and Elsner (eds) (2009) provides a general and comprehensive introduction to the author and his work. 
Philostr. Her. 23.24-25 De Lannoy

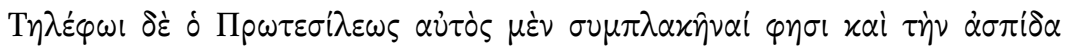

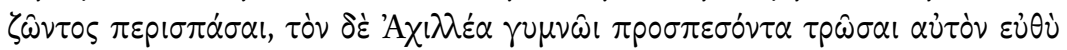

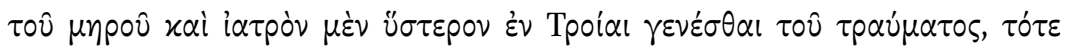

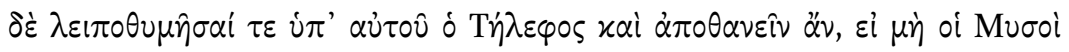

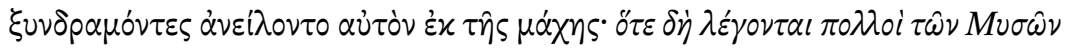

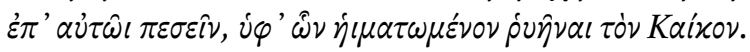

Protesilaos says that he himself fought Telephos and stripped him of his shield while still alive, but that Achilles fell upon the unprotected man, wounding him at once in the thigh. And although later in Troy he healed the wound, at that time Telephos lost heart because of it and would have died if the Mysians had not together run to Telephos and snatched him out of the battle. So many Mysians are said then to have fallen for him that the Kaikos river ran red with their blood.

trans. J.K. BERENSON MACLEAN - E. BRADSHAW AITKEN

The casualties among the ranks of the two fighting armies were such that the river Kaikos literally ran red with the blood of the soldiers. This detail is not a decorative addition to the tale ascribable to Philostratus' sensibility or perspective. Rather, as we have previously noted, this violent element providing a strong visual impact can be seen in the very first literary testimonies of the Mysian battle, i.e. in elegiac and lyric poetry, much more than in epic and tragedy. Philostratus' tale distinguishes itself by a striking visual proximity to Pindar's description of the same episode: in both cases the flow of blood stains red the banks of the river Kaikos, obstructed by the bodies of the fallen, and the

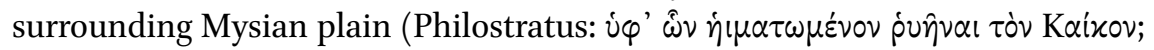

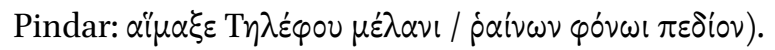

This representation of the bloodiness of the battle finds a close parallel in the iconography of the Mysian struggle on the Telephus frieze inside the inner porch of the so-called Great Altar of Pergamon. ${ }^{29}$ The representation of the myth, from Telephus' birth to his last exploits, runs from left to right, following an order which may be thought of as imitating the layout of a text

29 It is important to note that representations of violent battle-scenes can already be found in archaic Greek art, as demonstrated by Schefold (1992), esp. 231-244. On this topic see also Shanks (1999) 107-130. 
written on a papyrus roll. ${ }^{30}$ As is well known, the absolute novelty of this frieze lies in its use of a narrative structure which requires the spatial placement of human figures and objects according to their relative importance in the economy of the story. ${ }^{31}$ Far from conforming to the usual naturalistic criteria typical of Greek art, the images are arranged regardless of their real proportions: the organization of the figures is thus subject only to the needs of the story and the desire to show the viewers the main details of the myth. ${ }^{32}$ In spite of the fragmentary state of some pieces-as is well known, the fragmentary and unfinished state of the frieze has always been one of the main problems for the overall interpretation of the work, as well as for the understanding of its individual parts ${ }^{33}$ - the iconography of the scenes represented in some frames of the Telephus frieze ${ }^{34}$ resembles quite closely the narrative technique found in the literary evidence already examined. The narrative sequence begins with the death of Hiera, the Amazon wife of Telephus (fig. 3.1-3.2), who fell in battle after leading the Mysian women against the Achaean invaders. The frames which follow show some crucial moments of the battle, for example the death of two warriors (fig. 3.3-3.4), generally identified as Aktaios, son of the river-god Istros and a Trojan ally, and his brother Heloros, both killed by Ajax son of Telamon, as narrated by Philostratus (Her. 2.15). It is worthwhile examining the depiction of their death: the bodies of the two warriors lying upside down are interlaced and surrounded by the weapons which are no longer in their hands, clearly indicating their defeat. This seems to recall the image of the casualties in the Mysian battle described in vivid and bloody detail by both Archilochus and Pindar. After this scene we find the pieces showing the wounding of Telephus by Achilles

30 On illustrations on papyrus roll see Horak (1992) and the general remarks in Settis (2006), esp. 50-6o.

31 For an analysis of the narrative technique of the Telephus frieze see Stewart (1996). A reflection on the manner of representation of both space and landscape in the Telephus frieze can be found in Bianchi Bandinelli (1943) 98-101, 138, 222.

A clear description of the main characteristics of the style used in the Telephus frieze is given by Papini (2007) 384-392, who, in comparing the Gigantomachy with the Telephus frieze, states that in the latter 'balza all'occhio la ricerca di profondità spaziale, non senza inflessioni pittoriche, nonché la predilezione per una cornice paesaggistica; ... sul Piccolo Fregio si afflosciano le pieghe, che si fanno meno plastiche e più lineari, talora calligrafiche, si stemperano le forme e si ammorbidiscono le carni; ...' (p. 384).

On the difficulties in reconstructing the structure of the Telephus frieze see Heilmeyer (1996) 37, and Massa-Pairault (1998) 93.

34 See plates 22-33 LIMC s.v. Telephos VII.1, p. 860. 


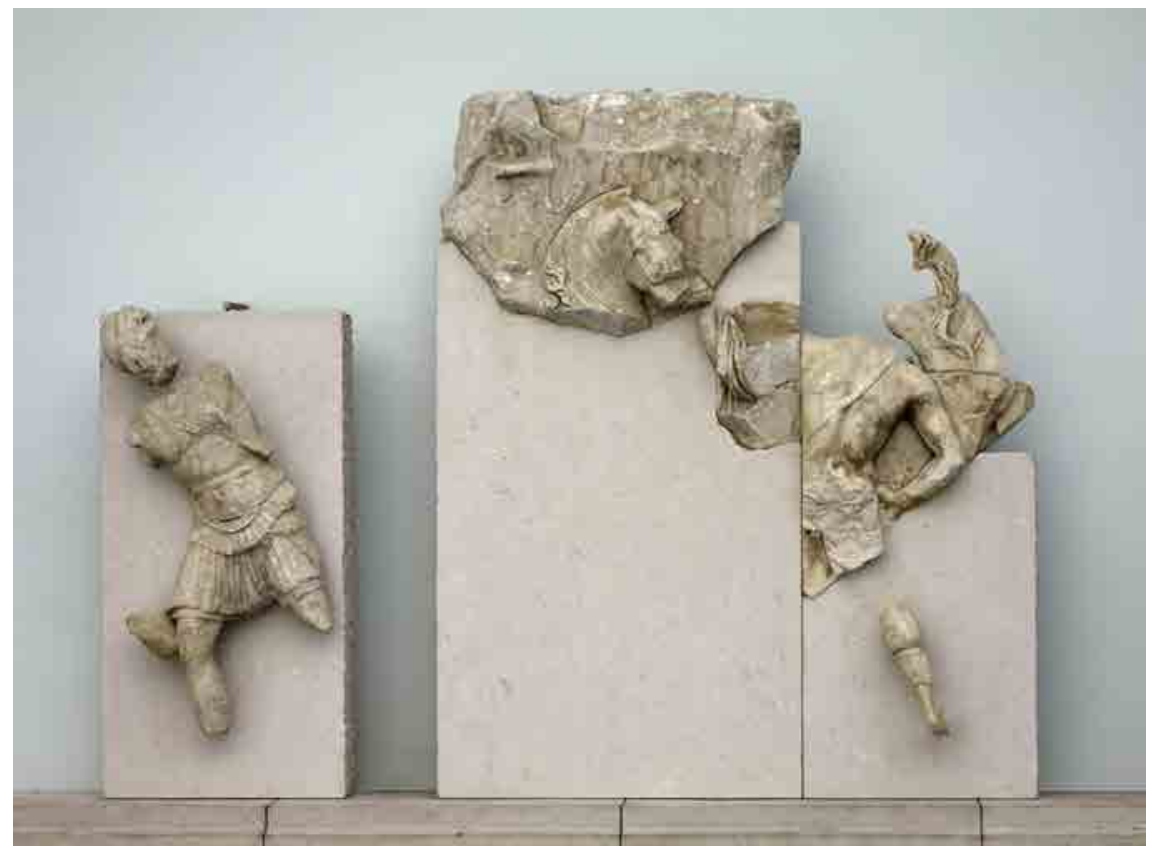

FIG. 3.1 Hiera, Telephus' wife, against the Greek warriors, from the Pergamon Great Altar (C) STAATLICHE MUSEEN ZU BERLIN, ANTIKENSAMMLUNG, PHOTOGRAPHER: JOHANNES LAURENTIUS

(fig. 3.5), helped by the epiphany of Dionysus. Lastly, the cycle of the Mysian battle is concluded by the stelai depicting the flight of the Achaeans to their ships.

The Telephus frieze, commissioned by the Attalids with the chief purpose of emphasizing the origin of their dynasty from Heracles, ${ }^{35}$ can be viewed as integral to their political and cultural strategy, which aimed to make Pergamon an undisputed capital of the Hellenistic world, a new Athens. ${ }^{36}$ In this context, as is well known, the recovery of the literary tradition of the archaic and classical periods played and important role; Pergamene scholars devoted huge efforts to this enterprise, in constant competition with other centres of erudite studies, above all Alexandria. The literary influences which the artists of the Telephus frieze must have had in mind without doubt included the earlier epic and tragic traditions, but it is not surprising that archaic lyric and narrative elegy played

\footnotetext{
$35 \quad$ See Moreno (1977) 451.

36 For an overall analysis of the main aspects of the Attalids' political and cultural perspectives see Virgilio (1993).
} 


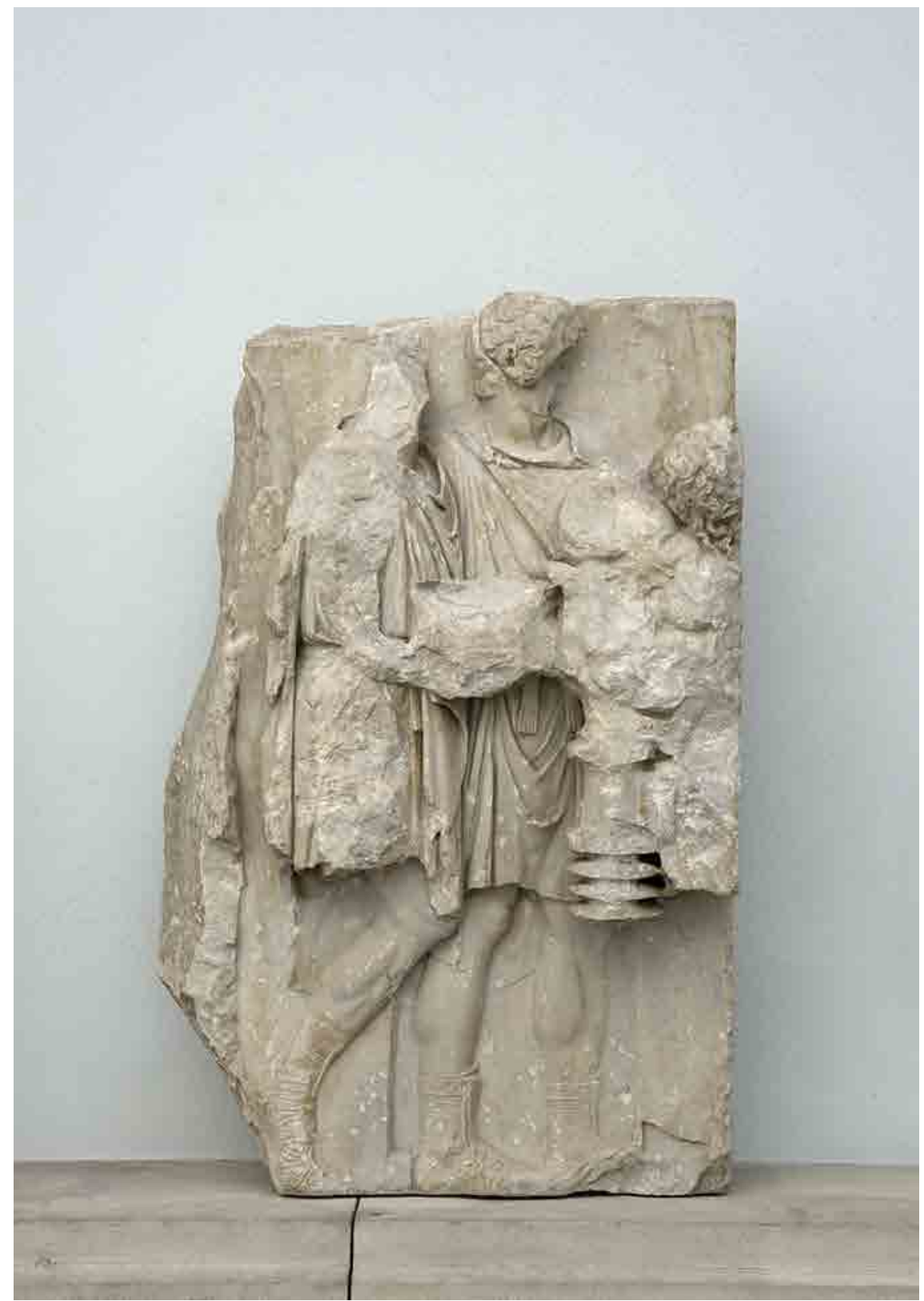

FIG. 3.2 Hiera's funeral, from the Pergamon Great Altar

(C) STAATLICHE MUSEEN ZU BERLIN, ANTIKENSAMMLUNG, PHOTOGRAPHER: JOHANNES LAURENTIUS 


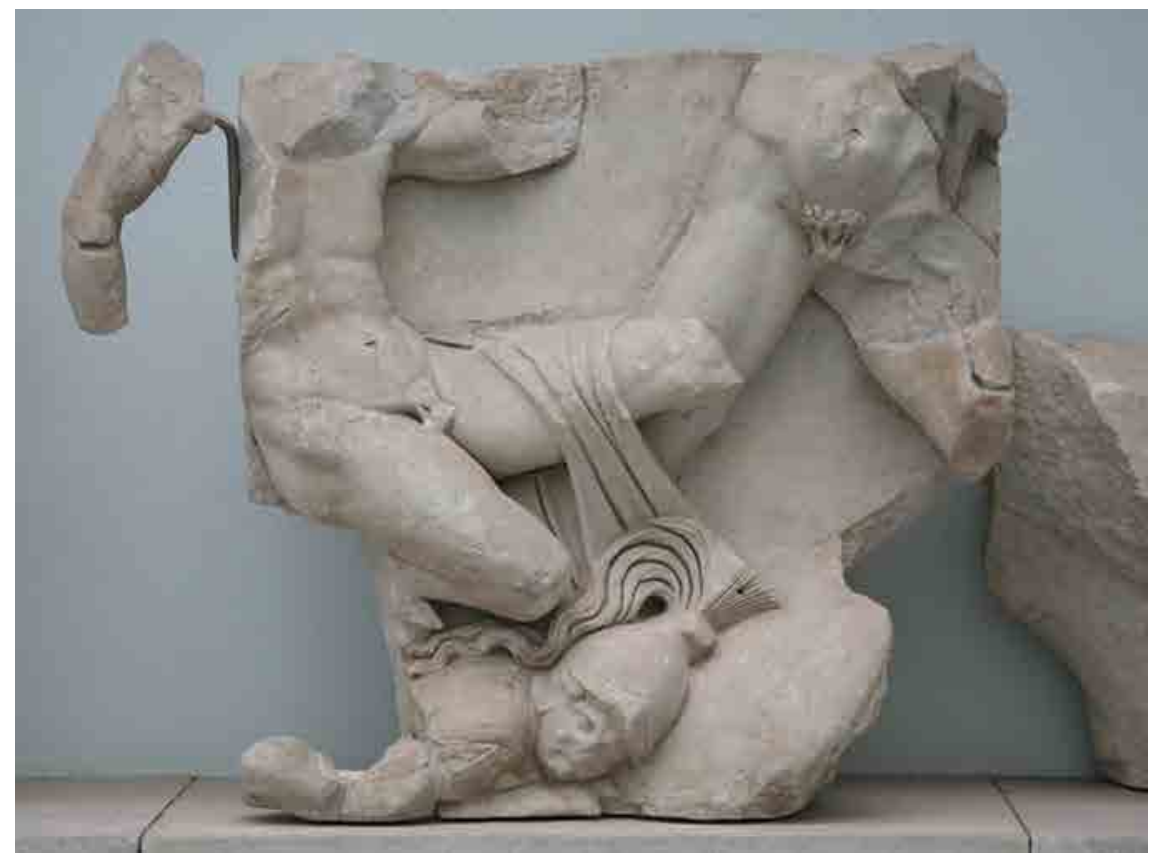

FIG. 3.3

The death of two warriors, from the Pergamon Great Altar

(C) STAATLICHE MUSEEN ZU BERLIN, ANTIKENSAMMLUNG, PHOTOGRAPHER: JOHANNES LAURENTIUS

a part in the formation of the iconography of the Telephus myth chosen in Pergamon. ${ }^{37}$ Indeed, thanks to the learned remarks of the Hellenistic scholars and the intellectuals of the Second Sophistic the image of the tragic and bloody Mysian battle passed beyond the chronological limits of Archilochus and Pindar, who were the first to display all its figurative potentialities. We can-

37 In this regard the following information offered by Pausanias (3.26.9-10) is also interesting:

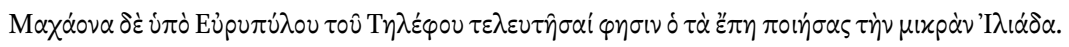

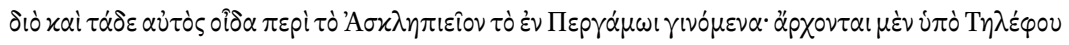

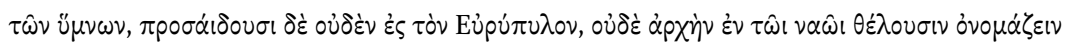

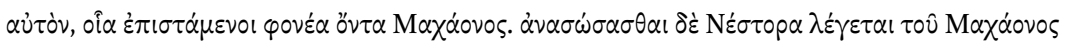

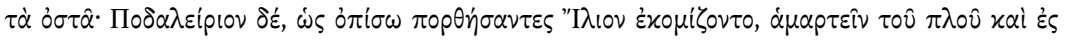

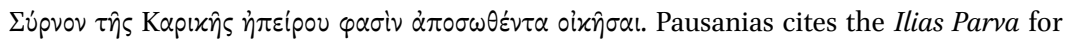
the report that Machaon was killed by Eurypylus, son of Telephus. This is followed by a reference to the rites at the temple of Asclepius and to the hymns in honour of Telephus. So in Pausanias' day not only was the distant memory of the hero's adventures still alive, but his value for the political and religious life of the city of Pergamon also lived on, so that the performace of hymns in his honour continued. 


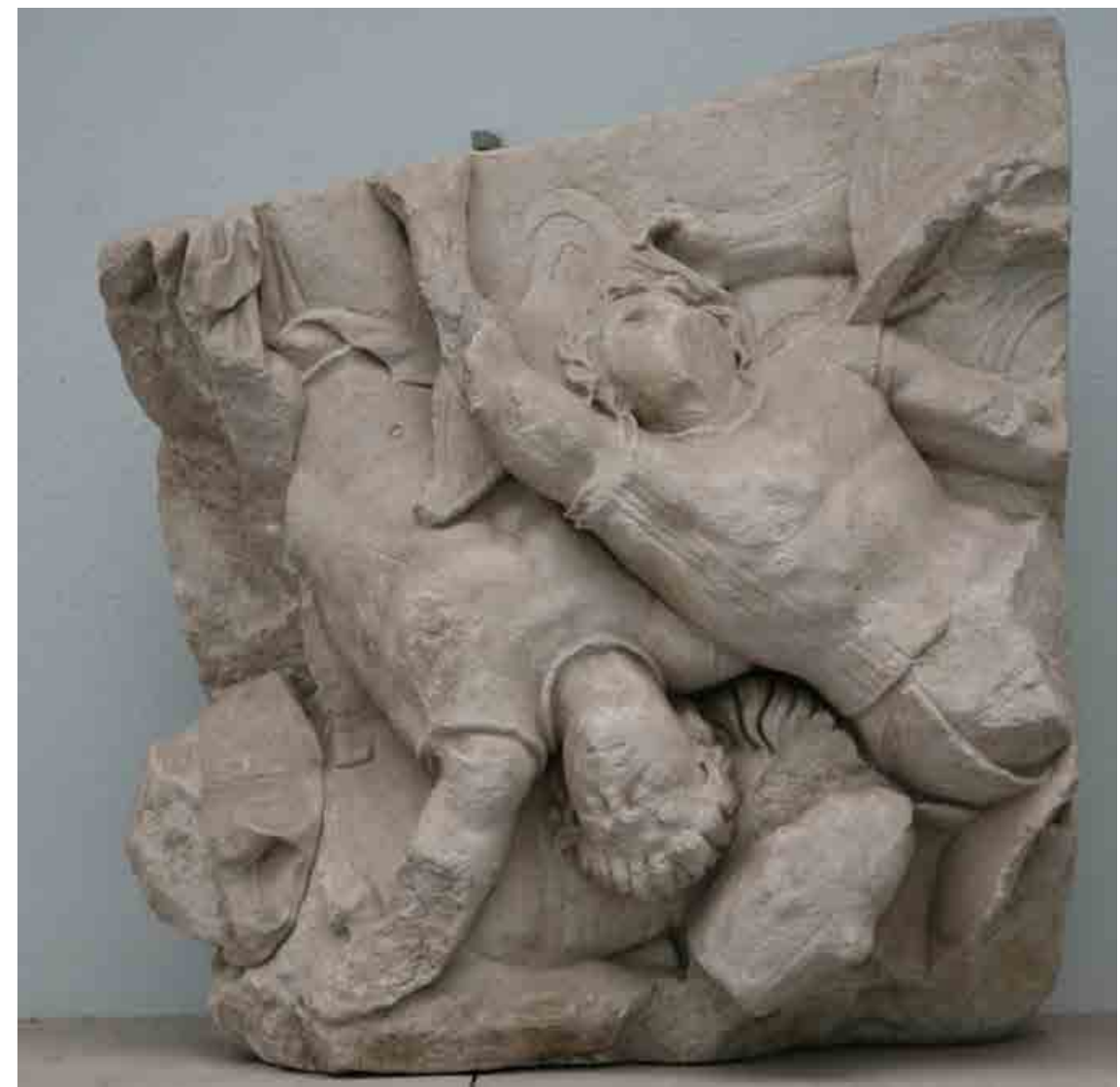

FIG. 3.4

The death of Aktaios, from the Pergamon Great Altar

(C) STAATLICHE MUSEEN ZU BERLIN, ANTIKENSAMMLUNG, PHOTOGRAPHER: JOHANNES LAURENTIUS

not exclude that the artists of the parts of the frieze showing the Mysian battle looked to those poetic compositions: on the one hand the Archilochean narrative elegy and on the other the Pindaric celebratory ode, both distinguished by a strong adherence to their contemporary historical and political reality.

In a period when Hellenistic rulers like the Attalids were devising political and cultural programmes, not only in order to emphasize their own superiority over the barbaric populations they confronted, but above all to re-establish a strong link with past tradition and present themselves as Greeks with a welldocumented identity, the use of the Telephus myth had a well-established strategic value: in Greek mythology Telephus, as an Arcadian hero and son of Heracles, always had to relate to 'other' populations, from the Trojans in the East to the Etruscans in the West, while always maintaining his own Greek- 


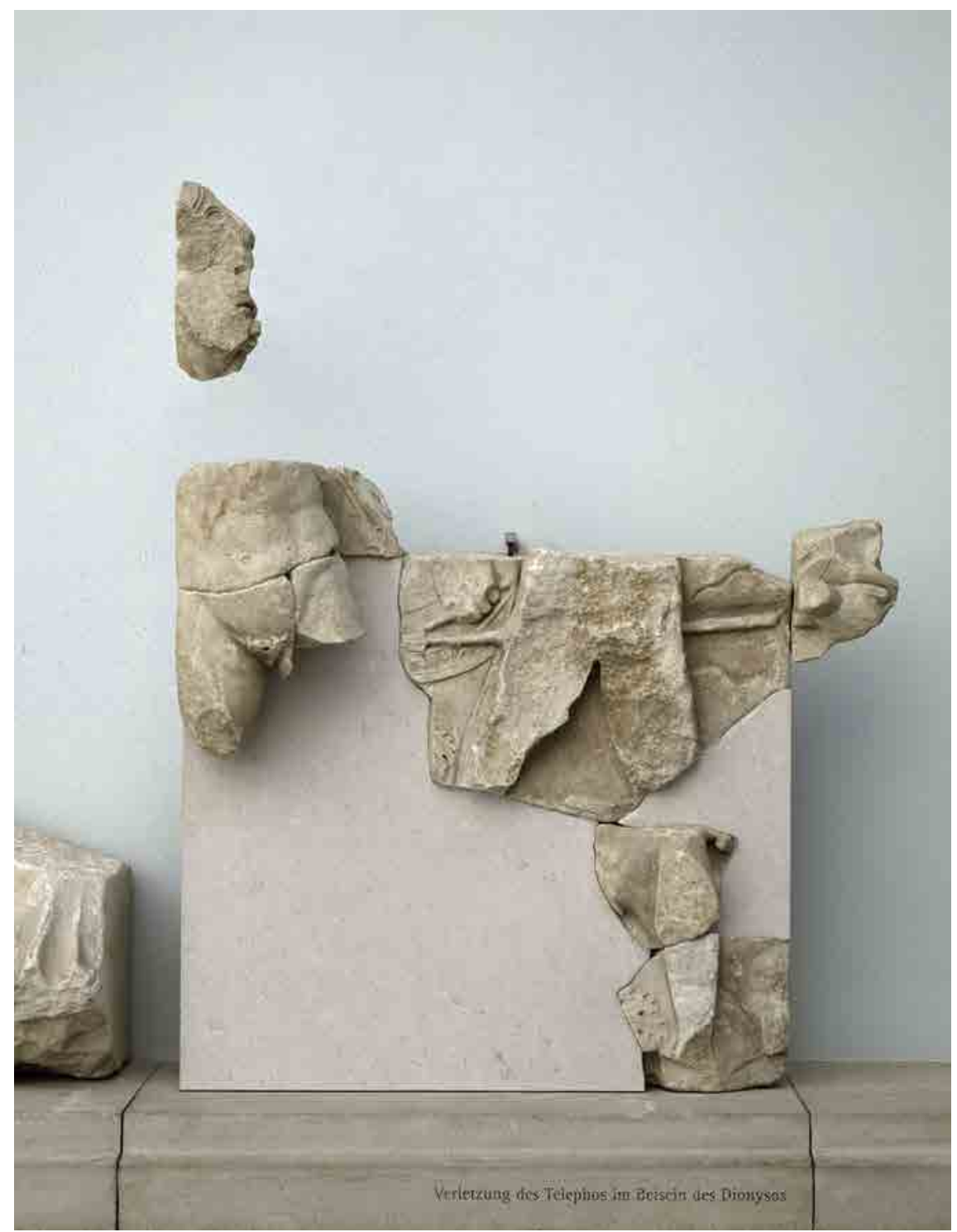

FIG. 3.5

The wounding of Telephus by Achilles, from the Pergamon Great Altar

(C) STAATLICHE MUSEEN ZU BERLIN, ANTIKENSAMMLUNG, PHOTOGRAPHER: JOHANNES LAURENTIUS

ness. In selecting the main features of Telephus' life in order to depict them on one of the most emblematic monuments in Pergamon, it was inevitable that the artists should draw on a manifold and complex iconographic heritage. Moreover, in the specific case of the Mysian battle the artists could have 
relied upon paradigms not limited only to epic and tragedy but also open to the influences of archaic elegy and lyric. The papyrological discoveries testify to the interest in such compositions on the part of the Greek population of Ptolemaic and Roman Egypt, and from this point of view one of the most important examples is the papyrus of Archilochus' Telephus elegy discussed above. It cannot be excluded, therefore, that in another corner of the Greek Hellenistic world the Pergamene scholars, who were in constant competition with Alexandria, devoted their erudition to the recovery of similar lyric and elegiac poems. Indeed, the library of Pergamon, which had been planned by the Attalids with storage rooms for the books and a main room for learned discussions and convivial meetings, and which was adorned with statues of authors of the past such as Herodotus, Alcaeus, and Timotheus, ${ }^{38}$ can be considered a privileged place not only for the conservation of the literary heritage of the past but also for the elaboration of a taste and an iconographic tendency which took into account all the previous, diverse literary influences. Among these a significant role could have been played by Archilochus' narrative elegy and Pindar's poems, in which the myth of Telephus was handled with special attention to the contemporary political and historical reality.

\section{Works Cited}

Canfora, L. (1997 $)$. 'Le biblioteche ellenistiche', in G. Cavallo (ed.), Le biblioteche nel mondo antico e medievale. Rome: $5^{-28}$.

Cavallo, G. (1998). 'Ambizioni universali e isolamento di una cultura', in S. Settis (ed.), I Greci. Storia Cultura Arte Società, 2. Una storia greca. III Trasformazioni. Turin: 215247.

Bach, J.N.(1829). Philetae Coi, Hermesianactis Colophoniiatque Phanoclis reliquiae. Halis Sax.

Bianchi Bandinelli, R. (1943). Storicità dell'arte classica. Florence.

Bowie, E. and Elsner, J. (eds) (2009). Philostratus. Cambridge.

Burgess, J.S. (1996). 'The non-Homeric Cypria'. TAPhA 126: 77-99.

D’Alessio, G.B. (2006). 'Note al nuovo Archiloco (P.Oxy. LXIX 4708)'. ZPE 156, pp. 19-22.

Del Freo, M. (1996). 'L' Alcesti di Euripide e il problema della tetralogia'.

pp. 197-213.

38 On the library of Pergamon see Cavallo (1998) 233-234, Hoepfner (1996) 40-46, and Canfora $\left(1997^{4}\right)$, 13. For a collection of the evidence on the library of Pergamon see Platthy (1968) 159-165. 
Dreyfus, R. and Schraudolf, E. (eds) (1996). Pergamon: the Telephos Frieze from the Great Altar, I. Austin-San Francisco.

Fantham, E. (2009). 'Telephos at Rome', in J.R.C. Cousland and J.R. Hume (eds), The Play of Texts and Fragments. Essays in Honour of Martin Cropp. Leiden: 421-432.

Ghiron-Bistagne, P. (1976), Recherches sur les acteurs dans la Grèce antique. Paris.

Ginzburg, C. $\left(1981^{3}\right)$. Indagini su Piero. Il Battesimo, il ciclo di Arezzo, la Flagellazione di Urbino. Turin.

Gombrich, E.H. (1966). Norm and Form. Studies in the Art of the Renaissance London. Handley, E.W. and Rea J. (1957). The Telephus of Euripides. BICs Suppl. 5. London.

Haubold, J. (2005). 'Heracles in the Hesiodic Catalogue of Women', in R. Hunter (ed.), The Hesiodic Catalogue of Women. Constructions and Reconstructions. Cambridge: $85^{-98 .}$

Heilmeyer, W.-D. (1996). 'History of the display of the Telephos frieze in the twentieth century', in Dreyfus and Schraudolf (eds) (2006): 29-38.

Heitsch, E. (1963). Die griechischen Dichterfragmente der römischen Kaiserzeit, I. Göttingen.

Hoepfner, W. (1996). 'The architecture of Pergamon', in Dreyfus and Schraudolf (eds) (2006): 23-58.

Horak, U. (1992), Illuminierte Papyri, Pergamente und Papiere, I. Wien.

Kim, L. (2010). Homer between History and Fiction in Imperial Greek Literature. Cambridge.

Lulli, L. (2011). Narrare in distici. L'elegia greca arcaica e classica di argomento storicomitico. Rome.

Massa-Pairault, F.H. (1998). 'Examen de la frise de Télèphe'. Ostraka 7 (1-2): 93-157.

Moreno, P. (1977). 'Da Lisippo alla scuola di Rodi', in R. Bianchi Bandinelli (ed.), Storia e civiltà dei Greci. La cultura ellenistica. Le artifigurative. Milan: 412-460.

Nicolosi, A. (2005). 'Recuperi di lirica greca arcaica da papiri'. A\&R 50: 80-94. (2006). 'Sul nuovo Archiloco elegiaco (P. Oxy. 4708 fr. 1)'. Eikasmos 17: 25-31.

(2007). Ipponatte, Epodi di Strasburgo. Archiloco, Epodi di Colonia (Con un'appendice su P. Oxy. LXIX 4708). Bologna.

Obbink, D. (2006). 'A new Archilochus poem'. ZPE 156: 1-9.

Papini, M. (2007). 'Dedica, datazione e stili del grande altare di Pergamo'. ArchClass 8: 371-395.

Pellin, A. (2010). 'Il mito di Telefo nell'epos ellenistico:l' 'Epyllium Telephi”, fr. ep. adesp. 3 Powell', in E. Cingano (ed.), Tra panellenismo e tradizioni locali. Generi poetici e storiografia. Alessandria: 519-540.

Pickard-Cambridge, A.W. (1933). 'The inscription from Aexone and the story of Telephus in Sophocles' plays', in J.U. Powell and E.A. Barber (eds), New Chapters in the History of Greek Literature, III. Oxford: 69-84.

Platter, C. (2007). Aristophanes and the Carnival of Genres. Baltimore. 
Platthy, J. (1968). Sources on the Earliest Greek Libraries with the Testimonia. Amsterdam. Privitera, G.A. (1982). Pindaro. Le Istmiche. Milan.

Robert, C. (1887). 'Beiträge zur Erklärung des pergamenisches Telephosfrieses (I-II)'. JDAI 2: 244-259.

- (1888a). 'Beiträge zur Erklärung des pergamenisches Telephosfrieses (III-IVv)'. JDAI 3: 45-65.

- (1888b). 'Beiträge zur Erklärung des pergamenisches Telephosfrieses (VI-VII)'. JDAI 3: 87-105.

Sbardella, L. (2000). Filita. Testimonianze e frammenti poetici. Introduzione, edizione e commento. Rome.

Schefold, K. (1992). Gods and Heroes in Late Archaic Greek Art. Cambridge.

Settis, S. (2006). 'Il Papiro di Artemidoro: un libro di bottega e la storia dell'arte antica', in C. Gallazzi and S. Settis (eds), Le tre vite del Papiro di Artemidoro. Voci e sguardi dall'Egitto greco-romano. Catalogo della mostra, Torino, Palazzo Bricherasio, 8 febbraio - 7 maggio 2006. Milan: 20-65.

Severyns, A. (1928). Le cycle épique dans l'école d'Aristarque. Liège-Paris.

Shanks, M. (1999). Art and the Greek City State. An Interpretive Archaeology. Cambridge. Shapiro, H.A. (1994). Myth into Art. Poet and Painter in Classical Greece. London.

Snodgrass, A. (1998). Homer and the Artists. Text and Picture in Early Greek Art. Cambridge.

Spanoudakis, K. (2002). Philitas of Cos, Leiden.

Stewart, A. (1996). 'A hero's quest. Narrative and the Telephos frieze', in Dreyfus and Schraudolf (eds) (2006): 39-52.

Sutton, D.F. (1974). 'A handlist of satyr plays'. HSCPh 78: 107-143.

Taplin, O. (2007). Pots \& Plays. Interactions between Tragedy and Greek Vase-Painting of the Fourth Century B.c. Los Angeles.

Vetta, M. (2001). 'Immagini e poesia', in M. Vetta (ed.), La civiltà dei Greci. Forme, luoghi e contesti. Rome: $185^{-223}$.

Virgilio, B. (1993). Gli Attalidi di Pergamo. Fama, eredità, memoria. Pisa.

West, M.L. (1985). The Hesiodic Catalogue of Women. Its Nature, Structure, and Origins. Oxford.

- (1995). 'The date of the Iliad'. $M H$ 52: 203-219.

- (2006). 'Archilochus and Telephos'. ZPE 156: 11-17.

(2013). The Epic Cycle. A Commentary on the Lost Troy Epics. Oxford. 


\title{
Choral Performance and Geometric Patterns in Epic Poetry and Iconographic Representations
}

\author{
Jesús Carruesco
}

The aim of this paper is to consider the relationship between some descriptions of choral performances in Greek archaic epic and the pictorial patterns and functions of artistic artifacts, mainly pottery, of the Geometric period. ${ }^{1}$ The relationship between Homeric and Hesiodic epic and Mycenaean or Geometric art has been a frequent subject of research. ${ }^{2}$ As a general methodological point, I wish to state from the beginning that I am not concerned here with the search for influences one way or another, trying, for example, to individuate specific mythic representations from the epic poems on some vases, as illustrations of certain passages from the poems which the artist might have had in mind. I view text and image as parallel means of expression, in this case of a cultural pattern fundamental for Greek culture, especially in the Archaic and Classical periods, that I would call 'chorality'. By this term I mean a symbolic construction which found various expressions in actual performances with different combinations of dance, music and song, eventually crystallizing into specific genres or subgenres of choral lyric. Beyond choral performance, however, chorality also functions as a cultural paradigm which informed different fields of the community's experience, such as agonistic or juridical procedures or, in the present case, other artistic discourses such as epic poetry or pictorial art. As Barbara Kowalzig puts it in her recent book on performances of myth and ritual, 'the chorus (...) supplies the fundamental communal aspect of

1 For a complete list of descriptions of choral performance in epic poetry see Richardson (2011); for a study of the iconographic representations of choruses in early Greek art see Buboltz (2002). The argument presented here relies partially on the assumption that the epic passages I am analysing were functional in the Geometric and Orientalizing periods (8th-7th c. BC), probably_but not necessarily —in the context of the poems more or less in the form in which they have come down to us. In any case, the correspondences here observed between the epic texts and the iconographic motifs and patterns from the Geometric period suggest a relevant connection, which even a low chronology for the Homeric poems would not rule out, given the traditional nature of oral poetry.

2 Cf. Snodgrass (1998) among others.

(C) JESÚS CARRUESCO, 2016 | DOI: 10.1163/9789004314849_005

This is an open access chapter distributed under the terms of the Creative Commons AttributionNoncommercial 3.o Unported (CC-BY-NC 3.0) License. 
religious ritual, and perhaps of many other aspects of Greek religion and history (...) without the chorus, neither community nor communal re-enactment could exist'. ${ }^{3}$

Obviously, the chorus by definition implies a communal aspect, in that it involves a plurality of people taking part in it, but also in that it requires a community of spectators watching it. The audience is a fundamental part of the performance; accordingly, it appears in all the epic descriptions of choral song and dance, and each time it is the visual dimension of the watching which is emphasized. But what is the nature and the object of this looking which establishes the essential bond between the chorus and its audience, the channel through which the performative action of song and dance operates on the onlookers? And how can this be compared to the iconographic record that has come down to us?

Let us consider in the first place the description of the shield of Achilles in the Iliad. ${ }^{4}$ As for its shape and layout, we may safely assume it is a round shield, with concentric circles made up of iconographic bands. There are three choral performances represented on it, all of which combine song and dance: a wedding procession, a vintage song, and, in the final, most detailed scene, a mixed chorus of boys and girls performing before the whole community. The first two scenes present processional choruses, and their descriptions are embedded in the overall description of their respective occasions, the wedding and the vintage. The last chorus, however, constitutes a scene in itself, surely occupying an independent band of the shield, the last one before the outermost ring $\left(\alpha^{\prime} \nu \tau \cup \gamma \alpha\right)$ with the representation of Okeanos, probably in the form of a snake. This layout is suggested by the introduction of the word marker $\dot{\varepsilon} v \delta \dot{\varepsilon}$ ... $\pi 0^{\prime} x \mid \lambda \lambda \varepsilon$ (590, 'therein he inlaid ...') at the beginning of the scene, with $\dot{\varepsilon} v$ $\delta^{\prime}$ ' $\tau^{\prime} i \theta \varepsilon \mathrm{l}$ (607, 'therein he set ...') introducing the next—and final—ring. These markers are repeated six times (with some further internal repetitions in the third and fourth rings) in the course of the description and they delimit the iconographical bands that make up the shield:

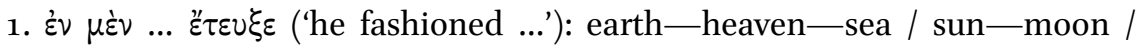
constellations: Pleiades-Hyades-Orion-Bear.

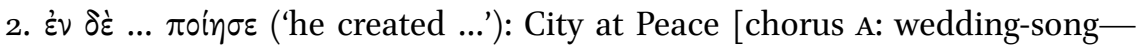
judicial scene] / City at War.

3 Kowalzig (2007) 394-395. For the chorus in Archaic Greece cf. Calame (2001), Lonsdale (1993), Kowalzig (2007), Athanassaki and Bowie (eds) (2011).

4 Il. 18.478-608; Richmond Lattimore's translation is adopted throughout this chapter. Cf. e.g. Duethorn (1962), Taplin (1980), Becker (1995), Nagy (2003). 
3. $\varepsilon^{\prime} \nu \delta^{\prime} \varepsilon^{\prime} t \theta \varepsilon \varepsilon$ (3 times): works of the seasons: ploughing-reaping-vintage [chorus B] ('he set ...')

4. $\dot{\varepsilon} \nu \delta \dot{\varepsilon}$... $\pi 0$ ín $\sigma \varepsilon$ (2 times): cattle: oxen (+ dogs + lions) —sheep.

5. $\dot{\varepsilon} \nu \delta \dot{\varepsilon} . . . \pi 0$ ix $x \lambda \lambda \varepsilon$ ('he inlaid ...'): chorus C.

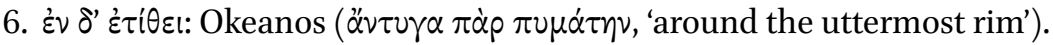

We find in these markers different verbs which allude to the making of the shield and the scenes placed upon it by its maker: $\tau \varepsilon^{\prime} \chi \omega, \pi 0 \varepsilon^{\prime} \omega, \tau i \theta \eta \eta$. But $\pi$ ol$x^{\prime} \lambda \lambda \omega$, used only for the choral scene, introduces an additional meaning: the concept of $\pi$ oi $x i \lambda \mu \alpha / \pi \circ x_{1} \lambda \lambda^{\prime} \alpha$. In other epic passages, weapons, chariots, jewels, and textiles are qualified as $\pi 0 x x^{i} \lambda{ }^{5}{ }^{5}$ Archaeology has indeed provided outstanding examples of weapons and chariots with figurative decoration (e.g., the magnificent series of votive shields at Olympia). As for the relevance of textiles and jewels in this context, it is interesting to observe that in the Homeric poems, while they share with weapons and chariots the epithet $\pi \circ x^{\prime} i \lambda \circ$, it is only in describing those objects that explicit mention is made of the representations $(\pi \circ x i \lambda \mu \alpha \tau \alpha)$ wrought or woven on them. ${ }^{6}$ Furthermore, by using the imperfect tense $\pi$ oi $x \backslash \lambda \lambda \varepsilon$, which suggests that the representations on the shield are being wrought by Hephaestus before our very eyes, the poet calls attention to the process of creation rather than the finished product, and in the poems this happens mainly with weaving (e.g. Helen weaving a tapestry with the deeds of heroes in 3.125-128)..$^{7}$ Thus, the use of $\pi 0^{\prime} x(\lambda) \varepsilon$ would have evoked in the audience textiles and weaving as much as weapons and forging, and significantly both kinds of products are found in the description of the chorus that is

5 Il. 3.327 (weapons), 4.226, 5.239 (chariots), 6.289 (peploi), etc.

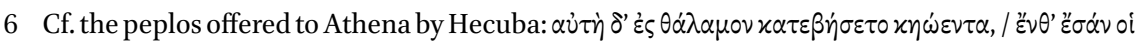

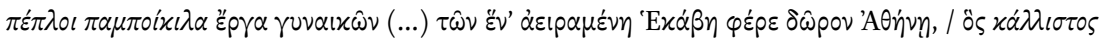

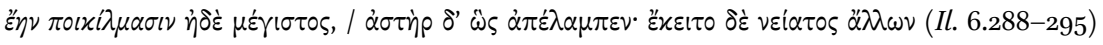
'She descended into the fragrant store-chamber. There lay the elaborately wrought robes, the work of Sidonian women (...) Hekabe lifted out one and took it as gift to Athene, that which was the loveliest in design and the largest, and shone like a star. It lay beneath the others.' (tr. Lattimore). For the correspondences between the description of the robes of the dancers on the shield and similar passages in the Homeric poems, cf. Taplin (1980) 9-11. Apart from textiles, figurative representations are also mentioned and described on another piece

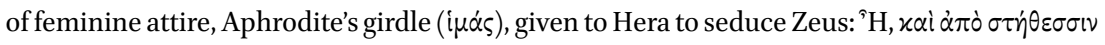

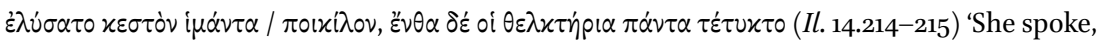
and from her breasts unbound the elaborate, pattern-pierced zone, and on it are figured all beguilements ...'

7 Cf. Il. 22.441. The parallel with Helen's weaving evokes a supplementary meaning: the analogy to the composition of the poem which is also relevant in the case of the shield. Cf. below, n. 12 . 
being introduced by that verb, namely, in the shining daggers and the beautiful robes of the dancing boys and girls (595-598). The shield's $\pi$ o $x i \lambda i \alpha$ is also that of the chorus represented in this particular section, manifest in the beauty of the objects displayed by the dancers as well as in their ability to trace figures on the ground with their movements.

At the same time, the term $\pi 0 x i \lambda \lambda \omega$ carries also a connotation of attraction, seduction, even deceit, equally relevant to the presentation here of the chorus as a variegated creation designed to make a visual impact on those watching it. In this sense, the chorus, too, is conceptualized as an $\alpha \gamma \alpha \lambda \mu \alpha$, it is itself a precious artefact, just like the shield on which it is represented, the beautiful robes of the dancers, and the garlands and daggers they carry. The chorus is an $\dot{\alpha} p \mu o v i \alpha$, also in the physical sense of an ensemble made up of several pieces which are artfully assembled through the interlocking hands of the dancers

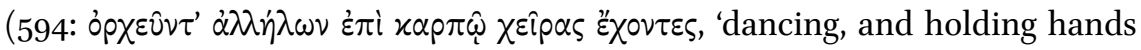
at the wrist'). ${ }^{8}$

This constructed character of the chorus is brought out from the very beginning of the passage through a simile (591-594). This simile is typically choral rather than epic, as it provides not a parallel scene out of everyday life, but a mythical paradigm, by comparing this figured xopós to that built for Ariadne by Daedalus. It is normally observed, and rightly so, that the allusion here is pri-

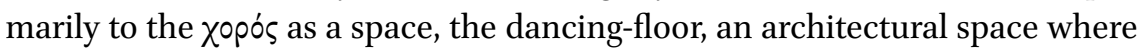
the dance takes place. ${ }^{9}$ However, the passage is better understood in all its richness if we do not separate the two senses of the word Хopós, as it is precisely through the choral performance that the space is defined as a Xopós. This is paralleled, on the larger scale, in the fact that the description of the shield is not the description of the final product, but rather of the process of its making in Hephaestus' forge.

But this comparison contains another ambiguity, also intrinsic to the choral performance, as it refers at the same time to the making of the shield and to the dance itself, for both of which the Cretan xopós functions as a mythical model. The first aspect, the chorus as a $\delta \alpha i \delta \alpha \lambda \circ v$, a technical, constructed reality, is brought out by the first part of the comparison, $\Delta \alpha i \delta \alpha \lambda \circ \varsigma$ ทे $\sigma x \eta \sigma \varepsilon$ ('Daedalus fashioned'), which recalls in a personified form the terms $\delta \alpha 1 \delta \alpha \lambda \lambda \omega$ and $\delta \alpha i \delta \alpha \lambda \alpha$ $\pi \circ \lambda \lambda \dot{\alpha}$, used at the very beginning of the ekphrasis of the shield to describe,

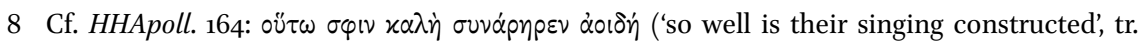
M.L. West). The ensemble here is that which is formed by the voices of the chorus of Delian girls, and this well-adjusted ensemble constitutes the condition for that chorus' extraordinary mimetic powers.

9 For the spatial dimension of $\chi$ opós (and its relationship to $\chi \hat{\omega}$ pos), cf. Boedeker (1974) 85-91. 
respectively, the fabrication of the object and the representations wrought on

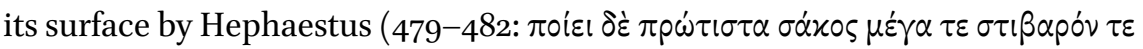

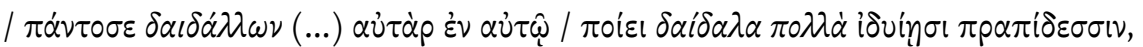
'First of all he forged a shield that was huge and heavy, / elaborating it about, (...) and upon it / he elaborated many things in his skill and craftsmanship').. ${ }^{10}$ But the second part of the comparison, through the allusion to Ariadne as the maiden who is to dance in Daidalos' chorus, refers to the Xopós as performance, and to its function as the mythical archetype re-enacted by the boys and girls represented on the shield, who of course are themselves the paradigm for any choral performance in the city (note the chiastic correspondence in the relative

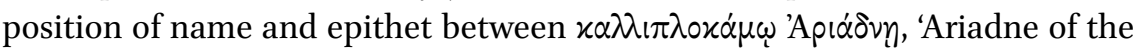
lovely tresses', and $\pi \alpha \rho \theta \varepsilon$ vol $\alpha \lambda \varphi \varepsilon \sigma i \beta o l \alpha l$, 'young girls, sought for their beauty with gifts of oxen', in the same metrical place at the end of successive lines, 592-593). So, on the one hand the construction of the yopós of Ariadne by Daedalus is the model imitated by Hephaestus fabricating his shield, which in turn constitutes the model for the Homeric singer composing his poem. ${ }^{11}$ On the other hand, the beautiful Ariadne dancing in her xopós is herself the model for the boys and girls dancing in the chorus on the shield of Achilles, which, given its status as an ideal representation of the polis at peace, itself constitutes the paradigm for every choral performance in the real world. In this way, this pattern defines, in a kind of mise en abime, a multiple mimetic relationship, both inwards and outwards from the chorus.

Thus, in the first of the two comparisons used to describe the chorus on the shield of Achilles, the mimetic nature of the choral performance comes out (note " $x \varepsilon \lambda \circ v)$. The chorus is a mimetic reality in the active, performative sense that it endlessly bridges the divide between the inside world of the representation and the outside world of the public watching it, projecting the one onto the other and making them interchangeable in a mirror-like way. We may find an example of this pattern being explicitly worked out in a true choral lyric text, at the end of Pindar's Pythian $9 .{ }^{12}$ There, the chorus that greets Telesicrates as he returns home victorious from Delphi re-enacts the victory of his homonymous ancestor in a wedding contest set up by a Libyan king, who in turn was imitating the competition designed by Danaos to marry his daughters - who are explic-

10 On the values attached to the $\delta \alpha^{i} \delta \alpha \lambda \alpha$ in Greek thought cf. Frontisi-Ducroux $\left(2000^{2}\right)$, Morris (1995).

11 The multiple parallels and correspondences between the shield and the whole Iliad are brought out in different ways by Taplin (1980) and Nagy (2003).

12 On Pythian 9 see Carey (1981) 65-103, Carson (1982). For a choral reading of the Danaides' myth in this ode cf. Myers (2007). 
itly referred to as a \opós-, bringing out the mimetic relationship between the Panhellenic mythical event, the local ancestral past and the present choral performance. ${ }^{13}$ This makes the chorus not only a synchronic chain of performers but also a diachronic chain of successive re-enactments imitating one another, a symbolic model that, following this mimetic logic, projects into and fashions the future chain of reperformances. In the same way as the heroic myth (Danaos) and its imitation by Telesicrates' ancestor have functioned as paradigms for Telesicrates' victory, the description of this victory and the allusions to the occasion of the first performance of the poem will function as symbolic paradigms for future reperformances and their eventual occasions (which may not necessarily be epinician, just as Telesicrates' Pythian victory is not a marriage).

A further example of this mimetic mise en abime of the choral performance is provided in the Homeric Hymn to Apollo by the description of the dances of the Ionians gathered at Delos. ${ }^{14}$ By setting up the $\alpha \gamma(\omega)$, which includes song and dance, the Ionians give pleasure ( $\sigma \varepsilon \tau \dot{\varepsilon} \rho \pi \circ v \sigma \iota)$ to Apollo, but as they gather to watch these performances, which of course include hymns to Apollo and all the gods (where the gods may be shown taking part in the dance themselves, as they are later in this particular hymn, ll. 189-206), the Ionians are in turn being watched, as if they had become gods themselves, by anyone (in primis the public of the Homeric Hymn, through the voice of the blind man from Chios)

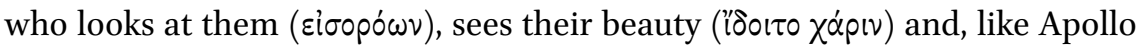

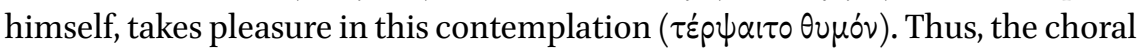

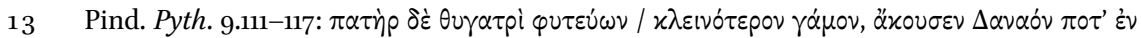

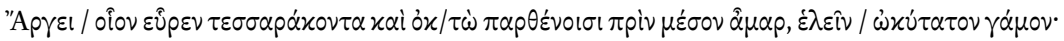

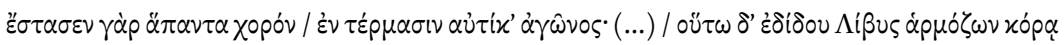

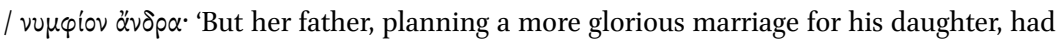
heard how in Argos Danaos in his day had devised a means to gain a most speedy marriage for his forty-eight unwed daughters before noon: at once he placed the whole throng at the finish line of the contest (...) The Libyan made a similar offer for matching a groom to his daughter' (tr. W.H. Race).

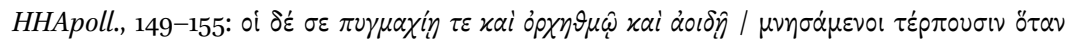

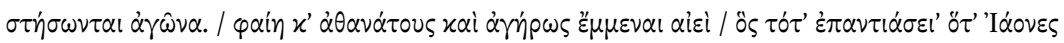

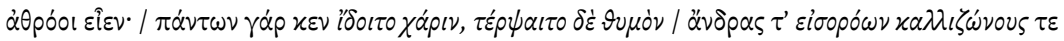

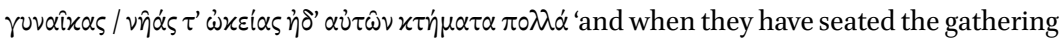
they think of you and entertain you with boxing, dancing, and singing. A man might think they were the unaging immortals if he came along then when the Ionians are all together: he would take in the beauty of the whole scene, and be delighted at the spectacle of the men and the fair-girt women, the swift ships and the people's piles of belongings' (tr. M.L. West). 
gaze acts both ways, by giving and taking pleasure ( $\tau \dot{\varepsilon} p \psi(\varsigma)$ through the creation and contemplation of beauty ( $\chi \alpha \dot{p} ı \varsigma)$; and this action works not only in a dual, reciprocal relationship, but in a chain of successive links that is also a chain of successive performances, as implied by the different levels involved: the gods, the Deliades, the Ionians and, through the appropriation of the choral model by the epic singer which is at work here (as in the Iliadic passage), the successive audiences of the present poem. ${ }^{15}$

But let us return to the chorus on the shield of Achilles. If we now proceed from the mythical model (Daedalus' and Ariadne's chorus) to the description of the performance itself and focus our attention on its perception by the spectator, which is precisely the position in which the describing voice of the poet puts himself and his audience, we can observe two relevant aspects: (i) as we have just seen in the Homeric hymn, the beauty of the chorus impresses itself upon the community watching it through the desire it awakes in them (i $\mu \varepsilon-$

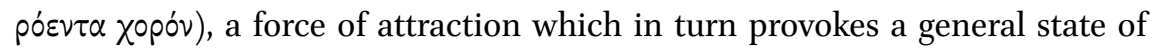

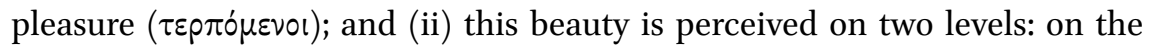
one hand, through the contemplation of the physical beauty of the dancers, of their robes, and of the objects they carry (garlands and daggers); on the other hand, through the contemplation of what we might call the syntax of the chorus, which manifests itself in two ways: (a) in the interlocking hands forming

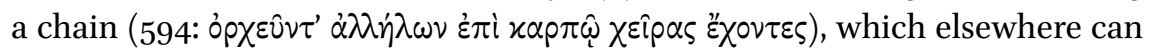

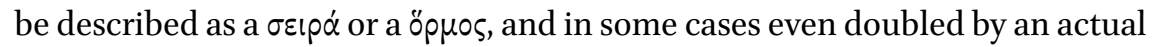
rope; and (b) in the patterns their movements trace on the ground. These are basically geometric, abstract patterns, namely: (i) the circle, compared here to a potter's wheel (and xúx入os will become almost a by-word for chorus, particularly, though perhaps not exclusively, dithyrambic choruses); (ii) the straight lines ( $\sigma \tau i \chi \chi \varepsilon \varsigma)$, which through their intersection form a grid or a web (602: $\theta p \varepsilon-$

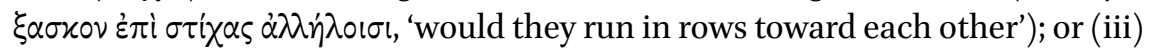
the sinuous or rotating lines traced by the tumblers evolving in the middle of the space, whether circular or quadrangular, which has just been defined by

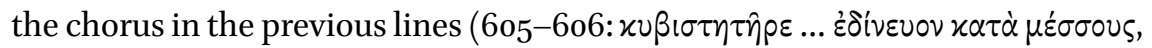
'two acrobats ... revolving among them').

15 It may be noted, of course, that, this being an epic poem, these performances can only be choral in a metaphorical sense, unlike in the previous example from Pindar. Chorality functions here as a symbolic paradigm, transferring the articulating and self-repeating dynamics of choral mimesis to other media, such as epic poetry, and thereby conferring to them the authority and efficiency of actual ritual performance, cf. Carruesco (2010). This observation, in turn, could help us understand the symbolic mechanism at work in the reperformance of choral lyric in non-choral (e.g. sympotic) contexts. 
To these two levels of the visual projection of the choral performance upon the spectators, namely the beauty of the dancers and the patterns they define with their movements, we must still add a further one, which is also conceptualized as a visual aspect of the performance: the song itself, and especially the images, symbolic or narrative, which it evokes in the public. The song is here alluded to by the term $\mu \circ \lambda \pi \dot{\eta}$, which is introduced by the tumblers ( $\mu \circ \lambda$ $\pi \hat{\eta} \varsigma \dot{\xi} \xi \dot{\alpha} \rho \times \chi v \tau \varepsilon \varsigma)$, and which, depending on whether or not we accept as genuine (in whatever sense of the word) the problematic lines 604-605, is to be assigned

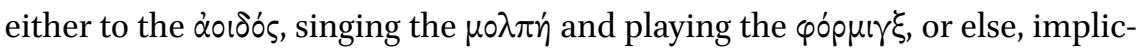
itly, to the chorus itself - unless, as Revermann proposes, we postulate a lacuna here, a musical instrument being perhaps necessary in this context. ${ }^{16}$

As for the images the choral song and performance can bring before the eyes of the public, they can be found in the other, non-choral scenes of the shield, at two levels: on the one hand, in the description of the very occasions for the choral performance in the life of the community (the wedding, the war and its outcome, be it the triumph song or the mourning for the dead, and the main events of the agricultural year); on the other hand, in some symbolic motifs very frequent in choral song as self-referential images, particularly the astral and the animal imagery. A cursory glance at Alcman's first partheneion (PMGF1) is enough to provide us with representative examples of both, with the choregoi being compared to racing horses and the Pleiades presented as a rival chorus. ${ }^{17}$

16 Revermann (1998). But the absence of an doı $\delta$ ós in this chorus would perhaps not be out of place in a text in which the epic singer is appropriating the choral model, if we take into account other such cases, such as the proem to Theogony, in which the chorus of the Muses, without a solo singer, confers to Hesiod and to all epic ḋolooi their voice; or the meeting of the girls at Delos and the blind man from Chios, in the Homeric Hymn to Apollo.

17 The passage concerning the Pleiades (ll. 6o-63) has been the subject of much debate: the Pleiades can be a rival chorus of girls (with perhaps the implication of the speaking chorus presenting themselves as the Hyades), or the constellation itself (Priestley [2007] 190-193); but the name could also simply mean 'the doves', and allude to the two choregoi (Puelma [1995]). In any case, the astral reference here rests assured by the comparison to the onplov

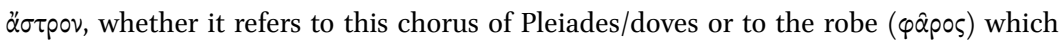
the girls are offering to the goddess, as Priestley has recently argued (I am grateful to the anonymous referee for this reference). As for the Pleiades, I take the name to refer both to the rival chorus and the constellation (similarly Segal [1998]). Cf. Call. fr. 693 Pf., where the Pleiades are presented as the first to have set up a chorus of parthenoi, thus embodying

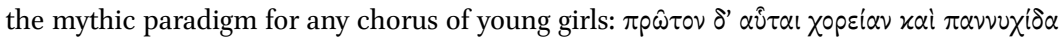
$\sigma \cup v \varepsilon \sigma \tau \dot{\eta} \sigma \alpha \nu \tau 0 ~ \pi \alpha \rho \theta \varepsilon v \varepsilon \dot{0} 0 v \sigma \alpha \mathrm{l}$. For the importance of astral references in Alcman's work cf. Ferrari (2008). 
TABLE 1

Level A Level в (imagery)

Dancers $\quad$ Astral bodies: sun, moon, Pleiades, Hyades, Orion, Arktos (485-489) > hymenaios (imagery: Orion attacking the Bear), (cf. Alcm. PMGF 1.6o).

Animals: cows ( $573 \beta \circ \omega \hat{~}>593 \pi \alpha \rho \theta \varepsilon \dot{v}$ ol $\alpha \lambda \varphi \varepsilon \sigma i \beta \circ / \alpha \mathrm{l})$

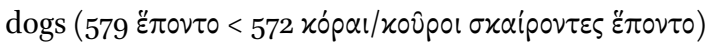

\begin{tabular}{|c|c|c|}
\hline $\begin{array}{l}\text { Patterns of } \\
\text { dance }\end{array}$ & xúx入os & 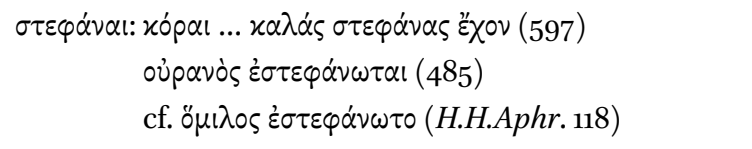 \\
\hline & $\sigma \tau \tau^{\prime} \chi \chi \varepsilon \varsigma$ & 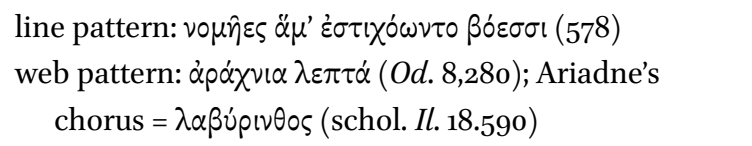 \\
\hline & $\begin{array}{l}\delta^{\prime}(\nu \eta \\
\left(=\sigma \tau \rho \circ \varphi \eta^{\prime}\right)\end{array}$ & 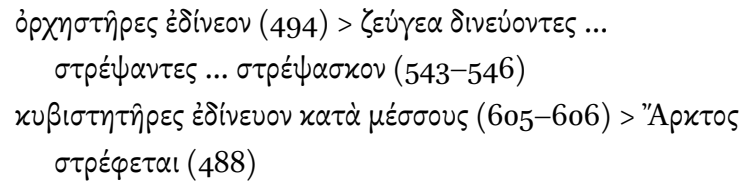 \\
\hline
\end{tabular}

Thus, the two aspects of the visual perception of the choral performance we have defined, the beauty of the dancers and the movements of the chorus, can function also at a second level, that of metaphoric imagery. On the shield, this is brought out in a whole series of textual parallels that mimetically link the three choral scenes to other passages of the poem, particularly those within the shield itself, which can be summarized by the diagram above (table 1).

On the shield, the astral band (483-489) immediately precedes the í $\mu \varepsilon$ v $\alpha 1 \circ$, where astral images are a regular feature (Hesperos, the stars, the moon, the sun), while the animal band, which is composed of two scenes-one narrative (573-586), the other emblematic (587-589) - is framed, significantly, by the second and third choral scenes, both of which contain terms that allude to

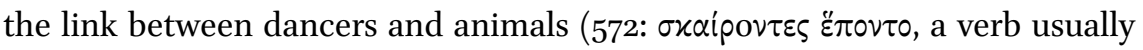
applied to animals; 593: $\pi \alpha p \theta \varepsilon \dot{v} 0 \mathrm{\alpha} \alpha \varphi \varphi \varepsilon \sigma i \beta o l \alpha l$, an adjective stressing the equivalence of the maids and the cattle).

These links between the choral and the non-choral scenes on the shield apply not only to the beauty of the dancers, but also to the second visual level 
mentioned above, that is, the geometric patterns defined by their movements. Since this is at the end of the ekphrasis, the audience of the poem could not fail to notice in the description of these patterns some verbal echoes from previous scenes, which are also relevant here. The verb $\delta$ ivé $\omega$ has already appeared twice: in the first choral scene, in which it is applied to the dancing boys in

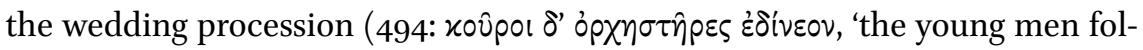
lowed the circles of the dance'); and later on, in the ploughing scene, in which it describes the change of direction of the team when the ploughman arrives

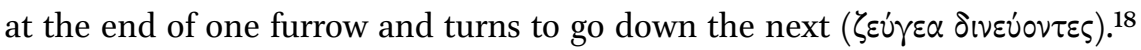
The pattern described here is the meander, which, when applied to writing,

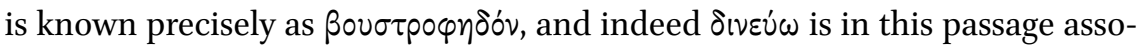
ciated with $\sigma \tau \rho \varepsilon \dot{\varepsilon} \varphi \omega$, used twice in quick succession, in the aorist participle

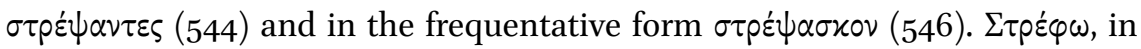

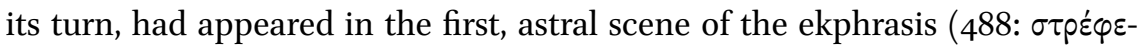
$\tau \alpha \mathrm{l}),{ }^{19}$ applied to the movement of the Bear, as a maiden turning round always in the same place, out of fear of an assault by Orion, an erotic scenario that is a characteristic motif in chorus descriptions and representations, namely, the abduction from the chorus. ${ }^{20}$ As for her endlessly circular movement, the mention of her alternative name, the Chariot, calls forth the image of the wheel, which in turn anticipates the potter's wheel to which the circular dance of the last scene will be compared. Furthermore, this circular motif echoes the pre-

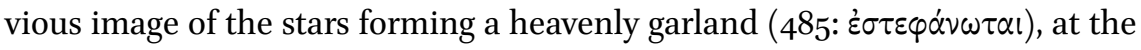
centre of which we must picture this revolving maiden, who never gets to bathe in the Ocean (another choral motif: the girls bathing in the spring or the river

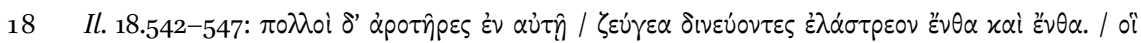

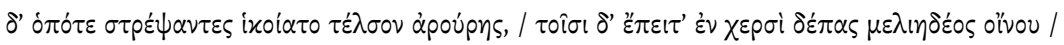

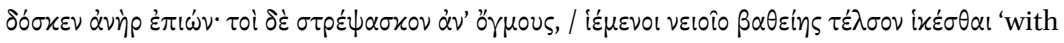
many ploughmen upon it / who wheeled their teams at the turn and drove them in either direction. / And as these making their turn would reach the end-strip of the field, / a man would come up to them at this point and hand them a flagon / of honey-sweet wine, and they would turn again to the furrows / in their haste to come again to the end-strip of the deep field'.

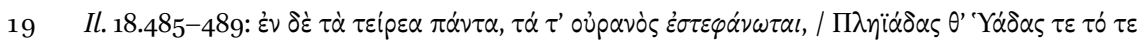

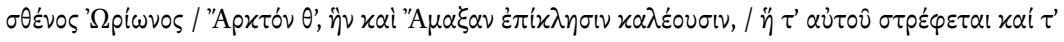

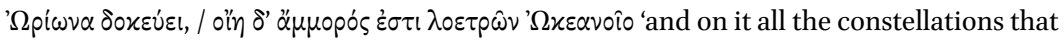
festoon the heavens, / the Pleiades and the Hyades and the strength of Orion / and the Bear, whom men give also the name of the Wagon, / who turns about in a fixed place and looks at Orion / and she alone is never plunged in the wash of the Ocean'. Cf. Il. 16.179-186; HHAphr. 117-121. The motif has been analyzed most recently by S. Langdon, in her study of Geometric iconography: Langdon (2008) 197-233. 
before going to the Xopós, cf. Hes. Th. $5^{-6)}$ ). The garlands will also reappear in the final choral scene, worn or carried by the dancing girls, just as the mention of Okeanos in this innermost band anticipates his final appearance as the outermost ring of the shield.

The pertinence of this pattern of concentric circles-one of the most common motifs in the contemporary iconographic repertoire-in relation to the perception of the choral performance is confirmed by the description of a sim-

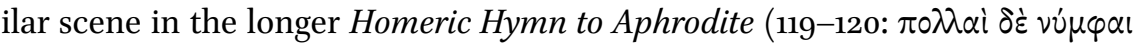

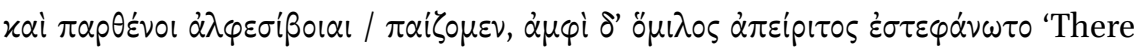
were many of us dancing, brides and marriageable girls, and a vast crowd ringed us about'). Here, the outer circle of spectators watching the chorus becomes itself a garland ( $\dot{\varepsilon} \sigma \tau \varphi \dot{\alpha} \nu \omega \tau 0)$ through this contemplation, a clear example of the articulating power of choral performance to project the images it creates upon the surrounding space-physical and social space alike - and to fashion it into the articulate order those images evoke. In this sense we may interpret the placing of the first choral scene after the description of the heavenly bodies as projecting this image of cosmic order upon the following scene, the judicial scene in the agora, to which it is inextricably linked through the opposi-

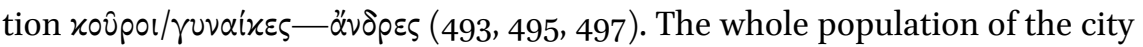
is thus distributed into two halves, with the women with their children and the young people taking part in the wedding scene as audience and actors, respectively, while the male adults (including the elders, acting as judges) participate, again both as witnesses and protagonists, in the judicial procedure, so that both episodes are presented as two symmetrical parts of a whole representation of the $\delta \hat{\eta} \mu \circ \varsigma$ or $\lambda$ aós forming the city. ${ }^{21}$ In the judicial scene, we find again the spatial order of the inner sacred circle where the elders sit, surrounded by the outer circle of the community watching and taking part in the proceedings. The polarity of the circular disposition here, with two semicircles of supporters to each of the contenders, reflects the tension (vEixos) of the occasion, but at the same time the two talents, which are to be the prize for the victor, foretell, at the outcome of the agonistic procedure, the resolution of this polarization into a renewed unity for the community. But this whole process has already been prefigured in the choral celebration of the wedding scene, which overcomes the sexual tension previously alluded to in the Bear's fear of abduction and rape by Orion, following the pattern rape-marriage so common in Greek myth. This constitutes also a well-known ritual pattern

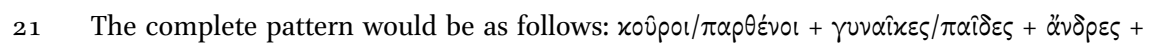

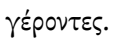


inherent to the initiatory nature of many choruses in Archaic Greece: the symbolic representation in song and dance of tension, rivalry, and conflict, to be finally solved or averted through choral performance itself (e.g. through the choral sequence that accompanied the maturation of young girls into wives and mothers, i.e. partheneion-hymenaios/epithalamios). Thus, the disposition of the first episodes of the description of the shield suggests that a choral ritual pattern projects onto and fashions a political procedure, perhaps reflecting or creating an historical, extra-textual reality, if we consider this text to be contemporary of the complex processes that, for the sake of simplification, are usually named as 'the rise of the polis.' ${ }^{22}$

Let us leave now the circular pattern of the dance and consider the straight line. In the first two choral scenes this constitutes the very structure of the performance, as they are processional dances defining important spatial axes, the first inside the city, linking the oixol brought together by the wedding

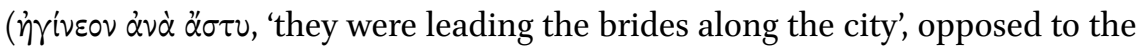
static scene in the agora that follows: $\lambda \alpha o i$ ' siv $\dot{\alpha} \gamma \circ p \hat{n}$ है $\sigma \alpha \nu \dot{\alpha} \theta$ póo, 'the people were assembled in the market place'); the second from the extraurban space of the vineyard (itself defined by a fence, हैpros) back to the city. Elsewhere, we find two paradigmatic examples of these processional dances and of the foundational power attributed to their movement: (i) at the beginning of the Theogony, the chorus of the Muses marching ( $\sigma \tau \varepsilon i \chi \chi 0 v, T h .10)$ from Mount Helicon to Olympus while they sing the divine order of the cosmos, which is the poem itself to which this choral scene is the prelude; and (ii), at the end of the Homeric Hymn to Apollo, the processional paean of the Cretans turned Delphians as they follow the god from the shore at Chrysa to the site of Delphi on Mount Parnassos. ${ }^{23}$ In the description of the shield of Achilles, the $\sigma \tau i x \varepsilon \varsigma$ traced by the final chorus recall the previous scene, in which the shepherds march alongside the cattle while the dogs follow them, an appropriate image

22 Cf. Nagy (2003).

23 This movement, with which the hymn closes, completes the articulation of geographical space centred on Delphi that began with the god leaving Olympus. Thus, the maritime axis Pylos-Chrysa-Delphi corresponds to the inland axis Olympus-TelphoussaDelphi previously traced by the god alone. It is interesting to note that the specifically choral part of all these movements is the last and final one, from Chrysa to Delphi, which ritually marks the actual foundation of the sanctuary. For spatial articulation through choral movements in the Homeric Hymn to Apollo cf. Reig and Carruesco (2012). An iconographic counterpart to this choral scene is the Delian chorus led by Theseus from the ship to the Horn Altar at the centre of the sanctuary, which occupies the uppermost band of one side of the François Vase. 
for the processional chorus, led by the choregoi, as it has been described in the previous scene, the vintage song $(579=572$ : हैं $0 v \tau 0) .{ }^{24}$ On the other hand, in the final chorus, being as it is a static dance, the $\sigma \tau i \chi x \varepsilon \varsigma$ wind around or intersect each other, defining a space (probably quadrangular, as opposed to the previous wheel) which we can picture as a grid, a web, or a maze. This last form would be especially appropriate for a dance that has as its model Ariadne's chorus in Crete, and we can perhaps suppose here, as the scholiasts point out, an implicit allusion to the labyrinth, as it was traced at Delos by the dancers of the répavos.

As for the web image, we can mention the dance of the Phaeacian boys accompanying Demodocos' song of the adulterous union of Ares and Aphrodite, caught under the view of the rest of the gods in a web fabricated by Hephaestus. I would argue that the swift, sparkling movements of the feet of the dancers which are the object of Odysseus' admiring gaze (Od. 8.265: $\mu \alpha p \mu \alpha p u \gamma \dot{\alpha} s$ $\theta \eta \varepsilon i \tau 0 \pi 0 \delta \hat{\omega} \nu, \theta \alpha \dot{v} \mu \alpha \zeta \varepsilon \delta \dot{\varepsilon} \theta \nu \mu \hat{\omega}$, "[Odysseus] gazed at the flashing of their feet and marvelled in spirit') are to be related to the image of the web imprisoning the two divine lovers in Demodocos' song. ${ }^{25}$ The description of the web makes it

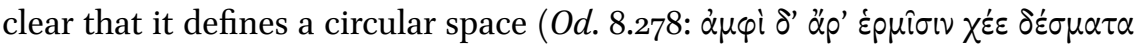
$x \dot{v} x \lambda \omega \dot{\alpha} \pi \dot{\alpha} \nu \tau \eta$, 'and threw the netting right round the bedposts'), like that in which the performance takes place, the Phaeacians' agora, described as a Xopós for the occasion (Od. 8.260, 264; for the ideal circular form of the agora, cf. Il. 18.504). Bearing in mind the description of the final chorus on the shield of Achilles, we may perhaps visualize the pattern of this dance as the winding or intersecting $\sigma \tau i \chi \chi \varepsilon \varsigma$ evoking the unbreakable bonds of the web ( $\ddot{\alpha} \varphi v \varkappa \tau \circ \iota \delta \varepsilon \sigma \mu \circ i$ ), which, like the shield of Achilles, is in and of itself a $\delta \alpha 1 \delta \alpha \lambda \varepsilon$ है by Hephaestus himself. Being at the same time a circle, as we have seen, this web can provide us with a clue to the understanding of the alternating forms, $x \dot{x} x \lambda \circ \varsigma$ and $\sigma \tau i \chi \varepsilon \varsigma$, of the dance in the last choral scene on the shield.

On the other hand, the web's bonds ( $\delta \varepsilon \tilde{\sigma} \mu \alpha \tau \alpha$ ), invisible even to the gods,

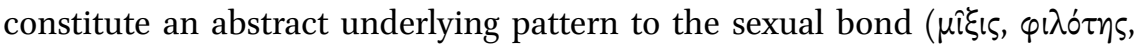

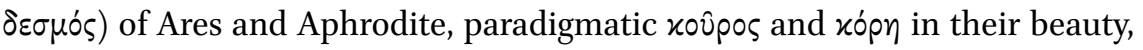
contemplated by the rest of the gods summoned there by Hephaestus himself, an aspect that is strongly emphasized by the abundance of visual terms present in this passage. Since this whole scene is a performance in the Phaeacians'

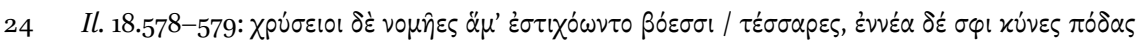

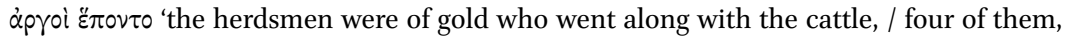
and nine dogs shifting their feet followed them'.

25 A more detailed analysis of this passage from the perspective of chorality will be pursued elsewhere. Cf. Burkert (1960), Braswell (1982), Brown (1989). 
agora, with a dance of youths accompanying the song, we can observe a mirroring motif in this disposition, with the Phaeacians and their guest Odysseus looking with admiration at the dazzling movements of the boys' feet just as the gods are watching with pleasure beautiful Aphrodite caught in the web with Ares - and, by implication, just as we admire the whole scene as narrated by the singer of the Odyssey. We have here, then, another example of the pattern of mise en abîme characteristic of the choral performance, adopting the ideal form of concentric lines ceaselessly expanding outwards, reaching out from the world represented by the song and the dance to the real world of the people watching it.

As for the actual effect of this contemplation on the viewers, we can single out three reactions among the gods watching the surprised lovers:

a) a general reaction among the gods remarking on how the transgressor, however beautiful or strong, gets caught in the end; a moral reaffirming of social values, albeit expressed in a humorous way;

b) the playful dialogue between Apollo and Hermes, two handsome xov̂por themselves, with Hermes gazing at Aphrodite's naked beauty and wishing he were Ares embracing the goddess, ${ }^{26}$ a wish, full of desire, which corresponds to the reciprocal mimesis of choral performance, achieved through

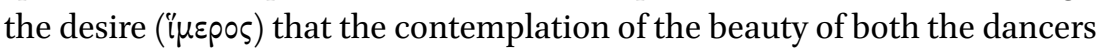
and the dance arouses in the spectator;

c) Poseidon's reaction, in contrast to the preceding gnomic and erotic remarks, takes us to the judicial aspect of the scene, in which the outrage ( $\chi 0^{\prime} \lambda$ ○ $)$ and the potential conflict ( $\nu \varepsilon i x \circ \varsigma$ ) the adultery has provoked is solved by the agreement to pay compensation.

It is difficult not to be reminded here of the sequence, in the shield of Achilles, of the wedding-scene, with the singing of the hymenaios - a context where the first two reactions to Ares' and Aphrodite's predicament just mentioned would not be out of place-followed by the litigation scene in the agora, where

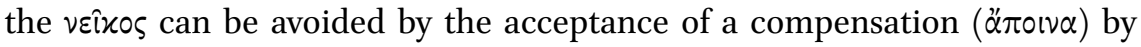
the injured party, a procedure held under the active contemplation of the community. In his study of this scene, Nagy has isolated the same pattern of

26 It is interesting to note here the exact inversion of this wish-again in the positive moral sense-in Alcman's partheneion, with the warning against a mortal aspiring to lie with golden Aphrodite (PMGF 1.17), or the narratization of this choral motif in Anchises' story, as told in the Homeric Hymn to Aphrodite, where the hero accepts to lie with the goddess believing her to be a maiden abducted from the chorus (117-118). 
expanding concentric circles that I have found in Demodocos' song. ${ }^{27}$ But I would further develop his analysis by arguing that also in the Iliad passage the source of this pattern and its performative function derives ultimately from a choral matrix. If we follow the logic of expanding concentric circles, each one spilling over into the next, as described by Nagy, we must not forget that the sequence has begun at the centre of the shield, the choral movements of the astral bodies, thence spilling over into the double scene of the wedding song and the litigation in the agora. Since at the other end of the chain, as Nagy rightly observes, we find the epic poet and his public (or rather an endless succession of epic performances), the importance of this choral matrix for the representation of epic as a genre and particularly for its function of creating a collective, articulate identity for its audience becomes evident. ${ }^{28}$

In the Phaeacian occasion we find a similar social function to that described in the litigation scene on the shield, as Demodocos' performance, like the dance

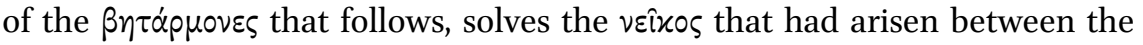
guest and Euryalos, and integrates the guest into the community by the gift of $\xi \xi \dot{v} / \alpha$, consisting here of richly woven robes and a talent of gold. As for the crowd watching the dance, this contemplation defines, collectively, the communal identity of the Phaeacians, who excel in dancing, in the highly agonistic context of the whole episode; individually, it provokes a pleasure that ranges from the image of youth and dexterity projected upon each spectator, who identifies with the dancers to the point of ideally exchanging places with them, to the satisfaction of the parents looking at their sons creating a better image of them and their oixos for all to see and admire, enhancing thereby their social status and preparing an advantageous marriage. ${ }^{29}$ Thus, Demodocos' song and its accompanying dance in the Odyssey provide a useful parallel, at several levels, to the description of the shield of Achilles in the Iliad, and particularly to the meaning and function of its choral scenes.

Let us now return to the description of the shield. It is in the context of these abstract patterns created by the dancers and enjoyed by the viewers that we find the second comparison of the passage, which, like Daedalus' Xopós, also regards the spatial dimension of the performance, namely the round form of

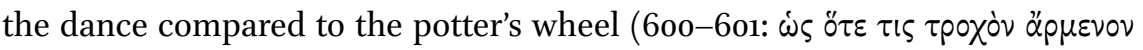

\footnotetext{
$27 \quad$ Nagy (2003).

28 On chorality as a pattern underlying epic poetry and providing it with the power to represent and generate order both inside and outside the poem cf. Carruesco (2010).

29 This feeling has previously been described in Odysseus' praise to Nausicaa's beauty (Od. 6.154-159), and finds its divine paradigm in Zeus and Leto watching their sons dancing in the xopós (HHApoll. 204-206).
} 


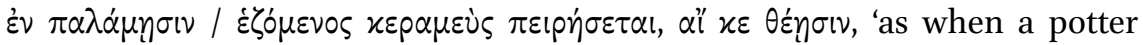
crouching makes trial of his wheel, holding / it close in his hands, to see if it will run smooth'). Through the epithet äprevov, the wheel, like the shield and the chorus, is itself presented as a complex artifact made up of closely fitted pieces. But the wheel is at the same time a tool for the production of other artifacts: the vases which are the potter's works. Thus, as in the case of Daedalus, here too the comparison bears as much on the fashioning of the shield as on the choral performance being described (as brought up by the use of the agonistic terms $\pi \varepsilon i p \alpha \dot{\alpha} \mu \alpha$ l, 'to test', and $\theta \varepsilon \dot{\varepsilon} \omega$, 'to run'). But by introducing the potter's work as a valid counterpart to the metalwork of Hephaestus and putting both in a symmetrical relationship to the chorus and the patterns it defines, as read by the watching crowd, the poet invites his audience (and us) to draw a parallel between the visual aspects of this representation and the reading of the iconographical language of contemporary artifacts. Since the shield is a piece of metalwork, iconographic comparisons have frequently been drawn between it and similar objects, notably the two series of Cretan shields and Cypro-Phoenician bowls, which indeed offer strikingly close parallels. ${ }^{30}$ However, taking a cue from the comparison of the patterns of the dance to the wheel of the potter, we can now try to read the iconography on vases from the Geometric period from the perspective opened up by the previous analysis of the scenes on the shield. ${ }^{31}$

In the extratextual world, the specific relationship between the potter and the chorus lies in the need for the former to supply vases that are to be used on the occasions where choral performances take place, such as weddings, funerals, even banquets, or that are destined to become votive offerings or prizes awarded to the best dancers in agonistic festivals. This is precisely the case for the famous Dipylon oinochoe that bears what may be the oldest inscrip-

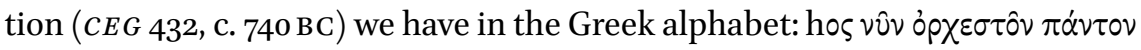

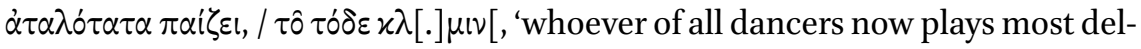

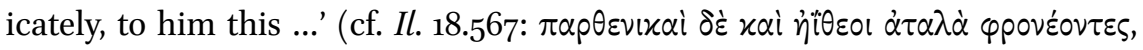
'young girls and young men of delicate spirit', my translation) (figs 4.1a and b). It is significant to remark that the inscription alludes to the dance in the context of a self-referential statement ( $\tau \dot{\delta} \delta \varepsilon)$ that links the vase and its function to a specific (vôv) performance - though this means any specific performance tak-

\footnotetext{
30 Edwards (1991) 203-206.

31 On the iconography of Geometric pottery, cf. Coldstream (1968), Himmelmann-Wildschutz (1968), Schweitzer (1971), Ahlberg (1971), Carter (1972), Whitley (1991), Rystedt and Wells (eds) (2006), Langdon (2008).
} 


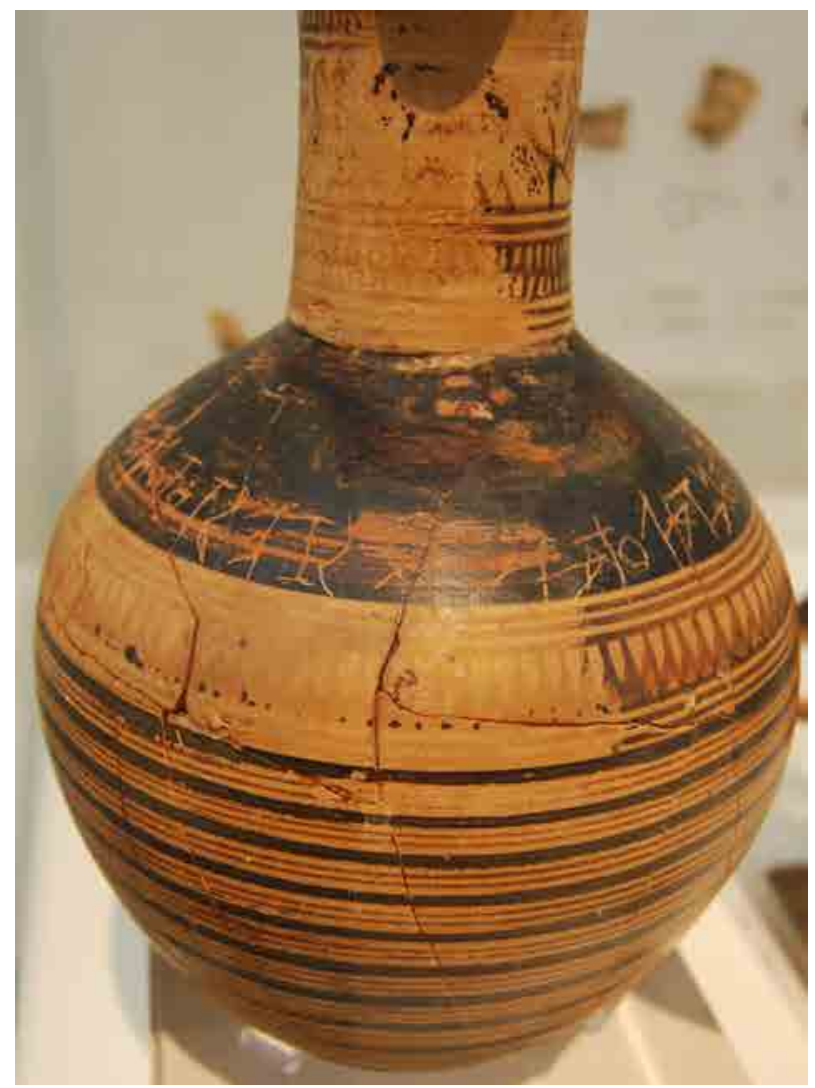

FIG. 4.1A Attic oinochoe, c. 740 BC, from Dipylon

(C) HELLENIC MINISTRY OF CULTURE AND

SPORTS-ARCHAEOLOGICAL RECEIPTS FUND

ing place in the here and now of repeated ritual. In a sense, the temporality of the dance ( $(\hat{v} v)$ materializes into the physical presence of the vase $(\tau \delta \delta \delta \varepsilon)$, and the correspondence between the adverb and the pronoun of proximity emphasizes that the object is somehow the equivalent or the substitute of the dance. Equally noteworthy is the display of the inscription around the vase, which, through the form and direction of the letters and by echoing the movement of the geometric bands below, seems to be trying to imitate the movement of the dance to which it alludes. A later, more explicit example of this choral layout of the letters on a vase can be seen on a Corinthian aryballos depicting a dancer and a flute-player (fig. 4.2), on which the movement of the dancer is suggested through the sinuous disposition of the letters of the inscription, which again alludes to the dance itself. It could be objected, of course, that the primitive, tentative character of such an early example of writing as that on the Dipylon 


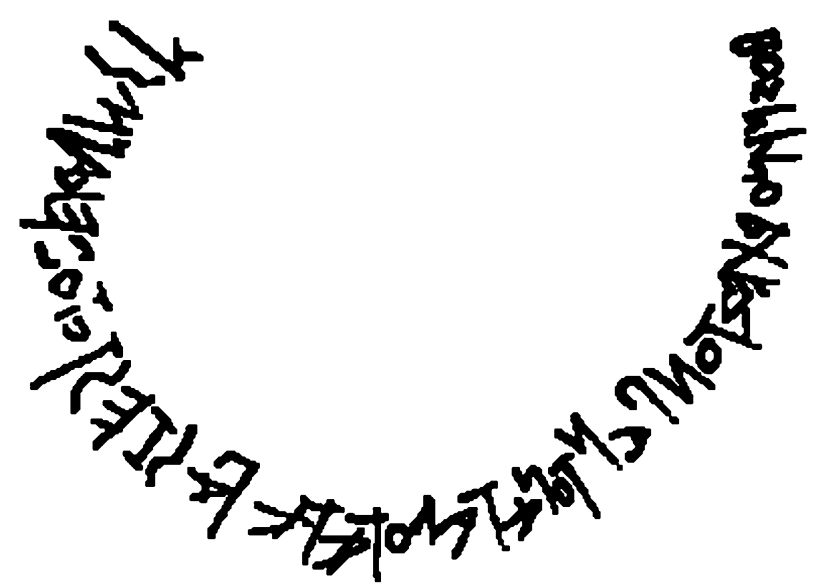

FIG. 4.1B Inscription on Attic oinochoe, c. 740 BC, from Dipylon NATIONAL ARCHAEOLOGICAL MUSEUM, ATHENS (INV. 192). DRAWING: PALOMA ALIENDE (CATALAN INSTITUTE OF CLASSICAL ARCHAEOLOGY)

oinochoe (the inscription even seems to have been left unfinished) would be at odds with the attachment of a conscious symbolic meaning to its spatial layout. On the contrary, I would argue that precisely because this is a pioneering effort, it would have been all too natural that the writer would have borne in mind a visual, not just textual, parallel, one familiar to him from the 'reading' of the geometric patterns he was accustomed to, namely a choral reading, as I will try to argue in what follows, particularly as it is naturally evoked

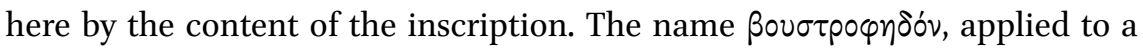
particular (and particularly early) layout of an inscription, bears witness to a similar understanding of the visual aspect of writing through a metaphoric image, one which, as we have just seen, also provides a model for the reading

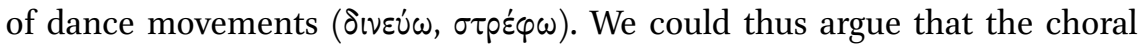
paradigm offered a mental frame that could make intelligible in the first place the possibility of visualizing speech in space and fixing it in time, in the same way as the abstract patterns the dancers make visible with their movement

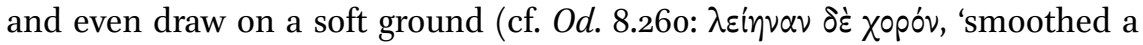
dancing space'). The last observation takes us back to our main argument in this paper, the relationship between epic descriptions of choral performance and Geometric iconography.

The high frequency of representations of choral performances on Geometric pottery, which sets a trend that will continue in later periods, testifies to the importance accorded to the chorus in this cultural context, a point I hardly 


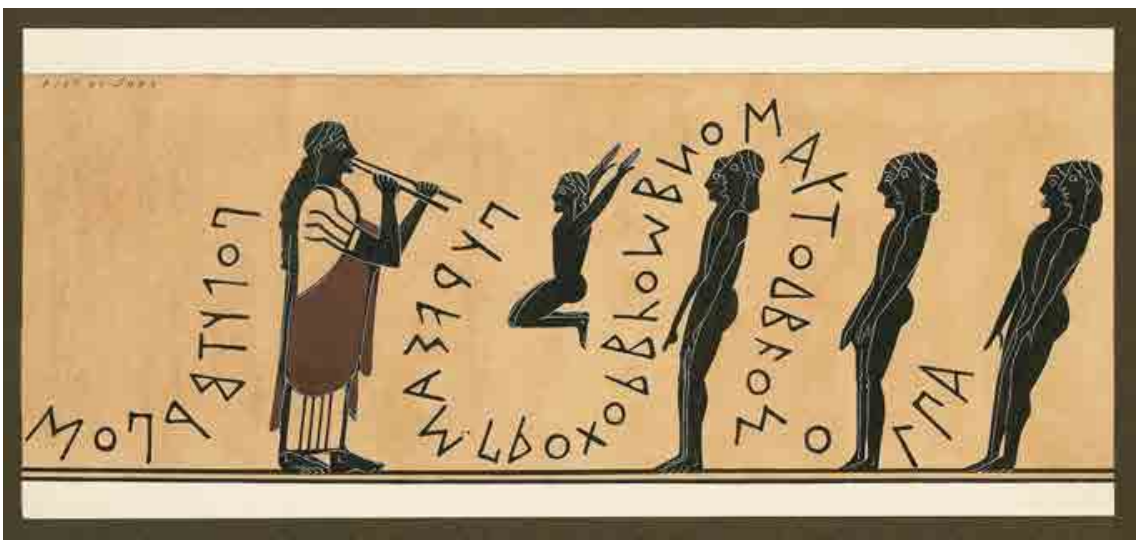

FIG. 4.2 Corinthian aryballos, with representation of dance and inscription, $c .590-580$ BC ARCHAEOLOGICAL MUSEUM, CORINTH (CORINTH C-54-51). C) HELLENIC MINISTRY OF CULTURE AND SPORTS-ARCHAEOLOGICAL RECEIPTS FUND. DRAWING: P. DE JONG.

need to develop here. ${ }^{32}$ But the point I would like to make is that the multiple levels of the visual apprehension of the performance by its audience, as we have seen in the epic texts, may have a close parallel in the reading of the iconography of the Geometric period (1000-700 BC), especially the Late Geometric (second half of the eighth century), during which the figured image coexisted with the geometric decoration.

We have seen that the spectators of the dance took pleasure in the simultaneous contemplation of (i) the physical beauty of the dancers and their robes and ornaments, and (ii) the abstract patterns traced by the dancers, and that both levels could also be contemplated through a limited range of fixed symbolic images (which, at least in the case of choral lyric, are often evoked in the song as self-referential metaphoric allusions): the astral bodies, some specific animals and their movements, the form or decoration of a precious object (e.g. a necklace), a mythical place, such as the labyrinth, or, in Demodocos' song, Hephaestus' web imprisoning Ares and Aphrodite. If we now apply this perception to a particular case, such as a Late Geometric krater from Argos (fig. 4.3), we can observe a similar relationship between the figured panels, which depict a female chorus, and the central one, occupying a privileged iconographic position, which can be read as the representation of a dance pattern. Similarly, in the bands of birds framing the dancing women a parallel can be drawn between both images, based on the bird imagery that is common also in textual descrip- 


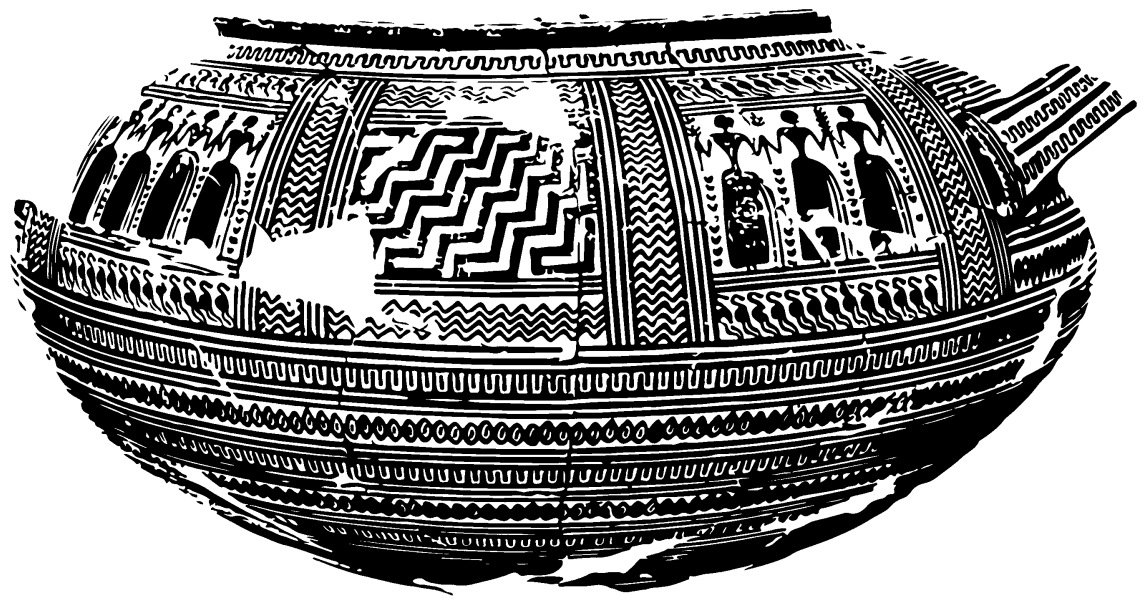

FIG. 4.3 Argive crater (Late Geometric), from grave T45 in Argos

(C) HELLENIC MINISTRY OF CULTURE AND SPORTS-ARCHAEOLOGICAL RECEIPTS FUND. DRAWING: PALOMA ALIENDE (CATALAN INSTITUTE OF CLASSICAL ARCHAEOLOGY).

tions of choruses such as in the texts of choral lyric. These bands have their counterpart in the zigzag lines framing the central panel, which in turn recall

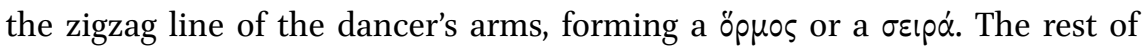
the space is filled with similar strings of linear motifs that become circular through their continuous display around the vase, and this is precisely the point of the comparison of the shield to the potter's wheel. ${ }^{33}$ In the Argive krater, other figurative meanings could conceivably be attached to the lines in the central panel, such as a watery surface, like a water meadow or a pond, which would then suggest an identification of the dancers as a chorus of nymphs. Nevertheless, this possibility does not exclude the interpretation that I have proposed, since, as we have seen, the geometric patterns of the dance were open to representational imaged readings, which were, nevertheless, neither compulsory nor necessarily restricted to one fixed meaning. I would argue that the decoration of the vase, with its different visual levels encouraging an equally multilayered reading, could be looked at and read in a similar way as we are told by the epic text the choral performance was, appropriating and transposing its efficacy and portability to another medium and to changing

33 We may mention in this context the name divos for a specific form of vase, where this layout of the decoration, perfectly matching the tectonics of the object, is most frequent. For the importance of the terms $\delta i v \eta$ and $\delta เ v \varepsilon \dot{\omega} \omega$ in the description of choral movements, cf. supra. 
social contexts, like marriage, ritual performance, the banquet and, ultimately, the grave. But let us now consider some of the methodological and cultural implications of this interpretation and test its viability (and thence its validity) for the reading of a larger corpus of vases.

The sources of the iconographical motifs of Geometric art can be fairly easily traced to Bronze Age Greece in some cases, to the Near East in others. What is specific to Greek Geometric art, as its very name implies, is the extraordinary development of the geometric patterns, which tend to occupy all the available space, and the rigour with which they are displayed over the surface of the vase with an exceptional sense of spatial articulation. It is not coincidental, I think, that this is precisely the fundamental feature of choral performance as a very powerful cultural tool to articulate the physical as well as the social space, particularly at the beginning of the polis, as numerous studies have pointed out. ${ }^{34}$ As for the origin of the motifs, the importance of textiles and weaving patterns has often been pointed out, ${ }^{35}$ and it is surely significant that this is

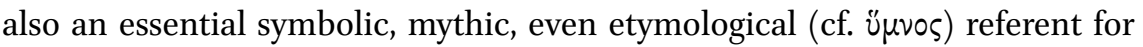
choral song and dance. ${ }^{36}$

The attribution of a meaning to this all-important geometric decoration in Dark Age Greece, which recurs on a number of objects besides vases, has frequently occupied scholars. Thus, Himmelmann-Wildschutz has interpreted the geometric patterns, such as the ubiquitous Kreisornamente, as vegetal motifs, reading, for instance, the meander as a stylized rendering of the wreaths crowning sympotic vessels. ${ }^{37}$ Similarly, Ahlberg, in her important study of the iconography of prothesis and ekphora scenes, sees every motif as representational (cf. fig. 4.4). ${ }^{38}$ On the opposite extreme, Whitley has argued for

34 Cf., e.g., de Polignac's analysis of the importance of processional choruses in defining the main organizing axes of the territory of the polis, especially those linking the extra-

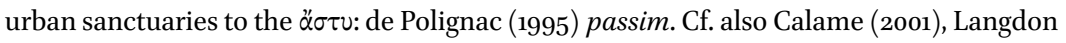
(2008).

35 Schweitzer (1971) 30: 'A series of phenomena suggest that (the Geometric style) developed alongside a lost textile art and this may even have been the origin of the Geometric art before gоо вс. (...) Surface ornaments such as the checkerboard, saw-tooth and lozenge patterns seem to be developed directly from weaving techniques.'

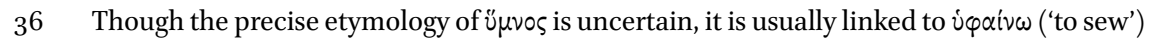
and/or i $\mu \eta^{\prime} \nu$ ('membrane', with etymological relations with words meaning 'sewing seam'; cf. Chantraine, DELG s.v.), which in turn could be related to i $\mu \varepsilon \dot{v} \alpha 10 \varsigma$. Whatever the true etymology, though, a Greek perception of the relationship is apparent in, e.g., Bacchyl. 5.10:

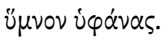

37 Himmelmann-Wildschutz (1962).

38 Ahlberg (1971); for example, according to her, 'the emblem zones denote a locality outside 
a purely social, non-iconographic interpretation, a non-representational code whose meaning lies in the conferral of status to the owners of the object. ${ }^{39}$ While I am in total agreement with him on the necessity for a social approach, rather than a purely iconographic one, from an analysis of the texts I would not exclude at least the possibility of a level of representation in the contemporary reading of these motifs, in the same way that the patterns of the dance could sometimes be read as imitating some element of reality, or simply as abstract images of kosmos or harmonia, beautiful in their own structural complexity. It is not, however, a naturalistic representation, albeit stylized, but rather a ritualized one. Since by and large we recognize the importance of ritual in figured scenes, when they exist, I do not think it can be denied when the object's decoration is purely geometric, since, as Kowalzig has recently argued, the chorus provides the main model for ritual as performative action in Archaic Greece. $^{40}$

If we look briefly to the repertory of geometric decoration, we find a striking correspondence between it and the patterns we have found in the epic passages just analysed, especially in the description of the shield of Achilles. The disposition of the patterns can be either linear, frieze-like, or arranged in closed panels, in the manner of a metope or an emblem, a polarity that has its parallel in the distinction between processional (such as the two first dances on the shield of Achilles) and stationary choruses (such as the third one). In the first type, we find straight lines, sinuous lines, zig-zags, meanders or frieze-like repetition of the same motifs, often all the way around the vase. The main motif

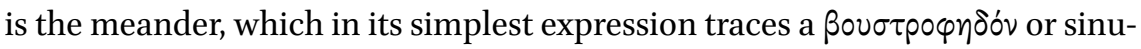
ous pattern (like a river or the movements of the ploughman), while in its most complex forms it gives the impression of a maze or a watery surface (fig. 4.5). Whatever its form, however, the meander suggests a movement based on the abstract principles of $\delta เ v \varepsilon v \varepsilon \varepsilon v v$ and $\sigma \tau p \varepsilon ́ \varphi \varepsilon \varepsilon v$, which are also choreographic concepts. Sometimes in the form of a key or a knot, rather than a single continuous line ${ }^{41}$ the meander can also refer to the interlocking hands of the chorus, the bond $(\delta \varepsilon \sigma \mu o ́ s)$ that is a defining feature of its figured iconographical representation.

the house and the circular motifs may be curtains, or some kind of drapery or belonging to the architectural domain' (146).

39 Whitley (1991) 17-19.

$40 \quad$ Kowalzig (2007) 394-395.

41 The swastika can also be regarded as an isolated, non-linear version of this motif, with the possible reference to a stationary, as opposed to processional, chorus. 


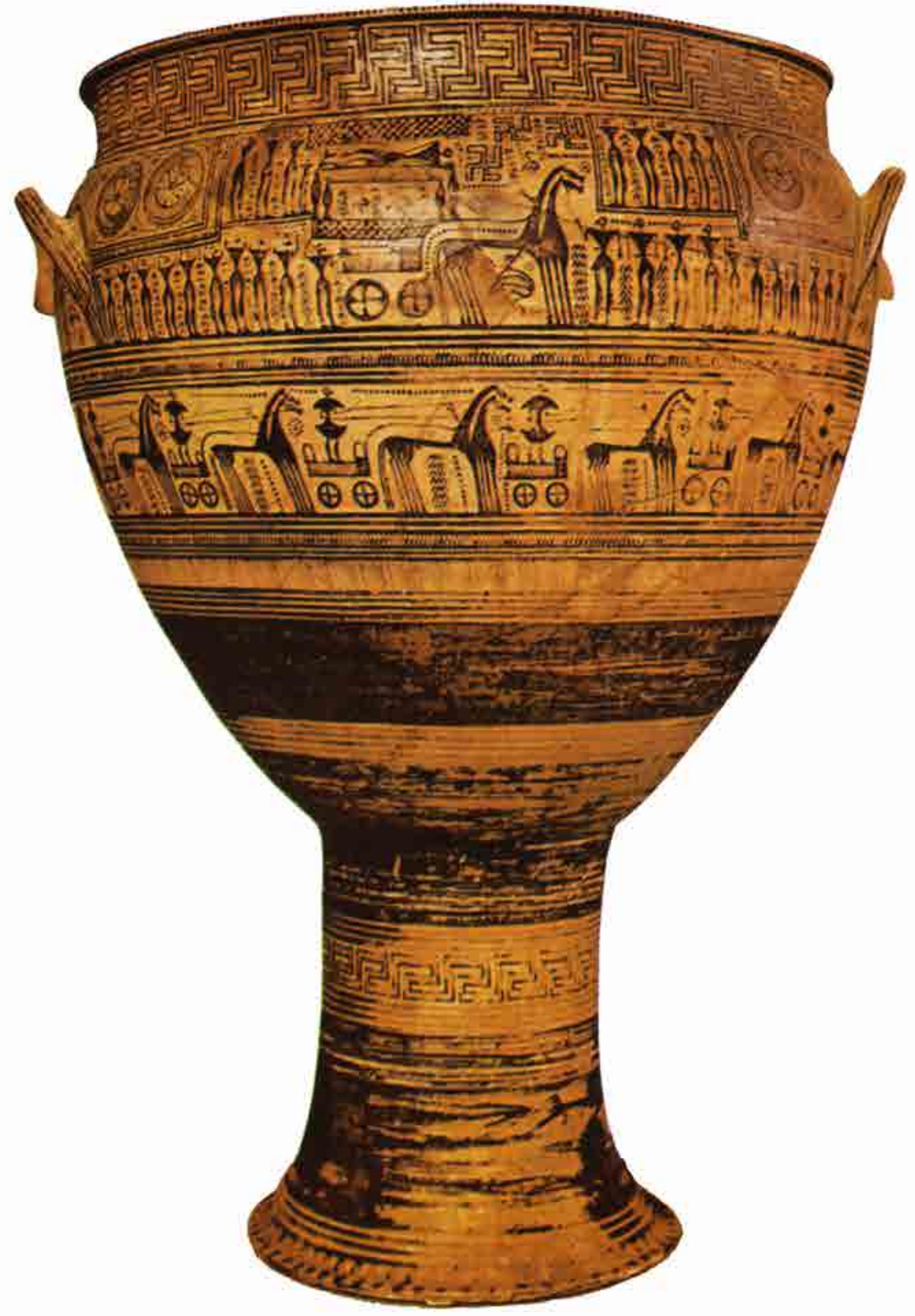

FIG. 4.4 Attic crater (LG1b), c. 740 BC, from Kerameikos

(C) HELLENIC MINISTRY OF CULTURE AND SPORTS-ARCHAEOLOGICAL RECEIPTS FUND. SOURCE: BEELDRESEARCH: CENTRUM VOOR KUNSTHISTORISCHE DOCUMENTATIE, RADBOUD UNIVERSITEIT 


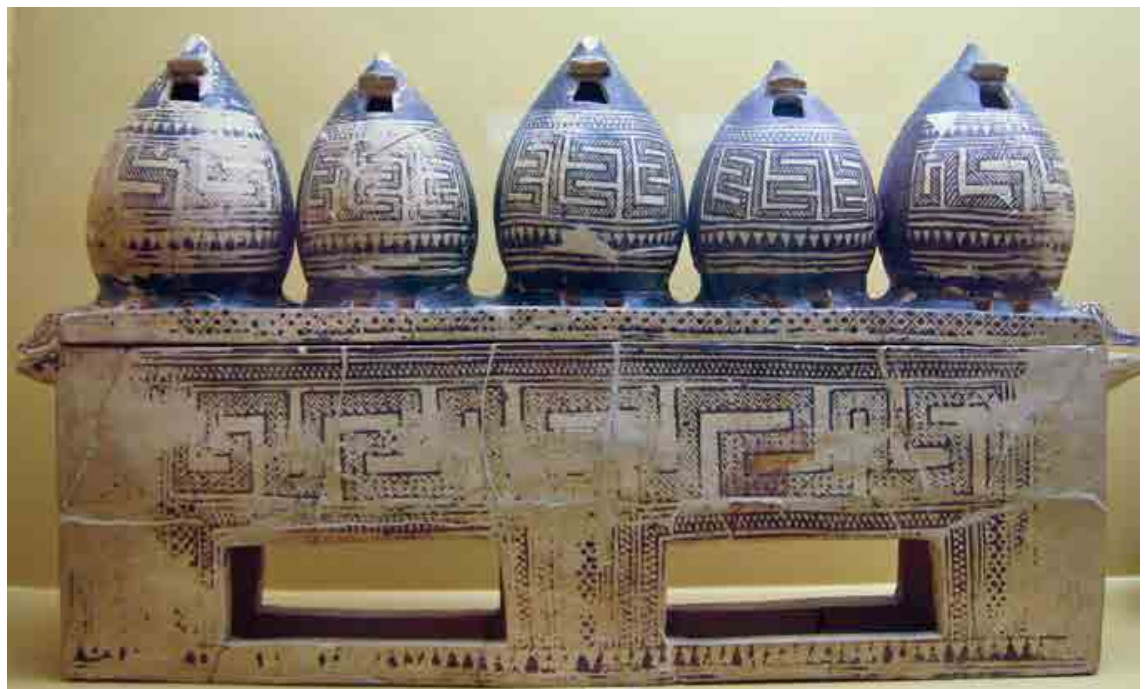

FIG. 4.5 Attic chest (MG I) with model granaries

AGora MUSEUM, ATHENS (P27646). (C) HELLENIC MINISTRY OF CULTURE AND SPORTS-ARCHAEOLOGICAL RECEIPTS FUND. PICTURE: SHARON MOLLERUS / WIKIMEDIA COMMONS / CC-BY 2.0

Also very common are the circular motifs, often in the form of concentric circles, which sometimes encircle another element in the centre, such as a dot, a cross, or a figured motif, such as an animal. Sometimes these circles are linked by tangential lines (fig. 4.8: note the bands under the grazing animals), giving concurrently both the impression of movement, like the meander, and of a combination of pieces, like a necklace or, indeed, a dancing chorus. In other cases these circles adopt a quasi-representational form, like a flower or, in a characteristic motif, an object resembling at the same time a wheel and an astral body, like the sun or the star-crowned heaven of the innermost band of the shield (fig. 4.6). Stars are also frequent, as is the swastika, possibly also an astral motif. As for the frequent grid patterns, made up of straight or diagonal lines, chequered or filled with dots, we have already encountered them in the intersecting $\sigma \tau i \chi \chi \varepsilon \varsigma$ of the dance, which could be read, for instance, as a web or a military or ritual formation (fig. 4.7).

It is hardly necessary to point out here the choral character of these patterns. In this respect, we may compare all these geometric motifs and their dazzling display over the whole surface of the vase to the flashing movements of the

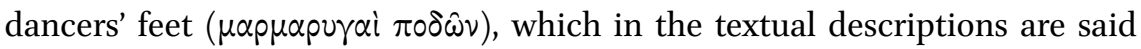
to attract the gaze of the spectator, fascinating him and provoking a sense of wonder $(\theta \alpha \hat{v} \mu \alpha)$ and pleasure $(\tau \dot{\varepsilon} p \psi(\varsigma)$. I would like to emphasize, however, 


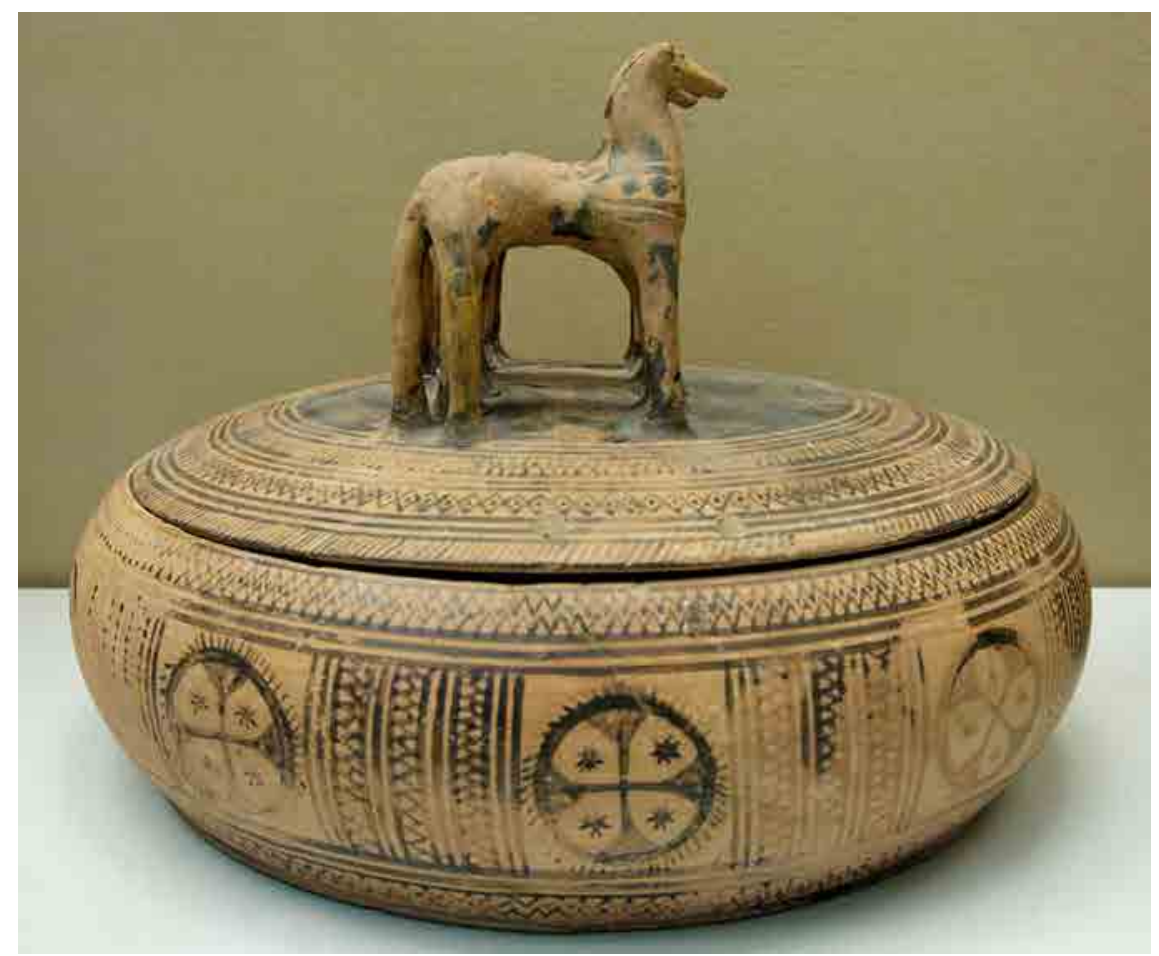

FIG. 4.6 Attic pyxis (MG II), c. $760-50$ BC

BRITISH MUSEUM (LONDON 1910.11-21-1). WIKIMEDIA COMMONS (PUBLIC DOMAIN).

that these geometric motifs are not necessarily a stylized representation of the dancers, thus ultimately a figured iconographic language, but rather a visual rendering of the same abstract patterns that the dance traces on the ground for the brief duration of the ritual occasion, representing and fixing down the ritual action in images as the poet of the Iliad does in words. That these patterns could eventually be read as evoking some choral images within a fixed and codified repertoire is suggested by the texts and by those images where figures and geometric motifs echoing each other are juxtaposed, but this attribution of meaning was not compulsory and could vary according to the occasion and even perhaps the individual viewer. Thus, there is no point in trying to assign a single, specific meaning to each of the motifs, but, on the other extreme, neither should they be considered as having no iconographic meaning at all.

When it comes to figured though still non-narrative motifs, the most frequent are animals, often repeated to form a continuous band (figs. 4.7 and 4.8). Here, also, the correspondence with the animal imagery of the chorus is significant: the bird, the horse, the cow, the deer, and the goat are the main species 


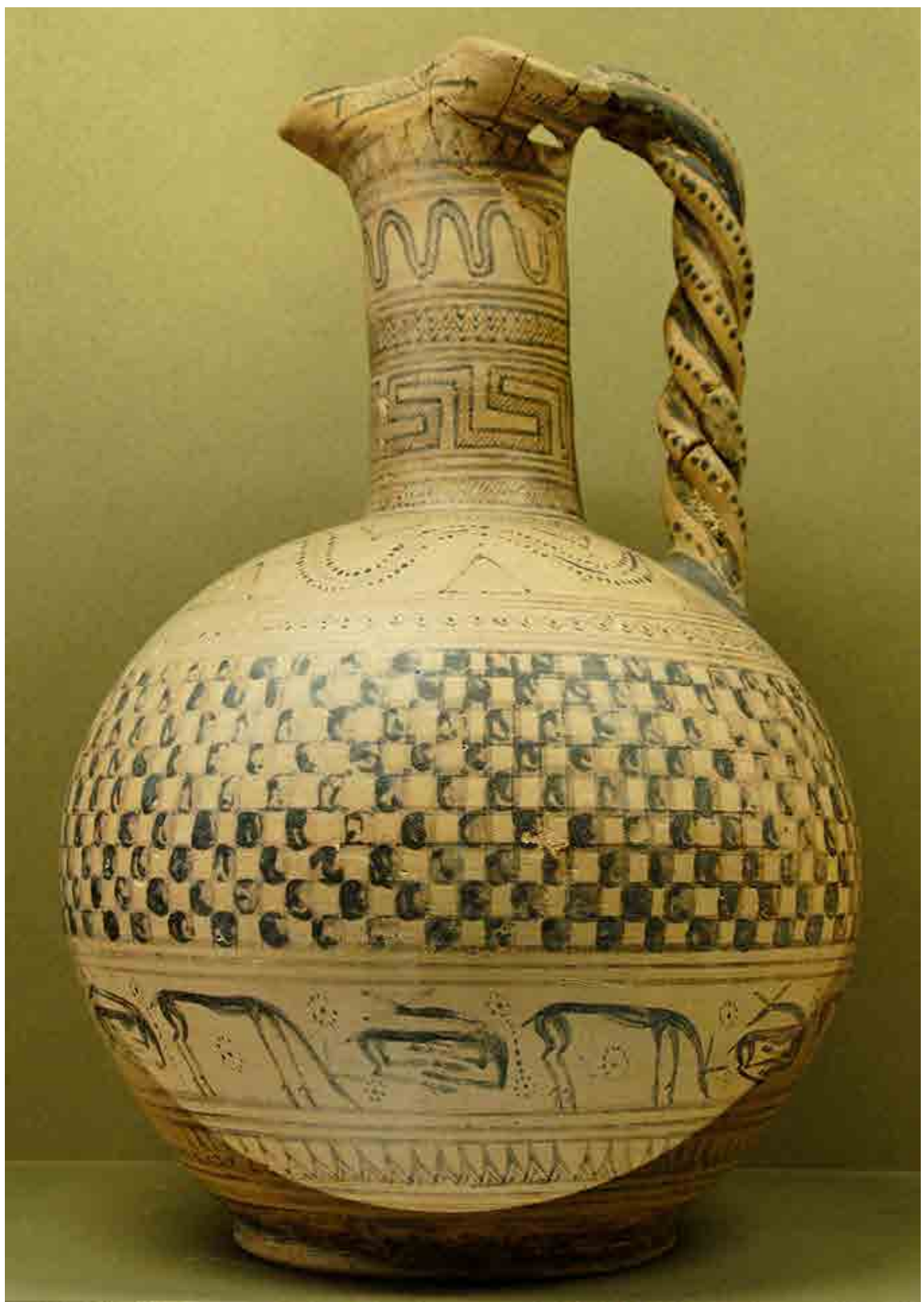

FIG. 4.7 Late Geometric oinochoe, c. 750 BC

MUSÉE DU LOUVRE (CA1821). WIKIMEDIA COMMONS (PUBLIC DOMAIN). 


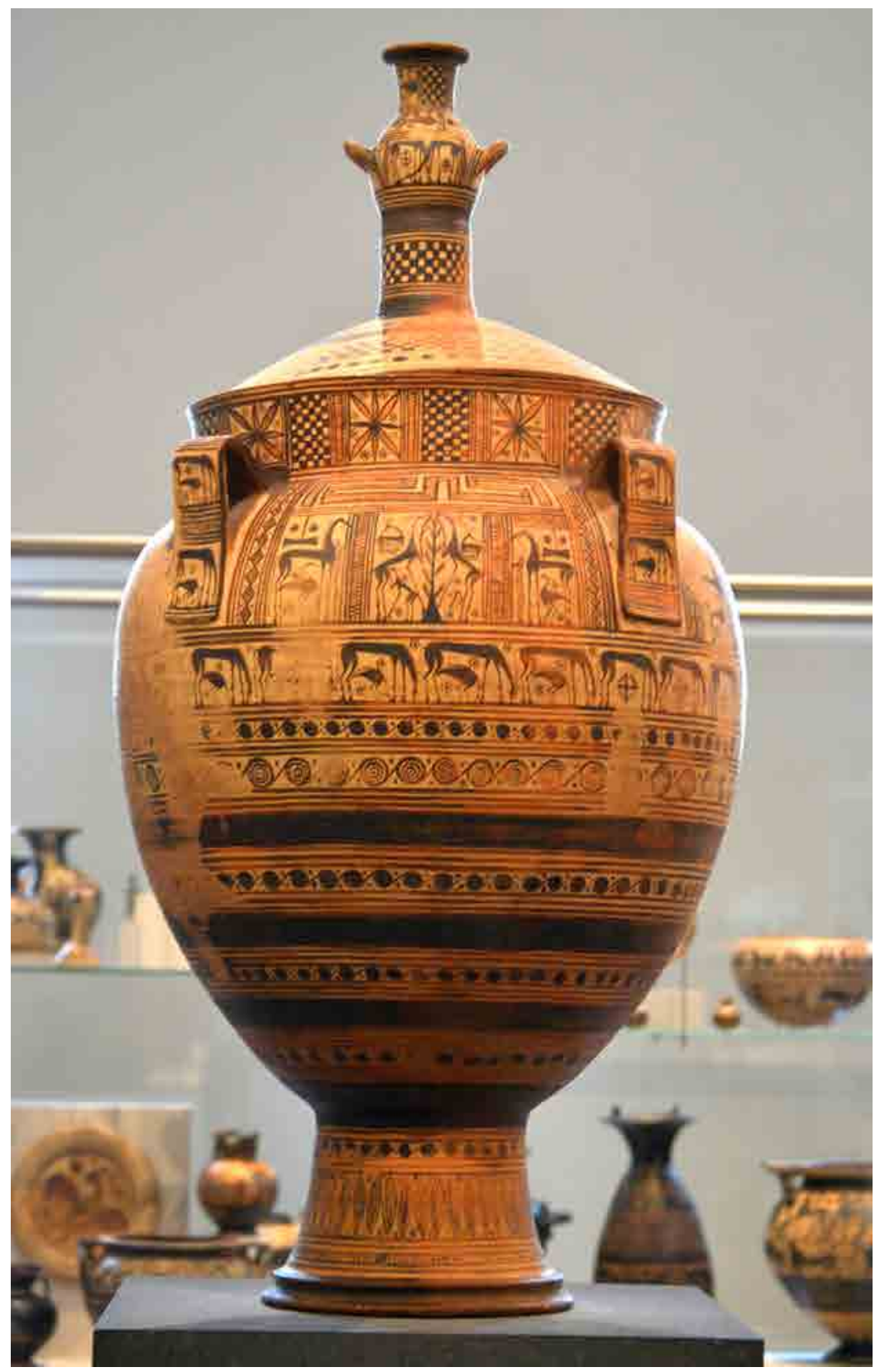

FIG. 4.8

Euboean LG crater from Cyprus by the Cesnola Painter METROPOLITAN MUSEUM OF ART, NEW YORK (1874.51.965). PICTURE: (C) USER:UPLOADER / WIKIMEDIA COMMONS / CC-BY-SA-3.0. 
represented, frequently shown grazing, suckling, marching or even jumping.

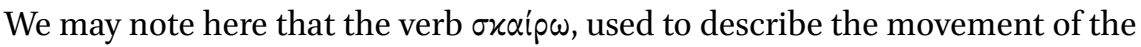
dancers in the vintage song on the shield of Achilles (Il. 18.572: $\mu 0 \lambda \pi \hat{\eta} \tau^{\prime}$ i

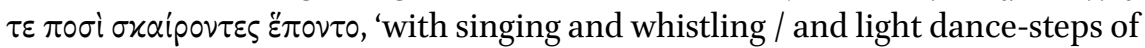
their feet kept time to the music'), reappears elsewhere in Homer to denote the jumping of the young calves to their mothers after grazing in the meadow $(\mathrm{Od}$. 10.412), a description that combines two very common iconographic motifs in the Geometric period: the grazing and the suckling animal.

It is interesting to note that when unequivocal figured motifs appear, whether in decorative layouts (such as friezes or panels) or in complex narrative scenes, there is often a perceived effort to establish morphological parallels between the figured and the geometric motifs on the vase, as, in the Argive vase considered above (fig. 4.3), between the angular arms of the Argive dancers and the zigzag lines framing the panels, or, in a funerary scene on an Attic Late Geometric krater in the Metropolitan Museum (fig. 4.9), between the eyes of the mourners and the dotted circles filling the void space around them. The same parallel can be seen in a strange representation on an oinochoe in Boston, dated c. 735-720 (fig. 4.10), which has been interpreted, rightly I think,

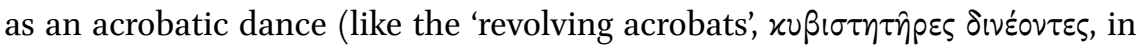
the epic texts). ${ }^{42}$ Here, the important feature of the open eye of the central inverted figure seems to correspond to the frame of dotted circles surrounding the scene.

It is very tempting to read these cases as representations of the crowd watching the ritual, be it the prothesis or the dance, but in accordance with our analysis it seems preferable to consider this reading as merely a possible one, for us as it probably was for the contemporary viewer. In any case, already in the Geometric phase, we can observe the importance of the eye as an iconographical motif, which is well known for later periods of vase painting (cf. the eye cups in Attic black- and red-figure pottery), and link it to the choral performance to which it primarily belongs (fig. 4.11). Indeed, references to the eyes and the gaze, both the dancers' and the spectators', are, not surprisingly, ubiquitous in the description of the chorus, in epic as in lyric texts: expressions like $\delta \varphi \theta \alpha \lambda \mu 0 i \sigma \nu$ $i \delta \omega^{\prime} v$ are frequent in choral contexts (cf. e.g. Il.16.182), and an excellent example from choral lyric is provided, in Alcman's first partheneion, by the apostrophe

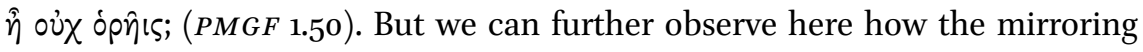
and projecting power of the choral gaze is expressed through the attribution to the eye of the beholder of some images appropriate to the chorus itself: thus, 


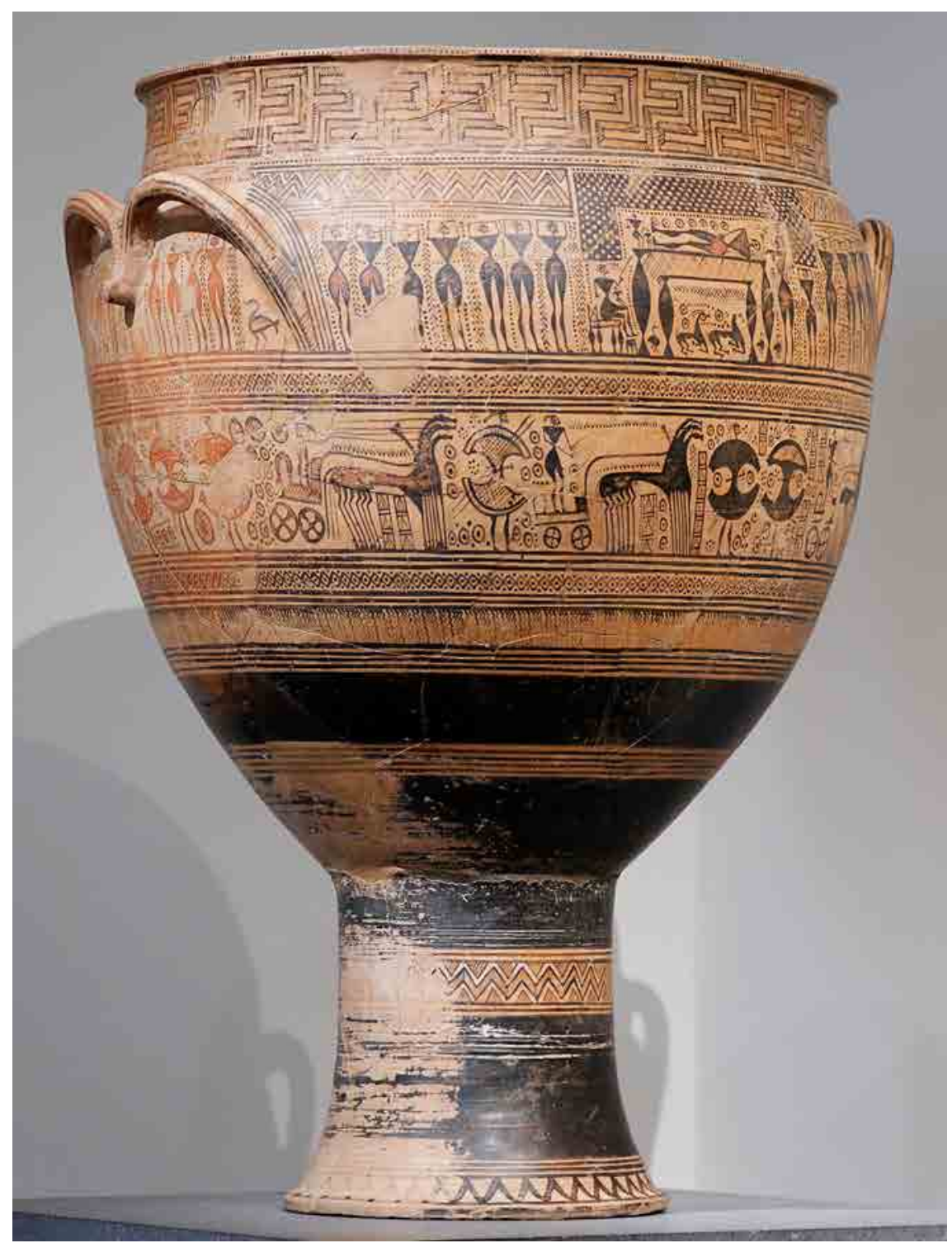

FIG. 4.9 Attic crater $(L G I b)$, c. 740 BC, from Dipylon

METROPOLITAN MUSEUM OF ART, NEW YORK (ROGERS FUND, 1914, 14.130.14). PICTURE: (C) USER: JASTROW / WIKIMEDIA COMMONS / CC-BY 2.5 . 


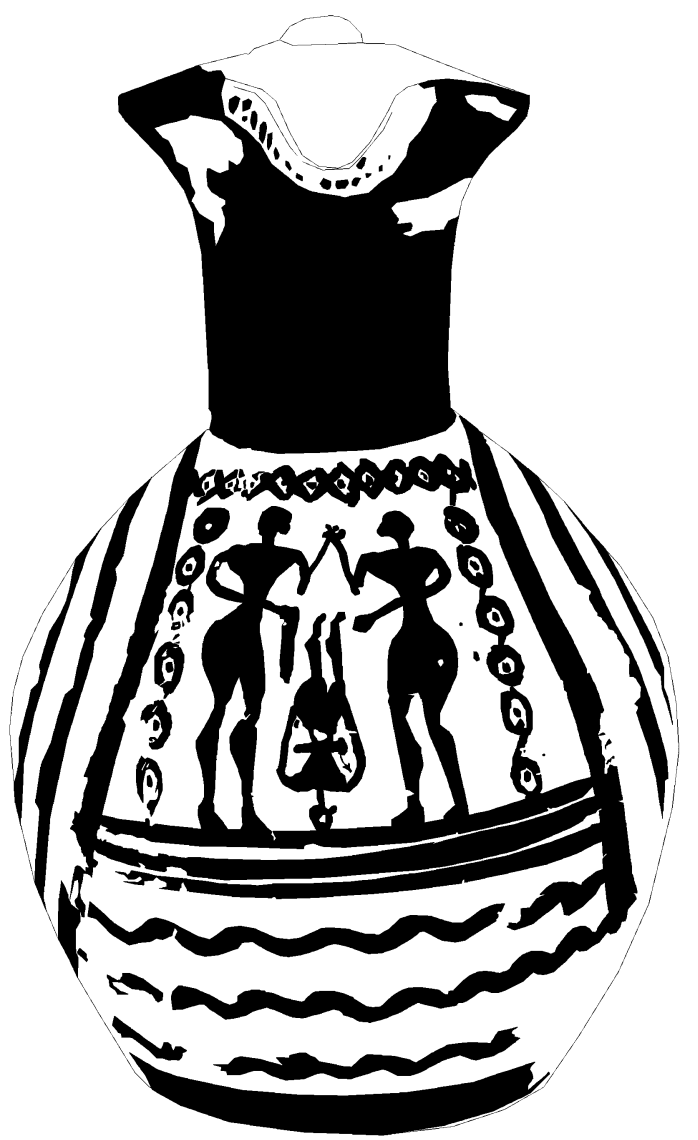

FIG. 4.10 Oinochoe, c. 735-720 BC. Boston 25.42, Richard Norton Memorial Fund.

DRAWING BY PALOMA ALIENDE, INSTITUT CATALÀ D'ARQUEOLOGIA CLÀSSICA.

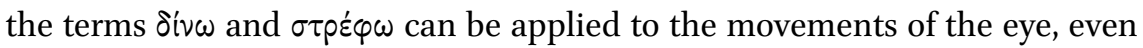
combined in a single verb to express the moment of Patroklos' death (16.792:

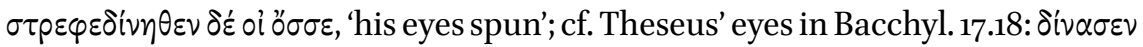
$\partial \mu \mu \alpha)$. Similarly, the epithet $\dot{\varepsilon} \lambda ı \varkappa \circ \beta \lambda \varepsilon \dot{\varepsilon} \varphi$ pos, also denoting beauty, attributes to the eye and the gaze a spiral movement that we find often in the movements of the chorus. Most significantly, the two terms for the pupil are associated to female attractiveness leading to marriage or intercourse, a concept that in early Greek thought finds a ritualized expression in the chorus: (i) the word $\gamma \lambda \eta \dot{\eta} \nu \eta$, denoting brightness, reappears in a derived form in the expression $\tau p i \gamma \lambda \eta \nu \alpha$ हैp $\mu \alpha \tau \alpha$, three-eyed earrings, mentioned among other female attires, jewels or 


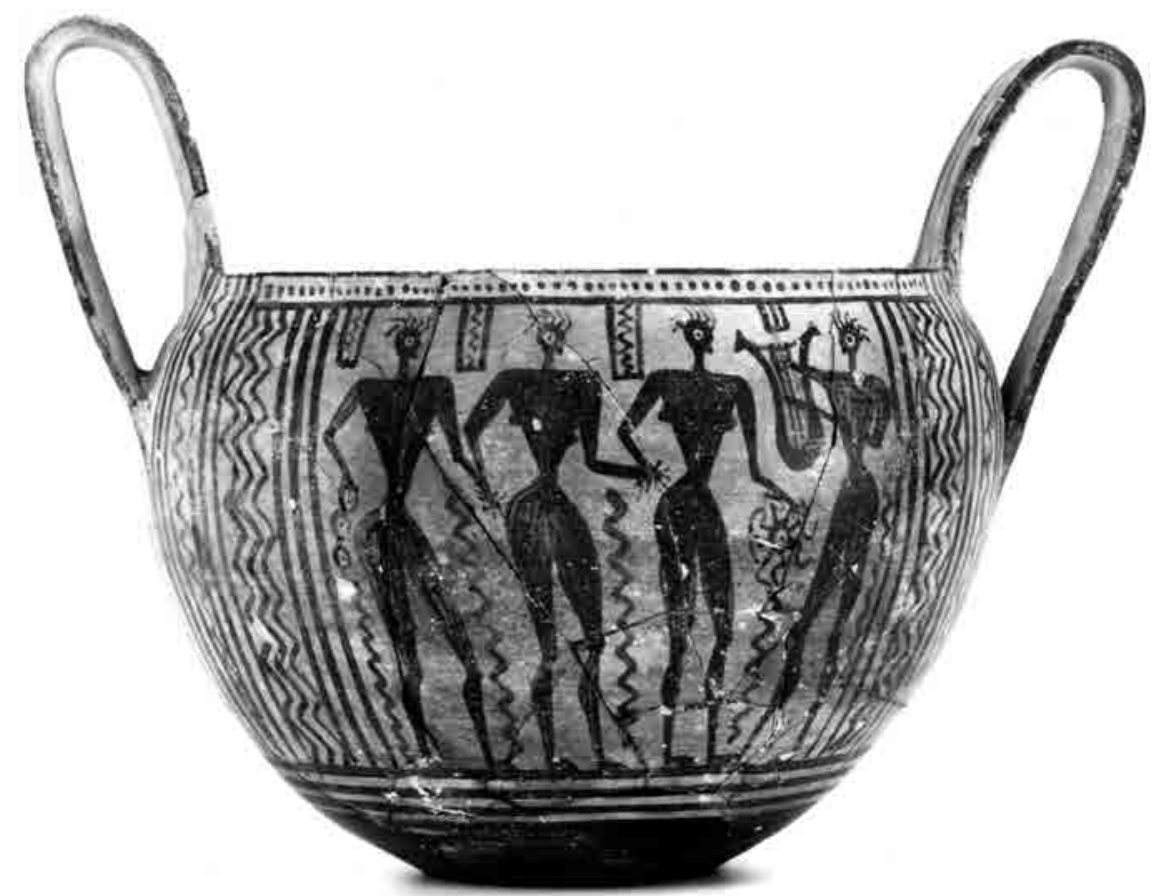

FIG. 4.11 Kantharos. Boiotian. Late 8th century BC.

STAATLICHE KUNSTSAMMLUNGEN ZV 1699. (C) SKULPTURENSAMMLUNG, STAATLICHE KUNSTSAMMLUNGEN DRESDEN.

robes, in contexts of wooing and seduction, ${ }^{43}$ and (ii) the pupil can be simply called the xópn, evoking the image of a maiden at the centre of a circular

43 Il. $14.182-183$ (the earrings worn by Hera to seduce Zeus), Od. 18.298 (earrings among the gifts of wooing offered by the suitors to Penelope). In both cases, the link with the

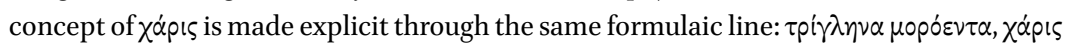
$\delta^{\prime} \dot{\alpha} \pi \varepsilon \lambda \dot{\alpha} \mu \pi \varepsilon \tau 0 \pi 0 \lambda \lambda \dot{\eta}$. In the first example, moreover, an association can be made with the previous episode in which Aphrodite sends Helen to lie with Paris (Il. 3.385-447), since Paris's words in seeing her (441-446) are very similar to those of Zeus seduced by the vision of Hera's beauty (Il. 14.314-328). In this case the choral connection is made explicit, though it is here referred to Paris, irresistibly attractive as though he was going

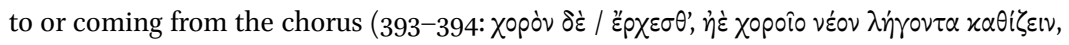
'he was going / rather to a dance, or rested and had been dancing lately'). The inversion of gender roles in that context is justified by the thematization of Paris' cowardice (cf. the insults of Priam to his surviving sons, linking them to the chorus in Il. 24.261), but the relevance of the choral association is none the less clearly established for both episodes (cf. following note). 


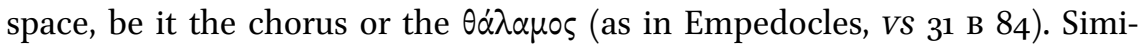

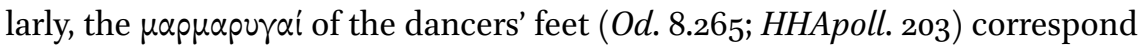
to the $\mu \alpha p \mu \alpha i p o v \tau \alpha$ ö $\mu \mu \alpha \tau \alpha$, the flashing eyes by which Aphrodite is recognized by Helen under her disguise as an old woman (Il. 3.397).44 Other images frequently used to describe the eye, based on its circular shape, include the astral bodies (sun, moon or stars) and the wheel. These verbal correspondences linking the eye and the chorus are also paralleled in the Geometric iconographic language, in which visual links are established, for example, between the eyes, the shields, the chariot wheels, and the garlands, in the figured scenes (figs. 4.11 and 4.12), ${ }^{45}$ as well as with the geometric dotted circles just mentioned, in the purely abstract fields, suggesting a reciprocal mirroring, both inside the iconographic space, between the different elements there, and outside, between the image and its viewer. Thus, the importance of the eye motif in choral contexts, in texts as well as in iconography, implies a mirroring effect, a dynamic relationship that opens up the field of representation to reach out to the beholders surrounding it, at the same time drawing them into it and projecting itself upon them.

With the appearance and generalization in the Late Geometric period of complex figured and narrative scenes, the geometric patterns tend to occupy the margins of the iconographic space, often adopting the function of frames, but also, occasionally, placed inside specific panels, though now in a marginal position to the central scenes. When the chorus appears in the representation, it tends to occupy this same position, often in or near the neck of the vase, as a framing or encircling motif of the whole iconographic space. ${ }^{46}$ This disposition became a recurrent iconographic feature, running from the Late Geometric period (e.g. a Boetian pythoid jar, [fig. 4.13]) through the Orientalizing (e.g. two Attic loutrophoroi by the Analatos Painter, one in the National Archaeological Museum at Athens, the other in the Louvre [fig. 4.14]) to the Black Figure (e.g.

44 On the choral connotations of this passage cf. Carruesco (2009).

45 A perfect match between the eyes of the human figures (female mourners above and charioteers below) and the central point of the chariot wheel, where the axis is fixed, can be found in a Late Geometric neck-handled amphora from the Kerameikos (Schweitzer [1971] figs. 49-50).

46 We can probably include in this group the representations of mourners in procession, as they are to be considered as singing the threnos (cf., e.g., an Attic amphora reproduced in Coldstream [1968] pl. 11d). Also here belong the frequent representations of friezes of grazing or marching animals around the neck of the vase (cf., e.g., an Attic Late Geometric amphora in the Benaki Museum, with a frieze of grazing horses and waterbirds: Schweitzer (1971) pl. 30). 


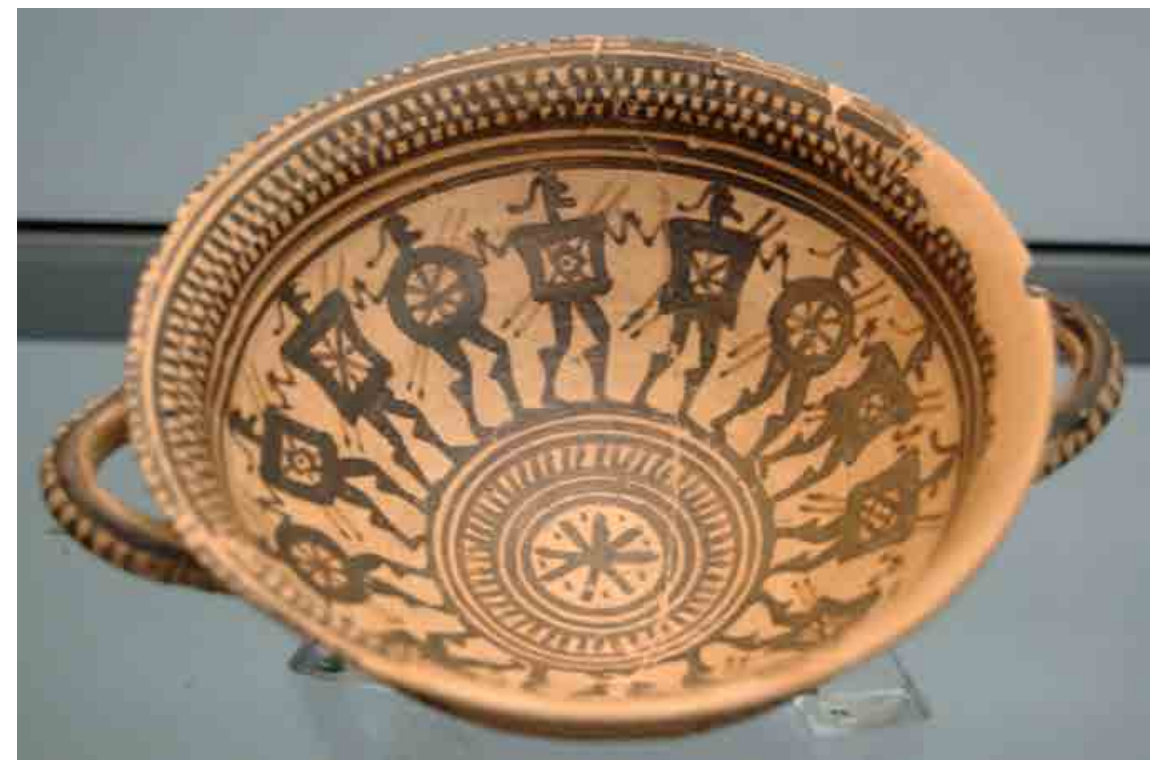

FIG. 4.12 Dancing warriors. LG cup.

STAATLICHE MUSEEN, BERLIN (INV. 6029). PICTURE: WiKimedia COMMONS (PUBLIC DOMAIN).

the representation of the arrival of Theseus and his companions to Delos on the François Vase). A kylix from Tarquinia (fig. 4.15) offers a very interesting example, with Heracles and Triton at the centre and chorus of girls (which can also represent Nereids) surrounding them. The centre of the space is occupied by the clasped hands of Heracles imprisoning Triton in a wrestling hold, an

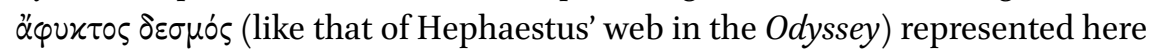
as a labyrinthine meander which echoes the locked hands of the surrounding chorus. This becomes even more evident if compared to another Attic redfigure kylix with the battle of Thetis and Peleus (fig. 4.16). Here, the place of the chorus is occupied by a geometric band, a $\pi \varepsilon p \iota \pi \lambda \circ x \eta$ exactly reproducing the central clasped hands motif, which in this mythical context is a nuptial as much as a wrestling motif.

It is important to note that this liminal disposition of the chorus is precisely that of the choral scenes in the shield of Achilles, with the first chorus opening the band representing the City at Peace and the City at War, the second chorus closing the band with the three seasonal agricultural works, and the last choral scene both occupying an independent space of its own and functioning as the closing band of the whole shield (with the exception of the non-narrative rim with the representation of the Ocean). We may also mention in this framing or liminal position the chorus of the Muses in the proems to the Catalogue of Ships 


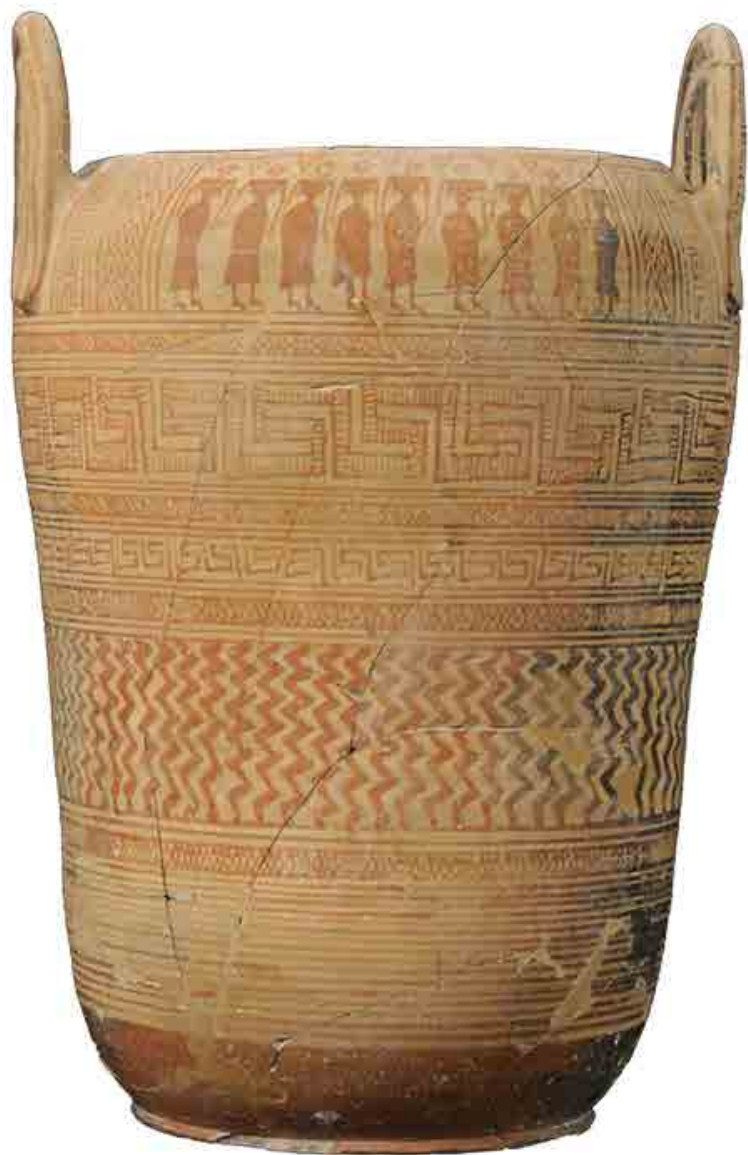

FIG. 4.13 Boeotian LG pythoid jar, from Thebes

ARCHAEOLOGICAL MUSEUM, THEBES BE469.

(C) HELLENIC MINISTRY OF CULTURE AND

SPORTS-ARCHAEOLOGICAL RECEIPTS FUND.

and to the Hesiodic poems, or the three choruses scanning the Homeric Hymn to Apollo (the Deliades at the end of the first, Delian part; the Olympians at the beginning of the Delphian section; and the processional chorus of the Cretans turned Delphians at the end). As all these examples show, this liminal position is not a minor, marginal one, but rather has a crucial importance in defining the place where mimesis takes place, where the exterior and the interior of the song, as of the iconographic space, meet and interpenetrate each other. This is, in my view, the main function of the choral mimesis, as presented in the well-known scene of the chorus of the Deliades in the Homeric Hymn to Apollo (ll. 156-176). Through the contemplation of their extraordinary, mimetic voice, 


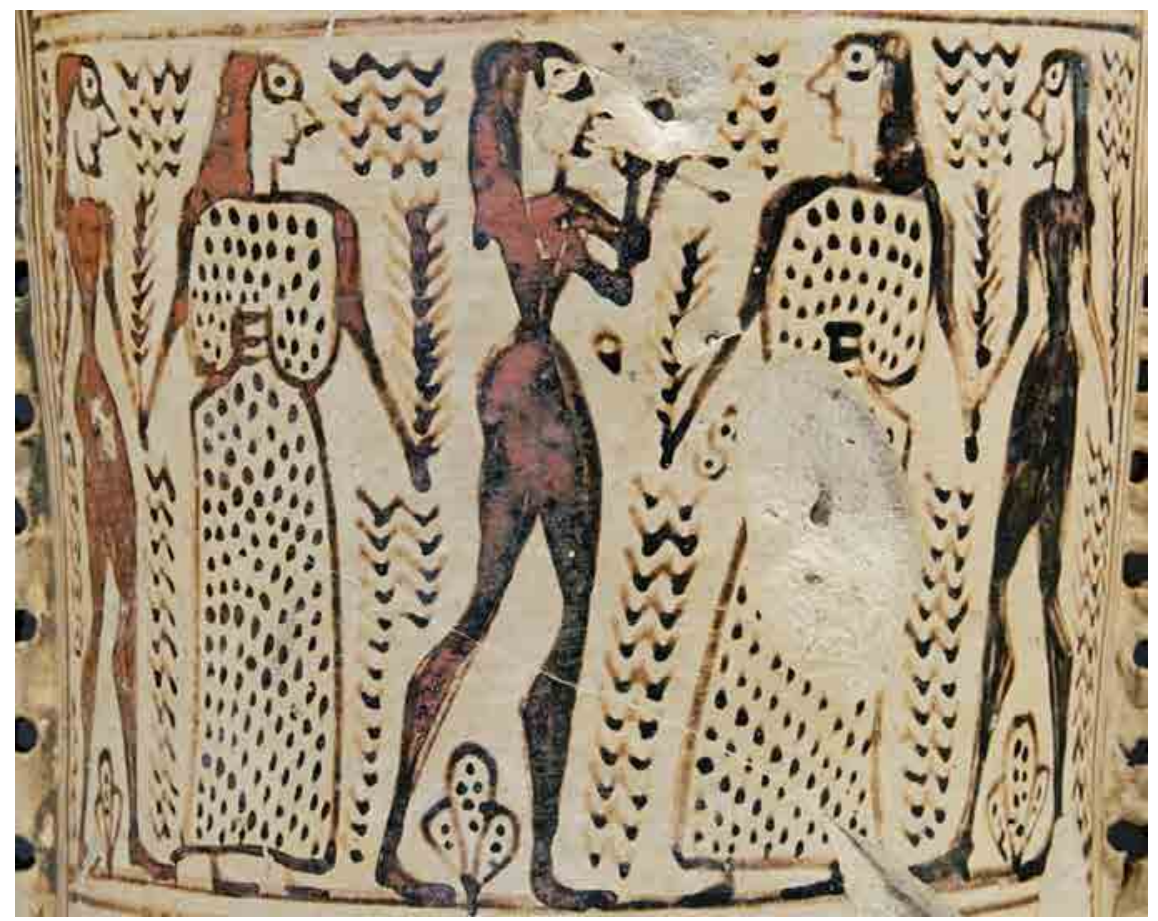

FIG. 4.14 Couples dancing. Neck of Attic (EPA) loutrophoros, by the Analatos Painter. LOUVRE CA2985. PICTURE: (C) MARIE-LAN NGUYEN / WIKIMEDIA COMMONS / CC-BY 2.5 .

the spectators enter the world of the chorus, believing that they are the ones singing, and by this mirroring look they are conferred with the quasi-divine beauty of the xópal as well as their collective identity as Ionians. But at the same time the chorus connects also the poet, the blind man from Chios, with his audience, the Ionians to whom the girls will confirm his excellence and that of his poems.

I have argued elsewhere that the epic passages I have just mentioned show that the epic poet needs to appropriate the chorus' voice and its mimetic force so that he may be able to order the world through the catalogic and genealogic mode of the discourse ${ }^{47}$ The three choruses that rhythmically scan the Homeric Hymn to Apollo, for instance, are to be closely related to the prominence of the geographical catalogues in this work, just as it is the invocation to the chorus of the Muses in Iliad 2, as opposed to the single thea at the beginning of the 


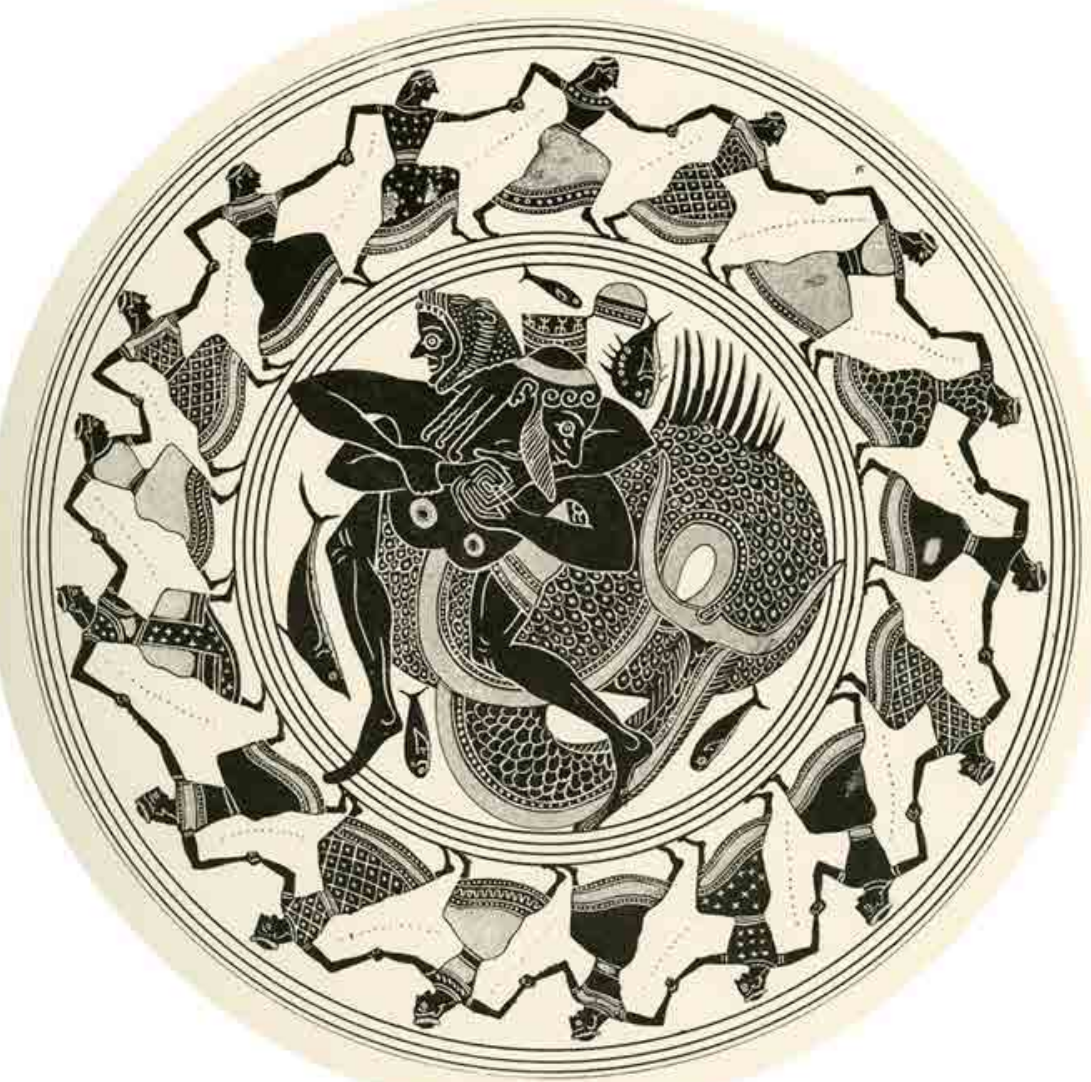

FIG. 4.15 Heracles and Triton. Attic Black figure kylix.

TARQUINIA MUSEUM (RC4194) DRAWING: J.E. HARRISON, D.S. MACCOLL, GREEK VASE PAINTINGS; A SELECTION OF EXAMPLES, LONDON 1894. PICTURE: WIKIMEDIA COMMONS (PUBLIC DOMAIN).

poem, that enables the poet to tackle the articulation of the Greek heroic world in the Catalogue of Ships, as Hesiod does in his works. Similarly, I would argue here that the potter too appropriates the active mimetic power of the choral performance, not only through the frequent representations of choruses, often in liminal spaces, but more generally through the extensive use of geometric patterns, first exclusively, and later in a framing relationship to the figured scenes. In this way, the chorus does not need to be actually represented to give the image its power of fascination, its ability to mirror the world surrounding it and project onto it its ideal images of order or heroic past (though it must also be stressed that, as in Demodocos' song, it can also do so in an inverted manner, as shown by the frequent representations of monsters, shipwrecks, or scenes of 


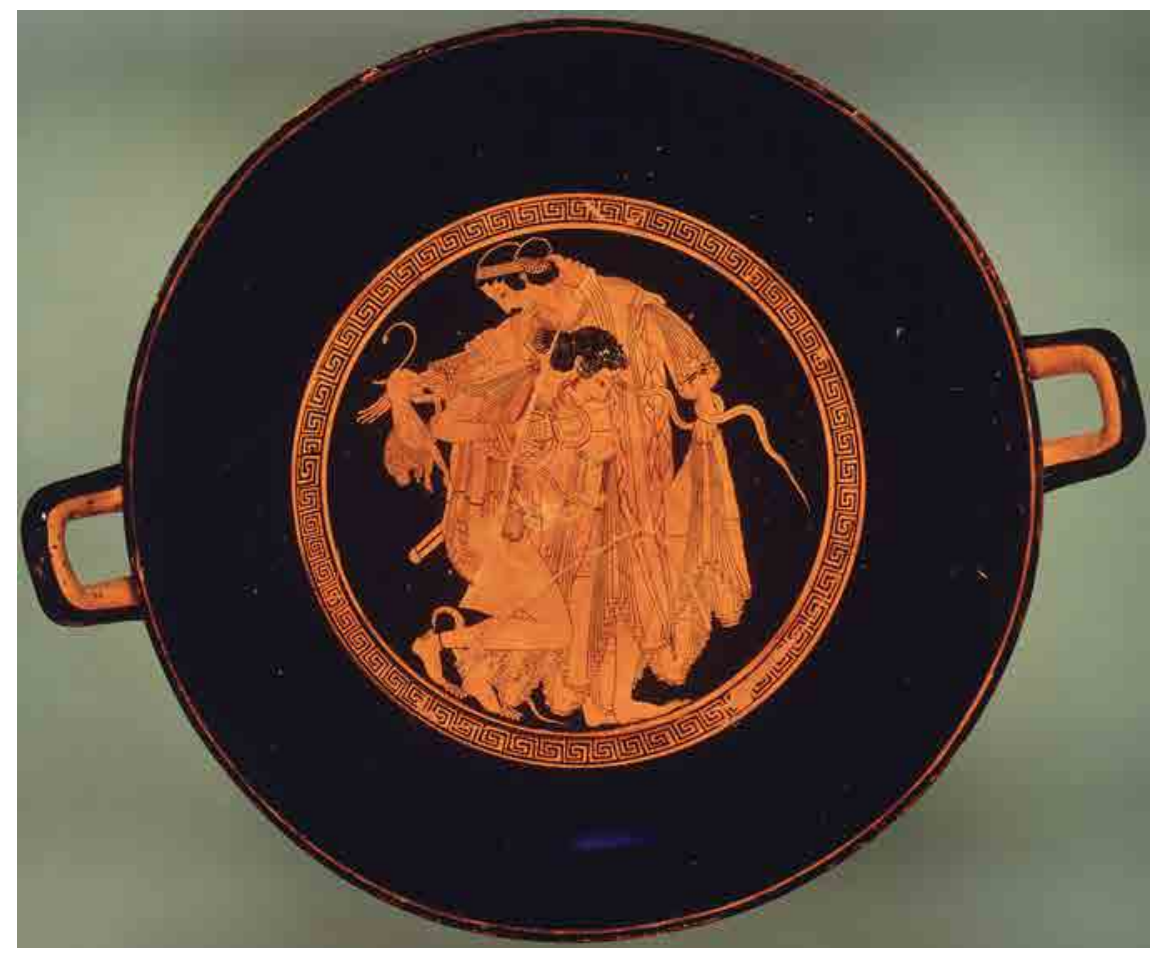

FIG. 4.16 Attic Red figure kylix

STAATLICHE MUSEEN, BERLIN (INV. F2279). THETIS AND PELEUS. BPK / ANTIKENSAMMLUNG, STAATLICHE MUSEEN ZU BERLIN / JOHANNES LAURENTIUS

violence) ${ }^{48}$ The xó $\mu$ os that is the ornamentation is at the same time the xó $\sigma$ os as an ordered and articulated world. In this respect, the iconographic language of Geometric pottery is the first episode in a long series of sophisticated experimentations with the power and limits of the image that is so characteristic of Greek art. The analysis of these iconographic strategies, recognized as deriving from the cultural model of chorality, can help us in turn understand better similar strategies in poetry, as they were 'looked at' and 'read' by the audience.

48 Cf. Plat. Leg. 79oe. Plato observes a similar mechanism at work in the Bacchic dances, which, by creating images of frenzy and violence, provoke in the audience tranquillity and order. 


\section{Works Cited}

Ahlberg, G. (1971). Prothesis and Ekphora in Greek Geometric Art. Studies in Mediterranean Archaeology, 32. Göteborg.

Athanassaki, L. and Bowie, E. (eds) (2011). Archaic and Classical Choral Song: Performance, Politics and Dissemination. Berlin.

Becker, A.S. (1995). The Shield of Achilles and the Poetics of Ekphrasis. London.

Boedeker, D. (1974). Aphrodite's Entry into Greek Epic. Leiden.

Braswell, B.K. (1982). 'The Song of Ares and Aphrodite: Theme and relevance to Odyssey 8'. Hermes 110: 129-137.

Brown, Ch.G. (1989). 'Ares, Aphrodite, and the laughter of the gods'. Phoenix 43:283-293.

Buboltz, L.A. (2002). Dance Scenes in Early Archaic Greek Vase-Painting. Diss. Harvard.

Burkert, W. (1960). 'Das Lied von Ares und Aphrodite'. RhM 103: 130-144.

Calame, C. (2001). Choruses of Young Women in Ancient Greece. Their Morphology, Religious Role, and Social Functions. Trans. D. Collins and J. Orion. Lanham, MD; London.

Carey, C. (1981). A Commentary on Five Odes of Pindar: Pythian 2, Pythian 9, Nemean 7 , Isthmian 8. Salem, NH.

Carruesco, J. (2009). 'La colère d' Aphrodite et d' Hélène dans la poésie grecque archaïque' in S.H. Aufrère, \& H. Mazoyer (eds) Clémence et châtiment. Paris: 39-47.

- (2010). 'Prácticas rituales y modos del discurso: la coralidad como paradigma del catálogo en la poesía arcaica griega' in Actas del XII Congreso Nacional de Estudios Clásicos, Valencia: 387-394.

Carson, A. (1982). 'Wedding at noon in Pindar's Ninth Pythian'. GRBS 29: 121-128.

Carter, J.C. (1972). 'The Beginnings of Narrative Art in the Geometric Period'. BSA: 25-58.

Coldstream, J.N. (1968). Greek Geometric Pottery. London.

Duethorn, G.D. (1962). Achilles' shield and the structure of the Iliad. Amherst, Mass.

Edwards, M. (1991). The Iliad: A Commentary, vol. v: Books 17-20. Cambridge.

Ferrari, G. (2008). Alcman and the Cosmos of Sparta. Chicago.

Frontisi-Ducroux, F. $\left(\mathbf{2 0 0 0}^{2}\right)$. Dédale. Mythologie de l'artisan en Grèce ancienne. Paris.

Himmelmann-Wildschutz, N. (1962). 'Der Mäander auf geometrischen Gefässen' in Marburger Winckelmann-Programm: 10-43.

(1968). 'Über einige gegenstandliche Bedeutungsmöglichkeiten der frühgriechischen Ornaments' in Abhandlungen der geistes- und socialwissenschaftlichen Klasse der Akademie der Wissenchaften und der Literatur in Mainz 1968 No. 7. Wiesbaden: $259-346$.

Kowalzig, B. (2007). Singing for the Gods. Performances of Myth and Ritual in Archaic and Classical Greece. Oxford.

Langdon, S. (2008). Art and Identity in Dark Age Greece, 1100-7оо всЕ, Cambridge.

Lonsdale, S. (1993). Dance and Ritual Play in Greek Religion. Baltimore. 
Morris, S.P. (1995). Daidalos and the Origins of Greek Art, Princeton.

Myers, M. (2007). 'Footrace, dance, and desire: The Xopós of Danaids in Pindar's Pythian 9'. Princeton/Stanford Working Papers in Classics. Paper No. 120701. Available at SSRN: http://ssrn.com/abstract=1426931i

Nagy, G. (2003). 'The shield of Achilles: End of the Iliad and beginning of the polis' in Nagy, G. Homeric Responses. Austin: 194-207.

de Polignac, F. (1995). La naissance de la cité grecque, Paris.

Priestley, J.M. (2007). 'The yapos of Alcman's Partheneion 1'. Mnemosyne 6o: 175-195.

Puelma, M. (1995). 'Die Selbstbeschreibung des Chores in Alkmans grossem Partheneion-Fragment' in Labor et Lima. Kleine Schriften und Nachträge. Basel: 51-110.

Reig, M. and Carruesco, J. (2012). 'Chôros-chore: la delimitació de l'espai en els textos homèrics' in E. Vintró, F. Mestre, and P. Gómez (eds), Homenatge a Montserrat Jufresa. Barcelona: 285-310.

Revermann, M. (1998). 'The text of Iliad 18.603 and the presence of an doเઠ́s on the shield of Achilles'. cQ 48: 29-38.

Richardson, N. (2011). 'Reflections of choral song in early hexameter poetry' in Athanassaki and Bowie (eds) (2011): 15-31.

Rystedt, E. and Wells, B. (eds) (2006). Pictorial Pursuits. Figurative Painting on Mycenaean and Geometric pottery. Acta Instituti Atheniensis Regni Sueci, Series in $4^{\circ}$, LIII. Stockholm.

Schweitzer, B. (1971). Greek Geometric Art. Transl. by P. and C. Usborne. London.

Segal, C. (1998). 'Sirius and the Pleiads in Alcman's Louvre Partheneion' in Aglaia. The Poetry of Alcman, Sappho, Pindar, Bacchylides, and Corinna. Lanham, MD: 25-41.

Snodgrass, A.M. (1998). Homer and the Artists: Text and Picture in Early Greek Art, Cambridge.

Taplin, O. (1980). 'The shield of Achilles within the Iliad'. G\&R 27: 1-21.

Whitley, J. (1991). Style and Society in Dark Age Greece. The Changing Face of a Pre-literate Society $1100-700$ BC. Cambridge. 


\title{
Making Monkeys: Archilochus frr. $185^{-187}$ w. in Performance* $^{*}$
}

\author{
Deborah Steiner
}

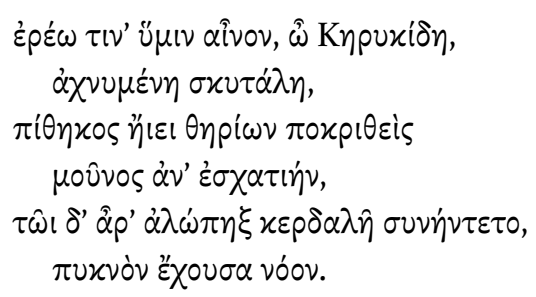

I shall tell you people a fable, Kerykides, a pained message stick: a monkey was going, keeping away from the beasts, alone in the back-country, and a fox with a view to gain met him, a fox with a guileful mind.

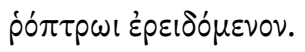

pressing on the trap spring

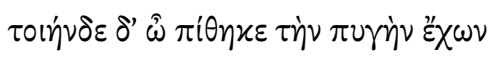

monkey, with buttocks like this

In the fragmentary Epode cited above (frr. $185^{-187}$ w.), the seventh-century Ionian iambographer Archilochus selects one Kerykides as his target, mocking

* This paper was first delivered, in very different form, to the Classics Department at NYU; I am most grateful for the helpful comments of the audience there, and also to the participants at the Delphi conference where it received a second airing. Many additional thanks are due to the editors of this volume for their several suggestions for improvement.

(C) DEBORAH STEINER, 2016 | DOI: 10.1163/9789004314849_006

This is an open access chapter distributed under the terms of the Creative Commons Attribution-

Noncommercial 3.0 Unported (CC-BY-NC 3.0) License. 
his interlocutor through his narration of an animal fable featuring an upstart monkey duped by a more wily fox. My aim in exploring a poem that has attracted relatively little commentary in existing scholarship is three-fold: ${ }^{1}$ first, better to understand the impetus behind Archilochus' song and its contents by contextualizing it within its performative milieu, the archaic symposium; second, to restore to its central place an element frequently omitted from the many recent discussions of the sympotic occasion, namely dance; and third, to demonstrate the overlaps between the verbal and visual dimensions of that occasion by investigating the place of monkeys in the late archaic images and texts broadly contemporary with Archilochus' composition. My analysis falls into four sections. I begin with the figure of Kerykides and the agonistic situation that Archilochus constructs vis-à-vis his addressee, which positions the victim in mimetic relation to his mocker and anticipates the monkey motif of the ainos still to come. Section two tracks the meta-sympotic language of the fable, and argues that Archilochus intends the story both as an attack on a symposiast who has violated the decorum of the private gathering and as a public shaming of a political rival whose sympotic failings demonstrate a corresponding unfitness for civic office. In section three I turn to the visual evidence, proposing that monkeys in vase images from the archaic to the early classical period function much like Archilochus' ape- that they too transgress the boundaries of acceptable sympotic behaviour and raise the problem of interlopers at the drinking party and other elite sites. The closing discussion suggests a connection between simians in painted and plastic media and a second set of individuals who in art, and probably in real life too, fulfill a very similar function to the monkeys in the visual ambience of the symposium: not satyrs, whose affinity to monkeys fine discussions by François Lissarrague and Herman Brijder have already explored, ${ }^{2}$ but the so-called 'fat dancers' or komasts who appear on painted pottery from the mid-seventh century on.

1 The notes to van Dijk (1997) 144-147 offer a comprehensive review of the bibliography, to which add the important discussion in Bowie (2008) 133-136. Existing treatments generally concern themselves either with the question of whether Kerykides should be understood as an actual individual and contemporary of Archilochus, or with the presence of fable as a characteristic element of Ionian iambos.

2 See Lissarrague (1997) and (2000) and Brijder (1988). 


\section{Archilochus vs. Kerykides; Performative Rivals}

My reading of the poem begins with the question that other treatments of the work pose: who is Kerykides, whom, following Ewen Bowie's recent discussion, ${ }^{3}$ I regard as a real-world individual (although one probably not present at the event), and what is the nature of the antagonism between him and the author of the attack? As I argue, in these opening lines Archilochus announces a relationship of rivalry — political, aesthetic/performative, and sexual all — with his addressee that both locates Kerykides as an (erstwhile) equal and cosymposiast and suggests the element of imposture in his assumption of that status. The larger purpose of this frame, which follows the conventions visible in other iambic poetry whose authors use fables to mount their attacks, is not just to mock the speaker's victim, but also to prepare the way for the motif that the ainos more fully explores: like monkeys, and fat dancers too, Kerykides is simultaneously homologous self and other, a replica and distortion of the authentic and more properly aristocratic article.

Commentators past and present agree as to the social implications of the patronymic Kerykides, prominently positioned at the end of the opening line, ${ }^{4}$ in seventh-century Paros: one reader calls the designation 'quasi-epic', and others find it appropriate for an historical noble, the scion of an elite family, a military chief, a fellow aristocrat or political rival. ${ }^{5}$ The very use of the patronymic, which bespeaks a hereditary and quasi-sacred calling, demarcates Kerykides as one of a select company in Paros' political and religious life. A dedicatory inscription from late-sixth-century Thasos records the fact that an individual who held the highest office, that of archon, in both Paros and Thasos also 'performed many missions as messenger among other peoples on behalf of his

3 Bowie (2008) 133-136.

4 The emphatic use of the target's name at the opening of the composition is entirely consistent with the pattern found in other iambic attacks that use fables as vehicles of mockery; see, most famously, the address to Lykambes at the opening of Archil. fr. 172 w. (with Hawkins [2008] 97-99). Commentators plausibly suggest that fr. 168 w., which overlaps so closely with the opening lines of fr. 185, would have continued with an ainos: 'Charilaus, son of Erasmon, much the dearest of my companions, I will tell you something funny ( $\gamma \varepsilon \lambda \circ i o v)$ and you will delight in hearing it' (see Zanetto [2001] 69 for this). For the pun implicit in the name and patronymic, see Philipiddes (2009) 15-16; this article appeared after the Delphi conference where my analysis was presented, and I hope adequately to have noted areas of agreement and divergence in our accounts. Note too Ar. Vesp. 1400 and Callim. Ia. 4.1 for imitations of this archaic iambic practice.

5 Archibald (1902) lxxxix; Pouilloux (1964) 12; Lasserre (1984) 76; Adrados (1993) 3. 
city' (CEG $416=$ IG XII suppl. 412). ${ }^{6}$ And in Athens, the highly prestigious genos Kerykes supplied the dadouchos who served at the rites of Demeter at Eleusis; ${ }^{7}$ since the worship of Demeter on Paros and Thasos (of which more later on) is well attested already for the archaic period, it seems plausible that Kerykides' family might also have provided personnel for those rites.

In fr. 185 , the name Kerykides does more than position this individual at the social apex. The larger point of the first two lines is the implicit pun and evident parallelism between 'Son of Herald/Messenger' and the skutalê or message stick. ${ }^{8}$ As Stephanie West argues, readers have been misled by later sources' focus on the object's use as a cryptographic device, evidence for which long postdates Archilochus. Instead, its foremost meaning is that of a staff or baton, 'part of an official messenger's equipment', the function of the object in Aristophanes' Lysistrata 991, where it equips the Spartan kêrux. ${ }^{9}$ Moreover, it supplies an authenticating device, ${ }^{10}$ confirming that the herald comes in his official capacity and that the message that he carries/issues is genuine and officially sanctioned. Indeed, as Thucydides makes clear, ${ }^{11}$ the staff not merely equips its carrier, but is indispensable to his function: when negotiations between hostile parties broke down, 'the essential thing at such

I owe this reference to Bowie (2008) 136.

$7 \quad$ Members of the Athenian genos are also visible in the cult of Apollo on Delos and at the Lenaea; in the fifth century, it had among its numbers a family that included both the super rich Kallias and his grandson of the same name, a general, ambassador and patron of many of the leading intellectuals of the time. For details, see Parker (1996) 302.

8 The following discussion of the nature of that pun and the relationship that it supposes between the poetic ego and Kerykides necessarily depends on an uncertain reading in the manuscripts: while the most recent editor of the poem and some earlier discussions take skutalê as a nominative (so Gerber [1999] 201; see too the discussion in S. West [1988] 47), making the stick a figure for the speaker's own person, Bowie (2008) and several others prefer to read it as a vocative, in which case it would apply to Kerykides. Most recently, Philippides (2009) 14-16 revisits the debate, and argues for the vocative. For a further alternative see n. 40. At the risk of making a circular argument, I opt for the first account, both because this seems to work best with the remainder of the mockery and because it conforms to the dynamic of rivalry integral to this and other iambic compositions.

$9 \quad$ West $(1988) 43$.

$10 \quad$ West (1988) 44.

11 See particularly 1.53.1, where the historian remarks of the Corinthians' 'unofficial' embassy, 'they decided to embark men on a skiff and send them to the Athenians without a herald's staff ... and make trial of what they had intended'. For discussion of this and other relevant passages, see Drew Griffith (2008) 182. 


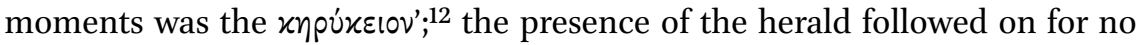
more reason than that the baton required a bearer.

With this opening phrase, Archilochus sets up a close but skewed bond between the speaker and his interlocutor: the poet has appropriated the now personified accessory from the individual to whom, following his name, it stands in metonymic relation, and, in a self-authorizing and message-authenticating gesture, makes himself qua stick spokesman of the communiqué that Kerykides should properly deliver in his own voice. In this sorcerer's apprentice-type scenario, the normally silent stick will go on to turn against its customary bearer, telling a story calculated to dismantle its target's self-construction and public image, and to demonstrate Kerykides' unfitness for the status and role seemingly announced by the opening patronymic. ${ }^{13}$ As West also acutely notes, Archilochus' choice to identify himself as message stick allows the speaker to distance himself from his mockery: he is only the reluctant (hence 'grieving'; see below) conduit for rather than author of his critique. Not only does this serve as a self-exculpatory gesture on the poet's part (and such placatory remarks are entirely typical of archaic fable tellers; cf. Hesiod, Works and Days 202), but, I would add, it makes the mockery still worse. What the ainos delivered by the stick goes on to articulate is not an individual attack, but a general, collective and even 'official' view, and one that, to boot, is broadcast loud and clear: from Homer on, to be a herald requires a powerful voice. ${ }^{14}$

But perhaps this is to take too naive a view of the skutalê. In Bowie's rich account, ${ }^{15}$ when the stick is read together with the monkey's buttocks that conclude the poem, and with Aristophanes' redeployment of Archilochus' closing extant line for a joke about anal penetration, ${ }^{16}$ it takes on the distinctly

12 Drew Griffith (2008) 183.

13 The attack that Archilochus launches belongs, moreover, in a time-honoured (and epic) tradition of mockery among peers: typical of 'flyting' exchanges between Homeric heroes on the battlefield is the suggestion that the object of rebuke is unworthy of his exalted paternal heritage (e.g. Il. 4.399-40o). Conversely, parentage can also be a source of mockery and abuse at the symposium; see Anacr. PMG 388.11 and Soph. OT 779-780.

14 See, for example, Il. 2.50, Arist. Pol. 132b8, Cic. Fam. 5.12.8. Note, too, how in the image comparing his chorus-leader to a skutalê at Ol. 6.90-91, discussed below, Pindar continues the evocation of the messenger when he then designates Aineas a 'mixing bowl of loudsounding ( $\dot{\alpha} \gamma \alpha \varphi \theta \dot{\varepsilon} \gamma \chi \tau \omega \nu)$ songs'.

15 Bowie (2008) 134-136.

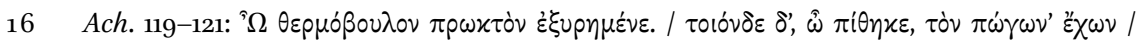

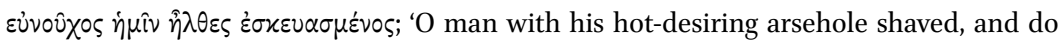
you monkey, with a beard like yours ...' (trans. Sommerstein). 
off-colour connotations so very much at home in the sympotic space. At Aristophanes' Lysistrata 991, the skutalê alludes not just to the baton that Spartan heralds regularly carry, but in a visible double-entendre, to this messenger's painfully erect phallos. A scholion to Thucydides (1.53.1 Hude) confirms that

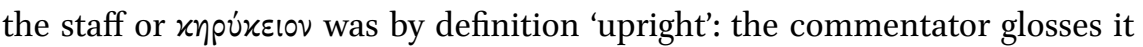

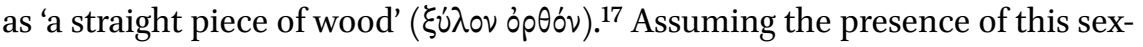
ual innuendo in Archilochus, though it is fully exploited only at the composition's end, the poet's mockery takes on a sharper edge. Since the 'stick' that the speaker claims for his own person more properly belongs to Kerykides, then Archilochus-in a typical iambic and literary/agonistic move that Hipponax also uses against Boupalos, and Aristophanes replicates in his mockery of Cratinus ${ }^{18}$ - impugns his target's manhood, appropriating the very symbol of his virility. ${ }^{19}$

But there is more to the skutale than just this typically sympotic word play; also consistent with a milieu that privileged displays of wit in the form of verbal and visual griphoi, ${ }^{20}$ and of eikones too, that game of comparisons in which the performer compared himself and others to some object or, typically, animal, the baton motif both presages the figure of the monkey soon to follow and comes accompanied by a term whose correct meaning will only be revealed in the song's concluding portion. Note that Archilochus designates the animal of the ainos a pithêkos, one among the several varieties of apes that appear in later discussions of the different simians known to the Greeks. Aristotle (HA 502ab) divides apes into three kinds, pithêkoi (Barbary apes, probably familiar to the Greeks from contacts with Phoenician traders and evidence for whose use as pets is apparent from the classical period on), kêboi (long-tailed monkeys) and kunokephaloi (baboons). What chiefly distinguished pithêkoi was their lack of tail. Jeffrey Henderson has amply documented the obscene meaning of kerkos, 'tail', in the ancient sexual vocabulary and its role as a symbol for the phallos; ${ }^{21}$ although his sources postdate archaic iambos, Archilochus' extant fragments, too, contain many instances of expressions that carry such double and sexually-

17 Cited in Drew Griffiths (2008) 182 who notes how the characterization conforms to visual representations of the herald's staff, and the caduceus of Hermes. Cf. too, Pi. Ol. 6.90-91, on which more below.

18 See Rosen (1988) 39 on Hippon. fr. 86 w., and Ar. Eq. 526-536, with Hawkins (2008) 104105 .

19 The link between messengers and virility is visible in the form of the message-bearing, phallic herms supposedly set up by Peisistratus in sixth-century Athens.

20 See Neer $(2002)$ 15, 46, 62-63 for these.

21 Henderson (1991) 20, 87, 128, 177. 
loaded meanings (e.g. frr. 42, 44, 119, 188 and 189 w.). Of course, then, Kerykides must be a pithêkos: deprived of his skutalê, he has, inevitably, lost his 'tail'.22

Nor is this quite the end to the joke. We can read the adjective used of the stick, 'grieving', as Archilochus' self-exonerating and mock declaration of his unwillingness to deliver his unwelcome message, or, understanding the expression in the objective sense, as an anticipation of the misery that his song will cause Kerykides. ${ }^{23}$ But the sexual implications of the co-presence of the skutalê and rump invest $\alpha \chi \chi v u \mu \varepsilon \dot{v} \eta$ with its own iambic sting. Since, as I go on to detail, the monkey plainly serves as a cipher for Kerykides, the fox's reference to his victim's buttocks implicitly invites the audience (retrospectively) to focus their attention on the corresponding portion of the addressee's anatomy. ${ }^{24}$ As visual and verbal accounts make clear, ${ }^{25}$ simian posteriors are notoriously misshapen or even missing, and we might assume a similar deficiency (real, or merely as one element of the poet's mockery) on Kerykides' part. Read this way, the enigma posed by $\alpha \chi \chi v \mu \varepsilon \dot{v} \eta$ is belatedly and amusingly resolved for a puzzled audience: just like the baton belonging to the Lysistrata herald, Archilochus' skutalê is 'pained' because, were it to seek out Kerykides in an erotic capacity (with all the relations of subordination that the latter's position as eromenos necessarily involves), it too would be bound to remain painfully

22 It is tempting to see the first element in Kerykides as also gesturing towards this 'tail' element, and an additional way in which an individual's name (or, in some instance, moniker) can generate the joke that follows. The same monkey/phallos pun probably underpins the myth of the roguish Kerkopes' theft of Heracles' bow, a story, our ancient commentators claim, familiar to Archilochus and already visible in his fr. $178 \mathrm{w}$. (the myth then reappears in Cratinus' Archilochoi, fr. 13 Kassel-Austin, further suggesting a link between the iambic poet and the story); not only does the brothers' encounter with Heracles feature the same set of elements — trapping, buttocks, genitals, and ridicule—as the Epode, but, in sources from the fourth century on, the Kerkopes, whose name means 'Tail-face', are transformed into pithêkoi. The joke becomes particularly pronounced on a fourth-century Lucanian pelike (Malibu, the J. Paul Getty Museum 81.AE.189) which displays the two brothers, characteristically hanging upside down from the pole carried by Heracles, both endowed with outsized genitalia; one of the two additionally has the face of a monkey; for discussion of the image and play on kerkos in the representation of the simian-faced brother on the vase, see Walsh (2009) 179 with his figs. 62a-c.

23 Philippides (2009) 16 argues for this last implication.

24 Bowie (2008) 134, observing how frequently in later Attic comedy and political rhetoric an allusion to the $\pi \cup \gamma \eta$ serves to brand an individual with the charge of pathic homosexuality, suggests that Archilochus anticipates that slander here, and directs the same imputation at his target.

25 So already in Semon. fr. 7.76 W. and Arist. $P A 689 \mathrm{~b}_{30}-35$; see further sections 2 and 3 below. 
upright. ${ }^{26}$ Compounding 'Herald's Son's' failure to fulfill his messenger's role is, then, his inadequacy qua partner in the humiliating sexual encounter projected here. $^{27}$

One further aspect of the polysemous skutale looks to this notion of a partnership manqué or gone awry. Several ancient sources cite the baton's use as a sumbolon, an object that could be split in two and, on being reassembled, would confirm the transactions and alliances between the individuals whose relations it physically instantiated. ${ }^{28}$ When Pindar uses the message-stick image at Olympian 6.90-91, where he styles the chorus trainer Aineas an 'upright mes-

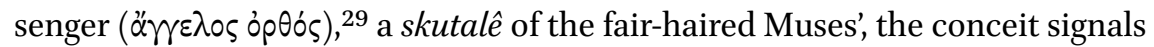
both Aineas' role as the wholly accurate deliverer of Pindar's composition and the exact 'fit' or homology between the encomiast and his co-worker: ${ }^{30}$ so perfectly matched are they that one can stand in for the other and Aineas lead the chorus in Pindar's absence. Archilochus' self-characterization as skutalê suggests the reverse dynamic, even a falling out between those who once were fellow-symposiasts and perhaps sworn hetairoi in the drinking group. ${ }^{31} \mathrm{Far}$

26 Such self-mockery, particularly of a sexual kind, is entirely at home in Ionian iambos (note Archilochus' famous Cologne Epode, fr. 196a w., with its closing suggestion of coitus interruptus). See Hedreen (2006) 294-298 for detailed discussion of the point, with additional evidence from Hipponax.

27 It is not inconceivable that the poetic ego suggests that some such erotic relationship did exist between him and his speaker; perhaps a sexual as well as political fallout or betrayal would then lie behind the attack.

28 West (1988) 44-45.

29 Here we have a play on the 'straight/upright' character of the baton, whose physical aspect forms a piece with the veridical and ethically correct nature of the messenger and his speech. Philippides (2009) 19 calls attention to the adjective in the context of a very different argument.

3o Here I somewhat modify the acute reading of the image in Carne-Ross (1979) 34. I would further suggest a consciousness of the iambic precedent in Pindar (as also argued by Philippides [2009] 18-20 on grounds different from those mentioned here). The poet

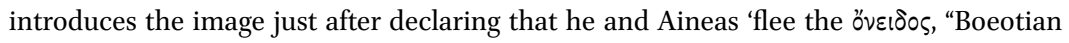
pig", presumably a standard piece of invective, and then goes on to equate Aineas with a sympotic krater, the centerpiece in the sympotic space where such iambic mockery would be performed.

31 In more explicit fashion, the Lykambes Epode (frr. 172-181 w.) attacks its victim for a violation of an earlier pact of friendship, or, in the reading of Bowie (2008) 137-141, Lykambes' betrayal of a political alliance between the speaker and his addressee. The motif of treachery between friends is a theme entirely typical of sympotic poetry; for this in Theognis, see Donlan (1985); Alcaeus fr. 129 v. explicitly addresses Pittacus' violation of the oath of alliance that he swore, quite possibly in the context of the symposium where such 
from existing in the relations of equivalence that the bi-partite message stick normally affirms, ${ }^{32}$ Kerykides' shortcomings, whether anatomical or heraldic, signal his incapacity to supply the requisite matching portion, to measure up.

Why then this fine-tuned demonstration of Kerykides' deficiencies in these several and interrelated spheres? While sexual ribbing is thoroughly at home at the symposium, ${ }^{33}$ and the iambic poet's construction of relations of symmetry and rivalry with his sparring partner are very much a hallmark of the genre, ${ }^{34}$ Archilochus' focus on the public status that his victim's name articulates takes this sympotic confrontation out of the confines of the dining room and projects it into the more civic domain. What motivates this song, I suggest, is an ongoing political agôn between Kerykides and the poet, with the role of public herald as the sticking point between them. ${ }^{35}$ As noted earlier, heralds figure prominently in rites celebrated on behalf of Demeter, and both Archilochus' poetry and the Vita record the link between the iambographer and his family and the Demeter cult on Paros and Thasos. Intriguing in this regard is a phrase in the Mnesiepes inscription ( $S E G \mathrm{XV} 517$ ), which describes the poet's scandalous introduction of 'something too iambic' for performance at a local festival. As Diskin Clay observes, the words $\varkappa \varepsilon \varkappa \circ \sigma \mu \eta \mu \varepsilon$ [ $\nu$ - and $\varkappa \dot{\eta}] \rho \cup x \circ$ in the inscription's lines $24-25$ could either suggest a herald in festival attire come to announce the new mode of worship that Archilochus was to initiate or describe the poet's appearance in herald's dress. ${ }^{36}$ This second scenario seems better to fit the context: presenting himself in the official capacity which properly belonged to him, Archilochus would be claiming the impunity that heralds enjoyed so as safely to perform his innovatory and risqué song. ${ }^{37}$

pledges were exchanged, while fr. $70 \mathrm{~V}$. paints the poet's political opponent as a symposiast, and so as a double of the performer of the current composition.

32 Note Kinesias' response at Ar. Lys. 992-993 for another declaration of homogeneity as demonstrated by the skutalê. Because he too has just such a baton/phallos as the Spartan messenger, he is already 'in the know' concerning the communication that the Spartan brings.

33 Cf. Hippon. fr. $30.1 \mathrm{w}$.

34 For this see Steiner (2009a).

35 Here I build on Bowie (2008) 136. His reading does not, however, include the possibility of a stylized element to this rivalry so as to bring it in line with the stereotypical interactions between iambographers and their echthroi. It is entirely possible to imagine a blend of reality and fiction here, in which the suggestive name of a fellow Parian aristocrat and contemporary political feuding serve as the starting point for Archilochus' witty construct.

36 Clay (2004) 17.

37 Note, however, that, according to the testimonia, the costume failed to protect its wearer, who was indeed punished for his composition. 
Clay's discussion notes in passing a striking 'follow up' to Archilochus' heraldic self-fashioning as the inscription records it: ${ }^{38}$ when attempting to persuade his fellow Athenians to resume an unpopular war with Salamis, and so as to escape prosecution from the current law explicitly prohibiting this type of speech, Solon presented himself in herald's guise ( $\alpha \dot{\tau} \tau \grave{\zeta} \varsigma \hat{\eta} \rho v \xi \hat{\eta} \lambda \theta_{0 \nu}$, 'I have, in person, come as a herald') to deliver his song of martial exhortation (frr. 1-3 w.). But Archilochus fr. 185 W. offers a no less compelling precedent than the incident reported in the Mnesiepes inscription for Solon's performance here. Not only, like his Parian predecessor, does the Athenian poetpolitician replace the herald's usual speech in prose for one in verse ( $\dot{\omega} \delta \dot{\eta} v$

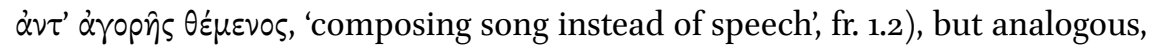
too, is his re-staging of a properly political message in what seems likely to be a sympotic context where, in keeping with the role-playing that went on at that site, the symposiast might even have dressed the part and engaged in an impromptu performance, ${ }^{39}$ baton and all. ${ }^{40}$ Like Archilochus too, the Solonian singer could plausibly expect that his message, invested with all the public warrant and truth-content that defines heraldic discourse, would travel beyond the present audience and reverberate in the civic world outside.

In every respect then, Kerykides is positioned as the poet's double, an alter ego who turns out imperfectly to mirror, or in sexual terms, to 'fit' the original. It is this near, but not-quite-exact homology that in part motivates the fable's simian motif as Archilochus taps into a notion that would prove ubiquitous in Greco-Roman culture: the monkey as the animal that, more than any other, most closely 'apes' men, supplying an almost perfect, but ultimately inauthentic and incomplete, imitation of the original. So a fragment of Phrynichus styles flatterers and illegitimate offspring - the ones posing as friends, the others as true-born citizens-'monkeys' ( $\pi$ in'xous, fr. 21 Kassel-Austin; the term is also regularly used in Attic comedy of sycophants and parvenus), while Plutarch similarly likens the flatterer's imitation of the conduct of a friend to

38 Clay (2004) 17, but without additional discussion.

39 Bowie (1986) 18-21 argues most strongly for a sympotic setting; for a discussion and review of the different possible positions on the question, see Noussia-Fantuzzi (2010) 205 and Steiner (2014) 3, where I also argue for the sympotic and iambic character of frr. 1-3 W.

40 In a third suggestion concerning the problem of the case of $\alpha \chi v v \mu \varepsilon \dot{v} \eta \sigma x v \tau \dot{\alpha} \lambda \eta$ (see n. 8 above and the review of alternatives in Philippides [2009] 14), some editors have taken it as a dative, and supposed that Archilochus delivered his message with a message stick; the nominative reading given here preserves that possibility if we assume a more dramatictype performance of the song complete with props. 
the behaviour of a monkey (Moralia $5^{2 b}$, $\left.64 \mathrm{e}\right) \cdot{ }^{41}$ For Lucian, telling an anecdote that features dancing monkeys (Piscator 36), ${ }^{42}$ the animals are the most prone to imitate $\left(\mu \mu \eta \lambda \hat{o}^{\prime} \tau \alpha \tau \alpha\right)$ men, and in a note on the passage in Plato's Republic where Thersites is described as putting on the soul of a pithêkos in the afterlife (620c), Proclus builds on this long tradition when he observes that the ape soul that Thersites assumes stands for the life of the imitator (In Platonis Timaeum commentarii $329 \mathrm{~d}){ }^{43}$ The act of betrayal integral to the imposture that the monkey practices, and the heinous deed of violating the sworn bond of hetaireia which typically motivates an iambic attack and may be operative here, is a second prompt for the entrance of the monkey: in a characterization of the Kerkopes as 'deceptive rogues' ( $\dot{\alpha} \pi \alpha \tau \eta \lambda \circ i$ i $\pi \alpha \nu 0 \hat{p} p \gamma \circ \mathrm{l}$ ), Semonides goes on to remark that 'monkey business ( $\varkappa \varepsilon p \kappa \omega \pi i \alpha)$ is deception' (fr. $34 \mathrm{~W}$.).

\section{The ainos and Its Sympotic Frame}

With this by way of preface, Archilochus goes on to narrate the fable promised in the opening lines. In discussing the story, I first map its several protagonists onto the individuals named in the incipit, and then highlight the metasympotic language that the fable includes, anchoring it to the occasion and to the concerns typical to that institution; the fable's sympotic commentary, I further suggest, functions much like the vocabulary deployed in the opening lines, uniting the events in the dining hall with affairs in the political arena.

With the later Aesopic version of the ainos at hand, ${ }^{44}$ unscrambling the lacunose story isn't hard: the ape stands for Kerykides, the fox for Archilochus,

The scholia to Pind. Pyth. 2.72 cited below (schol. 2.131b, 132c-f Drachmann) identify the 'monkey' here as Bacchylides, whom Pindar would be casting as his failed imitator and even 'plagiarist' (for this, see Bowra [1937] 9-21).

Here costumed apes performing the sword dance all but dupe their viewers into thinking the dancers human; the imposture is only revealed when the audience throws nuts on the stage and the monkeys display their real nature by rushing to the food. This 'imitative dancing, as well as the promise of extra rations, are themes that I take up in section 2.

43 For the mimetic monkey, see further the plentiful examples cited in the discussions in Bowra (1937) 10-11, Connors (2004), Lilja (1980) and Luria (1930).

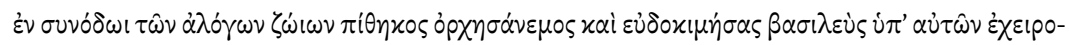

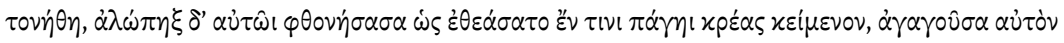

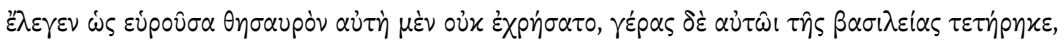

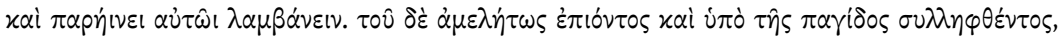

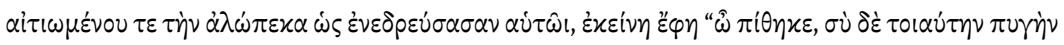

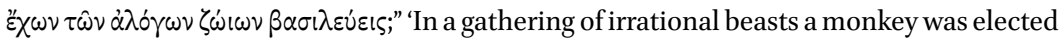


and the rest of the animals who cast their votes figure the larger audience at the performance. ${ }^{45}$ The monkey's double trajectory, first up, then down, closely corresponds to that of Kerykides, at least as the poem presents him. Matching Archilochus' initial acknowledgment of his interlocutor's high public status is the acclaim that the witnesses to the monkey's dancing grant the beast, and its subsequent election as king. The wooden trap into which the unwary ape later falls illustrates the way in which the two-faced and superficially entertaining ainos - a term cognate with ainigma and ainissomai, ${ }^{46}$ and which trap-like conceals its true nature or underlying meaning beneath a pleasing coveringwill similarly ensnare its gullible victim and deliver its painful correction. ${ }^{47}$ The fox's parting jibe also matches the fable frame: just as Kerykides' lack of skutalê indicates the element of imposture/inadequacy in his claim to herald's status, so the monkey's lack of rump proves the decisive element in the revelation that this monkey king has, as it were, no clothes.

Nor does the larger audience (as typically in archaic fables, which may address themselves to multiple interlocutors) get off scot-free. If the animals that elect the monkey after its display of dancing skills stand in for the broader sympotic group, then the 'king's' unmasking simultaneously reveals these individuals' failure of judgment - they too have rated Kerykides too highly both at the symposium and in civic affairs where they have allowed him to serve as herald. ${ }^{48}$ Elsewhere too, in Pindar's second Pythian, a monkey brings about the same aesthetic-cum-ethical confusion and exposure on the part of a group of auditors, and this in a composition in which, as I have argued elsewhere,

king by them after dancing and thus gaining distinction. A fox became jealous of him, and when she saw a piece of meat lying in a trap, she took him there and told him that she had found a treasure, but instead of using it herself had kept it as a prerogative of prestige for him as king, and she urged him to take it. He approached it thoughtlessly and was caught in a trap, and when he accused the fox of having ambushed him, she said, "Monkey, with buttocks like that are you really going to be king of the irrational beasts?"' (Aesop 81 Perry).

45 Van Dijk (1997) 146-147.

46 See Nagy $\left(1999^{2}\right) 240$ for this.

47 Babrius' reworking of this fable's motif for another story (130) appears to integrate the skutalê of Archilochus' incipit into the body of the fable itself; in this instance $\sigma x v \tau \dot{\alpha} \lambda$ เov is the term used for the 'trigger' that, when jogged, releases the trap. In the light of the earlier discussion of the monkey's buttocks, it is also intriguing that in Babrius' tale the

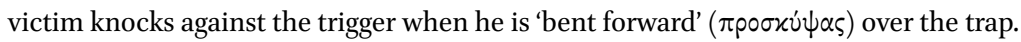

48 As Bowie (2008) 134 suggests, the term $\alpha$ $\lambda$ oro also belonged to the song's lost final line (which would be required by the metre), allowing the audience more easily to connect the world of the beasts with their own. 
Archilochus and his poetry of invective-and-ainoi form a leitmotif. ${ }^{49}$ Distinguishing his patron Hieron from those listeners who fail to give the poet's ode the reception that its aesthetic merits warrant, ${ }^{50}$ Pindar contrasts his laudan$d u s$ with individuals who 'don't get it'; they are figured as children captivated by the charms of a monkey: 'Pretty is the ape in the eyes of children, always

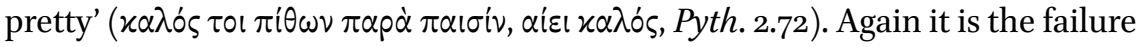
to discern the monkey's signature ugliness, and this within the context of passing aesthetic judgment, that indicates a larger flawed taste and want of mental wherewithal.

The fox-the Archilochean cipher both here and in the Lykambes Epode, and the wily-minded animal that the iambographer seems to view as particularly apt for projecting his poetic persona ${ }^{51}$-is the obvious star and victor in the tale, the one which displays the $\pi u x v o$ v ... vóov in the encounter. Promoting this identification is the fact that the fox's triumph depends not just on the mechanical trap, but on those verbal powers of flattery, enticement and mockery that the song's frame has just put on display on its performer's part. Part of the poet-fox's acumen also lies in knowing his victim; in keeping with a characterization apparent already in Sumerian and other Near Eastern sources which feature the ape, ${ }^{52}$ the monkey is a byword for stupidity and so eminently likely to fall for the ruse. And if, as several sources suggest, the poetry of mockery involves at least some portion (or impression) of an impromptu performance, then the bon mot with which the fable ends, and which fr. 187 w. most probably preserves, would supply an instance of the fox's ability to produce ex tempore exactly what the situation requires, a fitting counterpart to the singer's on-the-spot choice of an ainos so eminently suited to his target.

Over and above these parallels are the affinities between events in the fable and the performative setting, symmetries that make the tale so effective a commentary on the current situation. If we use the Aesopic ainos to reconstruct Archilochus' piece, the story opens at what is styled a ouvodos, a gathering where, having witnessed a performance by the dancing monkey, those present at the event go on to elect him king. For those attending the symposium, the

49 See Steiner (2011) 244-245 and Most (1985) 122-123, 126-127; Brown (2006) offers a detailed discussion of the centrality of Archilochus and the language of invective in the composition.

50 Here I follow the interpretation of Most (1985) 103-105.

51 Note, too, fr. 201 w.; on the Archilochean fox, see Steiner (2010) with earlier bibliography cited there, and Kurke (2011), esp. 154-156 and 225-259.

$5^{2}$ For these, see the material gathered in Dunham (1985). 
match between this beginning and their own position would be clear. They too had come together for an occasion that Solon fr. $4.22 \mathrm{~W}$. designates a бن́vodos, and just as some kind of dancing contest seems to occur in the ainos (hence the choice of a winner by vote; intriguingly at Aristophanes Vespae 855, גpu$\sigma \tau i$ ' 0 , jugs for drawing wine, also serve as voting jars, suggesting an analogous correspondence between the sympotic and political/judicial domains), so too the symposium hosts informally competitive performances of speeches, songs and dance. ${ }^{53}$

Following these other points of overlap, the capers performed by the monkey would then offer a derisive counterpart to the entertainment supplied by Kerykides in his bid for his fellow diners' accolades, one subsequently 'capped' by the poet's psogic réplique-cum-correction to another symposiast's ill-judged (and this in both senses) self-display. There is nothing implausible in the notion that 'Herald's Son' might actually have danced before the company, and that his inept (according to Archilochus' representation) performance would have occurred within an informally competitive frame. The eighth-century Dipylon oinochoe, whose single extant hexameter line reads 'whoever of the dancers now dances most lightly' (a declaration that could plausibly have concluded 'he will get me as his prize'), would have been awarded to the victor in a dancing contest. Not only is the prize-object itself very well suited to commemorating an occasion that featured convivial drinking, but if the inscription (whose meter and diction are impeccably Homeric) refers to Odyssey 8.248-249, where Alcinous summons the young Phaeacians to dance by way of diversion at a banquet, then it more narrowly locates the wine jug at the sympotic occasion. In one reconstruction, the oinochoe would even have supplied the host of the private event with an improvised prize to give to a particularly skilled guest. ${ }^{54}$

According to several sympotic poets and other later sources too, solo dancing not only regularly occurred in the dining hall, but, on some occasions at least, existed in close proximity to the type of ribald, mocking discourse delivered by the iambographer here. Ion of Chios combines the different modes in fr. 27.7-8 w. ('let us drink, let us play ( $\pi \alpha i \zeta \omega \mu \varepsilon v)$, let the song go through the night. Let someone dance; willingly begin the gaiety'); the 'play' ( $\pi \alpha i \zeta \varepsilon v)$

53 The designation of one of the symposiasts as 'king', basileus, is also suggestive, although the term designates the symposiarch only in post-classical sources. Note, however, Adesp. eleg. 27.9 W. with its exhortation to obey the $\pi 0 \tau \alpha \rho \chi 0 \hat{v} \tau \tau \circ$ s. See too Murray (1983) 260, and, for titles used of the symposiarch, Man in $R E \operatorname{IV}(1900) 612-613$.

$54 \quad \operatorname{Robb}(1994) 3^{2}$. 
cited here, other authors affirm, ${ }^{55}$ encompasses precisely the jokes, teasing and debunking that Kerykides' contribution then elicits from Archilochus. ${ }^{56}$ In Aristophanes' account of the symposium gone awry in his Wasps, the inebriated Philocleon, wholly failing to observe his son's recommendations concerning polite dinner party conversation and the singing of witty drinking songs, jumps up from his couch and mocks and jeers at the other guests ( $x \alpha \tau \varepsilon \gamma \varepsilon \dot{\varepsilon} \alpha$, 1305)

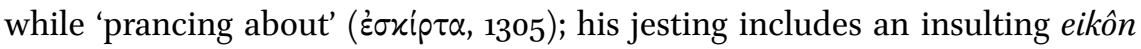

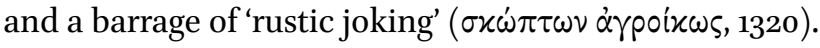

Further sources attest that dancing which breached the standards of sympotic decorum also occurred in the andrôn, and this on the part of symposiasts as well as the hired entertainers treated at my discussion's end. In Herodotus' well-known account (6.126-130, esp. 129.3-5), Hippokleides' unmannerly dance and literal self-exposure at Cleisthenes' dinner party (in the context of a larger competition that involved athletics and dining etiquette) prompt not just a piece of verbal wit and censure on the part of the outraged host - the youth, Cleisthenes famously remarks, has 'danced away his marriage' - but also that dancer's expulsion from the sympotic-cum-agonistic space. ${ }^{57}$ A scene from Xenophon's Symposium sets against the lovely movements of a beautiful young boy the parodic performance of the hired buffoon and aklêtos (the individual not actually invited to the dinner party), the Syracusan Philip. In Xenophon's account of the episode, 'At first, because the company had praised the way in which the boy's natural beauty seemed to be enhanced by the grace of his dance postures, Philip made a burlesque out of the performance by rendering every part of his body that was in motion more ridiculous than it naturally was' (2.22). As these and other episodes suggest, graceful and skillful dancing supplied a medium through which an individual at a symposium could

55 See Ar. Ran. 395 and Adesp. eleg. 27.4-6 w. The same verb can, in the context of choreia, signify dancing.

$5^{6}$ In a still earlier source, at the proto-sympotic dinner party hosted by Eumaeus in $\mathrm{Od}$. 14, the disguised Odysseus tells a tale that Eumaeus subsequently designates an ainos $(508)$ for the covert meaning that it contains; the hero narrates the story after a preface addressed to those whom he styles his hetairoi and in which he explains that wine is the catalyst for what he previews as a possibly indecorous anecdote; the same wine, he remarks, can set a man to dancing $(463-467)$. There is also mockery in Odysseus' 'fable': Thoas becomes the dupe of the ruse devised by the Odysseus-figure whom the 'beggar' includes within the story.

57 In this instance, however, that derisive remark elicits a rejoinder from the supposedly disgraced and banished party, which, in Herodotus' notoriously slippery account, is the source of Hippokleides' future renown. 
exhibit his overall bodily excellence and the ethos and genos with which that corporeal grace and condition(ing) formed a piece; as corollary to this, it was also an act that, performed by an inebriated and/or low-class individual, could turn into a tasteless and ridiculous display, a revelation of the performer's base nature. ${ }^{58}$

Read against these accounts of ungainly and burlesque dancing, fresh motives for Archilochus' choice of a monkey fable become evident. As Aelian attests, 'pithêkoi are ready to dance if they see a man dancing' (De natura animalium 17.25), and both the visual evidence considered in section 3 below and two other Aesopic fables ( 83 and 463 Perry) bear out the observation. The equation of Kerykides with the dancing ape also illuminates the fox's parting shot, rendering the applause that the audience gave the dancer still more ill-timed. While misshaped or deficient buttocks may be nothing more than a signature element in the animal's notorious ugliness, in Semonides' visualization of the monkey that particular feature forms a piece with the ape woman's awkward and risible manner of moving her body (fr. 7.73-77 W.)..$^{59}$ More than just gesturing towards the ungainly steps that Kerykides would have executed, the closing focus on the rump may also retrospectively suggest the type of dance that Archilochus (damagingly) invites his listeners to impute to his target, whether or not it corresponds to the mode in which the dancer actually performed. Is the poet perhaps suggesting that the symposiast tried to do the kordax (also associated with the 'fat-dancers' discussed later on), a lewd and vulgar dance in which the performer sticks out and wiggles his buttocks and that, according to Theophrastus, only the shameless man would perform in a state of sobriety

$5^{8} \quad$ For a particularly strong statement of this, see Pl. Leg. 654a9-bı. Note too Plut. Lyk. 28.4 with the description of how Helots would be introduced into the syssitia where they would be made to perform 'dances that were ignoble and risible' by way of negative exempla for the Spartan youths.

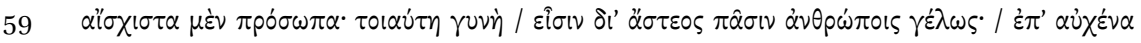

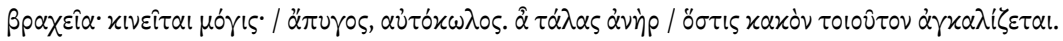
'This one is absolutely the worst plague that Zeus has given to men. Her face is extremely ugly; such a woman is an object of laughter to everyone as she goes through the town. She is short of neck, moves with difficulty, has no rump and is all legs. Ah, pity the man who embraces such a plague'. Semonides' description has many points of overlap with the Homeric representation of Thersites, with his own deformed anatomy and awkward motion; for the Thersites-ape equation, see Pl. Rep. 620c, Lycoph. Alex. 100o. Ogden (1997) 40-41 suggests that a representation of the anthropomorphized ape on the handle of a Caeretan hydria treated in section 4 depicts Thersites; for discussion of this, see Walsh (2009) 46. 
(Characteres 6.3)? And what could be more ridiculous than Kerykides attempting a dance for which, by virtue of his unlucky anatomy, he is singularly illequipped?

Several other sympotic offenses included within the Aesopic ainos and that may - although caution needs to be exercised here-have figured in the lost portions of Archilochus' fragmentary piece extend the suggestion of indecorous conduct. Consonant with the greed so regularly condemned by the iambographers, and by poets composing sympotic elegy and lyric too, is this monkey's eagerness for the choice portion of meat or geras that the fox claims to have set apart for it ${ }^{60}$ and the fact that this consumption, should it have occurred, would have gone on outside the collective space, in the 'back of beyond'; this is the detail that figures in fr. 185.4 W., where the monkey-fox encounter occurs. In the context of the andrôn, where, as vase representations show, commensal dining, egalitarian seating arrangements, and equal measures of wine and food are the order of the day, with no diner privileged above the rest, this monkey's wish to procure more than its initial share and to engage in solitary eating reveal its larger unfitness for inclusion in the group. ${ }^{61}$

If frr. $185^{-187} \mathrm{~W}$. did incorporate details included in the larger ainos, then the meta-sympotic language of the fable would align Archilochus' attack on Kerykides with the more generalized practice visible in the iambic, lyric and elegiac repertoires: there conduct at the symposium repeatedly supplies an index, positive or negative, for elite behaviour in the civic-cum-political sphere and the condition of the polis at large. By virtue of the fable's choice of terms that do double duty and apply equally to the public and private space, the animals can emblematize both the diners who granted Kerykides first place in the agôn at the drinking party and the same Parian aristocrats who had a voice in awarding or sanctioning preeminence in political affairs; the mention of voting, the office of basileus, and the geras which, a phrase from Solon attests (fr. 5.1 w.), refers not only to the honorific portion of meat that the host bestows on a fellow symposiast, but, by extension, to political privilege too, all gesture towards this external domain. Evidence from archaic and classical Greece suggests that Kerykides could have parlayed his star turn at the symposium into primacy in politics: inscriptions from Miletus demonstrate that the Molpoi-

6o For greed as a topos in Ionian iambos, see particularly Archil. fr. 124 W. and Hippon. frr. 118 and 128 w. For discussion, see Miralles and Pòrtulas (1983) 34-35.

61 The charge of excessive appetites and a taste for solitary dining would be frequently reused by characters in Aristophanes in their attacks on contemporary politicians. And as the visual evidence also attests, the 'monoposiast' or symposiast who dines alone offers an image of the dinner party gone awry. 
the elite group who sang, danced and officiated in honour of Apollo-occupied leading roles in the city's political hierarchy and supplied several among its chief magistrates (Milet I.3 no. 122 and no. 133). ${ }^{62}$

The purpose of Archilochus' finely-honed and $\pi u x v o ́ s$ composition is, then, not just to display the artistry and mental acumen that the performance of Kerykides-the-monkey so plainly lacked, but to shame a rival by making him a laughing stock in a way that diminishes his civic standing (the explicit aim of the ainos in the Lykambes Epode, where, as fr. $172 \mathrm{~W}$. asserts, the speaker makes his victim 'appear to the townspeople a source of much laughter', $\gamma \varepsilon \dot{\varepsilon} \lambda \omega \varsigma)$. Although the fable does not mention public mockery, the fox's words plainly invite ridicule, and the motif becomes explicit in the moral later appended to the Aesopic version of the fable. ${ }^{63}$ The fate of Semonides' ape woman, who is deemed 'an object of laughter ( $\gamma \dot{\varepsilon} \lambda \omega \varsigma)$ to everyone as she goes through the town', promotes the likelihood that public derision is the response that Archilochus intends for his victim; the same mocking laughter is directed against the (apelike) Homeric Thersites (Iliad 2.270), the monkey in Babrius 56.5 and, in one version of the myth, the soon-to-be simian Kerkopes too. ${ }^{64}$ All this by way of confirmation of what Catherine Connors succinctly remarks: 'calling a man a monkey is a strategy of precluding his social dignity and authority',65 the attributes, I would add, that permit an individual to take his place in the coextensive sympotic and political arenas.

\section{The Visual Evidence}

If Archilochus designs the ainos as a commentary on Kerykides' flaunting of upper class bodily decorum and dining ethics and his want of the necessary wherewithal for his self-styled role as 'Son of Herald', then the iambographer is not alone in featuring the ape as a choice site for articulating these critiques.

\footnotetext{
62 For the inscriptions, see Kowalzig (2004) 40 n. 2.

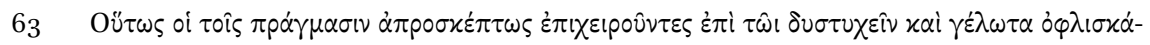
vovøw 'Thus those undertaking something without forethought bring ridicule upon themselves as well as misfortune'.

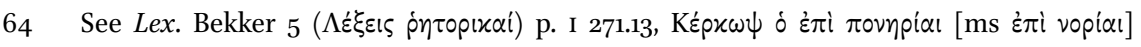

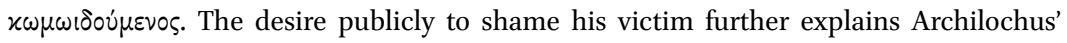
choice to style himself skutalê: as noted earlier, like a herald, he performs an official, publicly-enacted communiqué that takes place within the (notional, as in Solon fr. 1 w.) civic space.

65 Connors (2004) 184.
} 
Visual representations of the monkey from the archaic through to the classical period, ${ }^{66}$ and these on articles expressly designed for sympotic use and/or integral to the lifestyle of the upper class symposiast, assign the animal a set of properties consonant with those privileged in Archilochus' fable and similarly exploit the elements of proximity and difference that inform the monkey's standing vis-à-vis an (elite) man. ${ }^{67}$ Besides emphasizing the animal's signal ugliness, its contravention of normative standards of physical-cum-social decorum, and its status as outsider to the paradigmatic heroic world which the symposiasts view as most proximate to their own, artists show the monkey 'aping' the activities, frequently sympotic in character, proper to the high-class individuals handling the vessels and, by virtue of its simian body, necessarily distorting those practices and inadequately mirroring the aristocratic ideal. As my necessarily schematic review of the visual dossier also demonstrates, representations of simians on painted and molded vessels suggest several links between the apes and the fat dancers or komasts whom the concluding section further explores.

The first relevant item in William McDermott's very extensive catalogue is a work dated to the early seventh century, a Corinthian oinochoe (a typically sympotic vessel) featuring two sphinxes and an ape, ${ }^{68}$ visible already here is not only the beast's characteristic mal-proportioned physique-its arms are much too thin-but also its embrace of behaviour that carries a social stigma: the

66 McDermott (1938) still offers the most comprehensive collection of the images; for a much briefer but more up to date discussion of some of the works, see the suggestive accounts of Lissarrague (1997) and (2000) and Brijder (1988); most recently, Walsh (2009) includes a very helpful analysis of the place of monkeys on vases that belong to the tradition of the mythological burlesque; his rich account coincides with my discussion by drawing attention to overlaps between komasts and monkeys (noted in passing at 109 and $35^{2} \mathrm{n} .11$ ), and includes much material which I have incorporated. While the bulk of the evidence that I present here dates to the sixth and fifth centuries, surveys of the visual corpus demonstrate a considerable continuity and overlap in the iconography and thematics of the earlier and later pieces, a coherence that makes the vessels from these later periods still relevant to Archilochus' composition. Note too that Archilochus' works would have been re-performed at symposia in Athens and elsewhere, and that frr. $185^{-187} \mathrm{~W}$., as Aristophanes' 'citation' of the closing extant line in Acharnians attests, were among those very familiar to a late fifth-century Athenian audience.

67 Very apposite in this regard is a comment by Galen Nat. Fac. 1.22, who remarks that were an artist or sculptor seeking to parody a human hand in order to provoke laughter, he should take the ape's forepaw as his model.

McDermott (1938) no. 304. 
ape squats, ${ }^{69}$ adopting a posture associated with low-class individuals, slaves and craftsmen, or with satyrs and the padded dancers on the komast vases. Indeed, so close is the overlap between the squatting komast type and simians that some scholars designate a Middle Corinthian aryballos in the shape of a squatting, pot-bellied man with black dots on his front and sides a komast, while others describe the figure as a man dressed up as an ape..$^{70}$

A series of other representations from the archaic through the classical period imagines the monkey as equestrian, engaging in a pastime that is the preserve of the upper class, and awkwardly seated on a series of more or less conventional mounts. From the third quarter of the sixth century comes a plate in the Boeotian 'orientalizing' style, showing a monkey riding a lion; ${ }^{71}$ again, the deformations of human proportions are visible (the left hand lacks a thumb and the leg is reversed at the knee), while the monkey's choice of animal, the exotic lion for the domesticated horse that Greek men ride, demonstrates the gap between simian and human mores. This last asymmetry is still more emphatic on a near contemporary black-figured kylix, its interior decorated with an ape perched on a horse. ${ }^{72}$ Everything about the monkey's posture and appearance suggests the ridiculous, inept and transgressive nature of this would-be rider: again, the animal squats instead of sitting, it has positioned itself on the horse's shoulders instead of its back, and, assuming that being

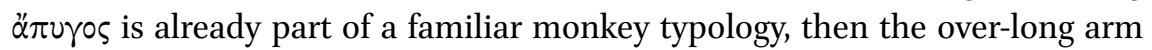
that rests beneath the figure's bottom calls attention to the all-but-missing feature. The finely executed horse highlights the ungainliness of the ape: its noble bearing and pleasing proportions suggest a mount more fitting for a hero or warrior than its simian rider. A Caeretan oinochoe of c. 500 presents a fresh variation on the theme: ${ }^{73}$ a mounted soldier on the rump of whose horse a large-bodied ape squats, its knees drawn up, clutching the warrior's shield with its forepaw. If, as one discussion suggests, 'the ape is a caricature of the attendant of a mounted hoplite, ${ }^{74}$ then the monkey not only assumes a subordinate status, but it does so in a fashion that betrays how imperfectly

69 Compare the red-figure hydria in London (British Museum E171, $A R V^{2} 579,87$ ) discussed below; here too the monkey squats.

$70 \quad$ Amsterdam, Allard Pierson Museum 3402; for discussion, see Brijder (1983) 65 and fig. 7 .

$71 \quad$ McDermott (1938) no. 315; Athens, National Archaeological Museum 12677.

72 McDermott (1938) no. 316; Athens, National Archaeological Museum 1054.

73 McDermott (1938) no. 318; see Walsh (2009) 45-48 for monkeys on Caeretan hydriai which, he suggests, following Bonaudo (2004) 20 and 28 , were originally used in sympotic contexts.

74 Cited in McDermott (1938) 226. 
it has interjected itself into the elitist sphere of equestrian warfare. One final example situates the burlesque in an Athenian context, giving it a possibly sharper political edge. On a red-figure cup in Vienna from the first half of the fifth century, a monkey is seated on a donkey in a patently Dionysiac and winefueled milieu ${ }^{75}$ David Walsh plausibly suggests a spoof on conventional scenes of young members of the cavalry setting out on their horses, and even of the annual inspection of the Athenian state cavalry, the so-called dokimasia. ${ }^{76}$

Several other early vessels display images more immediately relevant to sympotic practices. A mid sixth-century artist fashions one side of a terracotta kantharos (Dionysus' drinking vessel of choice) into a monkey face with large perforated ears (fig. 5.1): ${ }^{77}$ much in the manner of eye-cups used as drinking vessels and whose handles similarly function as 'ears', so this monkey face would impose itself onto the physiognomy of the individual who drained the vessel, transforming him into the smiling monkey for the amusement of his fellow diners. ${ }^{78}$ In a similar spirit of mockery, a cup from the Villa Giulia dated to c. $5^{20}$ offers two parodic visualizations of activities associated with the symposium and the komos that followed (figs $5.2 \mathrm{a}$ and b). ${ }^{79}$ On one face, five monkeys are poised, knees bent and over-long arms extended, on a seesaw, attempting to maintain a precarious equilibrium (and perhaps simulating the sensation of drunkenness that the diner using the vessel might be experiencing; preserving one's balance in a series of equilibristic games, as Archilochus' fr. $2.5^{-6} \mathrm{~W}$. already suggests, seems to have been a sympotic challenge, and one which the monkey on the far left, who is poised to fall, visibly cannot meet). The animal in the centre bends forward holding out a skyphos of exaggerated proportions, presumably filled with wine, while behind him another monkey brandishes a drinking horn, a vessel that regularly marks the uncouth drinker who lacks the greater dexterity required by the shallow wine cup. In his account

75 Archaeologische Sammlung der Universität 53a, $A R V^{2}$ 416, 9. See Padgett (200o) 63, fig. 2.6 and no. 65 .

$76 \quad$ Walsh (2009) $5^{2 .}$

77 New York, Metropolitan Museum of Art, 74.51.369.

78 Note a second, albeit more remote, equation between monkeys and objects containing wine, this in the verbal rather than visual domain. While some ancient authors associate the name of Pithecussae (modern day Ischia) with the Kerkopes who were consigned to the island after being transformed into pithêkoi, others derive it from pithoi, amphora-like vessels regularly used to transport and store wine. For the sources, see Connors (2004) 186187 .

79 Rome, Villa Giulia, inv. 64224; Paralipomena 300. See further Lissarrague (1997) 463 and fig. 9, whose reading I follow here. 


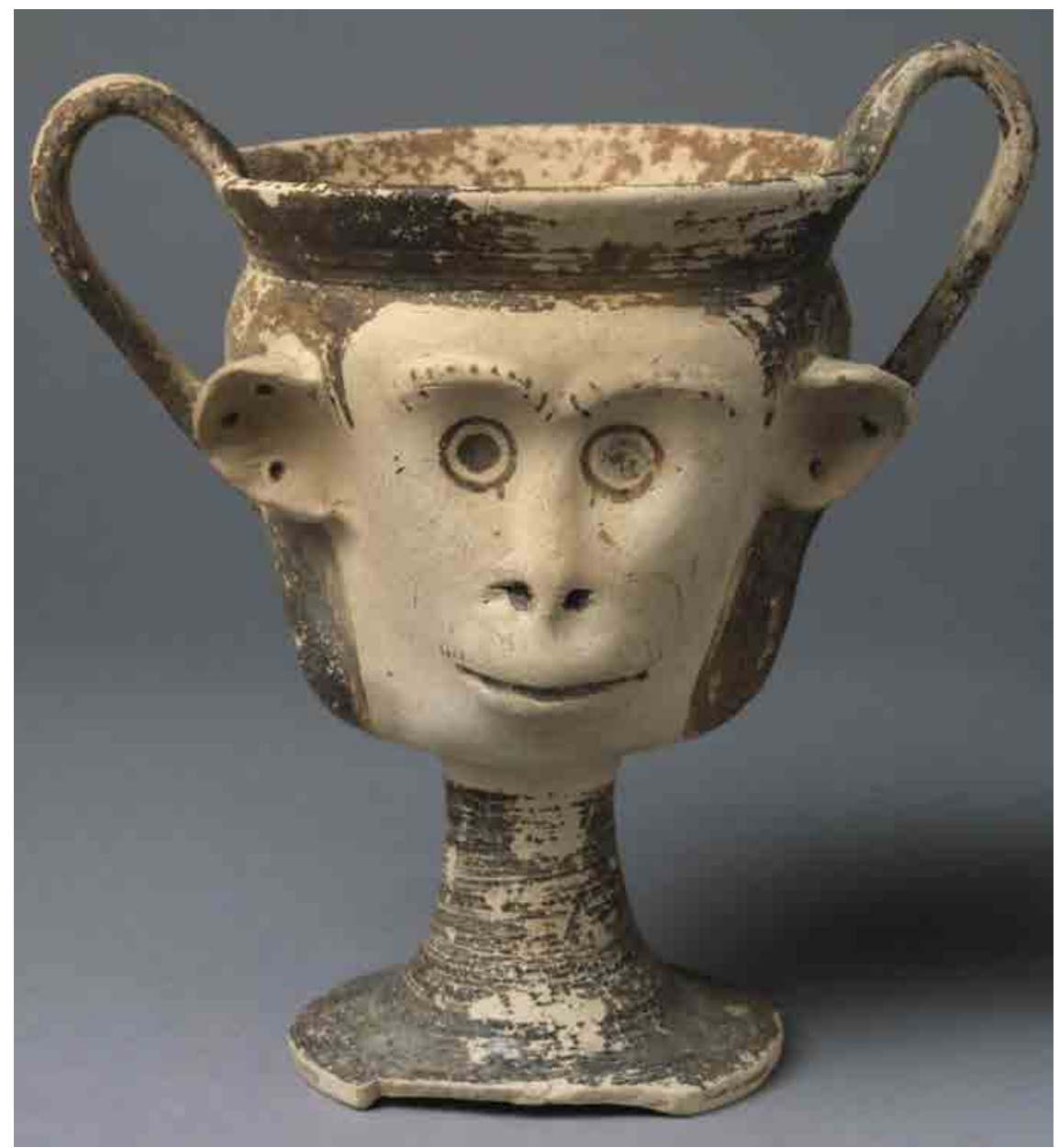

FIG. 5.1

Terracotta kantharos with monkey face

NEW YORK, METROPOLITAN MUSEUM OF ART, 74.51.369

of the image, Brijder suggests that the ape in the centre acts as the judge in the balancing competition, ready to award the skyphos to the winner of the (sympotic) agôn. ${ }^{80}$ On the reverse face, a satyr seated on a rock plays the pipes while three goats caper in a chorus line on their hind legs. The drinking horn reappears on an askos in London, now clutched by a four-footed monkey positioned so as to face a second animal; as Lissarrague observes, the ape deploys the horn in just the manner of the fat dancers, for whom it is the

8o $\quad$ Brijder (1988). 


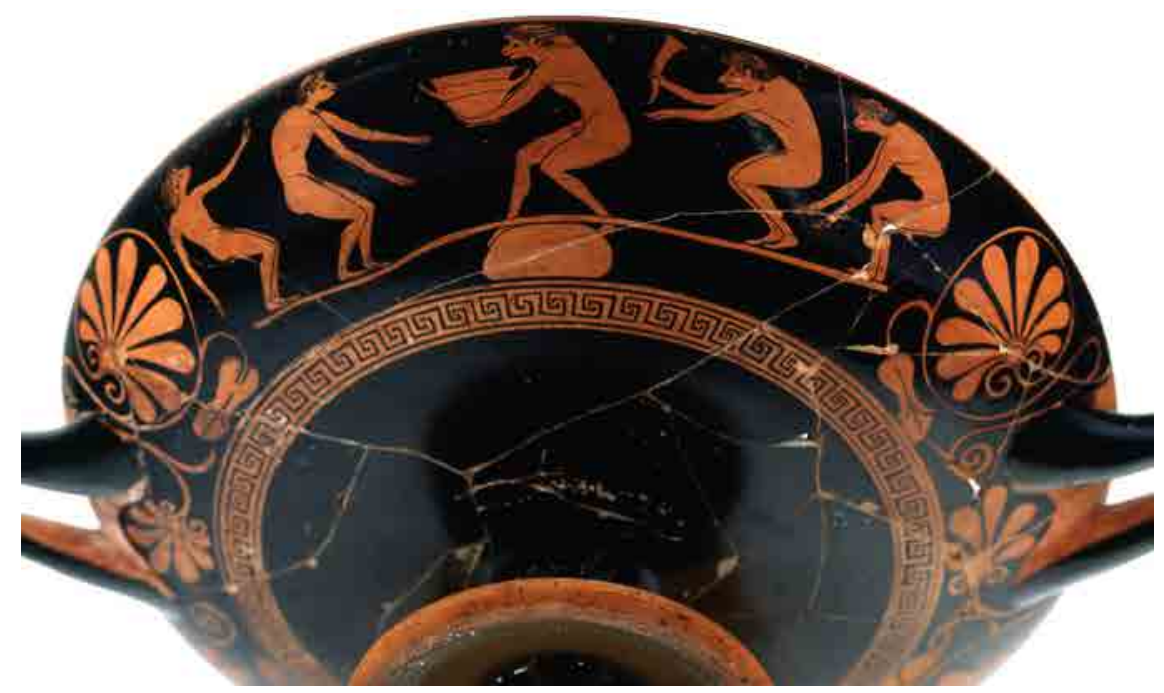

FIG. 5.2A Cup dated to circa 520

ROME, VILLA GIULIA, INV. 64224; PARALIPOMENA 300

drinking vessel of choice throughout the visual repertoire. ${ }^{81} \mathrm{~A}$ series of figure vases reiterate the monkey's association with wine; a vessel in Oxford takes the shape of a monkey straining to lift an outsized bowl, and a second terracotta simian in New York, this one with its body similarly covered in the dots that indicate the hairy pelt and dated to c. $565^{-550}$, holds an amphora-like vessel in its elongated arms (fig. 5.3). ${ }^{82}$

Monkeys have a fondness for food as well as drink (a craving for nuts causes the unmasking of some monkey dancers simulating men in another Aesopic fable, 463 Perry). ${ }^{83}$ An oinochoe in Paris dated to the first part of the fifth century depicts a diminutive ape standing upright on spindly back legs, displaying a patent interest in the apple that a young man holds out in front of him. ${ }^{84}$ The combination of ephebe, apple and approaching figure makes very plausible the reading endorsed by McDermott: the ape is 'a caricature of a boy loved by the ephebus' on whom the youth would bestow the love token. ${ }^{85}$ The image would then offer a spoof on another practice closely associated with the symposium, pederasty.

\footnotetext{
$81 \quad$ Lissarrague (1997) 463.

82 Ashmolean Museum 1880.11; Metropolitan Museum of Art 26.6o.92.

83 See $n .42$ above for this.

84 McDermott (1938) no. 319; Paris, Louvre G 241; $A R V^{2} 1648$.

85 McDermott (1938) 227-228.
} 


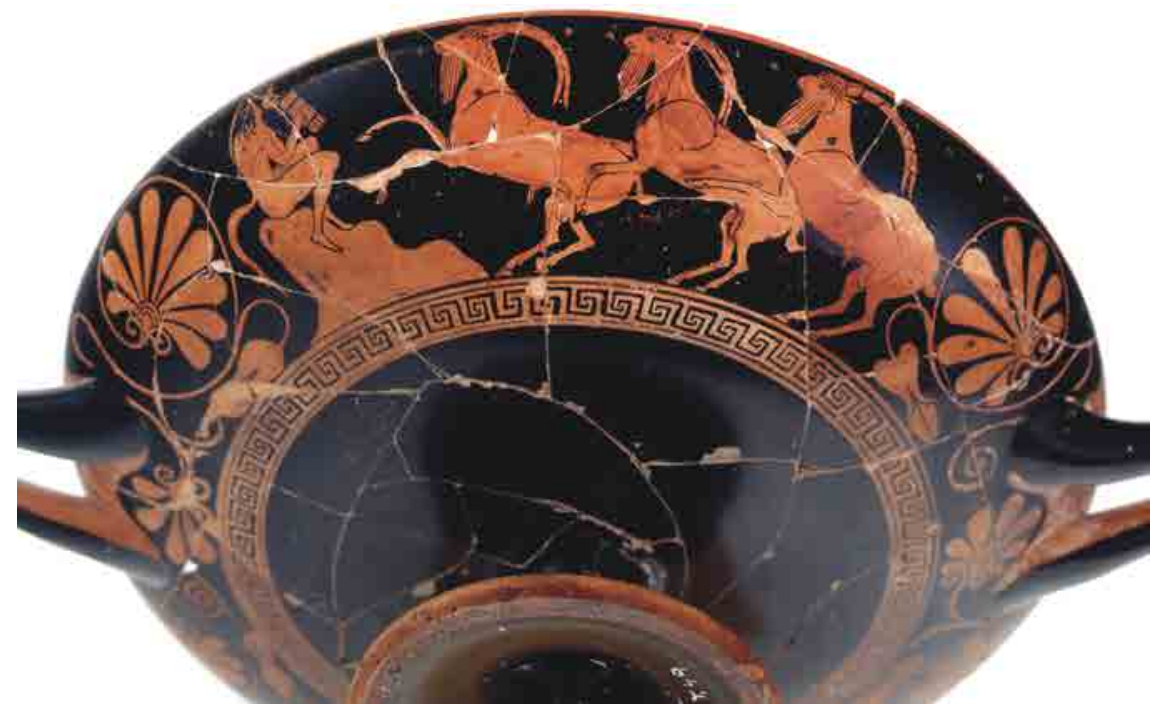

FIG. 5.2B Cup dated to circa 520

ROME, VILLA GIULIA, INV. 64224; PARALIPOMENA 300

Central to Archilochus' poem is the association of monkeys and dance, and Corinthian pottery includes two early representations of dancing ape-like creatures. In the right-hand corner of a frieze on a Transitional olpe - the small vessel used by athletes to carry oil for cleansing and anointing themselves after exercise-from the Villa Giulia (fig. 5.4a, b, and c), ${ }^{86}$ an apish figure with an s-shaped body and shell-shaped ear cavorts about; its legs are deformed and twisted inward, and one ends in a club foot. In the remainder of the image, three men accompanied by a dog pursue a hare. As Axel Seeberg's detailed discussion notes, ${ }^{87}$ the artist prompts the viewer to equate the human hunters with the ape: two of the men also display badly misshapen legs and twisted feet, while the third figure has an exaggeratedly distended arm and a grin so broad that its face resembles a comic mask. There is a striking affinity between these hunters and the padded dancers on komast vases, where figures with just such distorted limbs and feet participate in burlesque hunts. ${ }^{88} \mathrm{~A}$ second dancing ape appears on a poorly preserved image on a Middle Corinthian aryballos found in

\footnotetext{
86 Rome, Villa Giulia inv. 46781.

87 Seeberg (1966) 57-59; see, too, Ogden (1997) 103, 112-113; I am not persuaded by these authors' view that we have a representation of an episode from the myth of Astrabacos and Alopekos. Walsh (2009) 144-145 returns to the object.

88 For hunting komasts see Steinhart (2007) 196-220. I return to these images in the section 4.
} 


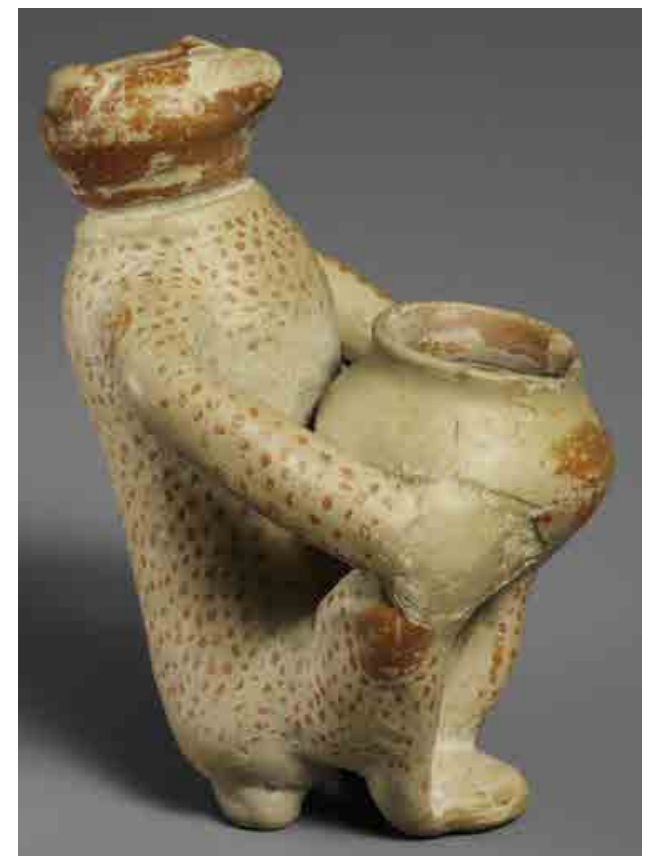

FIG. 5.3 Terracotta figure vase of a monkey,

ca $565-55^{\circ}$

METROPOLITAN MUSEUM OF

ART 26.60.92

Locri; ${ }^{89}$ the small figure on the left has a monkey head, and one of his feet is also misshapen. It is not just the dance that the creature seems to be performing in partnership with a fat dancer that signals his affinity to men but also the chitoniskos that, komast-like, he wears.

A symposiast should have the capacity not only gracefully to dance, but also to perform on the pipes and lyre, and a musical education is the sine qua non for participation at the event. ${ }^{90}$ On a red-figure hydria from the first half of the fifth century (fig. 5.5), ${ }^{91}$ a music lesson is in progress as a young man receives instruction from his lyre-teacher seated opposite him. Squatting next to another young musician in the scene, an ephebe sitting on a diphros and performing on the pipes, is a dressed-up monkey; like the youthful aulos-player,

89 Locri, Antiquarium 1248; see Brijder (1988) 63 and fig. 4.

9o For the close relations between training in mousikê and the symposium see the wellknown hydria by Phintias pairing a music lesson with a sympotic scene in the register above (Munich, Antikensammlungen 2421).

91 London, British Museum E171; $A R V^{2}$ 579, 87. 


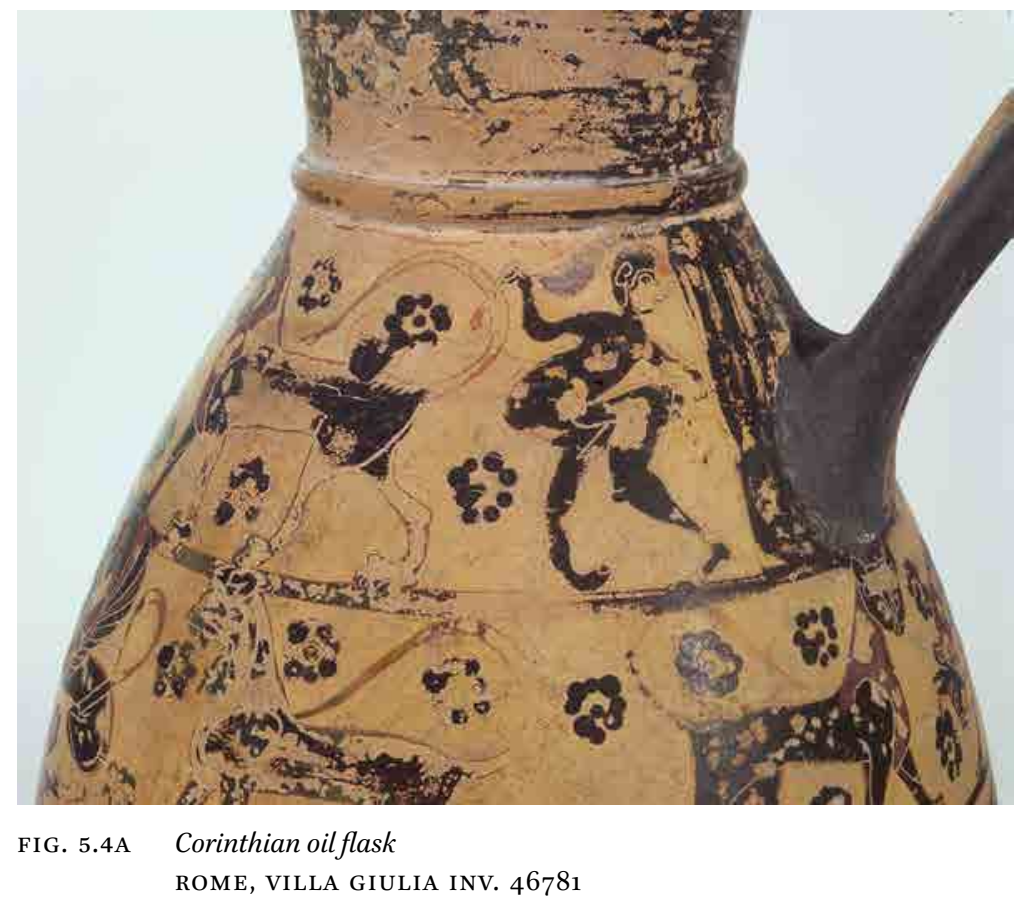

he wears the fillet suitable for a symposiast, bracelets, and bangles around his ankles (is he, perhaps, preparing to dance?). Both equivalent and other, he occupies a literally 'lower' position than his seated counterpart even as his fillet creates a visual link between the two.

Although there is no establishing the context in which the figurines would be displayed, a series of Boeotian and Corinthian terracottas dating to the archaic and classical period also show the monkey engaged in activities appropriate to a sympotic context: here apes eat, drink and play upon the lyre, albeit in a parodic or inappropriate manner. ${ }^{92} \mathrm{An}$ ape depicted in a small terracotta figure from Clazomenae and dating to the fifth century ${ }^{93}$ enjoys wine from a drinkingbowl while three more bowls stand ready on a table-shaped rock-no less sure a recipe for inebriation than the outsized skyphos on the Villa Giulia cup.

92 See Lissarrague (1997) 464 and figs. 11-14 for these.

93 Izmir, private collection; see Brijder (1988) fig. 14 and Lissarrague (1997) 464. 


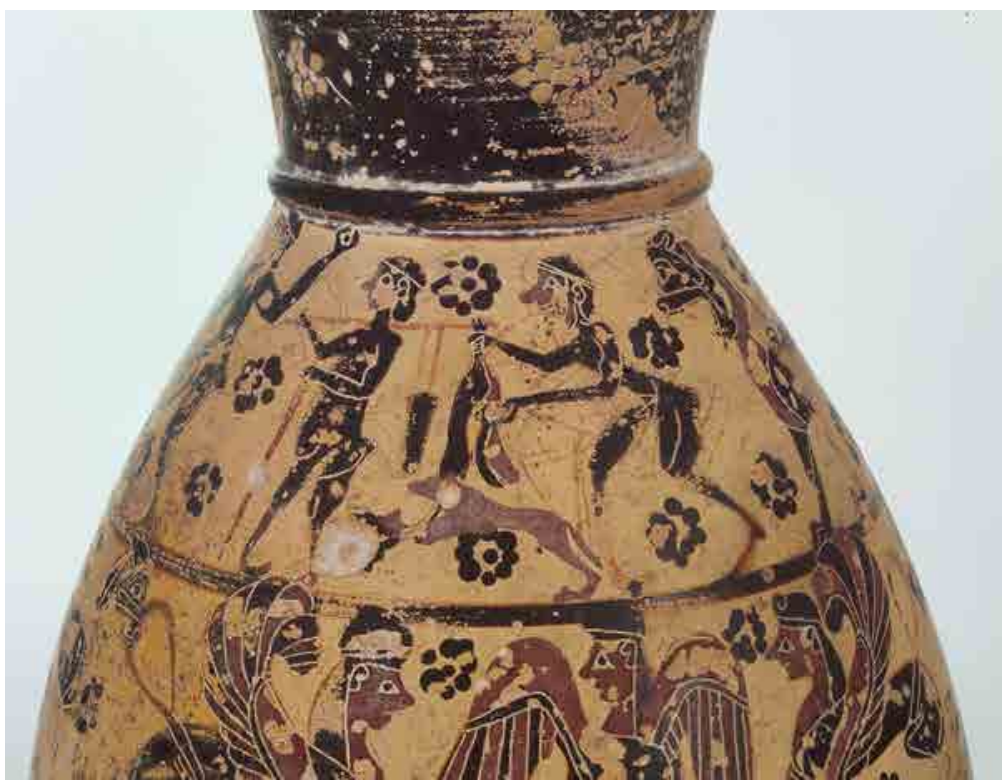

FIG. 5.4B Corinthian oil flask

ROME, VILLA GIULIA INV. 46781

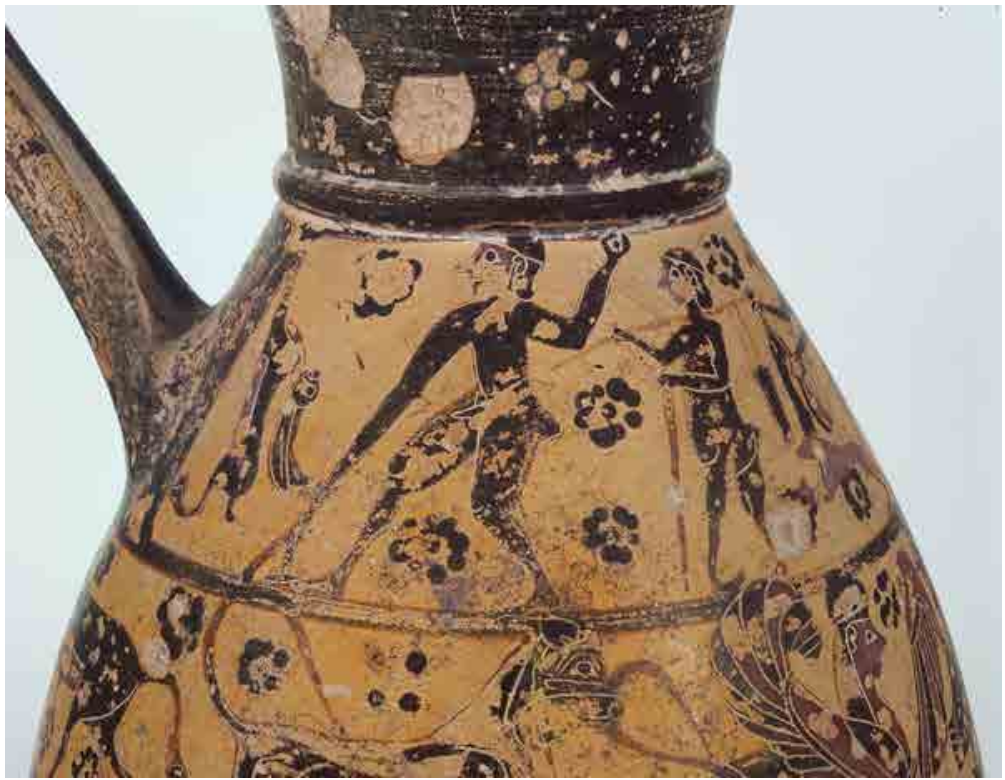

FIG. 5.4C Corinthian oil flask

ROME, VILLA GIULIA INV. 46781 


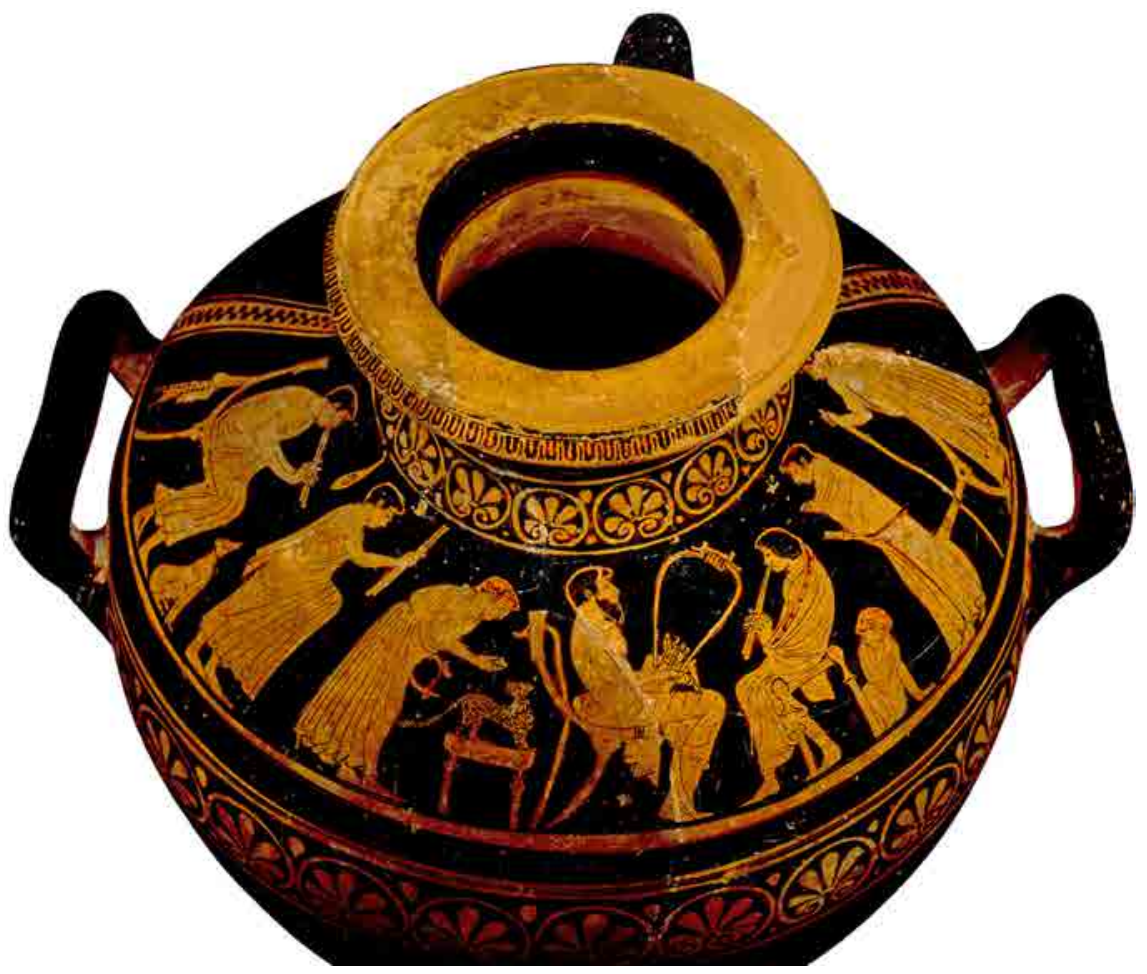

FIG. $5.5 \quad$ Red-figure hydria

LONDON, BRITISH MUSEUM E171; ARV $^{2} 579,87$

\section{Monkeys and Fat Dancers}

As this sampling of the visual dossier has already signaled, representations of monkeys on visual artifacts from the late archaic and early classical age overlap on many counts with the typology of fat dancers featured on pottery that dates from the seventh century to ca. 540 As the many studies of komasts have documented, ${ }^{94}$ and like the monkeys just described, fat dancers have misshapen anatomies, they squat, they consume wine in large quantities from askoi, and, of course they dance, very frequently in the context of the symposium. ${ }^{95}$ On several more particularized, seemingly less likely counts, simians

94 For the recent bibliography, see Steiner (2009b) 240 n. 1.

95 See Smith (2000) for the fullest discussion of the sympotic setting in which many komasts appear; see, too, Steiner (2009b) for an account of the characteristics assigned to komasts and the overlap between their representation and the properties that contemporary iambographers regularly impute to their targets of mockery and abuse. 
and the dancers on komast vases correspond; as already noted, pedal deformations characterize both sets of figures (all the more surprising given the propensity to dance typical of both), and just as some among the komasts prepare to throw the stones they carry as missiles in their mock brawls, ${ }^{96}$ so stonethrowing monkeys appear very early in the visual repertoire: ${ }^{97}$ Walsh identifies the curious figure covered in hair with a large nose and out-jutting jaw standing beneath the handle on the seventh-century Oresteia krater as having an 'ape-like appearance'; in each of its hands it carries a stone, seemingly ready to launch the projectiles at the mythological heroes in the principal scene. ${ }^{98}$

Further confirming these affinities are the several vases considered above that combine monkeys and fat-dancers in ways designed to highlight the figures' proximity. Just as the olpe in the Villa Giulia locates in the same hunting scene komast-like individuals with distorted feet and a similarly deformed monkey, and the aryballos from Locri pairs two dancers, one a komast, the other an ape, so the Oresteia krater presents two curious characters who visually respond to the monkey-like creature described above; similarly marginalized by their position beneath the second handle on the krater, this pair of more human but no less grotesque figures also prepare to throw their stones, while with their free hands they seem to scratch at their buttocks - these emphasized by a patterning that stands out from the solid black used for the remainder of their bodies-in a gesture that anticipates the bottom-slapping gesture so typical of komasts. ${ }^{99}$ Not just analogues, komasts and simians more broadly stand in inverse visual relation to one another: while the monkey is typified in visual and textual sources by its want of buttocks, this portion of the fat-dancers' anatomies is nothing if not over-endowed, frequently grotesquely exaggerated or bulked out with artificial padding. 100

96 Seeberg (1971) 104 catalogues these.

97 Walsh (2009) 66 suggests a Near Eastern prototype; a Phoenician gold-plated silver bowl found in the Bernardini Tomb in Latium includes a hairy ape that attacks a royal hunting party with a stone. The exoticism of apes, imported and not indigenous to Greece, would contribute to their 'otherness'. In the sympotic context, they might also be an indicator of the Eastern-style luxury and oriental mores that symposiasts typically embraced.

98 Walsh (2009) 40-41 with fig. 1a-b, who signals the parallel with the komast dancers. The vase (once East Berlin, Antikensammlung A 32 ) is now lost, but known through photographs and drawings.

99 I owe this point to Walsh (2009) 41.

100 For this, see Smith (2007) 56 with her fig. 14. Fehr (1990) 190 suggests that the bottomslapping gesture may also be designed to put the viewer in mind of a style of dancing considered particularly obscene-the kordax cited earlier. For Fehr, the action carries 
These overlaps in the appearance and conduct of the monkeys and fat dancers bear on the question of the function of these two sets of images and on the role that they play in the sympotic milieu where the objects featuring them would chiefly circulate. As recent discussion of the padded dancers suggests, artists portray the figures in ways that aim to articulate their simultaneous relations of likeness and difference, of identity and 'otherness' to the upper-class diners in whose company they disport themselves and whose physique, richlyornamented dress, hair-styles and sympotic deportment they both mirror and distort. ${ }^{101}$ For the elite audience, these visions of the abandonment of bodily and ethical decorum are at once appealing and repellent, cathartic and monitory. While they allow the symposiasts a vicarious departure and release from the norms of conduct regulating their own physical and moral stance, ${ }^{102}$ they also warn them of the consequences of such transgressions-their transformation into a grotesque object of their fellow diners' derision, disdain or sheer neglect. ${ }^{103}$ Charting the distance between his own anatomy, (relative) sobriety and decorous conduct and that of the padded dancers, the symposiast finds his sense of social superiority reaffirmed while joining with his companions in laughter directed at the interlopers. The monkey images, I have suggested, work in very similar fashion, displaying deformations of sympotic mores in ways that are designed simultaneously to provoke hilarity, elicit mockery and deliver admonition.

In one further respect, and that will return us to the iambic mockery delivered by Archilochus' fr. 185 W., the role of the painted simians and that of the komast dancers cohere. Following Burkhard Fehr's demonstration of the kinship between the komasts on the vases and the aklêto i in literary accounts (the uninvited guests whose outsider and even scapegoat-like position the sources

further implications; in his account, a number of vases on which one komast touches the buttocks or genitalia of another, or where bearded dancers approach beardless ones, appear reminiscent of —or more properly parodic of—homosexual courtship scenes. See too Steinhart (1992) 510 .

101 For this, see Kaeser (1990) 283-288 and Schäfer (1997) 30-32. On some occasions, as though to highlight the separation between the different spheres, artists portray symposiasts who seemingly ignore the revelers cavorting about them. So on a cup by the Malibu Painter (Heligoland, Coll. Kropatscheck; Brijder (1983) no. 246, pls. 23c-d, 46e) two diners on their couches talk to one another while disregarding two of the four komasts who are turned to face them.

102 This is the reading advanced by Kaeser (1990) $286-288$.

103 Here the images' role resembles that of the satyrs featured on vessels used at the symposia, where their indecorous conduct serves by way of warning against the abandonment of all restraint. 
so clearly mark), many of our monkeys are quite literally 'marginal' to the main event depicted on the main body or visual field of the vase, which is frequently mythological and heroic in character. In keeping with the ape-like figure located beneath the handle on the Oresteia krater, later monkeys are also consigned to the spatial periphery. A Caeretan hydria from c. $53^{-} 5^{20}$ positions a spindly-legged monkey hiding behind a bush (and masturbating no less) looking on as Herakles attacks Nessos in the act of assaulting Deianeira, ${ }^{104}$ while a second hydria in Paris (fig. 5.6a and b) displays that archetypal heroic endeavour, the Calydonian boar hunt, and includes in the scene a small-scale monkey (now very faint, but still discernible), half squatting and positioned off to the side. ${ }^{105}$ The artist signals the creature's exclusion and remoteness from the world of mythological heroics to which the vessels' users might aspire by showing it gesturing towards Atlanta and her fellow hunters as they confront the boar-a spectator, not a participant in this paradigmatic elite hunt. Much as the komasts can do, with their debunking of aristocratic pretensions by reperforming upper-class sympotic activities (drinking from fine cups, pederasty and the rest) in their basest form, so the Caeretan monkey demystifies the hunt, inviting us to join in laughing at the scene and to note the comic elements that the artist has incongruously introduced into his account. ${ }^{106}$ On a third Caeretan hydria in Vienna, ${ }^{107}$ a Return of Hephaistos occupies one side of the vase while two symplegmas of satyrs and maenads fill the other; a diminutive monkey, 'no more than a doodle, ${ }^{108}$ hangs from the line of the lower frieze. This marginality and 'extraterritorial' status is precisely what Archilochus' fragment would visit on Kerkykides; having proved himself unfit for inclusion at the symposium, and for the civic world beyond, he is effectively banished to that 'back of beyond' $(\dot{\varepsilon} \sigma \chi \alpha \tau i \eta \dot{v} \nu)$ where the monkey-fox encounter occurs.

104 Rome, Villa Giulia (no inv. no.); Bonaudo (2004) no. 20; see Walsh (2009) 45-46. Compare the early sixth-century Corinthian kotyle (Paris, Louvre CA 3004) that combines another of Herakles' feats, his defeat of the hydria, with a line of komast dancers with comic and obscene names inscribed alongside. On the Caeretan vessel, the monkey's action clearly glosses that of the equally beast-like Nessos, although in more comic and solipsistic vein.

105 Louvre E 696; Bonaudo (2004) and Walsh (2009) 46, whose reading I largely follow.

106 For these, see Walsh (2009) 46.

107 Kunsthistorishches Museum 3577; Bonaudo (2004) no. 5 .

108 Walsh (2009) 109, with discussion of the vase. Walsh (2009) 70-71 very suggestively compares the liminal position of these monkeys to the simians that appear in the marginalia of medieval illuminated manuscripts and whose role it was to parody, comment on, and demystify the central sacred text. 


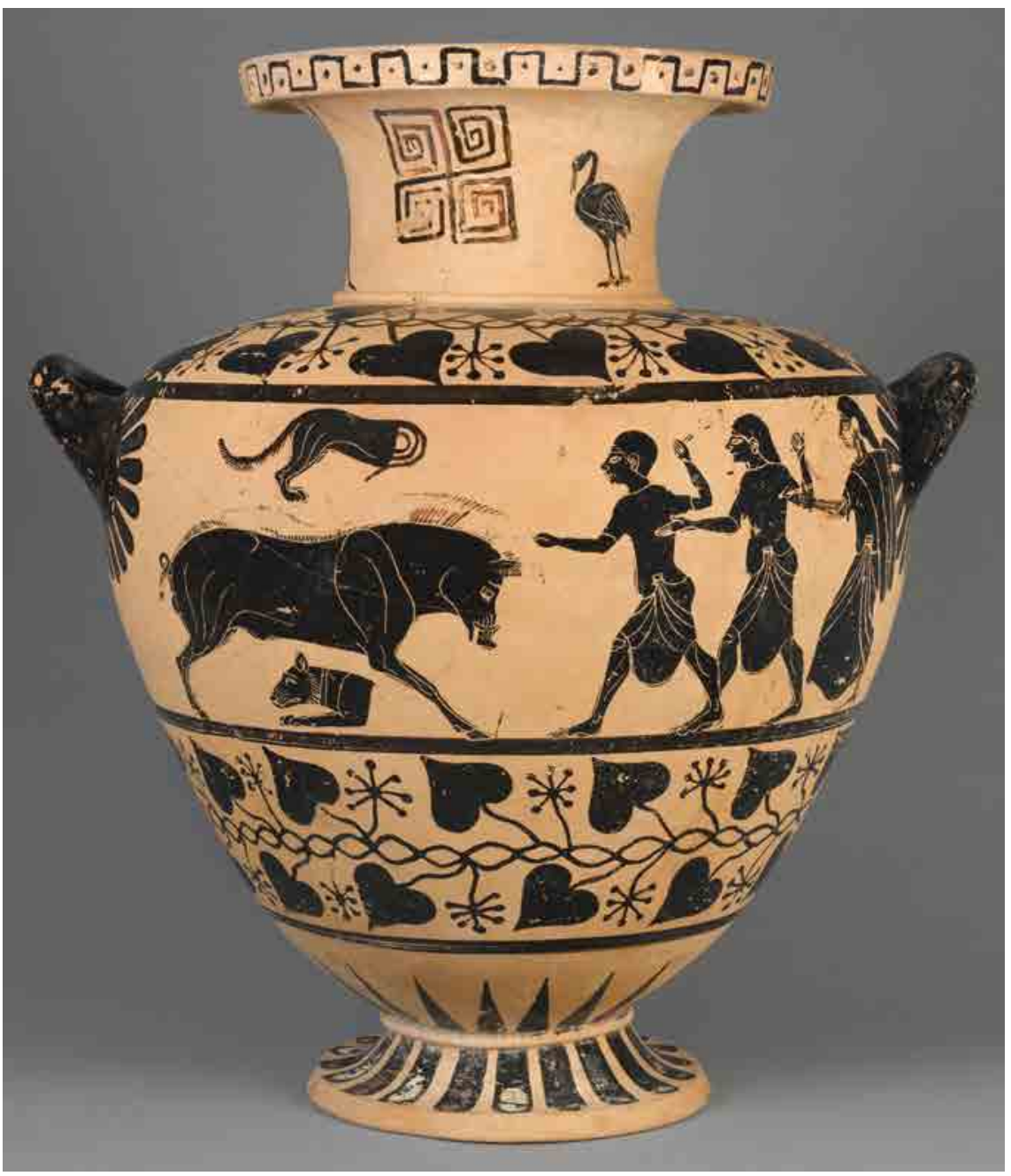

FIG. 5.6A Hydria depicting the Calydonian boar hunt LOUVRE E 696 


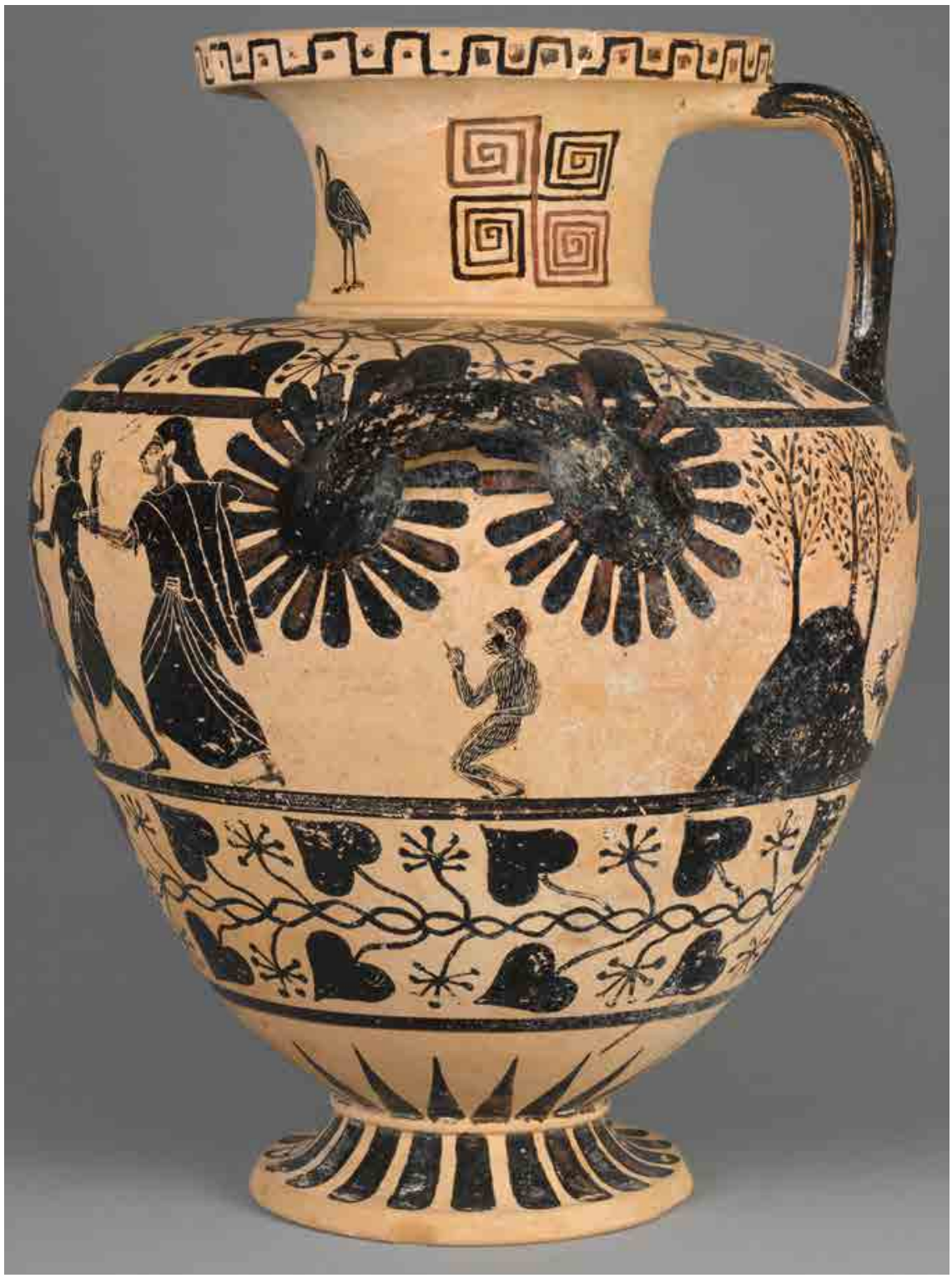

FIG. 5.6B Hydria depicting the Calydonian boar hunt

LOUVRE E 696 
One concluding suggestion brings komasts, monkeys and Archilochus' song into a cohesive whole and draws attention to the performative element that unites all three. ${ }^{109}$ While art historians still debate the precise identity of the fat-dancers, and the degree to which the painted figures are depictions of real-world performers familiar to late archaic audiences, several recent articles argue that the dancers should be understood as representations of costumed entertainers who would have appeared at public festivities and at symposia, both civic and private, where they would engage in proto-dramatic enactments of dithyrambic compositions. ${ }^{110}$ What makes the relationship with the apes particularly fascinating is that, if we examine the monkey images more closely, it turns out that like the fat dancers with their artificial padding and seemingly crippled feet, many of the figures are not monkeys, but men dressed in monkey costumes and 'aping' the animals in turn. So the 'balancers' on the Villa Giulia cup are nude youths equipped with wigs and monkey masks, participants, like the komasts, in a Dionysiac style revelry, and Brijder makes the same suggestion for the Corinthian aryballos also cited earlier, fashioned in the shape of a squatting monkey. ${ }^{111}$ Following Matthias Steinhart's reading of the fat-dancers depicted in a handful of scenes that seem to involve some kind of narrative scenario, the apes are likewise costumed individuals role-playing in mimetic representations involving music, dance and some form of narrative; the Corinthian vase that combines the monkey figure with the komast-like hunters would, in this account, portray a performance that featured both padded dancers and monkeys in a burlesque enactment that inverted standard hunting practices and was accompanied by music and song.

Returning to seventh-century Paros, could Kerykides' unfortunate, and possibly notorious, bid for sympotic distinction have involved that individual's dressing up in some kind of archaic version of a monkey suit (or at least a mask) and taking on a role that might more usually have been reserved for professional entertainers or the uninvited at the dining party (indeed, some art historians read the figures on the komast vases as upper class symposiasts engaged in a seventh-century form of slumming)? ${ }^{112}$ Or would Archilochus' song have taken its cue from, or even have generated, a mimetic dance performance with men dressed up as monkeys and foxes? Intriguingly, an archaic

109 For 'performativity' in the context of the symposium and particularly the komos that followed, see the key discussion in Bierl (2009).

110 For a particular strong statement of this view, see Steinhart (2007) 196-220.

111 Brijder (1988) 64-65.

112 For this, see Schäfer (1997) 30-34, endorsing the views of Kaeser (1990) 283-288. 
Boeotian terracotta depicts precisely the encounter that the ainos describes, pairing a monkey with a fox. ${ }^{113}$ This figurine, we might further speculate, not only visualizes the Aesopic story, but mirrors the type of entertainment that a much later text describes; in his Eikones, Philostratus includes a painting of Aesop in the act of composing a fable, surrounding the story-teller with a 'chorus' of the animals and men included in his fables who will perform the tales (1.3) ${ }^{114}$ It comes as no surprise to discover the Aesopic-Archilochean fox in the role of chorus leader here.

\section{Works Cited}

Adrados, F.R. (1993). 'Mito y fábula'. Emerita 61:1-14.

Archibald, H.T. (1902). 'The fable in Archilochus, Herodotus, Livy, and Horace'. TAPhA 33: lxxxviii-xc.

Bierl, A. (2009). Ritual and Performativity. The Chorus of Old Comedy. Trans. Alexander Hollmann. Washington, D.C.

Bonaudo, R. (2004). La culla di Hermes. Iconografia e immaginario delle hydriaiceretane. Rome.

Bowie, E.L. (2008). 'Sex and politics in Archilochus' in D. Katsonopoulu, I. Petropoulos and S. Katsarou (eds) Archilochus and his Age. Proceedings of the Second International Conference on the Archaeology of Paros and the Cyclades, Paroikia, Paros, 7-9 October, 2005. Athens: 133-141.

Bowra, C.M. (1937). 'Pindar, Pythian II'. HSCPh 38: 1-28.

Brown, C. (2006). 'Pindar on Archilochus and the gluttony of blame (Pyth. 2.52-56)'. JHS 126: $36-46$.

Brijder, H.A.G. (1983). Siana Cups I and Komast Cups. Allard Pierson Series vol. 4. Amsterdam.

- (1988). 'Apish performances in the sixth century B.c.' in J. Christiansen and T. Melander (eds), Proceedings of the Third Symposium on Ancient Greek and Related Pottery. Copenhagen: 62-70.

Carne-Ross, D.S. (1979). Instaurations. Essays in and out of literature. Pindar to Pound. Berkeley.

113 Berlin, Staatliche Museen, Antikensammlung 8229; Lissarrague (2000) fig. 5.6.

114 Lissarrague (2000) 144-145 also cites the text, although while making a very different argument. Extraneous to my discussion is the question of whether Philostratus has an actual image in mind or whether, as I prefer to think, it is clearly notional. Lissarague (1997) 469 and fig. 25 presents a small bronze from the Imperial period showing an actor wearing a monkey mask. 
Clay, D. (2004). Archilochos Heros. The Cult of Poets in the Greek Polis. Washington, D.C. Connors, C. (2004). 'Monkey business: Imitation, authenticity, and identity from Pithekoussai to Plautus'. ClAnt 23: 179-208.

van Dijk, G.-J. (1997). AINOI, LOGOI, MUTHOI. Fables in Archaic, Classical and Hellenistic Greek Literature. Leiden.

Drew Griffith, R. (2008). 'Heralds and the beginning of the Peloponnesian War (Thuc. 2.1)'. CPh 103: 182-184.

Donlan, W. (1985). 'Pistos philos hetairos' in T.J. Figueira and G. Nagy (eds), Theognis of Megara. Poetry and the Polis. Baltimore: $223^{-244}$.

Dunham, S. (1985). 'The monkey in the middle'. $z A$ 75: 234-264.

Fehr, B. (1990). 'Entertainers at the symposium: The akletoi in the archaic period' in O. Murray (ed.), Sympotica: A Symposium on the Symposion. Oxford: 185-195.

Gerber, D. (1999). Greek Iambic Poetry. Cambridge, MA.

Hawkins, T. (2008). 'Out-foxing the Wolf-Walker. Lykambes as performative rival to Archilochus'. ClAnt 27: 93-114.

Hedreen, G. (2006). "I let go my force just touching her hair”: Male sexuality in Athenian vase-painting of silens and iambic poetry'. ClAnt 25: 277-325.

Henderson, J. (1991). The Maculate Muse. Obscene Language in Attic Comedy. Oxford.

Kaeser, B. (1990). 'Komos—Tanz der Dickbäuche' in K. Vierneisel and B. Kaeser (eds), Kunst der Schale. Kultur des Trinkens. Munich: 283-288.

Kowalzig, B. (2004). 'Changing choral worlds: Song-dance and society in Athens and beyond' in P. Murray and P. Wilson (eds), Music and the Muses. The Culture of Mousike in the Classical Athenian City. Oxford: 39-66.

Kurke, L. (2011). Aesopic Conversations. Popular Tradition, Cultural Diolague and the Invention of Greek Prose. Princeton.

Lasserre, F. (1984). 'La fable en Grèce dans la poésie archaïque' in F.R. Adrados (ed.), $L a$ Fable. Entretiens Hardt 30. Geneva: 61-69.

Lilja, S. (1980). 'The ape in ancient comedy'. Arctos 14: 31-38.

Lissarrague, F. (1997). 'L'homme, le singe et le satyre' in B. Cassin and J.L. Labarrière (eds), L'animal dans l'antiquité. Paris: 435-454.

(2000). 'Aesop, between man and beast: Ancient portraits and illustrations' in B. Cohen (ed.), Not the Classical Ideal. Athens and the Construction of the Other in Greek Art. Leiden: 132-149.

Luria, S. (1930). 'Der Affe des Archilochos und die Brautwerbung des Hippokleides'. Philologus n.s. 39: 1-22

Miralles, C. and J. Pòrtulas, (1983). Archilochus and the Iambic Poetry. Rome.

McDermott, W.C. (1938). The Ape in Antiquity. Baltimore.

Most, G. (1985). The Measures of Praise. Hypomnemata 83. Göttingen.

Murray, O. (1983). 'The Greek symposion in history', in E. Gabba (ed.), Tria Corda. Scritti in onore di Arnaldo Momigliano. Como: 257-272. 
Nagy, G. $\left(1999^{2}\right)$. The Best of the Achaeans. Concepts of the Hero in Archaic Greek Poetry. Baltimore.

Neer, R. (2002). Style and Politics in Athenian Vase-Painting. Cambridge.

Noussia-Fantuzzi, M. (2010). Solon the Athenian, the Poetic Fragments. Mnemosyne suppl. 326. Leiden.

Ogden, D. (1997). The Crooked Kings of Ancient Greece. London.

Padgett, J.M. (2000). 'The stable hands of Dionysos: Satyrs and donkeys as symbols of social marginality in Attic vase painting' in B. Cohen (ed.), Not the Classical Ideal. Athens and the Construction of the Other in Greek Art. Leiden: 43-70.

Parker, R. (1996). Athenian Religion. A History. Oxford.

Philippides K. (2009). 'The fox and the wolf: Archilochus 81 D/185 W and Pindar's Olympian 6. 87-91'. QUCC 91: 11-21.

Pouilloux, J. (1964). 'Archiloque et Thasos' in O. Reverdin (ed.), Archiloque. (Entretiens de la Fondation Hardt 10), Geneva: 3-27.

Robb, K. (1994). Literacy and Paideia in Ancient Greece. Oxford.

Rosen, R.M. (1988). 'Hipponax, Boupalos, and the conventions of the psogos'. TAPhA 118: 29-41.

Schäfer, A. (1997). Unterhaltung beim griechischen Symposion: Darbeitungen, Spiele und Wettkampfe von Homerischer bis in spätklassische Zeit. Mainz.

Seeberg, A. (1966). 'Astrabica'. so 61: 48-74.

- (1971). Corinthian Komast Vases. BICs Suppl. 27.

Smith, T.J. (2000). 'Dancing spaces and dining places: Archaic komasts at the symposion' in G.R. Tsetskhladze, A.J.N.W. Prag and A.M. Snodgrass (eds), Periplous. Papers on Classical Art and Archaeology Presented to Sir John Boardman. London: 309-319. (2007). 'The corpus of komast vases. From identity to exegesis' in E. Csapo and M.C. Miller (eds), The Origins of Theater in Ancient Greece and Beyond. Cambridge: $48-76$.

Steiner, D. (2009a). 'Diverting demons: Ritual, poetic mockery and the Odysseus-Iros encounter'. ClAnt 28: 71-100.

- (2009b). 'Pot bellies. The komast vases and contemporary song' in D. Yatromanolakis (ed.), An Archaeology ofRepresentations. Ancient Greek Vase-Painting and Contemporary Methodologies. Athens: 240-281.

(2010). 'Framing the fox: Callimachus' second Iamb and its predecessors'. JHS 130: $97-107$.

(2011). 'Pindar's bestiary. The "coda" to Pythian 2'. Phoenix 65: 238-267.

(2014). 'Solon fr. 1-3 W: The poetics and politics of a gesture'. Cahiers "Mondes Anciens" 5: 1-17.

Steinhart, M. (1992). 'Zu einem Kolonettenkrater des KY-Malers'. AA 3: 486-512. (2007). 'From ritual to narrative' in E. Csapo and M.C. Miller (eds), The Origins of Theater in Ancient Greece and Beyond. Cambridge: 196-220. 
Walsh, D. (2009). Distorted Ideals in Greek Vase-Painting. The world of Mythological Burlesque. Cambridge.

West, S. (1988). 'Archilochus' message stick', cQ 38: 42-48.

Zanetto, G. (2001). 'Iambic patterns in Aristophanic comedy' in A. Cavarzere, A. Aloni, and A. Barchiesi (eds), Iambic Ideas: Essays on a Poetic Tradition from Archaic Greece to the Late Roman Empire. Lanham, MD: 65-76. 


\title{
Observing Genre in Archaic Greek Skolia and Vase-Painting*
}

\author{
Gregory S.Jones
}

\begin{abstract}
Skolion. A rather general term covering any after-dinner song; indeed, poems originally written for entirely different purposes (for example poems by Stesichorus) could be performed by a guest as a contribution to the entertainment, and called a skolion. The name comes from the irregular or 'crooked' order in which such pieces were offered during the evening, as opposed to the regular order $\dot{\pi} \pi \dot{\delta} \delta \xi \xi \dot{\alpha}$ in which everyone gave their compulsory piece after dinner. ${ }^{1}$
\end{abstract}

\section{Introduction}

Fowler's definition reflects a longstanding view held by a majority of scholars who have studied songs called skolia but generally assume that the term oxó$\lambda$ เov lacked any real generic significance in antiquity. ${ }^{2}$ Perhaps because of their well-known depictions in comedy (where their popularity among the masses appears to have been exploited for laughs), the Attic skolia are regularly trivialized as 'light' and 'informal' compared to other types of melic poetry, giving rise to a sweeping and often negative generalization of the term skolion that even

* I would like to thank the organizers, hosts, and participants of the conference at Delphi for facilitating such an enjoyable and stimulating event. I am especially grateful to Richard Martin, Alan Shapiro, and Vanessa Cazzato for helpful suggestions and conversations on many aspects of this paper. The present study incorporates several arguments first presented in my dissertation 'Singing the Skolion: a Study of Poetics and Politics in Ancient Greece' (2008 PhD diss., Johns Hopkins University). All translations are my own.

1 Fowler (1987) 93.

2 Notable exceptions include Smyth (1900) xcv-cvii, Bowra (1935), Van Groningen (1960), and Cingano (2003), though none offers a systematic definition of the genre relative to other lyric forms.

(C) GREGORY S. JONES, 2016 | DOI: 10.1163/9789004314849_007

This is an open access chapter distributed under the terms of the Creative Commons Attribution- 
skews the way many of Pindar's songs are perceived. ${ }^{3}$ This consensus derives largely from the work of Richard Reitzenstein (1893) and A.E. Harvey (1955) whose conclusions, provided one accepts them, preclude asking further questions about genre, original function, and the compositional pattern of songs known as skolia: if these songs only acquired that label in their after-supper afterlife as a kind of recycled lyric, then the choice of song and its link to the occasion would seem arbitrary indeed.

In this paper I offer a fresh analysis of the skolion based on current methodological approaches to genre. ${ }^{4}$ Using a wider variety of sources, including archaic red-figure vase painting, I arrive at a more restrictive definition of the skolion and reveal its proper status as a distinct and serious genre within the canon of Greek lyric poetry. Like the paian or threnos, the skolion exhibits a recognizable pattern of composition and performance that was known and respected in antiquity. I shall argue that ancient Greek singers and their audiences began in the late sixth century ВСЕ to distinguish the skolion from other forms of lyric poetry through differences of occasion, content, and style, specifically, the ritual aspects of communal symposia, $\mathrm{proverbial/gnomic} \mathrm{content,} \mathrm{and}$ a preponderance of Aeolic meters coupled with a preference for the Lydian and Ionian modes. ${ }^{5}$ This new generic awareness is most clearly reflected in the emerging pan-Hellenic musical tradition that projected the origins of fixed poetic genres into the quasi-mythical past where Terpander is said to have

3 In reference to Pindar's skolion for Xenophon (fr. 122 S.-M.), Carey (2009) 31-32 observes that 'already by Pindar's date (to judge by Aristoph. Ach.532, Wasps 1222, 1236-1240, Frogs 1302) the term skolion was in general use to designate more informal songs sung at the symposion. He goes on to say that ' $[\mathrm{i}] \mathrm{t}$ would be naive to suppose that Pindar seriously regarded this elaborate professional composition as equivalent to these light songs and we may reasonably doubt that he seriously termed it a skolion'. This reading unduly privileges not only the Attic usage, but also its comic representation. Other scholars treat Pindar's skolia as light and playful in contrast to the rest of his poetry. See Van Groningen (1960) 20-21; Kurke (1996) 69 n. 6.

4 As recent scholarship has emphasized, Greek genre concepts were fluid and changed over time. In the archaic period, occasion and the circumstances of performance created what Depew and Obbink (2000) 6 call 'a conceptual orienting device that suggests to a hearer the sort of receptorial conditions in which a fictive discourse might have been delivered'. Cf. Nagy (1994-1995). Moreover, the 'metadiscourse about genre' which developed in the late classical and Hellenistic periods often distorted or even fictionalized a poem's original 'productions-and performance-based' generic identity; Depew and Obbink (2000) 3. Cf. Rutherford (2001) 4-6; Yatromanolakis (2004). At the same time, however, content and style cannot be wholly divorced from the formation of genre concepts. See Nagy (1990) 99; Carey (2009) 23-24.

5 Cf. Yatromanolakis (2009). 
invented the skolion (in a lost poem by Pindar; Ps.-Plut. de musica 1140f.). Within the group of vases relating to this generic tradition, I identify an early reference to Terpander's legendary invention of the barbitos and its association with the skolion on a red-figure kylix by the Epeleios Painter (ca. 500 BCE). We may note from the outset that the invention of a creation myth for the skolion is a conceptual leap that requires an a priori understanding of what a skolion is, how it is to be defined, and what separates it from other named forms of poetry.

\section{Previous Scholarship}

Before offering a new assessment of the skolion's generic identity, it would be helpful to review briefly some of the major arguments and approaches to the subject advanced by earlier critics. By convention I begin with the two pieces of ancient scholarship that have exerted the most influence on modern studies. The first is a set of Hellenistic etymologies by Dikaiarchos and Aristoxenos preserved together in a single paraphrase (schol. Pl. Gorg. 451e p. 207 Cufalo):

In his treatise On Musical Competitions Dikaiarchos (fr. 88 Wehrli) says

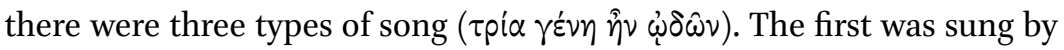
everyone, the second sung individually in order, and the third was sung only by the most skilled performers wherever they happened to be sitting, whereby the song is called a skolion because of this crooked order. But Aristoxenos (fr. 125 Wehrli) and Phyllis the musician say that at weddings they placed many couches around a single table and took turns singing

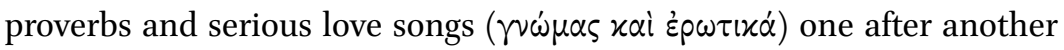
while holding myrtle. The path was crooked due to the placement of the couches in a polygonal room and because those reclining on them were shoved in corners. Therefore it was not because of their composition, but because of the crooked route of the myrtle that the songs are called skolia.

Modern scholars tend to treat these etymologies as an authoritative account of the skolion's generic and performative matrix despite their obvious deficiencies, not least of which is the fact that Dikaiarchos and Aristoxenos did not set out to provide a comprehensive explanation of generic classification and morphology, but merely describe an interesting mode of performance in the service of a rather speculative etymology. Both writers apparently sought an explanation for the skolion's 'crooked' generic nomenclature in that peculiar style of performance well known from Attic comedy in which singers of local Attic sko- 
lia cap the verses of other singers or take turns singing whole songs. ${ }^{6}$ Furthermore, the etymology's stilted division of songs into three genera of performance reflects a penchant for classificatory epistemology no doubt derived from the kind of Aristotelian thinking prevalent in the Lyceum at Athens where Dikaiarchos and Aristoxenos both spent time. It is interesting to note that despite a shared intellectual heritage each etymologist arrived at a different conclusion based on a different explanation of the skolion's variable modes of performance. Indeed, Dikaiarchos' tripartite subdivision of song seems to be more a reflection of Peripatetic methodology than fifth-century reality.

The second piece of evidence consists of a much later discussion of these same etymologies by Plutarch (Q. Conv. 615a-c), whose reworking of the material offers a mystifying jumble of disparate academic notions:

Indeed, the skolia are not a genus of obscurely constructed songs as they say. Rather, everyone first sang a song to the god in unison chanting the paian, and after that the myrtle was passed in turn to each person (the sprig, I think, being called aisakos because the one who takes it sings), after which the lyre was also passed around and anyone who was educated took it and sang, tuning it, while those who were unmusical did not accept it, and so the song was called skolion because it was not sung in common nor was it easy. Others say that the myrtle did not go around in order, but passed from each person from couch to couch. For the first man to sing passed it to the first man on the second couch, and he passed it to the first man on the third couch, and then likewise the second to the second man on the next couch, and so the seeming complexity and bending of the course was called 'skolion'.

Plutarch clearly elaborates upon Dikaiarchos' original etymology and speaks

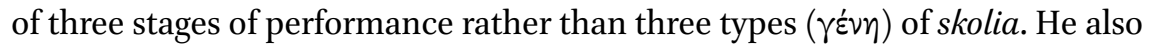
combines the original Peripatetic theory with a competing etymology based on the adjective's (skolios) variant sense of 'hard' or 'difficult.' This particular etymology is preserved in fuller form by the scholiast to Aristophanes' Wasps (1222a Koster):

It was an ancient custom for people at banquets to sing in order, following upon the first man wherever he happened to stop the song. The first man started, holding a sprig of laurel or myrtle and singing a song of Simonides

6 E.g. Ar. Vesp. 1222-1223; Cratin, fr. 254 K.-A. 
or Stesichoros as far as he wished, then handed it on to whomever he wanted but not in the order of the seating arrangement. The man who took it up sang the next verse after the first, and then he passed it along to whomever he wanted. Because everyone sang and recited them without forewarning the songs were called skolia because of the difficulty ( $\tau \dot{\alpha} \mu \dot{\varepsilon} \lambda \eta$

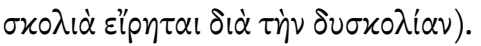

Some modern scholars have tried to reconcile these sources with one another and with earlier descriptions of the skolion found in Attic comedy. In his inaugural treatment of the ancient testimony, Reitzenstein drew heavily upon a well-known passage from the Clouds (1353-1354) in which Strepsiades asks his son to take up the lyre and sing a victory ode by Simonides (PMG 507); when he refuses, Strepsiades asks him to take a sprig of myrtle at least and recite something from Aischylos. Comparing this passage to the etymologies, Reitzenstein argued that Dikaiarchos originally applied the term skolion only to the third class of song performed by the most skilled performers, whom Reitzenstein identified via Aristophanes and Plutarch as those who possessed an ability to play the lyre and sing the more complicated lays of archaic lyric masters. Accordingly, he identified Dikaiarchos' first class of song as the paian and related the second class of song to the short simple verses of the Attic skolia. Conflating this tripartite division of performance with the scenario found in the Clouds - where, it is crucial to note, the term skolion is never used-Reitzenstein concluded that all of the poetry Strepsiades mentions there, including songs by Simonides and passages from Aischylos, were generally grouped together as a single category when performed over wine and called skolia. ${ }^{7}$ However, instead of being an independent source of corroborative evidence, as modern scholars have treated it, this passage from the Clouds and others like it seem rather to have inspired and contaminated later etymologies, which confuse a style of performance with generic nomenclature. No songs by Stesichoros or Simonides are otherwise known as skolia, and the scholiast/etymologist in this case probably never witnessed a live performance of the genre. ${ }^{8}$

7 Reitzenstein (1893) 3-5, 30-31.

8 The scholiast to Plato's Gorgias (451e p. 207 Cufalo) reports that some authorities attribute the Attic skolion on health (PMG 890) to Simonides, others to Epicharmos. Clement of Alexandria (Strom. 4.5.23) attributes it to Simonides or Aristotle (cf. Aristot. Rhet. 1394b). It is telling that Plato does not mention Simonides when quoting this song, referring to its author simply as 'the one who made the skolion' as if he were anonymous. See Fabbro (1995) 25-27. I generally find the scholiasts' attempts to attribute the otherwise anonymous Attic skolia to various 
Five decades later, A.E. Harvey attempted in greater detail to determine the semantic range of the word skolion. ${ }^{9}$ Following closely upon Reitzenstein's examination of Dikaiarchos, Harvey also drew a sharp distinction between the etymologists' second and third class of skolia. He maintained that during the fifth century ВСЕ the term skolion referred to anything performed over wine after dinner. Both Reitzenstein and Harvey believed that the ability to recite the great lyric poets of the archaic past while accompanying oneself on the lyre was in decline during the fifth century $\mathrm{BCE}$, giving rise to the degenerate practice of singing short simple songs and excerpts from tragedy while holding a myrtle sprig, as evidenced in the Clouds and the Wasps. ${ }^{10}$ In trying to determine why after the fourth century вСЕ the term skolion was no longer applied to the songs of archaic lyric masters like Pindar (who called one of his own songs a skolion, and whose other 'banqueting' poems are called skolia by various sources), Harvey concluded that 'the only drinking-songs which remained in use were those which had belonged to the second stage of the fifth-century convivialitiesthe short stanzas in fixed meters, sung by each of the guests in turn, holding in their hands the myrtle-branch instead of the more exacting lyre." ${ }^{\prime 1}$ According to Harvey, 'the word $\sigma x o$ ' $\lambda$ iov soon became restricted to denoting only the second class' when the general decline in musical education all but erased the once dominant practice of entertaining oneself on the lyre. ${ }^{12}$ Harvey's solution has been enormously influential, ${ }^{13}$ but is not beyond dispute. The over-

named poets unconvincing. For example, the scholiast to Ar. Vesp. 1239 Koster reports that some authorities attribute the Admetos song ( $P M G$ 897) to Alkaios or Sappho, though he places it among Praxilla's drinking songs.

10 Reitzenstein's (1893), 32-33 implausible reading of these passages also relies upon an excerpt from Cicero's Tusculan Disputations (1.4) in which the Roman orator reports that every Greek man in the time of Themistokles was educated in music and skilled in the lyre and that such men displayed their talents by playing the instrument 'at banquets' (in epulis). For a more recent and realistic reading of the comic evidence see Kugelmeier (1996) $76-77$, who continues to interpret them as an indication of 'kulturelle Wandel', but lays more emphasis on changing practices rather than strict decline.

11 Harvey (1955) 162.

12 Harvey (1955) 163.

13 Most major studies that touch upon issues of genre and performance begin from the conclusions of Reitzenstein and Harvey: e.g Collins (2004) 84: 'The term itself ... admits of several different usages already in the earliest literary sources.' See also Lambin (1992) 266-307; (1993); Liapis (1996); Teodorsson (1989) 129-131. After the publication of Harvey's article in 1955, Bowra $\left(1961^{2}\right)$, who once treated the skolion as a distinct genre $\left(1935^{1}\right)$, changed his approach completely and no longer considered it to be a distinct poetic form. 
complicated theory of musical decline seems especially dubious and finds little support in recent work on the cultural history of Greek music. There does seem to have been a move toward trendier contemporary poets in Athens during the last quarter of the fifth century вСЕ, but to see this phenomenon in terms of a general decline in musical abilities seems anachronistic and more reflective of modern tastes than ancient realities. ${ }^{14}$ The real answer to the question of why Alexandrian scholars abandoned the term skolion as a classificatory label may be a simple one: during the fifth and fourth centuries BCE the term skolion denoted a specific lyric genre and was consistently applied to those songs composed and performed in the appropriate manner-but when the skolion ceased to be a living genre in the Hellenistic period, the term and its generic significance were forgotten and most Alexandrian critics simply stopped using it.

\section{A New Approach}

In the half-century since Harvey's decisive declaration that any song sung after dinner could be called a skolion, classicists have developed a more nuanced understanding of the dynamics of genre and the problems of Alexandrian scholarship. We now know, for example, that later Hellenistic discourse on archaic lyric poetry often misrepresented original performance contexts with anachronistic fantasies, or, in the case of Dikaiarchos and the etymologists, distorted the reality of performance through imposed templates of philosophical theory. We are also more sensitive to the elasticity of genre and the variability of factors ancient audiences used, often in unpredictable ways, to categorize different types of poetry. ${ }^{15}$ Bearing this in mind, the skolion looks quite different when viewed from the perspective of classical sources: above all, it looks like

14 See generally Csapo (2004). As Peter Wilson (2004) 295-297 has emphasized: 'We have good evidence for the continued importance throughout the democratic period of the training "young Athenian gentlemen" received from their kitharist'. In fact, instead of degenerating into a boorish den of popular music, the symposion became the locus of aristocratic experimentation and renewed conservatism in late fifth- and early fourthcentury вСе Athens. Wilson draws particular attention to Kritias' musical activities in the latter decades of the fifth century вСE and his move to protect the 'cultural capital' of the lyre and old aristocratic poets like Anakreon.

15 E.g. Carey (2009) 21-22 reminds us that genre categories in archaic and classical Greece were porous and flexible, admitting a great deal of overlap and uncertainty, but enough firmness 'to generate a set of audience expectations'. 
a coherent and relatively stable generic concept. In the first instance, I see no reason to doubt Pindar's sincerity when he calls his song for Xenophon a skolion (fr. 122 S.-M.) in order to distinguish it from, among other things, the ode he wrote in connection with the same Olympic victory (Olympian 13; see below). Moreover, Pindar's story about Terpander being the inventor of the skolion (חiv-

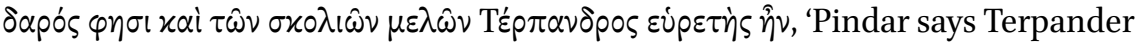
was the inventor of the skolia songs,' Ps.-Plut. de musica 1140 f.) suggests an affinity with the genre stemming from a considerable amount of experience. ${ }^{16}$ Based on Pindar's usage, we may conclude that the term skolion had already become a common genre label applied to new compositions during the first half of the fifth century BCE while also being applied retrospectively to older songs thought to have been composed within the same continuous tradition (as they probably were). Whether or not these older songs were originally called skolia or something else altogether, we may be fairly certain that other Pindaric compositions that fit the mold and are named skolia in later sources carried the same conceptual label as Xenophon's self-named skolion for most audiences from the beginning. We may also note that several passages from Attic comedy apply the term skolion restrictively to a number of songs that are labeled as such elsewhere in Greek literature: the Attic skolia (e.g. PMG 897) and a verse by Alkaios (fr. 141 L.-P.) are named in Wasps (1222-1248; cf. Athen. 693f.-695f.; Ath. Pol. 19.3, 20.5), skolia by Alkaios and Anakreon in Banqueters (fr. 235 K.-A.) and Birds (1410-1416; schol. 1410b Holwerda; Alc. fr. 345 L.-P.; cf. Alc. frr. 249, 348 L.-P.; PMG 891; Arist. Pol. 1285a), and a skolion by Timokreon (PMG 731) in Acharnians (532-534; schol. 532 Wilson). Additionally, in Frogs (1301-1303) Aischylos accuses Euripides of pilfering elements (probably linguistic and acoustic) from all kinds of songs, listing skolia alongside other forms of lyric like threnoi as if they all had unique characteristics that set them apart from one another; if the term skolion referred to any song whatsoever that happened to be performed after dinner then its inclusion here would be nonsensical. What, then, do all of these songs have in common?

To begin our search for an answer, let us turn (very carefully) to Athenaios, who echoes the old tripartite subdivision of Dikaiarchos' etymology, but frames the discussion in a way that adds consilient information about the nature of the skolion (694c):

16 Power (2010) 410 has suggested that Pindar's attribution of the skolion to Terpander belongs to the same skolion for Hieron (fr. 125 S.-M.) in which the poet credits him for inventing the barbitos. 
Most of the guests remembered the well-known Attic skolia, which are worth recounting because of their extreme archaizing and the simplicity

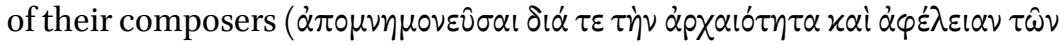
$\pi \circ \eta \eta \sigma \alpha ́ v \tau \omega)$. Alkaios and Anakreon are praised for this type of composition ( $\tau \hat{\eta} i \delta \dot{\varepsilon} \alpha \tau \alpha v i \eta \eta$ ) as Aristophanes shows in the Banqueters when he says, 'sing to me a skolion, choosing something from Alkaios or Anakreon.' Praxilla of Sicyon is also highly regarded for her composition of skolia. They are called skolia, not because their pattern of composition was crooked-for the skolia are said to be a relaxed form of song ( $\lambda \varepsilon \dot{\gamma} \gamma$ - volv

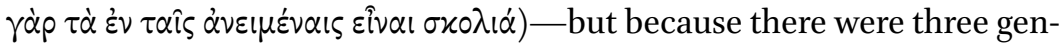
era, as Artemon of Cassandreia says in Book 2 of On the Use of Books (FHG IV 342), which includes the songs associated with social gatherings ( $\tau \dot{\alpha}$

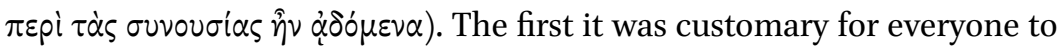
sing, the second type everyone sang also, but in order, one taking it over from another, and as for the third and most highly ranked type, not everyone participated, but only those who seemed sagacious, whatever place they happened to be in (...) This kind was sung when they finished the communal songs and the songs it was necessary for everyone to sing, for they would request each of the wise singers to offer a beautiful song to the group. By beautiful, they meant one that seemed to give some advice or

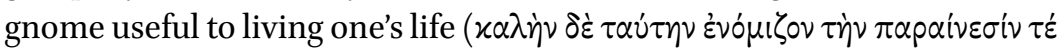

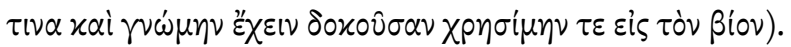

When purged of Peripatetic excess, the combination of Aristoxenos' etymology and Artemon's discussion in Athenaios yields three useful facts about the skolion:1) skolia were customarily performed over wine at communal symposia, 2) their content was characteristically gnomic/proverbial or contained 'serious love-songs', and 3) they were considered to be a relaxed form of song and easy to sing. These three generic elements correspond roughly to the formal concepts of occasion, content, and style/form (meter, melody, etc.), which contribute to the formation of genre categories in both ancient and modern systems of thought. ${ }^{17}$

17 See Nagy (1990) 47-51, 87-88, 98-115; (1994-1995); Yatromanolakis (2004) 6o-62; Kantzios (2005b) 11-29. If occasion was the most important factor in determining archaic genres, by the late classical period content and style became important generic markers, as indicated by Plato's tripartite division of song in the Republic (398d) and Aristotle's (Poet. 1447a) basic approach to distinguishing different genres through different means of representation, such as rhythm, language, and melody. 


\section{The skolion Reconsidered}

\section{Occasion}

In testing this outline of the skolion against the surviving corpus, we may begin with Pindar's skolion for Xenophon, which contains the earliest surviving use of the term $\sigma x \dot{x}^{\lambda} 10 \mathrm{v}$ in Greek literature. ${ }^{18}$ This song was performed at Xenophon's thanksgiving sacrifice in the sanctuary of Aphrodite at Corinth in the wake of his Olympic victory of $464 \mathrm{BCE}$. According to Athenaios (573e-f $=$ Chamaeleon fr. 31 Wehrli):

Pindar first wrote an enkomion for him [Olympian 13] ... but later com-

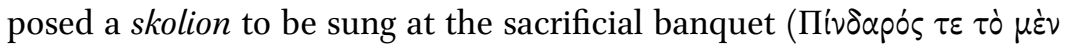

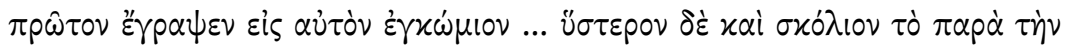
$\theta \nu \sigma i \alpha \nu \dot{\alpha} \sigma \theta \dot{\varepsilon} \nu)$, the beginning of which he composed as an address to the prostitutes who took part in the occasion when Xenophon was presiding over the sacrifice to Aphrodite ...

Athenaios quotes enough verses of the skolion to create a fairly intelligible whole (Pindar fr. 122 S.-M.):

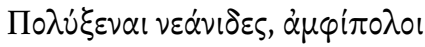

$\Pi \varepsilon i \theta 0 \hat{\varsigma} \varsigma$ ह่v $\alpha \varphi v \varepsilon i \omega \hat{~ K o p i v \theta \omega, ~}$ $\alpha i l \tau \varepsilon \tau \hat{\varsigma} \varsigma \chi \lambda \omega \rho \hat{\varsigma} \varsigma \lambda$ i $\beta \dot{\alpha} v 0 u \xi \alpha \nu \theta \dot{\alpha} \delta \alpha \dot{x} x \eta$

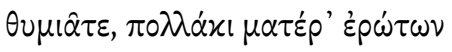

oujpavíav $\pi \tau \dot{\alpha} \mu \varepsilon v \alpha l$

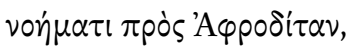

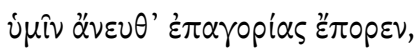

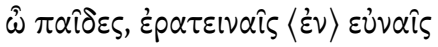

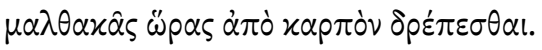

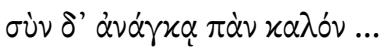

18 West (1974) 7 draws attention to the relatively early use of skolion as a generic term, which he argues reflects the occasion of the songs' performance. E.L. Bowie (1986) 26, on the other hand, maintains that the term 'refers not to the occasion but to the manner of performance of the songs.' 


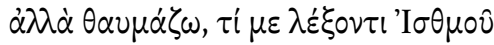

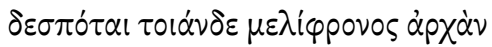

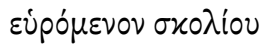

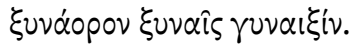

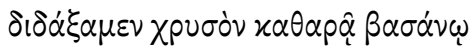

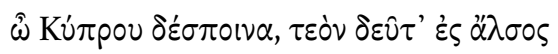

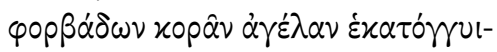

ov $\Xi \varepsilon v 0 \varphi \omega \hat{\nu} \tau \varepsilon \lambda \varepsilon \dot{\alpha} \alpha \zeta$

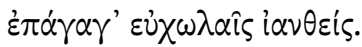

Young girls, much frequented attendants of Persuasion, in rich Corinth you burn the yellow tears of pale frankincense often flying in thoughts up to the mother of desires, Uranian Aphrodite;

to you she has permitted without blame to pluck the fruit of soft youth in welcome acts of love.

Under compulsion everything is beautiful ...

But I wonder what the lords of the Isthmus will say about me for composing a beginning such as this for a honey-minded skolion to accompany common women.

We test gold on a pure touchstone ...

O mistress of Cyprus, here to your grove A hundred-limbed herd of grazing women Xenophon has led, rejoicing in the fulfillment of his prayers. 
Based in part on the songs' respective performance contexts, both Pindar and Athenaios (via Chamaeleon) distinguish this skolion from the earlier enkomion, the skolion having been composed for performance at the banquet, the enkomion as part of the initial victory celebration (probably for performance during a kômos).${ }^{19}$ The skolion is clearly not a victory ode, as it mirrors the occasion of the sacrificial banquet and was most probably performed over wine. ${ }^{20}$ In addressing itself to the sacred prostitutes (perhaps in a spirit not unrelated to that of the skolia erôtika mentioned by Aristoxenos) the song positions itself primarily within the religious community of the sanctuary and the occasion of the feast, moderating Xenophon's original victory. Scholars now agree that Pindar expected his victory odes to be re-performed at a number of different venues, especially symposia, but there is no reason to believe that epinikia were ever called skolia by classical singers and their audiences. Even when performed over wine an epinikion remained an epinikion, just as a skolion remained a skolion even if the person singing it or writing it down were not drinking (e.g. Pl. Gorg. 451e). ${ }^{21}$

19 Van Groningen (1960) 20-21 followed by Kurke (1996) 50, 69 n. 5 rightly interprets the

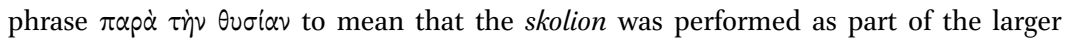
celebrations, not during the actual slaughter ('à côté, en marge du sacrifice' or à l'occasion du sacrifice'). Kurke rightly asserts that the occasion was the symposion. Cf. Fränkel (1973) 469-471; Budin (2006) 85. On the likely performance contexts of Pindar's victory odes see Heath (1988), Heath and Lefkowitz (1991), Carey (1991), and Morgan (1993), who argue in favor of choral performance. Morgan also demonstrates that Pindar (in Olympians 1 and 9) tried to distance his rather serious epinikia from the playful songs and lesser victory odes performed at symposia.

20 Cingano (2003) 24-25 argues that Xenophon's financial resources and the open space of the sanctuary, as opposed to the closed space of a private domestic banquet, encouraged a choral performance of the skolion. However, the dining facilities used for the sacrificial banquet, whether enclosed (perhaps by a tent) or open-air, would have been just as conducive to a solo performance.

21 See Morgan (1993); Currie (2004). Budelmann (2012) points out that the enkomia of Pindar and Bacchylides often explicitly situate themselves in a sympotic environment, while epinikia make more generalized references to symposia and tend to associate themselves with the larger occasion of the festival banquet. But what Budelmann calls enkomia I would call skolia (including Pi. fr. 122 S.-M.) as many ancient sources do, making the references to symposia quite natural. He is right to point out, however, that these epinikia and skolia (or enkomia) have much in common, especially strategies of praise. It is quite possible that in addition to the skolion (fr. 122 S.-M.) Ol. 13 was performed again at the banquet in the sanctuary of Aphrodite at Corinth where its original external occasion (the victory celebration) would have been re-created through performance, separating 
In Pindar's other skolia - all of which reference a sympotic occasion-we detect a strong correlation between the songs' function and the activities of the banquet, specifically, activities that accompany drinking. ${ }^{22}$ According to Athenaios (427d = Theophrastus fr. 118 Wimmer; Pindar fr. 128 s.-M.):

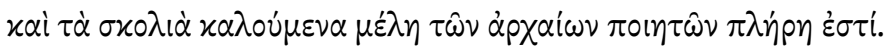

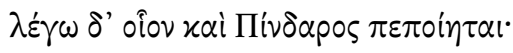

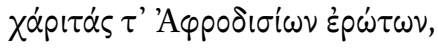

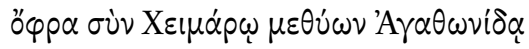

$\beta \alpha \dot{\lambda} \omega \omega$ xó $\tau \tau \alpha \beta \nu \nu$

the songs the ancient poets called skolia are full of [the kottabos]. I mean the kind Pindar composed:

'the charms of Aphrodite's love, so that while getting drunk with Cheimaros

I throw the kottabos for Agathonidas.'

A line preserved by Philodemos (De mus. 4.12), usually attributed to the skolion for Hieron, encapsulates the sympotic experience (fr. 124d s.-M.):

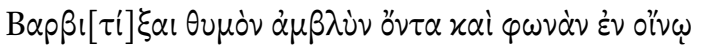

To rouse with the barbitos a mind that is dull along with the voice, over wine.

it generically from the indigenous skolion. On the re-creation or activation of the original occasion, and for the case of epinikia in particular, see Day (2000) 40-41 with relevant bibliography.

22 Only the fragments discussed here are explicitly identified as skolia in ancient sources. It is worth noting that Didymos (fr. 62 Braswell in inscr. a Pi. Nem. 11 Drachmann) associated Nemean 11 with Pindar's $\pi \alpha$ poivi $\alpha$. Pindar's song for Thrasyboulos of Akragas (fr. 124 S.-M. $=$ Athen. $480 \mathrm{oc}, 782 \mathrm{~d}$ ) is not explicitly identified as a skolion, but its content and meter are highly suggestive: in the opening verse Pindar clearly states: 'I am sending a chariot of lovely song for after dinner,' which he says 'may be a sweet goad for your fellow-drinkers'. On the echo of this line in the last verse of Pythian 6 (also composed for Thrasyboulos) see Kurke (1990) 102-103, who calls fr. 124 S.-M. a skolion. Van Groningen (1960) 99-100 suggests that the occasion was a 'fête privée', noting: 'Rien n'indique que le symposion ait présenté un caractère semi-officiel comme celui de Xénophon.' Even so, the message of the song is a universal one: when drinking 'we all sail to a false shore, just the same/then the poor man is rich and the rich man ...' For fuller discussions of this song see Van Groningen (1960) 92-94; Bowra (1964) 232-235. Cf. Bacchylides fr. 2ob s.-M. 
Athenaios records several more lines $(635 \mathrm{~b}-\mathrm{d}=$ Aristoxenos fr. 99 Wehrli; Pindar fr. 125 S.-M.):

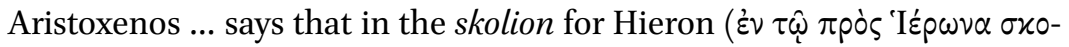
$\lambda(\omega)$ Pindar names the magadis and says 'antiphonal plucking' ... Pindar clearly says that Terpander invented the barbitos, a 'responding-voice' to the Lydian pêktis:

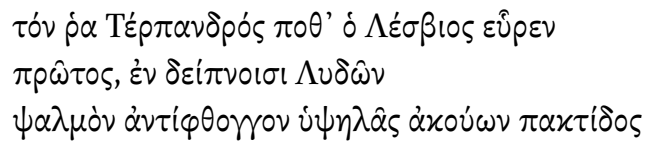

which [barbitos] Terpander the Lesbian first invented, when at Lydian banquets he heard the voice-answering plucking of the high-pitched pêktis. ${ }^{23}$

He also says (Athenaios 512d = Heracl. Pont. fr. 55 Wehrli; Pindar fr. 126 s.-M.):

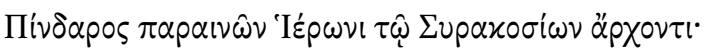

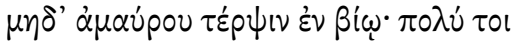

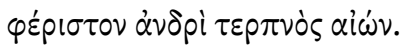

Pindar gives this advice to Hieron, the ruler of Syracuse:

'Do not impair pleasure in life; for by far the best thing for man is a pleasant lifetime.'

Pindar's idealized re-creation of the song's real occasion is augmented by an implicit comparison with imaginary symposia of the distant past, linking Hieron's western Greek present to Terpander's fantastic Lydian east. ${ }^{24}$ The skolion effectively situates the tyrant and his court within a much larger cultural/social/historical matrix. Members of the aristocracy no doubt constituted the bulk of the drinking group, but as the head of the city's power structure and

23 For a more detailed discussion of this skolion see Van Groningen (1960) 112-113. Pindar also composed Olympian 1 and Pythians 1, 2, and 3 for Hieron. On the problematic identification of Pythians 2 and 3, and Pindar's relationship with Hieron see Young (1983); Robbins (1990).

24 On internal references to the external realities of performance in Pindar see Nagy (1990) 94; Carey (2007). According to Schmitt-Pantel (1990) 22-23 Pindar often uses the term $\delta \varepsilon i \pi v o v$ to indicate 'the group around the symposion' as well as the formal banquet itself. 
representative of its sovereignty, the tyrant presided over symposia that were more than just private parties of like-minded hetairoi. The so-called 'princely banquets' of Pindar may be viewed in many respects as civic banquets. ${ }^{25}$ Their skolia spoke to the world - this is most evident in the song for Xenophon-and, in the words of Schmitt-Pantel, reflect 'a system which stresses fundamental values, as much religious as social—in a word, civic values.'. ${ }^{26}$

Evidence relating to the roughly contemporary Attic skolia also makes a fundamental connection between the skolion and wine, though internal references to the sympotic occasion are rare. ${ }^{27}$ We find only two: the voice of $P M G 906$ commands a servant to 'fill it up for Kedon [a martyr who died fighting the tyrants] ... since it is necessary to pour [wine] for good men,' while $P M G 902$ opens by asking no-one in particular to 'drink with me'. Fortunately, external testimony relating to the songs' performance offers an abundance of details. In several comic passages, the sympotic occasion is described or represented on stage, and while the songs themselves are frequently travestied for laughs, the prosaic set-ups appear to reflect everyday practice. In the Wasps, for example, Philokleon is instructed to sing the skolion in a proper fashion and in the proper order, following the libations and initial prayers (1216-1226):

Bdelykleon. Water for our hands! Bring in the tables! We're having our dinner. We've washed our hands. Now we're pouring libations.

Philokleon. For heaven's sake, is the feast just a dream?

Bdel. The auletris has begun her music. Your fellow drinkers are Theoros, Aeschines, Phanos, Kleon, and another foreigner at Akestor's head. With these men for company see that you do a good

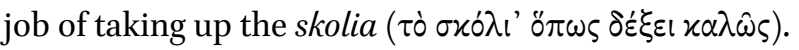

Phil. $\quad$ Are you kidding! I'll do it better than any Diakrian.

Bdel. We'll see. Now then, I'm Kleon and I begin by singing the Harmodios song, and you have to take it up:

'There never was any man in Athens ...'

25 Schmitt-Pantel (1990) 20, n. 42; Vetta (1983).

26 Schmitt-Pantel (1990) 24. We may compare the broad audiences of Pindar's skolia to those of his victory odes, whose purpose was the reintegration of the victorious athlete into the community at large. See Crotty (1982) 121; MacKie (2003) 100-101. Kantzios (2005a) argues that the tyrant's symposia in Athens included members of the community beyond the old aristocracy, such as urban hoplites.

27 Precise dating of the Attic skolia individually or as a group is difficult, if not impossible, but a general date of ca. 514-480 BCE is certainly applicable if somewhat broad. See Bowra $\left(1961^{2}\right)$ 375-376; Thomas (1989) 258-26o; Anderson (2003) 202-203. 
The same pattern is detected in a passage from Antiphanes' Diplasioi (fr. 85 K.-A. = Athenaios 503d) and Plato Comicus' Spartans (fr. 71 K.-A.) where the skolia are sung after the libations but before the kottabos:

A: Have the men already dined?

B: Every single one.

A: Very good. Why don't you run and carry out the tables, while I go and pour out the water for their hands.

$\cdots$

The libation had already occurred and the drinkers were well into it. The

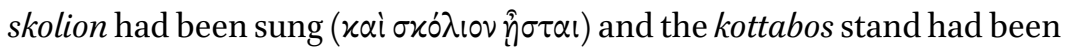
brought out.

The Attic skolia may have lacked structural complexity, but they appear to have been taken seriously as a ritualized component of the symposion's formal progression.

Several more scenes from Aristophanes attest to the popularity of the Attic skolia throughout the polis. The symposion in Aristophanes' Banqueters, where an instructive character commands someone to 'sing a skolion, choosing some-

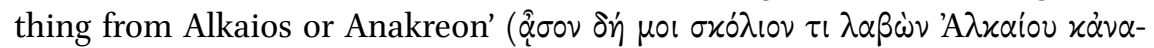

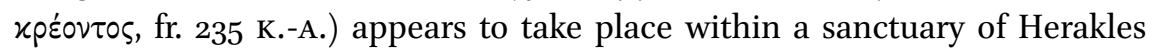
frequented by a group of local demesmen. ${ }^{28}$ References to traditional paraphernalia, including a kottabosstand and garlands, confirm the sympotic context of this scene as the proper occasion for the performance of skolia. ${ }^{29}$ The chorus of Acharnians (978-979) also speak of singing the Harmodios song during festive countryside symposia that may be linked to the Rural Dionysia or Anthesteria. ${ }^{30}$ We hear of the same group of traditional Attic skolia being performed

28 See MacDowell (1995) 27-29; Fisher (2000) 356; Wilkins (200o) 238, 276, 316, 384. The Suda

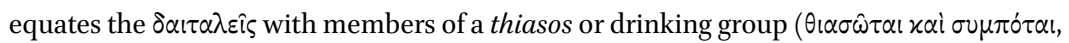
$\delta 125$ Adler). Orion 49.10 Sturz likewise associates the chorus with diners in a local tem-

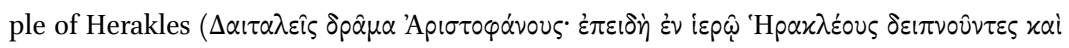

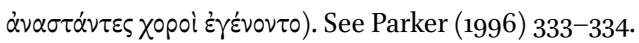

29 The bronze kottabosstand and the garlands mentioned in fr. 231 may serve as an indication that the profligate son was overly familiar with sympotic luxuries. The charisios mentioned in fr. 211 K.-A. is a kind of sesame cake that was most often consumed during late-night sympotic revels. Wilkins (2000) 238, 309-310.

30 On the role of these two festivals in the Acharnians see A.M. Bowie (1993) 26-39 who interprets the play in light of the festivals. Alternatively, Habash (1995) examines the play as evidence for the historical realities of the festivals. See also Sfyroeras (2004). 
in state sanctuaries and civic buildings where citizens from different social strata attended formal symposia. During the final reconciliation scene in the Lysistrata (1236-1237), for example, the Spartan and Athenian delegates ratify their peace treaty with an official ceremony on top of the Acropolis where they continue to celebrate with a formal banquet and symposion that includes the performance of skolia. ${ }^{31}$ The scholiast to Plato's Gorgias 451e (p. 207 Cufalo) also reports that the Harmodios, Admetos, and Telamon songs were routinely performed 'over cups' in the Prytaneion at Athens.

Finally, Aristotle's song to Hermeias ( $P M G$ 842), 'sung everyday in the syssitia'

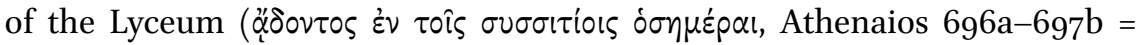
Hermippos fr. 48 Wehrli), was identified by some in antiquity as a skolion. Others called it a paian and accused Aristotle of impiety for treating its human subject as if he were a god. ${ }^{32}$ The song's classification, which is still being debated today, is illuminating all the same because it gives us some idea of what could be counted as a skolion in the minds of ancient critics; whether or not Aristotle composed it with a specific genre in mind or created a kind of hybrid as several modern scholars posit, the song must have exhibited enough characteristics of the skolion to make that label viable. ${ }^{33}$ Athenaios, relying on the third-century в В $\mathrm{E}$ biographer Hermippos and likely echoing Aristotle's own defense, tells us that the song lacked the standard paianic refrain and 'displays none of the characteristics of the paian, but is a certain type of skolion'. He may have added that, like all of Pindar's skolia, Aristotle's song was composed in dactylo-epitrite meters, ${ }^{34}$ and like several Attic skolia laments the death of

31 'If someone sang the Telamon song where the Kleitagora was required, we applauded' ( $\varepsilon i$

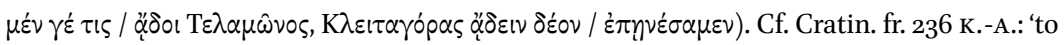
sing the Kleitagora when the aulos plays the Admetos song'. Such confusion suggests that both songs shared a similar rhythm and melody. The Admetos song and the Telamon are both in Greater Asclepiads. Kugelmeier (1996) 45-49.

32 Aristotle's accusers, Eurymedon and Demophilos, appear not to have been entirely successful in their prosecution. For the text and analysis of this song and the ancient controversy over its classification see Bowra (1938); Harvey (1955) 173-175; Renehan (1982); Rutherford (2001) 90-97; Ford (2011).

33 Didymus (in Dem. 10.32) and Diogenes Laertius (5.4-6) both cite the text and refer to the song as a paian and a hymn. Most recently, Ford (2011) 86-9o has revived and expanded the view that Aristotle's song is a kind of hybrid whose genre 'was up for renegotiation when it was performed in new places'.

34 Cf. Harvey (1955) 174: 'the great majority of the poems known to have been $\sigma x \dot{\partial} \lambda \iota \alpha-v i z$. all those of Pindar, all except one of the supposed $\dot{\varepsilon} \gamma x \dot{\omega} \mu \mu \alpha$ of Bacchylides, and the $\sigma x \dot{x}^{\lambda} \lambda_{10 \mathrm{~V}}$ of Aristotle-are in a straightforward dactylo-epitrite meter.' 
virtuous heroes like Achilles and Ajax (13-14; cf. PMG 894, 898), attempts to confer immortality upon its martyred subject (17-21; cf. $P M G$ 894, 896), and offers a bit of gnomic advice about the best thing in life for a mortal, in this case divine Arete (1-2; cf. Athen. 694c; $P M G$ 889-892, 903). In other words, Aristotle's song to Hermeias follows a very similar pattern of composition and performance as the one detectable in the larger corpus of surviving skolia, most notably with respect to content and style.

\section{Content}

Given the skolion's proximity to libations, it is no surprise that several of the Attic skolia address gods and heroes or provide various facts about the deities' lives and their ideal relationship with the drinking group:

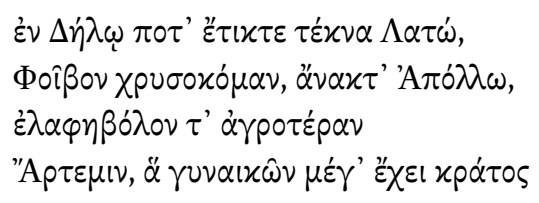

In Delos Leto once bore children, golden-haired Phoebus, lord Apollo, and the shooter of deer, the huntress Artemis, who holds great power over women.

PMG 886

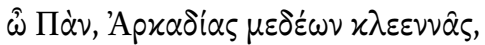

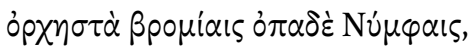

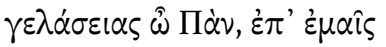

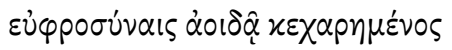

O Pan, ruler of glorious Arcadia, dancer, companion of the Bacchic Nymphs laugh, o Pan, at my merriment rejoicing in my song.

PMG 887

Others offer proverbial advice and maxims in accordance with Artemon's description of the skolion's characteristic didactic function:

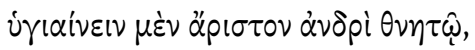

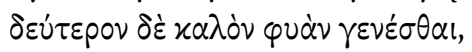




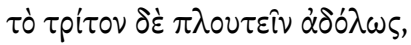

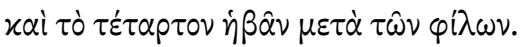

Health is best for a mortal man, second, to be beautiful in stature, third to be wealthy without guile, and fourth to be young with one's friends.

$P M G 890$

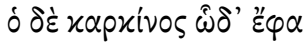

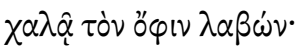

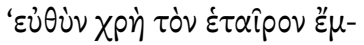

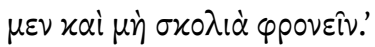

The crab spoke thus

taking the snake in its claw,

'a comrade ought to be straight

and not think crooked thoughts.'

$P M G 892$

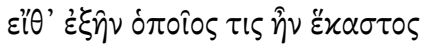

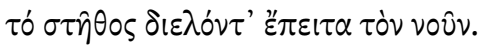

$\varepsilon \dot{\sigma} \sigma \delta \delta \nu \tau \alpha, x \lambda \varepsilon i \sigma \alpha \nu \tau \alpha \pi \dot{\lambda} \lambda เ v$,

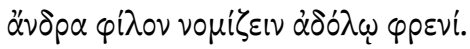

If only it were possible to see what everyone is really like by opening his breast, and looking at his mind to close it back again

and consider the man to be a friend with an honest heart. ${ }^{35}$ $P M G 889$

While the Attic skolion to health (PMG 890) declares outright what the best thing in life really is, Pindar's skolion for Hieron (see above) offers a competing gnomic pronouncement declaring that the best thing for man is a pleasant

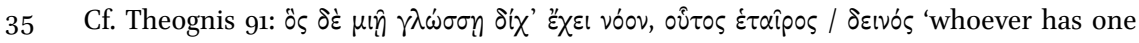

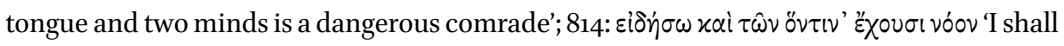
see what kind of mind they have'. Pistos among friends, or the lack thereof, is a consistent theme throughout the Theognidea. See in general Donlan (1985). 
life. Timokreon's moralistic tirade against the evils of wealth follows the same gnomic trajectory. According to a scholiast on Acharnians (532 Wilson):

The poet Timokreon of Rhodes wrote a skolion [PMG 731] like this against

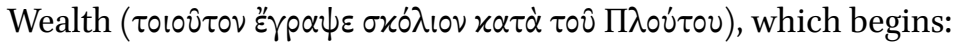

$$
\begin{aligned}
& \omega^{\prime} \varphi \varepsilon \lambda \varepsilon^{\prime} \nu \sigma^{\prime} \hat{\omega} \tau \cup \varphi \lambda \dot{\varepsilon} \Pi \lambda{ }^{\prime} \nu \tau \varepsilon \\
& \mu \eta \dot{\prime} \tau \varepsilon \hat{\eta} \mu \eta^{\prime} \tau^{\prime} \dot{\varepsilon} \nu \theta \alpha \lambda \dot{\alpha} \sigma \sigma \eta \\
& \mu \eta \tau^{\prime} \text { हे } \nu \dot{\eta} \pi \varepsilon i \rho \omega \varphi \alpha \nu \eta \hat{\mu} \mu \varepsilon,
\end{aligned}
$$

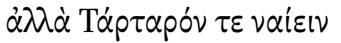

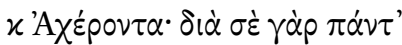

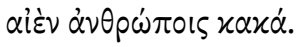

Long before Timokreon's song made the rounds over wine, however, Pythermos (who probably lived during the first half of the sixth century ВСЕ) ${ }^{36}$ proclaimed in his only surviving skolion that all else is nothing next to gold (PMG 910):

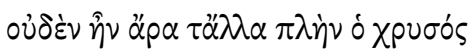

Other things are as nothing except gold.

\section{Style: Meter}

We also detect in the surviving corpus of skolia a limited choice of metrical patterns. Just as subsequent songs picked up Pythermos' moralizing tone, later composers of skolia continued to use the same Aeolic rhythms. The single surviving line of Pythermos' skolion consists of a standard phalaecian verse $\left(-\smile-\cup-\smile-\smile-\smile=g l i a_{\wedge}\right)$, which also stands at the beginning of a unique metrical pattern used for many of the Attic skolia, consisting of two

36 Athenaios (625b-c) cites a poem by Hipponax or Ananios (ca. 540 BCE) in which Pythermos is mentioned by name; Smyth (1900) 280 . 
phalaecian verses followed by a choriambic dimeter and a final verse with two dodrans (in West's notation): ${ }^{37}$

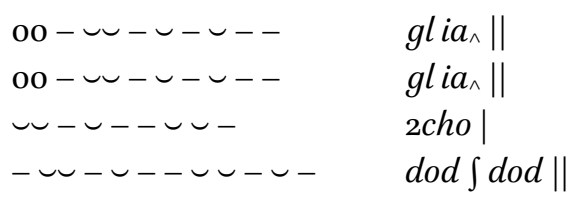

This meter is used for a variety of different songs, including those addressed to the gods ( $P M G$ 884-888), the four versions of the Harmodios song (893$896)$, proverbial songs about friendship and human advantage $(889,890)$, and the Leipsydrion lament (907). This scheme likely represents a local Attic tradition used exclusively for the skolion. It appears again in the Ekklesiazousai (938-945), where Aristophanes uses it to construct parodies of democratically charged skolia in the spirit of the Harmodios song. ${ }^{38}$

Otherwise, the collection of twenty-five Attic skolia displays a consistent repertoire of standard, mostly Aeolic meters, including 'major Asclepiads,' i.e. choriambically expanded glyconics ( $P M G$ 897, 902, 903, 904, 905, 908), ${ }^{39}$ one Alcaic stanza ( $P M G$ 891), which seems to be an alternative version of an older song (Alc. fr. $249.6-9$ L.-P.) that has been adapted to the Attic dialect, ${ }^{40}$ a simple piece composed in pure glyconics (892), ${ }^{41}$ and a single elegiac couplet (9o6).

$37 \quad$ West (1982) 59 .

38 See Ussher (1973) 206-207.

39 On this meter see West $(1982) 3^{2-33}, 192$.

40 The Attic version of $P M G 891$ runs as follows:

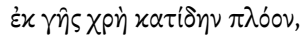

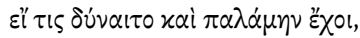

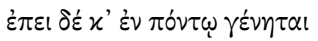

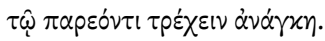

One ought to seek a fair voyage from the land

if one is able and knows how,

but when one is already at sea

it is necessary to run with the present condition.

The papyrus containing Alkaios' song in the Aeolic dialect (P.Oxy. 2298) suggests that these lines originally formed part of a larger composition. The stanza's adapted form in the collection of Attic skolia served as a general song of advice recommending the utility of foresight and perseverance, thus conforming to the skolion's characteristic content and general style. Hansen (1987) 108-109 speculates that this song was revived in Attica during Peisistratos' campaign against Pittakos for the possession of Sigeum.

41 West (1982) 6o describes this meter as 'two telesilleans and a dovetailed pair of glyconics'. Fabbro (1995) 53 . 
We also find a somewhat unusual yet undemanding pattern (PMG 898-901) consisting of a dovetailed glyconic and a dodrans with a second expanded line of the same rhythm: ${ }^{42}$

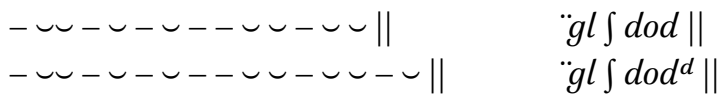

It is no coincidence that the three additional poems of Alkaios that are called skolia in the fifth and fourth centuries BCE were composed in 'major Asclepiads' (fr. 345; 348 L.-P.), and expanded glyconics, otherwise known as the fourteensyllable Sapphic (fr. 141 L.-P.). ${ }^{43}$ Timokreon's single surviving skolion against wealth ( $P M G$ 731) composed in trochaic dimeters also falls squarely within the Aeolic tradition.

We may notice that the straightforward glyconic-based metrical patterns of these Attic skolia are relatively simple, easy to sing, and, as we shall see, conducive to a relaxed melodic pattern. The ease and frequency of these standard metrical structures reflect the 'simple nature of their composers' (Athen. $693 \mathrm{f}$.; see above) and attest to the widespread popularity of such songs throughout the Attic population. ${ }^{44}$ Indeed, the somewhat common, even folksy language of the Attic skolia has not gone unnoticed. Martin West remarks, '[v]ersification in these ditties is a little lax', pointing out, for example, that the $x \alpha$ in in $P M G$ 893.2, 895.2, 896.2, and 907.3 resists elision. He also notes a peculiar pronuncia-

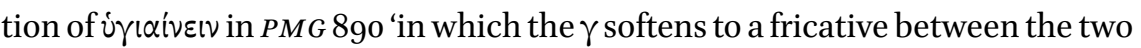
close vowels and a y-glide develops after it: hüg-y(i)',45 Although Pindar's skolia composed in straightforward dactylo-epitrite are more complex than the bulk of these short Aeolic songs, they are relatively simple compared to his epinikia and, we might even say, 'relaxed. ${ }^{46}$ It would seem that even Pindar respected an implicit expectation that a skolion ought to be easy to sing and readily followed.

\footnotetext{
42 West (1982) 60.

43 MacDowell (1971) 291-292.

44 Cf. West (1992) 349 n. 98: 'It can be observed from the meters that there were certain favorite tunes that were used again and again.'

45 West (1982) 18.

46 As Van Groningen (1960) 103 says of his skolion for Hieron (frr. 124d, 125, 126, 128 s.-M.): 'La structure est très simple.'
} 


\section{Style: Mode}

Lyric style may be understood, according to Gregory Nagy, as 'the interaction of phraseology, rhythm, and modes', or diction, meter, and melody (logos, rhythmos, harmonia), the three components of song Plato outlines in the Republic (398d). ${ }^{47}$ Closely related to a song's rhythmic qualities are its interdependent modes, or the distinctive harmoniai underlying its melodic performance. This too is an integral part of the genre's identity. ${ }^{48}$ Both the Lydian and Ionian modes are expressly associated with the skolion and are the only modes known to have been used in their composition. In fact, the invention of the Ionian mode is associated with Pythermos' skolia, as Athenaios reports $(625 \mathrm{c})$ :

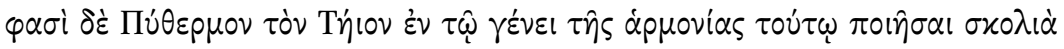

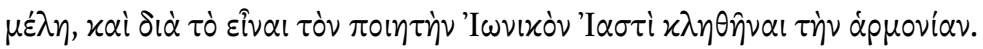

They say that Pythermos of Teos composed skolia in this type of harmoniai, and because the poet was from Ionia the harmony was called Ionian.

While this anecdote probably lacks genuine historical veracity, it does prove two crucial points about the nature of the genre. First, it shows that later generations formulated a separate history of the skolion to account for its unique status: Terpander is credited with originally inventing the form while Pythermos is said to have added the Ionian harmonia to its compositional tradition. ${ }^{49}$ Such quasi-mythical stories reflect the actual process of pan-Hellenization. ${ }^{50}$ Second, this etiological story confirms that certain harmoniai (in this case

$47 \quad$ Nagy (1990) 51.

48 Aristotle (Pol. 1342b) associates the dithyramb with the Phrygian mode, telling us that Philoxenos tried to compose one in the Dorian mode but was forced back into the appropriate Phrygian because the nature of the genre demanded it. However, as West (1992) 181 and Wallace (2005) point out, an Athenian dithyramb produced during the first half of the fifth century вСЕ was performed with 'Dorian auloi' [i.e. with a Dorian mode] at the Dionysia; the victory and the performance are described in an epigram (Anth. Pal. 13.28). Nevertheless, Philoxenus must have had a compelling reason for returning to the preferred mode.

49 On Terpander's invention of the skolion see Van Groningen (1960) 118, Bowra $\left(1961^{2}\right) 131$ n. 5 , Nagy (1990) 358, and Gostoli (1990) 89-90, 112, 132, who associates a fragment attributed to Terpander (fr. 3) with the skolion.

50 As Nagy (1990) 86-91 has shown, the gradual systematization of the major genres and musical elements of the Greek song-making tradition were explained through later myths and stories about early musical innovations and quasi-mythical inventors like Terpander, Arion, and Olympus. 
the Ionian) were associated with the skolion and served as a stylistic genre marker similar to that of meter. ${ }^{51}$

Pindar's skolia point to a second distinctive harmonia that came to define the skolion's generic identity. In his skolion for Hieron, Pindar tells how Terpander invented the barbitos after hearing the pêktis at Lydian banquets (fr. 125 S.M.; see above). Here, the internal reference to Lydian music and festivities signals the composition's own musical tradition, specifically, I would argue, its Lydian harmonia. Normally, the Aeolian and Dorian modes correspond to like meters such as Aeolic and the Dorian dactylo-epitrite, but the Lydian mode is adaptable to both, and in at least one other Pindaric composition (Nemean 8) it is again coupled with dactylo-epitrite. ${ }^{52}$

Plato links the Lydian and Ionian harmoniai in the Republic (398e-399a) when discussing the various melodic patterns and their moral impact upon the human psyche. ${ }^{53} \mathrm{He}$ begins by explaining the interdependence of a song's three constituent elements, declaring that its 'mode and rhythm must necessarily fit

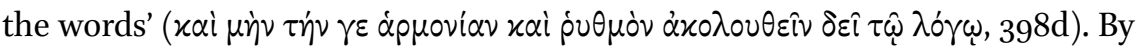
way of example, he draws attention to the inherent connection between the definitive content of poetic laments and the innate 'lamentatory' qualities of

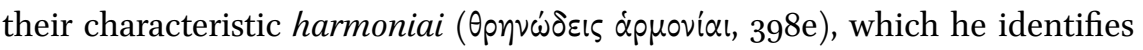
as the Mixolydian and Syntonolydian. After banning laments and threnodic modes from his ideal city, Plato turns his attention to drunkenness and sloth,

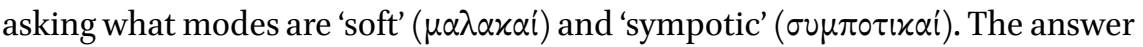
is of course the 'Ionian and Lydian, which are called lax' ('I $\alpha \sigma \tau i$ ', $\hat{\eta} \delta$ ' ö $\varsigma$, xai

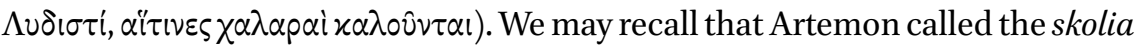

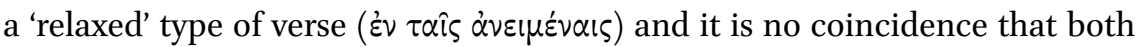

51 Dupont (1999) 84 makes this interesting observation in reference to the skolion's imagined invention: 'The association of Terpander, believed to have evolved musical techniques, once the music of a song had been separated from its words, proves that the skolion was a musical form, not a type of text.' I agree with her basic statement, that the skolion was a melodic phenomenon, but I must disagree with her general observation that 'when the heading skolion is used to assemble texts, it in fact covers more or less anything and everything'.

52 On the correlation between internal references to 'ethnic' instruments and a poem's own mode see Nagy (1990) 94-95. Other references to the Lydian harmonia occur in songs composed in Aeolic meters (Ol. 14; Nem. 4).

53 Plato lists the Ionian, Dorian, Phrygian, Lydian, Mixolydian, and Syntonolydian. Aristides Quintilianus (1.9 = pp. 15-19 Winnington-Ingram) also discusses this list of modes, often called the 'Damonian scale'. West (1992) 174 suggests that they were first described by Damon, Perikles' music teacher. 
Plato and Aristotle use nearly identical descriptions to explain the same two harmoniai normally associated with sympotic songs. Aristotle recognized the relaxed quality of the Lydian mode, but criticized Plato for censuring the easy harmoniai as being conducive to drunkenness (Pol. 1342b). He points out that 'the relaxed harmoniai' ( $\tau \dot{\alpha} \varsigma \dot{\alpha} v \varepsilon \mu \mu \dot{\varepsilon} v \alpha \varsigma \dot{\alpha} p \mu o v i \alpha \varsigma)$ have the effect, not of frenzied intoxication, but of the 'sluggishness' ( $\dot{\alpha} \pi \varepsilon i p \eta x v i \alpha \varsigma)$ that results from the routine consumption of wine and like wine are valued for their power to amuse and relax. They are especially suitable for older people who may have trouble

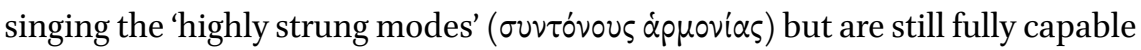
of performing with the easier relaxed harmoniai. Aristotle also ascribes to the Lydian mode in particular a kind of 'orderly' ( có$_{\mu \mu \circ \nu)}$ ) and 'educative' ( $\pi \alpha \iota \delta \varepsilon i \alpha \nu$ ) quality, which accords well with the skolion's didacticism.

\section{Vase-Painting and Performance}

The generic formation of the skolion, founded primarily on the drinking occasion and specific combinations of meter and mode, is likely to have coalesced in the sixth century вСЕ, roughly some time between Pythermos and the appearance of the Attic skolia; it is difficult to be more precise. The early history of the genre was obscure even in antiquity, prompting minds like Pindar's to mythologize its origins through the figure of Terpander. Although recorded texts and references to the genre from the archaic and early classical periods are rare indeed, insight into this period of the skolion's history, both real and imagined, can be garnered from early red-figure vase-painting, which helps to fill some of the gaps in our literary record. ${ }^{54}$ The earliest and arguably most comprehensive picture of the skolion's original performative matrix appears on a red-figure kalyx-krater by Euphronios dated to ca. 500 BCE. ${ }^{55}$ An elaborate symposion illustrates the entire vase, populated on the obverse by a number of reclining figures and a standing auletris, all with their names inscribed (fig. 6.1a). They are, from left to right, Tho[u]demos, Melas, Suko (the auletris), Smikros (often identified as the vase-painter), and Ekphantides, who tilts back his head beneath an upraised right arm and sings a song to Apollo (fig. 6.1b). ${ }^{56}$ The inscribed words

54 An M.A. thesis by P.J. Anderson, 'Verse-Scraps on Attic Containers and the Practice of the 'Skolion': the Material Evidence in its Literary Context' (1997, University of Ottawa) provides a convenient catalogue of poetry fragments on Attic vases associated with symposia. Munich 8935; $A R V^{2}$ 1619. First published by Vermeule (1965).

$5^{6}$ On the significance of these names see Vermeule (1965) 34; Neer (2002) 111-112. 


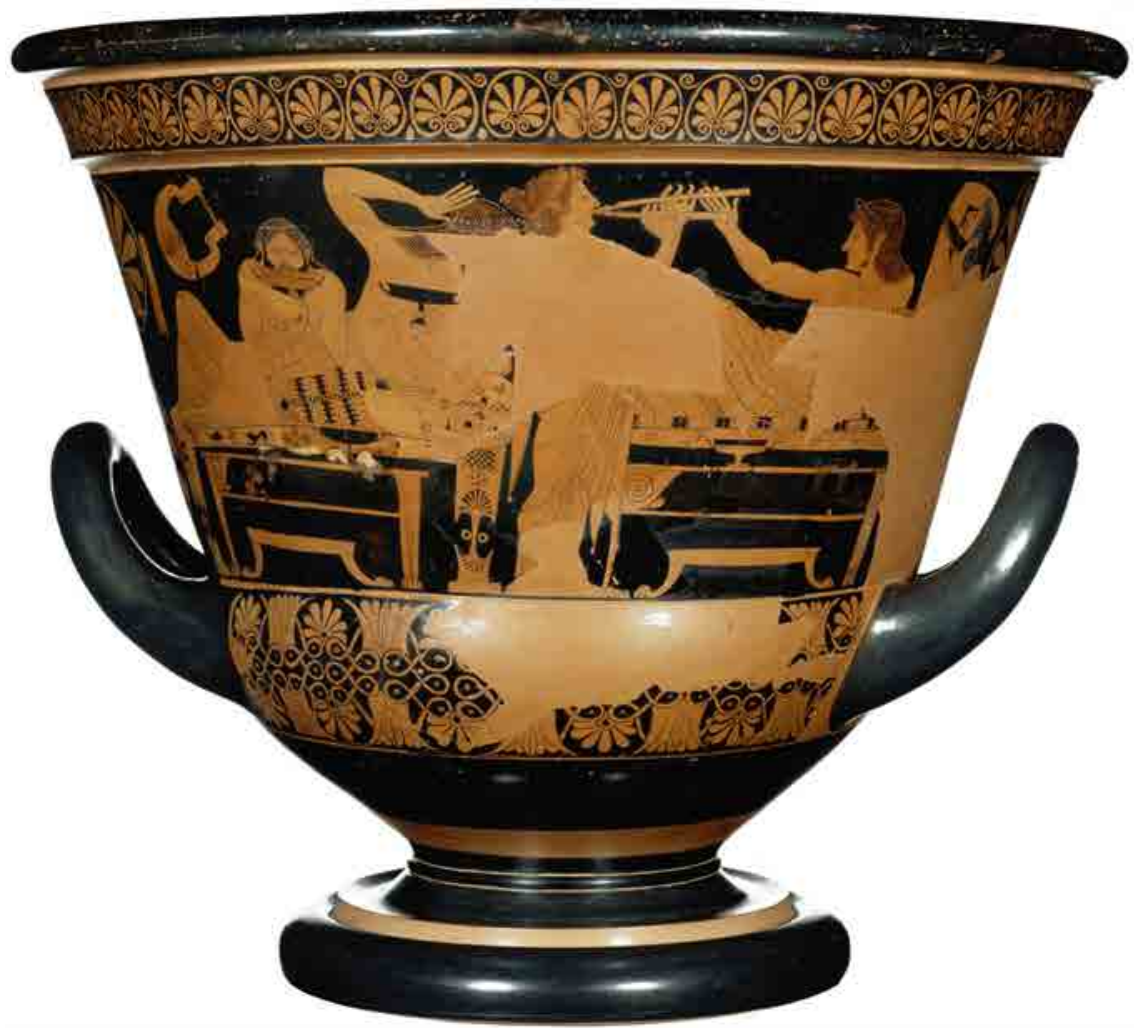

FIG. 6.1A Red-figure krater by Euphronios

MUNICH, STAATLICHE ANTIKENSAMMLUNGEN UND GLYPTOTHEK 8935

issue forth from his mouth in retrograde letters: OПO $\Lambda$ ON $\Sigma$ ЕГЕКАIMAKAI

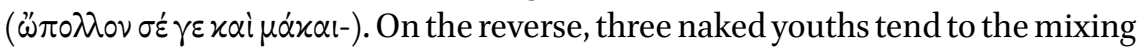
and serving of wine.

Sir John Beazley was the first to identify the inscribed song as a skolion, ${ }^{57}$ followed by Emily Vermeule who drew attention to some stylistic parallels among the Attic skolia, including the song to Pan that begins with a similar address (PMG 887), and the song in honor of Apollo and the Delian triad (PMG 886, see above). ${ }^{58}$ The sequence of syllables preserved on the vase is equivalent to a glyconic $(---\smile \cup-\smile-)$ and when fully expanded with three more syllables would

57 Beazley $\left(A R V^{2} 1619\right)$ first suggested that the line be restored as a Phalaecian verse and offers

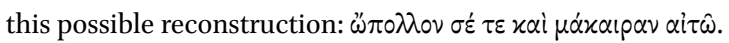

$5^{8}$ Vermeule (1965) 38-39 suggests that the inscribed verse may have represented 'another part' of this Apolline skolion, perhaps an additional set of verses that capped it. She 


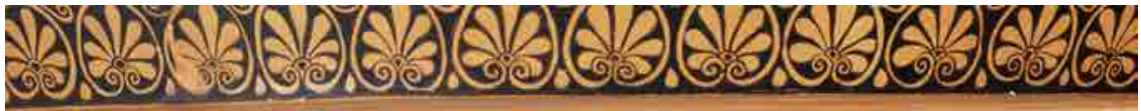

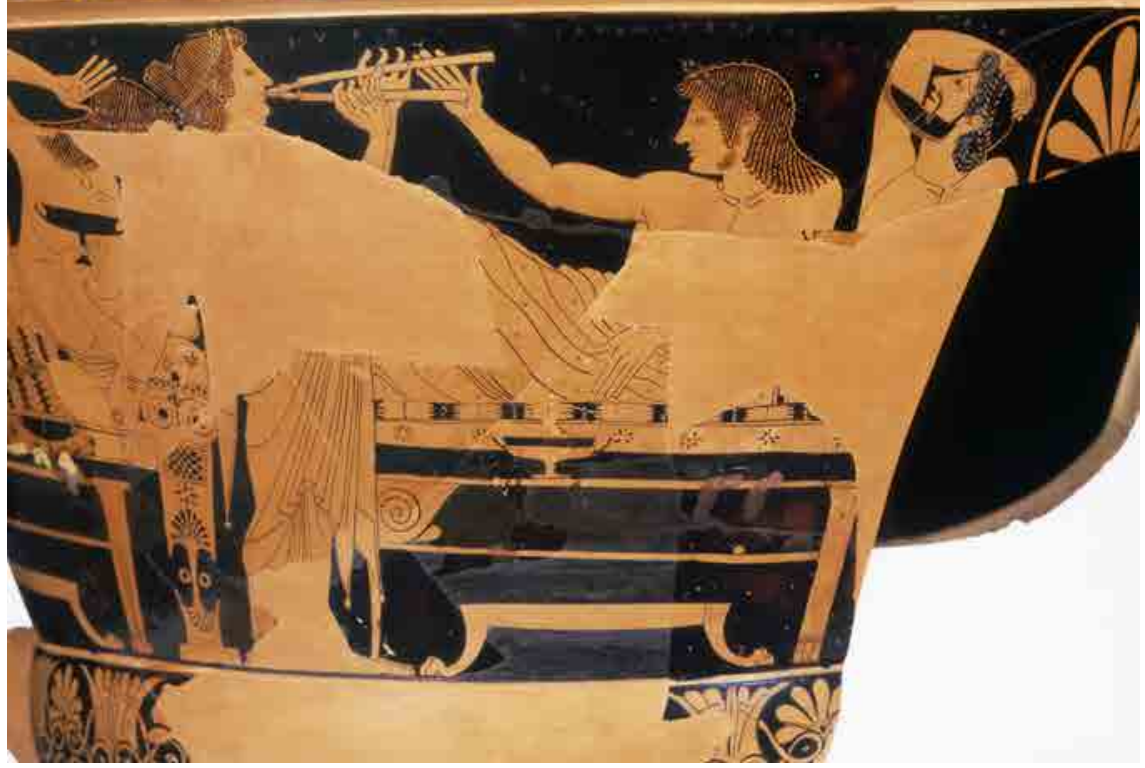

FIG. 6.1B Detail of red-figure krater by Euphronios

MUNICH, STAATLICHE ANTIKENSAMMLUNGEN UND GLYPTOTHEK 8935

represent a phalaecian verse of the kind that stands at the beginning of so many Attic skolia. It is the song's occasion, however, that interests Euphronios and helps us further identify the verse as a skolion. The elaborate equipment and the large scale of the wine service suggest a rather formal, somewhat expanded occasion redolent of the semi-public archaic banquets and symposia explicated by Schmitt-Pantel. Such gatherings were not strictly private affairs, since they normally involved equal members of the community whose actions reflected the larger social structure of the polis. ${ }^{59}$ The labeled presence of a

offers several possible reconstructions of the incomplete line, including this promising

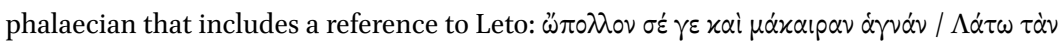

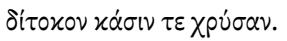

59 Schmitt-Pantel (1990), (1993) 17-31 has shown that images of reclining figures on archaic vases depict a montage of an extended event that incorporates elements from both the banquet and symposion. Schmitt-Pantel (1993) 31: 'ces superbes scènes archaïques expriment les différentes facettes de la convivialité archaïque en en soulignant les fonctions religieuses, sociales et civiques'. Such events should not be divided into public and private, banquet and symposion, but should be understood as a continuum of 'the Archaic aris- 
banausic vase-painter (Smikros) at the symposion contrasts with the larger image of aristocratic leisure, leading some scholars to interpret this scene as a subversion of elite culture or an imaginary world populated by the painter's fictional persona; either way, the skolion seems to lend the image a touch or verisimilitude just as the elaborate couches and wine-cups do. ${ }^{60}$ As I argue elsewhere, short simple skolia of this kind were most often associated with the common classes and popular symposia in fifth-century вСе Athens and so Ekphantides' inscribed song is in tune with the apparent non-elite grouping of painted symposiasts. ${ }^{61}$ Later, during the classical period, divergent sympotic manners became a common source of amusement: in the Wasps, for example, the boorish Philokleon, who is laughably unfamiliar with the eastern clothing stereotypically worn at aristocratic drinking parties and who 'never learned to play the kithara' (959), is nevertheless adept at singing the Attic skolia to the accompaniment of an aulos (1131-1169). ${ }^{62}$ Perhaps a similar contrast exists (whether intended or not) in the image of Smikros and his companions singing a traditional skolion without a lyre against the backdrop of a luxurious symposion.

We may also ask if the relaxed modes that characterize the genre are detectable in Euphronios' imagery. I think they are. Ekphantides sings a skolion in relaxed glyconics as Thoudemos takes a long, deep drink of wine, looking away from Ekphantides and out toward the spectator. His aloof Dionysiac posture seems to reflect the imaginary music filling the room. It surely is not the Apolline content of the skolion's narrative that provokes Thoudemos, but the

tocratic banquet' that included all the members of the egalitarian community: SchmittPantel (1990) 23-24.

6o For example, Neer (2002), 87-117 argues that the insertion of potter-portraits into elite environments transgresses the normal social order and is otherwise 'ideologically impossible'. However, it seems dubious to rely on the opinions of reactionary elites like Plato and Xenophon (as Neer does) for a wholesale description of the social attitudes of an entire city, especially a democratic one like Athens. Hedreen (2014), on the other hand, argues that Euphronios' Smikros functions as an imaginary alter-ego similar to the competing personas adopted by the iambists. See also Topper (2012) 147-153.

61 Jones (2014). Although the Attic skolia probably originated within popular symposia dominated by non-elites, they were in all likelihood known and performed by aristocrats through the 'common culture' of classical Athens. Gaunt (2014) has shown that vase inscriptions are normally drawn from a shared oral tradition as opposed to attributed works of literature; simple skolia like the one Euphronios has inscribed no doubt emerged from the same common tradition and were likely more familiar to vase-painters than compositions by named elite poets.

62 Cf. Swift (2010) 44-48. 
relaxed Lydian or Ionian harmonia that Plato said was conducive to drinking and that Aristotle associates with the relaxing, intoxicating effects of wine. ${ }^{63}$

\section{Visions of Terpander}

The images and inscribed verse on the Euphronios krater explicated above provide the earliest surviving evidence for the emergence of a stable pattern of composition and performance that ultimately led to the full recognition of a distinct genre called the skolion. Although the historical process of generic formation is mostly lost to us, images of the skolion's development continued to echo throughout the collective memory of successive generations of singers and audiences, surviving today as part of the historicizing mythology of the Greek musical tradition. It is fair to say that one of the clearest indicators of a fully recognized genre in Greek music is the development of a pan-Hellenic creation story. Arion's invention of the dithyramb is one of the best examples of this phenomenon, and, as I have noted throughout this paper, by Pindar's day the form and function of the skolion was likewise explained through the quasi-mythical devices of primordial musicians like Terpander. But, as Timothy Power has observed, there are no extant precedents for Pindar's attribution of the barbitos and skolion to Terpander, leading him to argue that the poetic image of a sympotic Terpander is merely a self-interested reflection of Pindar himself. Pindar's songs are more elaborate than the typical short skolion, including those attributed to Sappho, Alkaios, and Anakreon, and the professional poet may indeed have required a more appropriate model for his work, but is this version of Terpander nothing more than a construct of Pindar's imagination? ${ }^{64}$ It seems unlikely that he would have made such attributions ex nihilo; at the very least we may surmise that a common tradition had already traced the origins of the skolia back to the song culture of archaic Lesbos, and from there it is easy to imagine others associating the eastern overtones of Terpander's music with the phenomenon of singing skolia in the Ionian and Lydian modes. Early evidence linking Terpander to the invention of the barbitos and skolion might even be found in archaic red-figure vasepainting.

63 Frontal faces in Attic vase-painting often reflect the mood of figures captivated by music as well as wine. Thoudemos represents both: he is held in rapture by sympotic modes conducive to drunkenness. See Frontisi-Ducroux (1995) 95-97, fig. 42; cf. Korshak (1987) 11-14, 55 .

64 Power (2010) 410-414 hypothesizes that Pindar's image is based on a tradition in which Terpander sang at aristocratic symposia and public messes at Sparta. 
A large cup by the Epeleios Painter made around 500 вСе (fig. 6.2a) may contain allusions to the sympotic aspects of Terpander's life. ${ }^{65}$ In the center of the composition, two men, one young and smooth, the other bearded, flank a mammoth krater planted firmly on the ground; they are surrounded by a group of happy revelers highlighted by a number of kalos inscriptions floating about their heads and shoulders. The youth sips from a large skyphos while his free hand hovers over the mouth of the larger vessel. The bearded man approaches from the right, legs bent, holding out with both hands a tortoise-shell barbitos. ${ }^{66}$ His dress is eastern and exotic: a Lydian turban (or mitra) covers his head while a long himation drapes his body. The older man's emphatic presentation of the barbitos draws more attention to the instrument than to the krater below, which is partially hidden behind his left leg. ${ }^{67} \mathrm{His}$ actions and appearance are quite unique. ${ }^{68}$ The fashionable musician does not play his instrument or hand it to the youth in front of him, but looks as though he were parading the barbitos through the midst of the assembled symposiasts. Images like these are normally interpreted as genre scenes depicting a typical symposion and kômos, ${ }^{69}$ but I would like to propose a new interpretation of this particular image. Could the bearded man in the center of the composition be Terpander introducing his newly invented barbitos to a crowd of mainland Greeks? From the surrounding inscriptions, the word $\mathrm{KA} \Lambda \mathrm{O} \Sigma$ is written directly in front of the bearded figure's face, perhaps performing double duty as the voice of Terpander declaring that his instrument is beautiful. Images of famous poets are far from unknown in archaic and classical vase-painting. Sappho, Alkaios, and Anakreon were especially popular among the makers of sympotic pottery; Archilochos (or Hesiod) and a little known lyric poet named Kydias

65 Munich 2619a; $A R V^{2}$ 146.2. Lissarrague (1990b) 200-201, plate 19b; Bundrick (2005) 82-83.

66 For the barbitos and its representation in Attic vase-painting see Snyder (1972); Maas and Snyder (1989) 113-138; Bundrick (2005) 21-25. The instrument is most often associated with drinking, the kômos, and general sympotic revelry. It is above all an instrument of leisure.

67 Lissarrague (1990a) 32 notes: 'The two figures are making representative gestures that indicate the importance of both the lyre and the krater.' For representations of eastern poets in Athenian vase-painting see also Yatromanolakis (2008) 131-139.

68 In the many images of male figures, mostly youths, holding or playing a barbitos, often in front of a krater, they are normally shown holding the instrument close to their body, not out and away from it. For instance, in the tondo of a red-figure cup by the Triptolemos Painter (Louvre G 245, ARV 366, 86) a youth holding a barbitos stands between a herm and a krater, indicating an outdoor setting similar to the one on the Epeleios Painter's cup, but here the player's gesture is calm and static. Lissarrague (1990a) 32-37, fig. 22.

69 Cf. Lissarrague (1990a) 32-33; (199ob) 200-201; Bundrick (2005) 82-83. 


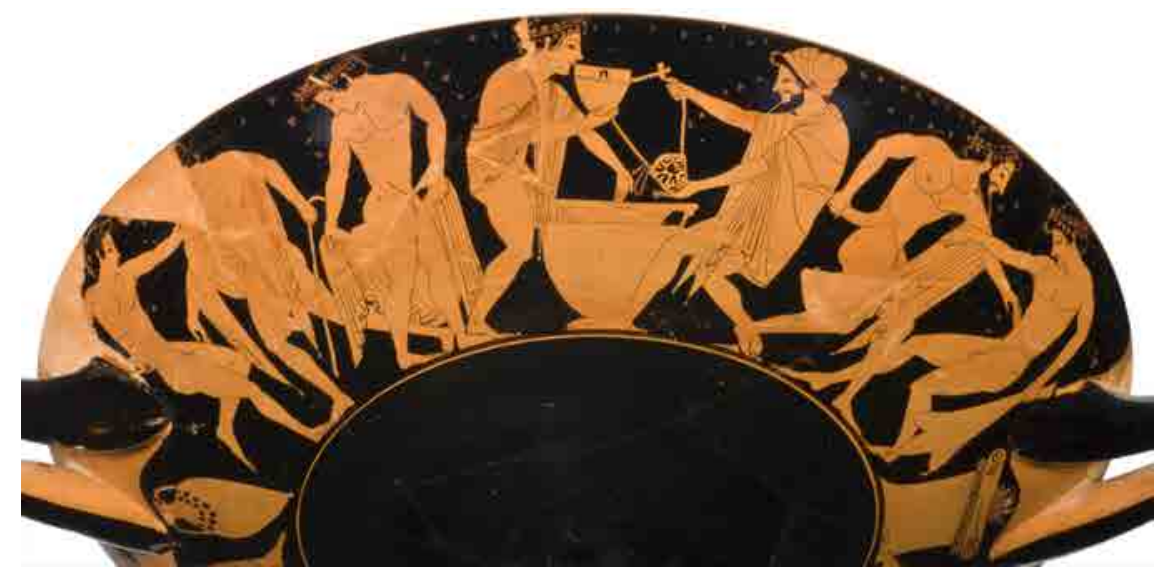

FIG. 6.2A Red-figure kylix by the Epeleios Painter

MUNICH, STAATLICHE ANTIKENSAMMLUNGEN UND GLYPTOTHEK 2619A

have also been identified..$^{70}$ We should not be surprised, then, to find an image of the primeval poet Terpander on an early red-figure vase.

Terpander was originally from Lesbos, though Pindar's tradition would have him traveling to Lydian territories picking up local traditions before making his way to the Greek mainland where he is said to have carried out many more innovations. ${ }^{71} \mathrm{He}$ is credited with being the first to organize Greek music and inventing the system of kitharodic nomes, which probably occurred once he had reached Sparta. He is also said to have increased the number of strings on

70 Sappho: hydria in Six's technique (Warsaw 142333, $A R V^{2}$ 300, Para 246); red-figure kalathos psykter by the Brygos Painter (Munich 2416, $A R V^{2} 385$ and 1649); red-figure hydria attributed to the Group of Polygnotos (Athens 126o, $A R V^{2}$ 106o, Para 445); red-figure kalyxkrater by the Tithonos Painter (Bochum s 508). See Yatromanolakis (2001); Bundrick (2005) 99-102; Yatromanolakis (2008). Alkaios: red-figure kalathos psykter by the Brygos Painter (Munich 2416, $A R V^{2} 385$ and 1649). See Lissarague (199ob) 125-126; FrontisiDucroux and Lissarrague (1990) 218-219. Anakreon (with name inscribed): fragment of a red-figure krater (Copenhagen MN 13365, $A R V^{2} 185$ ); red-figure cup by Oltos (London E 18, $A R V^{2} 62,86$ ); lekythos by the Gales Painter (Syracuse $26967, A R V^{2} 36,2$ ). See Boardman and Kurtz (1986); Frontisi-Ducroux and Lissarrague (1990). Yatromanolakis (2001) 16o notes the special popularity of these poets among the general population, which may explain the prevalence of their images on Attic vases during the late archaic and classical periods. For the contested identification of Archilochos (or possibly Hesiod) on a white-ground pyxis by the Hesiod Painter (Boston 98.887) see Clay (2004) 55-57.

71 Though ancient sources assign various birthplaces to Terpander, the more prominent tradition maintained that he was a native of Lesbos. Hellanicus FGrHist 4 F $85=$ Athen. 635e; Suda $\tau 354$ Adler; Marm. Par. Ep. 34. Nagy (1990) 86. 
the lyre from four to seven and to have been the first musician to win a musical contest at the Karneia. ${ }^{72}$ According to this tradition and on the assumption that it was internally coherent, Terpander must have introduced the barbitos to mainland Greece after arriving at Sparta, and either brought the skolion with him or invented it there. It is difficult to locate the Epeleios Painter's symposion geographically, but the detailed setting does give some clues about the scene's temporal location. A wreathed amphora and a smoking altar beneath either of the cup's handles are indicative of an outdoor sanctuary where sacrifice and ritual dining has just occurred, ${ }^{73}$ while the large krater at the center of the scene signals the onset of a symposion and the convivial pleasures that normally followed the deipnon. ${ }^{74}$ The outdoor setting of the painted scene and the apparent lack of couches suggest that the surrounding figures will recline on the ground when they are ready to drink, signaling the kind of ancient primitive symposion Kathryn Topper has explored in black and red-figure vasepainting. ${ }^{75}$ Symposia like these were imagined by the vase-painter to have taken place in the distant past, thus providing a chronologically accurate setting for Greece's first musician.

A pivotal clue in support of Terpander's identification comes from an inscription in the tondo of the cup where a lively satyr fills a garlanded krater from a large wineskin (fig. 6.2b). The inscription above his head $\Sigma$ I $\Lambda$ ANO $\Sigma$ TEPחON can either be read as a participial phrase, 'a silen enjoys himself', or as a title, 'Terpon the silen,76 which may be shorthand for 'Terpander,' whose name means 'he who gives pleasure to men'. ${ }^{77}$ A concentrated slew of additional

72 Ps. Plut. De musica 1132d-1134b, 1140f-1141d; Pollux 4.65 Bethe; Strabo 13.2.4; Hellanikos FGrHist 4 F 85 = Athen. 635e. The Karneia's origins date to the 26th Olympiad, between 676 and 672 BCE. Nagy (1990) 86. See generally Power (2010).

73 Lissarrague (1990b) 204-205 briefly discusses the significance of images that show kraters in close proximity to sacrificial altars, explaining how some painters emphasized the equal distribution of meat and wine within sanctuaries.

74 This scene depicts the drinking stage only, as opposed to an accumulated image of the sacrifice, banquet and symposion that often appears on archaic vases. Schmitt-Pantel (1990). Attic red-figure vases evolved to depict more specific stages and events of the banquet, including sacrifice, libation, feasting, symposion, and kômos. Dentzer (1982); Lissarrague (1990a) and (1990b) 196.

75 Topper (2009) and (2012) 23-52.

76 Lissarrague (1990a) 39 .

77 Nagy (1990) 86. An aulos-playing satyr named Terpaulos (ТЕРПАҮ $О \Sigma$ ) appears on a red-figure amphora by Smikros (Berlin 1966.19) with no obvious allusions to Terpander; however, this does not necessarily preclude the presence of such allusions on the Epeleios Painter's cup. See Lissarrague (1990a) 127. 


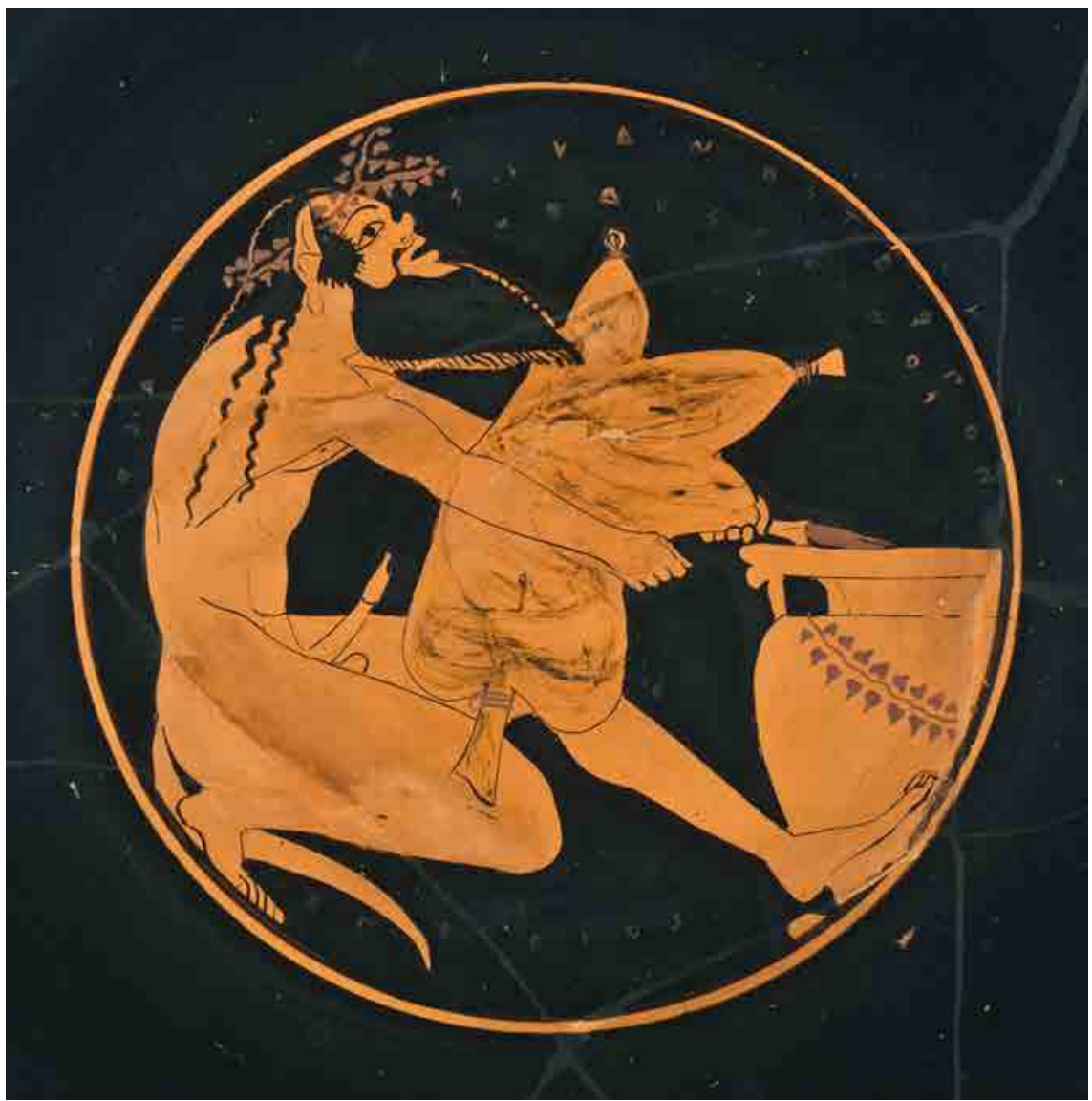

FIG. 6.2B Red-figure kylix by the Epeleios Painter (tondo)

MUNiCH, STAATLICHE ANTIKENSAMMLUNGEN UND GLYPTOTHEK 2619A

words in the tondo complement the visual play that occurs on the outside of the cup. Along the edge of the satyr we read KA $\Lambda \mathrm{O} \Sigma$ EПE $\Lambda$ EIO $\Sigma$ ('Epeleios [the vase-painter] is beautiful') echoing the many kalos inscriptions floating in space above the beautiful young men on the front of the vase. A second inscription above the wineskin informs us that 'the wine is sweet' (HEDY $\Sigma$ OINO $\Sigma) .{ }^{78}$ The actions and very name of the old satyr in the tondo hearken back to the pleasurable scene on the front of the vase where the bearded man holds his barbitos over the krater in a gesture similar to that of the Silen. Has the satyr appropriated the name of the exotic figure on the exterior of the cup,

78 Lissarrague (1990a) 38-39. 
shortening Terpander to Terpon? The use of the Doric dialect in the satyr's inscribed title may further connect his name to Terpander's Doric association. In this play on names, the pleasure of music given by Terpander on the outside of the cup is transferred to the satyr in the tondo, where his erect penis comically resembles a large aulos and further connects him to the matrix of wine, music, and song that defines the symposion. ${ }^{79}$ Both figures stand out as harbingers of sympotic pleasure, the satyr as a follower of Dionysos and conveyer of wine, Terpander as the inventor of the barbitos and the skolion.

It must be acknowledged, however, that the lack of an explicit name-inscription attached to the figure holding the barbitos leaves any identification of him open to question; and yet, the scene so closely matches the imagery we find in the skolion to Hieron that, at the very least, we may recognize the barbitos player as a kind of precursor to Pindar's Terpander-a prototypical poet from the east delivering the 'exotic' music of his symposion to mainland Greeks. Perhaps aristocratic singers and audiences were already making efforts to distinguish the more refined skolia of expert poets from local popular songs like the Attic skolia. The Epeleios Painter sets the Terpander figure apart from the others on the vase through his Lydian attire, which would have drawn attention to the eastern influences associated with his music and poetry. The mitra he wears is especially symbolic. In a colorful metaphor in Nemean 8 Pindar compares his own musical craft to 'a Lydian mitra embroidered with ringing melody' (8.13$15)$ :

A suppliant, I cling to the sacred knees of Aiakos on behalf of his dear city

and these citizens, bringing

a Lydian mitra embroidered with ringing melody ( $\Lambda \nu \delta^{\prime} \alpha \nu \mu i \tau p \alpha \nu$ « $\alpha \nu \alpha \chi \alpha \delta \dot{\alpha} \pi \varepsilon \pi \circ(x(\lambda \mu \varepsilon \dot{v} \nu \alpha)$,

Nemean glory in the double foot race for Deinias and his father Megas.

This verse refers to both the song and its Lydian harmonia. ${ }^{80}$ Such metaphors also suggest a strong general correlation between eastern melodies, the exotic mitra, and the ornamented poets who wear them. ${ }^{81}$ Does the eastern headgear worn by singers and poets in Athenian vase-painting signal the performance of harmoniai like the Lydian and Ionian? Alternatively, does the eastern apparel

\footnotetext{
79 Satyrs also hang aulos-cases from their erect phalloi. See Mitchell (2009) 167-169.

8o See Nagy (1990) 94; Henry (2005) 77.

81 For the mitra and its Lydian associations see Brandenburg (1966); Kurtz and Boardman (1986) 50-70; DeVries (2000) 358-363.
} 
worn by singers on the so-called Anakreontic vases act as a kind of visual metaphor for the eastern melodies they perform? ${ }^{82}$ We may imagine that the barbitos on the front of the Epeleios Painter's cup is tuned to one of the two appropriate modes in preparation for the performance of a skolion (the most common type of song performed over wine).

If this interpretation is correct, then the Epeleios Painter's cup and Euphronios' calyx-krater are indicative of a divergent sympotic culture as early as 500 вСЕ with two distinct views of the skolion, one absorbed in eastern luxury and expert musicians, the other rooted in a popular song culture conducted by laymen (like Smikros and his companions), but with both following the same pattern of composition and performance that characterized the pan-Hellenic concept of the skolion.

\section{Works Cited}

Anderson, G. (2003). The Athenian Experiment. Ann Arbor.

Bowie, A.M. (1993). Aristophanes: Myth, Ritual, and Comedy. Cambridge.

Bowie, E.L. (1986). 'Early Greek elegy, symposium and public festival'. JHS 106: 13-35.

Bowra, C.M. (1935 $\left.{ }^{1}\right)$. Greek Lyric Poetry. Oxford.

- (1938). 'Aristotle's Hymn to Virtue'. cQ 32: 182-189.

- $\left(1961^{2}\right)$. Greek Lyric Poetry. Oxford. (1964). Pindar. Oxford.

Brandenburg, H. (1966). Studien zur Mitra. Münster.

Budelmann, F. (ed.) (2009). The Cambridge Companion to Greek Lyric. Cambridge. (2012). 'Epinician and the symposion: a comparison with the Enkomia' in

P. Agócs, C. Carey, and R. Rawles (eds), Reading the Victory Ode. Cambridge: 173-19o.

Budin, S.L. (2006). 'Sacred prostitution in the first person' in C.A. Farone and L.K. Mc-

Clure (eds), Prostitutes and Courtesans in the Ancient World. Madison, WI: 77-92.

Bundrick, S.D. (2005). Music and Image in Classical Athens. Cambridge.

82 The scene on the Epeleios Painter's cup has many elements in common with this set of vases, though his barbitos player lacks the kind of extravagant apparel and motions most commonly found in scenes of the 'Anakreontic' type. The closest parallel is found on a redfigure lekythos in Syracuse $\left(26967 ; A R V^{2} 36[2]\right)$ where a bearded barbitos player wearing a chiton and turban and labeled Anakreon is flanked by two naked youths, one of whom carries a large skyphos toward the bearded singer. See Frontisi-Ducroux and Lissarrague (1990) 214-215, 237 who suggest that the name of Anakreon inscribed on the arm of a barbitos on a fragmented red-figure calyx-krater (attributed to the Kleophrades Painter; Copenhagen $\mathrm{MN} 13365 ; A R V^{2} 185$ [32]) acts as a general reference to Anakreontic poetry. 
Carey, C. (1991). 'The Victory Ode in Performance: The Case for the Chorus'. $c P$ 86: 192200.

(2007). 'Pindar, Place, and Performance' in S. Hornblower and C. Morgan (eds), Pindar's Poetry, Patrons, and Festivals. Oxford: 199-210.

- (2009). 'Genre, Occasion, and Performance' in F. Budelmann (ed.) (2009): 2138.

Cingano, E. (2003). 'Entre skolion et enkomion: Réflexions sur le "genre" et la performance de la lyrique chorale grecque' in J. Jouanna and J. Leclant (eds), La poésie grecque antique, Cahiers de la Villa 'Kerylos' 14. Paris: 17-45.

Clay, D. (2004). Archilochos Heros: The Cult of Poets in the Greek Polis. Cambridge, MA.

Collins, D. (2004). Master of the Game: Competition and Performance in Greek Poetry. Washington DC.

Crotty, K. (1982). Song and Action: the Victory Odes of Pindar. Baltimore.

Csapo, E. (2004). 'The Politics of the New Music' in Murray and Wilson (eds) (2004): 207-248.

Day, J.W. (2000). 'Epigram and reader: Generic force as (re-)activation of ritual' in Depew and Obbink (eds) (2000): 37-57.

Dentzer, J.M. (1982). Le motif du banquet couché dans le Proche-Orient et le monde grec du VII $I^{\text {ème }}$ au IV ${ }^{\text {ème }}$ siècle avant J.-C. Paris.

Depew, M. and Obbink, D. (2000). 'Introduction' in Depew and Obbink (eds) (2000): 1-18.

(eds) (2000). Matrices of Genre: Authors, Canons, and Society. Cambridge MA.

DeVries, K. (200o). 'The nearly other: The Attic vision of Phrygians and Lydians' in B. Cohen (ed.), Not the Classical Ideal: Athens and the Construction of the Other in Greek Art, Leiden: $338-363$.

Donlon, W. (1985). 'Pistos philos hetairos' in T.J. Figueira and G. Nagy (eds), Theognis of Megara: Poetry and the Polis. Baltimore: 223-244.

Dupont, F. (1999). The Invention of Literature: From Greek Intoxication to the Latin Book, trans. Janet Lloyd. Baltimore.

Fabbro, E. (1995). Carmina Convivalia Attica. Lyricorum Graecorum quae extant Omnia 11. Rome.

Fisher, N. (2000). 'Symposiasts, fish-eaters and flatterers: Social mobility and moral concerns in Old Comedy' in D. Harvey and J. Wilkins (eds), The Rivals of Aristophanes: Studies in Athenian Old Comedy. London: 355-396.

Ford, A. (2011). Aristotle as Poet: the Song for Hermias and Its Contexts. Oxford.

Fowler, R.L. (1987). The Nature of Early Greek Lyric: Three Preliminary Studies. Toronto.

Fränkel, H. (1973). Early Greek Poetry and Philosophy, trans. M. Hadas and J. Willis. New York.

Frontisi-Ducroux, F. (1995). Du masque au visage. Aspects de l'identité en Grèce ancienne. Paris. 
Frontisi-Ducroux, F. and F. Lissarrague (1990). 'From ambiguity to ambivalence: A Dionysiac excursion through the 'Anakreontic' vases' in D. Halperin, J. Winkler, and F. Zeitlin (eds.), Before Sexuality: The Construction of Erotic Experience in the Ancient World. Princeton: 211-256.

Gaunt, J. (2014). 'The poet and the painter: A hymn to Zeus on a cup by the Brygos Painter' in R. Scodel (ed.), Between Orality and Literacy: Communication and Adaptation in Antiquity. Mnemosyne suppl. 367. Leiden: 101-124.

Gostoli, A. (1990). Terpander: Introduzione, testimonianze, testo critico, traduzione e commento. Lyricorum Graecorum quae exstant 8. Rome.

Habash, M. (1995). 'Two complementary festivals in Aristophanes' Acharnians'. AJPh 116: $559-577$.

Hansen, O. (1987). 'An Attic drinking-song as a possible source for Peisistratus' campaign for the possession of Sigeum in the Troad'. PP 42: 108-109.

Harvey, A.E. (1955). 'The classification of Greek lyric poetry'. cQ 5: 157-175.

Heath, M. (1988). 'Receiving the $x \hat{\omega} \mu \circ \varsigma$ : The context and performance of epinician'. AJPh 109: 180-195.

Heath, M. and M. Lefkowitz. (1991). 'Epinician perofrmance: A response to Burnett and Carey'. CPh 86: 173-191.

Hedreen, G. (2014). 'Smikros and Epilykos: Two comic inventions in Athenian vasepainting' in J. Oakley (ed.), Athenian Potters and Painters III. Oxford: 49-62.

Henry, W.B. (2005). Pindar's Nemeans: A Selection. Munich.

Jones, G.S. (2014). 'Voice of the people: Popular symposia and the non-elite origins of the Attic skolia'. TAPhA 144: 229-262.

Kantzios, I. (2005a). 'Tyranny and the symposion of Anacreon'. $c J$ 100: 227-246. (2005b). The Trajectory of Archaic Greek Trimeters. Leiden.

Korshak, Y. (1987). Frontal Faces on Attic Vase Painting of the Archaic Period. Chicago.

Kugelmeier, C. (1996). Reflexe Früher und Zeitgenössischer Lyrik in der Alten Attischen Komödie. Stuttgart.

Kurke, L. (1990). 'Pindar's sixth Pythian and the tradition of advice poetry'. TAPhA 120: $85^{-107 .}$

(1996). 'Pindar and the prostitutes, or reading ancient "pornography"'. Arion 4: 49-75.

Kurtz, D.C. and J. Boardman (1986). 'Booners' in J. Frel and M. True (eds.), opA 2. GVGetty 3. Malibu: $35^{-70 .}$

Lambin, G. (1992). La chanson grecque dans l'antiquite. Paris.

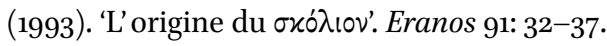

Liapis, V. (1996). Double entendres in skolia: the etymology of skolion'. Eranos 94: 111122.

Lissarrague, F. (1990a). The Aesthetics of the Greek Banquet: Images of Wine and Ritual, trans. A. Szegedy-Maszak. Princeton. 
- (1990b). 'Around the krater: An aspect of banquet imagery' in Murray (ed.) (1990): 196-209.

MacDowell, D.M. (1971). Aristophanes, Wasps. Oxford. (1995). Aristophanes and Athens. Oxford.

Maas, M. and J.M. Snyder (1989). Stringed Instruments of Ancient Greece. New Haven. MacKie, S. (2003). Graceful Errors: Pindar and the Performance of Praise. Ann Arbor. Mitchell, A.G. (2009). Greek Vase-painting and the Origins of Visual Humour. Cambridge. Morgan, K. (1993). 'Pindar the professional and the rhetoric of the $x \omega \hat{\omega} \mu \circ \varsigma^{\prime} . C P h$ 88: 1-15. Murray, O. (ed.) (1990). Sympotica: A Symposium on the Symposion. Oxford.

Murray, P. and Wilson, P. (eds) (2004). Music and the Muses: The Culture of 'Mousikê' in the Classical Athenian City. Oxford.

Nagy, G. (1990). Pindar's Homer. Baltimore.

- (1994-1995). 'Genre and occasion'. Métis 9/10: 11-25.

Neer, R. (2002). Style and Politics in Athenian Vase-Painting. Cambridge.

Parker, R. (1996). Athenian Religion: A History. Oxford.

Power, T. (2010). The Culture of Kitharôidia. Washington DC.

Renehan, R. (1982). 'Aristotle as lyric poet: The Hermias poem'. GRBS 23: 251-274.

Reitzenstein, R. (1893). Epigramm und Skolion: Ein Beitrag zur Geschichte der alexandrinischen Dichtung. Giessen.

Robbins, E. (1990). 'The gifts of the gods: Pindar's third Pythian'. cQ 40: 307-318.

Rutherford, I. (2001). Pindar's Paeans: A Reading of the Fragments with a Survey of the Genre. Oxford.

Schmitt Pantel, P. (1990). 'Sacrificial meal and symposion: Two models of civic institutions in the archaic city?' in Murray (ed.) (1990): 14-33.

(1992). La cité au banquet: histoire des repas publics dans les cités grecques. Rome.

Sfyroeras, P. (2004). 'From sacrifice to feast: A ritual pattern in Aristophanic comedy' in D.L. Cairns and R.A. Knox (eds.), Law, Rhetoric, and Comedy in Classical Athens: Essays in Honor of Douglas M. MacDowell. Swansea: 251-268.

Smyth, H.W. (1900). Greek Melic Poets. London.

Snyder, J.M. (1972). 'The barbitos in the classical period'. $c J 67: 331-340$.

Swift, L.A. (2010). The Hidden Chorus: Echoes of Genre in Tragic Lyric. Oxford.

Teodorsson, S. (1989). 'The etymology of scolion'. Eranos 87:127-132.

Thomas, R. (1989). Oral Tradition and Written Record in Classical Athens. Cambridge.

Topper, K. (2009). 'Primitive life and the construction of the sympotic past in Athenian vase painting'. AJA 113: 1-26. (2012). The Imagery of the Athenian Symposium. Cambridge.

Ussher, R.G. (1973). Aristophanes, Ecclesiazusae. Oxford.

Van Groningen, B.A. (1960). Pindare au banquet. Leiden.

Vermeule, E. (1965). 'Fragments of a symposion by Euphronios'. AntK 8: 34-39. 
Vetta, M. (1983). Poesia e simposio nella Grecia antica. Rome.

Wallace, R. (2005). 'Performing Damon's harmoníai' in C. Harrauer and S. Hagel (eds), Ancient Greek Music in Performance. Vienna: 147-158.

West, M.L. (1974). Studies in Greek Elegy and Iambus. Berlin.

- (1982). Greek Metre. Oxford. (1992). Ancient Greek Music. Oxford.

Wilkins, J. (2000). The Boastful Chef: The Discourse of Food in Ancient Greek Comedy. Oxford.

Wilson, P. (2004). 'Athenian strings' in Murray and Wilson (eds) (2004): 269-306.

Yatromanolakis, D. (2001). 'Visualizing poetry: An early representation of Sappho'. CPh 96: 159-168.

(2004). 'Ritual poetics in archaic Lesbos: Contextualizing genre in Sappho' in D. Yatromanolakis and P. Roilos (eds), Greek Ritual Poetics, Washington DC: 56-70. (2008). Sappho in the Making: The Early Reception. Washington DC. (2009). 'Ancient Greek popular song' in Budelmann (ed.) (2009): 263-276.

Young, D.C. (1983). 'Pindar Pythians 2 and 3: Inscriptional $\pi \circ \tau \dot{\varepsilon}$ and the "poetic epistle"'. HSCPh 87: 31-42. 


\title{
'Glancing Seductively through Windows': The Look of Praxilla fr. 8 (PMG 754)*
}

\author{
Vanessa Cazzato
}

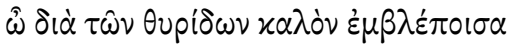

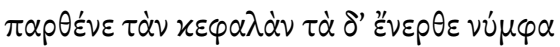

You who glance seductively through windows, maiden as regards your head, bride below

This tantalising fragment addressed to a woman glancing seductively through a window leaves us wondering who this woman might be and what kind of situation might have prompted the speaker to remark on her gaze. Since this couplet is all we have of the poem, it has been tempting to see a simple ironic contrast between the first line and the second. The opening image is one of irresistible seductiveness, with its appeal to the woman's gaze which is both beautiful and confronting. The implications of $\dot{\varepsilon} \mu \beta \lambda \dot{\varepsilon} \pi \omega$, 'to look directly, gaze intently', are clear from other classical instances: Plato's Socrates claims to be

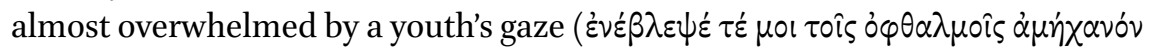

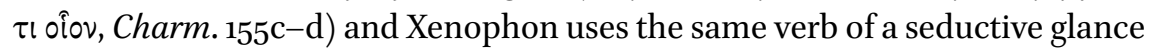
which is wielded like a hunting net to snare a suitor (Mem. 3.11.10). ${ }^{1}$ The seduc-

* My thanks to Peter Agócs, Holger Essler, Glenn W. Most, Enrico Emanuele Prodi, David Sider, and Giuseppe Ucciardello for advice at various stages, and to Winfred Van de Put for help with pottery. Special thanks are due to André Lardinois.

1 Page marks a corruption here: 'etiam $\dot{\varepsilon} x \beta \lambda \varepsilon \dot{\pi} \pi \circ \sigma \alpha$ expectasses: nisi huiusmodi erat sententia, "quae more meretricio vagabunda per fenestras intueri soles, scilicet ut virum foras unde unde elicias"'- this latter suggestion betrays an extraordinary strong expectation of the tenor of the poem of our poor Praxilla, on which see below. $\dot{\varepsilon} \mu \beta \lambda \dot{\varepsilon} \pi \omega$, however, does not mean 'to look in' e.g. through windows but rather to 'look in the face' (LSJ s.v. 1a). Cavallini (1992) 37-38

(C) VANESSA CAZZATO, 2016 | DOI: 10.1163/9789004314849_008

This is an open access chapter distributed under the terms of the Creative Commons AttributionNoncommercial 3.o Unported (CC-BY-NC 3.0) License. 
tiveness implied by the initial address is then overturned simply and ironically by the second line - or so goes the usual reading — which is understood as a revelation of the woman's true nature: her face may look innocent, but 'down below' she is well practiced-she is, in other words, a whore or a hetaira. But the key to understanding these lines may not be quite so simple; the lost continuation of the poem may have gone on to build a more complicated picture. In the second half of this paper I will argue that this may in fact have been a very different kind of poem from what it is usually understood to be. (To anticipate, I will propose the tentative view that it is a fragment of a wedding song.) But first I discuss some deeper reasons why such a 'racy' interpretation of this fragment has proven quite so attractive. These have to do with assumptions about the performance context for which the poem was originally composed (namely the symposion) as well as about the character of the female poet who composed it (a hetaira like the addressee of her poem, it would naturally follow); these assumptions are tied to what is thought to be a depiction on a drinking cup of this poem being sung by a symposiast. The 'look' of the title, then, refers not just to the woman's gaze, or to the deceptiveness of her appearance, but also to (what is usually thought to be) the visual testimony for the poem.

The identification of the fragment of Praxilla preserved by Hephaestion (Ench. 7.8, p. 24 Consbruch) with the inscription on a vase in the British Museum (95.10-27.2) (fig. 7.1c) has been adopted by modern editors with remarkable confidence considering that the inscription includes only the first three words of the fragment and that the reading is different, giving the sin-

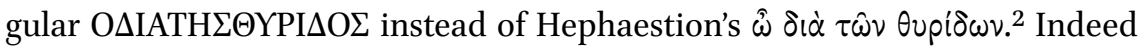
the editors go so far as relying on the inscription to emend the text. Page's apparatus reports that he would like to emend the plural $\tau \hat{\omega} v$ $\theta u p i \delta \omega v$ to the singular and that he refrains from doing so because he cannot account for the change from an easier reading to a more difficult one. Campbell, in his Loeb edition, does emend the text, emboldened by Renehan who refers to the vase inscription and outlines a plausible mechanism of corruption: the Doric

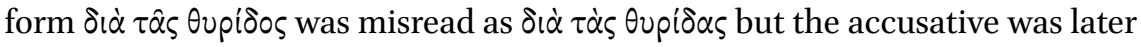
recognized to give the wrong sense and corrected to the genitive while main-

defends the manuscript reading, citing Meleag. 24 Gow-Page $=A P$ 12.94.3-4 as well as the classical instances cited here in the main text.

2 The identification, first made by Jacobsthal (1912), was taken up by Page and has since been accepted virtually unanimously (a notable exception is Ahl in his Pauly-Wissowa entry 'Praxilla', but his own alternative interpretation proved so unconvincing that his objection to the inscription went unheeded with it—see below). 
taining the plural, thus giving us the manuscript reading. ${ }^{3}$ This despite the fact that Page's perplexity over the use of the plural (on grounds of sense, not dialect) does not seem to have much justification in the first place: windows with their multiple openings can easily be thought of as plural and indeed we find an exact (if somewhat later) parallel for this use in Philodemus. ${ }^{4}$ The need to emend arguably arose from the supposed evidence of the inscription.

This readiness to identify the inscription with the fragment of Praxilla is probably owed to the fact that the vase shows the fragment issuing from a symposiast's mouth, that is to say being sung as a skolion, and this chimes with Praxilla's reputation as an author of skolia or paroinia, as the testimonia tell us; a notion which is, however, problematic, as we shall see presently. This in turn, by a circular argument, gives us the racy interpretation: since the fragment is depicted as belonging to a sympotic context, then it must be a lascive Anrede, as Wilamowitz put it, or an 'improper song' about a 'wanton lady' as Fraenkel

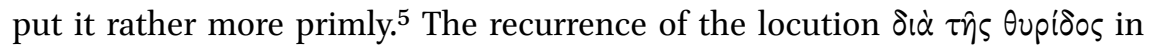
several other places (already noted by Page in his apparatus) is then taken not as diluting the relevance of the vase inscription to the poem but ratheragain with some circularity-as compounding the assumption that the poem, too, must be racy, since in some (though not all) of these other cases the expression occurs in contexts involving women's inappropriate behaviour. ${ }^{6}$ But

3 Renehan (1983) 29.

4 Phld. 14.2 Sider $=$ GPh $3213=A P$ 5.123.2; Asclepiades' Epigram 3 Sens may be indebted to Praxilla (see below), and so cannot be appealed to as a parallel, pace Cavallini (1992) 38. For multiple-paned windows on pottery see e.g. Athens 1560 (fifth cent.), Munich 6026 (fourth cent.).

5 Wilamowitz (1900) 9 n. 4; Fraenkel (1936) 263; most subsequent discussions have followed in their tracks. A representative summary of the common view on our distich in Graham (1998) $25^{-27}$, who, however, has a definite axe to grind (he is defending a new interpretation of a Thasian stele according to which a prohibition for women to look out of windows is in fact aimed at banning prostitution).

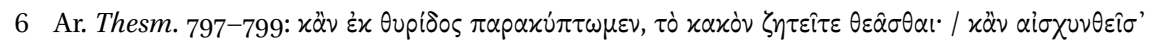

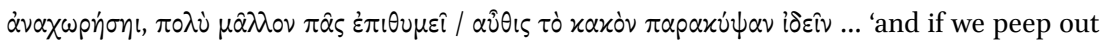
of a window you seek to take a look at us, 'bane' that we are; and if a woman is ashamed and withdraws then everyone is all the more eager to see this 'bane' peep out again ...'; Carmen populare 7 (= PMG $853=$ Athen. $15.697 \mathrm{~b})$, where it is cited as one of the 'rude

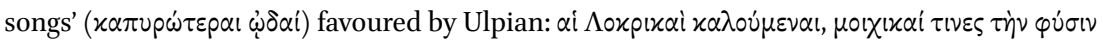

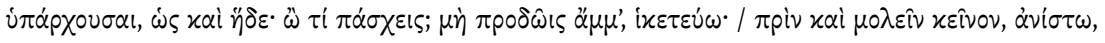

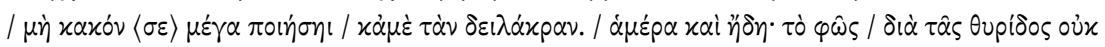

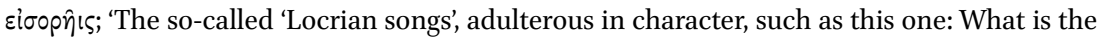


its frequent recurrence in several texts more plausibly betokens the fact that it was a familiar vernacular phrase. In a recent article, Jasper Gaunt places it in a context of broader literacy evident in metrical inscriptions on a number of other media as well as pottery, and he rightly assimilates it to various other similar sympotic 'buzzwords' known from both vase inscriptions and indirectly

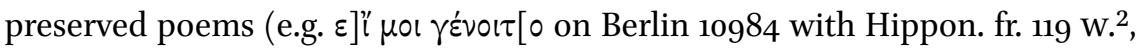
Archil. fr. $118 \mathrm{w}^{2}{ }^{2}$ ). As he demonstrates, artists (just like real-life symposiasts) 'drew on an oral sympotic tradition' rather than particular compositions, and it is to this, and not to specific texts by named authors which happen to have been preserved, that we should more plausibly relate the snatches of poetry we find on vases. ${ }^{7}$

Moreover, a closer look at the cup which is so blithely cited in apparatus enjoins even greater caution. It is in fact an unusually curious and fascinating object and one that demands to be considered on its own terms rather than be adopted unproblematically as a basis for emendation. The cup is a stemless kylix of uncertain provenance and date. It is a crude copy of the style of Douris. The drawing displays a clear attempt to emulate the striking composition of sympotic scenes where two couches are seen in profile and one in rear view which is most closely associated with the Athenian master-painter; indeed one panel is an almost exact copy of a famous vase belonging to his middle period, ca $490-485 .{ }^{8}$ If our British Museum cup is Athenian we might wish to assign it to a date close to this. A marginally later dating might be arguable if the vase is correctly identified as Boeotian, to allow for greater time-lag in copying. ${ }^{9}$ Boeotian red-figure's habit of emulating Athenian trends of particularly good works is a recognized trait, and the angular and awkward drawing would fit this well. ${ }^{10}$ In any case, it seems safe to say that the vase was produced in the first half of the fifth century. Our inscription, however, is added after firing and so arguments for its date need to be assessed separately.

Like the composition of the painting, the several inscriptions on our British Museum cup should probably be read as an attempt to emulate the work of Douris. His partiality for inscriptions is well known; in fact their unusually

matter with you? I beg of you don't betray us / get up before he arrives / lest he do great harm to you and to wretched me. / It is day: don't you see the light through the window?' But cf. Ar. Vesp. 379, where no such connotations are present.

7 Gaunt (2014).

8 Florence, Museo Archeologico 3922. For this composition with a view from the back of the couch see McNiven (2014), with a list of further instances at 125 and nn. 6 and 7.

$9 \quad$ Boeotian identification already by Lullies (1940) 6 .

10 Sabetai (2012a) and Sabetai (2012b). 


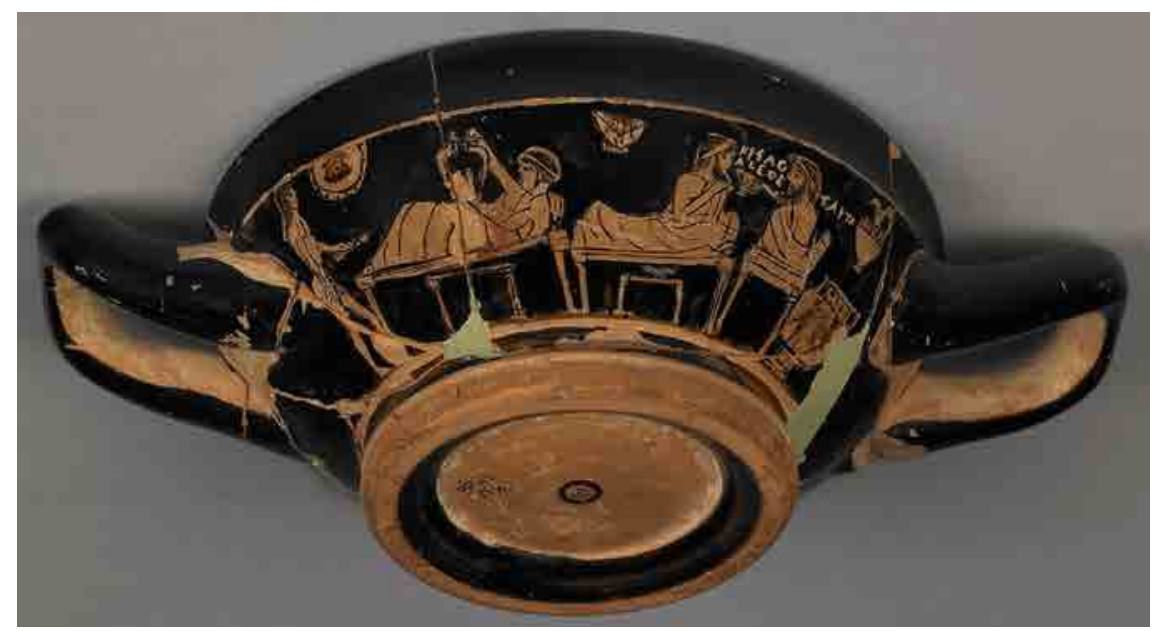

FIG. 7.1A Side A of unattributed red-figure kylix

LONDON, BRITISH MUSEUM 95.10-27.2. (C) TRUSTEES OF THE BRITISH MUSEUM

high incidence, including snatches of poetry, has led to the suggestion that 'the inspiration for some of his scenes might be literary'."1 Our cup includes 'speech-bubble' inscriptions in the panels on both exterior sides as well as in the tondo, all of which depict sympotic scenes. One side of the exterior portrays a symposion in which two fellow-drinkers seem to be having a conversation: the inscription reads $\Phi A \Sigma I N$ TAYTA A $\Lambda H \Theta E$, 'these things which they say are true ...' (fig. 7.1a)..${ }^{12}$ The other side of the exterior depicts symposiasts engaged in a game of kottabos while calling out the name of the love-prize: TOI $[\Lambda]$ AXETI, 'for you, Laches' (fig. 7.1b). ${ }^{13}$ Finally, in the tondo we have the scene which

11 Buitron-Oliver (1993) vii. But a krater by Douris serves as warning against using inscriptions as reliable witnesses to poems: Berlin 2285 includes a fragment of poetry, either lyric or epic, which has traditionally been thought to represent the beginning of a specific (possibly Stesichorean) poem but which has been argued to include-deliberately and humourously — mistakes which are to be attributed to the student seen writing it on a book-roll: Sider (2010); cf. Gaunt (2014) 108-109. For a cup by Douris with an inscription

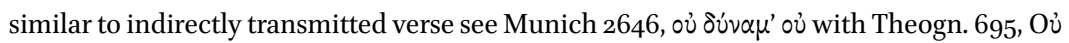

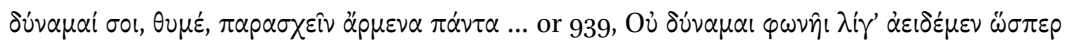

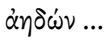

12 According to Campbell (1964) their words 'look like the introduction of a maxim and may well have been in elegiac metre'. Csapo and Miller (1991) 372 interpret this scene as representing conversation.

13 Csapo and Miller (1991). 


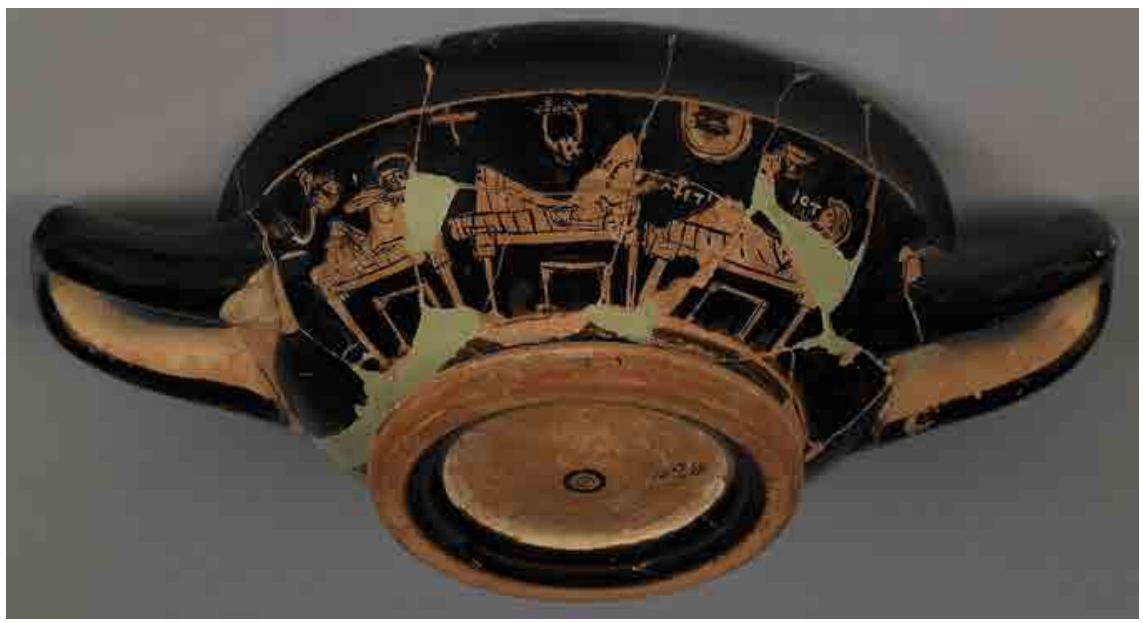

FIG. 7.1B Side в of unattributed red-figure kylix

LONDON, BRITISH MUSEUM 95.10-27.2. (C) TRUSTEES OF THE BRITISH MUSEUM

includes what has been taken to be the beginning of our Praxilla fragment (fig. 7.1c). It is tempting to imagine that the inscription was copied directly from Douris together with the images—but this is unlikely. As Csapo and Miller have argued, if the inscription were copied the letters would be correctly facing to the left in true retrograde, whereas our inscription is partly in retrograde partly not, suggesting that it was composed by an inexpert hand. ${ }^{14}$ This snatch of song would then have been added by someone (the painter? the buyer? a later user?) wanting to give the impression that they were copying Douris' script - by including for instance, his signature letter-shape, dotted delta-but not quite pulling it off. ${ }^{15}$ Csapo and Miller further argue that the fact that the inscription is not copied from Douris is evidence that it is archaic, since the letter-forms are archaic; while the possibility (which they do not mention) that it was copied from a different source cannot be ruled out, the likelihood does seem to be that the line was an improvised addition and that the inscription, like the cup, belongs in the first half of the fifth century.

Given that the conventional chronology for Praxilla places her floruit c. 450, the vase's dependence on a poem of hers seems difficult if not impossiblebut in this respect, too, it turns out on closer inspection that we are on shaky

\footnotetext{
14 So Csapo and Miller (1991) 371.

15 On dotted delta as a recognized hallmark of Douris' script among forgers and imitators see Barron (1964) 45 n. 6 o.
} 


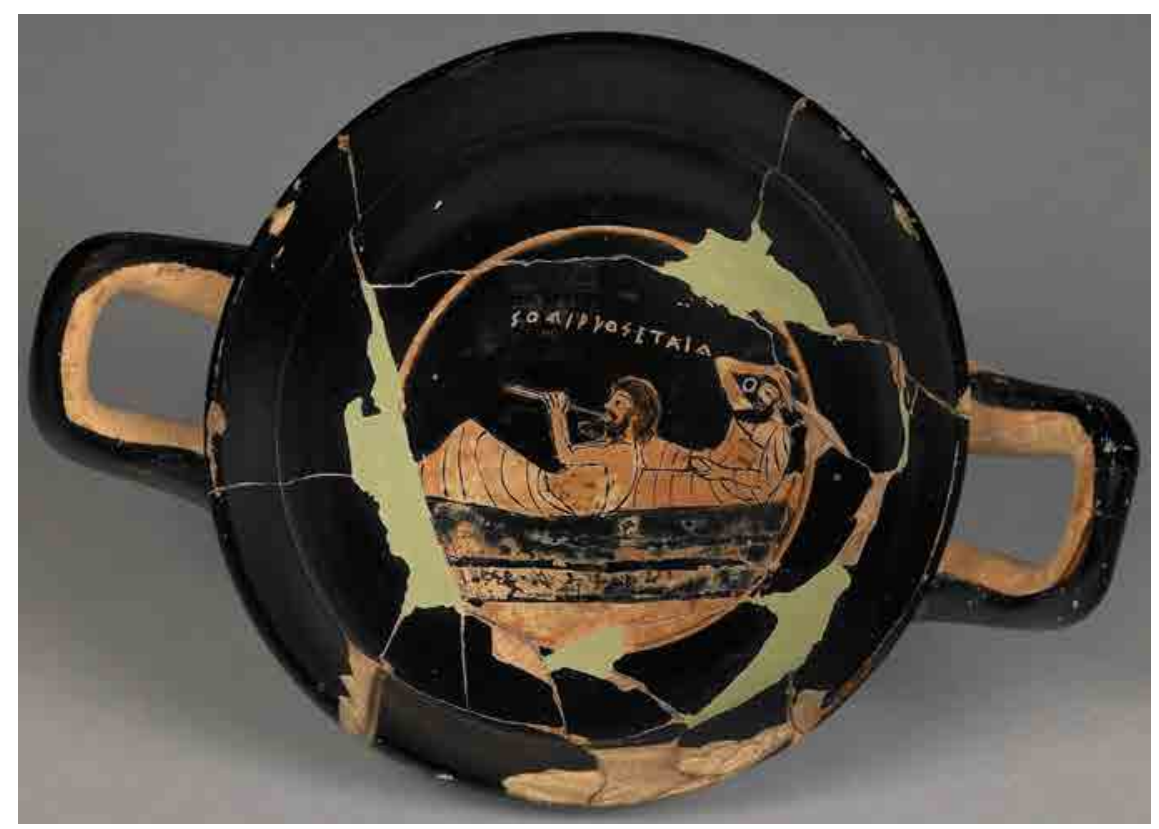

FIG. 7.1C Tondo of unattributed red-figure kylix

LONDON, BRITISH MUSEUM 95.10-27.2. (C) TRUSTEES OF THE BRITISH MUSEUM

ground. Praxilla's date is based solely on Eusebius' notice for the 82nd Olympiad, i.e. $45^{2} / 1 \mathrm{BC}$ (here quoted according to Jerome's report): Crates comicus et Telesilla ac Bacchylides lyricus clari habentur. Praxilla quoque et Cleobulina sunt celebres. ${ }^{16}$ The date of Crates must be accurate since we have a report of his victory at the City Dionysia in 450, but Bacchylides was surely earlier and Telesilla was famous in antiquity for her military involvement in Argos' defence against Cleomenes' attack in $494 \mathrm{BC}$, while Cleobulina's very existence is doubtful. ${ }^{17}$ Not much, then, can be made of Eusebius' report, but the hypothesis of the inscription's dependence on the poem remains tenuous indeed.

It seems best to interpret the cup on its own terms as evidence of a lively sympotic culture. Indeed, the cup's decoration conveys the sense that its owner

\footnotetext{
16 Euseb. Chron. Ol. 82.2 (p. 112 Helm).

17 Crates' victory: $I G \mathrm{II}^{2}$ 2325.52. Telesilla's military prowess: Paus. 20.20.8-10; Plu. Mor. 245cf; some scholars defend the essential veracity of this story (see Pizzocaro [1993]) while others dismiss it as a later invention prompted by the Delphic oracle on the 'defeat at the hands of women' reported by Herodotus 6.76 (who does not mention Telesilla): see Campbell (1992) 3-4.
} 
may have been trying a little too hard to live up to sympotic aspirations, for it exhibits a peculiar combination of pretension and ineptitude: everything about it, from the inscriptions to the comprehensive depiction of all verbal and ludic aspects of the symposion (poetry, gnomic conversation, competitive kottabos) to the inclusion of figurative decoration in mise en abyme on the amphora and the coverlet of the couch (which depicts cranes and pygmies) points to an attempt to display sophistication and mastery of the artistic and literary activities of the symposion - at the same time as the crudeness of the execution belies the accomplished nature of its context of production and use. We can only guess at the status and ambitions of the maker and the owner of this cup. But whatever its agenda, it does not seem reasonable to use this cup as reliable evidence that would justify emendation.

Impetus for connecting the inscription to the fragment of Praxilla has come, as already noted, from the fact that it is presented as a skolion and that we are told by the ancient testimonia that Praxilla was an author of skolia. However, the notion of Praxilla as an author of skolia, too, is problematic. The dispute surrounding the precise generic nature of the skolion is one I wish here to avoid. ${ }^{18}$ Instead I take a different tack by speculating on the impression given of Praxilla as a poet by what remains of her corpus (though this is admittedly very little indeed). This suggests that, rather than being an author of racy sympotic songs, Praxilla in the main composed civic ritual songs. The sympotic compositions which go under her name appear to be generic convivial ditties which came to be ascribed to her at some later stage; this in turn may have affected the transmission of her civic poetry through sympotic reperformance.

Only eight fragments survive, including our ambiguous fragment addressed to the gazing woman. Of these, five suggest with various degrees of certainty a ritual context, while only two are preserved as paroinia or paroimiai and belong clearly to a sympotic context. Let us start by looking at the two fragments which

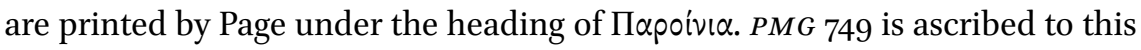
category by the scholiast to Wasps (1239 Koster), who also tells us that others ascribe it to Alcaeus or Sappho, in itself a reason to doubt the attribution to Praxilla. ${ }^{19}$

18 For this question see the discussion with a full doxography in Jones's chapter in this volume.

19 For the reuse of poems by famous authors as skolia and the specific case of Alcaeus see Fabbro (1992). 


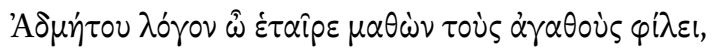

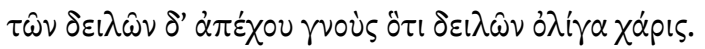

Learn Admetos' saying, my friend, and stick with the good sort, keep away from the wrong sort in the knowledge that they don't show much gratitude.

There are further clues arguing against attribution to Praxilla. The address to a hetairos suggests a male persona and sits uncomfortably with authorship by a Praxilla who was also the author of female ritual songs. What is more, the fragment recurs in almost identical form among the Carmina convivalia preserved by Athenaeus $(15.695 \mathrm{C}=P M G$ 897) and, still more tellingly, both the form and the sentiment are closely reminiscent of lines from the Theognidean corpus $(753,37,31-32 \sim 1165,854=1038 b) .{ }^{20}$

The second skolion fragment ( $P M G$ 750), is a single line-i $\pi$ ò $\pi \alpha v \tau i \lambda i \theta \omega \iota$

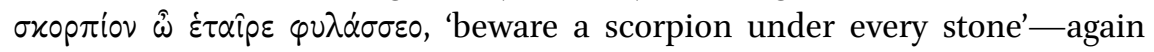
preserved in a scholion to Aristophanes in explanation of a passage (Thesm. 529-530) in which, as he is wont to do, Aristophanes willfully misquotes a paroimia substituting para prosdokian a rhetor for the scorpion. The scholiast tells us that it is recorded among the verses 'ascribed to Praxilla' ( $\dot{\varepsilon} \kappa$

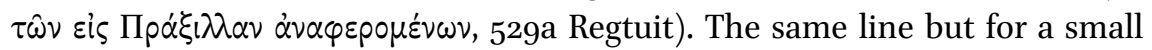

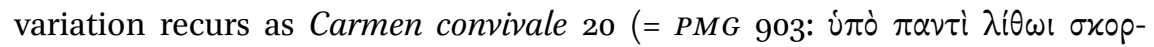

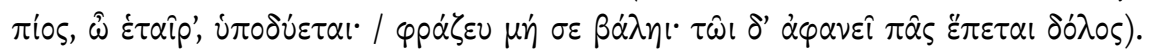
This paroimia clearly expresses a widespread generic sentiment (it occurs frequently among paroemiographers and lexicographers) and was adaptable to innumerable situations both in real life and in mythology (for the latter see its use by Sophocles in fr. 37 Radt, from his Captives). ${ }^{21}$ The version attributed to Praxilla would probably not have proceeded, like the carmen convivale, with an explication of the symbolic meaning of the scorpion image as applicable to deceit among friends, since it anticipates the warning in the first line. In any case, the ascription seems unconvincing and this seems rather another case of a generic tradition being tied to a named author, perhaps because of the existence of a Sicyonian collection which would naturally have been associated with Sicyon's most famous singer. ${ }^{22}$ Thus both skolia attributed to Praxilla

\footnotetext{
$20 \quad$ For Theognidean parallels see Fabbro (1995) 35; on these and on the possible meaning of the 'Admetus saying' see Scodel (1979).

21 Fabbro (1995) 175.

22 See already Smyth (1900) 347.
} 
suggest that generic sympotic compositions went under her name which are unlikely to have been composed by her originally.

The remaining fragments are ritual civic songs, several of which hint at the possibility that they were transmitted through sympotic reperformance. $P M G 748$ is a line of a dithyramb entitled Achilles preserved once again by

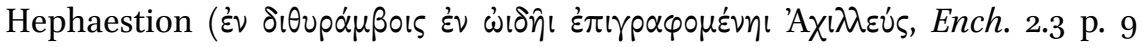

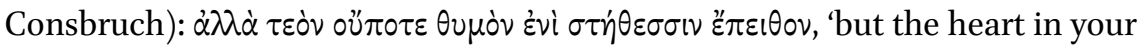
breast they (or I) could never persuade'. The longest of Praxilla's fragments consists of three lines of a hymn for Adonis preserved by the second century AD paroemiographer Zenobius in explanation of the proverbial phrase 'sillier than Praxilla's Adonis' ( $P M G$ 747). When asked what he most missed of the good things he had left behind when coming to the Underworld, Adonis is made to reply with the supposedly incongruous lines

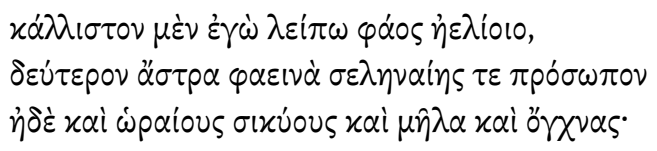

the most beautiful thing I leave behind is the light of the sun, next, the bright stars and the face of the moon, then, too, ripe cucumbers and apples and pears;

As Zenobius tells us, 'he is a silly man who reckons the sun and moon on a par

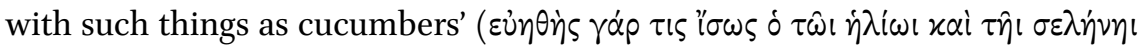

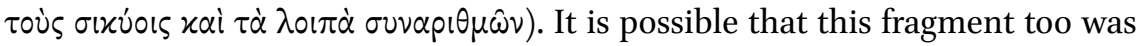
reperformed at symposia and that such reperformance left its mark on the textual tradition: the subject-matter, with its pithy exemplarity, lends itself well

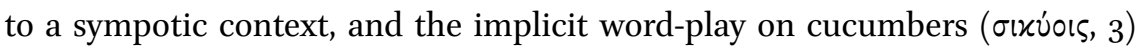
and the name of Praxilla's hometown of Sicyon, which is bowdlerized when the cucumbers become figs (or is it perhaps a rude joke of a different gender?) in a version preserved by Diogenianus (5.12, p. I 251 van Leutsch-Schneidewin), is just the kind of playfulness which we know went down well in the symposion. Three more fragments have subject-matter which might easily belong to hymns but also, in view of their affinity with the erotic and paederastic concerns of the symposion, might just as easily be thought to have been reperformed symposiastically. $P M G 75^{1}$ is no more than a brief report by Athenaeus (13.603a), in the context of a discussion on the origins of to paiderastein, that Praxilla mentioned the rape of the handsome young Chrysippus at the hands of Zeus. $P M G$ $75^{2}$ (cited by Hesychius $\beta 128$ Latte) is a passing citation as evidence for an alternative parentage for Dionysus, in which the pairing of the god with Aphrodite 
has obvious resonance with the symposion, the context par excellence for the mixing of wine and love. $P M G 753$ is said by the scholiast to Theocritus (5.83a pp. 170-171 Wendel) to have been composed for the festival of the Carneia; while the scholiast definitely implies that Praxilla referred to the festival, and he mentions Praxilla in the same breath as Alcman, it is notable that here too the subject-matter is paederastic, and so suitable for sympotic reuse.

Despite the fact that Praxilla's corpus consists in the main of hymns and dithyrambs and that the two skolia ascribed to her are suspiciously generic, the testimonia's report that she was an author of skolia has led some scholars to the conclusion that she must have been a hetaira. This embarrassment regarding Praxilla's status has led her to acquire something of a split personality; Martin West has even suggested the possibility that there were two different poets named Praxilla, one a respectable matron and one a hetaira, ${ }^{23}$ just as in ancient scholarship's treatment of Sappho. ${ }^{24}$ This is not necessary if we accept that Praxilla's poems could have been detached from their original context and reused in the symposion (as West also suggests). The 'split-personality' problem is particularly in evidence in the case of our fragment addressed to the gazing woman, which, as we will see, some scholars have tried to interpret in reaction to the prevailing reading in ways that would restore reputability to its author. In fact, as it stands the couplet does not lend itself easily to being grouped with either one or the other category, that is to say it resists being clearly identified either as a ritual song or as a skolion which was ascribed to her at a later date. However, it is arguable that once we have dissociated Hephaestion's quotation from the vase inscription and are more willing to preserve the plural $\tau \hat{\omega} \nu \theta u p i \delta \omega \nu$ (which does not have the vernacular ring of the singular) the latter possibility seems to lose force. It is time to return the woman's gaze and give the fragment a closer look.

We might start by noting that the attribution to Praxilla rests entirely on the context of quotation in Hephaestion's Handbook on Metres (7.8), where the fragment is cited as being an example of the verse called 'Praxilleion'. Elsewhere (11.3) two lines of Sappho (fr. 154 V., explicitly ascribed to her) are cited as an example of a different kind of Praxilleion; conversely, the Byzantine

23 West (1993) xix: 'She was credited on the one hand with songs suitable for the symposion — which might suggest a courtesan — and on the other hand with choral poetry and hymns, which would point rather to a respectable, matronly, chorus-leader. It is possible that two different women of the same name have been confused, or else that Praxilla's authorship of the sympotic songs, about which the ancients seem to have entertained doubts, was a fiction.'

24 Nymphodorus FGrH 572 F 6 = Ath. 13.596e, Suda $\sigma 108$ Adler; Most (1996) 15-16. 
scholar Trichas (presumably basing himself on Hephaestion or perhaps Choeroboscus) gives as an example of a Praxilleion ('so called because she used it often', as he says) a line which is (to my knowledge) otherwise unknown, remains unascribed, and may very well have been invented. ${ }^{25}$ Still, such lowlevel uncertainty can hardly be avoided and it is reasonable to assume that the fragment was thought in antiquity to be by Praxilla.

We have seen that the prevailing interpretation of the fragment, based on the assumption that Praxilla composed skolia and was therefore in all likelihood a hetaira, an assumption seemingly reinforced by the occurrence of the first few words of our fragment on a wine cup, is that the song is a bawdy drinking song, an address to a loose woman. ${ }^{26}$ I have begun to argue that, once freed of the close connection with skolia and the vase, this interpretation loses its appeal. I will now investigate the possibility that the fragment comes from a ritual song (though this does not, of course, preclude the possibility of reperformance at the symposion-indeed the irony of sympotic appropriation would be well placed).

Some attempts have in fact already been made to interpret the fragment in ways other than as a lascive Anrede. Aly's elaborate suggestion that the female addressee is the Moon, who shines chastely through our windows at night but when she dips beyond the horizon becomes Endymion's lover, is frequently cited in the literature for being farfetched and unpersuasive. ${ }^{27}$ Halporn's interpretation has $\tau \hat{\omega} \nu$ $\theta u p i \delta \omega \nu$ as referring to the windows of the soul, that is to say the eyes, but there are not any convincing parallels for that peculiar use of Eupic. ${ }^{28} \mathrm{~A}$ different attempt is made by Eleonora Cavallini, who aligns this fragment with the others attributed to Praxilla by interpreting it as a ritual song, and specifically a hymn to Aphrodite Parakuptousa, ${ }^{29}$ but there is no evidence for this cult outside of Cyprus. A simpler explanation will have to be sought.

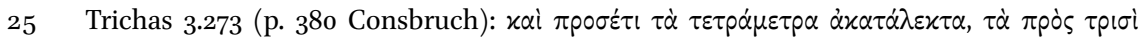

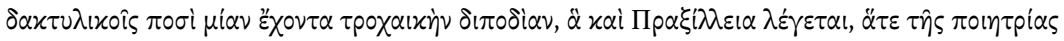

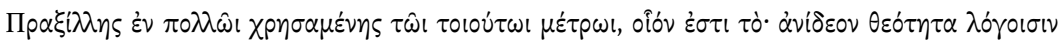
$\ddot{\alpha} \mu \nu \mathrm{\nu}$.

26 In fact, a similar interpretation is found already in the scholia A to Hephaestion: $\pi$ pòs

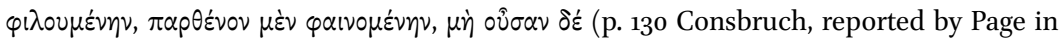
apparatus).

$27 \quad R E$ XXII $1764-1765$ s.v. 'Praxilla'.

28 Halporn (1983); arguments against in Renehan (1987).

29 Cavallini (1992) 37-41. For this Cypriot ritual see Plu. Mor. 766d-e (Amatorius) and cf. Ov. Met. 14.751-761; Borghini (1979). 
Among scholars who have voiced their doubts about the prevailing 'lascivious' interpretation is Alan Cameron, who has additional reason to want to reject such a reading of our fragment, since he thinks that a poem of Asclepiades' has been erroneously interpreted as representing the girl behaving inappropriately partly on the basis of its allusion to Praxilla (with the plural Evpí $\delta \omega v) .{ }^{30}$ I quote Cameron's misgivings on our Praxilla fragment (his emphases):

Most commentators have inferred from line 2 [of the Praxilla fragment] that the girl is a whore with the face of a virgin. [...] yet the traditional explanation is ... [not] satisfactory. While one can say in most languages that a girl has the face of a virgin but the heart or body of a whore, it is surely very odd to say that she has the head of a virgin but is a bride (or married woman) beneath. Marriage marks the end of virginity, to be sure, but most people consider it respectable enough. If we had the rest of Praxilla's poem these two lines might take on a meaning we could never have guessed. ${ }^{31}$

But a guess might be ventured yet. The fragment may be a snatch of a wedding song, and specifically a wedding song which was sung at the groom's house after the wedding night. We know that songs were performed outside the marriage chamber on the evening before the consummation and then again on the following morning, when a group of well-wishers would return for a second day of festivities. These were known as $\tau \dot{\alpha} \varepsilon \dot{\tau} \pi \alpha \dot{\lambda} \lambda$ l $\alpha$ and they celebrated the bride's taking up residence in the groom's house $(\dot{\varepsilon} \pi \alpha \nu \lambda i \sigma \theta \alpha l)$ and the consummation of the union. ${ }^{32}$ The festivities involved a procession to bring gifts to the bride,

30 Asclepiades, Epigram 3 (text and translation from Sens [2011]):

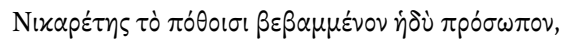

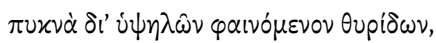

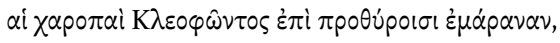

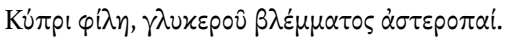

Nicarete's sweet face, imbued with desirability,

often visible through the lofty windows-

the bright lightning-bolts from the sweet gaze of

Cleophon at the front door, dear Cypris, dimmed it.

31 Cameron (1995) 499; cf. Kirkwood (1974): 'this intriguing start could lead almost anywhere. Is it praise? Invective? A riddle poem? We know no more.'

32 Eusth. Comm. ad Il. 24.29 (pp. 864-865 van der Valk), referencing the second century AD

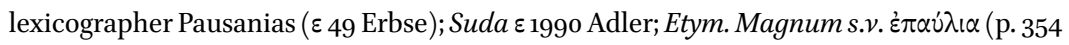
Gaisford). 
a scene which is frequently depicted on pottery. In paintings, this scene often involves ladders; this detail is interpreted both as a piece of realism (ladders had a utilitarian function in reaching the bridal chamber on the upper floor) and as having a symbolic function, signifying the transition from a virginal maiden, a parthenos, into a bride, a nymphe. ${ }^{33}$ Our fragment, with its address to the woman at the window and its arresting gesture to her changed status, seems to fit this template nicely.

But we do not have to rely on vase paintings alone: some textual evidence allows us a glimpse of the kinds of songs that might have been addressed to the bride on these occasions. Ancient scholarship attests to the existence of a subspecies of wedding song, 'reveille songs' which were sung at daybreak to awaken the bride and groom. ${ }^{34}$ They are labelled öp $p$ pı $\alpha$ or $\delta เ \varepsilon \gamma \varepsilon p \tau i x \alpha$ in the scholia to Theocritus' Idyll 18 ('Helen's epithalamion'): $\tau \hat{\omega} \nu$ हे $\pi \mid \theta \alpha \lambda \alpha \mu i \omega \nu \delta \dot{\varepsilon}$

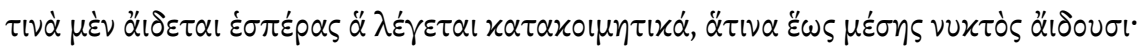

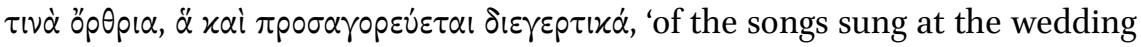
chamber some are sung in the evening — these are called "going-to-bed songs", the ones which they sing until midnight; then there are those sung in the mornings - these are called the "waking-up songs" ${ }^{35}$ The Idyll itself, which purports to be a song sung outside the bridal chamber of Menelaus and Helen just before the consummation of the marriage, is, like our fragment, addressed to the bride, and it clearly anticipates a reveille song the following morning; in so doing it, too, draws attention to the woman's changed status- the young girl is now an oikétis (38-41).

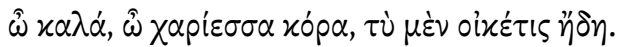

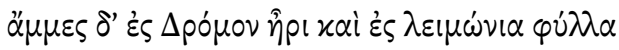

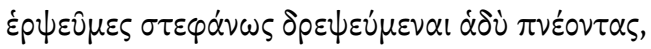

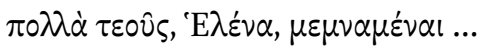

O beautiful, charming maiden, you are now a housewife. But we, early tomorrow, will to go the Course and to the flowery meadows to gather sweet-smelling garlands, much mindful of you, Helen ...

33 Oakley and Sinos (1993) 38-42 with a systematic account of visual evidence for this stage in the festivities; Rosenzweig (2004) 67-68.

34 A review in Mangelsdorff (1913), esp. 10, who adds that such songs were still known to be sung in Greece in modern times, and Lyghounis (1991), esp. 174-180.

Inscr. Theoc. 18 (p. $33^{1}$ Wendel). It is worth mentioning - though it has not won favourAlan Griffiths' interpretation of Alcman's Louvre Partheneion ( $P M G F 1$ ) according to which it is instead an epithalamion sung as a reveille song: see Griffiths (1972). 
and a little later on, at the closing of the song $\left(54^{-} 5^{8}\right)$ :

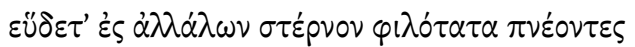

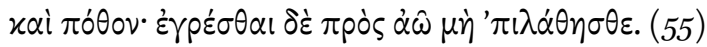

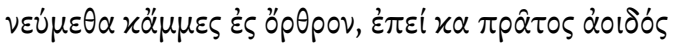

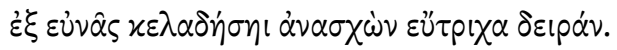

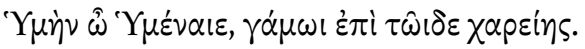

Sleep, breathing love and desire into each other's breasts, and do not forget to wake at dawn. We will return at daybreak, when the first songster raises his well-plumed neck from its bed to cry out. Hymen o Hymenaeus, rejoice in this marriage.

Earlier in the epithalamion the girls had drawn attention to Helen's preeminence by praising the beauty of her face as the dawning sun shines its light on it $\left(25^{-27}\right)$.

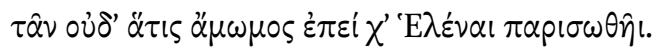

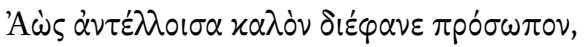

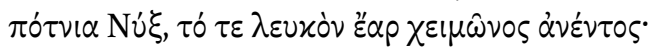

... of whom not one is without blemish when compared with Helen. The dawn rising shows her beautiful face, Lady Night, like the bright spring when winter retreats.

This rhetorical gesture, which here introduces an elaborate series of similes for the bride's beauty, is a convention of songs sung by parthenoi, ${ }^{36}$ but it may also be viewed as anticipating the coming of dawn when they will return to sing for the bride. The same kind of reveille song seems to be implied in a fragment from Aeschylus' Danaids (fr. 43 Radt): ${ }^{37}$

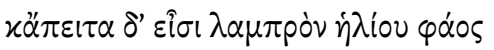

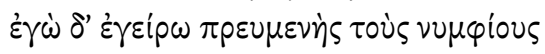

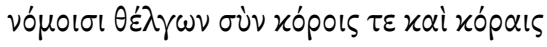

$36 \quad$ See Swift's chapter in this volume.

37 The text is especially problematic. I use Sommerstein's (Loeb) text and apparatus. See Garvie (1969) 228-230. 


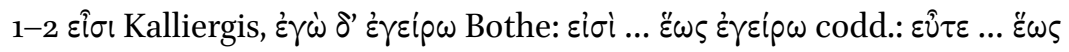

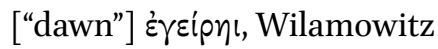

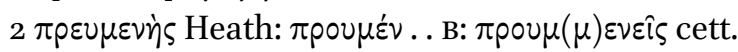

$3 \theta \dot{\varepsilon} \lambda \gamma \omega \nu$ Bothe: $\theta \dot{\varepsilon} v \tau \omega \nu$ codd.

And then will come the brilliant light of the sun, and I will graciously awake the bridal couples, enchanting them with song with a choir of youths and maidens.

A further and more intriguing parallel, not least on account of its dialogic form and for the emphasis on the transition from being a parthenos to being a numphe, can be found in a fragment of a marriage song by Sappho preserved by Demetrius (Peri hermeneias $140=\mathrm{fr} .114 \mathrm{~V}$.). This sees alternate lines sung in responsion by a bride on the one hand and maidenhood or parthenia on the other:

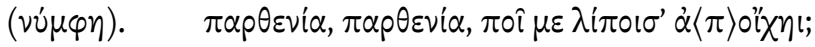

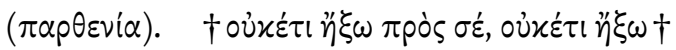

In our Praxilla fragment, the slightly risque tone (as it has been perceived by most commentators) is in fact not at odds with a marriage song. The fragment may conceivably imply a contrast between what is visible of the woman through the window and what is not, between her face and her sexual parts; the praise would then be combined with the kind of mock abuse and sexual innuendo which seems to have been a generic trait of marriage songs. ${ }^{38}$ We see it for instance in Sappho fr. $111 \mathrm{~V}$. (suggesting that the bridegroom is so largeor has such a fantastically large erection - that he will not fit under the roof of the bridal chamber) or fr. $110 \mathrm{~V}$. (about the doorkeeper with the huge feet). ${ }^{39} \mathrm{We}$ also see it in Theocritus' epithalamion to Helen cited above, where the chorus suggest that Menelaus might be so drunk he will fall asleep before consummating his marriage. On the other hand, it is perhaps more likely that the reference to what is 'below' the virginal face of the bride is not a reference to her sex but rather to her bosom. A woman's breasts seem to have had special signif-

$3^{8} \quad$ See especially Hague (1983) and Swift (2010) 247-248.

39 For these bawdy fragments and others see Dale (2011) $51^{-55}$. 
icance in a marriage context. A number of lebetes gamikoi portray the bride accepting her epaulia gifts while naked from the waist up; as Oakley and Sinos argue, this is a way to indicate conspicuously her transition from parthenos to nymphe. ${ }^{40}$ In Theocritus' epithalamion, when the parthenoi draw attention to the separation of the bride that comes after the wedding, they employ an arresting simile which draws attention to the woman's breasts: they will remember her 'as the milk-fed lambs who yearn for the breast of the sheep who bore them' (41-42)..$^{41}$ Perhaps more tenuously but still suggestively, among the fragments of Sappho we find a marriage song within a marriage song which refers to love-

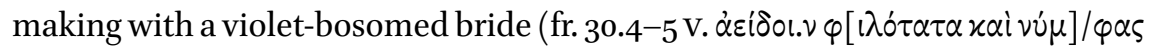
ioxó̀ $\pi \omega \omega) .{ }^{42}$

So looks, it seems, can deceive in more ways than one. The song by Praxilla of which the first two lines are preserved by Hephaestion may not be a skolion as commonly thought. Rather than being an address to a prostitute, it may be an address to a bride made by a chorus notionally positioned outside the bridal chamber. The suggestion that the fragment is from a marriage song seems a natural one for a poem by a female poet, and it is surprising that despite the fancifulness of some of the previous interpretations this more straightforward one has never been defended. ${ }^{43}$ More generally, it is intriguing to note that, while scholarship on Sappho tends to privilege the feminine ritual character of her poetry and make light of her association with the symposion, in the case of Praxilla the opposite has been true. ${ }^{44}$ The recent discovery of a poem by Sappho in which the speaker discusses the circumstances of her family (the now notorious 'Brothers Poem', P.Sapph.Obbink 21 ff.) has prompted a resurgence in the debate on the social context of her poetry. Praxilla may not have left as deep a mark in Greek literary history as Sappho, but it may be timely to revisit our ideas about her too.

$40 \quad$ Oakley and Sinos (1993) 42; see e.g. Athens National Museum 1371.

41 Dover (1971) 236 condemns this as 'a very odd simile indeed'.

42 See Contiades-Tsitsoni (1990) 79-8o, with argument to the effect that the 'violet' colour refers to the hue of the bride's skin rather than her garment.

43 It has barely (to my knowledge) been mentioned: Chris Carey remarks in passing, in his 'Praxilla' entry for the Oxford Classical Dictionary, that the fragment is 'probably' a wedding song. Cf. McIntosh Snyder (1991) 56: 'Presumably the person addressed is a young woman of innocent demeanor who is in fact not so innocent as she looks, but whether she is supposed to be a bride-to-be or a hetaira cannot be determined.'

44 Though this status quo is now being challenged in relation to Sappho, and the view is resurfacing that she was a courtesan of sorts and her poetry essentially sympotic: see especially Schlesier (2013). 


\section{Works Cited}

Barron, J.P. (1964). 'Religious propaganda of the Delian League'. JHs 84: 35-48.

Borghini, A. (1979). 'Riflessioni antropologiche sopra un mito di proibizione: la ragazza alla finestra (Ovidio met. 14, 795-861 e Antonino Liberale met. 39)'. MD 2: 137-161

Buitron-Oliver, D. (1993). Douris: A Master-Painter of Athenian Red-Figure Vases. Mainz Cameron, A. (1995). Callimachus and His Critics. Princeton

Campbell, D.A. (1964). 'Flutes and elegiac couplets'. JHs 84: 63-68

- (1992). Greek Lyric, Iv: Bacchylides, Corinna and Others. Cambridge, Mass

Cavallini, E. (1992). 'Note a lirici corali'. Eikasmos 3: 19-41.

Contiades-Tsitsoni, E. (1990). Hymenaios und Epithalamion. Das Hochzeitslied in der frügriechischen Lyrik. Stuttgart

Csapo, E. and M.C. Miller (1991). 'The 'kottabos-toast' and an inscribed red-figured cup'. Hesperia 60: $367-382$.

Dale, A. (2011). 'Sapphica'. HSCPh 106: 47-74.

Dover, K.J. (1971). Theocritus. Select Poems. London

Fabbro, E. (1992). 'Sul riuso di carmi d'autore nei simposi attici'. QUCC n.s. 41: 29-38.

- (1995). Carmina convivalia attica. Rome.

Fraenkel, E. (1936). 'Dramaturgical problems in the Ecclesiazusae', in Greek Poetry and Life: Essays Presented to Gilbert Murray. Oxford: 257-277.

Garvie, A.F. (1969). Aeschylus' Supplices: Play and Trilogy. Cambridge.

Gaunt, J. (2014). 'The poet and the painter: A hymn to Zeus on a cup by the Brygos Painter' in R. Scodel (ed.), Between Orality and Literacy: Communication and Adaptation in Antiquity. Leiden: 101-124.

Graham, A.J. (1998). 'The woman at the window'. JHS 118: 22-40.

Griffiths, A. (1972). 'Alcman's Partheneion: The morning after the night before'. QUCC n.s. 14: 7-30.

Hague, R.H. (1983). 'Ancient Greek wedding songs: The tradition of praise'. Journal of Folklore Research 20(2/3): 131-143.

Halporn, J.W. (1983). 'A note on Praxilla fr. 754 PMG'. Hermes 111: 499-500.

Jacobsthal, P. (1912). Göttinger Vasen nebst einer Abhandlung mit $\Sigma u \mu \pi \circ \sigma \iota \alpha \alpha \dot{\alpha}$ (AbhGött XIV, No. 1). Berlin.

Kirkwood, G.M. (1974). Early Greek Monody. The History of a Poetic Type. Ithaca.

Lullies, R. (1940). 'Zur boiotisch rotfigurigen Vasenmalerei'. AM 65: 1-27.

Lyghounis, M.G. (1991). 'Elementi tradizionali nella poesia nuziale greca', MD 27: 159198.

McIntosh Snyder, J. (1991). The Woman and the Lyre: Women Writers in Classical Greece and Rome. Bristol.

Mangelsdorff, E.A. (1913). Das lyrische Hochzeisgedicht bei den Griechen und Römern. Doctoral dissertation, Giessen. 
McNiven, T. (2014). 'The view from behind the kline: Symposial space and beyond' in J.H. Oakley (ed.), Athenian Potters and Painters III. Oxford: 152-133.

Most, G.W. (1996). 'Reflecting Sappho' in E. Greene (ed.), Re-Reading Sappho. Berkeley and Los Angeles: 11-35.

Oakley, J.H. and R. Sinos (1993). The Wedding in Ancient Athens. Madison.

Pizzocaro, M. (1993). 'Un profilo di Telesilla, famosa poetessa d'Argo, e guerriera'. AION ( filol) 15: 89-103.

Renehan, R. (1983). 'The early Greek poets: Some interpretations'. HSCPh 87: 1-29. (1987). 'Praxilla Fr. 8 Page (= PMG 754)'. Hermes 115: 373-377.

Rosenzweig, R. (2004). Worshipping Aphrodite: Art and Cult in Classical Athens. Michigan.

Sabetai, V. (2012a). 'Boeotian red-figure vases: Observations on their contexts and settings' in S. Schierup and B. Bundgaard (eds), Red-figure Pottery in its Ancient Setting. Rasmussen. Aarhus: 82-98.

- (2012b). 'Looking at Athenian vases through the eyes of the Boeotians: Copies, adaptations and local creations in the social and aesthetic culture of an Attic neighbour' in S. Schmidt and A. Stähli (eds), Vasenbilder im Kulturtransfer. Zirkulation und Rezeption greichischer Keramik im Mittelmeerraum. Munich: 121-137.

Schlesier, R. (2013). 'Atthis, Gyrinno, and other hetairai: Female personal names in Sappho's poetry'. Philologus 157: 199-222.

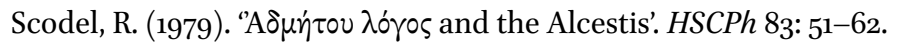

Sens, A. (2011). Asclepiades of Samos. Epigrams and Fragments. Oxford.

Sider, D. (2010). 'Greek verse on a vase by Douris'. Hesperia 79: 541-554.

Smyth, H.W. (1900). Greek Melic Poets. London.

Swift, L.A. (2010). The Hidden Chorus: Echoes of Genre in Tragic Lyric. Oxford.

West, M.L. (1993). Greek Lyric Poetry. Oxford.

Wilamowitz, U. von (1900). Die Textgeschichte der griechischen Lyriker. Berlin. 


\title{
How to Construct a Sympotic Space with Words
}

\author{
Jenny Strauss Clay
}

The Greek symposium, where most archaic Greek monodic poetry was performed, took place in a space defined by couches arranged along the walls of a special room on which the company reclined; the krater in which wine and water were mixed for the communal drinking occupied the center of the andron. ${ }^{1}$ As vase-paintings show, the walls were often decorated with various objects that contributed to the definition of the sympotic group: armor, baskets, and musical instruments. I intend to examine Alcaeus fr. 140 V., Xenophanes fr. 1 W., and Theognidea $467-496$ to show how all three compositions construct the setting of the symposium verbally. Both Alcaeus and Xenophanes describe the andron by, in the first case, visualizing the space from the ceiling to the floor, while in Xenophanes, inversely, the eye moves from the floor to the central space occupied by the krater before ascending, metaphorically, to the gods above. Using yet another strategy, Theognis' verses shape the sympotic space through a series of deictic pronouns that progress through the exclusion and inclusion of participants and appropriate modes of behavior. The sequence culminates in the creation of a community that shares in the harmony and euphrosyne that are the hallmarks of the ideal symposium.

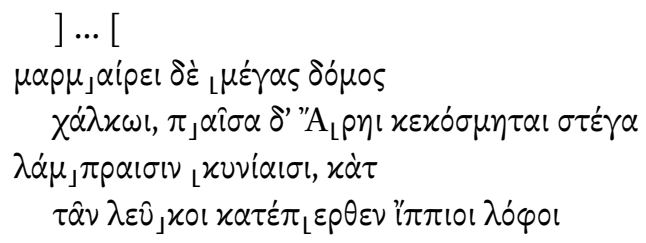

1 For the symbolism of the central position of the krater, see Lissarrague (1990) 19-46. This paper grew out of a serendipitous coincidence: I was completing my book on space and vision in the Iliad (Homer's Trojan Theater, Cambridge 2011), and happened also to be team-teaching a course on the Greek symposium with my colleague at Virginia, Malcolm Bell III, from which I greatly benefited. The Iliad project allowed me to see things in a way I hadn't before with a far greater sensitivity to the spatial dimension of early Greek poetry including its performance setting. This paper was submitted in 2010; I have not been able to revise it drastically, but am happy to acknowledge the help of Vanessa Cazzato who directed my attention to Faraone (2008) and Hobden (2013).

(C) JENNY STRAUSS CLAY, 2016 | DOI: 10.1163/9789004314849_009

This is an open access chapter distributed under the terms of the Creative Commons Attribution- 


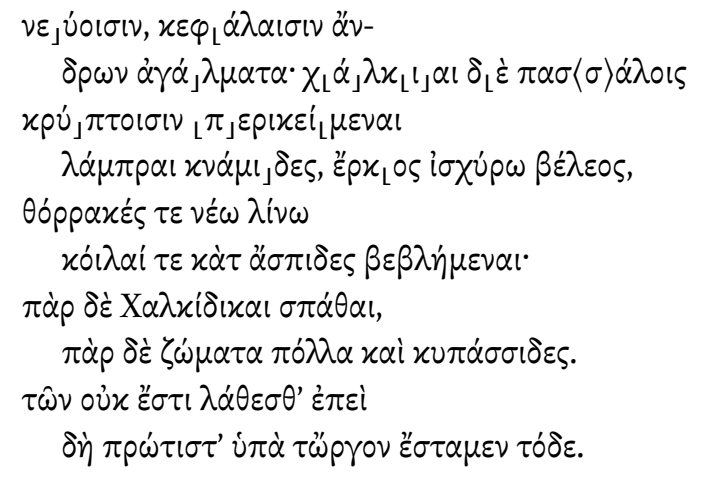

The great house sparkles

with bronze, the whole ceiling is adorned for Ares

with shining helmets, from which horse-hair crests

nod down, ornaments for

the heads of men; bronze shining greaves

hanging about hide the pegs,

a barrier against mighty missiles,

corselets of new linen

and hollow shields thrown down;

beside them broad swords from Chalcis, and beside them many belts and tunics.

It is impossible to forget these things, ever since first we undertook this task.

Most discussions of Alcaeus fr. $140 \mathrm{~V}$. focus on the description of the armor catalogued in the poem. Is it contemporary or antique? 'Eccentric and oldfashioned' claimed Page, but nevertheless 'Alcaeus is describing the equipment of his comrades-in-arms, not that of legendary heroes'.2 Snodgrass, however, believes that 'apart from the linen corselets ... and the belts which go naturally with them, this is standard hoplite equipment.'3 If the items are indeed those in use in Alcaeus' own time, do they belong to typical local armor or are they possibly armor captured from enemies? In other words, are they spoils or not? ${ }^{4}$

2 Page (1955) 211-212.

3 Snodgrass (1967) 65.

4 Spoils: Bonanno (1990) 125-146; Cirio (1995): spoils, but expected to be re-used. Perrotta, Gentili, and Cantenacci (2007) 176 argue that the armor is new and therefore cannot be votives offered at a temple. 
The second focus of discussion has been on the mega domos: is it a temple, a heroon, or a sympotic andron $?^{5}$ On the basis of the dative "Appı at line 2, Bonnano, followed by Marzullo, has argued that the megas domos must be identified as a temple of Ares and that the various pieces of armor should be considered votives. ${ }^{6}$ And, indeed, armor constitutes a common form of votive dedication in early sanctuaries - one need only think of Olympia and Delphi. But the notion of a temple to Ares on Lesbos is extremely unlikely. In fact, we have evidence for only one temple dedicated to Ares in Greece, and that is the notorious and very late 'wandering temple' in the Athenian agorawhich originally may not have been a temple to Ares at all. ${ }^{\text {"Apn }}$ เ in line 2 may simply be the common metonymy for 'war'. ' Cirio argues for a heroon of the Mycenaean tholos type, where indeed we find votive deposits, but the island of Lesbos has not produced such tombs. Citing Athenaeus 14.626 f.-627b, who calls the poem's locale an oikia, Colesanti more persuasively argues for the performance setting of an andron, ${ }^{9}$ but we do well to keep in mind that sympotic spaces are often to be found in sanctuaries, whether connected to a heroon or a temple dedicated to a god. ${ }^{10}$ Some of our earliest evidence for sympotic architecture comes from sanctuaries; here I mention the recently excavated series of dining rooms, among the earliest known, in the archaic sanctuary of Apollo on the tiny island of Despotiko near Antiparos. ${ }^{11}$ Indeed, dining and sympotic activity have been demonstrated at many such sites; as a result any simple distinction between private and public banquets has rightly been thrown into question by, among others, Schmitt-Pantel. ${ }^{12}$

Insofar as so much of Greek lyric poetry was performed in a sympotic context, it thus makes sense to situate Alcaeus' poem in such a setting, but

Temple of Ares: Bonanno (1990) 125-146; Marzullo (2009) 12; arsenal or storeroom: Treu (1952) 158; heroon: Cirio (1995), (2001) with reference to Alcaeus fr. 383 v.; andron: Page (1955) 222-223; Rösler (1980) 148-158; Perrotta, Gentili, and Catenacci (2007) 176.

$6 \quad$ Marzullo (2009); Bonanno (1990).

7 Cf. Der neue Pauly I 1049-1050, s.v. Ares; and Spawforth (2006) 136-137.

8 Some scholars have suspected the reading "Apทl; see Voigt's apparatus ad loc.

9 Colesanti (1995), who, however, denies the disposition of the arms from ceiling to floor: 'Una tale disposizione è però strana e niente affatto probablile', and he opts for 'una disposizione mista' (390). Cf. Page (1955) 222: 'The poem was presumably sung by Alcaeus to his comrades at the dining table', and he cites the andron of Croesus, which was similarly furnished with weapons and other armaments (Herodotus 1.34.3) as well as the megaron of Odysseus' palace (Od. 16.284). See also Colesanti (1995) 393 n. 1.

10 See, for instance, Bookides (1990); Goldstein (1978); Will (1976); Roux (1973).

11 See Kourayos (2005) 105-133.

12 Schmitt-Pantel (1990) and (1992). 
my interest here is rather in the space constructed within the poem. We begin with the roof adorned with shining helmets; our gaze then follows the horsehair crests 'nodding down' from above (lines 4-5). As our gaze proceeds downward, we encounter greaves hanging from pegs, which one assumes are affixed to the walls, as well as corselets of new linen. Now we arrive at the ground, where shields are thrown down on the floor; beside them, presumably also on the floor, are broad swords from Chalcis and tunics or perhaps cloaks. ${ }^{13}$ Armor is often depicted as adorning the walls of sympotic scenes on vase painting. ${ }^{14}$ But the objects on the ground may suggest a more immediate use, i.e. ready for action? Finally, in light of the spatio-visual ordering of the catalogued items, the exhortation not to 'forget these things' may involve more than merely remembering their symbolic value to inspire courage, but may offer a mnemonic device for recalling the scene and its setting each time the poem is sung, creating for the hetairia a shared communal vision.

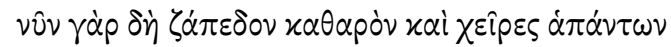

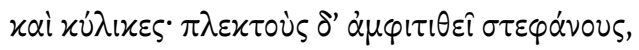

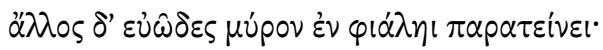

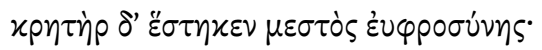

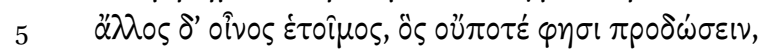

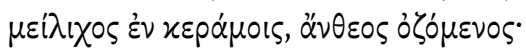

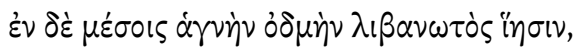

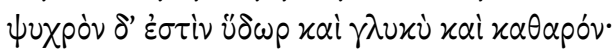

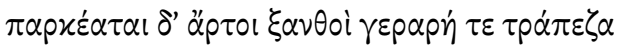

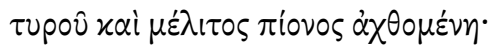

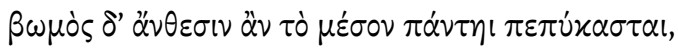
$\mu о \lambda \pi \dot{\eta} \delta^{\prime} \alpha \mu \varphi i \varsigma$ है $\chi \varepsilon l \delta \omega^{\prime} \mu \alpha \tau \alpha$ xai $\theta \alpha \lambda i \eta$.

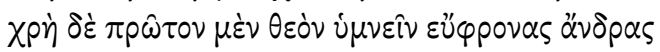

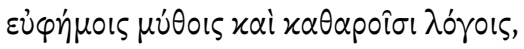

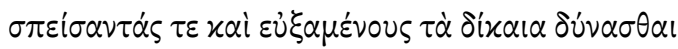

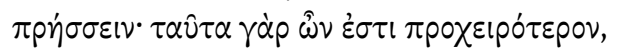

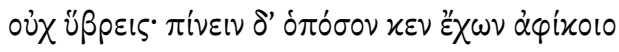

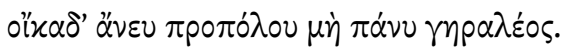

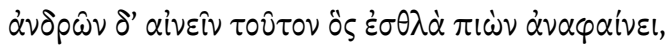

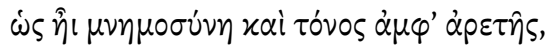

13 Cf. Bonanno (1990) 137.

14 See the plates in Colesanti (1995). 


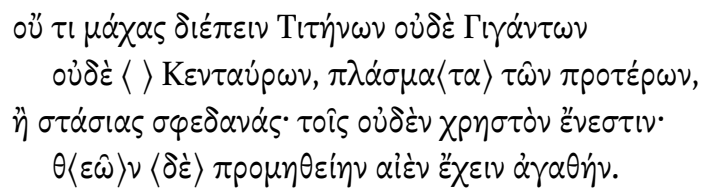

For now indeed the floor is clean and everyone's hands

And the cups; one dons braided garlands, another passes fragrant myrrh in a bowl;

the krater filled with good cheer has been set up;

another wine is at the ready, which claims it never will prove false,

mellow in the cups, and smelling of flowers;

and in the middle incense sends forth a pure fragrance,

cool is the water and sweet and pure;

blonde loaves of bread are set out too and a splendid table weighed down with cheese and thick honey;

an altar in the center is completely covered with flowers, and song and festivity pervade the house.

Men of good cheer must first hymn the god with reverent words and pure speeches, while pouring libations and praying to be able to do what is just, for these things are closer at hand, rather than acts of hybris; and to drink only so much to make it home without a servant (unless you're very old); praise the man who when drinking reveals excellent things, so that there is recollection and striving for excellence; nor at all recounting the battles of the Titans nor of the Giants nor of the centaurs, fabrications of men of old, or of violent factions - in which there is nothing of usebut always to have a good regard for the gods.

Xenophanes' fr. 1 w. likewise describes a sympotic space, this one perhaps more symbolic and ideal than real. But here the order is inverted: Xenophanes begins from the floor, freshly swept. He then enumerates various accoutrements of the participants, their clean hands and cups; then movement enters the scene with their sundry preparations: putting on of garlands, passing of perfumes. We proceed to the middle space, occupied by the krater, incense, and pure water. Nearby are tables laden with bread, cheese, and honey. The altar at the center is covered with flowers; finally music and thalia, the sense of well-being and

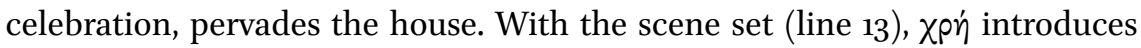
the activities appropriate in this setting. The emphasis on purity/cleanliness 
and the altar, mentioned in line 11, prepares for them: hymns to the gods, libations and prayers, 'for these things are closer to hand' (line 16) as opposed to immoderation and excessive drinking. Song and prayer introduce the subject

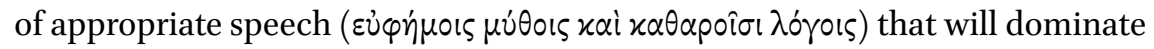
the rest of the poem.

As we know from several sources, ${ }^{15}$ the singing of the sympotic paean along with a series of libations preceded the orderly competition from right to left, epi dexia, among the symposiasts, whether with poetry or speeches. In Xenophanes' symposium, the prize goes to the man who brings noble things to light, deeds that 'inspire commemoration and competition in virtue' ( $\dot{\omega} \varsigma \hat{\eta} \iota \mu \nu \eta \mu \mathrm{o}$

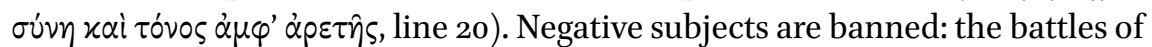
the Titans and Giants are here viewed not as paradigms of the triumph of the Olympian order against chaotic forces, but rather as negative examples to be excluded from the party. Likewise Centaurs, who frequently function as warning exemplars of barbaric behavior at a symposium, ${ }^{16}$ are similarly barred, as are all kinds of violent strife, especially civic strife: they have nothing useful to teach. The important thing is to have a positive attitude, $\pi \rho \circ \mu \eta \theta \varepsilon i \eta \eta \dot{\alpha} \gamma \alpha \theta \dot{\eta} v$, toward the gods.

Now, my paraphrase has not gone into some of the controversies surrounding the final lines of the poem, nor whether Xenophanes is offering a new theology. Here again I am more interested in the way Xenophanes constructs the symposium both spatially and temporally. The preparations (lines 1-12) are described as a visual progression (I recognize also the importance of smells in the catalogue), moving from the floor to the krater, the tables, the altar, and finally the whole house awash with music and conviviality. The second 12 lines (lines 13-24) balance the first, but focus on sound and speech and the appropriate temporal sequence of sympotic activities: hymns, libations, prayers, and competitive speeches. I suggest that the two sequences come together in the last line of the poem with the gods, present in the central bomos and in the culminating vertical trajectory of the poem, from floor to heaven itself, the abode of divinity. In his commentary, Lesher aptly speaks of the poem's 'progressive elevation of sentiment, aptly symbolized by the upward progression from the floor (l. 1) to table (l. g) to house (l. 12) to human excellence (l. 20) to respect

15 E.g. Xen. Symp. 2.1; Xen. Cyrop. 4.1.6; Plat. Symp. 176 a.

16 As early as the Odyssey; see Od. 21.295-304. Centaurs and Lapiths are common motifs in sympotic vases; see Lissarrague (1990) 30-31 for an example. The exclusion of even a negative example from Xenophanes' symposium reveals that he is describing not just acceptable behavior, but something more radical and new. 
for the gods (l. 24)'. ${ }^{17}$ However, Lesher overlooks the sympotic character of the poem, comparing the scene to 'the wholesome family dinner' Plato describes at Republic 372b. Yet Xenophanes' scenario has nothing rustic about it, and the fare is typical of sympotic snacks or tragemata. ${ }^{18}$

Having now explored the sympotic space from the top down with Alcaeus, and from the bottom up with Xenophanes, we will join Theognis (467-496) or whoever the author of these verses might be (perhaps Euenus) ${ }^{19}$ - in a tour around the andron.

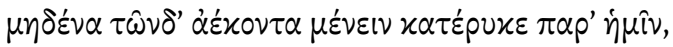

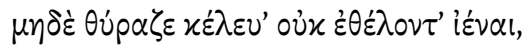

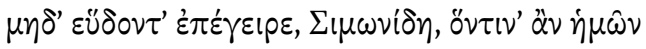

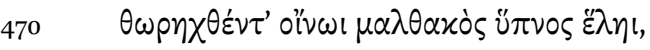

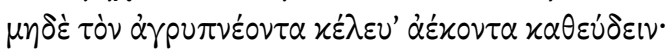

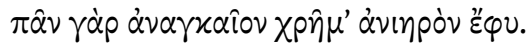

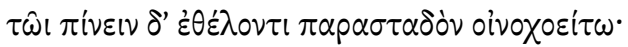

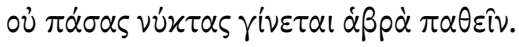

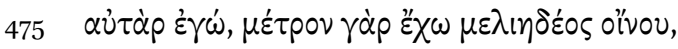

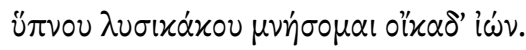

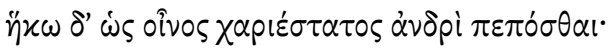

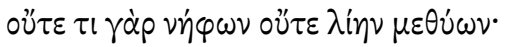

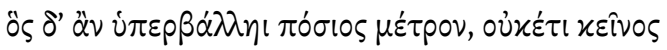

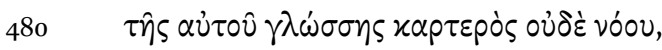

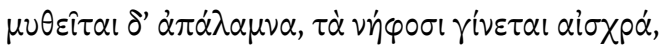

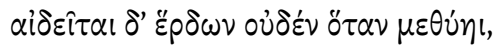

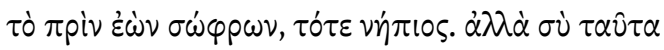

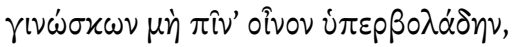

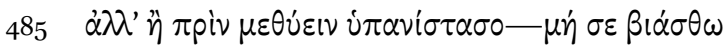

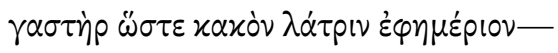

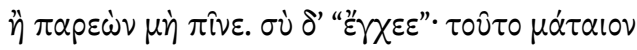

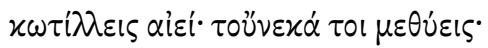

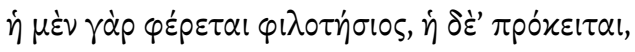

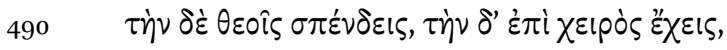

17 Lesher (1992) 54 .

18 Cf. Marcovich (1978) 5 .

19 The elegy has been attributed to Euenus on the grounds that Aristotle cites Euenus as the source for line 472 (cf. Carrière [1948] 110). But the line is surely proverbial and may be drawn from the Theognidea or from a common source. It is unnecessary to identify Simonides with the poet of Ceos. 


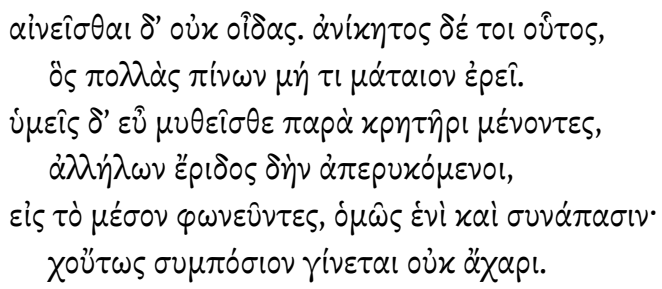

Do not force anyone of those here to remain among us against his will, nor order anyone to leave if he doesn't wish to;

nor, Simonides, awaken the one who is sleeping, whoever of our company, soft sleep overcomes, drunk on wine, nor order the wakeful to go to sleep against his will; everything done under compulsion is naturally irritating. Let him pour standing by for the one who wants to drink; it's not every night that one can luxuriate.

But I, for I have a due measure of honeyed wine, I'll bethink myself of sleep that frees from pain going home. ${ }^{20}$

But I have arrived at the point when wine is most pleasing for a man to imbibe; for I am neither too sober or too drunk;

but whoever should exceed the due measure of drink, no longer is that one in charge of his own tongue or mind, and he blathers useless stuff which is embarrassing to the sober, nor does he feel shame no matter what he does whenever he's drunk, the same man who was sensible, then acts the fool. But you, knowing these things don't drink wine to excess, but before getting drunk, get up from under-so that your stomach doesn't plague you like a bad day-laborer-

20 Gerber (1999) 243 translates $475^{-476}$ as follows: 'But I'll go home-I've had my limit of honey-sweet wine - and I'll take thought for sleep that brings release from ills.' This is at odds with the following line, which Gerber translates: 'I've reached a stage where the consumption of wine is most pleasant for a man.' I do not believe that the speaker is threatening to go home or that he has reached his limit. Cf. Faraone (2008) 87, who gives Gerber's translation, and Hobden (2013) 59, who translates: 'But I, since I hold the measure of honey-sweet wine, shall give heed to evil-ending sleep and go home'. Rather, the speaker claims emphatically $\left(\dot{\varepsilon} \gamma \omega^{\prime}\right)$ that he has at hand a due measure of wine and will think about going home and sleeping in due time. At present he has reached that most pleasant state described in the following line. 
Or stay around without drinking. But you always keep up your empty

babbling: 'fill 'er up'; that's why you get drunk;

The first round is for a friendship toast; another appears,

the next you pour to the gods; the next you have in hand;

you don't know how to say no. Unbeatable is the man who,

while drinking lots, does not speak nonsense.

But you all speak decorously as you stay near the krater,

keeping quarrels at a distance from each other, speaking for the common good, both for one and all.

And thus our symposium will be not without its charm.

While West and others view lines $467-496$ as one poem, and hence one of the longest sustained compositions in the collection, Faraone has argued that we have here what were originally three independent ten-line stanzas that nevertheless form a chain and respond to one another. ${ }^{21}$ Faraone's analysis of the poem's structure is, however, problematic. First, he must consider his first stanzaic division at line 476 , whereas the previous couplet ending with 474 (oi

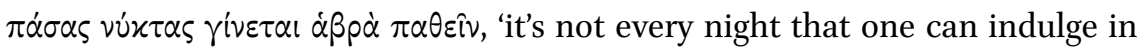

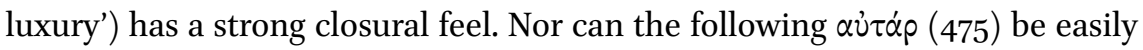
separated from " $\chi^{\prime} \omega \omega \delta^{\prime}$ (477), which continues to explicate the 'due measure' ( $\mu \dot{\varepsilon} \tau$ ipov, 477) expounded by the $\dot{\varepsilon} \gamma \dot{\omega}$. Finally, as Hobden has already pointed out, Faraone is obliged to divide line 487 and use special pleading to argue 'that a scribe placing the poems together altered their last and first lines to fit. ${ }^{22}$

My understanding of the poem is not only predicated on its unity, but also involves careful attention to its deployment of the pronouns and deictics and on our recognition of the configuration of a typical andron. It seems to me most effective to trace the progress of the composition from beginning to end and to understand how the poem itself functions to construct the sympotic group both spatially and ethically.

The opening establishes the presence of various participants $(\tau \hat{\omega} v \delta$ ', 'these here') in the here and now of the enunciation. Moreover, it creates a shared group identity ( $\dot{\eta} \mu \hat{\imath} v, \dot{\eta} \mu \hat{\omega} v$, 'we') from which no one of those present is excluded ( $\mu \eta \delta \dot{\varepsilon} v \alpha \tau \hat{\omega} v \delta^{\prime}$, 'no one of these here'). Finally, $\mu \dot{\varepsilon} v \varepsilon \varepsilon v$ indicates a space which each of the members shares. However, that membership is a matter of choice: to depart from this deictic center ( $\theta \dot{\rho} \rho \alpha \zeta \varepsilon$... ićval, 467) should be a matter not

\footnotetext{
21 Faraone (2008) 86-92.

22 Hobden (2013) 6o, n. 76. Nevertheless, Hobden later (61) speaks of 'the third segment or poem'.
} 
of compulsion, but of personal preference, and it does not lead to expulsion from the community. Similar is the couplet that follows: the one who is asleep,

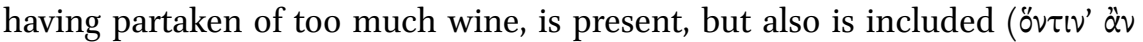
$\dot{\eta} \mu \hat{\omega} v$, 'whoever of us'); while 'this one' ( $\tau \dot{o} v)$ is not to be compelled to sleep (469470). So far, an inclusive membership, but this unity will soon be splintered. The ultimate function of the poem will be to restore that initial unity. At this point, an addressee emerges: Simonides, to whom, as we now recognize, the previous commands have been addressed. He too belongs to the group, but it appears that the speaker is in a position to give him advice. ${ }^{23} \mathrm{~A}$ proverb provides a

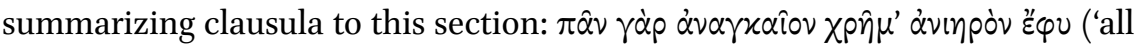
compulsion is a source of irritation,' 472).

The second person address is now abandoned as the speaker continues: 'let him pour the wine standing beside the one who wishes to drink', which continues the idea of freedom of choice. In sympotic depictions the winepourer is often a youth, a kind of apprentice-symposiast, who stands rather than reclines, and is not yet fully a member of the group-which may explain the third person imperative. Another generalizing statement complements the earlier gnome concerning the absence of compulsion; it too characterizes the sympotic environment, $\dot{\alpha} \beta p \dot{\alpha} \pi \alpha \theta \varepsilon i v$, the atmosphere of ease and luxury so typical of sympotic activity (474).

The emphatic entrance on the scene of the speaker raises the question of his relation to Simonides. I am inclined to think that the $\dot{\varepsilon} \gamma \omega \dot{\omega}$ is playing the role of symposiarch, while Simonides may be the host at whose house the party takes place-but this is pure speculation. $\gamma^{\prime} \boldsymbol{\omega}$ then outlines an ethic of moderation; he will drink in moderation, neither falling asleep at the party, nor staying up all night, but go home neither too drunk nor too sober (475-478). Against ego's model behavior stands Mr. Keinos, the one who is distant, not just physically but ethically; he provides a paradigm for the present company to avoid. Unlike Mr. Ego, 'That One' oversteps the $\mu$ ŕtpov of drink, loses control of tongue and mind, and babbles pointlessly so as to shock the sober; then losing all sense of shame and whatever good sense he previously possessed,

23 Hobden (2013) 59 sees a rivalry between the speaker and Simonides, whom she calls 'the leader of the symposium.' She follows Faraone in viewing the speaker to be claiming 'to be heading out the door' (6o) and that $\ddot{\eta} \kappa \omega$ (477) refers to a second singer who usurps the position claimed by the previous performer and that 'Simonides" remains in control' (61). There is indeed a rhetorical shift at line 475 from the address to Simonides to the speaker speaking in his own name $\left(\varepsilon^{\prime} \gamma \dot{\omega}\right)$ and directly addressing other members of the symposium, but the speaker remains the same throughout. 
he plays the fool (479-483). Such nepiosity has no place at our party! With $\alpha \lambda \lambda \dot{\alpha}$ $\sigma \dot{v}$ ('but you'), the speaker turns to a new addressee among the symposiasts who is to draw the lesson from the preceding exemplar of negative behavior: leave before getting plastered or stay, but stop drinking $(483-487)$. $\sigma \dot{\nu} \delta^{\prime}$ at line 487 again indicates a different guest and elicits a different rhetoric on the part of the speaker who here mocks and mimics the incessant empty babbling ( $\tau 0 \hat{\tau} \tau 0 \mu \dot{\alpha} \tau \alpha 10 v, 487$ ) of another member of the party, who just can't say 'No'. Finally, o $\tau \tau$ ¿ , who apparently lies near the previous symposiast, is his complete opposite: while drinking his fill, he manages nevertheless to say nothing vain or foolish ( $\mu \dot{\alpha} \tau \alpha \iota 0 \nu, 492$; cf. $\mu \dot{\alpha} \tau \alpha \iota 0 \nu$ line 487).

At this point, the speaker has presumably completed the tour of the guests. By my count, there are 11 in all, a fairly canonical number for a sympotic reunion. ${ }^{24}$ Praise and blame have been meted out, ending with an award ( $\dot{\alpha} v^{\prime}-$ « $\eta$ Tos) to the one who, like the speaker, can judiciously combine drinking and thoughtful talk (491-492). The individual members have now formed a unified

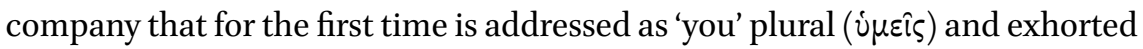
to continue appropriate drinking and speaking, and to avoid strife (493-495). The poem itself, as it circles the andron, has achieved the sense of community

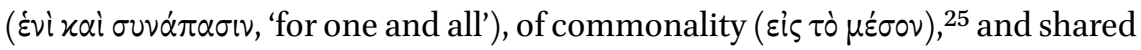
reciprocity and moderation ( izes the symposium.

L.E. Rossi defined the symposium as a 'spettacolo a se stesso', emphasizing its self-sufficiency and its lack of need for external entertainment. ${ }^{26}$ But the phrase also indicates the high degree of self-consciousness that characterizes the Greek symposium. In a visual mise en abîme, the participants would drink from krateres and cups with sympotic scenes that mirrored themselves. ${ }^{27}$ These vessels frequently present images of the ideal symposium as well as of symposia gone wrong or out of hand; ${ }^{28}$ the Gorgon at the bottom of the kylix graphically

24 Note that the speaker ( $₹ \gamma \dot{\omega}, 475)$ introduces the second part of the poem and also is number seven and hence the central figure among the symposiasts. See Berquist (1990) and her tables on p. 40 and 42 . Tomlinson (1990) 95 notes that: 'By the end of the fifth century B.C. ... in public rather than private architecture, the eleven couch-room emerges as a standard'. Of course, we have little evidence for earlier private structures.

25 See Detienne (1965) for the significance of to meson as the focus of community.

26 Rossi (1983).

27 See, for example, Gericke (1970); and the tables in Schmitt-Pantel (1990) 27-30. Also Lissarrague (1990) 19-46 and passim.

28 Lissarrague (1990) 28. 
warns the drinker of the consequences of excess. Most notorious are those vases where the potters depicted themselves participating in drinking parties. ${ }^{29}$

Much archaic monody has a similarly meta-sympotic character. Each of the poems I have discussed constructs a spatio-visual image, a verbal icon, of the setting of the symposium, the andron. In the case of Alcaeus, the members of the hetairia are asked not to forget the armaments catalogued in a spatial sequence extending from the ceiling to the floor. Such an ordering itself facilitates recall and transforms the andron into a lieu de mémoire. This context inevitably calls to mind the famous anecdote that credits the poet Simonides with the invention of mnemonics within the framework of the symposium; ${ }^{30}$ the poet was able to recall the participants by re-envisioning their seating arrangements, no doubt by making a mental map of the andron. Through its ascending trajectory, the Xenophanes composition literally raises the level of discourse that the poet prescribes as appropriate to the chaste symposium he orchestrates; and the Theognidean elegiacs create a sympotic space via a tour of the andron, reenacting, no doubt, the age-old custom governing both drink and song, the traditional order epi dexia, from left to right. The symposiarchspeaker of the poem has asserted his authority, exhorting each guest in turn, transforming the motley crew into a unified company, and restoring the reciprocal harmony (charis) that is the hallmark of the symposium.

\section{Works Cited}

Berquist, B. (1990). 'Sympotic space: A functional aspect of Greek dining-rooms', in Murray (ed.) (1990): 37-65.

Bonanno, M.G. (1990). L'allusione necessaria. Ricerche intertestuali sulla poesia greca e latina. Rome: 125-146. (= 'Alcaeus fr. 140v'. Philologus 120 (1976): 1-11).

Bookides, N. (1990). 'Ritual dining in the sanctuary of Demeter and Kore in Corinth: Some questions', in Murray (ed.) (1990): 5-94.

Carrière, J. (1948). Théognis. Poèmes élégiaques. Paris.

Cirio, A.M. (1995). 'Alceo, Fr. 140v'. RccM 37: 179-186.

(2001). 'Nuovi dati sul culto degli eroi: una interpretazione di Alceo 140 v', in S. Ribichini, M. Rocchi, and P. Xella (eds), La questione delle influenze vicino-orientali sulla religione greca: prospettive della ricerca. Atti del colloquio internazionale, Roma 20-22 Maggio 1999. Rome: 299-305.

29 See Neer (2002) 87-134.

30 E.g. Cicero, De Oratore 2. 352-354; Quintilian Institutio oratoria 11.2.11-16. 
Colesanti, G. (1995). 'La disposizione delle armi in Alc. 140 V'. RFIC 123: 385-408.

Detienne, M. (1965). 'En Grèce archaïque: géométrie, politique et société. Annales 20: 425-441.

Faraone, C.A. (2008). The Stanzaic Architecture of Early Greek Elegy. Oxford.

Gerber, D. (1999). Greek Elegiac Poetry. Cambridge, MA.

Gericke, H. (1970). Gefäßdarstellungen aufgriechischen Vasen. Berlin.

Goldstein, M.S. (1978). 'The Setting of the Greek Ritual Meal in Greek Sanctuaries 6oo300 в.C... Ph.D. dissertation, Berkeley.

Hobden, F. (2013). The Symposion in Ancient Greek Society and Thought. Cambridge.

Kourayos, Y. (2005). 'Despotiko Mandra: A sanctuary dedicated to Apollo', in M. Yeroulanou and M. Stamatopoulou (eds), Architecture and Archaeology in the Cyclades: Papers in honour ofJ. J. Coulton. Oxford: 105-133.

Lesher, J.H. (1992). Xenophanes of Colophon. Fragments. Toronto.

Lissarrague, F. (1990). The Aesthetics of the Greek Banquet, transl. A. Szegedy-Maszak. Princeton (= Un Flot d'Images. Paris 1987).

Marcovich, M. (1978). 'Xenophanes on drinking parties and Olympic games'. ICs 3:1-26. Marzullo, B. (2009). Il "miraggio" di Alceo. Berlin.

Murray, O. (ed.) (1990) Sympotica: A Symposium on the Symposion. Oxford.

Neer, R. (2002). Style and Politics in Athenian Vase-Painting. Cambridge.

Page, D. (1955). Sappho and Alcaeus: An Introduction to the Study of Ancient Lesbian Poetry. Oxford.

Perrotta, G., Gentili, B., and Catenacci, C. (2007). Polinnia (third ed.). Florence.

Rösler, W. (1980). Dichter und Gruppe. Munich.

Rossi, L.E. (1983). 'Il simposio greco arcaico e classico come spettacolo a se stesso', in Spettacoli conviviali dall'antichità classica alle corti italiane del '4oo: Atti del VII ${ }^{\text {mo }}$ convegno di studi. Viterbo: 41-50.

Roux, G. (1973). 'Salles de banquets à Délos', in Études déliennes. BCH suppl. 1. Athens: 525-554.

Schmitt-Pantel, P. (1990). 'Sacrificial meal and symposion: Two models of civic institutions in the archaic city?', in Murray (ed.) (1990): 14-33.

_ (1992). La cité au banquet: Histoire des repas publics dans les cités qrecques. Rome.

Snodgrass, A.M. (1967). Arms and Armour of the Greeks. Ithaca, NY.

Spawforth, A. (2006). The Complete Greek Temples. London.

Tomlinson, R.A. (1990). 'The chronology of the Perachora hestiatorion and its significance', in Murray (ed.) (1990): 95-101.

Treu, M. (1952). Alkaios Lieder. Munich.

Will, E. (1976). 'Banquets et salles de banquet dans les cultes de la Grèce et de l'Empire romain', in P. Ducrey (ed.), Mélanges d'histoire anciennes et d'archéologie offerts à Paul Collart. Lausanne: $353-362$. 


\title{
Turning Sound into Sight in the Chorus' Entrance Song of Aeschylus' Seven against Thebes
}

\author{
Caroline Trieschnigg
}

\section{Introduction}

The appeal to the imagination in Aeschylus' Seven against Thebes, first performed in $467 \mathrm{BC}$, is already clear in the play's title: the seven attackers from Argos under Polynices' command never appear on stage. ${ }^{1}$ Still, they have a central role in this play and the spectators are able to conjure up a vivid picture of the Argive enemies based on various descriptions by the characters on stage. The scout gives the Theban king Eteocles an overview in the prologue and a detailed report of the seven attackers in the so-called 'shield scene' in the second episode. The most emotional and vivid description is given, however, by the chorus in its entrance song.

The chorus in this play is a group of Theban girls who panic as their city is about to be attacked. Their behavior and verbal expressions help the audience to visualize the dangers that await the city of Thebes. This chapter explores the remarkable way in which the chorus' entrance song stimulates vision among the spectators. The picture that the chorus sketches of the enemy results from what the chorus says it is hearing rather than seeing outside the city walls. This 'ear-based' image contrasts sharply with the scout's eyewitness report. At the same time, the chorus in its movements and behavior acts out the enemy approaching the city. In this way the audience sees the enemy visualized on stage.

After a few general comments on vision in tragedy, I will analyze the soundbased visualization of the enemy in the parodos. Next, I will compare the cho-

1 I do not mean to suggest that Aeschylus himself invented this title. Lech (2008) discusses the question of when the play received its traditional title in relation to the play's revival as a single play between 411 and 405 B.c. I would like to thank the participants and organizers of the Look of Lyric Conference, in particular André Lardinois, Richard Martin, Anton Bierl and Claude Calame for their valuable suggestions. The Greek text of the Seven against Thebes is that of the Loeb edition of Sommerstein (2008). Translations also are Sommerstein's unless noted otherwise.

(C) CAROLINE TRIESCHNIGG, 2016 | DOI: 10.1163/9789004314849_010

This is an open access chapter distributed under the terms of the Creative Commons AttributionNoncommercial 3.o Unported (CC-BY-NC 3.0) License. 
rus' description of the enemy with the scout's report and relate their differences to the different characters of the scout and the chorus. Furthermore, I will show how the chorus acts out the enemy, and discuss the opposition between hearing and seeing in the play. Finally, I will briefly examine the rest of the play and make some suggestions about visualization in other tragedies of Aeschylus in order to answer the question 'how exceptional is the use of visualization in the Seven?'.

\section{Actual Vision and Visual Imagination in Tragedy}

An examination of vision in tragedy can deal with actual or imaginary vision during the performance. What did the Athenian spectators actually see when they watched the chorus and actors performing the Seven against Thebes on stage? At the centre of the theater was a circular orchestra, in which a chorus of twelve men sang and danced. The chorus members wore costumes and masks impersonating a group of Theban girls. ${ }^{2}$ It is uncertain whether the Seven against Thebes was performed with a skênê building. There may have been at least a tent where actors could change masks and costumes during their performance. The stage where the actors played may have been higher than the level of the orchêstra, where the chorus sang and danced. In the entrance song the chorus supplicates the gods for the city's rescue. Since the chorus addresses eight gods by name (109-152), it is not unlikely that the stage represented the acropolis of Thebes and contained the statues of these Theban gods. ${ }^{3}$ The girls perhaps carried peploi (robes) and garlands and clothed the images of the gods with these. ${ }^{4}$ The audience saw this group enter screaming and running. ${ }^{5}$

2 It is unclear whether the age or status of the women was immediately visible to the audience. Little is known about costumes and masks in drama. On this topic see Pickard-Cambridge (19882) 208-209, Gould (1989) 24-27, Green (1994), and Taplin (1997).

3 Stehle (2005) 101-102 (with references). On the playing space in the Seven see Ley (2007) 2023. For a detailed reconstruction of the distribution of the statues on stage see Wiles (1997) $114-119$ and $197-200$. Cf. too Groeneboom (1938) 78 on lines 1-77, 99 on lines 78-180, and 136 on lines 287-368, Thalmann (1978) 88-89 and Edmunds (2002) 106-107.

4 This is suggested by the question the chorus asks itself in lines 101-102. However, if the girls carry peploi and garlands with them, this is not mentioned later on by Eteocles, unlike the other behavior of the chorus. See Trieschnigg (2009) 89 .

5 This group of anxious girls may convey to the audience a highly contrasting picture to that of the prologue, where Eteocles addresses a probably physically present group of Theban citizens. See Taplin (1977) 130 and Trieschnigg (2009) 63. 
The use of masks, a decorated stage and special attributes helps to create the dramatic world on stage. Yet the restrained stage scenery implies that the audience would have needed extra information and had to use their imagination to visualize the dramatic situation: the verbal performance by the actors and the chorus is the main device in the Seven against Thebes to bring to life the Argive attack on the city of Thebes. It is no surprise then that the tragedy's text functions as a script containing much information about the dramatic setting. ${ }^{6}$ The prologue in particular helps to inform the audience about the time and place of

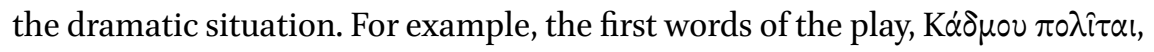
citizens of Cadmus, indicates that the location is the city of Thebes.

Tragedies narrate also actions that are not visualized on stage. Violence is usually not put on stage. Most cases of murder and suicide take place outside the city or inside the skênê building, representing a palace or another building, and are reported by messengers. In the Seven, the Argives are never seen on stage because they never enter the city. The confrontation between the Argives and the Thebans, and in particular the fight between Polynices and Eteocles, are discussed extensively on stage beforehand. The outcome is reported by a messenger in the third episode.

Tragedies do not differ from epic or non-dramatic lyric in their appeal to the imagination of the audience through long narratives when telling or singing of other realities. For example, the chorus of Alcman's First Partheneion ( $P M G F$ 1) tells an old story of Castor and Polydeuces. Lack of evidence about choreography makes it impossible to determine whether this chorus acted out this story in its dance movements. Wiles and Foley speculate about the mimetic action of the chorus in tragic songs. ${ }^{7}$ In the Seven against Thebes, the chorus probably acted out the movements of the Argive enemy, as I will explain later.

Though the urge to arouse imaginary visualization is an important feature of both tragic and non-dramatic choruses, tragic lyric differs from other lyric in the setting of the choral singing. ${ }^{8}$ A non-dramatic ritual or song is performed

6 Cf. Taplin (1977) 28-39 and (1978) 4-5.

7 Wiles (1997) ch. 4, reconsidered by Foley in a paper 'Reconsidering "The Mimetic Action of the Chorus", delivered at the Annual Meeting of the American Philological Association in Philadelphia in January 2012.

8 For want of a better term, I use 'non-dramatic chorus' to refer to a chorus which does not perform in a tragedy, comedy, or satyr play. Alternative terms are 'cultic chorus' (Zimmermann [2002], cf. Calame [1994-1995] 136-138), 'ritual chorus' (Stehle [2004] 121), 'lyric chorus' (Wilson [2000] 134 and Murnaghan [2005] 189), or 'melic chorus' (Stehle [2004] 150, referring to Calame [1999] 151). A problem with these positive terms is that they can also apply to the tragic chorus. 
before an audience to whom the context of the performance is already known, for the audience itself is part of the performance: for example, the audience of Alcman's First Partheneion would have known the occasion of the song. Although an audience of a tragedy knows the performance context of the Dionysia festival, it must be told about the imaginary world of the play before it can situate the tragic chorus' song.

\section{The Chorus' Sound-Based Representation of the Argives}

Let us turn to the representation of the Argives in the prologue and parodos of the Seven against Thebes. The descriptions of the scout (42-61) and the chorus (79-127 and 151-165) only agree on the outlines. The main part of the scout's narrative concerns a report about the oath-swearing and lot-drawing by the seven leaders of the Argive army (42-56). The scout concludes his account with a short remark to the effect that the Argive army is approaching (59-61). The chorus' description in the parodos gives the impression of being mainly an expansion of this final general remark: it contains a vivid picture of the approaching Argive army but adds few details on the seven leaders (124-127). ${ }^{9}$

These different descriptions result from the different ways the scout and the chorus obtain their information. The scout achieves his knowledge about the enemy by visual perception: he has been sent outside the city walls by Eteocles and has actively spied on the Argives, calling himself $x \alpha \tau o ́ \pi \tau \eta$ ('overseer', 41)

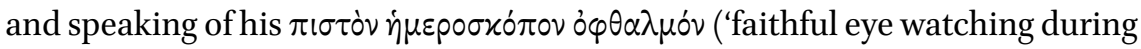
daytime', 66-67). ${ }^{10}$

Unlike the scout, the chorus becomes aware of the enemy because it hears the Argives coming. I would argue that the chorus bases its description mainly on aural perception, given the numerous words for sounds and hearing and the very few references to sight and seeing. As far as I know, Helen Bacon is alone in noting the dominance of sound in the parodos and first episode as well as the contrast with the scout's sight, but she fails to provide an explanation. ${ }^{11}$

9 Several of the scout's words in lines 59-61 recur in the parodos: 'Apreíwv recurs in 120

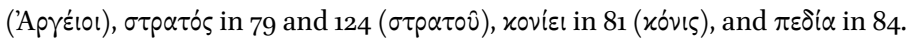

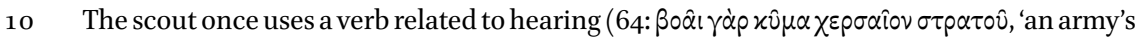
wave on dry land roars').

11 Bacon (1964) 29 notes that sound predominates in the first two choral songs and the first episode, whereas the 'messenger, who is the means by which the sights and sounds of the war outside the gates are transmitted is called a $x \alpha \tau$ ' $\pi \tau \eta$ ('one who sees', lines 41 and 
Some scholars, such as William Thalmann, argue for an alternation of visual and acoustic descriptions in the chorus' entrance song, but this view should be rejected, as I will show presently. ${ }^{12}$

The chorus does not consider itself a messenger at the lookout. It presents itself as someone being informed rather than someone informing others. ${ }^{13}$ The dust in the air announces the Argive arrival to the chorus at lines $81-82: !^{14}$

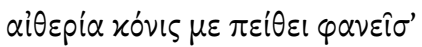

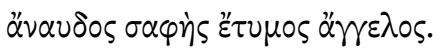

The appearance of dust in the air persuades me, a voiceless, clear, and true messenger. ${ }^{15}$

Here at the beginning the chorus sings of the dust it sees. ${ }^{16}$ It turns out that being within the city walls, the girls can only see what is (high) in the air, although they are perhaps imagined as standing on the acropolis (240). ${ }^{17}$ From their vantage point they can just catch a glimpse of what is happening outside the wall. ${ }^{18}$ On the whole, the chorus relies on aural perception for its description of the enemy. It hears the horses' hooves in lines 83-84:

$369)$ '. She considers seeing and hearing as two vehicles of knowledge, rather than in opposition to each other. Lupaş and Petre (1981) 46 on lines 81-82 merely mention the opposition between seeing and hearing.

12 On the question whether the chorus can see the attacking army see Thalmann (1978) 89 and 168 n. 24. Mesk (1934) 455 suggests that in the beginning the chorus cannot yet hear the enemy but can only see them. This is incorrect as the enemy's sound is the reason why the girls enter (203-207, quoted below).

13 I will return to this active versus passive distinction below (see note 44 below on hearing vs seeing).

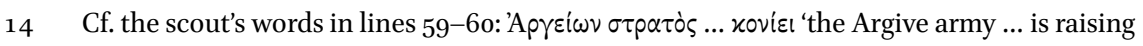
dust'. Johansen and Whittle (1980) on A. Supp. 180 note that a cloud of dust 'is notoriously the first intimation that an army is approaching', with references.

15 My translation.

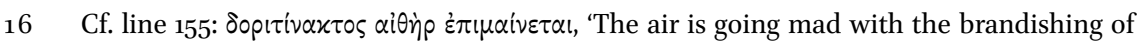
spears'.

17 The audience in Athens may have been aware that the Theban acropolis was not as high and steep as the Athenian one. See Schoder (1974) 220 on 'The low broad acropolis of the Kadmeion citadel'; I thank Stephan Mols for this reference and his suggestions about the landscape around Thebes.

18 Compare the prologue of E. Phoen. In Euripides' play the servant has a function similar to that of the scout in the Seven. The servant says he is well informed about the Argive 


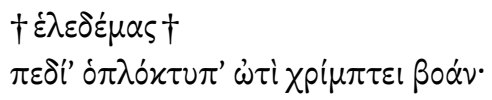

The soil $\langle$ of my land〉, struck by hooves, sends the noise right to my ear!

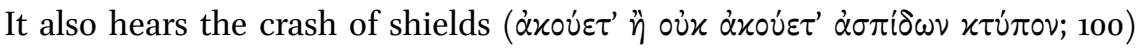

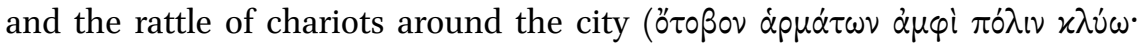
151). ${ }^{19}$ Examples of other noises are: the clashing of spears ( $\chi \tau \dot{v} \pi \circ v$ and $\pi \dot{\alpha} \tau \alpha \gamma \circ \varsigma$,

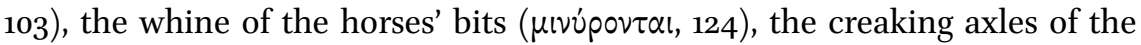
chariots ( $(\dot{z} \lambda \alpha x \circ v, 153)$, a shower of stones struck from afar ( $\alpha$ x poßó $\left.\lambda_{0} \circ \lambda_{1} \theta \dot{\alpha} \varsigma, 159\right)$,

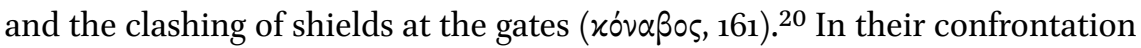
with Eteocles in the first episode, the girls emphasize that the sounds of the enemy terrified them and made them run to the gods' statues. ${ }^{21}$ Their first words addressed to Eteocles summarize the noises mentioned in the parodos, lines 203-207:

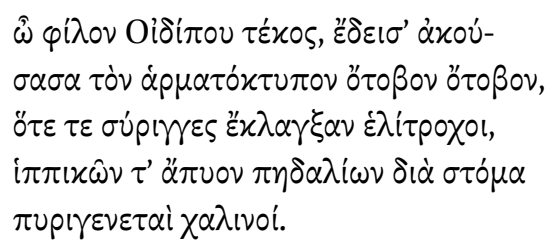

Dear son of Oedipus, I was frightened when I heard the sound of the rattle, the rattle of the chariots, and the noise of the whirling sockets of their wheels,

situation, because he went to Polynices to offer him a truce (E. Phoen. 95-98, cf. [142144]). In the prologue he is standing on the roof of the palace. He tells Antigone to climb the ladder so she will see the enemies whom he will explain to her (E. Phoen. 100-103). This scene recalls the teichoscopia in Iliad 3, but the explicit explanation of how Antigone sees the Argives may also be a reference to the parodos in the Seven. Antigone standing on the roof sees more of the enemy than the chorus standing near the statues of the acropolis.

19 In the dialogue with Eteocles which follows, the chorus also refers to its hearing: 203-204

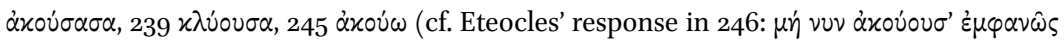

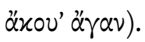

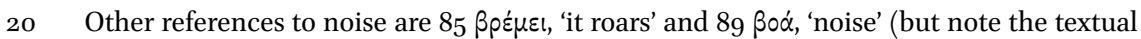
problems).

21 Also see lines 211-213, 239-241; cf. 245-246, 249. 
and when the fire-fashioned bits that are horses' steering-gear howled in their mouths.

Some of the chorus' remarks suggest that it sees more of the enemy than merely the dust in the air, though without altering the overall impression that the chorus bases its depiction of the enemy on sound. First of all, the chorus uses a

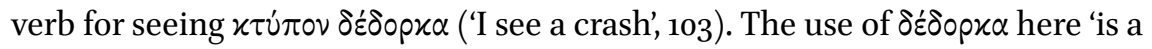
fairly common extension of the specific "see" to the general "perceive", because the object of $\delta \varepsilon \delta \delta \rho p \alpha$ is a sound'.22 Being at most an example of synaesthesia, $\delta \varepsilon \delta \delta \rho p \alpha \alpha$ is the only self-reference by the chorus to seeing in the parodos and first episode. This contrasts with the frequent use of verbs of hearing.

Furthermore the chorus uses several adjectives with apparently visual details about the enemy: $\lambda \varepsilon \dot{x} x \alpha \sigma \pi \mathrm{l}$ ('white-shielded', 90), ${ }^{23} \delta 0 \chi \mu 0 \lambda \circ \varphi^{\prime} \omega \nu$ ('with slanting, nodding plume', 114 ), ${ }^{24}$ and $\chi \alpha \lambda \varkappa 0 \delta \varepsilon \tau^{\prime} \omega \nu$ ('bronze-rimmed', 161). All of these may be considered stock epithets in poetic descriptions of warriors, which may explain their presence in a narrative dominated by sound. ${ }^{25} \mathrm{X} \alpha \lambda$ -

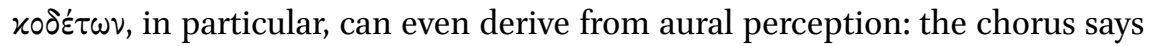
that it hears the clashing of shields, which it calls $\chi \alpha \lambda \varkappa 0 \delta \varepsilon \tilde{\varepsilon} \omega \nu$, 'bronze-rimmed'. If the girls cannot see the shields they must have deduced the bronze rims otherwise, perhaps from the noise of the clashing shields or from the tradition that shields are made from bronze.

Finally the descriptive passage in lines 125-127 implies visual perception:

22 Rose (1957) 171 on line 103 (with examples); cf. Tucker (1908) 30 on line 100: 'The verb of seeing is somewhat freely applied in Greek' (with examples). Sommerstein (2008) 163 n. 15 explaining line 103: 'it creates a vivid picture in my mind's eye'. Strictly speaking, this line combines a verb for seeing with an object of sound, which would make it an example of synaesthesia. Stanford (1942) 107 argues in favor of synaesthetic imagery. Edmunds (2002) 107 also notes the synaesthesia in this passage and argues for a dramaturgical function.

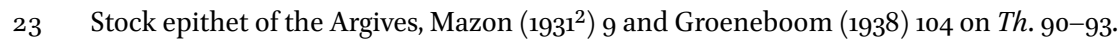

24 Though this is a hapax, the phenomenon of nodding helmet-crests as the warrior moves is familiar from Homer onwards and has a fearsome connotation, Sommerstein (2008) 165 n. 17. For the fearful association of a nodding crest see $I l .3 .337,16.138$, cf. 6.469, 15.537, A. Th. 384 .

25 In lines 90-91 the chorus uses the word $\varepsilon \dot{\pi} \pi \rho \varepsilon \pi \eta \dot{\varsigma}$ or $\varepsilon \dot{\tau} \tau \varepsilon \varepsilon \pi \eta \dot{\zeta}$ of the Argive army. Hutchin-

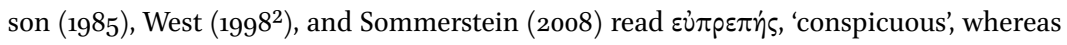

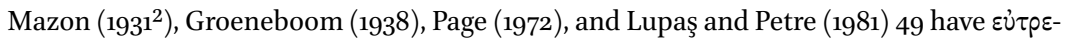
$\pi \eta \dot{\varsigma}$ 'prepared', 'ready'. Both readings occur in the manuscripts. $\varepsilon \dot{\pi} \pi \rho \varepsilon \eta \dot{\zeta} \varsigma$ concerns outward appearance, implying visual perception. Yet the word does not occur frequently as a description of persons. I therefore consider it more likely that we should read $\varepsilon \dot{\tau} \tau \varepsilon \pi \eta \dot{\zeta} \varsigma$. 


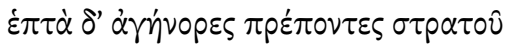

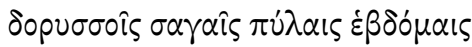

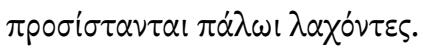

and out of the army seven distinguished leaders of men, assigned by lot, are taking their stand

against the seven gates,

fully armed, brandishing their spears.

I suggest that the chorus derived this information from the scout's report, or from similar reports that the girls may have heard in the city, rather than from its own observation. This assumption would also explain why the chorus does not elaborate on the appearance of the Argive leaders taking their positions.

The references to visual perception are very few in number, while sound dominates the choral song. Lowell Edmunds considers the possibility that at the time of performance sounds were produced off-stage to represent the noise of the Argive army and could be heard by both the chorus and the audience. ${ }^{26}$ The chorus concentrates its remarks on sounds and hearing. The production of real sounds during performance would reinforce this focus on hearing. The result is nevertheless that the audience is able to visualize the approaching Argives. Perhaps Aeschylus employed this dramaturgical technique on purpose, just as horror movie producers do nowadays: when spectators do not see anything but hear particular noises the danger becomes all the more chilling. ${ }^{27}$

\section{The Chorus versus the Scout}

I will now relate the different ways in which the chorus and scout perceive the enemy to other differences. The narratives of the chorus and scout also differ in tone. The chorus' description of the Argive army is punctuated with terrified screams and prayers, conveying a sense of panic to the audience. This contrasts with the restrained report by the scout based on facts and focused on finding an appropriate military response.

26 Edmunds (2002) 107-108. Moutsopoulos (1959) $53 \mathrm{n} .17$ states that it is certain that these noises were reproduced in the theater, citing Pl. Resp. 3.396a-b, but this view is rejected by Stanford (1973).

27 I owe this suggestion to Richard Martin. One may think of movies by Hitchcock, such as Psycho (1960), or the Blair Witch Project directed by Daniel Myrick and Eduardo Sánchez (1999). 
This emotive difference is also evident in the different modes of delivery. The scout speaks in iambic trimeters whereas the chorus sings in lyric meters. This is more than a formal distinction between actors and chorus. Lyrics in tragedy are generally considered to be more suitable to express emotion, and here the chorus' lyric meter can be said to signal panic for two reasons. In the first place, it is striking that the chorus does not enter the orchêstra with recitative anapaests, but sings in a lyric meter from the start. In the second place, the meter in itself, consisting of dochmiacs, is suited to expressing urgency or emotion. The dochmiac song characterizes the panic-stricken girls of the chorus, who may also have entered out of formation or conveyed distress in their dance. $^{28}$

This difference in emotive tone can be explained from the different perspectives of the scout and the chorus. The scout, who has been sent by Eteocles to spy on the enemy (36), is a self-assured messenger: he says he is bringing clear information from the army outside, ${ }^{29}$ and he calls himself an overseer of the situation. ${ }^{30} \mathrm{He}$ ends his speech by emphasizing the reliability and importance of his observations (66-69):

$$
\begin{aligned}
& x \dot{\alpha} \gamma \dot{\omega} \tau \dot{\alpha} \lambda \circ เ \pi \dot{\alpha} \pi l \sigma \tau \dot{\partial} \nu \dot{\eta} \mu \varepsilon \rho \circ \sigma x o ́ \pi \circ \nu
\end{aligned}
$$

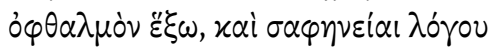

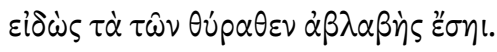

And I for the rest will have a trusty lookout, my eye, and knowing by the clarity of my word the things outside you will be unharmed. ${ }^{31}$

The scout is confident that he can provide Eteocles with useful military advice. His confident attitude contrasts with the confusion of the chorus: the Theban girls are struck with panic as soon as they become aware of the enemies' approach. They do not know how to respond. They pose questions to the gods and to each other expressing uncertainty about what is going to happen

28 Scott (1984) 81 and 160 and Stehle (2005) 104. On the use of dochmiac meter in drama see Dale (19682) 104-119, esp. 110-111, Rosenmeyer (1982) 34-35, West (1982) 108-115 and Scott (1984) 217 n. 26 for further references. Ley (2007) 138-143 (cf. 198) discusses the possible significance of individual meters in tragedy with special reference to Scott's approach.

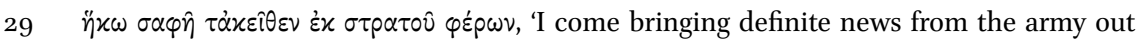
there', 40.

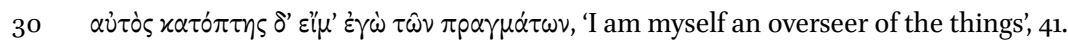

31 My translation. 
and what they should do. They scream and run. Thus, the parodos opens with the words $\theta p \varepsilon \dot{0} \mu \alpha \iota$ l $\varphi \beta \varepsilon \rho \dot{\alpha} \mu \varepsilon \gamma \alpha \dot{\lambda} \lambda$ ' $\alpha \chi \chi \eta$ ('I shriek heavy fearful pains', 78). ${ }^{32}$

\section{The Chorus Mimicking the Argive Army}

The differences in perception, emotional expression and self-confidence do not lead to a clash between the scout and the chorus in the play. Yet the chorus' panic and terrified behavior is criticized vehemently by Eteocles in the first episode. He accuses the girls of endangering the city by their wild screaming and running, which spreads panic and cowardice among the citizens while aiding the enemy (191-194). Like the Argive army, the chorus is an enemy to the city. This parallel can be drawn further. First of all, just as the Argives are said to produce a lot of sounds, the chorus itself makes a lot of noise: this already becomes clear from the chorus' first words in line 78 (quoted above).

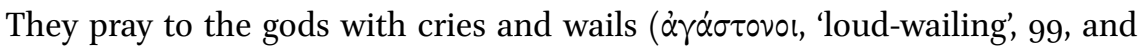

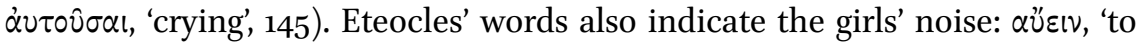
cry', and $\lambda \alpha x \alpha$ ' $\zeta \varepsilon l v$, 'to howl' (186). Eteocles orders the chorus several times to be quiet $(232,250,252,262)$ and not to terrify the Thebans $(262)$ but to give them confidence (270).

Secondly, many of the words for sounds, which the chorus uses to describe the enemy, can be used of choral performative actions. ${ }^{33}$ For example, the verb $\beta \rho \varepsilon \dot{\mu \varepsilon}$ เ in line 85 , referring to the clash of arms, can denote the sound of music. ${ }^{34}$ $\chi \tau \dot{\pi} \pi \circ v$ in line 100, meaning the crash of shields, can also be used of voices and music. ötoßov in lines 151 and 204 denotes the rattling of chariots, but can also refer to the sound of a flute. бóptres in line 205 concerns the holes in the naves of wheels but can also refer to musical pipes. The use of these words enhances the semblance between the Argive army and a chorus. ${ }^{35}$

Thirdly, when referring to itself, the chorus once uses a word that can also apply to a military group: $\lambda$ óxos in line 110. Its usual meaning is 'ambush', but it can also denote the men who tend the ambush, a band of armed men or a

32 On the panic and behavior of the chorus in the parodos see Stehle (2005) and Trieschnigg (2009) 67-101 with references.

33 I thank Anton Bierl for this suggestion.

34 Cf. $\beta$ pópos in lines 213 and 476.

35 For performatives of choral dance see Bierl (2001) 59-60, 107-110 and 130-150 (with a discussion of Ar. Th. 947-100o; this passage contains $x \tau \cup \pi \varepsilon i \tau \alpha l ~(995)$ and $\beta p \varepsilon ́ \mu 0 \nu \tau \alpha l ~(998 b)$ in a choral sense). For ö $\tau 0 \beta$ ○ used as the sound of a flute see s. Aj. 1202. For $\sigma \hat{v} p l \gamma \xi$ in the sense of a musical pipe see Il. 10.13 or s. Ph. 213. 
group of people in general. It is used twice in the rest of play, both times by the scout to refer to troops of soldiers of the Argive enemy, in lines 56 and $460 .{ }^{36}$ Dawson also notes that $\lambda$ óxos both occurs in 56 and 110, and he explains: 'the group Eteocles has to cope with inside the city is similar to the enemy outside. ${ }^{37}$ So by $\lambda$ óxos, the chorus uses a word that elsewhere describes the enemy in the play and has a military connotation.

The resemblances between the Argive army and the chorus provide the audience with another means to visualize the enemy: the Theban girls themselves mirror the Argive army with their wild running and screaming. ${ }^{38}$ The chorus of Theban girls brings the 'chorus' of the army to life. Behaving like a disordered army, the chorus visualizes war.

The resemblance between the chorus and the Argive army exists only to a certain degree and is mainly confined to the domain of sound. Visually, the chorus on stage represents young girls. The chorus' sounds, however, are not merely girlish screams but also resemble the noises of the approaching enemy. A closer look at the presentation of the second strophe and antistrophe (150157 and 158-165) can illustrate this. Both strophe and antistrophe start with a

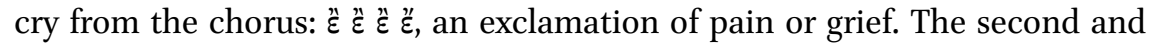
fourth lines of both strophes describe noises from the enemy $(151,153,159$, 161, mentioned above). The third and fifth lines are invocations of the gods by the chorus. Together, the first five lines of the second strophe and antistrophe present a close alternation of sounds by the chorus and the enemy.

\section{Hearing versus Seeing}

I have shown the way in which the chorus visualizes the enemy: it gives a sound-based description and mimics the approach of the Argives in its noise and movement. The chorus' hearing contrasts with the scout's seeing, and these different ways of perception can be related to their contrasting characters and attitudes. In this section, I will take a closer look at the contrast between

$36 \quad$ The scout uses a derivative of the word when describing the seven leaders of the Argive troops in line 42: $\lambda \circ \chi \alpha \gamma \varepsilon \dot{\varepsilon} \tau \alpha$, 'troop leaders'.

37 Dawson (1970) 43. Several scholars have noted that the chorus in the Seven mirrors the Argive army: Cameron (1971) 33 and 80-81, Zeitlin (1982) 29-30, Jackson (1988) 291, Giordano-Zecharya (2006) 71 n. 64; cf. Torrance (2007) 95.

38 On similarities between an army and a chorus in ancient Greece in general see Trieschnigg (2009) $5^{0-52}$ with references. 
hearing and seeing. ${ }^{39}$ I suggest that this contrast at the beginning of the play represents a hierarchical relation and belongs to a broader set of dichotomies, which is thematized in the play also in other ways.

Several sources testify to the hierarchical relation between seeing and hearing in ancient Greece. According to Heraclitus eyes are more accurate witnesses than ears. ${ }^{40}$ The Greek verb 'to know', oi $\delta \alpha$, derives from the stem i $\delta$ - of the verb 'to see', which recurs in عiঠov and in the Latin vidère..$^{41}$ In his invocation in Iliad 2, Homer contrasts the Muses, who are present and know everything, from himself, since he only has the $x \lambda$ źos, the rumor, he hears, and knows nothing (Il. 2.484-486). Herodotus regards information derived from what he has seen himself to be more reliable than that based on hearsay. ${ }^{42}$ In tragedy, reports are considered more trustworthy when the messenger himself has witnessed the story he tells. ${ }^{43}$ Seeing entails presence and first-hand knowledge, hearing absence and second-hand knowledge.

At the start of the Seven against Thebes the chorus' hearing does not concern hearsay but the direct perception of sounds. Still, the contrast between hearing and seeing is here also related to a difference in knowledge and presence. The chorus' references to hearing imply that the chorus, being within the city, has a less immediate perception of the enemy than the scout, who went outside the city to spy actively upon the Argives. He has seen the enemy up close and his report contains reliable information for Eteocles.

This difference in knowledge and presence is related to the different ways in which the scout and the girls have been prepared for the war. The scout has

39 Christoper Brown, in his paper 'Pindar's Vision of Archilochus (Pyth. 2.54)' delivered at the original Look of Lyric conference in Delphi also discussed the relation between eyes and ears: eyes would be more trustworthy than ears.

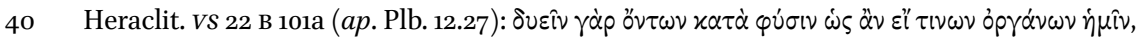

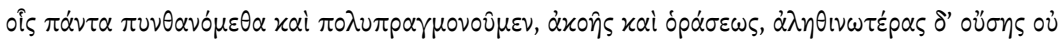

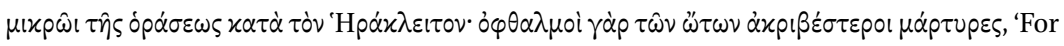
we have by nature, as it were, two organs by the aid of which we learn and inquire of everything: hearing and sight. And of the two sight is much more truthful according to Heraclitus, for eyes are more accurate witnesses than the ears' (my translation).

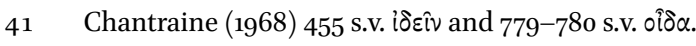

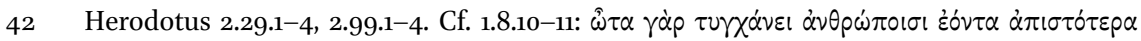
$\delta \varphi \theta \alpha \lambda \mu \hat{\omega} \nu$ ('ears happen to be less trustworthy for people than eyes'). Plato and Aristotle also rank sight over hearing and closely associate vision with reason. Pl. Ti. 47a, Tht. 156b, Arist. de An. 3.3.428b.3o f., Sens. 3.437a.3ff. and 5.445a.4ff. The first sentence of Aristotle's Metaphysics also shows a favoring of sight over the other senses. References found in Vinge (1975) 18 and Chandler (1994) Graphocentrism.

E.g. A. Pers. 266-267 and Ch. 852-853; see de Jong (1991) 9-12. 
received orders from Eteocles to spy actively. The girls, however, do not await the enemy actively or with instructions from Eteocles. Rather, their hearing of the enemy is something that happens to them unexpectedly, and this passive perception confuses and frightens them. Unlike the scout, the chorus is presented as being informed rather than informing others. ${ }^{44}$ Once they have arrived at the statues of the gods to pray, Eteocles tells the girls to be silent and stay inside (200-201, 232). Because the scout and the chorus receive different instructions from Eteocles, they perceive the enemy differently: the scout is outside the city and sees the Argives, whereas the chorus is inside the city and hears the Argives.

The dichotomy between seeing and hearing reflects traditional patterns of relations between masculine and feminine and the conventional dichotomy between men and women which was prevalent in ancient Greece. ${ }^{45}$ Separation of the sexes was an important (though not an absolute) value. Women's knowledge was often confined to the domain of hearing, whereas men were often witnesses of events outside. Andromache in Iliad 22 is an example: she knows nothing of Hector's death because she is weaving inside. ${ }^{46}$ Upon hearing a lament she wants to check her suspicions by looking outside. ${ }^{47}$ The situation in the Seven also illustrates this traditional separation between masculine and feminine. The Theban girls resemble Andromache. Hearing the clatter of arms and chariots, they get frightened and run outdoors to the statues of the gods to pray to them for protection. Eteocles, however, claims that because they are women, they should stay indoors and keep quiet: war is an out-of-doors affair and is the concern of men (200-202, 230-232) ${ }^{48}$ Eteocles' demand for a strict separation between men's and women's duties and whereabouts suits the traditional separation between men and women.

\footnotetext{
44 See lines 81-82, discussed above (p. 221).

45 McClure (1999) 19-24, and Trieschnigg (2009) 118-120. Blok (2001) 115-116 argues that this convention is part of a system of values which determined the opportunities for women in ancient Greece to perform; under certain circumstances women could act and speak in the public space.

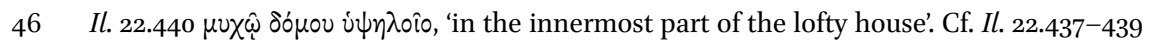

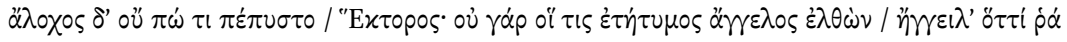

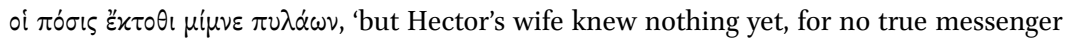
had come to tell her that her husband remained outside the gates'. Andromache becomes frightened when hearing the lament $\left(I l .22 .447-45^{2}\right)$. She wants to see what has happened (22.450, cf. 463). Translations adapted from Wyatt (1999).

47 I owe many of the examples in this section to David Rosenbloom.

48 Cf. Hector's remark to Andromache in Il. 6.490-493.
} 
The polarity between seeing and hearing, outside and inside, men and women, illustrates the conflict between two contrasting perspectives on war in this play. These dichotomies are not unique for the Seven, rather they fit traditional ancient Greek views. The scout and Eteocles embody a masculine view focusing on military strategies and achieving glory. The chorus embodies a feminine view concerned with suffering and pain. The play does not present the dichotomies in a hierarchical way such as would suggest that Eteocles is right and the chorus is wrong. The tension between their perspectives is problematized. At their entrance, for example, the Theban girls may have expressed their panic too vehemently, but Eteocles' command to them to be completely silent strikes us as being excessively harsh. Under certain circumstances women were allowed to perform in public. At the end of the first episode, Eteocles adapts his instruction: the girls can stay outside and are allowed to express a prayer.

\section{Rest of the Play}

After the first episode, the visualization in the Seven does not continue in the same way through sound and hearing. The scout returns with a description of the seven Argive leaders, and he gives Eteocles an eyewitness report. He gives an account of what the Argive leaders look like, what they say, and what their shield emblems look like. The chorus does not hear the enemy anymore, but only hears the scout's report. Neither does the chorus seem to mimic the Argive army anymore. Vision and sound are important in the scout's descriptions because all the Argives attempt to make an intimidating impression by looking terrifying and speaking horrifying words, except for the prophet Amphiaraus: he does not want to appear an excellent warrior but to be one (592), which indicates that vision can be deceptive too.

In this scene, the dramatic conflict is between the scout's reports about the Argives and Eteocles' responses concerning the Thebans who will take position against the Argives. Because the audience does not see the military leaders, this scene appeals to the spectators' imagination. The chorus combines

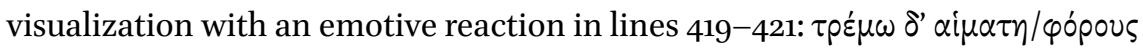

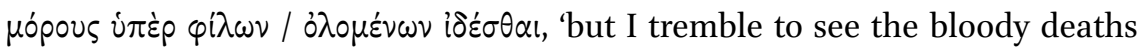
of men who perish fighting for their dear ones'. Once the chorus refers to its hearing in combination with a reaction of fear in lines $563^{-566 \text { : }}$

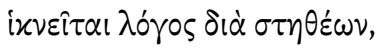

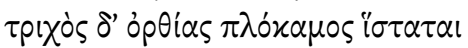




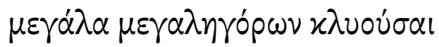

$\dot{\alpha} \nu 0 \sigma i \omega \nu \dot{\alpha} \nu \delta \rho \omega \nu$.

The word comes through my breast, and each lock of my hair stands on end as I hear the boastings

of vaunting impious men. ${ }^{49}$

The play never brings onto the stage the Argives, nor the battle between Eteocles and Polynices; only their two corpses are eventually brought before the audience, following the tragic convention not to stage violence.

\section{Other Plays of Aeschylus}

We may wonder how unique this manner of visualization at the beginning of the Seven is: is the act of seeing in general done better by characters on stage than by the chorus? Does a tragic chorus usually combine perception with emotion? I will offer a few tentative answers to these questions. Several other plays of Aeschylus suggest that a character on stage can see better than the chorus. In the prologue to the Agamemon, a watchman, sitting on the roof of the palace, sees the agreed beacon-signal that indicates that Troy has been taken. When the chorus of old men enters, it does not know that Troy has fallen, nor does it know about the beacons, but wants to question Clytemnestra about the sacrifices being made in the city on her instruction (85-103).

In Aeschylus' Suppliants, Danaus twice tells his daughters what he is seeing. The first time, he sees Pelasgus and his men arriving (180-185). Danaus' perception recalls the chorus' words in the Seven in lines 81-82 (quoted above). In both descriptions, the dust (xóvi५) is the first sign that some people are coming, and

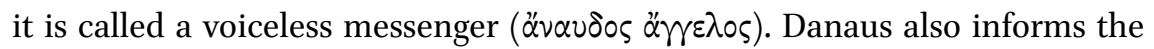
chorus when the Egyptians are coming $(713-723)$. He twice mentions his act of

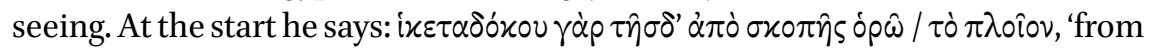
this lookout post, which received you as suppliants, I can see the boat' (713-714). He continues by saying that it is conspicuous and that the sails do not escape his notice ( ov $\mu \varepsilon \lambda \alpha \nu \theta^{\alpha} \dot{\alpha} \varepsilon \mathrm{l}, 714$ ). Later on, the chorus refers to Danaus' watching:

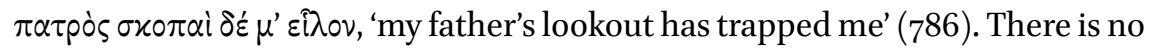
indication that the chorus sees Pelasgus and his men or the Egyptians before

49 My translation. 
they enter the stage in lines 234 and 825 respectively. Apparently Danaus can see better than his daughters from his position. Perhaps this would be easy to understand for the spectators in the theater, when they saw Danaus and the chorus at their different positions: the chorus in the orchêstra and Danaus on what was probably a raised stage.

On the whole, one may assume that individual characters are better able to see what is happening than the chorus since they can leave the stage to investigate or go onto the roof of the skênê building to claim a better view of who is approaching. Usually the chorus relies on other characters for information about what has happened or is happening elsewhere.

Tragic choruses themselves usually do not have a purely informative role, unlike the primarily informative function of a messenger or, in the Seven, a scout. Choruses also have an emotive and a performative voice. ${ }^{50}$ Aeschylean choruses in particular often express fear. In the Seven, the chorus sings of the enemy, utters fear, and prays to the gods. In the aforementioned Agamemnon, the chorus does not immediately believe Clytemnestra who tells the old men how the news about Troy's fall reached Argos (281-316). They first hear the news confirmed by a herald coming from Troy and then see it confirmed when Agamemnon appears on stage. But in the following song the chorus admits that, though it has seen the return with its own eyes ( $\pi \varepsilon v^{\prime} \theta 0 \mu \alpha 1 \delta^{\prime} \dot{\alpha} \pi^{\prime} \dot{\partial} \mu \mu \alpha^{\prime} \tau \omega \nu$ /

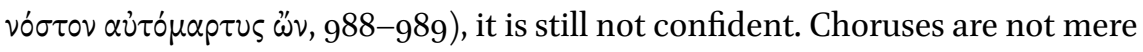
receivers or reporters of information but tend to offer an emotive response towards the action on stage.

It is no surprise, then, that the chorus in the Seven combines the description of the Argives with emotive interruptions, although the degree of panic is exceptional. I am inclined to think that the sensory play between eyes and ears is unique to the Seven. It is possible that the special sensory perception of the chorus and its difficulty to see the enemy is especially significant for the Oedipus myth, in which blindness both literal and metaphorical plays such an important role. But since we know so little about the other plays in the trilogy, it remains a matter of speculation whether the vivid sound-based picture elaborates on a theme about vision, blindness, and knowledge in the preceding play.

50 Calame speaks of a hermeneutic, emotive and performative voice: Calame (1994-1995), (1999), esp. 126-129, and (2005), esp. 217-218, discussed in Trieschnigg (2009) 42-43. On the complex role of the tragic chorus, see among others, Goldhill (1996) and Foley (2003) with further references. 


\section{Conclusion}

I have explored the ways in which the chorus stimulates vision among the spectators at the beginning of the Seven against Thebes through sound and hearing. Spectators of tragedy have to use their imagination to visualize the dramatic situation. The chorus in the Seven helps the audience to imagine what is happening by describing what it is hearing and by acting out the Argive enemy outside the city walls. This description gives a different impression of the Argive army than does the previous report by the scout. The chorus' narrative of the enemy is based on sounds and is interjected with screams and desperate questions to the gods. The scout has been spying outside the city and offers Eteocles a clear account of the Argive leaders. The chorus derives its information from sounds, but at the same time it also produces a lot of sounds itself: according to Eteocles, the chorus' screams pose a danger to the city comparable to the Argive noises. Both the chorus' description and its behavior help the audience to imagine a frightening enemy outside the city walls.

The contrast between seeing and hearing is part of a broader set of dichotomies in the play. The chorus' description contains less detailed information than that of the scout, and more expressions of fear. The differences between the chorus and scout can be related to differences attributed to gender. In ancient Greece, hearing, fear, confusion, and being inside the house were associated with the domain of women, whereas seeing, self-confidence, and taking care of the things 'outside' were associated with the domain of men.

The differences between the chorus and the scout can also be ascribed to the different modes of delivery. The chorus' lyrics are more suitable to express emotion than the iambic trimeters of the scout. In this respect, the chorus of Theban girls resembles non-dramatic choruses who can express feelings of uncertainty as a response to a frightening situation. Yet, there is a difference: non-dramatic choruses also provide the audience with a 'model' of how to overcome these emotions, by demanding a critical stance and a certain amount of self-control. ${ }^{51}$

Pindar's Paean 9, for example, can be considered a response to a frightening situation. It was performed at Thebes after a solar eclipse, probably in 463 BC. ${ }^{52}$ The speaking 'I', either a male solo singer or a male chorus, asks for divine aid to avert a threat against the Theban community. Also the entrance song

$51 \quad$ Calame (2005) 229.

$5^{2}$ On this song see Stehle (1997) 46-51, Rutherford (2001) 189-200 and Stehle (2004) 138-139. 
in the Seven bears signs of a supplication to the gods to avert evil. Yet there are some crucial differences between these two songs. Unlike the chorus in the Seven, the chorus of Pindar's paean does not express vehement emotion: in spite of the supplication, the song does not contain explicit references to fear or indications of running or shouting. Furthermore, Pindar's song displays a change of emotional tone in the course of the prayer from 'an admission of helplessness' to 'an assertion of confidence', as Eva Stehle has argued. ${ }^{53}$

In the chorus' entrance song of the Seven, however, confusion prevails over an encouraging prayer and the girls display little self-control. The vehemence of the chorus' emotion at the start of the play can be explained better by reference to the chorus' identity as frightened girls rather than by attributing it to the emotive expressions of (non-dramatic) lyric. In the course of the play, the chorus' strong emotions disappear and it is able to comment on the situation with more self-control. ${ }^{54}$ This way it becomes more like a non-dramatic chorus expressing and modeling the emotions of a larger community than merely a group of girls.

The contrast between hearing and seeing contributes to the contrast between two irreconcilable views on war in the play. On the one hand the play presents a 'male-associated' view, represented by Eteocles and the scout and focused on achieving glory. On the other hand the play shows a 'femaleassociated' view, represented by the chorus, which is antimilitaristic and focused on suffering. The beginning of the play shows how different these views are, as their views already start from two literally different ways of perception, seeing and hearing.

\section{Works Cited}

Bacon, H.H. (1964). 'The shield of Eteocles'. Arion 3: 27-38.

Bierl, A. (2001). Der Chor in der Alten Komödie. Ritual und Performativität. München.

(English trans. by A. Hollmann: Ritual and Performativity: The Chorus in Old Comedy. Cambridge, MA 2007).

Blok, J.H. (2001) 'Virtual voices: Toward a choreography of women's speech in classical Athens', in A.P.M.H. Lardinois and L. McClure (eds), Making Silence Speak: Women's Voices in Greek Literature and Society, Princeton: 95-116.

53 Stehle (1997) 50.

54 Stehle (2005) 105-108 argues that the chorus already shows more self-control in the course of the parodos. 
Calame, C. (1994-1995). 'From choral poetry to tragic stasimon: The enactment of women's song'. Arion 3: 136-154.

- (1999). 'Performative aspects of the choral voice in Greek tragedy: Civic identity in performance' in S. Goldhill and R. Osborne (eds), Performance culture and Athenian democracy. Cambridge: $125^{-153}$.

- (2005). 'The tragic choral group: Dramatic role and social functions' in R.W. Bushnell (ed.), A Companion to Tragedy, Malden, MA: 215-233.

Cameron, H.D. (1971). Studies on the Seven against Thebes of Aeschylus. The Hague.

Chantraine, P. (1968). Dictionnaire étymologique de la langue grecque: histoire des mots. Paris.

Chandler, D. (1994). 'Biases of the ear and eye: "Great divide" theories, phonocentrism, graphocentrism \& logocentrism'. https://web.archive.org/web/20150803152224/ http://visual-memory.co.uk/daniel/Documents/litoral/ [2016-02-09].

Dale, A.M. $\left(1968^{2}\right)$. The Lyric Metres of Greek Drama. Cambridge.

Dawson, C.M. (1970). The Seven against Thebes by Aeschylus. London.

de Jong, I.J.F. (1991). Narrative in Drama: The Art of the Euripidean Messenger-Speech. Leiden.

Edmunds, L. (2002). 'Sounds off stage and on stage in Aeschylus, Seven against Thebes' in A. Aloni (ed.), I Sette a Tebe. Dal mito alla letteratura. Atti del Seminario Internazionale Torino 21-22 Febbraio 2001, Bologna: 105-115.

Foley, H.P. (2003). 'Choral identity in Greek tragedy'. CPh 98: 1-30.

Giordano-Zecharya, M. (2006). 'Ritual appropriateness in Seven against Thebes. Civic religion in a time of war'. Mnemosyne 59: 53-74.

Goldhill, S. (1996). 'Collectivity and otherness - the authority of the tragic chorus: Response to Gould' in M.S. Silk (ed.), Tragedy and the Tragic: Greek Theatre and Beyond, Oxford: $244^{-25} 6$.

Gould, J. (1989). 'Tragedy in performance' in P.E. Easterling and B.M.W. Knowx (eds), The Cambridge History of Classical Literature, I/2: Greek Drama. Cambridge: 6-29.

Green, J.R. (1994). Theatre in ancient Greek society. London and New York.

Groeneboom, P. (1938). Aeschylus' Zeven tegen Thebe. Groningen.

Hutchinson, G.O. (1985). Aeschylus: Seven Against Thebes. Oxford.

Jackson, E. (1988). 'The argument of Septem contra Thebas'. Phoenix 42: 287-303.

Johansen, H.F. and Whittle, E.W. (1980). Aeschylus: The Suppliants. Copenhagen.

Lech, M.L. (2008). 'A possible date of the revival of Aeschylus' The Seven against Thebes'. CQ 58: 661-664.

Ley, G. (2007). The Theatricality of Greek Tragedy: Playing Space and Chorus. Chicago.

Lupaş, L. and Z. Petre. (1981). Commentaire aux 'Sept contre Thèbes' d'Eschyle. Bucarest.

Mazon, P. $\left(191^{2}\right)$. Éschyle, I: Les suppliantes; Les Perses; Les sept contre Thèbes; Prométhée enchainé. Paris. 
McClure, L. (1999). Spoken Like a Woman: Speech and Gender in Athenian Drama, Princeton.

Mesk, J. (1934). 'Die Parodos der Sieben gegen Theben'. Philologus 89: 454-459.

Moutsopoulos, E. (1959). 'Une philosophie de la musique chez Eschyle'. REG 72: 1856 .

Murnaghan, S. (2005). 'Women in groups: Aeschylus's Suppliants and the female choruses of Greek tragedy', in: V. Pedrick and S.M. Oberhelman (eds.), The Soul of Tragedy: Essays on Athenian Drama. Chicago and London: 183-198.

Page, D. (1972). Aeschyli Septem Quae Supersunt Tragoedias. Oxford.

Pickard-Cambridge, A.W. $\left(1988^{2}\right)$. The Dramatic Festivals of Athens, revised by J. Gould and D.M. Lewis. Oxford

Rose, H.J. (1957). A commentary on the surviving plays of Aeschylus, I. Amsterdam.

Rosenmeyer, T.G. (1982). The Art of Aeschylus. Berkeley, Los Angeles and London.

Rutherford, I. (2001). Pindar's Paeans: A Reading of the Fragments with a Survey of the Genre. Oxford.

Schoder, R.V. (1974). Ancient Greece From the Air. London.

Scott, W.C. (1984). Musical Design in Aeschylean Theater. Hanover.

Sommerstein, A.H. (2008). Aeschylus, I: Persians, Seven against Thebes, Suppliants, Prometheus Bound. Cambridge, Mass.

Stanford, W.B. (1942). Aeschylus in His Style: A Study in Language and Personality. Dublin.

- (1973). 'Onomatopoeic mimesis in Plato, Republic 396b-397c'. JHS 93:185-191.

Stehle, E. (1997). Performance and Gender in Ancient Greece. Princeton.

- (2004). 'Choral prayer in Greek tragedy: Euphemia or aischrologia?' in P. Murray and P. Wilson (eds), Music and the Muses: The Culture of Mousike in the Classical Athenian City. Oxford: 121-155.

- (2005). 'Prayer and curse in Aeschylus' Seven against Thebes'. CPh 100: 101-122. Taplin, O.P. (1977). The Stagecraft of Aeschylus: The Dramatic Use of Exits and Entrances in Greek Tragedy. Oxford.

- (1978). Greek Tragedy in Action. London.

(1997). 'The pictorial record' in P.E. Easterling (ed.), The Cambridge Companion to Greek Tragedy, Cambridge: 69-9o.

Thalmann, W.G. (1978). Dramatic art in Aeschylus's Seven against Thebes. New Haven.

Torrance, I. (2007). Aeschylus: Seven Against Thebes. London.

Tucker, T.G. (1908). The Seven against Thebes of Aeschylus. Cambridge.

Trieschnigg, C.P. (2009). Dances with Girls: The Identity of the Chorus in Aeschylus' Seven against Thebes. Ph.D. Diss. Radboud University Nijmegen.

Vinge, L. (1975). The Five Senses: Studies in a Literary Tradition. Lund.

West, M.L. (1982). Greek Metre. Oxford.

- $\left(1998^{2}\right)$. Aeschyli tragoediae cum incerti poetae Prometheo. Stuttgart. 
Wiles, D. (1997). Tragedy in Athens: Performance Space and Theatrical Meaning. Cambridge.

Wilson, P. (2000). The Athenian Institution of the Khoregia: The Chorus, the City and the Stage, Cambridge.

Wyatt, W.F. (1999). Homer: Iliad. Cambridge, MA.

Zeitlin, F.I. (1982). Under the Sign of the Shield: Semiotics and Aeschylus' Seven against Thebes. Rome.

Zimmermann, B. (2002). 'Coro e azione drammatica nei Sette contro Tebe di Eschilo' in A. Aloni (ed.), I Sette a Tebe. Dal mito alla letteratura. Atti del Seminario Internazionale Torino 21-22 Febbraio 20o1, Bologna: 117-124. 


\title{
Light and Vision in Pindar's Olympian Odes: Interplays of Imagination and Performance*
}

\author{
Michel Briand
}

In archaic Greece light and vision were understood to operate on a similar basis, namely the emission of fire-rays, which might be strong or smooth, focused or

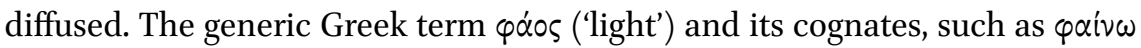

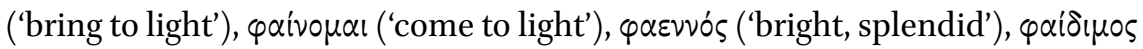
('shining, radiant'), belong to various intricate metaphorical systems and play a major role in Pindar's poetics and pragmatics of imaginary and spectacular vision (as defined below). These terms associate human and divine sights with the glare of the sun, shaping out positive concepts such as excellence, glory, success, wealth, beauty, truth, harmony, etc. In this paper I focus on the Olympian Odes and analyse two aspects: the visual images that cluster in mythological narratives, especially in Olympian 2 (the island of the blessed), Olympian 6 (Iamos' birth), and Olympian 7 (the emergence of Rhodes), and the pragmatics of light and vision that appear in the melic frame, especially in Olympian 1 (the initial priamel), Olympian 9 (the third triad), and Olympian 10. The efficiency of the light imagery, however, ultimately depends on echoes and reverberations between the two components of the odes, between the diffused daylight images and other kinds of light and vision, and between the metaphors and other textual and musical effects in the audience's imagination and reception.

First, however, I will have to make some preliminary remarks about light and vision and about the hybrid nature of Pindar's victory odes. Sight and vision were a dynamic activity for the archaic and early classical Greeks. They saw the emission of light as fiery radiation: ${ }^{1}$ the ancient Greek vocabulary of light (which can be diffuse, radiant, whirling, diffracted, or vibrating) is organized in a group of metaphorical matrices by which the actions of seeing, gleaming, burning, and showing have similar qualities and may represent each other. Thus, the lights of stars and gods are made of fire, like the blazes from human

* I would like to thank the organisers of the Delphi Conference, the participants, and the two anonymous readers who helped me to improve this piece, as well as Pascale Drouet for her translation. Any remaining errors are mine.

1 Cf. Simon (2003), especially ch. 1 ('L'optique antique et la représentation du visible').

(C) MICHEL BRIAND, 2016 | DOI: 10.1163/9789004314849_011

This is an open access chapter distributed under the terms of the Creative Commons Attribution- 
and animal eyes; stars are eyes, and vice versa. ${ }^{2}$ More significantly, both in poetic and rhetorical works, as well as in technical, scientific, and philosophical texts, there are numerous analogical (and especially metaphorical) transfers between the fields of sight, hearing, touch, and smell, in synaesthetic evocations in which light and glare figuratively represent, for instance, the strength of voices or the suavity of fragrances. ${ }^{3}$

Aristotle argues that 'unless one perceived things one would not learn or understand anything, ${ }^{4}$ while modern cognitivist philosophers, such as Lakoff and Johnson, ${ }^{5}$ speak about metaphorical thinking and 'philosophy in the flesh'. For the ancient Greeks as for most of us visual images are not bare ornaments but, like sensations, ways of thinking, feeling, and behaving, indistinctly. ${ }^{6}$ And because the words of light and colour are sung during the epinician performances, the conceptual field of light participates in building up and shaping other fields typical of praise poetry, like those of glory, wealth, excellence, and harmony, while constantly contrasting with fields of dark or violently shining opposites, like shame, dissimulation or excess. ${ }^{7}$

Visual images can be found in the mythological component of the odes (both narrative and descriptive) which, when referring to ancient times, is

2 Cf. Briand (2003b) and (2005b). Light and vision in Greek science, language, poetry, and aesthetics, are crucial anthropological issues; they are discussed in, e.g., Bremer (1976), Ciani (1974), and Frontisi-Ducroux and Vernant (1989).

3 Some of these metaphorical matrices play a significant role in other papers in this volume: see especially Katerina Ladianou's contribution (discourse / fragrance/ seeing).

4 Arist. De An. $432 \mathrm{a} 8$ (transl. D.W. Hamlyn).

5 Lakoff and Johnson (1980) and (1999), and Lakoff (1987). I here refer to cognitive poetics, especially to notions like conceptual metaphor, interaction of figures and grounds, mental spaces, or literature as parable, as presented by Stockwell (2002) and exemplified in Gavins and Steen (eds) (2003), especially in the chapters by by R. Tsur ('Deixis and abstractions: adventures in space and time', 41-54), P. Crisp ('Conceptual metaphor and its expressions', 99-111), and M. Burke ('Literature as parable', 115-128). Cf. also Semino and Culpeper (eds) (2002), e.g. the chapter by Y. Shen ('Cognitive constraints on verbal creativity: The use of figurative language in poetic discurse', 211-230, esp. on zeugma, synaesthesia and oxymoron).

6 The structure and the sensorial, ethical, religious, or cognitive efficiency of visual poetry are at the core of important Pindaric studies: cf. Duchemin (1952) and (1954), Bernard (1963), Hubbard (1985), Nünlist (1998), Wersinger (2008), and Calame (2008). This is obvious for archaic times, when poetry and philosophy were similar activities: cf. Most (1999). In this respect, enargeia has aesthetic and logical effects: cf. Calame (1991), and Lévy and Pernot (eds) (1997). For a philosophical/stylistic perspective, with a comparison between Pindar and Theocritus, see Otto (2009).

7 Cf. Briand (2003a). 
the quasi-epic nucleus of epinikia. ${ }^{8}$ Here, on the illocutionary level, the poetic performance intends to produce images and ideas in the audience's minds. These visual and acoustical images appeal to phantasia and their efficiency relies upon the joined effects of $\dot{\varepsilon} \nu \alpha \dot{p} \gamma \varepsilon i \alpha$ (vividness), $\pi 0 \varkappa(\lambda i \alpha$ (variedness), and $\sigma \alpha \varphi \eta^{\prime} v \varepsilon i \alpha$ (clarity). ${ }^{9}$ In this case, I shall speak of imaginary vision. Other visual images help structure the melic frame of the odes, which is mostly encomiastic. ${ }^{10}$ They are directly related to the ritual performance, including the poetic enunciation itself, and to the contemporary reception of the human and divine audience. This audience is sensitive to the aesthetic and deictic effects ${ }^{11}$ of musical harmony, which comprise an active association of dance, ${ }^{12}$ music, song, and lyrics. In this case I shall speak of spectacular vision. ${ }^{13}$

8 Cf. Koehnken (1971) and Mann (1994). The mythical narrative modifies the enunciative frame of the epinicians, as in hymnic poetry: cf. Calame (1995).

9 Cf. Briand (2006). For Pindar I here refer above all to Steiner (1986). Before presenting my paper at the Delphi conference and writing this article, I was not aware of Patten (2009), which is illuminating on the relations between poetics, rhetoric and philosophy (in postmodern theory as well as in Pindar), and the figurality of deep meaning, necessary for any immanent conception of interpretation. All that might seem not to be directly connected to the 'visual aspects of performance as inscribed and embodied in the poems themselves' (to quote an item from the brief of the Delphi conference), but in fact I think it is, on a metapoetic level. Cf. Patten (2009) 238: 'If the theoretical project can be seen as the attempt to view viewing, then the moments at which the methodological presuppositions of close reading subvert themselves will be a part of this necessary theoria - an abyss, perhaps, but one from which classical literary studies should no longer draw back'. This kind of visual images makes Pindar's poetry a crucial part of the religious, social, and economic system with which it interacts: cf. Gentili (1988), Kurke (1991), Dougherty and Kurke (eds) (1998), and Kowalzig (2007).

11 On deixis see e.g. Danielewicz (1990), D’Alessio (1994), and the contributions in Felson (ed.) (2004), especially those of G.B. D'Alessio ('Past future and present past: temporal deixis in Greek archaic lyric', $267-294$ ), N. Felson ('The poetic effects of deixis in Pindar's Ninth Pythian ode', 365-389), L. Athanassaki ('Deixis, performance, and poetics in Pindar's First Olympian Ode', 317-341), A. Bonifazi ('Communication in Pindar's deicitic acts', 391414), and C. Calame ('Deictic ambiguity and auto-referentiality: some examples from Greek poetics', 415-443). For epinician poetry as a combination of ritual and discursive performing art cf. Bonifazi (2001).

12 On dance in melic poetry, in a ritualistic, aesthetic, and philosophical perspective, cf. Calame (1977), Mullen (1982), Miller (1986), Lonsdale (1993), and Naerebout (1997), of special interest for methodological issues.

13 For the dialectics of ritual and performance (esp. theatre) cf. Schechner (2003) and Turner (1986). For another spectacular genre of choral poetry see e.g. the essays in Kraus, Goldhill, Foley, and Elsner (eds) (2007) by R. Martin ('Outer limits, choral space', 35-62) and 
These two discursive genres, quasi-epic and melic, ${ }^{14}$ act together, with the help of two complementary kinds of visible effects, imaginary and spectacular ones, on which the social and religious usages of the odes are grounded. ${ }^{15}$ The echoes, especially visual, between the melic and mythological components of the odes build up the cohesion and the coherence of the praise that is justified by the correspondence between past and present excellence. ${ }^{16}$ Gnomic assertions occur in both these components of the odes and appeal to ritual and imaginary vision. In the same way myths are sung by a chorus which strengthens their visual evocations with spectacular processes, while the melic frames may provoke, when sung, the audience's phantasia.

In what follows I examine firstly some mythological statements in the Olympian Odes in which visual images help to structure narratives, descriptions, and gnômai; secondly, some encomiastic utterances, based on strong spectacular effects; and finally the dialectics of those two types of vision at the core of epinician poetics. ${ }^{17}$

L. Kurke ('Visualizing the choral: Poetry, performance, and elite negotiation in fifthcentury Thebes', 63-101). For the relations between spectacular and imaginary vision see now Briand (2013).

14 I here refer to 'melic', rather than 'lyric', poetry: the category of 'lyric' might be considered a post-classical construction, and 'melic' is useful because it expresses in one term the different performative, ritual, and political aspects of epinician poetry. Cf. Calame (2000), ch. 1 ('Poésie épique et mélique: la projection du je et de son discours oral dans l'instance divine', 49-86), Calame (2006), Briand (2008a), (2008b), and (2010). For an history of the notions of 'lyric' and 'lyrism' cf. Guerrero (1998).

15 Cf. Bernardini (1983).

16 The structural cohesion of the epicinian poems relies both on the thematic and pragmatic correspondence of the myth and its melic frame (cf. Wüst [1967], Hornblower [2004], Krummen [1990], Currie [2005]), and upon the dynamic and tense coherence which Pindar's severe style produces (cf. Cole [1988], Race [1990], and Hummel [1993], on 'la valeur cohésive de la disjonction' and its 'harmonie paradoxale'). See Briand (2005a). In this respect, metaphor, on a paradigmatic level, and metonymy, on a syntagmatic one, build up an efficacious, though harsh, cooperation, typical of Pindaric style and thought: cf. Stoneman (1981). All this might become a particular way to deconstruct and actualize the question of unity: cf. Young (1964).

17 Throughout the text and translation of Pindar is from Race (1997). The critical frame to which I most adhere is a kind of 'bricolage', in Levi-Straussian terms, as developed in Budelmann (ed.) (2009), especially by C. Carey ('Genre, occasion and performance', 21-38), S. Hornblower ('Greek lyric and the politics and sociologies of archaic and classical Greek communities', 39-57), G.B. D'Alessio ('Language and pragmatics', 114-129), and H. Pelliccia ('Simonides, Pindar and Bacchylides', 240-262). 


\section{Constructing Visual Images in the Mythological Discourse: The Manifold Plays of enargeia}

The first passage I would like to discuss is Pindar's description of the Isle of the Blessed in Olympian 2.53-74:

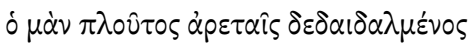

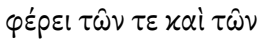

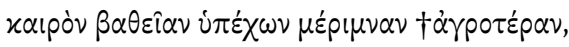

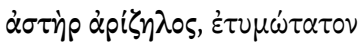

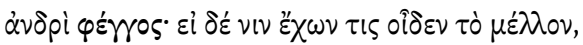

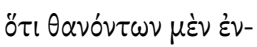

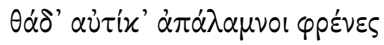

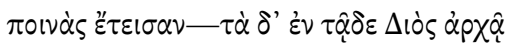

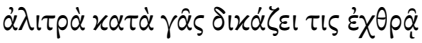

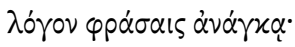

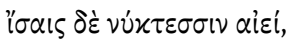

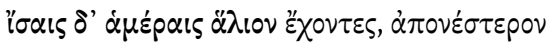

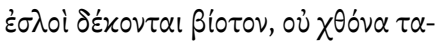

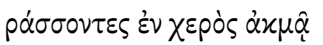

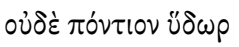

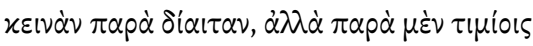

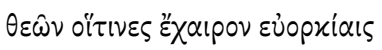

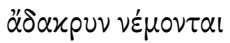

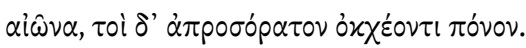

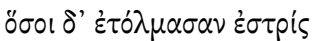

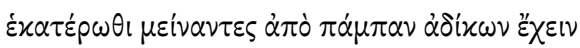

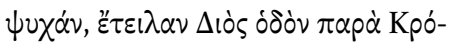

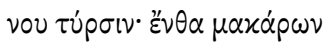

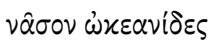

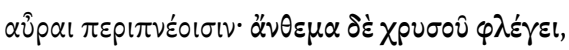
$\tau \dot{\alpha} \mu \varepsilon \dot{\varepsilon} \nu \chi \varepsilon \rho \sigma \theta^{\prime} \varepsilon v \dot{\alpha}^{\prime} \pi^{\prime} \dot{\alpha} \gamma \lambda \alpha \omega \hat{\omega} \nu \delta \varepsilon \delta \delta \rho \varepsilon \dot{c}^{\prime} \omega \nu$,

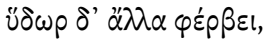

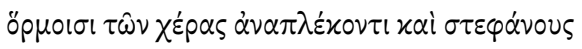

... Truly, wealth embellished with virtues / provides fit occasion for various achievements // by supporting a profound and questing ambition;

it is a conspicuous lodestar, the truest // light for a man. If one has it and knows the future, // that the helpless spirits / of those who have died on earth immediately // pay the penalty - and upon sins committed here // in Zeus' realm, a judge beneath the earth // pronounces sentence with hateful necessity;

but forever having sunshine in equal nights // and in equal days, good men // receive a life of less toil, / for they do not vex the earth // or the water of the sea with the strength of their hands // to earn a paltry living. No, in company with the honored // gods, those who joyfully kept their oaths / spend a tearless // existence, whereas the others endure pain too terrible to behold.

But those with the courage to have lived // three times in either realm, while keeping their souls // free from all unjust deeds, travel the road of Zeus / to the tower of Kronos, where ocean breezes // blow round // the Isle of the Blessed, and flowers of gold are ablaze, // some from radiant trees on land, while the water / nurtures others; with these they weave // garlands for their hands and crown for their heads, ... 
In this passage visual imagery comes to the support of rhetorical argumentation. In lines $55^{-56}$ a descriptive maxim metaphorically describes wealth

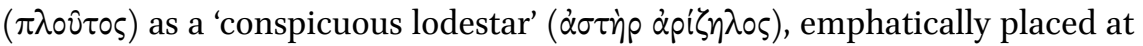
the beginning of the third epode. It brings together the semantic features of truth and light, both aesthetic and ethical, and connects these with 'the truest

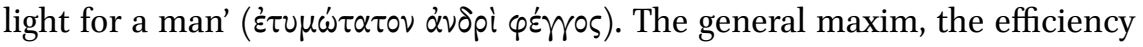
of which relies upon the poetic performance, resorts to strong visual images to make the audience reflect on ethical issues. It arouses feelings and invites them to experience the illocutionary strength of a more-injunctive-than-affirmative discourse, thanks to the enargeia complementing rhythm, melody, and dance. ${ }^{18}$ Finally it asks them to internalise the praise of wealth, in which they are directly involved. This gnômê is expanded by the description of the Isle of the Blessed in the fourth strophe and antistrophe. ${ }^{19}$ It stands between lines 61-62 (on the spring equinox steeping this paradise for good men with propitious sunshine 'in equal days') and lines $72^{-73}$, in which wealth, the topic of the visual maxim in $53^{-56}$, is exemplified in a vivid ekphrasis: flowers are made of fire - they are

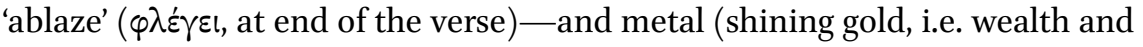
immortality), and trees are 'radiant' ( $\dot{\alpha} \gamma \lambda \alpha \hat{\omega} v)$. These visual images mainly aim at helping the audience's imagination conceive of another world, a wonderful one, in which the social and moral values that were praised in the gnômê materialize through their senses. These values are in turn reinforced by those visual pictures. ${ }^{20}$ Here imaginary vision supports mystical and moral persuasion.

Visual images can also support the narration of primary mythological events, as is the case in Olympian 6.39-58.21 This episode describes the epiphanic birth of Iamos, divine seer and ancestor of Hagesias of Syracuse, the ode's laudandus:

18 On the visual aspects of choral dance and poetry, see Carruesco's contribution to this volume.

19 About the religious overtones of this myth, cf. Hampe (1952), Lloyd-Jones (1984), Bollack (1963), and Defradas (1971). The light imagery of the poem (and its analogy with some Orphic-Pythagorean documents) plays a crucial role in its mystical or mysteric interpretations through the notions of revelation, epiphany, metempsychosis, and happy afterlife.

20 On the cultural aspects of visuality and the poetic interplay of phantasia and enargeia see the contribution of Kantzios to this volume and, more generally, Webb (2009).

21 Cf. Felson (2008). See the paper presented at the Look of Lyric conference by Z. Stamatopoulou, 'Visual Perception and Re-performance in Olympian 6', now published as Stamatopoulou (2014). The whole poem, comparable to a variegated and cohesive tapestry, is structured by this light-, colour-, and matter-imagery: cf. Carne-Ross (1976). 


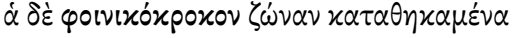

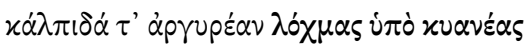

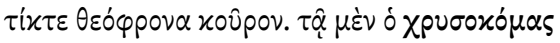

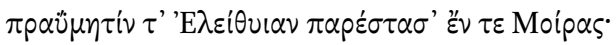

\section{$\hat{\eta} \lambda \theta \varepsilon v \delta^{\prime} \dot{\nu} \pi \dot{\partial} \sigma \pi \lambda \alpha^{\prime} \gamma \chi \omega \nu$ í $\pi^{\prime} \dot{\omega}-$

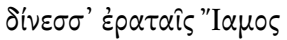

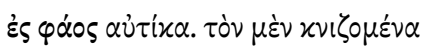

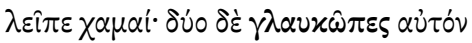

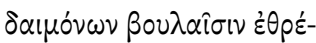

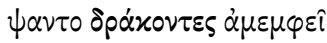

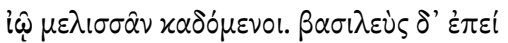

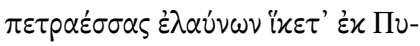

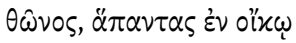

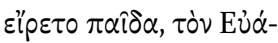

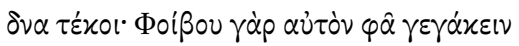

She, though, laid down her crimson girdle // and silver pitcher under a dark thicket and began to bear // a divinely inspired boy. To aid her, the golden-haired // god sent gentle-counseling Eleithuia and the Fates,

and from her womb amid the welcome / birth pains Iamos // came immediately into the light. In her distress // she had to leave him on the ground, but two gray-eyed // serpents tended him through the god's designs / and nourished him with the blameless / venom of bees. But when the king // arrived after driving from rocky Pytho, / he questioned everyone in the house // about the child whom Euadne / bore, for Phoebus, he said, was his

father, and he would become foremost of mortals // as a seer for mankind, and his lineage would never fail. // Such did he declare to them, but they vowed // not to have seen or heard of him, / although it was the fifth day since his birth. But in fact, // he had been hidden in a bed of reeds within a vast thicket, // while his tender body was bathed / by the golden and purple rays // of violets. That was why his mother declared / that for all time he would be called

by that immortal name.

First, at the end of the second epode (39-41) some striking features, set in a clair-obscur, oppose Euadne's 'crimson girdle' (

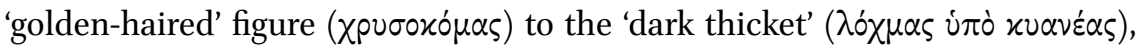
where she is about to give birth. Next, the formula छ̇ $\varsigma$ quos, meaning both visually 'into the light' and existentially 'coming into life' here, is emphatically placed at the beginning of line 44 and introduces the description of the two

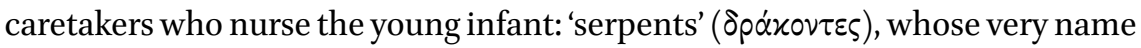
is associated with 'to see, to gleam', and who are described as 'radiant-eyed' 
( $\gamma \lambda \alpha u x \omega \hat{\omega} \pi \varsigma$, rather than the 'grey-eyed' found in Race's translation). Finally, as the imaginary enargeia of the whole story increases, the concealment of the child ('they vowed not to have seen (iঠeiv) or heard of him', 53; and the first word of line 54: $x \varepsilon$ x p $\pi \tau \tau$, 'he had been hidden') is in sharp contrast to its tender body, which was 'bathed by the golden and purple rays of violets' (' $i \omega \nu \xi \alpha \nu \theta \alpha i \sigma l$

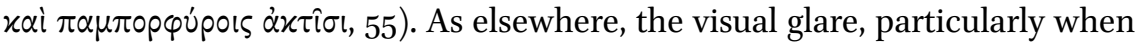
coloured, conjoining nature and art (flowers, purple and gold), is fiery and the vivid splendour of the violets (maybe purple and yellow wallflowers, French giroflées) is described as the radiance of a real sun. These visual images, which help to stimulate the audience's imagination, are an epideictic argument but this time in a less obvious encomiastic setting. They are reinforced by the plays of sounds and the paronomasy of the Greek names of 'violets' (' $(\omega \nu, 55)$ and 'venom' (i $\hat{\omega}, 47$, used for 'honey'), which support the myth's coherence and bring it to an end with the reference to the 'immortal name' of Iamos at the first verse of the third epode.

In the mythological parts of the odes visual images may also be used to evoke aetiological events, as is the case in Olympian 7.54-71. Here the emergence of the island of Rhodes, the city of the laudandus Diagoras and property of the sun god Helios, is reminiscent of a rose blooming in the sunshine: ${ }^{22}$

$\varphi \alpha \nu \tau i \delta^{\prime} \alpha \dot{\alpha} \nu \rho \omega^{\prime} \pi \omega \nu \pi \alpha \lambda \alpha \iota \alpha i^{\prime}$

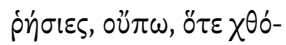

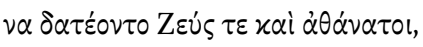

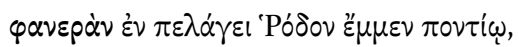

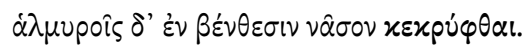

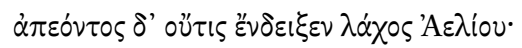

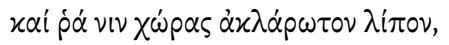
arvòv $\theta$ sóv.

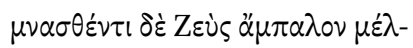

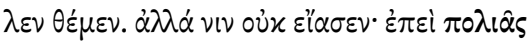

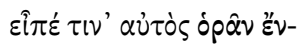

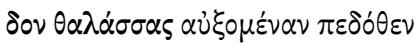

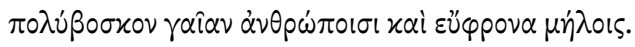

... The ancient reports of men // tell that when Zeus and the immortals / were apportioning the earth, // Rhodes had not yet appeared in the expanse of the sea, // but the island lay hidden in the salty depths.

Since he was absent, no one designated a lot for Helios, // and thus they left him with no portion of land, // although he was a holy god. // And when he spoke of it, Zeus was about to recast/ the lots for him, but he would not allow it, because // he said that he himself could see a land / rising from the floor of the gray sea // that would be bountiful for men and favorable for flocks. 


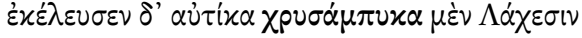

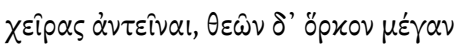

$\mu \eta \dot{~} \pi \alpha \rho \varphi \alpha \dot{\mu} \mu \nu$,

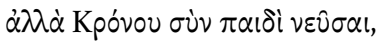

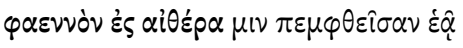

$\varepsilon \varphi \alpha \lambda \hat{\alpha}$

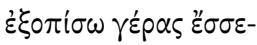

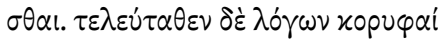

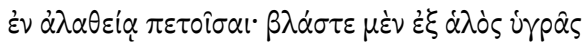

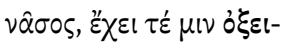

$\hat{\alpha} \nu \dot{\delta} \gamma \varepsilon v \varepsilon \dot{\varepsilon} \theta \lambda \cos \alpha x \tau i v \omega \nu \pi \alpha \tau \eta \dot{\rho} \rho$,

$\pi \hat{\rho} \rho \pi v \varepsilon \dot{v} \nu \tau \omega \nu$ àpXòs i $\pi \pi \omega \nu$.
He immediately ordered Lachesis of the

golden headband // to raise her hands and not to forswear // the mighty oath of the gods, // but to consent with Kronos' son / that once it had arisen into the bright air// it would henceforth remain a possession of honor / for himself. The essential points of these words // fell in with truth and were fulfilled. The island grew

from the watery sea and belongs to the father / who engenders the piercing sunbeams, // the master of the fire-breathing horses ...

The beginning of the narrative is emphasized by a clair-obscur (54-57), opposing the adjective $\varphi \alpha \nu \varepsilon \rho \dot{\alpha} \nu$ ('visible, radiant, shining', first word of line 56 ) and the

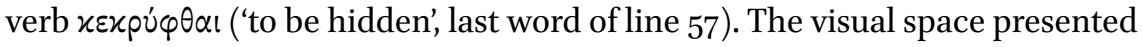
to the audience's imagination is vertically organized between the moving 'gray

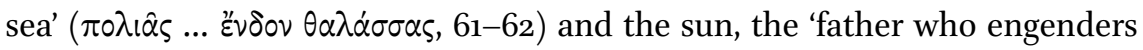

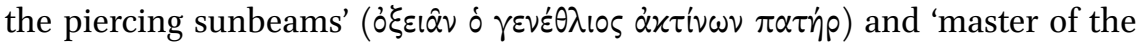

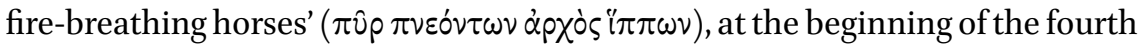
epode (70-71). In between we find two complementary movements: the gaze

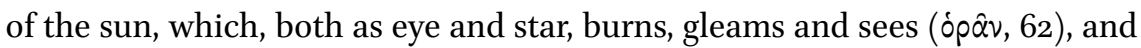

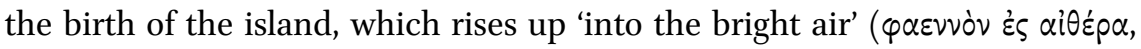
66). This doubly luminous phrase is reinforced by the evocation of 'Lachesis of the golden headband' (64), and connects the adjective $\varphi \alpha v \varepsilon p \alpha \nu$ (56) with the sharp radiance in line 70 . The ascension by which Rhodes/Rose has access to life and to light, reminiscent of Iamos' birth, is more directly related to the epinician celebration, whose ritual and cosmic dimension is infused through these images. Not only is the epiphanic triumph of the laudandus increased, both visually and ethically, by the enargeia and the poikilia which characterize this mythical discourse, but the universal celebration of the island, on which the melic festival takes place, is based on effects similar to those by which the epinician chorus celebrates the victorious athlete and his city. Instead of competing with the spectacular vision, the visual imagination to which these mythological evocations give shape reinforces it. In the following section I will further examine the way in which imagination and performance interact in the odes. 


\section{Melic Praise as Spectacular Action: Interplays of Ethics and Aesthetics}

The overture of an epinician ode is necessary to its spectacular efficiency. It is based upon the conjunction of visual images, as developed in the melic component of the poem (direct praise of the laudandus, the sponsor, their family, city, and gods; prayers, warnings and maxims), with the musical and choreographic qualities of the performance, which is revealed to the audience by the poetic action itself. So, in the famous priamel of the first Olympian Ode (1-11) the festive celebration depends on the successful interplay between gnomic imagination, conjuring up vivid visual effects which support the audience's phantasia, and the ritual scenography, which is more difficult to establish and has to be reconstructed, for example, from deictic marks occurring in the text: ${ }^{23}$

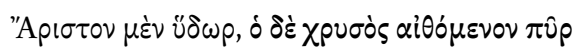

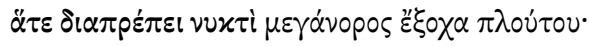

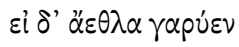

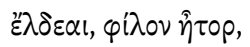

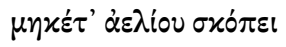

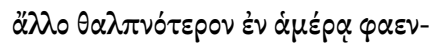

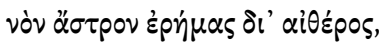

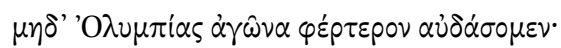

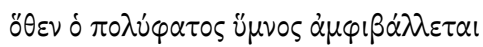

$\sigma \circ \varphi \omega \hat{\omega} \nu \mu \eta \tau i \varepsilon \sigma \sigma l, \chi \varepsilon \lambda \alpha \delta \varepsilon \hat{\imath} \nu$

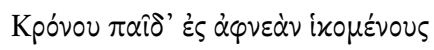

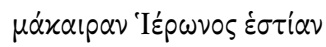

Best is water, while gold, like fire blazing // in the night, shines preeminent amid lordly wealth. // But if you wish to sing // of athletic games, my heart, // look no further than the sun // for another star shining more warmly by day / through the empty sky, // nor let us proclaim a contest greater than Olympia. // From there comes the famous hymn that encompasses // the thoughts of wise men, who have come // in celebration of Kronos' son to the rich // and blessed hearth of Hieron, ...

After a quick and surprising start ('Best is water'), the first two lines lay stress on the semantic isotopy of golden gleam, blazing fire, efficient warmth, and contrastive light. They are linked together by a run-on line that bridges the term to be compared, 'fire' ( $\pi \hat{\rho} \rho)$, emphatically placed at the end of the line, and the conjunction that introduces the comparison $(\ddot{\alpha} \tau \varepsilon)$. As the priamel reaches its climax, the third element, the highest of its kind, that is the Olympic Games, is celebrated with the same set of visual images that express excellence, light, heat, glory, and elevation $\left(5^{-6}\right)$. For a full understanding, one should

23 Cf. the general study by Gerber (1982) and, on this particular passage, Race (1981), (1982), and (1992). 
also try to express the rhythmical effects, which were reinforced by dance movements, as in the enjambment of lines 5 and 6: the verb $\sigma x o ́ \pi \varepsilon$, placed at the end of line 5 and followed in the next line by its object ( $\alpha \lambda_{0} \theta \alpha \lambda \pi v o$ ó

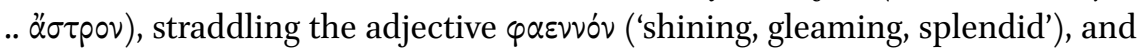

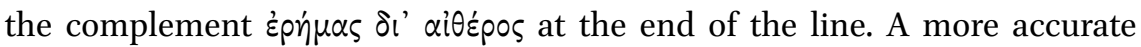
translation would be 'more than sun, don't look, shining more warmly, by day, another star, through the empty sky'.

Melic poetry can also represent the epinician ritual itself through a significant mise en abyme, as in Olympian 9.89-99: ${ }^{24}$

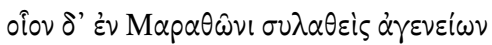

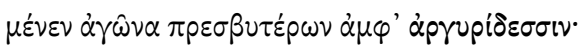
$\varphi \omega \hat{\tau} \alpha \varsigma \delta^{\prime}$ o $\xi \cup \rho \varepsilon \pi \varepsilon \hat{~} \delta \dot{\lambda} \lambda \omega$ $\dot{\alpha} \pi \tau \omega \tau i \delta \alpha \mu \dot{\alpha} \sigma \sigma \alpha 1 \varsigma$

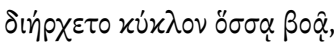

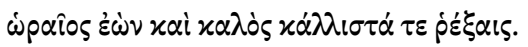

$\tau \dot{\alpha} \delta \dot{\varepsilon} \Pi \alpha \rho p \alpha \sigma i \omega \sigma \tau \rho \alpha \tau \hat{\iota}$

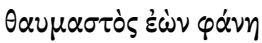

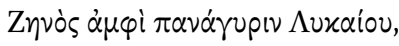

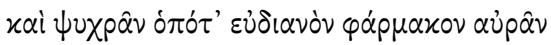

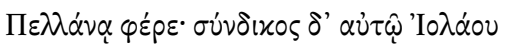

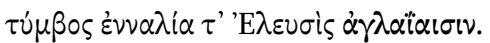

And what a contest he endured at Marathon against older men // for the silver cups, when wrested from the beardless class: // with deftly shifting feints // he subdued the men without falling once, // and passed through the ring of spectators to such great shouting, // being young and fair and performing the fairest deeds.

Then too he made a marvelous appearance // among the Parrhasian host / at the festival of Lykaian Zeus, // and at Pellana, when he carried off the warming remedy // for chill winds. Witnesses to his splendid successes // are Iolaos' tomb and Eleusis by the sea.

Here the poetic celebration stages, with enargeia, the triumph of the laudan$d u s$, Epharmostos of Opous. He was honoured by the audience's gaze, which is inserted in the description as if to recall the audience of the choral performance

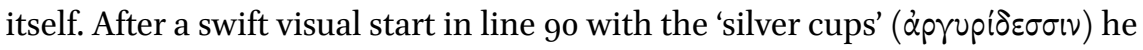
won as his prize, a stylized outline of the victor and his triumph is presented: 'being young and fair and performing the fairest deeds' (94). This occurs at the end of the fourth strophe, just before the real epiphany at the beginning of the antistrophe. In line 96, the verb $\varphi$ aivo $\mu \alpha \iota$ carries its full visual meaning, that is 'shine, appear', in relation to the admiring amazement $(\theta \alpha \hat{v} \mu \alpha)$ of the

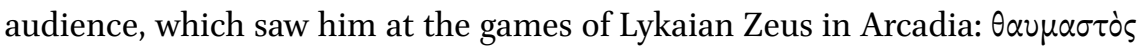

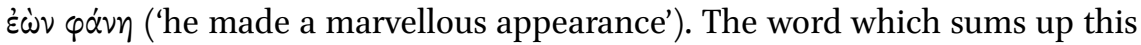

24 Cf. Miller (1993). 
harmonious alliance of perception and thought, shining light, success, wealth, splendour and feast, is the last word in line 99: $\dot{\alpha} \gamma \lambda \alpha i \alpha \omega \sigma \omega v$, literally meaning by his splendours'. It refers simultaneously to the winner's athletic achievement, his outstanding presence, and the melic festival, full of light and splendour, which celebrates him. The epinician performance, by praising the victors and their mythical paradigms, also celebrates itself as a spectacular action that is brilliant and successful. ${ }^{25}$

This is also the case in Olympian 10.20-25, where the polysemous word $\varphi \alpha$ os ('light') appears at the end of line $23:{ }^{26}$

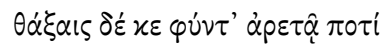

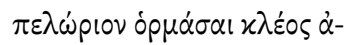

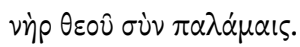

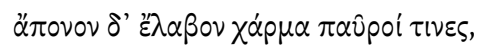

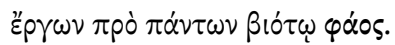

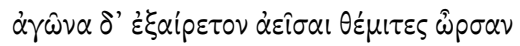

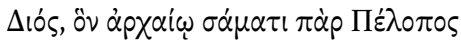

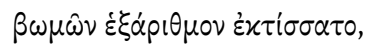

... By honing someone born for excellence // a man may, with divine help, / urge him on to prodigious fame;

and few have won without effort that joy // which is a light for life above all deeds. But the ordinances of Zeus have prompted me to sing / of the choice contest, which Herakles founded // with its six altars by the ancient tombs of Pelops ...

In these gnomic verses, in a simple yet strong way, the visual image of diffused and powerful daylight, while appealing both to the audience's phantasia and deictically referring to the present celebration, metaphorizes a whole chain

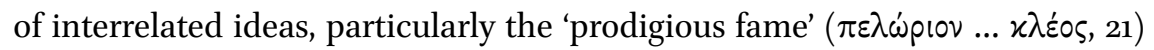
of the winner, Hagesidamos of Western Lokroi, and the splendour of the first Olympic games, founded by Heracles (24). This maxim about the extreme scarcity of deeds without labour ends with the word 'light' and so establishes a transition between the encomiastic frame of the ode and the inserted myth, that is between the most spectacular parts of the poem, ritual and present, and the most imaginary ones, narrative or descriptive. Here, $\varphi$ áo links together performance (spectacle) and imagination (description), the celebration of the present and the praise of the past, both near (the celebrated victory) and far (the first Olympic Games, in heroic times).

\footnotetext{
25 The poetic performance is successful both when relating imaginary and spectacular vision with past and present, and mediating the tension between the agonistic dynamics of rituals and the community they intend to construct. See Carey (1980).

26 Cf. Nassen (1975) and Briand (1994).
} 


\section{Conclusion}

We have noticed the important role played by $\varphi$ ós and its cognates in the text of the Olympian Odes and in its staging. It refers to daylight, both diffused and strong, and weaves structural webs, both formal and semantic, through the whole poem, completed by references to other kinds of light, like the $\alpha \gamma \lambda \alpha \sigma^{2}$ ('splendid, bright') or the $\pi$ ox xi $\lambda$ ov ('many-coloured, varied'), and to flames of fire, rays of the sun, or the splendour of gold. The prototypical epinician light, which builds and represents collective values like excellence, glory, harmony, is yóos, both when it is described or narrated in the mythological parts of the poem to stimulate the audience's imagination, and when, in the directly epidictic frame of the poem, it increases and justifies the spectacular effects of the epinician ritual. As a spectacle and a polygeneric mimesis (epic and hymnic, textual, musical and choreographic), Pindar's epinician odes work as a visual piece of art, in which the sung text, employing visual figures, plays a major role. Through their language the odes stimulate the audience's phantasia and contribute to the performance, or, more exactly, intertwine these two kinds of poetic action.

\section{Works Cited}

Bonifazi, A. (2001). Mescolare un cratere di canti. Pragmatica della poesia epinicia in Pindaro. Alessandria.

Bernard, M. (1963). Pindars Denken in Bildern. Vom Wesen der Metapher. Pfullingen.

Bernardini, P.A. (1983). Mito e attualità nelle odi di Pindaro. La Nemea 4, l'Olimpica 9, l'Olimpica 7 . Roma.

Bollack, J. (1963). 'L' or des rois: le mythe de la Deuxième Olympique'. RPh III 37: 234-254. Bremer, D. (1976). Licht und Dunkel in der frühgriechischen Dichtung. Bonn.

Briand, M. (1994). 'À propos de $\pi v p \pi \alpha ́ \lambda \alpha \mu \circ \varsigma$ (Pindare, Ol. x, 80)'. Lalies 13: 195-205. (2003a). 'Le vocabulaire de l'excellence chez Pindare'. RPh 77.2: 203-218. (2003b). 'La figuration poétique des météores dans l'épinicie classique: gestes divins et passions humaines' in C. Cusset (ed.), La météorologie dans l'Antiquité, entre science et croyance. Saint-Étienne: 217-242. - (2005a). 'Questions de cohérence et de cohésion dans la poésie mélique grecque archaïque: la transition entre discours d'actualité et récit mythique' in A. Jaubert (ed.), Cohésion et cohérence. Études de linguistique textuelle. Lyon: 79-98. - (2005b). 'Les (en)jeux du regard et de la vision dans la poésie mélique grecque archaïque et classique' in L. Villard (ed.), Études sur la vision dans l'antiquité classique. Rouen and Le Havre: $57-79$. 
- (2006). 'Aesthetics and ethics of poikilia in Longus' Pastorals' in M. Skoie and S. Velazquez (eds.), Re-inscribing Pastoral in the Humanities: Essays on the Uses of a Critical Concept. Bristol: $42-52$.

- (2008a). 'Les épinicies de Pindare sont-elles lyriques? ou Du trouble dans les genres poétiques anciens' in D. Moncond'huy and H. Scepin (eds), Le genre de travers: littérature et transgénéricité. Rennes: 21-42

- (2008b). 'La limite et l' envol: les fins paradoxales des épinicies de Pindare' in

B. Bureau and C. Nicolas (eds), Commencer et finir. Débuts et fins dans les littératures grecque, latine et néolatine. Lyon: 557-572.

- (2010). 'Callimaque, (ré)inventeur de Pindare: entre archivage et performance, une poétique seconde' in S. Rabau and J.-L. Jeannelle (eds), Poétiques de la philologie, Littérature-Histoire - Théorie, $\mathrm{n}^{\circ} 5$ (http://www.fabula.org/lht/5/70-briand).

(2013). 'Vision spectaculaire et vision imaginative dans la poésie mélique grecque. Le cas des épinicies de Pindare' in R. Courtray (ed.), Regard et représentation dans l'Antiquité (Pallas 92). Toulouse: 115-131.

Budelmann, F. (2009). The Cambridge Companion to Greek Lyric. Cambridge.

Calame, C. (1977). Les Chœurs de jeunes filles en Grèce archaïque, I: Morphologie, fonction religieuse et sociale. II: Alcman, Roma. (Engl. transl. by D. Collins and J. Orion, Choruses of Young Women in Ancient Greece: Their Morphology, Religious Role, and Social Functions. London $2001^{2}$ ).

_- (1991). 'Quand dire c'est faire voir: l' évidence dans la rhétorique antique'.Études de Lettres. Lausanne: 3-23.

(1995). 'Variations énonciatives, relations avec les dieux et fonctions poétiques dans les Hymnes Homériques'. MHelv 52.1: 2-19.

- (2000). Le récit en Grèce ancienne. Énonciations et représentations de poètes, Paris.

(2006). 'Identifications génériques entre marques discursives et pratiques énonciatives: pragmatique des genres "lyriques"' in R. Baroni and M. Macé (eds), Le savoir des genres. Rennes: $35^{-55}$.

- (2008). 'Métaphores et images comme agents poétiques: espace et temps dans la poésie grecque rituelle'. Images Re-vues, hors-série n. 1, 2008 (http://imagesrevues .org).

Carey, C. (1980). 'Three myths in Pindar: N. 4, o. 9, N. 3. Eranos 78: 143-162.

Carne-Ross, D.S. (1976). 'Weaving with points of gold: Pindar's Sixth Olympian'. Arion n.s. 3: 5-44.

Ciani, M.C. (1974). Ф́́os e termini affini nella poesia greca. Introduzione a una fenomologia della luce. Firenze.

Cole, T. (1988). Epiploke: Rhythmical Continuity and Poetic Structure in Greek Lyric. Cambridge, MA.

Currie, B. (2005). Pindar and the Cult of Heroes, Oxford. 
D’Alessio, G.B. (1994). 'First-person problems in Pindar'. вICs 39: 117-139.

Danielewicz, J. (1990). 'Deixis in Greek choral lyric'. Qucc 63: 7-17.

Defradas, J. (1971). 'Sur l' interprétation de la deuxième Olympique de Pindare'. REG 84: 131-143.

Dougherty, C. and Kurke, L. (eds.) (1998). Cultural Poetics in Archaic Greece. Cult, Performance, Politics. Oxford.

Duchemin, J. (1952). 'Essai sur le symbolisme pindarique: or, lumière et couleurs'. REG $65: 46-58$.

Duchemin, J. (1954). 'L'iconographie funéraire et l' exégèse pindarique'. $R E L$ 32: 284-297.

Felson, N. (2008). 'Epinician Apollo in story time: Pythian 9, Olympian 6 and Pythian 3 ' in L. Athanassaki, R.P. Martin, and J.F. Miller (eds), Apolline Politics and Poetics. Athens: 149-168.

Felson, N. (ed.) (2004). The Poetics of Deixis in Alcman, Pindar, and Other Lyric. Arethusa 37.3: $253-466$.

Frontisi-Ducroux, F. and Vernant, J.-P. (1989). Dans l'oeil du miroir. Pisa.

Gavins, J. and Steen, G. (eds) (2003). Cognitive Poetics in Practice. London.

Gentili, B. (1988). Poetry and its Public in Ancient Greece. From Homer to the Fifth Century. Transl. T.A. Cole. Baltimore.

Gerber, D.E. (1982). Pindar's Olympian One: A Commentary. Toronto.

Guerrero, G. (1998). Poétique et poésie lyrique. Paris.

Hampe, R. (1952). 'Zur Eschatologie in Pindars zweiter Olympischer Ode, EPMHNEIA', in Festschrift Otto Regenbogen. Heidelberg: 46-65

Hornblower, S. (2004). Thucydides and Pindar. Historical Narrative and the World of Epinikian Poetry, Oxford.

Hubbard, T. (1985). The Pindaric Mind. A Study of Logical Structure in Early Greek Poetry. Leiden.

Hummel, H. (1993). La syntaxe de Pindare (B IG 24). Louvain and Paris.

Koehnken, A. (1971). Die Funktion des Mythos bei Pindar. Berlin and New York.

Kowalzig, B. (2007). Singing for the Gods. Performances of Myth and Ritual in Archaic and Classical Greece. Oxford.

Kraus, C., Goldhill, S., Foley, H.P., and Elsner, J. (eds) (2007). Visualizing the Tragic: Drama, Myth, and Ritual in Greek Art and Literature. Essays in Honour of Froma Zeitlin. Oxford.

Krummen, E. (1990). Pyrsos Hymnon. Festliche Gegenwart und mythisch-rituelle tradition als Voraussetzung einer Pindarinterpretation (Isthmie 4, Pythie 5, Olympie 1 und 3). Berlin.

Kurke, L. (1991). The Traffic in Praise. Pindar and the Poetics of Social Economy. Ithaca and London.

Lakoff, G. (1987). Women, Fire, and Dangerous Things. What Categories Reveal about the Mind. Chicago. 
Lakoff, G. and Johnson, M. (2003 [1980]). Metaphors We Live By. Chicago.

(1999). Philosophy in the Flesh. The Embodied Mind and Its Challenge to Western Thought. New York.

Lawall, G. (1961). 'The cup, the rose, and the winds in Pindar's Seventh Olympian'. RFIC n.s. 39: 33-47.

Lévy, C. and Pernot, L. (eds) (1997). Dire l'évidence. Philosophie et rhétorique antiques. Paris.

Lonsdale S.H. (1993). Dance and Ritual Play in Greek Religion. Baltimore.

Lloyd-Jones, H. (1984). 'Pindar and the after-life' in A. Hurst (ed.), Pindare (Entr. Hardt 31) Vandoeuvres: $245^{-283}$

Mann, R. (1994). 'Pindar's Homer and Pindar's myths'. GRBS 35.4: 313-337.

Miller, A.M. (1993). 'Inventa componere: Rhetorical process and poetic composition in Pindar's ninth Olympian ode'. TAPhA 123: 109-147.

Miller, J. (1986). Measures of Wisdom. The Cosmic Dance in Classical and Christian Antiquity, Toronto.

Most, G. (1999). 'Poetics of early Greek philosophy' in A.A. Long (ed.), The Cambridge Companion to Early Greek Philosophy. Cambridge: 332-362.

Mullen, W. (1982). Choreia. Pindar and Dance. Princeton.

Naerebout, F.G. (1997). Attractive Performances. Ancient Greek Dance: Three Preliminary Studies. Amsterdam.

Nassen, P.J. (1975). 'A literary study of Pindar's Olympian 10'. TAPhA 105: 219-240.

Norwood, G. (1945). Pindar. Berkeley.

Nünlist, R. (1998). Poetologische Bildersprache in der frühgriechischen Dichtung. Stuttgart.

Otto, N. (2009). Enargeia. Untersuchung zur Charakteristik alexandrinischer Dichtung. Stuttgart.

Patten, G. (2009). Pindar's Metaphors. A Study in Rhetoric and Meaning. Heidelberg.

Race, W.H. (1981). 'Pindar's Best is water: Best of what?'. GRBS 22: 119-124. (1982). The Classical Priamel from Homer to Boethius (Mnemosyne suppl. 74). Leiden.

(1990). Style and Rhetoric in Pindar's Odes. Atlanta.

(1992). 'How Greek poems begin' in F.M. Dunn and T. Cole (eds), Beginnings in Classical Literature, Cambridge.

- (1997). Pindar. Cambridge, MA.

Schechner, R. (2003 [1988]). Performance Theory. London and New York.

Semino, E. and Culpeper, J. (eds) (2002). Cognitive Stylistics. Language and Cognition in Text Analysis. Amsterdam and Philadelphia.

Simon, G. (2003). Archéologie de la vision. L'optique, le corps, la peinture. Paris.

Stamatopoulou, Z. (2014). 'Inscribing performances in Pindar's Olympian 6'. TAPhA 144: $1-17$ 
Steiner, D. (1986). The Crown of Song. Metaphor in Pindar. London.

Stockwell, P. (2002). Cognitive Poetics. An Introduction. London.

Stoneman, R. (1981). 'Ploughing a garland: Metaphor and metonymy in Pindar'. Maia n.s. $33: 125^{-138 .}$

Turner, V. (1986). The Anthropology of Performance. New York.

Webb, R. (2009). Ekphrasis, Imagination and Persuasion in Ancient Rhetorical Theory and Practice, Farnham.

Wersinger, A.-G. (2008). Le schème de l'Harmonie dans la pensée des anciens Grecs d'Homère à Platon. Grenoble.

Wüst, E. (1967). Pindar als geschichtschreibender Dichter. Interpretationen der 12 vorsizilischen Siegeslieder, des sechsten Paians und der zehnten olympischen Ode. Tübingen.

Young, D.C. (1964). 'Pindaric criticism'. The Minnesota Review 4: 584-641. 


\title{
Visual Imagery in Parthenaic Song*
}

\author{
Laura Swift
}

This paper aims to reach a better understanding of what is distinctive about parthenaic song. This may seem a rash undertaking: the quantity of surviving parthenaic poetry is tiny, and gives us a narrow window onto the genre. The problem is further exacerbated by our limited knowledge of the ritual contexts in which partheneia were performed: we should therefore remain aware of the risks of generalising. ${ }^{1}$ Nevertheless, in recent years some scholars have attempted to understand parthenaic song by focusing on the role the song might have played in the life-cycle of the parthenoi themselves, and by reading the poems as relating to some form of transitional experience. ${ }^{2}$ If we follow this line of reasoning, whether or not we regard partheneia as a genre-category in the same sense as paian or epinikion, we can accept that songs performed by young girls may be united by a shared social function. ${ }^{3}$ In this chapter I aim to take this analysis a step further, by isolating a distinctive feature of songs performed by choruses of young girls: its focus on the visual. Parthenaic song pays particular attention to the appearance and actions of the singers

* I am grateful for the useful feedback provided by the participants at the Delphi conference in 2009 and by the audience at the Nottingham University Classics research seminar, where I gave a revised version of this paper in 2010. Thanks are also due to Bill Allan, Claude Calame, and André Lardinois, for their comments on earlier versions.

1 E.g. Calame (2001) 2-3 questions the validity of conceptualising partheneia as a genre at all, and prefers to structure young women's song by the other ritual roles it performs (7488).

2 This work was originally pioneered by Calame (1977). Many scholars read the poem as related to issues of female transition and sexuality in general terms, even if they are not convinced by Calame's idea of a specific initiation ritual, and the idea that emerging female sexuality is an important aspect of parthenaic song is widely accepted. For recent treatments see e.g. Lonsdale (1993) 193-205; Stehle (1997) ch. 2; Ingalls (2000); Cyrino (2004).

3 For the purposes of this article I use the adjective 'parthenaic' simply to mean 'performed by parthenoi', without prejudice to whether the chorus is a partheneion in any stricter sense. For further discussion on partheneia as a genre see Calame (1977) II 147-176, and for my own position see Swift (2010) ch. 5. Recent work on the broader issue of genre-definition in the archaic period rightly stresses the importance of performance context: see Nagy (1990) 360; Dougherty (1994) 43-44; Ford (2002) 8-13; Ford (2003); Carey (2009).

(C) LAURA SWIFT, 2016 | DOI: 10.1163/9789004314849_012

This is an open access chapter distributed under the terms of the Creative Commons AttributionNoncommercial 3.o Unported (CC-BY-NC 3.0) License. 
who perform it; the poems constantly attempt to set up a visual interchange between performers and audience, and do so by directing the gaze of the onlookers. This should not be understood simply as a decorative feature, but rather as one connected with the poetry's function, and with Greek attitudes towards parthenoi on a more general level. ${ }^{4}$

Since so few partheneia survive, we must turn to other sources in order to build a case; as we shall see, visual language is not used only by genuine parthenaic song, but is also deployed in other types of lyric poetry when the singers describe or evoke female choral performance. Examining these parallels therefore provides corroborating evidence, but also serves an additional purpose, for it suggests that this trope of parthenaic song was not limited to one particular community but was a widespread feature of song performed by unmarried girls. Hence the visual focus in our surviving partheneia is not simply a coincidence but rather a distinctive feature of the poems, which later authors drew upon to allude to the genre.

The best place to begin this investigation is with an examination of how surviving partheneia deploy visual and physical language (section 1). In order to establish visual self-referentiality as a specifically parthenaic trope, we must also compare the evidence of the parthenaic fragments with the types of selfreferentiality we find in male choral lyric (section 2). Male and female singers use different methods to describe their performance, with visual language a feminine speciality. ${ }^{5}$ Conversely, texts which contain descriptions of female choral performance make a rich use of visual language (section 3). Visual selfreferentiality is therefore singled out as a distinctive feature of parthenaic performance, and becomes an easy 'short-cut' for evoking this form of song. Having established this pattern and examined the evidence for it, the final part of this article will investigate how this affects our understanding of female choral song and the symbolic role it held in Greek society (section 4).

4 In drawing the audience's attention to the visual beauty of the girls, female choruses add an erotic charge to their song: see Calame (1977) II 87-91; Calame (1999) 20-33, 186-188. Yet it is important to note that this gaze is one constructed by the chorus for the purpose of public praise, and we cannot therefore assume that it reflects private erotic emotions: cf. Lardinois (2010); Lardinois (2011).

5 This is of course not to deny that the gaze plays a role in male as well as female eroticism: cf. e.g. Pind. fr. 123 S.-M. What distinguishes female singers, however, is the way in which the singers draw attention to their own visual appeal. 


\section{Exploring the Visual in Parthenaic Fragments}

The most important parthenaic fragment is Alcman's first partheneion (PMGF 1), and it is here that we find the densest clustering of visual language. ${ }^{6}$ The surviving section of the poem is highly self-referential, and this is achieved by means of a systematic focus on the girls' identity and appearance. The poem begins with a (mostly lost) mythological section; the girls then turn to the subject of their own leaders, and the ritual activities they are engaged in. ${ }^{7}$ Two girls, Hagesichora and Agido, are singled out for praise for their exceptional beauty and their importance to the ritual. ${ }^{8}$ This praise is couched in visual terms: the chorus comment on the girls' appearance, and the spectacle they present to the watching audience. Both girls are described through imagery of shining and light. The imagery is introduced with the striking metaphor of Agido herself as sunlight (39-43):

$$
\begin{aligned}
& \varepsilon \bar{\gamma} \omega \dot{\omega} \nu \delta^{\prime} \alpha \dot{\alpha} \varepsilon \delta \omega
\end{aligned}
$$

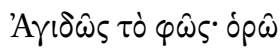

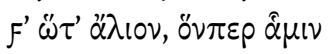

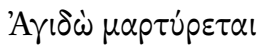

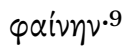

But I sing of the light of Agido: I see her like the sun, which Agido summons to shine for us. ${ }^{10}$

Thus Agido is not only involved in a ritual involving the sun, but she becomes sun-like in her visual splendour,11 her appearance and her ritual activity are

6 For a detailed study of the visual as an important theme in Alcm. PMGF 1 see Peponi (2004). The importance of visual imagery is also noted by Ferrari (2008) 114-116.

7 The connection between the myth and the surviving sections of the poem is much discussed, and the most convincing explanations see it as moralising on suitable and unsuitable ways to find marriage partners: see Page (1951) 31-33; Garvie (1965); Stehle (1997) 30-35. For the thematic connections between myth, performance context, and the imagery used by the chorus, see Bowie (2011).

8 I agree with West (1965) 197 that the question as to which of the two is more desirable is not a useful one: we should see the praise as singling these girls out from the others rather than comparing the two.

9 I print the text of Alcm. frr. 1 and 3 as given in $P M G F$, except at 1.77 where I print $\tau \eta p \varepsilon \hat{\imath}$ (see n. 17) and 1.80-81 where I print the text as given in Hutchinson (2001).

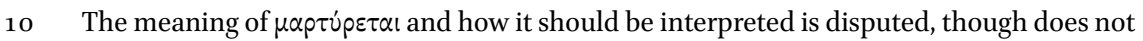
affect my argument here: see West (1965) 194-195; Hutchinson (2001) 86.

11 Cf. Peponi (2004) 299. 


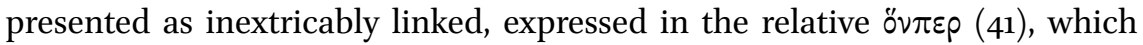
indicates a specific and definite connection. ${ }^{12}$ Hagesichora also shines, but her brightness is portrayed as that of precious metals $\left(5^{-}-57\right)$ :

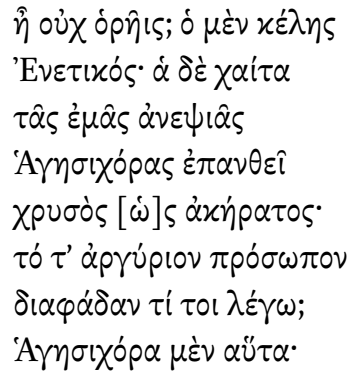

But don't you see? The racehorse is Enetic, and the hair of my cousin Hagesichora blooms like pure gold, and her face is silver-but why do I tell you openly? This is Hagesichora here.

Imagery of shining and of precious metal is a conventional way of praising female beauty, but it is the visual aspect of such imagery which is stressed here. ${ }^{13}$ In the case of Agido this is achieved by combining the visual focus with the ritual activity being performed (41-42). With Hagesichora the audience is

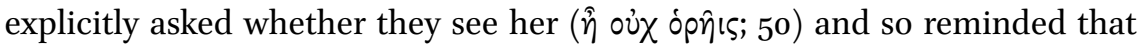
she is present before them. They then go on to question why they should need to verbalise what is visually obvious $\left(5^{6-57}\right)$, and in doing this they alert the audience to their visual focus and foreground it as a poetic technique. ${ }^{14}$

The focus on the visual is not limited to the girls' leaders but extends to the other members of the chorus. Eight other girls are named, and singled out for aspects of their appearance (64-81):

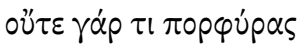

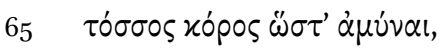

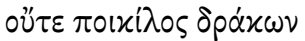

\footnotetext{
12 Moreover, ö $\sigma \pi \varepsilon \rho$ is rare in lyric (cf. West (1965) 195) and so the emphasis is likely to be particularly significant.

13 Cf. Sapph. fr. 16.17 v. for the 'bright sparkle' ( $\dot{\alpha \mu \alpha} \rho \cup \chi \mu \alpha \lambda \dot{\alpha} \mu \pi \rho \circ v)$ of Anactoria, and frr. 34, 96.8-9 v. where the girl shines like the moon. In any case, the visual focus of this imagery may fit into the same broad pattern as described here, with the light imagery used as a strategy to focus on the girls' visual display.

Cf. Peponi (2004) 302.
} 
$\pi \alpha \gamma \chi p \dot{\sigma} \sigma 10 \varsigma$, ởঠż $\mu i \tau p \alpha$

$\Lambda \cup \delta i \alpha, \nu \varepsilon \alpha v i \delta \omega \nu$

$i \alpha v 0 \gamma[\lambda] \varepsilon \varphi \dot{\alpha} \rho \omega \nu \alpha \dot{\alpha} \gamma \alpha \lambda \mu \alpha$,

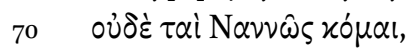

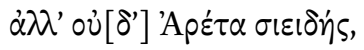

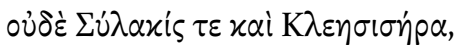

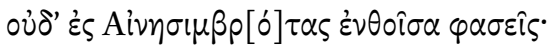

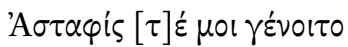

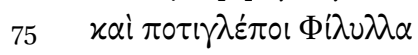

$\Delta \alpha \mu \alpha \rho[\dot{\varepsilon}] \tau \alpha \tau^{\prime} \dot{\varepsilon} \rho \alpha \tau \dot{\alpha} \tau \varepsilon$ Fi $\alpha \nu \theta \varepsilon \mu i \zeta^{\circ}$

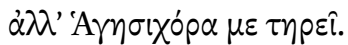

ov $\gamma \dot{\alpha} \rho \dot{\alpha} x[\alpha] \lambda \lambda i \sigma \varphi u p o s$

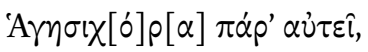

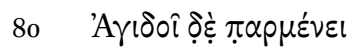

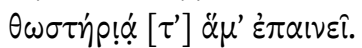

For so much purple is not sufficient to protect us, nor an intricate snake of solid gold, nor a Lydian headband, the glory of dark-eyed girls, nor the hair of Nanno, nor godlike Areta nor Thylacis and Cleesithera, and you will not go to Aenisimbrota and say "if only Astaphis could be mine and Philylla could look my way and Damareta and lovely Wianthemis." No, it is Hagesichora who protects me. But Hagesichora with her fair ankles is not here; she stays by Agido and approves of our ritual.

The girls' desirability is expressed through the beauty of their bodies, in partic-

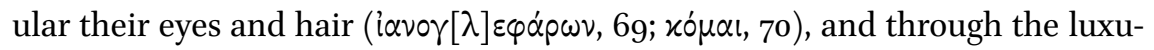
rious splendour of their accessories. The purple they wear is so extensive that

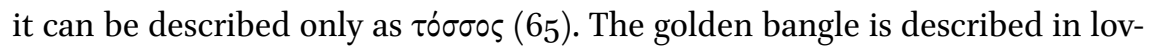
ing detail: not only are we told that it is shaped like a coiled snake, but the singers also highlight its intricate craftsmanship ( $\pi$ oxi $i$ os, 66) and its value ( $\left.\pi \alpha \gamma \times p \sigma^{\sigma} \sigma{ }^{\circ}, 67\right)$. The Lydian headband also suggests visual glory and exoticism, drawing on ideas of the East as a source of luxury. ${ }^{15}$ Each item is listed and described quickly, before the girls move on to the next: again the implication is that the chorus are drawing the audience's attention to what they can already see, and encouraging them to focus their gaze on these details. The importance of looking as an act of desire is reflected in the idiom $\pi 0 \tau \imath \gamma \lambda \varepsilon \dot{\varepsilon} \pi \circ$

15 Cf. Sapph. fr. 98 v. where Sappho explains to Cleis that she cannot give her a Lydian headband. 
(75) used to express the speaker's longing for Philylla. The description culminates with a recapitulation of how exceptional Hagesichora is, ${ }^{16}$ and once more the chorus break off to remind their listeners that what they describe is simultaneously taking place: the actions of Hagesichora and Agido need no further elucidation, as the audience can see them performing their roles in the ritual.

When we turn to Alcman's other surviving partheneion (PMGF 3) a similar pattern emerges. The poem is much more fragmentary, but what remains demonstrates a striking focus on the visual and physical aspects of female performance. ${ }^{17}$ The song opens with a description of the chorus' arrival in the public sphere, and the dance they will perform $(7-10)$ :

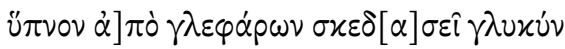

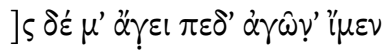

$$
\begin{aligned}
& \hat{\alpha} \chi\llcorner\mu \dot{\alpha}] \lambda_{1} \sigma \tau \alpha \alpha x^{\prime} \mu[\alpha \nu \xi] \alpha \nu \theta \dot{\alpha} \nu \tau \imath \nu \alpha \dot{\xi} \xi \omega \text {. } \\
& \text { ]. } \sigma \chi[\quad \dot{\alpha} \pi] \alpha \lambda \circ i \pi \delta_{0} \delta \varepsilon \varsigma
\end{aligned}
$$

It will scatter sweet (sleep) from my eyes and it causes me to go to the assembly (where) I will vigorously shake my blonde hair ... tender feet

The action of shaking the hair is presented as a future event, yet refers to an action which the audience is imagined as seeing (or being about to see) taking place in the dance before them. ${ }^{18}$ The intensity implied in $\left.\mu \dot{\alpha}\right] \lambda$ i $\sigma \tau \alpha(9)$ encourages the audience to focus on this gesture as a significant one, while also suggesting its speed and vigour. The chorus direct our attention to their feet, described as 'tender' ( $\dot{\alpha} \pi] \alpha \lambda \circ$ i, 10 ), and this suggests further emphasis on their movements and the steps of their dance. ${ }^{19}$ When the text resumes

16 For the purposes of the argument here, it makes little difference whether we read $\tau$ $\eta \varepsilon \hat{\imath}$ or $\tau \varepsilon i p \varepsilon l:$ in either case the girls list their own beauty and finery in order to set Hagesichora up as the most important. I print $\tau \eta p \varepsilon \hat{\imath}$ as it it seems to make most sense of the earlier use of $\dot{\alpha} \mu v_{v} \alpha \mathrm{l}$ (65) and with the wider pattern of Hagesichora's protective role: for a fuller explanation see Swift (2010) 178-179.

17 See Peponi (2007).

18 Cf. Hutchinson (2001) 107: 'the words accentuate the beauty the audience see'. For a discussion of this future deictic projection see D'Alessio (2004).

19 For $\dot{\alpha} \pi \alpha \lambda$ ós used with erotic overtones cf. Sapph. frr. 94.22, 96.13, 122, 140 V., Semon. fr. 7.57 w. Likewise, women's feet (and particularly ankles) are often described as a mark of 
after the damaged section the chorus are discussing Astymeloisa, and as with Hagesichora and Agido, it is her appearance and gestures which are stressed $(61-81)$ :

$\lambda \nu \sigma \mu \varepsilon \lambda \varepsilon \varepsilon \hat{\imath} \tau \varepsilon \pi \dot{\sigma} \sigma \omega l, \tau \alpha \chi \varepsilon \rho \omega \dot{\tau} \tau \varepsilon \rho \alpha$

$\delta^{\prime}$ '

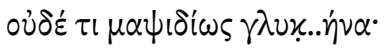

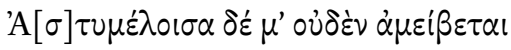

$65 \quad \dot{\alpha} \lambda \lambda \dot{\alpha} \tau \dot{\jmath}] \nu \pi \cup \lambda \varepsilon \omega \hat{\omega} v^{\prime} \varepsilon^{\prime \prime} \chi 01 \sigma \alpha$

$[\ddot{\omega}] \tau i \varsigma \alpha i \gamma \lambda \dot{\alpha}[\varepsilon] \nu \tau \circ \varsigma \dot{\alpha} \sigma \tau \dot{\eta} \rho$

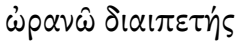

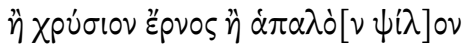

$\therefore] \nu$

70

]. $\delta ا \varepsilon \varepsilon \beta \alpha \tau \alpha \nu \alpha \circ \hat{\varsigma} \pi \circ[\sigma i \cdot]$

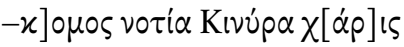

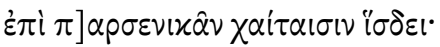

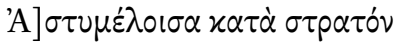

] $\mu \dot{\varepsilon} \lambda \eta \mu \alpha \delta \dot{\alpha} \mu \omega \iota$

75

]$\mu \alpha \nu \dot{\varepsilon} \lambda \circ \hat{i} \sigma \alpha$

]$\lambda \dot{\varepsilon} \gamma \omega$.

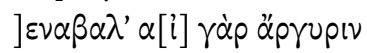

].[.]' $\alpha$

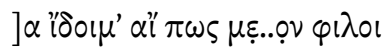

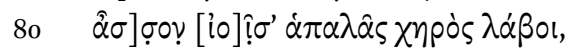

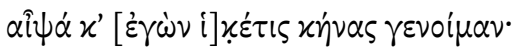

And with limb-loosening desire, and she looks at me more meltingly than sleep or death; not in vain is she sweet. But Astymeloisa does not reply to me (but) holding her garland like a bright star flying through the skies or a golden shoot or delicate down ... she goes through on her outstretched feet ... the moist charm of Cinyra sits on the girl's hair. Astymeloisa ... through the crowd as the care of all the people ... taking ... I say ... silver cup ... I could see whether she might love me; if only she would come (nearer) and take my soft hand I would immediately become her suppliant.

youthful beauty: cf. HHDem 2, 77; Sapph. fr. 44.15 v. (conversely for fat ankles as a mark of female ugliness, Archil. fr. 206 w.). 


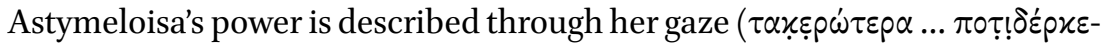
$\tau \alpha 1,61-62)$; the act of looking comes once again to the fore, and this activity is also construed as sexually charged. ${ }^{20}$ Like Hagesichora and Agido, Astymeloisa is described with imagery of shining light: she is like a bright star or a golden shoot (68), and her beauty and sensuality is expressed through the focus on her perfumed hair. ${ }^{21}$ Again the chorus stress their physical separation from her and comment on the actions which the audience can see her performing: in particular, her carrying of the ritual basket (65).

Pindar's daphnêphorikon partheneion (fr. 94b s.-M.) was composed in a different time and place to Alcman's partheneia, yet on analysis we see a similar focus on the actions of the girls in his chorus. ${ }^{22}$ Like Alcman $P M G F 3$ the poem begins with a focus on the girls' activities (9-12):

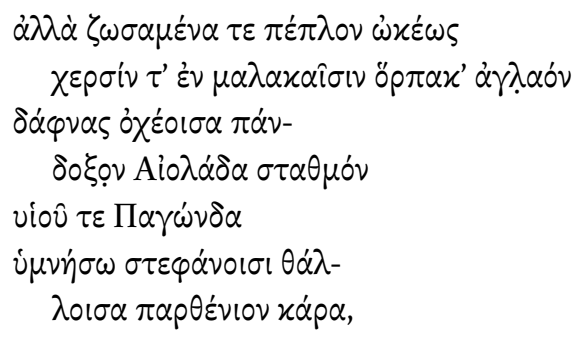

But quickly tying up my robe and carrying in my gentle hands a splendid branch of laurel, I shall hymn the all-glorious house of Aioladas and of his son Pagondas, my maidenly head flourishing with garlands.

The girls draw the audience's attention to the details of their costume: the robes they wear, the laurel in their hands, the garlands on their heads. Their

20 The power of the beloved's gaze is a common topos of erotic poetry: cf. Ibyc. PMGF 287; Anacr. $P M G$ 36o; Simon. fr. el. $22 \mathrm{~W}$.

21 For hair as an erotic symbol cf. Archil. fr. 31 w.; Sapph. frr 98, 103.12 v. Semon. fr. 7.57 W. describes excessive attention to hair as a mark of the luxurious 'mare' woman.

Klinck (2001) suggests that Pindar's adoption of the female persona is more forced than Alcman's, yet she does not in my view demonstrate adequately that this is so. Differences between Pindar and Alcman (for example the absence of homoerotic language in Pindar) can be better ascribed to differences in ritual occasion and cultural context rather than the style of the poets. Similarly, the fact that Pindar's chorus contains more explicit praise (of the daphnêphoros) is surely more to do with the requirements of the festival itself than the poet's personal taste. Rather, we should turn the argument round and say that it is particularly striking that a poet such as Pindar, who often speaks in propria persona, composes so firmly in a parthenaic voice in this poem. 
description of tying up their robes further eroticises the act of watching, for the audience is not only encouraged to notice their clothing but to imagine them in the brief moment ( $\dot{\omega} x \dot{\varepsilon} \omega \varsigma, 9)$ while they are in the process of putting it on. This erotic charge is perpetuated by the epithets they give to their bodies: their hands are 'gentle' ( $\mu \alpha \lambda \alpha \kappa \alpha \hat{\sigma} \sigma \nu)$ and their heads 'maidenly' ( $\pi \alpha \rho \theta \dot{\varepsilon} v i o v$, 12) and both adjectives remind us of their status and desirability, while the transference of $\theta \dot{\alpha} \lambda \lambda_{0} \sigma \alpha(12)$ from the garlands to their heads suggests their own potential fertility, and evokes the tradition of comparing youthful beauty to natural growth. ${ }^{23}$

Poetry performed by parthenoi therefore shows a systematic focus on visual beauty and physical activity: we are constantly reminded what the performers look like, how they are dressed, and what they are doing. Yet the degree to which this is a distinctive feature of parthenaic song becomes still more apparent if we compare what we have seen in surviving partheneia to choral lyric performed by male singers.

\section{Self-Referentiality in Male Choral Song}

Self-referentiality and deixis are common features of choral lyric, found throughout the surviving poetry. ${ }^{24}$ Yet on analysis the type of self-referentiality we find in poetry performed by males is qualitatively different to that of female song: we find none of the visual focus of parthenaic lyric. While male singers may refer to the fact that poetry is being performed, to the performance occasion, or to the poet's control over the song, they refrain from drawing attention to their own appearance, dance, or gestures.

A good place to begin this comparison is epinikion, the choral genre with which modern scholars are most familiar. ${ }^{25}$ Pindar's poetry is steeped with self-referentiality: the songs regularly remind us that they are a crafted piece of praise poetry determined by the poet's choices. To take a single example, Olympian 2 begins with the poet pondering his topic and theme of song (1-6):

23 This imagery can be applied to both men and women: cf. e.g. Hom. Il. 17.53, 18.56, 18.437, Od. 14.175; Sapph. fr. 115 v. (of men); Sapph. fr. 105ab v.; Hom. Od. 6.162-169; Aesch. Suppl. 998, 1015; Soph. Trach. 144-150; Theoc. 18.29-30 (of women).

24 For general discussions of deixis in lyric poetry see Rösler (1983); Danielewicz (1990); Bonifazi (2004); Calame (2004a) esp. 427-432, and see also n. 30 below.

25 I take as a starting premise that epinikia were probably most commonly performed by choruses, yet as I argue below, the lack of certainty on this issue is indicative of the poems' lack of interest in the actions of their performers. 


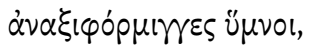

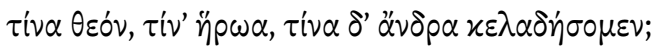

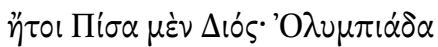

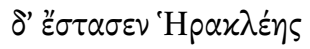

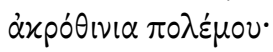

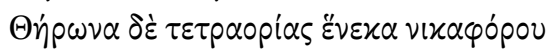

$\gamma \varepsilon \gamma \omega \nu \eta \tau \varepsilon \dot{\varepsilon}$,

Songs, lords of the lyre, which god, which hero, which man shall I sing of? Indeed, Pisa belongs to Zeus, and Heracles established the Olympic Games as the spoils of battle, and Theron must be proclaimed because of his victorious chariot.

The ode begins by questioning its genre, as the poet feigns uncertainty as to whether his topic of song will be a god, a hero, or a mortal man, before combining all three in the story of Theron's victory at Olympia. This type of poetic deliberation and control of the song is extremely common in Pindar, and found extensively throughout the surviving poems. ${ }^{26} \mathrm{~A}$ particularly striking use of the motif of poetic control is found at the start of Isthmian 2, where the poem begins by criticising the contemporary system of paid poets and looks back with nostalgia to a nobler era when the Muse was free to choose (1-16). Pindar is felt to be unusually self-conscious in style yet we also see the same tropes used by Bacchylides. ${ }^{27}$ For example, after telling the lengthy narrative of Heracles in the underworld in poem 5 , he breaks off with a stern appeal to his Muse to return to more typical epinician material (176-186):

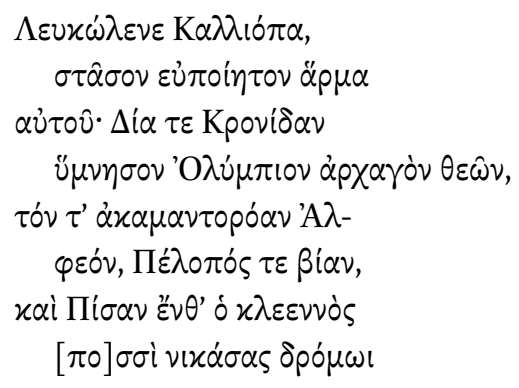

26 For ownership of the praise-song, cf. also $\mathrm{Ol}$. 3.1-9, 4.1-5, 7.1-10, 9.21-27, 10.1-6, 11.8-15, 13.11-12, Pyth. 2.1-6, 9.1-4, 10.4-7, Nem. 1.7, 3.9-17, 4.9-13, 5.1-5, 10.19-22, Isth 1.1-12, 8.5-7.

27 For the differences between Pindaric and Bacchylidean style, see Carey (1999) 18-19; however, see Bacch. 1.183-184 and 5.16-33 for a similar focus on poetic control of praise and aretê. 


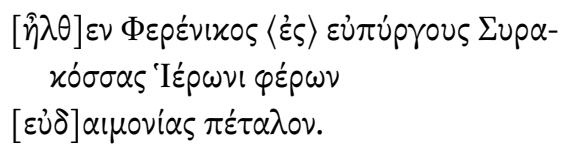

White-armed Calliope, stop your well-wrought chariot here. Sing of Zeus the son of Cronus, the Olympian chief of the gods, and of the tireless stream of Alpheus, and the might of Pelops, and Pisa, where famous Pherenicus sped on his feet to victory in the race and brought back the leaf of good fortune for Hieron to Syracuse of the fine towers.

The poetic style here plays on a high level of self-referentiality: the poem alludes to its audience's awareness that they are listening to a piece of epinikion, composed around certain conventions, and that the poet can control the degree to which these conventions are followed or manipulated. ${ }^{28}$ Similar techniques include Pindar's self-conscious rejection of particular versions of myth (e.g. $\mathrm{Ol} .1 .52, \mathrm{Ol} .9 .30-36)$, and his construction of a reciprocal relationship with his patron (e.g. Ol. 1.108-117, Nem. 1.19-22, Nem. 7.61-67). ${ }^{29}$ Moreover, Pindar makes regular use of deixis, drawing his audience's attention to the fact that a real performance is taking place before them. ${ }^{30}$ Yet despite this high level of metapoetic awareness, we find virtually no explicit comment on what the singers are doing when the poetry is performed. ${ }^{31} \mathrm{~A}$ comparison between the examples we have examined in partheneia and the description of dancing at the start of Pythian 1 makes clear how different a style this is (1-4):

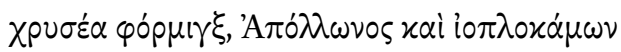

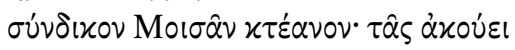

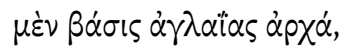

28 For this kind of 'Abbruchsformel' as an epinician device see Mackie (2003) ch. 1.

29 For praise poetry construed as a form of reciprocal gift-giving see Martin (1984); Gentili (1988) 162-176; Nagy (1989); Kurke (1991) 97-107; Maclchlan (1993) 103-105; Hornblower (2004) 30-32; Boeke (2007) 81-87; Burnett (2008) 20-21.

30 For discussions of how analysing deixis can add to the interpretation of individual odes, see e.g. Felson (1999); Athanassaki (2004); Felson (2004); Martin (2004); Calame (2008).

31 Scholars who see the poetic 'I' as referring exclusively to the poet might give this as an explanation for the omission. Yet even if one were to take the line that epinician ' $\mathrm{I}$ ' always represents Pindar and never the chorus, it would still be striking that Pindar should have so little interest in portraying the moment of the ode's actual performance. A better explanation might be that epinician poets avoid pinning the ode down to a particular setting to increase its potential for future reperformance by the victor's family. 


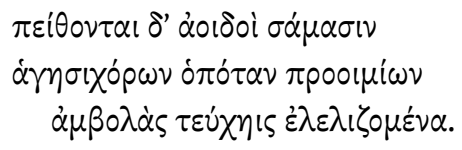

Golden lyre, rightful possession shared by Apollo and the violet-tressed Muses, it is to you the dance-step listens as it begins the glorious celebration, and the singers obey your signals whenever you prepare with your vibrations to strike up chorus-leading preludes.

The song alludes to a choral performance, but any connection between this dance and the current song is unstated and left for the listener to infer. The audience is equally free to interpret the lines as a general statement about the powers and role of the lyre: we as modern readers are given no solid evidence to guide us as to the actual performance of the lines. Indeed, the scholarly debate about the performance of epinikia is the result of similar vagueness throughout extant epinician poetry. If epinikia gave us even a small fraction of the performance detail we find in partheneia the controversy would be largely resolved. ${ }^{32}$

Another important feature is the complexity of the poetic persona: this too has prompted much scholarly discussion, and it is also a telling example of the stylistic differences between epinician and parthenaic song. In epinikia there are occasions when the poetic 'I' seems to represent the voice of the poet, and other occasions when it is less clear-cut, and where the 'I' makes general statements which could equally well be attributed to poet or to chorus. ${ }^{33}$ Whatever the response of modern readers we must assume from the regularity with which epinikia do this that it would not have been troubling or unusual to the original audience. Conversely, the choruses of partheneia do not allow us to forget the identity of the chorus that performed them: even though Pindar's parthenoi can fulfil general choral functions such as public

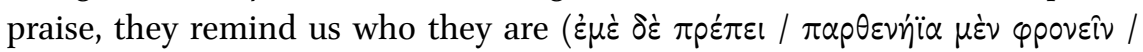

32 Arguments for or against choral performance are required to tackle the question of how much we should connect performance-related concepts (e.g. the use of the word $x \hat{\omega} \mu \circ \varsigma$, or the mention of dancing within the poems) to the poems' own performance context: see Heath (1988); Burnett (1989); Carey (1989); Heath and Lefkowitz (1991); Carey (1991); Currie (2004).

33 For various perspectives on this phenomenon see Rösler (1985); Bremer (1990); Gentili (1990); Lefkowitz (1991) 1-71; D'Alessio (1994); Lefkowitz (1995). D'Alessio's notion of a shifting persona is particularly illuminating, and accounts for the flexibility of lyric personae. For the shifting nature of the 'I' in Bacchylides, see Calame (2011). 
$\gamma \lambda \omega^{\omega} \sigma \sigma \alpha l \tau \varepsilon \lambda \varepsilon^{\prime} \gamma \varepsilon \sigma \theta \alpha l$, 'it is right for me to think maidenly thoughts and to speak them with my tongue,' $33-35){ }^{34}$

Epinikia and partheneia are distinguished by more than just the gender of their performers, so in order to make the case that male and female selfreferentiality are different we must look to other male lyric genres. An examination of Pindar's paianes tells a similar story: again, self-referentiality is common, but little of it is visual. As in epinikia, we find self-conscious comments on the fact that a piece of poetry is being performed. For example, Paian 2 begins with a confident statement that the singers will 'drive this paian' $\left.(\pi \alpha l] \hat{\alpha} v \alpha[\delta l] \omega^{\prime} \xi \omega, 4\right)$ from Abderus to Aphrodite and Apollo. Thus the chorus not only comment on the context in which the song is being performed (for the Abderites) but also hint at their meta-poetic awareness that the song they are singing belongs to a particular genre. ${ }^{35}$ Similarly, one of Pindar's thrênoi contains a list of alternative genres_-paian and Dionysiac song-before explaining the aetiology and sub-divisions of the type of song that it actually is (fr. $128 \mathrm{c} \mathrm{s.-M.).}{ }^{36}$

As well as self-conscious control of the song, we find a focus on the performers' own identity. Thus, for example, Pindar's Paian 4, composed for the Keans, includes a discussion of what it means to be a Kean (21-24):

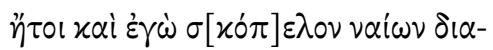

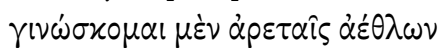

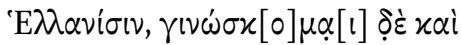

$$
\begin{aligned}
& \mu \circ \hat{\imath} \sigma \alpha \nu \pi \alpha \rho \dot{\varepsilon} \chi \omega \nu \stackrel{\alpha}{\lambda} \iota \varsigma^{\circ}
\end{aligned}
$$

Although I live on a rock, I am well-known throughout Greece for excellence in games; and I am known also for providing the Muse with plenty.

The poem goes on to discuss themes of identity and community in more general terms, but here the focus is explicitly on the chorus, whose involvement is emphasised by the confident The performers' identity is of central importance to the poem; indeed the chorus represents all aspects of Keos, including both its harsh environment and

\footnotetext{
34 Cf. D'Alessio (1994) 120: 'it was only in this kind of poem that the exact identity of the members of the chorus was of ritual importance.' See also Lehnus (1984) 81; Stehle (1997) 98-99.

35 Cf. also Pind. Pa. 5.45-48 where the chorus ask to be welcomed to the sound of the paian

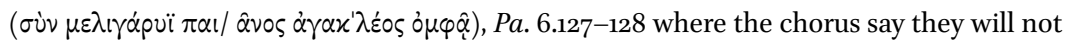

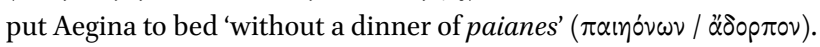

36 Cf. Cannatà Fera (1990) 137-144.
} 
its claims to greatness. ${ }^{37}$ The locality of the performance can also be important, and Paian 6 opens by paying attention to its Delphic setting. The poem begins with an appeal to Pytho to welcome the singer $\left(\lambda i \sigma \sigma o \mu \alpha l \ldots\right.$... $\boldsymbol{\varepsilon}^{2} \zeta \alpha \theta \dot{\varepsilon} \omega l \mu \varepsilon \delta \varepsilon \dot{\varepsilon} \xi \alpha l$

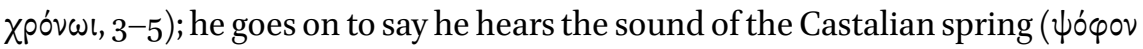
$\alpha i i \omega \nu \operatorname{K} \alpha \sigma \tau \alpha \lambda i \alpha \varsigma, 8)$ before stating once more that he has come to the shrine of Apollo ( $\left.\varkappa \alpha \tau \dot{\varepsilon} \beta \alpha \nu \ldots \alpha^{\prime} \lambda \sigma \circ \varsigma^{\prime} A \pi \dot{0} \lambda \lambda \omega \nu \circ \varsigma, 8-9\right)$, described through its identifying feature, the omphalos (o $\mu \varphi \alpha \lambda \dot{o} v$... $\sigma x i \alpha \dot{\varepsilon} \tau \tau \alpha, 17) .{ }^{38}$

Yet the attention paid to the chorus' identity also serves to highlight the differences with partheneia. The male choruses we have examined may draw attention to their identity, their location, or the type of poetry they perform, yet we do not find a parallel to the focus on appearance, accessories, or actions to what we have seen in choruses of young women.

Indeed, a moment's reflection should tell us that the level of visual selfreferentiality we find in partheneia is surprising. While we as modern readers lack access to the details of the performance, the original audience had no such problem: they could see the appearance, movements and gestures of the chorus before them. Hence the question arises as to why parthenaic choruses feel the need to inform their audiences about details which were visually apparent. The words of the poems treat the audience as though they are unable to see, and need to be guided verbally. Peponi's study of visual deixis in Alcman PMGF 1 argues that this use of language should be taken as relevant to the performance context: if we imagine the ritual as a dawn one, the audience may not be able to make out the details of costume and gestures clearly in the half-light; hence the chorus claim to be describing what the audience can see but are actually directing them. ${ }^{39}$ Yet while this may be a factor in the performance of this particular poem, it is unlikely to be an explanation in other cases: for example, there is no reason to believe that the daphnêphorikon was a dawn ritual. ${ }^{40}$ As we

37 Cf. also Pind. $P a .2 .24-31$ where the chorus speak in the persona of Abderus.

38 On the question of the speaker's identity in this passage, see D'Alessio (1994) 125, and also Kurke (2005) 86-90, who argues that the use of the poetic persona in this poem is unusual for paian.

39 Peponi (2004) 308. The timing of the ritual is another source of contention, and partly

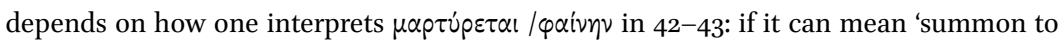
shine', this implies that the sun is not yet in the sky, while if it must mean that she invites the sun to witness (cf. West [1965] 194-195), it implies that it is already visible: see also n. 11. Of course, this opposition between dawn / not dawn may be misleading: the sun either is or is not over the horizon, but the growing light of dawn is a gradual progression not a binary state, and the ritual can still be a dawn one (as most scholars agree) even if the sun is visible by this point.

40 The fullest ancient description is that of Proclus (Chrest. 69-78 Severyns ap. Phot. Bibl. 
shall see, visual self-description is a feature of all kinds of choruses of parthenoi, regardless of the details of performance context. We must therefore seek an explanation which does not depend on a particular ritual setting, for it seems that the performers' appearance and actions are embedded into parthenaic poetry in a way we do not find in other types of song.

\section{Visual Self-Reference in Evocations of Parthenaic Song}

Analysing descriptions of female song in other texts confirms the impression that visual self-referentiality is a fundamental feature of this type of song. When poets want to evoke a chorus of parthenoi, this is a device they make use of. For example, in Pindar's Paian 2, the chorus describe a dance performed by Delphian maidens (97-102):

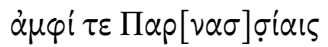

$$
\begin{aligned}
& \pi \dot{\varepsilon} \tau p \alpha \alpha \varsigma \dot{\nu} \psi \eta \lambda \alpha \hat{\imath} \varsigma \text { } \theta \alpha \dot{\alpha} \Delta[\varepsilon \lambda \varphi] \omega \hat{\omega} \nu
\end{aligned}
$$

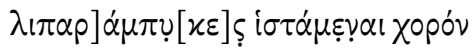

$$
\begin{aligned}
& \tau \alpha \chi \dot{v}] \pi 0 \delta \alpha \pi[\alpha \rho] \theta \underline{\varepsilon} v 0 \text { o } \chi \alpha \lambda- \\
& \left.x \varepsilon^{\prime} \alpha l\right] x \varepsilon \lambda \alpha \delta\left[\varepsilon^{\prime} 0 v\right] \tau l ~ \gamma \lambda u x \dot{v} v \alpha \dot{\delta} \delta \hat{\alpha} l \\
& \tau \rho \dot{\pi} \pi] \circ v^{\circ}
\end{aligned}
$$

Among the high rocks of Parnassus the maidens of Delphi with their (gleaming) headbands often set up a (swift)-footed chorus and sing a sweet (melody) with voices strong as bronze.

The singers describe the female chorus in visual terms, dwelling on the trappings of finery (the headbands) and the physicality of their movements (the emphasis on the swift beat of their feet). Similarly, Bacchylides 13 includes a description of a dance of parthenoi in honour of Aegina. It begins with a focus on a single girl, whose vigorous movement is emphasised in the phrase leaping lightly on her feet like a carefree fawn' ( $\pi \dot{\delta} \delta \varepsilon \sigma \sigma l \tau \alpha \rho \varphi \varepsilon ́ \omega \varsigma$ / 86-87). Attention then shifts to her companions in the chorus, and here the poet dwells on the details of their costume: the bright colours of the flowers they wear in their hair, and the unusual detail of reeds woven into the garlands

239.321a34-b31), but we have no evidence for the timing of the ritual. Bernardini (1989) 44-45 suggests that the daphnêphoria took place at nightfall, by analogy with similar ceremonies in other poleis, but it is risky to extrapolate details from rituals from other communities and cults: cf. Finglass (2007) 31 . 


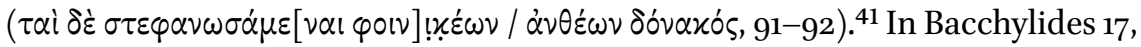
Theseus sees the dance of the Nereids in his visit to the bottom of the sea. These are a chorus of mythological and divine parthenoi and represent an idealised form of parthenaic chorus: as such the visual splendour of their dance is given particular force (101-108):42

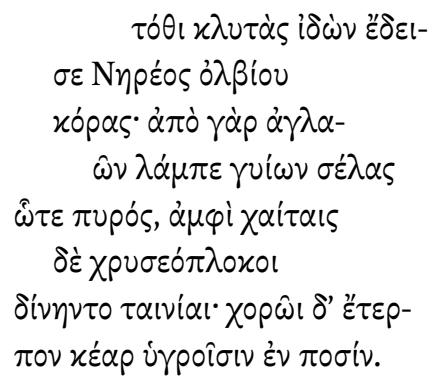

There he was struck with awe as he beheld the glorious daughters of blessed Nereus, for a beam shone from their brilliant limbs as from a fire, and gold-braided ribbons were twirled around their hair. They were delighting their hearts in choral dance with their watery feet.

The Nereids are not simply compared to bright objects, but actually emanate light from their bodies; not only do they wear gold in their hair, but its intricate

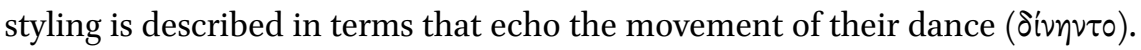
Rather than the usual emphasis on the beating or quickness of the girls' feet to capture their physical movements, we find the adjective irpoîtv, which highlights the bizarre and supernatural nature of this chorus. Even within the context of male choral lyric, then, we see a difference in presentation of male and female choruses: the singers dwell on the visual appeal of watching female choruses, yet do not apply similar language to their own performance.

Dramatic texts are full of occasions where characters either describe parthenaic song or self-represent as parthenaic singers, and the dramatists too look to visual self-reference as a way of evoking such performances. This is

41 For the erotic overtones of this description see Power (2000) 78-80. Power also discusses the use of parthenaic projection to enhance the message of praise sung by the male chorus: cf. also Fearn (2007) 116-119.

42 The Nereids are associated with female transition, as demonstrated by their inclusion in artistic scenes of marriage or abduction, or in traditionally feminine roles: see Barringer (1995) 69-137. Hence they represent a model for parthenaic dance as a precursor to marriage. 
particularly striking given that we have little evidence for public performances of female choruses in Athens (though evidence from vases suggests that female choruses did perform at private occasions such as weddings). ${ }^{43}$ In evoking these details dramatic poets assume that a mass Athenian audience not only knew about parthenaic choral song, but also that they were familiar with its distinctive features. Either Athenians must have had access to the tradition from other poleis (from contemporary performances elsewhere, or from earlier lyric such as Alcman circulating as texts), or Athens did in fact have a culture of parthenaic song, albeit one which performed in a more low-key way than its male equivalents, and without the funding and recognition they received. What does seem indisputable, though, is that Aristophanes and the tragedians were well aware of the stylistic tropes of parthenaic song and that they assumed a wide enough knowledge on the part of their audience for it to be worth their while including such references. ${ }^{44}$

The clearest example of this device comes at the end of Lysistrata, where we are given a close parody of a Spartan female dance $(1302-1320):^{45}$

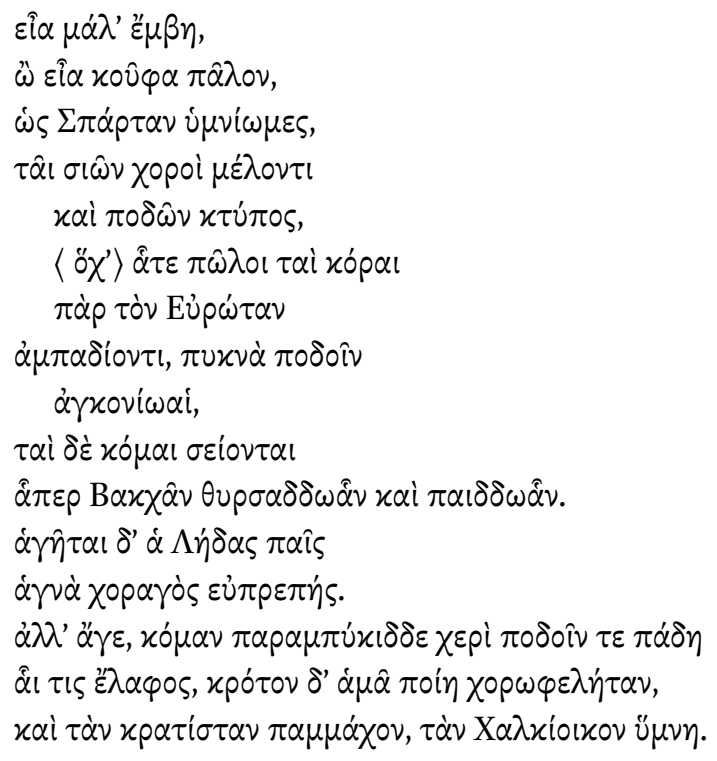

43 For a thorough account of this issue see Parker (2005) 182-183; Trieschnigg (2009): 23-27.

44 Hamilton (1989) discusses the similarities between parthenaic ritual language from different communities.

45 For a discussion of the use of non-dramatic choral forms at the end of Lysistrata see Calame (2004b) 162-172. 
Step out then! Dance it lightly, in order to celebrate Sparta, which delights in choruses in honour of the gods and in the pounding of feet. The girls leap like fillies beside the Eurotas, raising clouds of dust with their feet, and their hair flows like the hair of bacchants who play waving their thyrsuses. Leda's daughter leads them, the sacred and noble chorusleader. Come now, bind up your hair with your hand, and let your feet leap like a deer, and make a noise to help the dance, and sing in praise of the most powerful one, who vanquishes all in battle, she of the Bronze House.

This passage shows a surprising level of familiarity with the details of Spartan cult and with the style of Spartan partheneia. ${ }^{46}$ As in Alcman we find a particular woman singled out as a choragos figure; here she is Helen, a figure with her own links to Spartan ritual and who did indeed have a shrine by the banks of the Eurotas. Moreover the description of the girls as $\pi \hat{\omega} \lambda$ o r may spring from the general topos of describing girls as young animals, but it also ties into their presentation in Laconia, for example the relevance of the Leucippides and the prevalence of horse-imagery in Alcman $P M G F 11^{47}$ As part of this evocation of Spartan female dance, we find a striking focus on the visual. We are told of the girls' dance movements: the lightness of their step ( $\varkappa 0 \hat{\varphi} \varphi \alpha, 1304)$; the beating of their feet ( $\pi \circ \delta \hat{\omega} \omega \nu \tau \tau \dot{u} \pi \circ \varsigma, 1307)$; their energetic leaping $(\dot{\alpha} \mu \pi \alpha \delta \delta 0 \nu \tau 1,1310)$ and

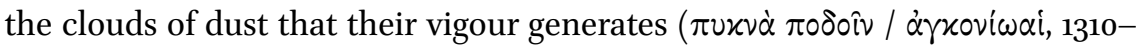
1311). Attention is drawn to other gestures, in particular the shaking of their

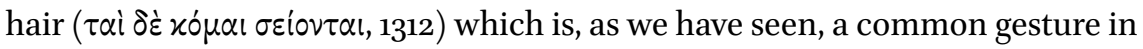
girls' description of their own dance. Aristophanes presents this choral dance as something characteristically Spartan and connects it with other Spartan details such as cult. Yet as we have seen, the visual focus is found not only in Alcman but also in Pindar's Theban partheneion, as well as being evoked in descriptions of female choruses in odes produced for cities across the Greek world. It therefore makes more sense to see this as a feature not embedded within one

46 Revermann (2006) 254-259, following a suggestion in Taplin (1993) 58 n. 7, argues that the ending of Lysistrata was not originally composed for an Athenian audience but was a later addition for a Spartan or Spartan-derived audience at a reperformance. However, I find such a radical solution unnecessary: the fact that the ending is unusual is not sufficient reason to suppose that it is not original, or that it could not be poetically effective for an Athenian audience.

For the cult of the Leucippides see Wide (1893) 326-332, Kannicht (1969) 381-383, Calame (1977) I 323-330. 
particular community, but rather a deep-rooted association which can trigger associations in a range of poleis. ${ }^{48}$

Indeed, if we turn to other examples of dramatic choruses evoking parthenaic song, we see that it is presented as a general feature rather than one which indicates a particular polis-association. For example, in the parodos of Euripides' Electra, the chorus describe a festival in honour of Hera in which all the parthenoi of Argos will participate (173-174). Like Alcman's partheneia these are performances aimed to please a goddess $\left(\dot{\varepsilon} \gamma \hat{\omega}[\nu] \delta \dot{\varepsilon} \tau \hat{\alpha} \iota \mu \dot{\varepsilon} \nu\right.$ 'A $\omega^{\prime} \tau ا$ $\left.\mu \dot{\alpha} \lambda \_\sigma \tau \alpha F_{\alpha} \alpha \nu \delta \dot{\alpha} \nu \eta \nu \dot{\varepsilon} \rho \hat{\omega}, P M G F \quad 1.87-88\right)$, but the identity of the goddess and the civic context in which the chorus will perform is a different one. ${ }^{49}$ In their description of this choral performance, both Electra and the chorus show a similar focus on visual appearance and accessories. In refusing to join the dance, Electra claims she has no interest in gold necklaces (oن̉ '

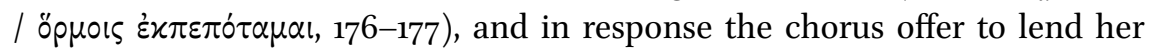
fine clothing ( $\pi 0 \lambda \dot{v} \pi \eta \nu \alpha \varphi \dot{\alpha} \rho \varepsilon \alpha, 191)$ and gold accessories ( $\chi \rho \dot{\sigma} \sigma \varepsilon \dot{\alpha} \tau \varepsilon \chi \alpha \dot{\alpha} \rho \sigma \omega \nu, 192)$. Again, the description of the dance focuses on its speed and movement, and

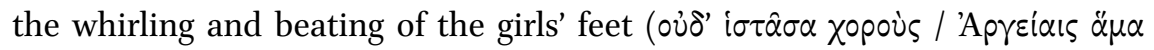

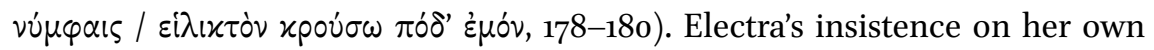
visual inadequacy and physical squalor therefore serves a symbolic purpose: whereas clothing and hair are normally mechanisms for evoking female dance, Electra uses them in order to justify her own refusal to dance ( $\sigma x \varepsilon \dot{\varepsilon} \psi \alpha \iota$ rov

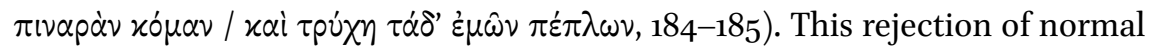
parthenaic activities is connected to Electra's own liminal status, as someone who is neither truly parthenos nor gunê. ${ }^{50}$ Hence Electra refuses to dance with the other parthenoi but also rejects the company of the married women

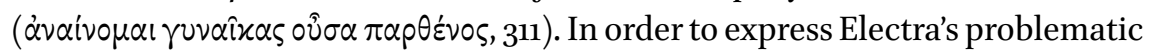
status and her alienation from female ritual normality, Euripides draws on the tropes of parthenaic song, and like Aristophanes he uses visual and physical language to do so. ${ }^{51}$

48 Bierl (2007), who also notes the parthenaic associations of this passage, suggests a theme of female transition and sexuality running throughout Lysistrata, which would add further weight to the parthenaic allusion here. See also Bierl (2011).

The identity of the goddess in Alcm. PMGF 1 is a source of much contention, though not important to the argument here: for various suggestions see Page (1951) 76; Burnett (1964) 32-33; Garvie (1965); Griffiths (1972) 24-27; Clark (1996) 157; Cyrino (2004).

$5^{\circ} \quad$ Cf. Zeitlin (1970) 650; Cropp (1988) on 312-313.

$5^{1} \quad$ For a fuller discussion of the symbolic connotations of this passage see Swift (2010) 189191. 
Other tragic descriptions of choruses of partheno $i$ also follow this trend: visual language is used in order to create a quick sketch of a chorus of parthenoi. The connection between parthenaic song, female transition and visual appeal is encapsulated by Cassandra's appeal for a parthenaic performance to partici-

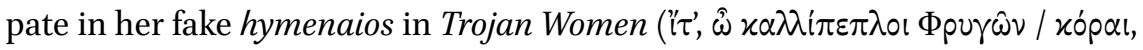

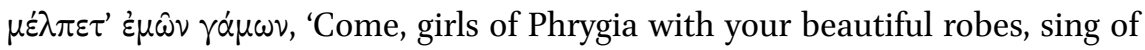
my marriage,' 338-339). The chorus of this play are not parthenoi but married women (cf. 1081), but the imaginary wedding calls for a performance by maidens, and so the chorus are construed in that light for the purpose. ${ }^{52}$ And in portraying them as a chorus of parthenoi, Cassandra describes them via the detail of their dresses, again emphasising the close connection between the dance she requires and the visual display involved. Similarly, in Iphigeneia among the Taurians, the chorus imagine returning to Greece and performing to celebrate a wedding $\left(1143^{-1152):}\right.$

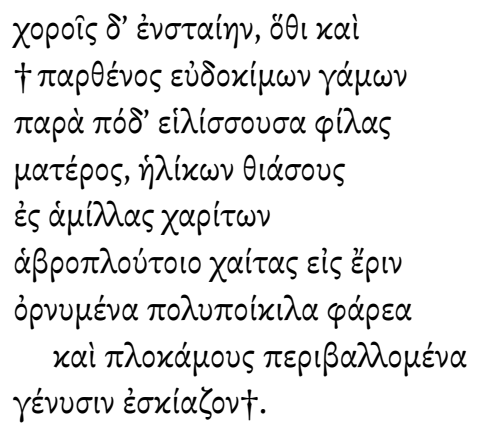

May I take part in the choruses where $\dagger$ as a girl at glorious weddings I once whirled around near my dear mother, and in a contest of grace with my age-mates, stirring up competition with my luxurious hair and intricate clothing, I let down my tresses to shade my cheek. $\dagger$

This imaginary chorus takes place in a context different from that in which Alcman's parthenoi performed, and different too from the parthenaic chorus of Electra: rather than being part of a religious festival it is for a wedding. ${ }^{53}$ Yet

$5^{2}$ Portraying married women as parthenoi in order to express a form of transition they are undergoing is a common technique in Greek poetry: see Swift (2010) 192.

53 Some scholars have suggested that Alcm. PMGF 1 was in fact a wedding song: see Griffiths (1972); Gentili (1988) 75-76. I see it as more likely to have represented an earlier stage in the development of parthenoi (part of their transition to a marriageable state of life rather 
the symbolic connection is clear, for wedding song is an action which symbolises the successful completion of the journey to maturity. Moreover, it is the chorus' status as parthenoi which is foregrounded in this description: they are

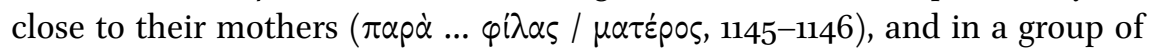

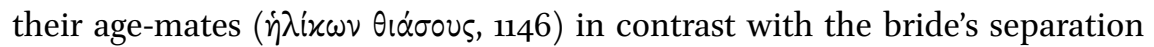
from both mother and companions. ${ }^{54}$ Here too we find an emphasis on the performers' visual splendour. Once again, the girls' dance is a whirl of movement ( $\varepsilon i \lambda i \sigma \sigma o v \sigma \alpha, 1145)$; the poet dwells on the details of their hair and cloth-

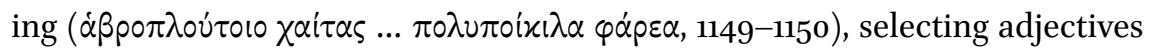
which emphasise their luxury and beauty. The gesture of the loosening of the hair recalls the shaking of the hair we have seen elsewhere in female choral dance, yet is also an erotic motif which highlights the girls' desirability. ${ }^{55}$ The importance of the visual here is emphasised by the description of the dance as a 'contest in beauty' ( $\dot{\alpha} \mu$ í $\lambda \alpha \varsigma \chi \alpha \rho i \tau \omega \nu, 1147)$, which construes the girls' appearance as one of the main functions of the performance. ${ }^{56}$

When poets seek to evoke choral performance by parthenoi, then, they draw on a store of visually-oriented descriptions similar to those we have seen in songs that really were performed by choruses of young women. The repeated use of this motif reinforces the suggestion that this was a distinctive feature of songs performed by partheno $i$; visual language is felt to be a way of alluding to this type of song and of triggering its associations. Having established a focus on physical appearance, dress, and actions as an important feature of female song, it now remains for us to investigate what light this can shed on the songs themselves, and the role that they played in Greek society.

\section{$4 \quad$ Parthenoi on Display}

Visual imagery is thus a widespread and pervasive feature of parthenaic performance, and its frequency suggests that it may enrich our understanding of female song in Greek society. We can begin with the songs' own performance

than to marriage itself). The suggestion that the song was connected with transition was first made by Calame (1977), but cf. also Lonsdale (1993) 193-205; Ingalls (2000).

Cf. Sapph. fr. 104ab v.; Theoc. 18.12-14, 41-42; Catull. 62.20-22; Plut. Lyc. 15; Dion. Hal. 2.30.5. See Seaford (1987) 106-107; Jenkins (1983); Alexiou (1974) 120 (on modern Greek parallels); Swift (2006) 129-130.

Cf. Archil. fr. 31 w., where the girl's loosened hair is presented as a central part of her erotic appeal.

$5^{6}$ For a discussion of parthenaic imagery in Eur. IT more generally, see Swift (2010) 197-218. 
context. The constant reference made to the singers' appearance and gestures sets up a relationship between chorus and audience; the technique construes the audience's gaze as a central part of the performance, and so the onlookers are drawn in to become active participants themselves. In terms of the songs' performance, this is suggestive. Firstly it adds extra weight to the idea that this is a public occasion and not a closed initiation group: the audience is presented as integral to the performance, and the words of the songs attempt to control and guide their response. ${ }^{57}$ Moreover, this adds weight to the views of those scholars who have seen the poems as engaging with the issues that surround female transition. ${ }^{58}$ The visual language is a feminine phenomenon, associated strongly with descriptions of female choruses; this indicates that the performers' own identity is fundamental to the poetry's purpose.

The idea that parthenaic song is associated with female display is further supported by the tragic cases we have examined, where we see these ideas used in a way which demonstrates not only that the poets recognised the visual as a parthenaic motif but also that they were interested in exploring the reasons for it. In the plays discussed above, the chorus evoke the language associated with parthenaic choruses in order to juxtapose the malfunctioning tragic world with the ritual normality associated with the genre. Thus in Euripides' Electra, female adornment is used to contrast Electra's dysfunctional state as a parthenos whose journey to maturity has failed with the normative model of female development offered by the chorus, while in $I T$, the chorus contrast joyous female display at a wedding - the ultimate goal of female transition - to their state as parthenoi kept from a normal female life and forced to participate in the destruction of men. As the poets explore these themes, they deploy visual language as a way to evoke the audience's expectations regarding female song, and, by implication, to create a contrast with the dysfunctional world of tragedy. And foremost among these associations seems to be the connection between parthenaic choruses, visual display, and the transition to sexual maturity.

Nevertheless, the very fact that this motif is so widespread, and is found in texts from a range of periods and poleis, should lead us to approach this idea of transition with care. In particular, the pervasive nature of the imagery may suggest that it is misguided to see this transition as rooted in particular ritual 
tasks or moments. The occasions on which real parthenaic choruses performed varied, and the descriptions we have examined vary still further, incorporating a range of religious occasions as well as secular ones such as weddings, yet the focus on appearance and action remains the same in all these contexts. In all cases, the element of transition appears to be grounded in the very act of performing publicly in a chorus, rather than the external context in which the song is taking place.

This role of the chorus as an opportunity for female display is indicated by the common mythological motif of choral performance as an opportunity for girls to be seen by or abducted by gods. ${ }^{59}$ Thus for example in Iliad 16, we are told that Hermes was struck by lust when he saw Polymela performing in a choral dance (181-185):

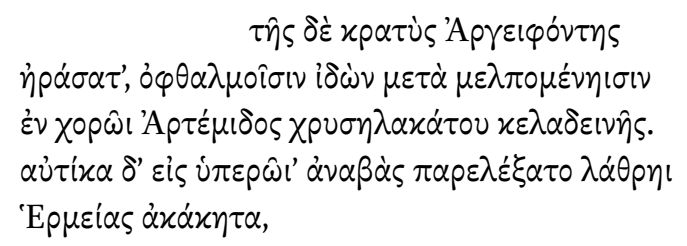

The strong Slayer of Argus desired her when with his eyes he saw her among the girls singing in a chorus for Artemis of the golden spindle and the loud cry. Straight away gracious Hermes went up to her chamber and lay with her in secret.

Similarly, Aphrodite's story to Anchises in the Homeric Hymn to Aphrodite includes the detail that she was abducted by Hermes in strikingly similar circumstances (117-120):

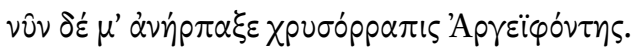

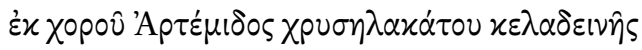

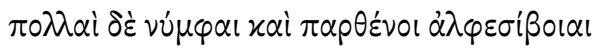

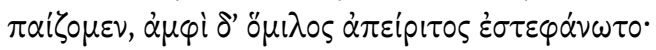

Just now Hermes the Slayer of Argus, bearer of a golden wand, snatched me away from the chorus performing for Artemis of the golden spindle and the loud cry; many of us, nymphs and maidens worth large dowries, were playing together, and a large crowd stood in a circle around us. 
In order to present herself as innocent yet sexually desirable, Aphrodite claims that she was one of a group of parthenoi performing in a choral dance. The public nature of the dance is emphasised: it is watched by a 'boundless' group of spectators ( $0 \mu 1 \lambda \circ \varsigma \dot{\alpha} \pi \varepsilon i p \iota \tau \circ \varsigma, 120)$. The girls on display are viewed as potential marriage-partners whose value is stressed ( $\left.\alpha^{\lambda} \phi \varepsilon \varepsilon \sigma^{\prime} \beta \circ 1 \alpha l, 119\right) .{ }^{60}$ The girls' are described as 'playing' ( $\pi \alpha i \zeta o \mu \varepsilon v, 120)$ : a word which is also used of Persephone's activities before her abduction in the Homeric Hymn to Demeter $(4-8): 61$

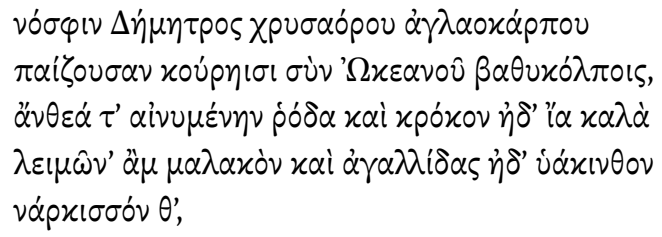

Away from Demeter of the golden sword and the shining fruit she was playing with the deep-bosomed daughters of Oceanus, and picking flowers across a soft meadow: roses and crocus and lovely violets, irises and hyacinthus, and the narcissus.

The idea of the girls as a chorus is not made as explicit as in the Hymn to Aphrodite, but Persephone is nevertheless snatched from play among her companions, and we are perhaps meant to understand the girls' activities as a dance: the word $\pi \alpha i \zeta \omega$ is regularly used in this sense. ${ }^{62}$ Euripides' description of Persephone's abduction in Helen makes the choral element explicit ( $\tau \dot{\alpha} \nu$

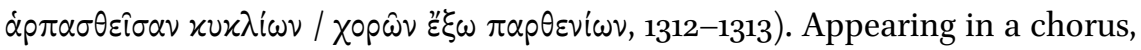
then, is a common topos for the ending of virginity, expressed in myth through divine abduction, and it functions similarly to the better-known trope of flowerpicking in a meadow. ${ }^{63}$ The image of the flowery meadow as a location for seduction is a commonplace of myth and poetry; it is not rooted in any individual instance or ritual but rather a deep-seated cultural idea which is regularly

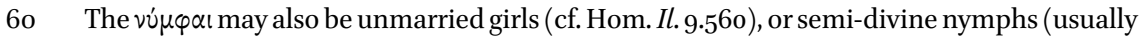
presented as sexually desirable).

61 For the erotic connotations of $\pi \alpha i \zeta \omega$ used of young girls, see Rosenmeyer (2004).

62 Cf. Hom. Od. 8.251, 23.147; [Hes.] Shield 277; Aristoph. Frogs 390, 409, Thesm. 1227. For the connection between dance and play see Lonsdale (1993) 21-24.

63 For girls abducted from choruses of nymphs see also Hes. frr. 26, 140 M.-W.; Plut. Thes. 31.2. For 'historical' abductions from a chorus cf. also Paus. 4.16.9. 
used to express the transition to female maturity. ${ }^{64}$ We should view the topos of parthenaic choral dance similarly: dancing in a chorus is considered a symbolic act of female display and sexualisation across Greece. It may also have been the case that parthenaic choral dance was associated with particular rituals of female transition, just as we find evidence for flower-picking festivals in which parthenoi participated. ${ }^{65}$ Yet we should see any specific ritual association as arising from the more general association between choral dance and female display, rather than the other way around.

This story-pattern is echoed in the Nausicaa episode in the Odyssey: an interlude which draws on the topoi and language of transition in order to achieve its poetic aims. When Odysseus comes across Nausicaa, she is not performing in a formal chorus, but she and her girls act in a way which evokes the topos of female dance as a medium for sexualisation and visual display (6.99-109):

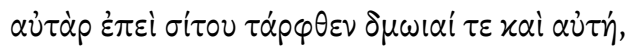

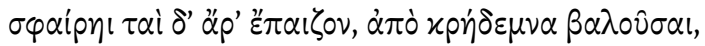

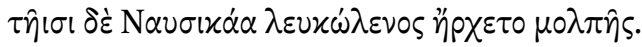

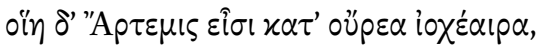

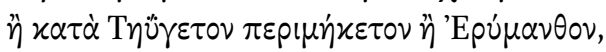

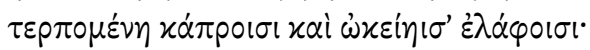

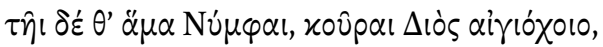

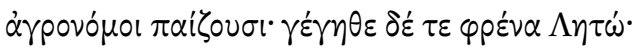

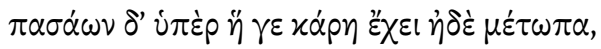

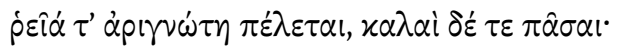

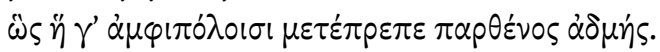

But when she and the maidservants had had their enjoyment of the food, they began to play with a ball, throwing off their veils, and white-armed Nausicaa led the song among them. As Artemis the archer comes down from the mountains, from high Taygetus or Erymantus, delighting in chasing boar or swift deer, and with her play the Nymphs of the wilderness, the daughters of Zeus who bears the Aegis; Leto rejoices in her heart since

64 For the meadow as an erotically charged location cf. Hom. Il. 14.294-351; Sapph. fr. 2 V.; Archil. fr. 196a w. For abduction while flower-picking cf. HHDem. 4-18; Eur. Ion 887-896, Hel. 244-249. See Segal (1981) 27-29; Vernant (1983) 135-142; Calame (1999): 151-174; Swift (2009) $365-368$.

65 See Strabo 6.1.5.33-38; Pollux 1.37; Paus. 2.35.5; schol. Aristoph. Frogs 344b Chantry = Soph. fr. 891 Radt. 
Artemis holds her head and brow above all of them, and she is easily known although all of them are beautiful. Thus did the unmarried maiden stand out among her servants.

The girls' play is not an organised chorus, but it is imagined as a type of dance to music: the idea of a ball-game as a dance re-emerges again in Alcinous' palace, when he orders the performance of a ball-dance (this time by a group of young boys) in order to entertain Odysseus (8.250-265): this too is described as a form of 'play' ( $\pi \alpha i \sigma \alpha \tau \varepsilon, 8.251)$. The gesture of taking off the veils is an erotically charged one, hinting at the girls' sexuality, and also perhaps recalls the loosening and tossing of the hair we see elsewhere in female dance. ${ }^{66}$ Nausicaa's ball-dance is followed by a simile comparing her to Artemis preeminent among her nymphs, whose purpose is to stress Nausicaa's beauty and the degree to which she outstrips the other girls. Like Hagesichora or Astymeloisa, Nausicaa is exceptional, and all eyes are focused upon her. In order to make this point the poet dwells on the act of viewing, focalizing this through the imagined figure of Leto (106-107); yet the motherly joy of Leto is implicitly contrasted with the less innocent impression that Nausicaa may make on Odysseus when he sees the girls.

Nausicaa and her maids do not intend their dance to be witnessed by outsiders, yet we as the audience can see how it reflects more organised types of female dance, and these evocations link into the sexual overtones of the scene. The idea that the ball-dance echoes cultural topoi involving visual display of parthenoi is confirmed by the rich clustering of marital language throughout the scene. ${ }^{67}$ Nausicaa's expedition is motivated by her anticipation of her own future marriage (6.27-35), a theme which Odysseus also draws upon in

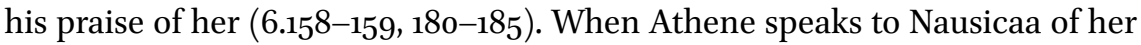
future marriage, she singles out fine clothing as an important focus for a brideto-be (6.26-28), and once again makes the connection between visual display and sexual appeal. Odysseus' comparison of Nausicaa to a sapling (6.160-169) draws on hymenaeal tropes, as well as the convention of comparing human and natural fertility, while Nausicaa responds by imagining the prospect of a marriage to Odysseus himself (6.244-245). Here too, Nausicaa's sexual desirability is connected with a public and choral display, for Odysseus praises Nausicaa by imagining her family's response as they see her dance (153-159):

66 Cf. Hainsworth (1990) on 6.10o. For the krêdemnon as a symbol of chastity and marriage see Nagler (1974) 44-6o.

67 See Hague (1983) 136-137; Lonsdale (1993) 206-210. 


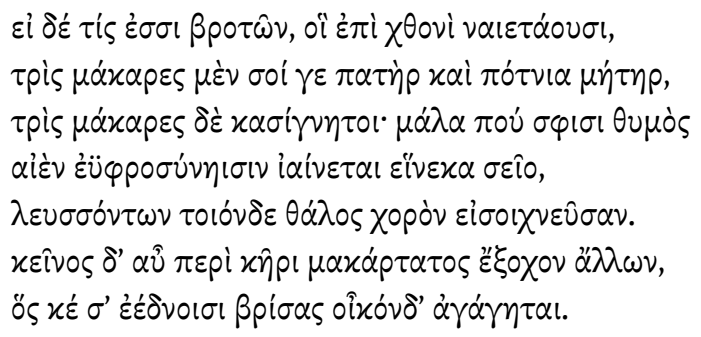

But if you are one of the mortals who dwell upon the earth, thrice-blessed are your father and lady mother, thrice-blessed your brothers. Indeed their heart must grow warm with gladness every time they see this sapling of theirs entering the chorus. But the man who is blessed above all others in his heart is he who shall win you with his bride-gifts and lead you to his home.

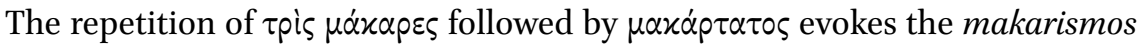
which formed an important element of wedding ritual. ${ }^{68}$ Thus the blessedness of Nausicaa's parents and brothers is implicitly connected to their hopes for her marriage, while the man who wins her hand is the most blessed of all. Nausicaa's participation in the choral dance is presented as part of this marital process; moreover we again see emphasis placed on the experience of watching the dance as an observer: it is seeing Nausicaa perform publicly which brings her family joy.

The Nausicaa episode, then, is configured in such a way as to evoke the topos of parthenaic dance as a form of female display and a precursor to marriage. For the scene to work effectively, the audience must be aware of these cultural triggers, and so recognise that Nausicaa's interaction with Odysseus is cast in the mould of a seduction scene. Nausicaa's participation in a quasi-choral dance presents Odysseus as a potential seducer or even rapist; likewise, Odysseus' role as observer of this dance heightens our concern that he may become trapped on Phaeacia. Implicit in this scene, then, are a set of associations related to female dance and display, which even at this early period are firmly embedded in the audience's expectations.

68 Cf. Hes. fr. 211.7 M.-W.; Sapph. fr. 112 v.; Aristoph. Birds 1721-1725, Peace 1333. 


\section{Conclusion}

The connection between parthenaic performance, visual language, and female transition is a deep-rooted one, and one for which we need not seek a particular ritual context or initiation ritual. When choruses of young women perform, emphasis is placed on their physical appearance and the gestures and movements of their dance, and this focus remains consistent regardless of the polis they belong to or the details of the festival in which they participate. Not only is this borne out by an examination of the few surviving parthenaic fragments; it is also demonstrated by analysis of the way in which female choruses are presented in a range of other texts. Moreover, this form of visual self-referentiality is a phenomenon particularly associated with female song, and which we do not find in the types of deixis employed by male performers.

This observation is further connected with the idea that female choral dance was an opportunity for young girls to be safely displayed to society at large, and potentially to prospective suitors and their families. The emphasis on luxurious trappings and accessories becomes relevant in this context, for emphasising the fine clothes and jewellery the girls wear may also be a way of hinting at the wealth of their families, and the dowries they can command. Yet the male gaze is not simply a process endured by the female dancers, for the choruses actively attempt to control and direct the gaze of their audience. Thus the girls are not presented as passive objects but rather they engage with and court the attention of the onlooker, and do so as part of a strategy to portray themselves as sexually desirable, while simultaneously chaste because of the civically sanctioned context in which this erotic language is found. Moreover, any potential 'marriage market' is a secondary context, for the performances are most frequently presented as part of a religious festival. Thus the girls' fine appearance and captivating movements may be part of the way in which choruses aim to please the gods, with the pleasure given to the mortal spectators safely subsumed as a corollary rather than as the immediate function.

On analysis, the transitional aspect of parthenaic dance is implicitly connected with the figure of the parthenos herself, rather than with a specific ritual context. Being a parthenos is not a perpetual state but rather one which automatically looks towards a change. At the heart of the parthenos' identity lies a paradox: she is attractive precisely because she is not yet a mature and married woman, yet it is also her capacity to undergo that transition which makes her desirable. Hence scholars are right to see transition as essential to the understanding of partheneia, yet this transition is connected to the performers and their identity rather than to any external context, and its pan-Hellenic cultural importance is attested by its presence in myth and in poetic scenes associ- 
ated with female sexual development. Thus despite the paucity of authentic parthenaic poetry, the evidence of the surviving fragments is enriched and supported by other texts. Partheneia's focus on the visual is not a coincidence, nor is it simply a decorative feature, but rather it is a mechanism for exploring ideas central to the songs' social function.

\section{Works Cited}

Alexiou, M. (1974). The Ritual Lament in Greek Tradition. Cambridge.

Athanassaki, L. (2004). 'Deixis, performance and poetics in Pindar's First Olympian Ode'. Arethusa 37: 317-341.

Barringer, J.M. (1995). Divine escorts: Nereids in Archaic and Classical Greek Art. Ann Arbor.

Bernardini, P.A. (1989). 'Il proemio della Pitica XI di Pindaro e i culti tebani' in H. Beister and J. Buckler (eds), Boiotika. Vorträge vom 5. Internationalen Böotien-Kolloquium zu Ehren von Professor Dr. Siegried Laufer, Institut für Alter Geschichte, LudwigMaximilians-Universität, Münchener Arbeiten zur Alten Geschichte 2. Munich: 39-47.

Bierl, A. (2007). 'L'uso intertestuale di Alcmane nel finale della Lisistrata di Aristofane. Coro e rito nel contesto performativo' in F. Perusino and M. Colantonio (eds), Dalla lirica corale alla poesia drammatica. Forme e funzioni del canto corale nella tragedia e nella commedia greca. Pisa: 259-290.

_ (2011). 'Alcman at the end of Aristophanes' Lysistrata: Ritual interchorality' in L. Athanassaki and E.L. Bowie (eds), Archaic and Classical Choral Song:Performance, Politics and Dissemination. Berlin: 415-436.

Boeke, H. (2007). The Value of Victory in Pindar's Odes. Gnomai, Cosmology and the Role of the Poet. Leiden.

Bonifazi, A. (2004). 'Communication in Pindar's deictic acts'. Arethusa 37:391-414.

Bowie, E.L. (2011). 'Alcman's first Partheneion and the song the Sirens sang', in L. Athanassaki and E.L. Bowie (eds), Archaic and Classical Choral Song:Performance, Politics and Dissemination. Berlin: $33^{-65}$.

Bremer, J.M. (1990). 'Pindar's paradoxical egô' in S.R. Slings (ed.), The Poet's 'T' in Archaic Greek Lyric. Amsterdam: 41-57.

Burnett, A.P. (1964). 'The race with the Pleiades'. CP 59: 30-34.

(1989). 'Performing pindar's odes'. CP 84: 283-293. (2008). Pindar. London.

Calame, C. (1977). Les choeurs de jeunes filles en Grèce archaïque. Rome. (1999). The Poetics of Eros in Ancient Greece. Trans. J. Lloyd. Princeton. (2001). Choruses of Young Women in Ancient Greece. Their Morphology, Religious Role, and Social Functions. Trans. D. Collins and J. Orion. Lanham, Md.; London. 
(2004a). 'Deictic ambiguity and auto-referentiality: Some examples from Greek poetics'. Arethusa 37: 415-443.

(2004b) 'Choral forms in Aristophanic comedy: Musical mimesis and dramatic performance in Classical Athens' in P. Murray \& P. Wilson (eds), Music and the Muses: The Culture of Mousikê in the Classical Athenian City. Oxford: 157-184.

- (2008). 'Entre récit héroïque et poésie rituelle: le sujet poétique qui chante le mythe' in S. Parizet (ed.), Mythe et littérature (Poétiques comparatistes). Paris: 123141.

(2011). 'Enunciative fiction and poetic performance. Choral voices in Bacchylides' Epinicians' in L. Athanassaki and E.L. Bowie (eds), Archaic and Classical Choral Song: Performance, Politics and Dissemination. Berlin: 115-138.

Cannatà Fera, M. (1990). Pindarus: Threnorum Fragmenta. Roma.

Carey, C. (1989). 'The performance of the victory ode'. AJP 110: $545^{-565}$.

- (1991). 'The victory ode in performance: The case for the chorus'. $C P$ 86: 192200.

(1999). 'Ethos and pathos in Bacchylides' in I.L. Pfeijffer and S.R. Slings (eds), One Hundred Years of Bacchylides. Amsterdam: 17-29.

- (2009). 'Genre, occasion and performance' in F. Budelmann (ed.), The Cambridge Companion to Lyric. Cambridge: $21-38$.

Clark, C.A. (1996). 'The gendering of the body in Alcman's Partheneion 1: Narrative, sex, and social order in archaic Sparta'. Helios 23: 143-172.

Cropp, M., ed. (1988). Euripides: Electra. Warminster.

Currie, B. (2004). 'Reperformance scenarios for Pindar's odes' in C.J. Mackie (ed.), Oral Performance and its Context. Orality and Literacy in Ancient Greece vol. 5. Leiden: 4969.

Cyrino, M.S. (2004). 'The identity of the goddess in Alcman's Louvre Partheneion'. $c J$ 100: $25-38$.

D’Alessio, G.B. (1994). 'First-person problems in Pindar'. BICs 39: 117-139.

- (2004). 'Past future and present past: Temporal deixis in Greek archaic lyric'. Arethusa 37: 267-294.

Danielewicz, J. (1990). 'Deixis in Greek choral lyric'. QUCC 34: 7-17.

Dougherty, C. (1994). 'Archaic Greek foundation poetry: Questions of genre and occasion'. JHS 114: 35-46.

Fearn, D. (2007). Bacchylides: Politics, Performance, Poetic Tradition. Oxford.

Felson, N. (1999). 'Vicarious transport: Fictive deixis in Pindar's Ninth Pythian Ode'. HSCP 99: 1-31.

- (2004). 'The poetic effects of deixis in Pindar's Ninth Pythian Ode'. Arethusa 37: $365-389$.

Ferrari, G. (2008). Alcman and the Cosmos of Sparta. Chicago.

Finglass, P.J. (2007). Pindar: Pythian Eleven. Cambridge. 
Ford, A. (2002). The Origins of Criticism: Literary Culture and Poetic Theory in Classical Greece. Princeton, N.J.

(2003). "From letters to literature: Reading the "song culture" of Classical Greece' in H. Yunis (ed.), Written Text and the Rise of Literate Culture in Ancient Greece. Cambridge: $15^{-37}$.

Garvie, A.F. (1965). 'A note on the deity of Alcman's Partheneion'. cQ (N.s.) 15: 185-187.

Gentili, B. (1988). Poetry and its Public in Ancient Greece: From Homer to the Fifth Century. Transl. T.A. Cole. Baltimore; London.

- (1990). 'L' “io" nella poesia lirica greca'. AION ( filol) 12: 9-24.

Griffiths, A. (1972). 'Alcman's Partheneion, the morning after the night before'. QUCC 14: 7-30.

Hague, R.H. (1983). 'Ancient Greek wedding songs: The tradition of praise'. Journal of Folklore Research 20: 131-143.

Hainsworth, J.B. (1990). Commentary: Books V-VIII in A. Heubeck, S. West and J.B. Hainsworth (eds), A Commentary on Homer's Odyssey. Oxford.

Hamilton, R. (1989). 'Alkman and the Athenian Arkteia'. Hesperia 58: 449-472.

Heath, M. (1988). 'Receiving the $\varkappa \hat{\omega} \mu \circ \varsigma$ : The context and performance of epinician'. AJP 109: 180-195.

Heath, M. and Lefkowitz, M.R. (1991). 'Epinician performance'. cP 86: 173-191.

Hornblower, S. (2004). Thucydides and Pindar: Historical Narrative and the World of Epinikian Poetry. Oxford.

Hutchinson, G.O. (2001). Greek Lyric Poetry: A Commentary on Selected Larger Pieces. Oxford.

Ingalls, W.B. (2000). 'Ritual performance as training for daughters in archaic Greece'. Phoenix 54: 1-20.

Jenkins, I. (1983). 'Is there life after marriage? A study of the abduction motif in vase paintings of the Athenian wedding ceremony'. BICs 30: 137-145.

Kannicht, R. (1969). Euripides: Helena. Heidelberg.

Klinck, A.L. (2001). 'Male poets and maiden voices: Gender and genre in Pindar and Alcman'. Hermes 129: 276-279.

Kurke, L. (1991). The Traffic in Praise: Pindar and the Poetics of Social Economy. Ithaca; London.

- (2005). 'Choral lyric as "ritualization": Poetic sacrifice and poetic ego in Pindar's Sixth Paian'. ClAnt 24: 81-130.

Lardinois, A. (2010). 'Lesbian Sappho revisited' in J. Dijkstra, J. Kroesen and Y. Kuiper (eds), Myths, Martyrs and Modernity: Studies in the History of Religions in Honour of Jan N. Bremmer. Leiden: 13-30.

(2011). 'The parrhesia of young female choruses in ancient Greece' in L. Athanassaki and E.L. Bowie (eds), Archaic and Classical Choral Song:Performance, Politics and Dissemination. Berlin: 161-172 
Lefkowitz, M.R. (1991). First-Person Fictions: Pindar's Poetic 'T'. Oxford.

(1995). 'The first person in Pindar reconsidered-Again'. BICS 40: 139-150.

Lehnus, L. (1984). 'Pindaro: Il dafneforico per Agasicle (Fr. 94b Sn.-M)'. вIcs 31: 61-92.

Lonsdale, S. (1993). Dance and Ritual Play in Greek Religion. Baltimore.

Mackie, H. (2003). Graceful Errors: Pindar and the Performance of Praise. Ann Arbor.

Maclachlan, B. (1993). The Age of Grace. Charis in Early Greek Poetry. Princeton.

Martin, R. (1984). 'Hesiod, Odysseus, and the instruction of princes'. TAPA 114: 29-48.

- (2004). 'Home is the hero: Deixis and semantics in Pindar Pythian 8'. Arethusa 37: $343-363$.

Nagler, M.N. (1974). Spontaneity and Tradition. Berkeley.

Nagy, G. (1989). 'The "professional Muse” and models of prestige in ancient Greece'.

Cultural Critique 12: 133-143.

(1990). Pindar's Homer: the Lyric Possession of an Epic Past. Baltimore.

Page, D.L. (1951). Alcman: The Partheneion. Oxford.

Parker, R. (2005). Polytheism and Society at Athens. Oxford.

Peponi, A.-E. (2004). 'Initiating the viewer: Deixis and visual perception in Alcman's lyric drama'. Arethusa 37: 295-316.

- (2007). 'Sparta's prima ballerina: Choreia in Alcman 3 PMGF'. CQ 57: 351-362.

Power, T. (2000). 'The parthenoi of Bacchylides 13'. HSCP 100: 67-81.

Revermann, M. (2006). Comic Business: Theatricality, Dramatic Technique, and Performance Contexts of Aristophanic Comedy. Oxford.

Rosenmeyer, P.A. (2004) 'Girls at play in early Greek poetry'. AJP 125: 163-178.

Rösler, W. (1983). 'Über Deixis und einige Aspekte mündlichen und schriftlichen Stils in antiker Lyrik'. WJA 9: 7-28.

(1985). 'Persona reale o persona poetica? L'interpretazione dell'io nella lirica greca arcaica'. QUCC 48: 131-144.

Seaford, R.A. (1987). 'The tragic wedding'. JHS 107: 106-130.

Segal, C.P. (1981). Tragedy and Civilization: An Interpretation of Sophocles. Cambridge, Mass.

Stehle, E. (1997). Performance and Gender in Ancient Greece: Nondramatic Poetry in its Setting. Princeton.

Swift, L.A. (2006). 'Mixed choruses and marriage songs: A new interpretation of the third stasimon of the Hippolytos'. JHS 126: 125-140.

- (2009). 'The symbolism of space in Euripidean choral fantasy'. cQ 59: 364-382. (2010). The Hidden Chorus: Echoes of Genre in Tragic Lyric. Oxford.

Taplin, O. (1993). Comic Angels: And Other Approaches to Greek Drama through VasePaintings. Oxford.

Trieschnigg, C. (2009). Dances with Girls: The Identity of the Chorus in Aeschylus' Seven against Thebes. Diss. Nijmegen.

Vernant, J.-P. (1983). Myth and Thought Among the Greeks. London. 
West, M.L. (1965). 'Alcmanica'. cQ (N.s.) 15: 188-202.

Wide, S.K.A. (1893). Lakonische Kulte. Leipzig.

Zeitlin, F.I. (1970). 'The Argive festival of Hera and Euripides' Electra'. TAPA 101: 645-669. 


\title{
The Amorous Gaze: A Poetic and Pragmatic Koinê for Erotic Melos?
}

\author{
Claude Calame
}

In his treatise on sensation, Theophrastus gives an account of Empedocles' theory of the senses which has generated much controversy. His attempt at a critical synthesis has been all the more influential in that historians of philosophy have not hesitated, in their customary eagerness to rationalize and systematize, to gloss over its apparent inconsistencies; and this project is all the more contestable since Theophrastus himself is expounding in prose a system of propositions formulated in poetry, in the tradition of hexameter verse. ${ }^{1}$ In any case, according to the poet and sage Empedocles sensation (aisthêsis) depends on two physiological principles. On the one hand, sensory perception depends on the arrangement of various 'passages' (poroi) which permit communication between the perceived object and the perceiving organism; in our terms, this principle would amount to one of the physical permeability of the body to what is outside it. On the other hand, perception can take place because its organs are made up of the same elements as the objects perceived; for example, in the case of vision, of fire and water surrounded by air and earth, the highest-quality perception being guaranteed by just the right mixture of the opposing elements. In addition, the emotions, joy and sorrow, obey the same physical principles of similarity, mixture and communication via pores, and these are also the principles that are foundational to thought (phronêsis is the term used by Theophrastus), to which is added noûs, intellectual capacity.

It is certainly no accident that the example chosen by Theophrastus to illustrate Empedocles' theory is that of vision and colours, which 'are brought to vision by a flood' (aporroê). ${ }^{2}$ There is all the more reason for this choice in that throughout his poem Empedocles makes numerous appeals to his addressee to grasp his propositions through vision; and this vision of cosmo-

1 Thphr. Sens. 1-2, 7-24 = Emp. vs 31 A 86 = fr. 420 Bollack; on this particular theory of vision, see also Pl. Men. $76 \mathrm{c}-$ d. For a typical attempt at a rationalizing reading, see for example the classic study of von Fritz (1971) 594-622.

2 Cf. Sassi (2009) 281-285.

(C) ClAude CALAME, 2016 | DOI: 10.1163/9789004314849_013

This is an open access chapter distributed under the terms of the Creative Commons AttributionNoncommercial 3.o Unported (CC-BY-NC 3.0) License. 
logical evidence can itself be physically dependent on touch: 'Come, see by each palm by what path each thing comes to our notice.' ${ }^{3}$ Already implicit in Homeric poetry, this physiology was eventually reoriented — not surprisingly, in an atomist direction — by Democritus: sight, hearing, smell, taste, touch — in everything we grasp, everything is but atoms and void. As far as perception by looking is concerned, the sophos of Abdera replaces Empedocles' emanations with eidôla, 'images' which he envisions as detaching themselves from objects made up of atoms and coming to strike the relevant sensory organ. If, as mere aggregates of atoms, objects produce 'primary' qualities naturally, the perspective of the person perceiving them is inevitably involved in their perception, so that 'secondary' qualities are produced by convention. ${ }^{4}$

The Divine Physiology of the Amorous Gaze and Erotic Poetry

It happens that the conception of the amorous impulse animating Greek erotic poetry is founded on a particular physiology and anthropology of looking. ${ }^{5}$

O heart, we must pluck loves (erotes)

in the opportune time of youth.

He who, seized (drakeis) by the flickering rays cast by Theoxenus' eyes is not submerged in desire (pothoi)

Must have a black heart, forged of steel or iron by a cold flame

Disdained by Aphrodite of the arching eyebrows,

Whether he toils under the pressure of poverty

Or is a slave on the hard road of female arrogance.

But as for me, because of the goddess I melt

3 Emp. vs 31 в 3.9-13 = fr. 14.9-13 Bollack; see also vs 31 в 17.19-20 = 31.19-2o Bollack, vs 31 в 21.1-3 = 63.1-3 Bollack, etc., with the commentary by Rosenfeld-Löffler (2006) 30 and 94-97, citing the additional appeals which punctuate the sections of Empedocles' poem now known from the Strasbourg Papyrus.

4 Democr. vs 68 в 9, 11 and 125, as well as A 77; on the material component of colours in Democritus, see Sassi (2009) 285-287.

5 Pi. fr. 123 Snell-Maehler, lines 1-12; see Hubbard (2002) and the commentary I have provided on the physiology of amorous desire in Calame $\left(2009^{3}\right) 3^{1-38}$ (this self-citation prompts me immediately to tender my apologies to the reader of this article for the repeated references to my previous work-part of growing old ...). The gaze also plays an essential role in erotic iconography; examples in Skinner (2004) 85-97. As for the frequent 'eroticization' of the addressee of a melic praise-poem, see the recent study by Rawles (2011) 146-159. 
Like the wax of holy bees bitten by the heat of the sun

As soon as I see the youthful bodies of boys in their prime of life.

So, for sure, in Tenedos, Persuasion and Grace

Dwell in the son of Hagesilas.

Leaving aside the masculine presumption of this symposium piece, it is precisely the gaze that is revealed here as the vector of erotic desire. It is an active gaze in so far as it concerns the young Theoxenus of Tenedos, and a passive one (drakeis corresponds to a form of the passive) for the adult poet who has composed this song of praise, taken up again by the guests at the banquet. The oxymoron of the 'cold flame' that forged the unfeeling heart combines fire and water, just as the earlier metaphor of the flickering effect of the gaze was enhanced by being juxtaposed to that of the submerging wave. ${ }^{6}$ But the force of desire conveyed by the gaze is not alone in acting upon the senseorgan and emotions of the anonymous figure who is clearly distinguished from the poetic 'I'; Aphrodite also intervenes-she, too, mobile in the intensity of her gaze. The physical and material effects of eros are animated, then, by the divine force embodied by Aphrodite. No doubt this conception, which combines a purely physical process and a divine energy, has something surprising about it. Nonetheless, we find it in Empedocles himself, since the material and physical movements of the cosmos from unity to multiplicity and vice versa are animated by the alternation of Neikos and of Philotes-Strife and Love: both are understood by Empedocles as a force of unifying aggregation and as one of balanced harmonization. ${ }^{7}$ The same idea is present in the interpretation given by the post-classical Derveni commentary for the process of the creation of the cosmos, as it is displayed in the classical cosmo-theogonic poem attributed to Orpheus. If the Orphic account of the creation of the world out of a primordial ejaculation is reduced to a purely physical process of emergence, agglomeration and configuration of particles, the process as a whole is nonetheless still dominated by the creative force of Zeus; and the divine cosmogonic force itself is identified, in the Orphic manner, as Aphrodite, Persuasion and Harmony. ${ }^{8}$

6 Greek melic poetry contains a vast range of visual metaphors centred on light, notably to express the impact of a desirable person: see Nünlist (1998) 162-177; for the metaphors of the stream and the source, cf. 189-193.

7 Emp. vs 31 в 17.7-8 and 16-20; cf. Trépanier (2004) 160-163 and 184-186. On the erotic gaze as medium of Peitho, the servant of Aphrodite, in classical iconography, see Frontisi-Ducroux (1996) 81-85.

8 P.Derveni col. xxi.1-12; on this cosmogonic movement, see now the extended commentary by Kouremenos, Parássoglou and Tsantsanoglou (2006) 243-252; see also Calame (2010) 29-31. 
Outside of any 'lyricism', Greek melic poetry, animated by the feeling of love, provides a series of metaphorical phrases for the verbal expression of a desire which is conceived as a physical stream conveyed by looking, but which acts like a divine force. This power is incarnated in the young adolescent with wings who is such a common presence in the later Attic iconography of the symposium, especially in scenes of erotic pursuit and amorous courtship; the name of this deity is, of course, Eros. ${ }^{9}$ Now, marked as it is by first-person forms describing in a self-referential manner the activity of a poetic persona engaged hic et nunc, the different forms of melic poetry cannot be reduced to the simple textual expression of the feelings of the poet considered as an individual author. As musical forms sung and danced according to rhythms inscribed into their diction, the melic poems lead back to collective practices involving the body. ${ }^{10}$ That is to say that their performance includes the physiological dimension at the foundation of the Greek understanding and representation of erotic desire. From here it is no surprise to notice that, particularly in erotic poetry, the communicative energy of the poem is transmitted by the gaze. It is these correspondences between the role of sight in the manifestation of amorous desire through the power of eros and the role of the gaze in the performance of a song that was danced to (?) as a physical practice involving the body that we would like now to illustrate briefly, by discussing a few poems which, to tell the truth, have come down to us in a lamentably fragmentary state.

Among these poems inspired by eros are those which Alcman composed for choruses of young girls in the service of the city-state of Sparta. Bringing together adolescents from aristocratic families and from Lacedaimonia's two royal families, these choral groups - let us briefly remind ourselves-followed a course of initiation; through musical and gymnastic training, this choral cursus led adolescents from good families in Sparta to the erotic maturity of the adult woman and to the status of spouse, in the full bloom of fertile feminine

For the pre-classical and classical iconography of Eros, represented as a young boy with wings, see the documents collected in LIMC III/2 s.v. Eros, 60o-605, 615-618, 619-626 and 628-633 in particular.

On the necessity of abandoning, for the pragmatic poetry of the Greeks and for compositions which present themselves as acts of song, the modern concept of 'lyric' and returning to the indigenous category of melos, see my studies of (2006) and (2009). 
beauty. Among the educational and initiatory tests to which these young girls submitted in a truly 'anthropopoietic' process of collective and cultural construction of man and woman, was the musical performance of choral songs; they were performed on the occasion of different cultic celebrations which provided a rhythm to the calendar of civic and social life in pre-classical Lacedaimonia. ${ }^{11} \mathrm{~A}$ few textual traces of these initiatory choral performances have come down to us thanks to poems which the Alexandrian editors classed under the generic label of partheneia.

The partheneion of Alcman transmitted by the Mariette Papyrus ( $P M G F 1$ = fr. 3 Calame, P.Paris 71), is dominated by the gaze, both from the semantic and from the enunciative point of view; and that is the case from the moment of transition in the poem from 'narrative' to 'discourse', marked by the 'formal apparatus of enunciation' (to take up the three concepts central to the analysis of Émile Benveniste). ${ }^{12}$ After the initial narrative of the struggle of the Dioscuri-as sons of Tyndareus, exemplary figures for young Spartansagainst the sons of Hippocoon, their probable rivals in love (and not without a gnomic allusion to the vanity of wanting to 'marry Aphrodite'), and after a makarismos assuring the transition from the 'mythic' past to the present of mortal men and their ephemeral joy, the choreutai move to a self-referential description of action, marked by the enunciative repetition of the forms I/you, here and now. ${ }^{13}$

Divine retribution exists.

Happy is he who, forewarned, passes his days without tears.

As for myself, I sing

40 the light of Agido;

I see it rising like the sun;

Agido conjures it into appearing for us.

11 In Calame (2012a), I have returned to the central role played in the political culture of preclassical Sparta by the arts of the Muses in performance as an anthopopoetic process of ritual education of the citizen and his spouse.

12 On the implications for Greek poetry of the three concepts proposed by Benveniste in his classic studies of (1966) 237-250 and 258-266, and (1974) 79-88, see for example Calame (2005) $1-13,(2008)$, and (2009).

13 Alcm. PMGF 1.1-39 = fr. 3.1-39 Calame; as for the double mythic narrative which opens the partheneion, I prefer the hypothesis of Gengler (1995) (a local version of the struggle of the Tyndaridae against the sons of Aphareus over the abduction of the Leucippidae [?]) to that formulated by Ferrari (2008) 53-67 (insertion of the myth of Phaethon). 
But the illustrious choregos does not allow me to address to him either praise or blame.

45 Indeed, she appears to me to distinguish herself as much as if, in the middle of a herd of mares, a vigorous charger (?) was placed, victorious in the games, of thunderous gallop, a horse worthy of winged dreams.

5o But don't you see?

On one side the Enetic courser; on the other the locks of my cousin Hagesichora flower like pure gold.

55 Her face of silver, why describe it to you in her light? It's Hagesichora. And Agido, second in beauty, courts with her like a Colaxean horse after an Ibenian mare.

6o Indeed, like two doves, they fight for us, who bring to Orthria a robe, rising in the ambrosial night like Sirius the star.

First off, the gaze which the poetic 'I' casts in the present (horô, line 40) upon Agido; comparing its brilliance to that of the rising sun, the choral group sings about this young woman in a performative manner (egôn d'aeidô, line 39), and the act of singing which casts the gaze without a doubt corresponds to a ritual gesture, the witnessing of the sun as it rises (phainên, line 43) hic et nunc. Immediately, the visual isotopy joins together the description of the beauty of the young girl and the act of song coinciding with the verbal praise; in a recent reading of this line, an interpreter of Alcman's poem has judiciously drawn attention to the ritual dramatization of an 'optical perception.'14 This line of imagery focused on sight continues in the comparison (by now much commented upon) of the chorus-leader herself to a mare distinguished from a herd of chargers (?) by her appearance (this is the etymological sense of

14 Peponi (2004) 296, in an article that should be read in conjunction with the brief comments offered here. 
ekprepês, line 46). ${ }^{15}$ The simile not only evokes the chorus of Theocritus, struck by the light and golden beauty of Helen who, as Aurora, shines among the young chorus-members singing the poem; but it also recalls the troupe of young Spartan girls (Lakaina parthenôn agela) mentioned by Pindar, or again, the adolescents who (in the famous Spartan song at the end of Aristophanes' Lysistrata) are guided by the brilliant (euprepês) Helen in her role as chorusleader, and gambol like mares along the banks of the Eurotas. ${ }^{16}$

At the beginning of the next strophe it is again to the gaze that the poetic 'I' invites the generic you: 'But don't you see?' (ê oukh horêis; line 50), in a performative echo of the 'I see' (horô, line 40) in the preceding strophe. While this enunciative you has been seen as referring to the public assistant at the performance by the chorus of Alcman's song, ${ }^{17}$ it seems preferable to link it to the choristers in an act of negative self-description that develops in the following strophe. In an equally self-referential way, the gaze is called to direct itself to Hagesichora: the chorus-leader advertises through her own name her role as leader of the choral group. From the semantic point of view, the beauty of the young girl is once again verbally perceived in the light of its brilliance: locks of hair like pure gold and a face of silver; these comparisons finally exempt the choir from having to go on with its 'luminous' (diaphadan, line 56) evocation, so brilliant is the light of the chorus-leader. As for the enunciative dimension, this description of the beauty of the chorus-leader is punctuated, through the interposition of demonstratives, by a sequence of gestures of verbal deixis; they refer the perception of Hagesichora's beauty, hic et nunc, back to the power of words. ${ }^{18}$ This semantic-enunciative dynamic, centered on vision, continues in the following line about Agido: first, in the use of a visual term, to (w)eidos (line 58), to describe her beauty; and then in the comparison of the two young women to two doves rising in the sky like the star Sirius, known for its brilliance. ${ }^{19}$ The visual effect produced by the light

\footnotetext{
15 On the visual role and the erotic dimension of this simile, see Calame (1977) II 67-70.

16 Theoc. 19.21-31; I take up the question of the subtle enunciative structure of the poetic and aetiological song of praise to Helen 'of the rose skin' disguised as a ritual epithalamium in Calame (2012b). For agela in which adolescent girls and boys seem to have held symbolic ties of kinship (at the level of cousins) see Pi. fr. 112 Snell-Maehler, with the comments by Calame (1977) I 372-385; cf. Ar. Lys. 1305-1315.

17 This is the suggestion put forward by Peponi (2004) 300, 309 and 313.

18 The deictic role of these demonstratives has been well described by Peponi (2004) 301304.

19 See my commentary on these lines: Calame (1977) II 72-79.
} 
which emanates from these two beautiful bodies is redoubled by the movement of the (ritual?) race in which the two young women are engaged.

Between the visually evocative power of the similes and metaphors and the gestures of verbal deixis which refer back to the visual reality of the performance, Alcman's partheneion oscillates ceaselessly between demonstratio ad oculos and Deixis am Phantasma, to take up two more concepts dear to another linguist by whom I have willingly allowed myself to be influenced. ${ }^{20}$

Consisting of the enumeration of various items of finery that the $I / w e$ claims not to possess - at the same time naming through their anthroponym the choristers who can assume this stance of denial — the next strophe appeals again to perception through vision: an abundance of purple, a finely worked gold bracelet, a mitre from Lydia used as pride (agalma, 69) for young girls, the locks of Nanno's hair, the divine beauty (sieidês, 71) of Areta, etc., all culminating in the love-charm (erata) of (W)ianthemis, whose name evokes the violet. Each of these items of finery, just like the young girls who might wear them, excites amorous desire. ${ }^{21}$ But in fact - the choreutai conclude - it is Hagesichora who 'besets me' (me teirei, 77), from a verb which expresses the physical despondency that being in love provokes. ${ }^{22}$ And verbally induced vision of the objects arousing erotic desire has its effect at the enunciative level when the poetic ' $\mathrm{I}$ ' expresses the wish of retaining the amorous gaze of one of the young girls: 'May Astaphis be mine, may Philylla look (at me)' (potiglepoi, 75). 'And if a beautiful and tender young girl was mine' sings Hipponax, in the same way, in an isolated tetrameter iambic; 'I would want to see (idên) her charming (eraton) walk and the striking sparkle of her gaze (prosôpou)' sings 'Sappho' of a young girl who has by now left her group, having probably arrived at adulthood as a mature woman. ${ }^{23}$ It is the erotic power of the gaze which excites, from the point of view of poetic expression and from the point of view of the action in the song, the ritual song of young girls of whom Alcman is probably the khorodidaskalos. ${ }^{24}$

20 I argue for the pertinence of these concepts for Greek poetry in Calame (2004) 420-423 and (2005) 1-4; cf. Bühler (1934) 102-148.

21 On the erotic character of most of the items of finery and of some of the speaking names of the young girls (cited above) see my commentary: Calame (1983) 335-340, with the references to the second volume of my 1977 work.

22 See notably Hes. fr. 298 Merkelbach-West.

23 Hippon. fr. 120 Degani = 119 West; Sapph. fr. 16.17-18 Voigt: according to the etymology of the word, grounded in sight, prosopon here refers back to looking (cf. Hutchinson [2001] 166); see also the other parallels which I list in Calame (1977) II 88-90, to explain the erotic connotations of these two expressions.

24 This particular realisation of the 'author-function' in the context of choral poems destined 
But what provides, as it were, the key to the 'optical dramatization' energizing the entire poem is the voice of the chorus-leader, which is compared in the final section to the song of the swan. In fact, after a strophe dedicated to the ritual celebrated for the goddess of the dawn (without a doubt Helen) and marked again by verbs of erotic desire (erô, line 88; eratas, line 91), the poem of praise focuses once more, probably at the end of the partheneion, on Hagesichora, addressing not only the strong feeling of desire caused by her hair, but also the brilliance of her voice, even sweeter than those of the Sirens. As in numerous other melic songs, the coincidence between the erotic desire that is sung about and the erotic pleasure which pre-classical Greek poetics attributes generally to song in musical performance, is remarkable. ${ }^{25}$ From the point of view of pragmatics, the aesthetic effect of pre-classical Greek poetry was almost deliberately described in erotic terms because of the erotic predisposition that listeners brought to performances.

\section{The Partheneion of Astymelousa: Diction in Erotic Poetry}

My claim is that the poetic perception of erotic feeling through the gaze refers back to an asymmetric relation between a beautiful person who, in his or her full bloom, arouses desire, and an older person who feels its impact (or a younger person who aspires to feel it). Through the intermediary of poetic performance, the relation is generally established between two people of the same sex: not a 'homosexual' relationship, but a 'homophilic' one, to the extent that the relationship is transitory. This poetic experience of asymmetric eros, which has an educational as well as an initiatory quality, is realized in the musical performance itself. The performance of pre-classical erotic poetry confers upon the perpetual amorous gap between adolescent and adult of the same sex a transitory, collective and ritual character which evokes the tribal initiation ritual. ${ }^{26} \mathrm{~A}$ later development of this will be the philosophical relationship between eromenos and erastês.

for a sung performance is attested for Alcman in test. 9 Campbell $=5$ Calame. This does not necessarily mean that the voice of the poet is implicated in the indefinite and anonymous tis in line 47, as Peponi (2004) 313-316 hypothesizes; but in the polyphony of the choral poem in its entirety (cf. Calame [2008]) the voice of the chorus-master can sustain all the gnomic affirmations which, generally speaking, punctuate the melic poem.

25 See Calame $\left(2009^{3}\right) 77-96$.

26 For numerous attestations of an asymmetric relationship constructing a characteristically Greek kind of homophilia with an initiatory function, see Calame $\left(2009^{3}\right) 119-145$. 
The frequent focalization of melic poetry on homophilic erotic desire receives striking confirmation from a papyrus fragment of an other partheneion by Alcman that came to light some sixty years ago (PMGF $3=$ fr. 26 Calame, P.Oxy. 2387). Composed, like the Mariette partheneion, in a mixture of trochaic and dactylic meters, the lines which we can read from this fragmentary poem are in a familiar fashion full of erotic desire (again conveyed by sight), both in the semantic description and in the enunciative course of the poem. In a prelude which is unfortunately fragmentary, a strophe containing an invocation to the Muse describes the preparations for a choral performance before ending in a performative verb-form; in a moment of self-reflexive choral anticipation, this verb-form (tinax $\hat{o}, 9)$ refers to the musical action in which the poetic ' $\mathrm{I}$ ' is engaged in shaking her blond tresses. Then, after a possible mythical narrative, attention is focalized on the figure of the young Astymelousa, whose name means 'love for the town' and is glossed as 'object of solicitude for the community of citizens' (melêma damôi, 74) by the young girls who sing the poem while dancing; Astymelousa is probably the chorus-leader. Now, described in the enunciative present but in the third person (just like Hagesichora in the 'first' partheneion), the young woman is in turn the (probable) subject of a verb of seeing: 'By the desire which loosens the limbs, she casts a glance which dissolves more quickly than sleep or death., ${ }^{27}$

It is well known that from epic and iconography to tragedy there are numerous similes and metaphors comparing the 'out of body' state induced by the power of amorous desire which puts us in to sleep, if not to death itself. 'It seems to me that I am almost dead', declares 'Sappho' in the famous poem where she describes the blockage of sensation provoked by the sight of the young girl she loves with her future spouse: passing from the vision of the young girl ( $s^{\prime} i d \hat{o}$, 7), through the hearing of her soft voice and again to the sight of her desireprovoking smile, amorous perception blocks successively speech, hearing and sight (literally: 'I don't see anything through my eyes anymore', line 11) to leave the body prey to a fiery current, to trembling, to sweating and finally to the pallor of death. ${ }^{28}$ Whatever is to be said about this somatic 'symptomatology' of

\footnotetext{
27 Alcm. $P M G F$ 3.1-10 and 61-64 = fr. 26.3-10 and 61-64 Calame; for poetic parallels to these various expressions of erotic desire, see Calame (1983) 396-401 and 403-406.

28 Sapph. fr. $3^{1}$ Voigt, with the references in the excellent commentary on the poem by Burnett (1983) 231-243; for choral features in the enunciation of the poems of Sappho see the good study by Lardinois (1996); on eros between sleep and death, including in iconography, cf. Calame $\left(2009^{3}\right) 5^{6-57}$ (with the small number of bibliographical suggestions in note $5^{0}$ ) and 201-206.
} 
amorous desire, of which we already find isolated traces in Homeric poetry and which are taken up in Hippocratic physiology, the role played by sight is central, along with that played by hearing; it refers back directly to the seductive sweetness of the poetic word.

The remaining lines of the poem grant us a glimpse of the desirable Astymelousa elegantly traversing public space, wearing a crown, apparently in silence; in this walk, which is without a doubt ritual in nature, the young girl appears 'like a star which crosses the sky twinkling or like a golden bough or again like a soft feather' (lines 65-70). Just as in the partheneion of the Mariette papyrus, what is being poeticized here is both the splendor of the beauty of the young girl (in the simile with the star and the reference to gold) and her movement; this is compared to the light flight of a feather, with a probable allusion to choral dance. Added to this is the perfumed oil from Cyprus which, evoking the seductiveness and charm (kharis, 71) of Aphrodite, perfumes the young girl's hair. The anthropological comparison shows that this sensory perception of the body of the young girl in her grace and fragrance contributes to the social construction not only of the gender, but also of the age-class. ${ }^{29}$

If, as in the other partheneion, visual impressions lay the foundation for the laudatory description of the young girl assuming the role of the chorusleader, sight also underwrites the act of singing. Indeed, at the end of the strophe dedicated to the erotic praise of Astymelousa, looking re-establishes the enunciative dimension of the poem. In these very lacunose lines, the poetic 'I' expresses the wish to see (the chorus-leader), to get close to her and to take hold of her delicate hand; the gesture is certainly erotic, but it could also be involved in a choral dance. This is shown by contemporary iconography, which often represents groups of young girls dancing in a circle, holding each other by the wrist. ${ }^{30}$ Accompanying the song of action identified in the following line by the temporal deictic nun de (line 82; a reference to the hic et nunc of the melic poem), looking is now associated not with hearing, but with touch, which emerges as in some way complimentary to the seeing, hearing and touching that are longed for in this poem of praise for the beautiful Astymelousa, leader of the chorus.

29 Gélard (2010) 175-186, gives a good example of a ritual and 'gendered' appeal to the sense of smell in a traditional society. For parallels in the similes of Alcman see again my commentary: Calame (1983) 407-412. 
But let us return to looking and its double semantic and enunciative role. As we have already seen in our discussion of poems by Pindar and Sappho, poetic and metaphorical descriptions of erotic physiology are not are not to be found only in the partheneia composed by Alcman and sung by young girls from Sparta. Echoing the word potiglepoi ('may she cast her gaze', 75) in the first poem we discussed by Alcman, the form potiderketai ('she casts her gaze towards', 61 ), which marks the praise of the chorus-leader in the second partheneion, is inserted into an explicitly amorous expressive context. Without a doubt, it is the poetic 'I' himself who is struck by the desire which is conveyed by the gaze of the young woman with the charming gait and the elegantly perfumed locks. In any case, as well as being compared to sleep and death for the effect of sweet annihilation that it provokes, this erotic gaze is also described as takeros, 'melting' (61). Now, this melting effect is attributed to Eros himself not only in an expression drawn by a scholiast from a poem by Anacreon, but above all in the first lines of a famous poem of Ibycus: ${ }^{31}$

Eros again casts me a humid (takeros) look

From beneath his somber eyelashes;

Through his charms of a thousand detours

He throws me into the nets of Aphrodite.

Ah yes, I tremble when I see him come near me

Just as the courser (?) destined for victory, when age comes on,

Turns against his will, under the yoke of his harness, towards the racecourse.

The dissolving effect of Eros' glance evokes the sparkling gaze of the young and beautiful aristocrat from Tenedos poeticized by Pindar, which provoked a wave of desire and en effect of melting (takomai, line 11) like that produced on beeswax by the biting heat of the sun. ${ }^{32}$ In the same way, the eyes of the handsome Echecratidas of Thessaly fill the poetic ' $\mathrm{I}$ ' with desire in these elegiac lines by Simonides published in 1992:33

\footnotetext{
31 Anacr. $P M G$ 459, then Ibyc. $P M G F$ 287, whose first lines are cited by Pl. Prm. 137a.

32 For Pi. fr. 123 Snell-Maehler, cf. above, note 5.

33 Simon. fr. 22.9-14 West ${ }^{2}$ (the first two lines of the Greek text are incomplete); see the comments of Bowie (2009) 132-135, with the parallels collected by Mace (2001).
} 
And, on perceiving with my eyes Echecratidas of the shining locks, I would take his hand

So that the young flower of his body full of charm [touched me] and so that he with his gaze poured on me a libation of dissolving lust.

And I, stretched out with the young lad among the flowers, would enjoy a moment of delicate happiness ...

Whatever the scenario that lies behind this hypothetical scene described in lines that are, once again, very fragmentary, what is central to the poetic expression of erotic desire is the liquid quality of the gaze which melts what it looks upon. And here it is very precisely the complexion of the young man which produces charm, a charm created by desire transmitted by a look; just as in the choral song that Alcman dedicates to the erotic praise of Astymelousa, in the following lines there is a description of the sensory effect (visual or olfactory) created by the young man's flowing locks and the tactile impression produced by taking his hand. From a homophilic feminine relationship we have thus passed, with the same poetic vocabulary and the same physiology of erotic feeling dependent upon the gaze, to the relationship between an aging poet and a young and beautiful adolescent. The allusion to a flowery couch evokes, moreover, the numerous poetic scenes of lovers' trysts on soft grass covered with flowers dear to Aphrodite; there is a possible reference to similar prairies in the great beyond, if it is true that the poem is about an adolescent who has died prematurely and has already passed on to the Isles of the Blessed. $^{34}$

Now, the expression lusimelês pothos (or eros: 'which loosens limbs') which precedes in the poem the mention of the gaze dissolving one more effectively than sleep and death, goes well beyond the admittedly blurry boundaries of melic poetry. For sure, Sappho sings 'Eros again shakes me, the one that breaks limbs, the irresistible animal, the sweet-bitter'; in a hymn she also describes, in relation to dazzling beauty and a gaze sweet as honey, the eros which is poured out onto the desirable face of a young married woman, honored by Aphrodite. But the cosmogonic Eros of Hesiod is also characterized as lusimelês, the one that 'tames in their breasts the reason and will of all gods and men'; the formula slides easily into the epic diction and dactylic hexameter of the Theogony. And in an asynartete by Archilochus, the poetic subject

34 For similarities between the gardens of love and the prairies of the world beyond see my study: Calame (2007). On the gesture of taking a beloved's hand see above, n. 30. 
addresses himself to a companion who has been, so to speak, tamed by 'the passionate desire which loosens the limbs' (ho lusimelês pothos). ${ }^{35}$

\section{$5 \quad$ An Erotic Poetics between the Semantics and Pragmatics}

In its formulaic quality, the poetic language of amorous desire has apparently little concern for the boundaries drawn by sexual identities. Both from the lexical and the syntactical points of view, the poetic expressions that we meet offer possibilities for variation and for adaptation to the meter, genre, and enunciative context of each particular poem; they belong to a traditional language of some plasticity for the poetic and pragmatic expression of desire animated by Eros and Aphrodite.

If the young girls singing Alcman's second partheneion can pronounce themselves struck by the dissolving gaze emanating (without a doubt) from the chorus-leader, in the banquet-poem by Pindar it is the masculine poetic 'I' which melts like wax in the sun under the Aphrodite-inspired gaze of the young man. On the one hand, then, we have a homophilic and asymmetric female relationship, and on the other hand a male relationship of the same sort; in the first case, the perspective is that of the adolescent choreutai, and in the second case, that of the male singer. But the Eros of Hesiod also favors the perfectly symmetrical and reciprocal union of the gods with goddesses for theogonic procreation, in the most ordinary type of heterosexual relationship. In the great scene of seduction which marks the middle of the Iliad it is only when Zeus perceives (iden, repeated several times) Hera decked up in all the finery given her by Aphrodite that Eros fills the king of the gods with desire. Both the use of the term philotês and that of the dual in the description of the love-scene which follows indicate the reciprocity of feeling in this relationship of love between two adults. ${ }^{36}$

It is Eros, then, who, notably through the medium of vision, establishes the amorous relations that Greek poetry so often describes, traversing not only sexual identities, but also age classes and enunciative relations. No doubt because

35 Sapph. frr. 130.1-2 and 112 Voigt; Hes. Th. 120-121 (cf. also 910-911, with reference to the beautiful gaze of the three Graces); Archil. fr. 196 West $^{2}$; see also Carm. pop. PMG 873.3-4, in an address to paides: 'with courage, Eros who breaks limbs flourishes in the cities of the Chalcidians'; on acts of violence by Eros cf. Pironti (2007) 94-100.

36 Il. 14.292-296, with the commentary which I have provided in Calame $\left(2009^{3}\right) 67-72$ and 209-216. 
of its strongly pragmatic dimension, erotic melic poetry is, from this point of view, essentially focused on asymmetric erotic relationships, expressing an erotic desire that coincides with the act of singing itself: a poetic ' $\mathrm{I}$ ', masculine and adult, is drawn to the stunning beauty of a tender adolescent boy (Pindar and Simonides) or of a fresh young girl (Anacreon); but this 'I' can also be feminine and receptive to adolescent girls in their bloom (Sappho). In other cases, in an inversion of the usual poetic relationship, it is the young girls in a choral group who express, in a poetic 'we' that is collective though articulated only through the mediation of an adult poet, the erotic emotion produced by a young woman (Alcman); this young woman, usually the chorus-leader, is in charge of the girls' choral development and thus also of their musical and amorous education, which has a significance that comparative cultural anthropology reveals to be initiatory.

But taking our cue from the pragmatism of a form of poetry which is also ritual act we must now turn back from the semantics of the physiology of the erotic gaze to the poetic enunciation of desire embodied in Eros. The opening phrase 'Eros again strikes me' attested in the verses just cited by Ibycus and Sappho also marks the beginning of a poem (the rest of which is lost) by Alcman himself: ${ }^{37}$

Eros again, by the will of Cypris,

Warms up my heart, which he gently invades.

This same formulaic phrase also animates in an enunciative way the fragmentary beginning of a poem by Anacreon:

Eros again, like a blacksmith, has struck me

With his powerful hammer; he has plunged me into an icy torrent.

If we are ignorant of both the genre and the enunciative context of these two beginnings of poems (though we can assume that the first is a partheneion and the second a song for a symposium), the phrase Eros (me) daute implies both the presence of the first person and the verbal gesture of deixis indicated by

37 Alcm. PMGF 59(a) = fr. 148 Calame, then Anacr. $P M G 413$ (cf. also $P M G 358$ for an erotic relationship between a masculine poetic 'I' and a young girl from Lesbos). See above Sapph. fr. 130.1-2 Voigt and Ibyc. PMG F 287.1-2. For the probable context of Alcman's poem, see Calame (1983) $55^{8-564}$, and for the combined formulaic and pragmatic quality of the phrase Éros (me) daûte, see my study, Calame (1997). 
the word $d e$. Inserted into a formula, ${ }^{38}$ daute means the 'reenactment', at the beginning of a poem, hic et nunc, by the persona cantans of an erotic experience that is expressed in the poem itself, whether its performance was 'monodic' or choral. Along with the meter of the poem, these formulae contribute to the ritualization of the poem as it is danced and sung, and of the movements or practices of the body that correspond to it. Using language made rhythmical and metaphoric, they activate the gaze, the vehicle of erotic desire, with physiological and anthropopoietic effects.

We are facing a poetic language of eros which crosses the various poetic forms, differences of genre and asymmetries of age, all the while conforming to a metrical, dialectal and sometimes lexical point of view to specific localities: is this not a paradigm of the dialectic between the 'pan-Hellenic' and 'epichoric' identified by scholars? For ourselves, we would prefer to this idea, as far as the arts of the Muses are concerned, the concept of a 'Greek network of musical poetry' or of a 'song and performance culture network'; a notion to be developed in some other study.

To return finally to the physiology of the erotic gaze in a poetic aesthetic, we can conclude our discussion with two brief references to Plato. First, it may be helpful to recall the etymologizing speculations offered in the Cratylus concerning the vocabulary of erotic desire. On the one hand, besides pothos, nostalgic desire, which alludes to something absent (located 'somewhere', pou), himeros (according to Plato) signifies imperious desire, since it flows impetuously (hiemenos rhei) to sweep away the soul in its flow; on the other hand, eros too is conceived of materialistically as a current (rhoê) since from outside it flows into (esrhei) the soul and it 'runs into the inside through the eyes'. ${ }^{39} \mathrm{But}$ it is also Socrates who, in his speech in front of Phaedrus inspired by the poet Stesichorus, seizes on the amorous relationship between an adult erastês and a young eromenos to signpost the way towards beauty in itself: ${ }^{40}$

38 No doubt it is this formulaic character that explains the probable taking up of some of Alcman's poems by men's symposia, according to the hypothesis advanced by Carey (2011) 447-451; for example, the two verses of Alcman mentioned in n. 36 (no doubt extracts from a partheneion) were interpreted by the ancient scholar who cited them in terms of a heterosexual relationship between the poet and the chorus-leader, now transformed into a poetess (!); cf. Rawles (2011) 140-143.

39 Pl. Cra. $420 a-b$.

$40 \quad$ Pl. Phdr. 244a-b and 251a-d. 
On the other hand, he who is a recent initiate, he who has eyes full of visions of the beyond, this man, when he comes to see the face (prosôpon idêi) which is divine, which is a felicitous imitation of beauty (kallos) or form of a body, he begins by trembling (...); then he is covered in sweat, feeling a heat he is not used to. And indeed, when he has taken in the onrush (aporroê) of beauty, then he finds that his body is hot and that his hair is standing on end; and this heat melts (etake) the hard material which, for a long time, had been blocking up the holes where the wings come out, stopping them from sprouting (...). Each time then that, lifting up his eyes towards the beauty of the young boy and taking into his body the particles which detach themselves to come towards it - whence the expression 'a wave of desire' (himeros) - the soul is enlivened and warmed up, it is healed of suffering and is completely joyful.

Such is the liberating effect of the erotic current that, transmitted by the gaze, courses from the beautiful young body to the man who perceives it, bringing him joy and freedom; this is why, as Socrates will comment ironically quoting a line from Homer, Eros 'gives you wings'. And this is how the foundations are laid for a truly anthropopoietic aesthetics.

\section{Works Cited}

Benveniste, É. (1966). Problèmes de linguistique générale. Paris. (1974), Problèmes de linguistique générale, II. Paris.

Bowie, E.L. (2009). 'Wandering poets, archaic style', in R. Hunter and I. Rutherford (eds), Wandering Poets in Ancient Culture. Travel, Locality and Pan-Hellenism. Cambridge: $105^{-136 .}$

Bühler, K. (1934). Sprachtheorie. Die Darstellungsfunktion der Sprache. Jena. Engl. trans. by D.F. Goodwin, Theory of Language: The Representational Function of Language. Philadelphia 1990.

Burnett, A.P. (1983). Three Archaic Poets: Archilochus, Alcaeus, Sappho. London.

Calame, C. (1977). Les chœurs de jeunes filles en Grèce archaïque. Rome. Engl. transl. of vol. I by D. Collins and J. Orion, Choruses of Young Women in Ancient Greece: Their Morphology, Religious Role, and Social Functions. New York $2001^{2}$.

(1983). Alcman. Introduction, texte critique, témoignages, traduction et commentaire, Rome.

(1997). 'Diction formulaire et fonction pratique dans la poésie mélique archaïque' in F. Létoublon (ed.), Hommage à Milman Parry. Le style formulaire de l'épopée homérique et la théorie de l'oralité poétique. Amsterdam: 215-222. 
(2004). 'Deictic ambiguity and auto-referentiality: Some examples from Greek poetics'. Arethusa 37.3: 415-443.

(2005). Masks of Authority: Fiction and Pragmatics in Ancient Greek Poetics. Ithaca.

- (2006). 'Identifications génériques entre marques discursives et pratiques énonciatives: pragmatique des genres "lyriques"' in R. Baroni and M. Macé (eds), Le savoir des genres. Rennes: $35^{-55}$.

(2007). 'Gardens of love and meadows of the beyond: Ritual encounters with the gods and poetical performances in ancient Greece', in M. Conan (ed.), Sacred Gardens and Landscapes: Ritual and Agency. Washington, DC: 43-54.

(2008). 'Entre récit héroïque et poésie rituelle: le sujet poétique qui chante le mythe', in S. Parizet (ed.), Mythe et littérature (Poétiques comparatistes). Paris: 123141.

(2009). 'Referential fiction and poetic ritual: Towards a pragmatics of myth (Sappho 17 and Bacchylides 13)'. TiC 1: 1-17.

$-\left(2009^{3}\right)$. L'Éros dans la Grèce antique. Paris. Engl. transl. by J. Lloyd, The Poetics of Eros in Ancient Greece. Princeton 1999.

- (2010). 'The authority of Orpheus, poet and bard: Between oral tradition and written practice' in P. Mitsis and C. Tsagalis (eds), Allusion, Authority, and Truth: Critical Perspectives on Greek Poetic and Rhetorical Praxis. Berlin: 13-35.

- (2012a). 'Arts des Muses et poètes citoyens: la Sparte archaïque comme culture du chant', in v. Azoulay, F. Gherchanoc, and S. Lalanne (eds), Le banquet de Pauline Schmitt. Genre, moeurs et politique dans l'Antiquité grecque et romaine. Paris: 399426.

(2012b). 'Les figures d'Hélène et de Ménélas dans le poème XVIII de Théocrite: entre fiction poétique, pratique rituelle et éloge du pouvoir royal' in Ch. Cusset, N. Le Meur-Weisman, and F. Levin (eds), Mythe et pouvoir à l'époque hellénistique. Leuven / Paris / Walpole, MA: 253-271.

Carey, C. (2011). 'Alcman: from Laconia to Alexandria' in L. Athanassaki and E. Bowie (eds), Archaic and Classical Choral Song. Performance, Politics and Dissemination. Berlin: 437-46o.

Ferrari, G. (2008). Alcman and the Cosmos of Sparta. Chicago.

Fritz, K. von (1971). Grundprobleme der Geschichte der antiken Wissenschaft. Berlin.

Frontisi-Ducroux, F. (1996). 'Eros, desire, and the gaze' in N.B. Kampen (ed.), Sexuality in Ancient Art. Near East, Egypt, Greece, and Italy. Cambridge: 81-100.

Gengler, O. (1995). 'Les Dioscures et les Apharétides dans le Parthénée d'Alcman (Frgt 3 Calame)'. LEC 63: 3-21.

Gélard, M.-L. (2010). 'De la perception sensorielle d' autrui dans le Sud Marocain (Tafilalt, Aït Atta)'. Communications: 175-193.

Hubbard, T.K. (2002). 'Pindar, Theoxenus, and the homoerotic eye'. Arethusa 38: 255296. 
Hutchinson, G.O. (2001). Greek Lyric Poetry: A Commentary on Selected Larger Pieces. Oxford.

Kouremenos, T., Parássoglou, G.M., and Tsantsanoglou, K. (2006). The Derveni Papyrus. Florence.

Lardinois, A. (1996). 'Who sang Sappho's songs?' in E. Greene (ed.), Reading Sappho: Contemporary Approaches. Berkeley: 150-172.

Mace, S. (2001). 'Utopian and erotic fusion in a new elegy by Simonides' in D. Boedeker and D. Sider (eds), The New Simonides: Contexts of Praise and Desire. Oxford: 185-207.

Nünlist, R. (1998). Poetologische Bildersprache in der frühgriechischen Dichtung. Stuttgart.

Peponi, A.-E. (2004). 'Initiating the viewer: Deixis and visual perception in Alcman's lyric drama'. Arethusa 37-3: 295-316.

Pironti, G. (2007). Entre ciel et guerre: Figures d'Aphrodite en Grèce ancienne. Liège.

Rawles, R. (2011). 'Eros and praise in early Greek lyric' in L. Athanassaki and E. Bowie (eds), Archaic and Classical Choral Song. Performance, Politics and Dissemination. Berlin: 139-159.

Rosenfeld-Löffler, A. (2006). La poétique d'Empédocle: Cosmologie et métaphore. Bern.

Sassi, M.M. (2009). 'Entre corps et lumière: réflexions antiques sur la nature de la couleur' in M. Carastro (ed.), L'antiquité en couleurs. Catégories, pratiques, représentations. Grenoble: $277-300$.

Skinner, M.B. (2005). Sexuality in Greek and Roman Culture. Oxford.

Trépanier, S. (2004). Empedocles: An Interpretation. London. 


\title{
Visualizing the Cologne Sappho: Mental Imagery through Chorality, the Sun, and Orpheus*
}

\author{
Anton Bierl
}

\section{Introduction}

My focus in this essay is on the visualizing quality of the Cologne Sappho fragment (henceforth CS $=P$. Köln inv. $21351+21376$ ), all the while holding in mind its particular transmission history. ${ }^{1}$ In volume 15 of the Oxyrhynchus Papyri, 26 line endings were published as P. Oxy. 1787 (fr. 1.1-25 and fr. 2.1). Lines 11-22 of fr. $5^{8} \mathrm{~V}$., of which the left margin is heavily damaged, can now largely be reconstructed, so that a complete poem has been recovered which seems to represent a lament on old age (I will designate this as $\mathrm{T}$, for Tithonus).

* An earlier and longer version of this paper was first published electronically in German as Bierl (2008); on that occasion I was unable to take account of Yatromanolakis (2008) (which appeared in 2009) and the papers assembled in Greene and Skinner (eds) (2009). An English version with emphasis on the question of reperformance was published electronically as Bierl (2010). I thank audiences in Cambridge, Oxford, Berlin, Philadelphia, and Stanford for much useful criticism; I also thank Deborah Boedeker for a copy of her lecture delivered at the Symposium Lesbium at Molyvos, Lesbos 7-14 August 2005 (= Boedeker [forthcoming]), and Greg Nagy with whom I shared many discussions and papers (including Nagy [2009]) at an early stage. Independently of me, in two unpublished contributions at the conferences of MOISA (Lecce, Oct. 2010) and NSACGS (Yale, July 2011) Elisabetta Pitotto and Amedeo Raschieri take similar theoretical assumptions as their starting point; I thank them for giving me access to these papers and exchanging their view with me at a very late stage. See now also Pitotto (2010-2011). Just before submission of the typescript I became aware of Boehringer (2013), who comes to similar conclusions to my own as far as the 'old age poem' is concerned, and Calame (2013), on the pragmatics and the aspect of immortality. The kernel of my contribution with its main ideas was first composed in 2007 and presented as papers in Cambridge and Oxford in June 2008. Last but not least, I express my warmest gratitude to Vanessa Cazzato, André Lardinois, Richard Martin, and Natasha Peponi for their encouragement and editorial advice.

1 For a concise description of the Cologne papyrus and its relation to the Oxyrhynchus papyrus, see Obbink (2009). A high-resolution image of the papyrus can be viewed at http://www.unikoeln.de/phil-fak/ifa/NRWakademie/papyrologie/Verstreutepub/bilder/PK21351+21376r.jpg.

(C) ANTON BIERL, 2016 | DOI: 10.1163/9789004314849_014

This is an open access chapter distributed under the terms of the Creative Commons AttributionNoncommercial 3.0 Unported (CC-BY-NC 3.0) License. 
While $P$. $O x y .1787$ originated in the second century AD, the Cologne papyrus is to be dated on the basis of paleographical analysis to the Ptolemaic period, specifically to the early third century $\mathrm{BC}$, and is thus the oldest extant fragment of Sappho. The 'old age poem', which presents and ends with Tithonus as a mythical exemplum, is preceded by the end of a poem (henceforth designated as A1), which differs from the text situated before T in P. Oxy. 1787 (= fr. 58.110, henceforth A2). In the second column, after the eighth line, there follows a further fragment of a poem (here designated as $\mathrm{O}$, for Orpheus) which, due to the writing, meter, and linguistic form, is certainly not to be ascribed to Sappho. ${ }^{2}$

The Cologne papyrus, around half a millennium older than the previously known Oxyrhynchus papyrus, is particularly interesting in that it does not come from a scholarly edition, but rather it is the product of earlier Hellenistic performance or reading practice which might still reflect earlier performance practices of the sixth and fifth centuries BC. We can therefore detect a very interesting case of diachronically shifting receptions of Sappho. After its original setting in the female Sapphic circle around 600 BC, the oral text was copied and transmitted via Panionic cities in Asia Minor and perhaps tyrannical courts like Polycrates' Samos until it reached Athens, which had grown under Pisistratus into the new cultural hub of the Hellenic world. Two new occasions of Sapphic reception were certainly of special significance, also in the fifth century: the symposium ${ }^{3}$ and public festivals, particularly the Athenian Panathenaea. ${ }^{4}$

The great media revolution from a predominantly oral reception culture to a literate culture, starting with the late fifth century and culminating in the Hellenistic era with the establishment of the great Alexandrian library, is another decisive step in the reception of Sappho. The process of transmission of the songs can take various forms in papyrus rolls: the arrangement of the poems

2 Gronewald and Daniel (2004a), (2004b), (2005). See the overview based on the recent research by Gronewald and Daniel (2007a) and (2007b); Yatromanolakis (2008), and the essays collected in Greene and Skinner (eds) (2009). On different Hellenistic arrangements of Sappho and on P. Oxy. 1787, cf. Yatromanolakis (1999) and Puglia (2007).

3 On the reperformance of Sappho at symposia, cf. Plut. Quaest. conv. 1.622c, 7.711d; Gell. NA 19.9.3-4. On earlier visual sources, cf. Yatromanolakis (2007), esp. 51-164. Cf. Yatromanolakis (2008) 245-247; for the performance of skolia at symposia, cf. Yatromanolakis (2009c) 270275. On the symposium, cf. Yatromanolakis (2009a).

4 Cf. also Boedeker (forthcoming); the publication by the Turin research group Buzzi et al. (2008), under the direction of Antonio Aloni; Yatromanolakis (2008) and (2009b) 220-225; Boedeker (2009), esp. 72-76; Lardinois (2009) esp. 47-48; Nagy (2009). 
can now be determined by older reperformance traditions as well as by newer anthologies compiled according to modern Hellenistic tastes. In this era the audience develops a predilection for literary refinement as well as aesthetic and metapoetic topoi, and is eager to learn about the archaic woman poet's Panhellenic star-status. Moreover, religious concerns about the afterlife and mystery cults might have influenced the selection of passages. ${ }^{5}$ The Cologne Papyrus, inasmuch as it is a 'best of' selection, thus probably reflects a post-classical Athenian reperformance tradition of fluid texts which, now transposed to new occasions, are assembled in a thematic order and sung consecutively. ${ }^{6}$ In other words, it seems to be a transcript of this specific new practice in which even non-Sapphic songs can be linked to parts of Sapphic ones and sung in a catena. ${ }^{7}$ In the slightly later canonical and scholarly Alexandrian edition in nine books, on the other hand, the texts were arranged according to meter, so that within each group the poems were copied alphabetically according to Sappho's first lines. ${ }^{8}$

With the discovery of the Cologne Sappho a debate has arisen as to whether or not the last four lines of fr. $5^{8} \mathrm{v}$. (henceforth referred to as B) belong to song $\mathrm{T}$, which can now be distinguished as a self-standing poem. ${ }^{9}$ Can the song as it is preserved in the Cologne papyrus, that is to say ending with the Tithonus myth, give an intelligible and satisfactory resolution? In other words, is $\mathrm{T}$ (cs coll. i.12-15 and ii.1-8) complete as it is, ${ }^{10}$ or was something omitted

Cf. Hardie (2005) esp. 29-32. This makes the selection a veritable religious testimony, not least because, in the last anonymous poem of the Cologne papyrus, Orpheus is associated with Sappho. Previously, the lyric singer par excellence had never occurred in connection with Sappho; he is first attested by Simonides ( $\left.P M G{ }_{5} 67\right)$. Our understanding of Sappho has recently been altered in a significant respect on the basis of a new evaluation of the question of the afterlife and the existence of mysteries of the Muses: see Hardie (2004) and (2005). The discovery of the Cologne papyrus was itself in part the catalyst for this reassessment.

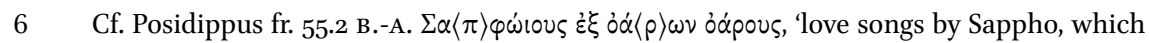
flow out of one another and continue themselves'. Cf. Nagy (2009) 187. For a similar arrangement of arias taken from tragic choral songs, cf. Gentili (2006a) 37-72, esp. 37-49. Cf. also Pitotto in Buzzi et al. (2008) 157-163 and Pitotto (2010-2011) 641-643.

8 In this latter edition, the occasion of the performance is also a criterion for the arrangement: the edition concludes with wedding songs in book nine.

9 Gallavotti $\left(1962^{3}\right) 113$ and Di Benedetto (1985) 147 had already ventured the hypothesis that with fr. $58.11 \mathrm{~V}$. a new poem begins.

10 Di Benedetto (2004) and (2006) 9-11; Luppe (2004); West (2005); Janko (2005); Bernsdorff (2004) and (2005); Geissler (2005); Hardie (2005) 13 n. 3, 28-29; Radke (2006); Rawles (2006a); Austin (2007); Steinrück (2007). 
in the anthology?"1 Gregory Nagy has suggested-and I concur-that both versions are complete, but that they reflect different performance traditions, the original in Lesbos and the secondary in Athens. ${ }^{12}$ At the private symposium or at the public Panathenaea only excerpts from various songs were presented, taken from a thematic compilation in order to achieve smoother transitions from one excerpt to the next. ${ }^{13}$ The limits of a poem could thus be fluid, as the Cologne papyrus shows.

\section{Primary and Secondary Reception: The Choral Context}

The division between primary and secondary intention as well as reception of performance is relevant for the evaluation of the so-called 'old age poem' $\mathrm{T}$ and fr. $5^{8} \mathrm{v}$. We have to find an answer to the question of what message Sappho originally wished to convey with such a text, and how the girls in her circle understood these words. ${ }^{14}$ The poem displays certain parallels with fr. 16 v., the famous priamel fragment. ${ }^{15}$ The girls are being prepared for their wedding, and in the chorus they are made conscious of the importance of an allencompassing beauty. This instruction occurs not only through the didactic word but also by means of performance, which presupposes the engagement of their entire bodies and mediates a total experience through visual, acous-

11 Gronewald and Daniel (2004a); Puelma and Angiò (2005); Magnani (2005) 43; Latacz (2005); Edmunds (2006); Livrea (2007) 69-70; Burzacchini (2007) 102-110; Lardinois (2009); Edmunds (2009).

12 Nagy (2009) 186. Cf. already Boedeker (2009) (even speaking of 'Sapphic mouvance', 72-76) and (forthcoming); Lardinois (2009) 48 and Yatromanolakis (2008).

13 For anthologies that contain excerpts from poems, cf. the examples given by Lundon (2007) $160 \mathrm{n} .5^{2}$ and Yatromanolakis (2008) 248-250. For the technique of borrowing, adaptation, and anthologizing in archaic performance composition cf. Gentili (1984) 64$66=(2006 \mathrm{~b}) 79-81$, with the summary: 'Una tecnica di tipo associativo o antologico che permetteva di riutilizzare testi già pronti, appartenenti al repertorio tradizionale 0 composti dal poeta stesso per altre analoghe occasioni', (1984) $66=($ 2006b) 81 (in English, Gentili [1988] 49).

14 In light of the new emphasis on questions of reperformance, I do not share commentators' recent reservations (e.g. Yatromanolakis [2007], esp. 33-34) about the usual efforts to reconstruct the original setting of Sappho. Such postmodern skepticism against unidirectional constructs of grand narratives and fictionalizations would exclude any possibility of understanding the primary context and intention.

15 For the priamel fragment, see my more detailed discussion in Bierl (2003). 
tic, tactile, olfactory, and kinaesthetic signals. ${ }^{16}$ Sappho thus assumes a living choral culture for the reception of her poetry, even when the songs are performed by an individual singer. ${ }^{17}$ I designate this phenomenon as the 'virtual chorus':18 although her songs may not have been sung by a chorus, Sappho nonetheless notionally employs the girls' chorus of her circle as a cultural and visual reference point that is omnipresent for the girls. ${ }^{19}$ Perhaps the maidens did, in fact, dance to the song as well.

In a traditional society, which defined itself to a considerable extent through myth and ritual, it is precisely such mythic-ritual discourses in the choral paideia that assume central importance. Music, rhythm, and collective movement to song and melody lead to a deeper understanding of beauty. The education in bellezza is also reinforced through premarital homosexual relationships among the girls in the group. The attraction of the girls for one another as well as that between the perfect chorus-leader Sappho and individual group members results in a comprehensive aesthetic training. In a process similar to that depicted by Plato in the Symposium, through physical love one acquires increased sensitivity and greater insight into nature, the environment, the cosmos, and aristocratic values. This common training also provides an aesthetic acquaintance with the media that strengthen these feelings-words, music, and dance-which together mediate visual poetry. ${ }^{20}$ In a permanent synaesthesia, attraction and learning combine in a cognitive awareness of to kallos in an almost philosophical sense. ${ }^{21}$ The noble girls are thus prepared for their marriage, for which they need both physical and inner beauty, and in the recollection of their shared experiences beauty is kept alive even after they have left the Sapphic community.

16 Cf. here Bierl (2001) (in English, Bierl [2009]).

17 On the possibility of an actual performance by a chorus, for example of frr. 16, 31, and $96 \mathrm{~V}$., cf. Lardinois (1996) 169-170. On Sappho generally as a chorus leader, cf. Calame (1977) I 127, 369-370 (in English, Calame [1997] 65, 212); Lardinois (1994) esp. 73 n. 61; contra: Parker (1993) 331-333. On the chorus as the social context of initiation, cf. e.g. Calame (1977) I $385^{-}$ 420 (in English, Calame [1997] 221-244) and Bierl (2001) (in English, Bierl [2009]) Index

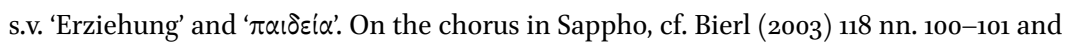
frr. 16.17-18, 24a(?), 44, 94.27(?), $103 \mathrm{~V}$.

18 On the choral elements of fr. 58 V., cf. West (2005); Di Benedetto (1985) 148-149; Lardinois (1996) 169 (she sings, as the chorus dances); cf. also Hardie (2005) esp. 27-32; Lardinois (2009).

19 On Sappho's circle, cf. Merkelbach (1957) and Gentili and Catenacci (2007).

20 On fr. 16, cf. Bierl (2003).

21 On the (proto-)philosophical in Sappho, esp. in fr. 16, cf. duBois (1995) 77-97, 98-126, esp. 101, 105-115. Cf., on fr. $5^{8}$ v., Greene (2009). 
In a secondary stage of reception, the aesthetic and philosophical potential of these poems within the female circle can then influence the male sphere. Thus Sappho's poetry found entry to the symposium and achieved Panhellenic status as a cultural achievement, so that it was also performed at larger festivals. $^{22}$ In this process, the songs are removed from their original, pragmatic Sitz im Leben and can assume new functions and meanings. They can be combined according to internal criteria alone, without reference to their function within the girls' group. ${ }^{23}$

In many respects, Sappho represents the 'closest foreign' of Greek culture. ${ }^{24}$ It is my contention that the focal point of the Cologne Sappho, the 'old age poem', is not the vexed outcry of the individual lamenting her condition; rather, it has to do with aesthetic education in the Sapphic circle and with ideas of rejuvenation. Moreover, its entire meaning is acted out against the visual foil of a living culture of chorality, where the education of young women in social roles and gender values takes place. The central myth is not simply a narration, but an exemplary reflection, a piece of cultural memory that confers social cohesion, acted out in the imagery of choral dance. ${ }^{25}$

\section{The Look of Lyrics and Iconic Poetics}

Lyric song depends heavily on visual images and tableaux. But whereas other genres tend to describe or represent scenes or visual impressions so that they are clearly envisaged and fully alive before the mind's eye of the recipients, lyric poems tend to provide no more than a rough sketch. Whereas ekphrasis in epic, Hellenistic poetry, or prose narrative reenacts the pictorial with enargeia and brings it to life, Sappho often no more than alludes to the visual in order to convey didactic messages to the members of her circle. The recipients have

22 Cf. Bierl (2003). On Panhellenism, cf. Mitchell (2007).

23 On the transition to 'literature' from the perspective of fr. 31 V., cf. Rösler (1990) esp. 271272, 285-286 and Bierl (2003) 122-123, with reference to fr. 1 v.6.

24 Hölscher (1965) 81: 'das nächste Fremde', on how Greek culture can be felt to be at once estranging and very close.

25 Such a view is radically different from subjective and feminist approaches; among others, cf. Winkler (1981); Parker (1993); duBois (1995); most of the contributions in Greene (ed.) (1996); Williamson (1995); Wilson (1996); Stehle (1997) 262-318. These contributions anachronistically reproject the modern view of the female individual to a traditional society of alterity, where gender roles are rather strictly defined. Against this neoliberal, feminist approach, cf. also Calame (1998); Bierl (2003); Gentili and Catenacci (2007). 
to supplement this information within the range of a cultural imagery that is mentally generated in what Aristotle called phantasia (de Anima 428a1). For such mental imagery Aristotle already used the term phantasma (ibid.), though he did not apply it to inner images in the Sapphic sense. ${ }^{26}$

In Sapphic poetry the visual dimension is generally blended with auditory, kinaesthetic, olfactory, and haptic 'imagery' to produce an effect of synaesthesia. The actual song, its sound, music, rhythm, and movement, is connected with the iconic, with specific images or impressions, which can be seen in the hic et nunc or are projected onto elsewhere by means of the imagination. Rituals and myths typically underline these sensations. The festival, the occasion of the song, emphasizes the synaesthetic experience, which finds its way into its poetic discourse, and it supports the highly sensational atmosphere of the poem in performance as well as the written text. Myths, on the other hand, with their intense potential for creating mental visions and perceptions, frequently serve as additional examples or proofs of statements.

Poetry generates pictures by means of tropes, particularly through metaphoric language, and by evoking iconic scenarios. In the archaic song culture visualizing occurs both with reference to stimuli that are before the eyes and in the absence of such stimuli-in Bühler's terms through deixis ad oculos or ad phantasma respectively. ${ }^{27}$ In short, Sappho conjures up images by referring to impressions that are actually present in the hic et nunc (at least in the original occasion of the primary reception, e.g. the bodies of young choral dancers) or she stimulates vision in the mind's eye of the recipients by mentally produced imagery.

Metaphors, the quintessential source of visualizing in language, often represent the vessel for myths and rituals. ${ }^{28}$ Ancient songs are frequently embedded in ritual and mythic scenes or in tableaux. Image, performance, environment, mental concepts all enter into the texture of a poem in a dialogic manner. ${ }^{29}$

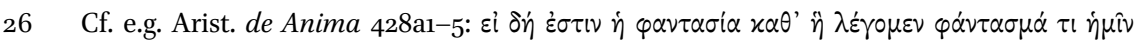

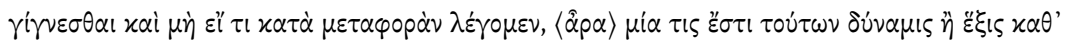

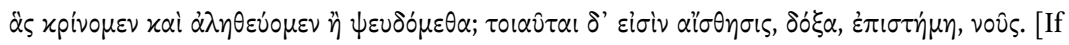
then imagination is that in virtue of which an image arises for us, excluding metaphorical uses of the term, is it a single faculty or disposition relative to images, in virtue of which we discriminate and are either in error or not? The faculties in virtue of which we do this are sense, opinion, science, intelligence (Trans. J.A. Smith)] and Nussbaum (1978) (citing and discussing numerous passages).

27 Cf. Bühler (1934) and Bierl (2001) 38 n. 63 (in English, Bierl [2009] 24 n. 63).

28 Cf. Alexiou (2002) esp. 317-319.

29 Cf. Ferrari (2002) esp. 61-86. 
Furthermore, a metaphor can generate a ritual by setting further metaphors in motion which are activated through similarity and/or contiguity. ${ }^{30}$ Myth often transforms ritual in performance and accompanies it with stories. It is multidimensional, dynamic, and in constant movement or transfer, ${ }^{31}$ and it draws on the visual to a large extent.

I argue that Sappho builds her poetic discourse in general, and the poems of the Cologne papyrus in particular, on very specific cultural and visual patterns which help to shape cognitive reception through mental imagery, especially in oral performance contexts. ${ }^{32}$ Moreover, rituals and myths can function as a decisive framing device to determine the visualizing force.

Thus it will become evident that $\mathrm{Al}$ is based on the actual festivity, music, and performance. In the new poetics of an anthology these themes provide a fluid transition to the central poem $\mathrm{T}$ so that one can maintain that $\mathrm{Al}$ is the proem to $\mathrm{T}$. The central song on old age further draws on images and concepts of chorality of the Sapphic circle as virtual chorus, and the exemplary myth reflects these cultural pictures of dancing in a solar context. Old age is conveyed by very drastic symptoms in the body, while the physical parts affected are all linked to choral dancing. Furthermore, the myth becomes effective only by reference to the visual perception of Tithonus and Eos, as it manifests itself on later vase paintings and in larger narratives. The last four lines (в) are again deeply embedded in solar imagery, which gives way to the solar connections to Orphism in the last, non-Sapphic passage (o). It will be demonstrated that without visualization and contextualization in cultural and anthropological images and concepts such as the daily change from night to daylight, choral dancing, renewal, rejuvenation, and hope for the afterlife, we risk missing the sense of the centerpiece (т) of the Cologne Papyrus. As a result, it has been widely read as a subjective and personal lament on the depressing effects of old age.

Let us take a look at the text in its entirety.

3o Cf. Fernandez (ed.) (1986) and (1991).

31 Cf. Alexiou (2002) 166.

32 On mental imagery and cognitive psychology, cf. e.g. Finke (1989); Richardson (1999); Denis (1991); Kosslyn et al. (2006); on textual iconicity, cf. e.g. Iser (1976) esp. 221-222; Lerchner (2000); on iconicity and 'traditional referentiality' in Homer, cf. e.g. Foley (1999). 


\section{The New First Part (A1)}

$\mathrm{Al}$ (=P. Köln col. i.1-11) is apparently the end of a poem, in which Sappho returns to the present ( $v \hat{v} v$ ) and at this point speaks of her position of honor as a poetess in Hades after her death, which she describes as identical to the prestige she enjoys in her earthly life.

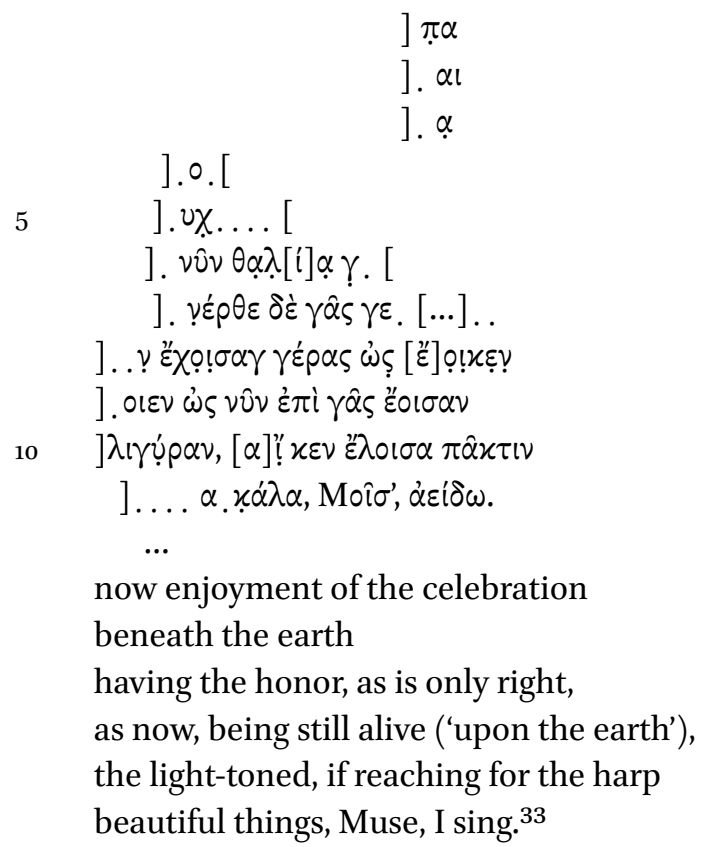

Sappho clearly returns to the frame and the parameters of performance in a concluding coda in which she addresses the festive enjoyment of the chorus in singing and dancing. She imagines herself in Hades after her death and vividly pictures how, even there, she will be granted a place of honor as a singer. She desires for herself the explicit admiration among the dead that she still enjoys among the living. Her present fame parallels her reputation in the realm of the dead. In their mystery cults, the Muses inspire conceptions of an existence in the afterlife which reflects that on earth. ${ }^{34}$

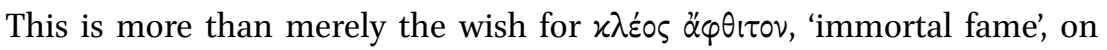
the part of the poet. Sappho illustrates her situation when she crosses the

33 Text by Gronewald and Daniel (2004a) 2, 4-5, and Gronewald and Daniel (2007a) 4, 6.

34 Cf. Hardie (2005) esp. 22-32. 
threshold of death in concrete terms: her existence in the afterlife resembles that which she now enjoys. In Hades, she will reach for her lyre and begin to sing, accompanied at least in imagination by the dance of the girls' chorus, just as she does now. She imagines how she will be admired by the souls gathered about her, who will also form a choral circular dance.

In the underworld as in this world above, Sappho needs the inspiration of the Muse. The last two lines establish a chiastic mirroring of the first two lines of the following poem (T.1-2) and thus form the prelude to the song about old age. One motif proceeds from the other, while the rhythm remains unchanged. As in Al, death and the overcoming of death, performance in the chorus, the Muse, immortality, and the recovery of youth are presented in a utopian, pastoral context.

\section{The Poem on Old Age (T)}

In the reconstruction of West (2005), the centerpiece $\mathrm{T}$ of the Cologne papyrus (= P. Köln coll. i.12-15 and ii.1-8) reads thus:

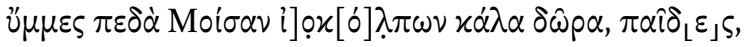

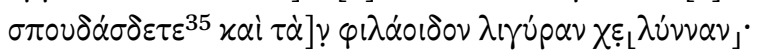

35 Di Benedetto (2005) 17-18 regards West's emendations ([2005]) $\pi \varepsilon \delta \dot{\alpha}$ and $\sigma \pi 0 v \delta \dot{\alpha} \sigma \delta \varepsilon \tau \varepsilon$ in line 1 as scarcely plausible. The girls have to attend to the Muses and the gifts of the Muses, so that Moíav would then stand apo koinou in two syntactically different relations. Moreover $\sigma \pi 0 \cup \delta \dot{\alpha} \sigma \delta \varepsilon v \nu$ is perhaps not the most suitable verb, and even the construction with the accusative is somewhat unusual. Di Benedetto (2005) 18 therefore proposes: $v_{\mu} \mu \nu \nu \varphi$ i $\lambda \alpha$

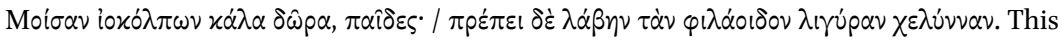
supplement would give a welcome contrast to the dative $\varepsilon^{\prime \prime} \mu o$. Thus: 'Let the gifts of the violet-bosomed Muses be dear to you, girls. / It is right to take up (perhaps also $\varepsilon \lambda \eta \nu$ )

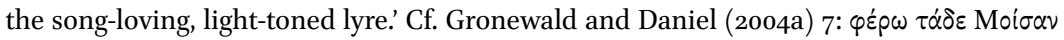

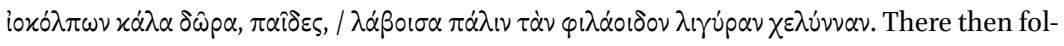
lows: 'Age has already taken hold of me'. West's difficult suggestion admittedly captures more effectively the busy activity, the movement of the choral dance directed towards the

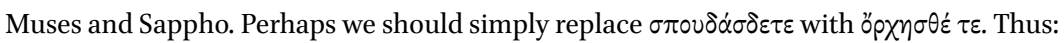

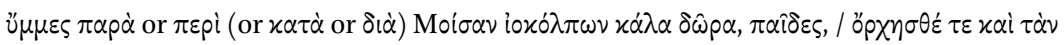

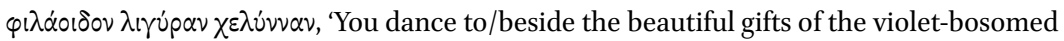
Muses (around the ..., according to the ... because of the ...), girls, and also to the (around, according to, because of the) song-loving light-toned lyre'. On the prepositions, for $\pi \alpha \rho \dot{\alpha}$ ' at, beside', cf. Sappho fr. 168в.3 V. and for $\pi \varepsilon p$ ' 'all around', Sappho fr. 154.2 V., to be understood in terms of the disconnection from the object as tmesis; for $\varkappa \alpha \tau \dot{\alpha}$ or $\delta i \alpha$, where a dactylicepic form should be assumed (Sappho fr. 44.12 v.), cf. Hamm (1957) 110-111 §195 a and b, 


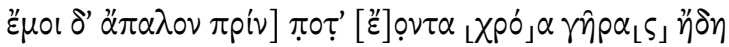

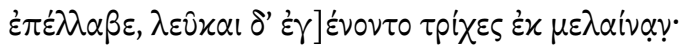

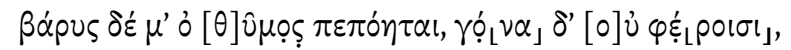

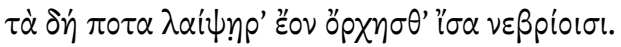

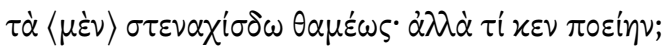

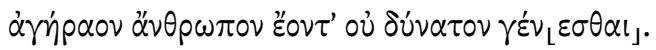

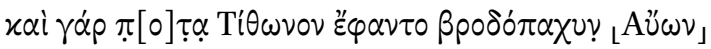

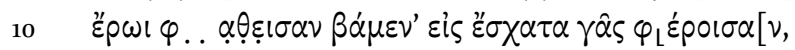

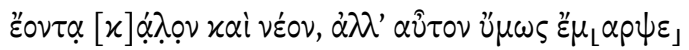

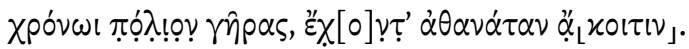

[You for] the fragrant-blossomed Muses' lovely gifts

[be zealous,] girls, [and the] clear melodious lyre:

[but my once tender] body old age now

[has seized;] my hair's turned [white] instead of dark;

my heart's grown heavy, my knees will not support me,

that once on a time were fleet for the dance as fawns.

This state I oft bemoan; but what's to do?

Not to grow old, being human, there's no way.

Tithonus once, the tale was, rose-armed Dawn,

love-smitten, carried off to the world's end,

handsome and young then, yet in time grey age

o'ertook him, husband of immortal wife. ${ }^{36}$

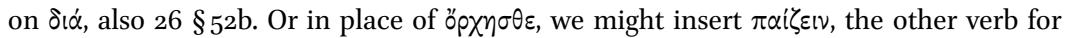

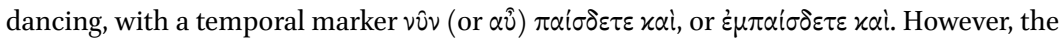

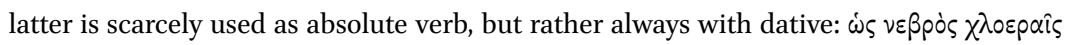

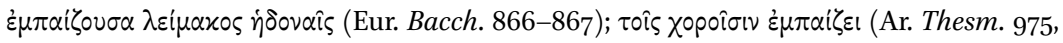

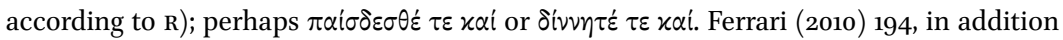

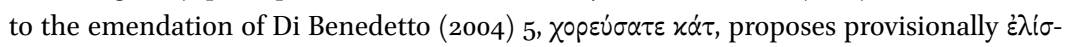

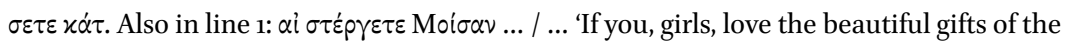

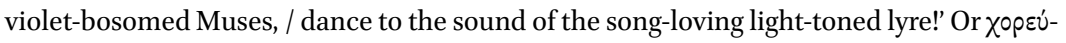

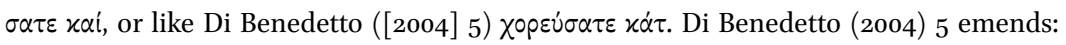

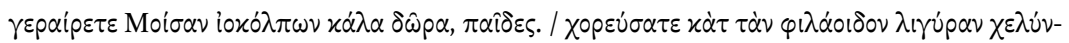
$\nu \alpha \nu$ - Honour the beautiful gifts of the Muses, girls: dance to the song-loving light-toned lyre', an idea which he then apparently ([2005] 18) abandons. Austin (2007) 116-118 sug-

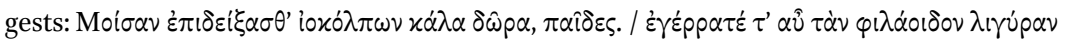
$\chi \varepsilon \lambda u^{\prime} v \alpha \nu$. For numerous proposed emendations of T, cf. Gronewald and Daniel (2007a) 8-11; Burzacchini (2007) 98; Livrea (2007) 73-74.

36 Text by Gronewald and Daniel (2004a) 4-5, and Gronewald and Daniel (2007a) 7-8, with the reconstructions by West (2005) 5 and his translation. 
The song $\mathrm{T}$ is structured as follows:

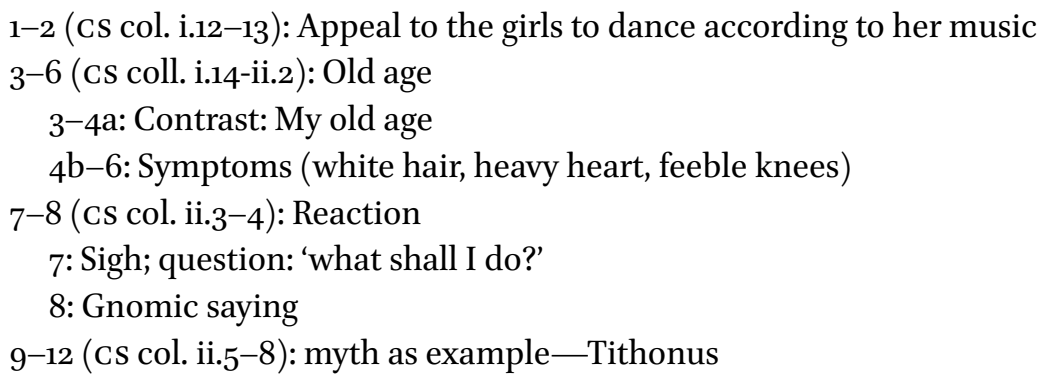

The poem is characterized by opposites. The girls should devote themselves to the Muses, who will help them to coordinate their movement. Sappho sets the rhythm and melody with the lyre. The situation of the chorus is decisive. In contrast to the girls summoned to the round dance, the lyric 'I', who here is certainly Sappho - for a repeated performance, however, any woman can assume her place-positions herself opposite the group of young girls at the emphatic first verse position in line 3. Age has conquered her body, her skin: now it is weak, fragile, but once, like the young paides who engage in paizein, dancing, it was nimble and agile $\left(\alpha^{\prime} \pi \alpha \lambda \circ \nu \pi \rho^{\prime} \nu \pi \circ \tau^{\prime}\right) \cdot{ }^{37}$ Initially, the entire body is addressed. The choral dance expresses itself entirely in physical movement. Then the corporeal entity is divided into three sections in the perspective $a$ capite ad calcem:

1. The hair, the youthful glory which characterizes the beauty of the dancing girls, has become white. Above all, the earlier condition, black hair, which the girls still have, is emphasized. White and black mark the beginning and end of the colon.

2. The heart, the $[\theta] \hat{\mu} \mu \varphi_{\text {ș }}$ localized in the diaphragm, represents emotional

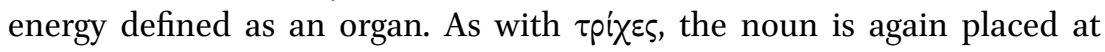
the center, while 'heavy' stands like 'white' as the predicate adjective in an emphatic first position. Just as abstract old age has overcome the 'I' and the

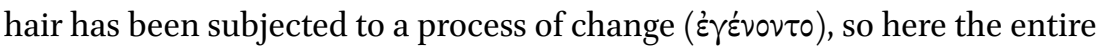
drama is rendered in the perfect passive of $\pi$ oเ $\varepsilon \hat{v}$. The subject is helpless; she is condemned to an inevitability which she endures. The mood, the gay dis-

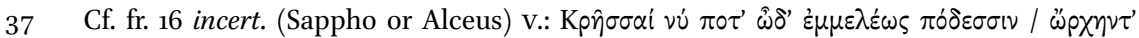

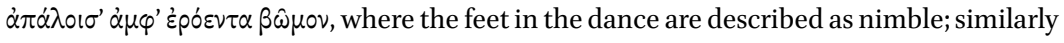
Hes. Theog. $3^{-4}$, in the appeal to the Muses. The adjective $\alpha \pi \alpha \lambda$ os thus belongs in the context of the chorus. 
position which manifests in the lightness (cf. $\ddot{\alpha} \pi \alpha \lambda \circ v)$ of bodily movement, is dampened. Physical weight prevents gliding and rising into the air.

3. The knees, which metonymically and as synecdoche represent the legs, suggest the movement in dance. Following the Gesetz der wachsenden Glieder, they are explained with a relative sentence or with a deictic main sentence (6): 'These were once light' —in chiasmus the often expanded $\alpha^{\prime} \pi \alpha \lambda$ ov $\left.\pi \rho i v\right]$ $\pi \circ \tau$ ' in line 3 is resumed-'to dance.' The knees were like those of young deer. ${ }^{38}$

In line 7 , we come to the passive enduring of age that overcomes the victim, and the subject's reaction: 'I lament this often-I sigh often and groan'. The 'I' asks almost with resignation: 'But what should I then do?' The question is rhetorical: Sappho cannot actively do anything against it. Aging is an inevitable natural process. There follows the asyndetically justifying gnomic statement: as in

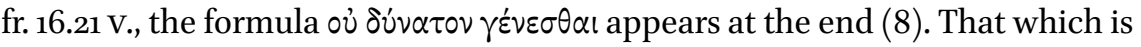
most decisive is again placed in the first, emphatic position. As a human being

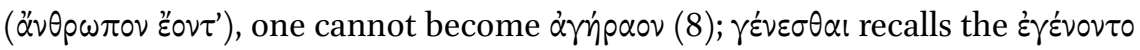
of the changing color of the hair (4). The adjective, negated with the alpha privative, is with a further explicit negation effectively affirmed in a kind of litotes.

A mythic example is introduced in support of this thesis and justified with ráp (9). The myth, the authoritative word, is appealed to in the past tense: ${ }^{39}$ 'And it was said, that once' - the $\pi \circ \tau \alpha$ is again taken up, contrasting with the here and now of the performance- 'that Eos abducted Tithonus'. Tithonus is placed in extreme prolepsis: he is the decisive example. As a man, he will still grow old, although a goddess loves him and seeks to obtain immortality for him - forgetting in the process, however, to request that he also remain ageless. Eos is a companion of Helios: she travels the heavenly course in his tracks. Besides sunrise, she symbolizes the entire day, and pursues her journey with undivided attention on Helios, accompanied by her herald, the morning star Eosphorus. Love and sexuality are localized in the realm of night, death, the subconscious mind, dreams, and the ocean. ${ }^{40}$ Recreation is identified with the

38 The comparison of young dancing girls with deer is common; cf. the Homeric Hymn to Demeter 174-175; Bacchyl. 13.86-90; Eur. El. 860-861, Bacch. 862-867, esp. 866; Ar. Lys. 13181319, Thesm. 1180. The Dionysian deer calf is often associated with dancing Maenads. Cf. also Méndez Dosuna (2008).

39 Edmunds (2006). On the mythical example, cf. now Edmunds (2009).

40 On this aspect as well as the subject of rejuvenation, cf. Nagy (1990) 226-262, esp. 260262, to whom Gronewald and Daniel (2004a) 3 also refer. Cf. also Nagy (1996) 87-103 and (2009). 
sexual. Following the effort of the journey, the aging of the day, one then retires to the shared bed, in order to return rejuvenated to the next day's labors.

The abduction undoubtedly occurs as a result of erotic desire. The personified dawn, enflamed with love, transports the son of the Trojan king to the edge of the world, to Ethiopia. Eos abducts Tithonus under the effect of his beauty and youth (11), and she enjoys physical love with him at the end of the earth. She must still return there daily from the West, like Helios, but in spite of the love of a goddess, Tithonus is in the course of time overcome with grey old age (12). The attribute 'grey' refers back to the 'greying' and the white color of the hair in line 4.

The micro-narration is restrained to such a minimum that the circumstances of Tithonus' misfortune are not explicitly mentioned. We know from the Homeric Hymn to Aphrodite (221-224) that Eos, out of negligence and foolishness, forgot to ensure the agelessness of her beloved when obtaining immortality for him. In a traditional, oral society the audience would have been familiar with the variants of the myth. In artistic representations, Tithonus is depicted as a beautiful young man, wearing a crown and holding a lyre in his hand. He is obviously also a servant of the Muses who brings them gifts. ${ }^{41}$ Eos' conventional violence in seizing male youths like Cephalus is transferred here to the terrors of aging: it attacks him even though he is the beloved of his immortal spouse. है $\mu \alpha p \psi \varepsilon$ stands conspicuously at the end of the line; while it was initially Eos who captured him, now it is 'grey old age' which does so.

The mythic example is manipulated in a complex manner similar to that of the Helen myth in fr. $16 \mathrm{v} .{ }^{42}$ where too the allusions are unusually ambivalent. ${ }^{43}$ After beginning with a reflection on her own aging, Sappho compares herself clearly with Tithonus: once young and beautiful, now she too has grown old. Both figures are also characterized by the lyre-playing of the Muses and singing, and they continue to sing as they become older. ${ }^{44}$ Sappho, however, also reflects

41 See, above all, the famous painting of the pursuit of Tithonus by Eos on the red-figure vase by the Achilles painter ( $470-460 \mathrm{BC}$ ), found in Vulci (Louvre G438). On several other vases Tithonus is represented as a singer and lyre player (e.g. Boston 03.816, Museum of Fine Arts, ca. 48 о вС).

42 Cf. Bierl (2003) 107-112.

43 Cf. Bierl (2003) 108 n. 6o, 111 n. 74 for further literature.

44 Tithonus is ultimately confined to the bedroom and fed on nectar, while his emaciated body is merely an unending, echoing voice ( $\varphi \omega \nu \grave{\eta}$... $\ddot{\sigma} \sigma \pi \varepsilon \tau 0 \varsigma$, Hymn to Aphrodite 237). In later sources, he is even transformed into a cicada (Callim. fr. ${ }^{1.32-38}$ Pf.). Some interpreters regard these passages as evidence of an attempted conciliatory end, according to which Tithonus continues to live, in a certain sense, as a singer. Cf. e.g. Geissler (2005) esp. 111-112; Janko (2005); Rawles (2006a) 5-7; Livrea (2007) 72, 78-79. 
Eos, just as the speaking ' $\mathrm{I}$ ' in fr. 16 also stands in relation to Helen. Both are active as female subjects, and travel away over the sea for love. Helen also embodies the aspect of Eos-Aotis in Sparta. ${ }^{45}$ She is the symbol of the young girl being initiated on the eve of her wedding. Like Helen, Eos embodies an aspect of Aphrodite: both go to the East motivated by an insatiable longing and enjoy themselves in bed with a Trojan youth. ${ }^{46}$

Like Eos, Sappho loves radiant young bodies. She takes pleasure in the dancing girls, and burns with desire for them. Moreover, she carries them away on artistic wings to the limits of the unconscious, into the pastures of the night, of dreams, and of a perfect aesthetics. The poetess even crosses the threshold of death, sinks like Eos into the tides, into the ocean of love, and draws out of it ever new love and youth. Eos has her 'house and dancing places' (Odyssey 12.3-4) in Aiaia, ${ }^{47}$ at the edge of the earth where the sun rises. The image of the xopoi (Odyssey 12.4) is probably very concrete: the sexually attractive goddess indeed leads circles of dancers and takes members of the chorus into her house, just like Sappho. Eos is the chorus leader of the girls gathered around her, who symbolize the attendant stars. After she has indulged in a night of love, she dances in the early morning together with her companions. As the sun rises, Dawn shines increasingly upon them. In the course of the day, she becomes old, before recovering her youth in the underworld. From the journey through death, dreams, and the unconscious, she derives new energy. Eos is immortal as a chorus leader, and like Sappho she will continue to perform as a celebrity above and below the earth (see Al). Therefore, Sappho identifies herself constantly with the mythic personification of dawn, as well as with Aphrodite. ${ }^{48}$

At least in the later tradition, Sappho is associated with Aphrodite. The poetess and her model are united in their love for pretty youths such as Adonis and Phaon, whose pursuit is repeatedly depicted on vases. This ongoing pursuit is the emblem of the eternal perpetuation of love. The erotic poetics of Sappho precisely coincides with the logic of love as the discourse of absence, as defined by Roland Barthes. ${ }^{49}$ It is a matter of the imaginative quest for the object of

Cf. Alcm. PMGF 1.87 (cf. also her possibly additional name of Orthria, line 61), and Calame (1977) II 122-127.

46 On fr. 16 v. and Helen, cf. Bierl (2003) 106-111.

47 On Aia (and Aiaia) as the country of Eos, cf. West (2007). On the dances of Eos, cf. Zusanek (2005) 87-88, 138.

48 With Eos: Sappho fr. 103, 123, 157, possibly 6 v.; with Aphrodite: among others, Sappho fr. 1, $2 \mathrm{~V}$.; on the dive from the Leucadian cliffs, $\mathrm{T} 23$ Campbell = Strabo 10.2.9. On the parallelism Eos-Aphrodite, cf. Nagy (1990) 246-250.

Barthes (1979) 13-17. 
desire in which limitations can be overcome through music, poetry, and other aesthetic expressions. Sappho thus moves in imagination through the sphere of death, which is reflected in concrete terms in her aging body, in order then through the sphere of music and love to obtain youth once more..$^{50}$

This exact configuration is displayed on a red-figure oinokhoe by the Achilles Painter dated ca. 470-46о вС and found in Vulci (Louvre G438). Eos, as a tall, mighty and winged figure is shown running after Tithonus, her human lover. She is stretching her hand towards the much smaller man, who looks back at her while running away with big steps and carrying in his left hand a lyre. These are the mental images and cultural associations which the recipient has in mind when she/he listens to the oral performance in the Sapphic circle or to ongoing reperformances in different venues and contexts at a later stage. Through visualization the meaning of the poem or of a series of thematically concatenated songs is configured in the act of perception.

Consistently with the approach of the Hellenistic tradition and the new contextualization, the outcome of the story in the new papyrus remains open. It suggests the rejuvenation of Eos and Tithonus, and the continuing performance of music and dance. The deferral to the next poem on Orpheus also reflects to some extent the erotic poetics, the ongoing gap of absence between pursuing lover and the hunted object of desire, and the technique of thematic allusions. The abrupt ending of the myth allows reflection on the subjects of eros, life after death or immortality, renewal, and music. The cyclic poetics of suspension and permanent deferral is manifested in the antithetical juxtaposition with the possibility of renewal. Sappho finds new energy in her attention to the dancing girls, who find a counterpart in Eos and her choruses. The poetess may be old, yet in her enthusiasm for youth and in her appreciation of their glowing bodies, she can always overcome age. At the same time, in the primary reception within her circle, the pedagogical function that resides precisely within khoreia assumes an important role. ${ }^{11}$ Eos' marriage is reflected in the situation of the young women who are being prepared for marriage. Sappho can also give them the message that both they and their future husbands will grow old. Through the later recollection of their shared activities, above all in dance and music, and through a continued devotion to beauty and aesthetics, they can remain beautiful and young in spirit—and thus also desirable. By reperforming the same songs, Sappho and the girls of whom she sings can

\footnotetext{
50 Cf. Nagy (1990) 260-262 and (2009); cf. also Gronewald and Daniel (2004a) 3; Nagy (2007).

51 Cf. Bierl (2001) (in English, Bierl [2009]) Index s.v. 'Chor/sozialer Ort der Altersgenossin-

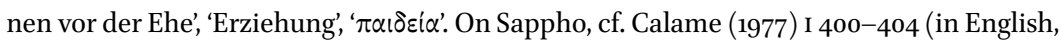
Calame [1997] 231-233); Ingalls (2000) 12-14; Bierl (2003) 100-123; Hardie (2005) 16, 27-32.
} 
preserve their virginal freshness. As long as the song is performed, it remains current, being performed by ever new figures: an elderly chorus leader instructs in dance young girls who continuously leave the group and are replaced by others. It is precisely in this way that Sappho lives on, even after she is dead. ${ }^{52}$ Thus she anticipates metapoetically her own literary success.

The song is influenced by other laments on old age, but is in itself not at all such a lament. An emotional outburst of such feelings would, in fact, have been ineffective and counterproductive within Sappho's circle. ${ }^{53}$ The composition is much more a pedagogical statement for the benefit of the young, aristocratic women in her group and a self-referential, poetic reflection against the foil of the girls' chorus. ${ }^{54}$ The 'beautiful gifts of the Muses' serve as inspiration for the aesthetics of movement, whereby Sappho is in a sense the tenth Muse ${ }^{55}$ who as chorus leader performs at the head of the dancing circle, the image of the group of Muses. ${ }^{56}$ One remains ever beautiful when one orients oneself toward the beautiful. Sappho rejuvenates herself in exactly the same way as her $\pi \alpha \hat{\imath} \delta \varepsilon \varsigma$.

The tone is optimistic and never melancholic or self-pitying. Naturally, the girl is at the same time confronted through the myth with the finitude of life and the conditio humana. Music and the social institution of the Xopós are, however, intransient. In this way, every querulous thought about old age is overcome.

Alcman's famous song PMGF 26 could have provided the model here with another capturing image: 57

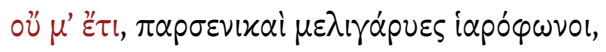

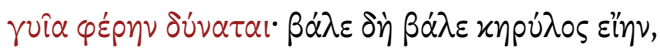

$5^{2}$ Cf. also Geissler (2005) 109-111; Rawles (2006a) 4-7.

53 Thus, Sappho's 'emphatic response "Nonetheless!"' which Latacz (2005) believes he can find in these lines is not warranted; similarly Preisshofen (1977) 56-64, esp. 64; Meyerhoff (1984) 187-198, esp. 194-196; Falkner (1995) 102-107; Tsomis (2001) 247-250, esp. 249. All of these interpretations assume that the last four lines of fr. $5^{8} \mathrm{~V}$., which are missing in the Cologne papyrus, belong to this poem.

54 For this reason, Schadewaldt's biographical interpretation ([1950] 157-161) is misplaced: 'Sappho ist alt geworden, jedenfalls so alt, daß sie, die so an Anmut und Jugend hing, die Dunkelheiten des Alters sehr empfand. Sie trauerte darüber in einigen ihrer Lieder ...' (157).

55 Plato, To the Muses = Anth. Pal. 9.506, Antip. Sid. 12 Gow-Page = Anth. Pal. 9.66; cf. the anonymous author of Anth. Pal. 9.571 and Gosetti-Murrayjohn (2006).

56 Anth. Pal. 9.189 (anonymous). Cf. also Battezzato (2003) esp. 36-42.

57 For the comparison, cf. Gronewald and Daniel (2004a) 7; Bernsdorff (2004) 33-34; Gronewald and Daniel (2007a) 9; Ferrari (2010) 198, on the Cologne Sappho 193-204. 


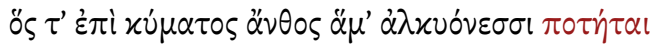

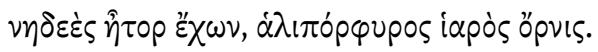

No longer, girls, honey-toned and holy-voiced, can my limbs bear me. If only I were a kingfisher,

who flies together with his mates, the halcyons, over the frothy crests of the waves

with powerful courage, sea-coloured, holy bird.

In this poem, khoreia represents likewise the decisive image, which supports the real chorus (or rather the solo singer). The chorus leader is old and contemplates his circle of maidens. In erotic desire for the girls who sing and dance under his instruction, the khoregos places himself in the role of the kingfisher. Birds function as a typical metaphor and visual emblem for choral dance; their hovering and formation in a group is reminiscent of the movement of the group of dancers. ${ }^{58}$ The 'I' nurses the wish to be joined as a kingfisher in flight with its mate. The kingfisher, as is well known, floats happily over the surface of the water and dives head first in a stabbing motion into the water in order to catch fish. This movement resembles the immersion of Eos and Helios into the water, and particularly Sappho's leap from the Leucadian cliffs. ${ }^{59}$ From desire for the girls and their youth, the chorus leader, who as a lyre-playing man cannot join the circle of girls and who represents himself as no longer dancing, springs figuratively into the ocean, and thus into the realm of death and dreams, in pursuit of the object of his desire, which he can never capture. The bird is described as being sea-blue-mauve because in its diving it loses itself to a certain extent and becomes part of the sea. The erotic poetics of absence, the yearning for the other, thus finds its concrete expression. ${ }^{60}$ As in the case of Sappho, the erotic relationship is based on reciprocity: the dancing maidens also long for the unattainable chorus leader.

The poetry of Sappho and Alcman's Partheneia expresses itself in mutual desire and inspiration, as well as in erotic rejuvenation. Sappho's poem, then,

58 Cf. also Eur. IT 1089-1152, esp. 1138-1152, where the chorus of Greek women, who serve as temple servants in Tauris, wish like a kingfisher to fly the radiant beams of the sun in order to be able to join the choruses at home, in which they had already danced as girls at weddings. The song begins with an allusion to the kingfisher.

59 Cf. sources and treatment by Nagy (1990) 223-233. On the Leucadian cliffs as boundary to death and the unconscious, cf. Hom. Od. 24.11.

6o On solar symbolism, Halcyone and Ceyx, and the Leucadian cliffs, cf. Levaniouk (1999) 119-126, with reference to Penelope. 
is not simply a 'correction' of Mimnermus, ${ }^{61}$ but the image of extreme old age is merely the pronouncement of the impossibility of choral and sexual union.

I present the text of poem $\mathrm{T}$ here once more with various forms of emphasis in color intended to draw particular attention to the central visually charged terms for dancing and age: ${ }^{62}$

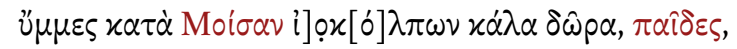

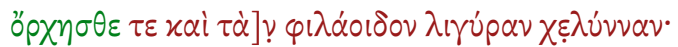

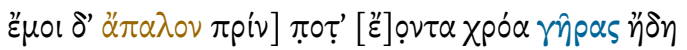

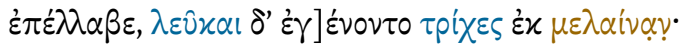

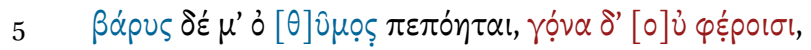

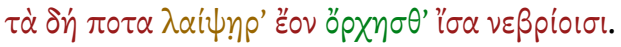

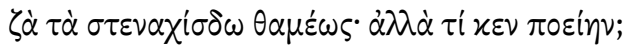

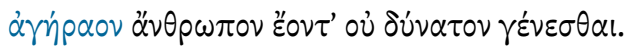

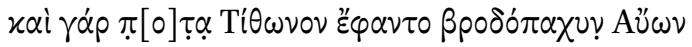

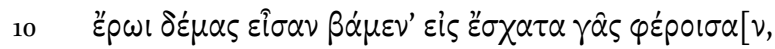

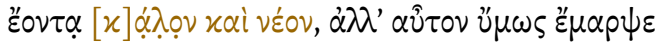

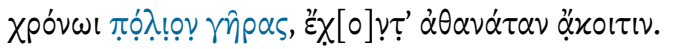

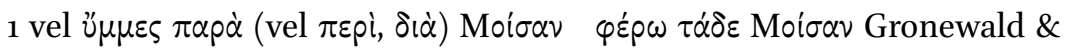

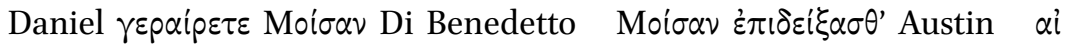

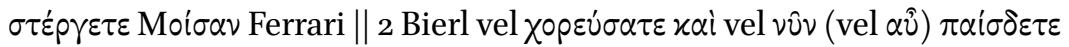

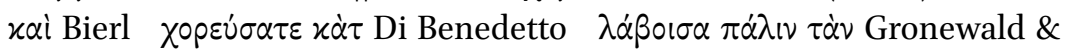

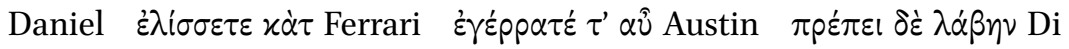

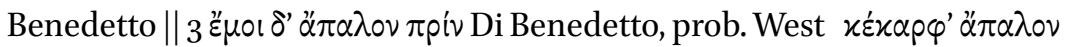
$\mu \circ i$ Gronewald \& Daniel $\| 4$ West $\delta \iota \omega \dot{\lambda} \varepsilon \sigma \varepsilon$ Di Benedetto || 7 Lundon $\| 10$

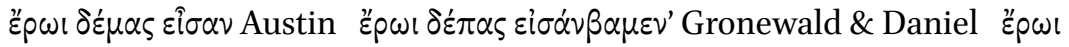

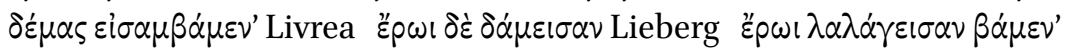

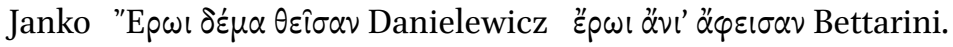

My translation of this passage is as follows:

You, girls, to the beautiful gifts of the violet-bosomed Muses, dance, and to the song-loving, light-toned lyre.

61 Di Benedetto (1985) 157. On Tithonus, cf. Mimnermus fr. 4 W. = 1 Gentili-Prato, lines 1-2.

62 Cf. also text by Gronewald and Daniel (2004a) 4-5, and Gronewald and Daniel (2007a) $4-5,7-8$. The color red highlights choral self-referentiality; the color green dance and choral self-referentiality; the color blue old age and its qualities; the color brown qualities of youth. 
Though old age has already overcome my body, once soft, white has become my hair from black.

Heavy has my heart become, my knees carry no more, which once were nimble to dance like deer.

Over this I sigh often. Yet what should I do?

Ageless as man one cannot become.

For it is said that once rosy-armed Eos,

to love her body surrendered, bore away Tithonus to the end of the earth,

when he was beautiful and young. But grey old age overtook him in time, though he had an immortal wife.

\section{The End of the 'Old Age Poem' (в)}

An abrupt ending, such as we find in the Cologne papyrus, can readily be appreciated from a more modern, or even a Hellenistic, perspective. However, the four-line coda (B.1-4) would certainly have stood within its original context. In the primary didactic intention the return to the 'here and now' - the function of the poem within the circle of girls-assumes considerable importance. ${ }^{63}$ We may consider my exposition of frr. 16 and 31 v. ${ }^{64}$ In $P$. Oxy. 1787 , fr. 1.22-25 and fr. 2.1, the original ending is still preserved. The last two lines of the coda (= fr. $58.23-26 \mathrm{v}$.) were already familiar in the indirect tradition preserved by Clearchus (in Athenaeus 15.687b). The much-discussed question of whether critical indications can clarify whether these lines belong to poem $\mathrm{T}$ remains open. ${ }^{65}$ The single available piece of evidence is their content. I cite the four lines:

63 Cf. also Edmunds (2006) and (2009).

64 Cf. Bierl (2003) 120-122.

65 The left margin of $P . O x y .1787$, fr. 1 is lost, but for fr. 2, partially preserved. Here, there are traces of two paragraphoi after line 1 (= fr. 58.26 v.) and line 3 (= fr. 59.2 v.). There are no paleographical remains of a coronis. Lobel (1925) 26 introduces one; Lobel and Page $\left(1963^{2}\right) 42$ place it in brackets (as a reconstructed lacuna); in Voigt (1971) 78 it appears again without brackets. Cf. Burzacchini (2007) 102-104, who concludes correctly that, in view of the condition of the material, the question remains open (104). West (2005) 3-4 justifies the separation of the coda on the grounds that there is no coronis - admittedly, the left margin of fr. 2 of $P$. $O x y .1787$ is so damaged that no certain interpretation is possibleand joins the verses to fr. 59 v. (= P. Oxy. 1787, fr. $2.2-4)$, thus forming a longer, but still fragmentary, poem (7-9). He is followed by Austin (2007) 120. 

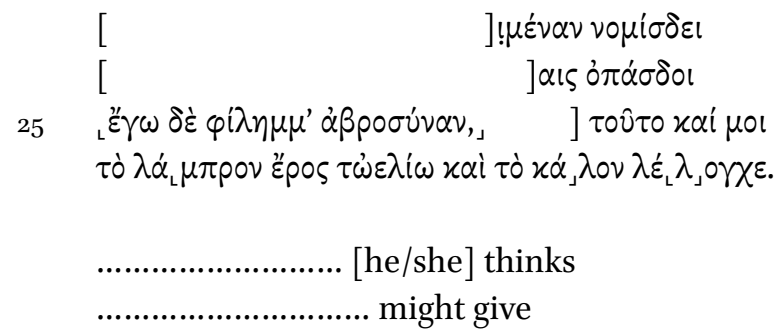

but I love delicacy ... [this and] love has obtained for me the brightness and beauty of the sun.

as translated by Campbell; or, the last two lines in my translation,

But I love shining elegance, and you knew this, and love of the sun has allowed me to share in its radiance and beauty. ${ }^{66}$

The four lines thus make explicit for the girls and the audience that which can only be imagined in the case of an open, abrupt ending. Like the famous priamel in fr. 16 v., the concluding lines could almost stand as a motto for Sappho's entire poetic œuvre. ${ }^{67}$ Sappho, or the lyric 'I', says as chorus leader that she loves shining elegance. In $\alpha \beta p o \sigma o v \alpha$, the recollection of the radiant, oriental beloved is preserved, whether Phaon, Adonis, or Tithonus. ${ }^{68}$ In the original ending of the so-called 'old age poem', Sappho elucidates that she loves the beautiful from which radiance originates. In concrete terms, this means the girls. The chorus leader and the dancing maidens are reciprocally bound to one another, and each yearns for the other. Yet this passion is far removed from any direct sexual satisfaction. Sappho styles herself an old woman because she cannot and may not dance together with the girls as their equal. Of course she is older, but she is still captivated by the grace of the virginal, glowing bodies as they move in dance, from which a particular effect of grace and radiance

66 For a discussion of both possibilities, cf. Lardinois (2009) 43-44; Boedeker (2009) 72; Nagy (2009) 189-191, with a preference for 'love of the sun'. Cf. also Bierl (2008) ch. 5 n. 74; Buzzi et. al. (2008) 41-42, 120-121.

67 Thus also Schadewaldt (1950) 161; Preisshofen (1977) 61.

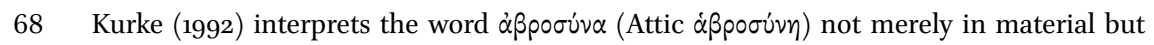
also in political terms, in the sense of an aristocratic oriental luxury; on our passage, 9399. Maehler's definition ([1963] 61) is comprehensive: 'Die Gesamtheit der Werte, die sie in der Gemeinschaft mit ihren Mädchen pflegte'. On پ̈ßpos, Sappho frr. 2.14 (Aphrodite), 128 (Charites), 44.7 (Andromache as bride), 140.1 (Adonis), 100 v. (cloth). Cf. also Buzzi et al. (2008) 126 n. 64 . 
proceeds. While Sappho sings enchantingly and accompanies herself on the lyre, the girls dance in graceful movement. The entire scene is pure aesthetics, perfect beauty. In a reperformance the speaker would have experienced this in the same manner. Finally, we come to the curious sentence to the effect that love of, that is, desire for the sun has won for her its brilliance and beauty. In her yearning for the highest beauty, concretized in the sun-here she almost anticipates Plato-she receives a share of it. Eos also acquired her radiance from the permanent devotion to the sun.

The solar dimension of the myth of Eos and Aphrodite, who both take oriental lovers, now becomes more apparent. This love can never really be fulfilled: one leaps after the 'luminous' in longing and erotic ecstasy in the realm of passion and fantasies. Sappho's poetics conceives this desire for the absent one, whom one can never win, as an eternal postponement. In Sappho's fr. 1.21 v., pursuit and flight are pinpointed: 'And if she flees, she will soon pursue'. Within her circle, she chases and longs for the bodies of the girls. Through her desire for the physical, she achieves aesthetic satisfaction, just as the girls do in their relationship to her. ${ }^{69}$ And on the famous picture of the Vulci oinokhoe discussed above, Sappho's model Eos, to whom she refers in poem T, is depicted precisely in the same posture of following after Tithonus, her object of erotic yearning.

Every girl who sings Sappho's songs can identify with this motto, and through the emphasis on artistic perfection and synaesthetic harmony, each enjoys participation in it like Sappho. Beauty has an effect in turn on the girls' radiance and sex appeal, which are necessary for marriage in an aristocratic oikos. And the sentence bears a potential to be transferred to male recipients in new contexts as well.

Last but not least, Sappho seems to evoke a mystical notion in the image of the sun. In the afterlife, one gazes at the radiant light, takes delight in blessed choruses, and lives on. Here, as in the context of the mysteries, there is a cosmic dimension. Does Sappho perhaps display evidence of early Orphic experiences, which came to the Greeks in this period from Asia Minor via Lesbos? ${ }^{70}$ On the

69 On this poetics, cf. Yatromanolakis' interpretation of the red-figure kalyx bowl of the Tithonus painter, 480-470 вС (Bochum, Ruhr-Universität, Kunstsammlungen, Inv. s 508), where on one side Sappho with a garment pursues a girl (with the inscription HE ПAI $\Sigma$ ). Cf. Yatromanolakis (2001), (2005), (2007) 88-110. On the Cologne Sappho, cf. Yatromanolakis (2007) 203-205, 360 n. 341. Cf. also Nagy (2007) 233-265, (2009) 183-195.

70 I distance myself here decidedly from Böhme (1970) esp. 143-163 (with numerous, definitely imaginative examples of motifs): e.g. he associates (148) fr. 58 with the imagery of

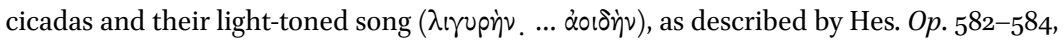


Orphic-Bacchic gold leaves, light, radiance, Helios, the stars, and the heavens are often mentioned. ${ }^{71}$ In mythology, Orpheus is himself often closely associated with Helios. The sun, the moon, and night assume a significant role in both Sappho's poetry and in Orphism, an importance which is now confirmed by the Derveni papyrus. In the hermeneutics of a possibly reform-oriented Orphic devotee, the sun is the central principle. ${ }^{72}$ There it is placed on an equal footing with Uranus' phallus, which Zeus swallowed (col. 13;16.1 K.-P.-T.). The sun is the highest principle (col. 13.12 K.-P.-T.). The explicit erotic statement of love of the sun in Sappho could be explained by such a context. Similarly, Phaon, the embodiment of the shining sun, is associated with Sappho's fascination with the phallus (Sappho fr. 211c v.). ${ }^{73}$ In the Derveni papyrus, Helios is the principle of life, ${ }^{74}$ the giver of life as encapsulated fire, which lends movement and stimulation. Precisely in the obscure gold leaf Thurii 2, 492 Bernabé, Helios and fire also stand at the center of the cosmic interchange (line 4), the reciprocal exchange of opposites, in a manner similar to the account of Heraclitus, who is in turn cited in the Derveni papyrus (col. 4 K.-P.-T.) and who is often associated with Orphic ideas. ${ }^{75}$ The sight of the sun means simply life (Sappho frr. $5^{6}$ and

with $\lambda$ r $v \rho \alpha \dot{\alpha} \nu \chi \varepsilon \lambda u ́ v v \alpha \nu$ (T.2). Turyn (1942) esp. 313-318 had already associated Sappho with Orphism, and combined the description of the locus amoenus on the Florentine ostracon, Sappho fr. 2 V., with notions of paradise in Orphic eschatology, which in his opinion

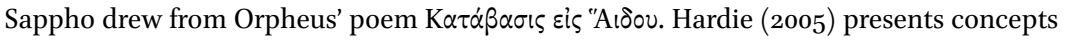
derived from Orphism similar to those offered here.

71 Cf. the leaf from Petelia, ca. 35 в вс, 476 Bernabé, lines 6-7: 'A child of the earth am I and of the starry heavens / but I have a divine descent ...'; cf. similarly the Thessalian lamella of unknown provenance 484 Bernabé, lines 3-4, and the leaf from Pharsalos 477 Bernabé, lines $8-9$ (where the second part is replaced by 'my name is "star-like"', Asterios). On the first part, cf. the lamellae from Rethymnon 484a Bernabé, line 3; from Mylopotamos 481 Bernabé, line 3; from Eleutherna 478, 479, 48o, 482, 483 Bernabé, line 3; and from Hipponion 474 Bernabé, line 10.

72 Cf. e.g. Most (1997); West (1997); Tsantsanoglou (1997) 98-99, 117; Betegh (2004) esp. 349372. Cf. Bierl (2014).

73 Fr. 211C V. = Pliny $H N 22.20$ (on sea holly, Eryngium maritimum): portentosum est quod de ea (sc. erynge) traditur, radicem eius alterutrius sexus similitudinem referre, raro inventu, sed si viris contigerit mas, amabilis fieri; ob hoc et Phaonem Lesbium dilectum a Sappho. According to this story, Phaon became particularly attractive sexually because he found a root of sea holly which resembled the phallus, and thus Sappho fell so deeply in love with him.

74 On the notion of the vision of the sun as the expression of life, cf. Hom. Il. 24.558 and Sappho fr. 56 v. The indirect source of Clearchus (fr. 41 Wehrli), preserved by Athenaeus $15.687 \mathrm{~b}$, where the quotation occurs, has as explanation of 'love of the sun' $\dot{\eta} \tau 0 \hat{v} \zeta \hat{\eta} \nu$ غ่ $\pi \imath u \mu i \alpha$.

For more Orphic parallels, cf. Bierl (2008) ch. 5 . 
$65 \mathrm{~V}$.; Iliad 24.558), to which the highest significance is ascribed, as in the relevant passage of our poem. Likewise, in view of the epithets denoting radiance, Eos assumes an important role in the extant fragments of Sappho (frr. 6, 103, 104a, 123, 157, 175 V.).

The last four lines, extant only in $P . O x y \cdot 1787$, thus lend depth to this assertion. The context, however, does not necessarily have to do with consolation or with a farewell to youth and beauty, themes conventionally read into many of Sappho's fragments. ${ }^{76}$ Rather, these verses expand the statement to a philosophical and aesthetic level. Love of the sun and devotion to radiance imply a poetics both of loss and of deferral. It is never possible to possess the beloved entirely for oneself; one can only aspire to this. Sappho's song is completely indebted to the poetics of Eros, the eternal discourse of Barthesian absence. ${ }^{77}$ In the pursuit of the erotic object and the sun, she herself obtains through her erotic Muse a share in beauty and radiance, by means of which she is continuously renewed and rejuvenated. With the help of the Muses and what is beautiful, death and old age can be overcome.

\section{Orpheus and the New Section (o) of an Anonymous Lyric Poem}

The section that is included in view of its thematic association, but which is certainly not to be ascribed to Sappho, remains something of a riddle in its fragmentary condition.

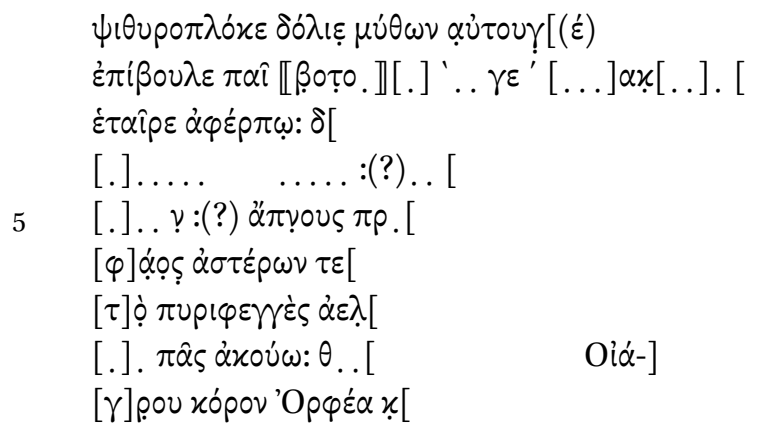

$7_{6}$ Cf. Lardinois (2009) 51-53; he situates the song in the context of the wedding, where Sappho playfully contrasts herself with the youthful bloom of the bride and the groom. At the same time, it perhaps contains a warning for the happy pair, that they, too, will one day become old. 
[. . ]. $\tau \dot{\alpha} \nu \dot{\varepsilon} \rho \alpha \tau \dot{\alpha} \nu \lambda \alpha[$

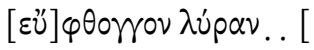

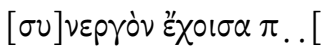

Chirping-whispering, slander-weaving, sly, inventor of stories

malicious boy ...

friend, I am going away/crawl away

$5 \mathrm{dead} /$ breathless

light of the stars and

[the radiance], the fire-glowing, the sun

completely I hear. ... Oia-

gros' son Orpheus [bewitching

10

all the animals [and stones]

the enchanting [taken up with hands

the fine-sounding lyre

as a help having [completely ${ }^{78}$

The first editors, Gronewald and Daniel, regarded the text as belonging to the 'erotic theme', particularly given the allusion to Sappho's fr. 1 and to Eros at the beginning. ${ }^{79}$ Rawles, on the other hand, related the text to Hermes because of the epithets, ${ }^{80}$ and thus to music and life after death, although these two motifs also constitute an association with Sappho's songs. I consider all of these three subjects, which also characterize Sappho, to be present: love, self-referential poetic reflection with regard to music, and notions of life after death. The presence of these motifs supports the thesis of an anthology that might have been composed for reperformance in symposia or for recital on other occasions. Love and lamentations, reflections about music, and general questions about life, old age, death, and the afterlife are certainly prominent themes here, and when such songs were removed from their original context, they could have been arranged as extracts according to these themes. ${ }^{81}$

78 Text (= P. Köln col. II.9-21) following Gronewald and Daniel (2005) 9 and (2007b) 15-16. On the fragment, cf. also Rawles (2006b); Lundon (2007) esp. 154-166; Puglia (2008); Clayman (2009).

79 Gronewald and Daniel (2005) 8.

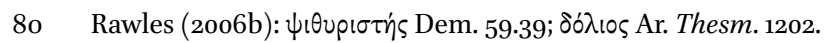

81 We can only speculate about other possible occasions in which they may have been performed, for example, at informal gatherings, or those of intellectuals or Orphic initiates. In 
Gronewald and Daniel structure the anonymous poem as follows: ${ }^{22}$ a long address to a 'youth' and 'friend' (1-3), a part which speaks of the 'light of the stars' and 'the fire-glowing ... sun' (6-7), after which Orpheus is mentioned (9), to which is added a reference to a woman who plays her lyre as well as Orpheus did (11-13). The first editors emphasize that these lines connect smoothly with the end of A1.10-11 (CS col. i.10-11) and the prelude of T.1-2 (CS col. i.12-13). Orpheus matches the motifs and mental images in $\mathrm{T}$ very closely. He is the mythical musician who crossed the threshold of death, and with his singing even mesmerized the underworld in order to win back his beloved. Yet, in spite of his legendary musical skill, he is doomed to fail, as the conditio humana and the poetics of eros oppose any possibility of success. Following his brutal death by mutilation, his head, borne on the waves to Lesbos, sings on. The principles of selection and arrangement of this collection thus consist in self-referential reflection of the singer and lyre player, the overcoming of death, erotic pursuit, magical bewitching, the endless deferral of the unattainable object of desire, sublimation in the continuation of the personal lament through music even beyond one's own death, and especially the Lesbian musical tradition.

Gronewald and Daniel suspected a 'change of speaker or singer' on the basis of the two obvious dicola after $\dot{\alpha} \varphi \dot{\varepsilon} p \pi \omega$ (3) and $\dot{\alpha} \times v^{\prime} \omega$ (8); two more in lines 4 and 5 are much less certain. In their opinion, there would have been both a woman and a man, perhaps Sappho and Phaon, or Sappho and Alcaeus (cf. Sappho fr. 137 v.), as in a theatrical dialogue. ${ }^{83}$ Perhaps Sappho was also performed dramatically like Homer. The woman reproaches the man and is about to leave, whereupon the man responds with an oath 'by the sun (, moon,) and stars' and insists that he wants to listen. The woman then begins her song, like Orpheus. Gronewald and Daniel are nonetheless aware of the dicolon's ambiguity and note that it could equally well have been used merely as punctuation, as in the mimetic poem 'The Girl's Lament' (P. Grenf. I $1=$ P. Lond. Lit. $5^{0}=$ P. Dryton ${ }^{50)} .{ }^{84}$ It is therefore possible to interpret the song as a female solo, while $\pi \hat{\alpha} \varsigma$, as the only male form which might appear to contradict this view, can also be construed as $\pi \hat{\alpha} \sigma$. The Fragmentum Grenfellianum is also relevant in view of its contents, as Gronewald and Daniel recognized. The parallels

view of the non-definitive form of the text (casual hand, corrections and improvements), Lundon (2007) 16o and Puglia (2008) 16-17 regard it as an early poetic attempt on a still blank part of the papyrus.

82 Gronewald and Daniel (2005) 8 .

83 Gronewald and Daniel (2005) 8 with n. 5 .

$84 \quad C A$ 177-180 Powell. A new critical edition by Elena Esposito has appeared, which refers to this fragment: Esposito (2005) 11, 61, 101, 105, 111, 123. 
considered by Lundon and Puglia are even more striking. ${ }^{85}$ The monologue of an abandoned woman who addresses herself characterizes both texts. Lundon adds as a further parallel the monody from $P$. Tebt. I 1, in which Helen, left alone by Menelaus, compares the happy past to the present in a long lament. ${ }^{86}$

Rawles views the two responses, emphasized through the dicola in lines 3 and 8, less literally and only as 'verbal markers' of a change of speaker, in the sense of 'your turn,' so that one speaker follows the other antiphonally. ${ }^{87}$ In his opinion, the song of the two musicians presents the mythical history of the lyre from its invention by Hermes to Apollo and Orpheus.

Let us consider the various suggested solutions, of which I prefer the interpretation as a monody by a girl.

A female singer or speaker invokes Eros or Hermes (1-2) in the form of a prelude. Rawles takes the crossed-out $\beta$ oto (2, grazing animals, with reference to the Homeric Hymn to Hermes) as supporting his argument in favor of Hermes. ${ }^{88}$ The female speaker sings a continuous, monodic lament. With $\pi \alpha \hat{\imath}(2)$ she emphatically addresses a beloved person. The vocative also establishes a connection with paides in T.1 = Cs 9. The speaker perhaps despairs that he is

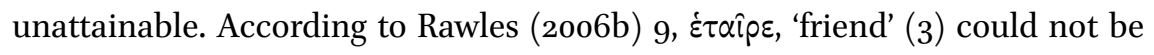
identical with the addressee of $\pi \alpha \hat{\imath}(1-2)$, but must rather address the fellow performer: for example, 'Now it's your turn, friend, I am going off stage'. Another alternative would be to take all the vocatives as the addressee of the abandoned lover, who is well-skilled in the arts of love in composing flatteries and inventing lies. ${ }^{89}$

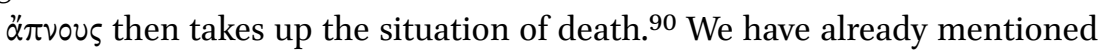
the sun, the moon, and the stars. However, as Gronewald and Daniel also note,

85 Lundon (2007) 162-163; Puglia (2008).

86 Puglia (2008) also accepts this possibility and attempts a purely monodic reconstruction.

$87 \quad$ Rawles (2006b) 9 .

88 Rawles (2006b) 10

89 Thus also Puglia (2008) 13. Boto might also be an allusion to the comparison of young girls

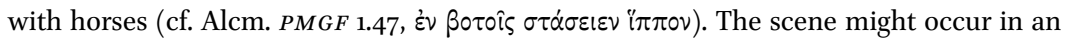
idyllic grove as in Sappho fr. 2 v., where animals and particularly horses graze (cf. $\lambda$ zí $\mu \omega \nu$ $i \pi \pi \dot{\beta} \beta 0 \tau \circ \varsigma)$. The scribe may have omitted something, written only $\beta \circ \tau o$ mechanically and then seen his mistake, or did he intend to write, for example, $\beta$ poto in the sense of $\dot{\varepsilon} v$

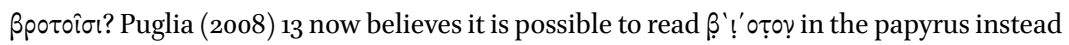

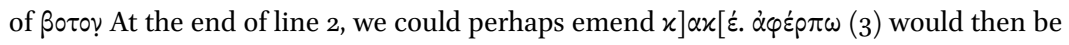

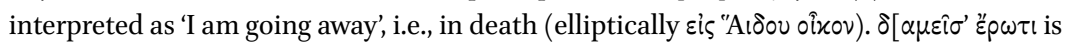
perhaps to be emended.

90 Cf. Leonidas, Anth. Pal. 7.652.6; Dioscurides, Anth. Pal. 7.299.1; further references in Gronewald and Daniel (2005) 11. 
this is not merely an oath on the planets but also a reference to the life that one is forsaking. ${ }^{91}$ In place of a connection with the object, a new sentence might begin here along the following lines: 'I love the light of the stars and the moon

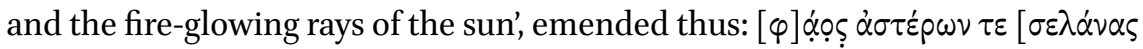

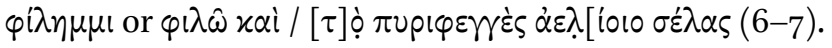

'I am listening completely' (8) is translated by Gronewald and Daniel as 'I am all ears', while Rawles once more takes it as a bridge to the next singer. ${ }^{92}$ In scriptio continua, $\pi \hat{\alpha} \varsigma$ must be understood as $\pi \hat{\alpha} \sigma$. The lamenting girl would then, listening in her totality, be referring to something. The question then arises as to what the object of this action is. Is it "you" (informal), that is, a conversation partner, or Eros, or perhaps Hermes, who gives her instructions or sings himself? Or does it refer to the aforementioned cosmic, visual phenomena, which in a way sound a harmony of the spheres? Puglia wants to employ $\alpha$ $\left.\alpha \alpha^{\prime} i \tau 10\right] \varsigma \pi \hat{\alpha} \sigma^{\prime}$ here and considers as possible objects in the situation of abandonment such

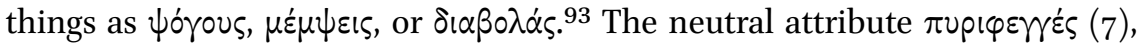
attested only in Orphic and magical literature, would effectively indicate the magical 'transition to Orpheus' ${ }^{94}$ and mark the passage from the act of seeing the radiant heavenly manifestations to that of hearing. The singer again turns to the cosmos, like Sappho in T and B.1-4, and focuses on the radiant and aesthetically beautiful. With the dicolon, as in line 3 , the asyndetically added sudden reaction is once more emphasized: 'the Thracian youth Orpheus, Oiagros' son, imitating ${ }^{95}$... who with his song mesmerizes ${ }^{96}$ all the animals (and stones) (xai $\lambda\left(\theta_{0}\right.$ ऽ), I take the sweet, fine-sounding lyre in my hands ( $\lambda \dot{\alpha}[\beta \circ \sigma \alpha \chi \varepsilon \rho \sigma i)$, and have it completely as my helper. ${ }^{\prime 7}$

91 Gronewald and Daniel (2005) 11, (2007b) 18. With reference to Praxilla $P M G$ 747.1-2

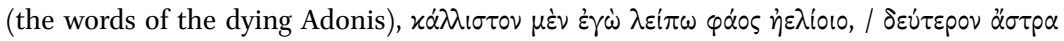

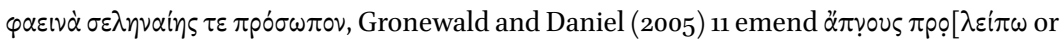
$\pi \rho \circ[\lambda i \pi \circ \mu u$. As Adonis is speaking here, the references to the cosmos have a deeper significance than a mere poetic euphemism for death. It would be possible to take $\pi \rho 0[\lambda \varepsilon i \pi \omega$ here as absolute, or to emend with $\pi \rho \circ[\lambda \varepsilon i \pi \omega$ ßíov, 'I am dying'. Puglia (2008) 15 reports that Ferrari considered here the emendation $\pi \rho \grave{̣}[\theta \nu p \omega \hat{~ \varepsilon ี \sigma \tau \eta \varkappa \alpha . ~}$

92 Gronewald and Daniel (2005) 9; Rawles (2006b) 9.

93 Puglia (2008) 14.

94 Gronewald and Daniel (2005) 11.

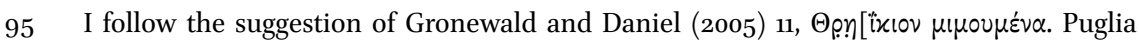

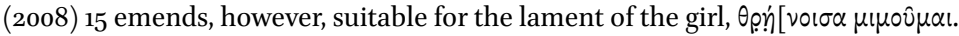

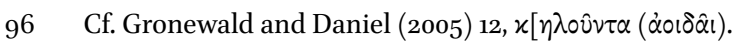

97 Puglia (2008) 15 prefers to take $\dot{\varepsilon} p \alpha \tau \dot{\alpha} \nu$ as referring not to the lyre but to Eurydice (see below

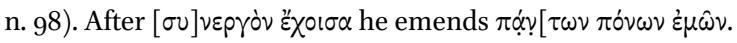


The poetics of the Hellenistic song captures the visual in a rather different manner compared to Sappho. Whereas the archaic poetess builds her pedagogical utterances on evident and iconic scenes, which are based on common imagery as well as cultural patterns and concepts-I mean the playing of the lyre in the underworld, the accompaniment of blessed choruses, physical decay on the foil of young maidens engaged in chorality, and the cycle of the sun as hope for rejuvenation - the Hellenistic poem focuses on the real experience of extenuating love and on a concrete image of Orpheus who enchants nature and thus provides hope for the afterlife. Moreover, the last poem is rather dramatic, as dialogue or melodramatic expression of lament by a single person. All cosmic images and the myth of Orpheus seem to be deployed in a specific narrative context which because of the fragmentary status of the lines is almost impossible to reconstruct, and not, like in Sappho's previous songs, in function of a didactic message to be conveyed in the lyric situation of reflection and persuasion.

\section{Conclusion}

Like Orpheus, who as singer and lyre player par excellence in the underworld and on earth bewitches everything with his song, so the girl who embodies Sappho as singer in the Hellenistic reperformance sings and captivates us, perhaps even as she enchants Eros or the beloved youth. Yet even so, through her song she will never obtain the object of her desire; rather, love finds its expression only in the form of a lament. Eros is needed in order to inspire others to dance or to charm them through the musical performance. The singer is dead, or at least feels herself to be, yet continues to sing of love, just as Orpheus and Sappho did. Death can be associated in turn with old age. Through song and her focus on the cosmos, she will again become young.

The mention of Orpheus lends additional confirmation to the metapoetic and self-referential reading of Sappho's new poem T. The girl in o almost becomes a Muse, who in a context of cosmic choral performance attains immortality in harmony with the planets, and much the same occurs with Sappho. Death, night, lament, love, song, music, and the cosmos-in short, all that Orphism represents-are the decisive themes that unite the fragments. ${ }^{98}$

98 Di Benedetto (2005) 12-13 assumes that the story of Eurydice is mentioned in A2, the section preceding $\mathrm{T}$ in fr. $P$. Oxy. 1787 , of which little is extant. Admittedly, we can only 
Orpheus embraces in his cosmogonies above all the construction of harmony, resolution of conflict, and a balancing of opposites. On the other hand, lamentation and loss are prominent in the erotic poetics.

The deferral of love becomes its own song in the interruption and continuation of a reperformance. It is only in the anthological combination that a unity occurs which makes Eros dependent upon the artistic production of song. Even the interest in a further existence in the afterlife, which is usually the object of the mystery cults, is associated with the projection of the continued performance of music in the afterlife. The original pedagogical-didactic reception gives way to secondary receptions, determined by changing occasions of reperformance. In the fourth century $\mathrm{BC}$ the new performative practice even showcases a Hellenistic cult of poets and metapoetic self-consciousness. Cyclic rejuvenation and the erotic poetics of desire and absence are more constitutive than ever. Through their deep visualizing power Sappho's songs have lived on indeed, even until they have reached us today.

We have seen that Sappho builds her poetic discourse in the Cologne Papyrus on very specific cultural and visual patterns which, through mental imagery, help to shape cognitive reception, particularly in oral performance contexts. Sappho draws on images and concepts of chorality and mythic dancing in a solar context. As cultural symbols they are in service to highlight the unifying themes of beauty, poetic and musical self-referentiality, and rejuvenation.

\section{Works Cited}

Alexiou, M. (2002). After Antiquity. Greek Language, Myth, and Metaphor. Ithaca.

Austin, C. (2007). 'Nuits chaudes à Lesbos: Buvons avec Alcée, aimons avec Sappho' in Bastianini and Casanova (eds) (2007): 115-126.

Barthes, R. (1979). A Lover's Discourse. Fragments (transl. R. Howard). London.

Bastianini, G. and Casanova, A. (eds) (2007). I papiri di Saffo e di Alceo. Atti del convegno internazionale di studi, Firenze, 8-9 giugno 20o6. Studi e Testi di Papirologia N.s. 9. Florence.

Battezzato, L. (2003). 'Song, performance, and text in the new Posidippus'. ZPE 145: 3143.

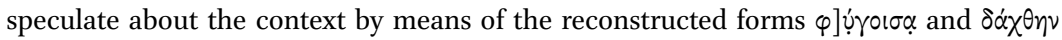
(fr. $5^{8.5}-6$ v.). He also perceives in the few letters of fr. 58.7 v. a reference to Orpheus' mother Calliope, $[\mathrm{K}] \alpha \lambda \lambda[$ เó $\pi \alpha$. 
Bernsdorff, H. (2004). 'Schwermut des Alters im neuen Kölner Sappho-Papyrus'. ZPE 150: 27-35.

\section{- (2005). 'Offene Gedichtschlüsse'. ZPE 153:1-6.}

Betegh, G. (2004). The Derveni Papyrus. Cosmology, Theology and Interpretation. Cambridge.

Bierl, A. (2001). Der Chor in der Alten Komödie. Ritual und Performativität (unter besonderer Berücksichtigung von Aristophanes' Thesmophoriazusen und der Phalloslieder fr. 851 PMG). Munich. Revised English edition = Bierl (2009).

- (2003). “'Ich aber (sage), das Schönste ist, was einer liebt!" Eine pragmatische Deutung von Sappho Fr. 16 LP/V.. QUCC 103: 91-124.

- (2008). 'Der neue Sappho-Papyrus aus Köln und Sapphos Erneuerung. Virtuelle Choralität, Eros, Tod, Orpheus und Musik', electronic publication on the CHS website http://chs.harvard.edu/CHS/article/display/2122.

(2009). Ritual and Performativity. The Chorus in Old Comedy (transl. A. Hollmann). Cambridge, MA.

(2010). 'Sappho in Athens. Reperformance and performative contextualizations of the new Cologne papyrus, or old age and rejuvenation through chorality', electronic publication on the Athens Dialogues-website http://athensdialogues.chs .harvard.edu/cgi-bin/WebObjects/athensdialogues.woa/wa/dist?dis=36.

(2014). " "Riddles over riddles:" Mysterious and symbolic (inter)textual strategies' in I. Papadopoulou and L. Muellner (eds), Poetry as Initiation. The Center for Hellenic Studies Symposium on the Derveni Papyrus. Cambridge, MA and London: 187-210, electronic version on the CHS website http://chs.harvard.edu/CHS/article/ display/5694.

Boedeker, D. (forthcoming). 'Sappho old and new (P.Köln 21351 and 21376, and P.Oxy. 1787): An overview of texts and contexts' in A. Pierris (ed.), Symposium Lesbium: Poetry, Wisdom and Politics in Archaic Lesbos: Alcaeus, Sappho, Pittacus. Oxford.

(2009). 'No way out? Aging in the new (and old) Sappho' in Greene and Skinner (eds) (2009): 71-83.

Boehringer, S. (2013). “Je suis Tithon, je suis Aurore”: performance et érotisme dans le 'nouveau' fr. $5^{8}$ de Sappho'. QUCC 133: 23-44.

Böhme, R. (1970). Orpheus. Der Sänger und seine Zeit. Bern.

Bühler, K. (1934). Sprachtheorie. Die Darstellungsfunktion der Sprache. Jena.

Burzacchini, G. (2007). 'Saffo Frr. 1, 2, 58 v. Tra documentazione papiracea e tradizione indiretta' in Bastianini and Casanova (eds) (2007): 83-114.

Buzzi, S. et al. (2008). Nuove acquisizioni di Saffo e della lirica greca. Per il testo di P. Köln inv. $21351+21376$ e P. Oxy. 1787 (ed. A. Aloni). Alessandria.

Calame, C. (1977). Les chœurs de jeunes filles en Grèce archä̈que, I: Morphologie, fonction religieuse et sociale. II: Alcman. Rome. Revised English edition of vol. I = Calame (1997). 
- (1997). Choruses of Young Women in Ancient Greece: Their Morphology, Religious Role, and Social Function (transl. D. Collins and J. Orion). Lanham, MD.

— (1998). 'Éros revisité: La subjectivité discursive dans quelques poèmes grecs'. Uranie 8 (= Figures d'Éros): 95-107.

- (2013). 'La poésie de Sappho aux prises avec le genre: polyphonie, pragmatique et rituel (à propos du fr. 58b)'. QUCC 133: 45-67.

Clayman, D. (2009). 'The New Sappho in a Hellenistic poetry book' in Greene and Skinner (eds) (2009): 131-146.

Denis, M. (1991). Image and Cognition. New York.

Di Benedetto, V. (1985). 'Il tema della vecchiaia e il fr. $5^{8}$ di Saffo'. QUCC 48: 145-163.

- (2004). 'Osservazioni sul nuovo papiro di Saffo'. ZPE 149: 5-6.

- (2005). 'La nuova Saffo e dintorni'. ZPE 153: 7-20.

- (2006). 'Il tetrastico di Saffo e tre postille'. ZPE 155: $5^{-18 .}$

duBois, P. (1995). Sappho Is Burning. Chicago.

Edmunds, L. (2006). 'The New Sappho: EФANTO (9)'. ZPE 156: 23-26.

(2009). "Tithonus in the "New Sappho" and the narrated mythical exemplum in archaic Greek poetry' in Greene and Skinner (eds) (2009): 58-70.

Esposito, E. (2005). Il Fragmentum Grenfellianum (P. Dryton 5o). Bologna.

Falkner, T.M. (1995). The Poetics of Old Age in Greek Epic, Lyric, and Tragedy. Norman, OK.

Fernandez,J.W.(ed.) (1986). Persuasions and Performances. The Play of Tropes in Culture. Bloomington.

(1991). Beyond Metaphor. The Theory of Tropes in Anthropology. Stanford.

Ferrari, F. (2010). Sappho's Gift. The Poet and Her Community (transl. B. Acosta-Hughes and L. Prauscello). Ann Arbor.

Ferrari, G. (2002). Figures of Speech. Men and Maidens in Ancient Greece. Chicago.

Finke, R.A. (1989). Principles of Mental Imagery. Cambridge, MA.

Foley, J.M. (1999). Homer's Traditional Art. University Park, PA.

Gallavotti, C. $\left(1962^{3}\right)$. Saffo e Alceo: Testimonianze e frammenti, I: Saffo. Naples.

Geissler, C. (2005). 'Der Tithonosmythos bei Sappho und Kallimachos. Zu Sappho fr. 58 v., 11-22 und Kallimachos, Aitia fr. 1 Pf.. GFA 8: 105-114.

Gentili, B. (1984). Poesia e pubblico nella Grecia antica da Omero al $v$ secolo. Rome. English edition $=$ Gentili (1988).

- (1988). Poetry and Its Public in Ancient Greece. From Homer to the Fifth Century (transl. A.T. Cole). Baltimore.

- (2006a). Lo spettacolo nel mondo antico. Teatro greco e teatro romano arcaico. New revised ed. Rome.

- (2006b). Poesia e pubblico nella Grecia antica da Omero al v secolo. New revised fourth ed. Rome.

Gentili, B. and C. Catenacci. (2007). 'Saffo "politicamente corretta"'. QUCC 115: 79-87. 
Gosetti-Murrayjohn, A. (2006). 'Sappho as the tenth Muse in Hellenistic epigram'. Arethusa 39: 21-45.

Greene, E. (ed.). (1996). Reading Sappho. Contemporary Approaches. Berkeley.

Greene, E. (2009). 'Sappho 58. Philosophical reflections on death and aging' in Greene and Skinner (eds) (2009): 147-161.

Greene, E. and M.B. Skinner (eds) (2009). The New Sappho on Old Age: Textual and Philosophical Issues. Hellenic Studies 38. Washington, DC.

Gronewald, M. and R.W. Daniel (2004a). 'Ein neuer Sappho-Papyrus'. ZPE 147: 1-8.

- (2004b). 'Nachtrag zum neuen Sappho-Papyrus'. ZPE 149: 1-4.

- (2005). 'Lyrischer Text (Sappho-Papyrus)'. ZPE 154: 7-12.

- (2007a). ‘Griechische Literarische Texte: 429. Sappho' in C. Armoni et al. (eds), Kölner Papyri (P. Köln) XI. Papyrologica Coloniensia VII. Paderborn: 1-11.

- (2007b). ‘430. Lyrischer Text (Sappho-Papyrus)' in C. Armoni et al. (eds), Kölner Papyri (P. Köln) XI. Papyrologica Coloniensia VıI. Paderborn: 12-19.

Hamm, E.-M. (1957). Grammatik zu Sappho und Alkaios. Berlin.

Hardie, A. (2004). 'Muses and mysteries' in P. Murray and P. Wilson (eds), Music and the Muses. The Culture of "Mousikê" in the Classical Athenian City. Oxford: 11-37.

- (2005). 'Sappho, the Muses, and life after death'. ZPE 154: 13-32.

Hölscher, U. (1965). 'Selbstgespräch' in Die Chance des Unbehagens. Zur Situation der klassischen Studien. Göttingen: 53-86.

Ingalls, W.B. (2000). 'Ritual performance as training for daughters in archaic Greece'. Phoenix 54: 1-20.

Iser, W. (1976). Der Akt des Lesens. Theorie ästhetischer Wirkung. Munich.

Janko, R. (2005). 'Sappho revisited'. TLs 5360 (23/12/2005): 19-20.

Kosslyn, S.M. et al. (2006). The Case for Mental Imagery. Oxford.

K.-P.-T. = T. Kouremenos, T., G.M. Parássoglou, and K. Tsantsanoglou (eds), The Derveni

Papyrus. Edited with Introduction and Commentary. Florence 2006.

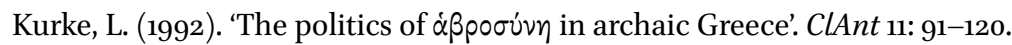

Lardinois, A. (1994). 'Subject and circumstance in Sappho's poetry'. TAPhA 124: 5784.

(1996). 'Who sang Sappho's songs?' in Greene (ed.) (1996):150-172.

- (2009). 'The new Sappho poem (P. Köln 21351 and 21376): Key to the old fragments' in Greene and Skinner (eds) (2009): 41-57.

Latacz, J. (2005). 'Veilchenbusige Geschenke'. Frankfurter Allgemeine Zeitung 168 (22/7/ 2005): 33 .

Lerchner, G. (200o). 'Kultursemiotische Aspekte textuell erzeugter ästhetischer Ikonizität' in U. Fix and H. Wellmann (eds), Bild im Text-Text und Bild. Heidelberg: 217-227.

Levaniouk, O. (1999). 'Penelope and the Pênelops' in M. Carlisle and O. Levaniouk (eds), Nine Essays on Homer. Lanham, MD: 95-136. 
Livrea, E. (2007). 'La vecchiaia su papiro: Saffo Simonide Callimaco Cercida' in Bastianini and Casanova (eds) (2007): 67-81.

Lobel, E. (1925). $\Sigma \alpha \pi \varphi \circ \hat{\varsigma} \varsigma \mu \dot{\varepsilon} \lambda \eta$. Oxford.

Lobel, E. and Page, D.L. $\left(1963^{2}\right)$. Poetarum Lesbiorum fragmenta. Oxford. (= L-P)

Lundon, J. (2007). 'Il nuovo testo lirico nel nuovo papiro di Saffo' in Bastianini and Casanova (eds) (2007): 149-166.

Luppe, W. (2004). 'Überlegungen zur Gedicht-Anordnung im neuen Sappho-Papyrus'. ZPE 149: 7-9.

Maehler, H. (1963). Die Auffassung des Dichterberufs im frühen Griechentum bis zur Zeit Pindars. Hypomnemata 3. Göttingen.

Magnani, M. (2005). 'Note alla nuova Saffo'. Eikasmos 16: 41-49.

Méndez Dosuna, J. (2008). 'Knees and fawns in the new Sappho'. Mnemosyne 61: 108-114.

Merkelbach, R. (1957). 'Sappho und ihr Kreis'. Philologus 101: 1-29. Repr. in W. Blümel et al. (eds), Hestia und Erigone. Vorträge und Aufsätze. Stuttgart (1996): 87-114.

Meyerhoff, D. (1984). Traditioneller Stoff und individuelle Gestaltung. Untersuchungen zu Alkaios und Sappho. Hildesheim.

Mitchell, L.G. (2007). Panhellenism and the Barbarian in Archaic and Classical Greece. Swansea.

Most, G.W. (1997). 'The fire next time. Cosmology, allegoresis, and salvation in the Derveni Papyrus'. JHS 117: 117-135.

Nagy, G. (1990). 'Phaethon, Sappho's Phaon, and the white rock of Leukas: "Reading" the symbols of Greek lyric' in Greek Mythology and Poetics. Ithaca, NY: 223-262.

(1996). Poetry as Performance. Homer and Beyond. Cambridge.

(2007). 'Did Sappho and Alcaeus ever meet? Symmetries of myth and ritual in performing the songs of ancient Lesbos' in A. Bierl, R. Lämmle, and K. Wesselmann (eds), Literatur und Religion, I: Wege zu einer mythisch-rituellen Poetik bei den Griechen. Berlin: 211-269.

_ (2009). "The "New Sappho" reconsidered in the light of the Athenian reception of Sappho' in Greene and Skinner (eds) (2009): 176-199.

Nussbaum, M.C. (1978). 'The role of phantasia in Aristotle's explanation of action' in Aristotle's De Motu Animalium: Text with Translation, Commentary, and Interpretative Essays. Princeton: 221-269.

Obbink, D. (2009). 'Sappho fragments $5{ }^{8-59}$. Text, apparatus criticus, and translation' in Greene and Skinner (eds) (2009): 7-16.

Parker, H.N. (1993). 'Sappho schoolmistress'. TAPhA 123: 309-351. Repr. in E. Greene (ed.), Re-Reading Sappho. Reception and Transmission. Berkeley (1996):146-183.

Pitotto, E. (2010-2011). 'Agoni, performance a staffetta e proemi: possibili trace in PKöln inv. 21351 + 21376'. Rudiae 22-23: II 625-658.

Preisshofen, F. (1977). Untersuchungen zur Darstellung des Greisenalters in der frühgriechischen Dichtung. Hermes Einzelschriften 34. Wiesbaden. 
Puelma, M. and F. Angiò. (2005). 'Sappho und Poseidippos: Nachtrag zum SonnenuhrEpigramm 52 A.-B. des Mailänder Papyrus'. ZPE 152: 13-15.

Puglia, E. (2007). 'Per la ricomposizione del quarto libro dei canti di Saffo (P. Oxy. 1787)'. SemRom 10.1: 17-39.

- (2008). 'Appunti sul nuovo testo lirico di Colonia'. ZPE 164: 11-18.

Radke, G. (2006). 'Junge Musen — alte Sappho' in K. Reichert (ed.), Radikalität des Alters. Prosa-Lyrik-Essay. Göttingen: 57-70.

Rawles, R. (2006a.) 'Notes on the interpretation of the "New Sappho"'. ZPE 157: 1-7. (2006b). 'Musical notes on the new anonymous lyric poem from Köln'. ZPE 157: 8-13.

Richardson, J.T.E. (1999). Mental Imagery. Hove.

Rösler, W. (1990). 'Realitätsbezug und Imagination in Sapphos Gedicht ФAINETAI MOI KHNO $\Sigma$ ' in W. Kullmann and M. Reichel (eds), Der Übergang von der Mündlichkeit zur Literatur bei den Griechen. Tübingen: 271-287.

Schadewaldt, W. (1950). Sappho. Welt und Dichtung, Dasein in der Liebe. Potsdam.

Stehle, E. (1997). Performance and Gender in Ancient Greece. Nondramatic Poetry in Its Setting. Princeton.

Steinrück, M. (2007). 'Sapphos Alterslied und kein Ende'. QUCC 115: 89-94.

Tsantsanoglou, K. (1997). 'The first columns of the Derveni Papyrus and their religious significance' in A. Laks and G.W. Most (eds), Studies on the Derveni Papyrus. Oxford: 93-128.

Tsomis, G. (2001). Zusammenschau der frühgriechischen monodischen Melik (Alkaios, Sappho, Anakreon). Stuttgart.

Turyn, A. (1942). 'The Sapphic ostracon'. TAPhA 73: 308-318.

Yatromanolakis, D. (1999). 'Alexandrian Sappho revisited'. HSPh 99: 179-195.

- (2001). 'Visualizing poetry: An early representation of Sappho'. CPh 96: 159168.

- (2005). 'Contrapuntal inscriptions'. ZPE 152: 16-30.

(2007). Sappho in the Making. The Early Reception. Cambridge, MA.

(2008). 'P. Colon. inv. $21351+21376$ and P.Oxy. 1787 fr. 1: Music, cultural politics,

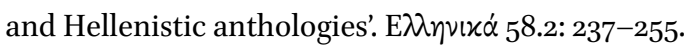

- (2009a). 'Symposia, noses, $\pi$ pó $\sigma \omega \pi \alpha$ : A kylix in the company of banqueters on the ground' in D. Yatromanolakis (ed.), An Archaeology of Representation: Ancient Greek Vase-Paintings and Contemporary Methodologies. Athens: 414-464.

- (2009b). 'Alcaeus and Sappho' in F. Budelmann (ed.), The Cambridge Companion to Greek Lyric. Cambridge: 204-226.

- (2009c). 'Ancient Greek popular song' in F. Budelmann (ed.), The Cambridge Companion to Greek Lyric. Cambridge: 263-276.

Voigt, E.-M. (1971). Sappho et Alcaeus: Fragmenta. Amsterdam. (= v.)

West, M.L. (1997). 'Hocus-pocus in East and West: Theogony, ritual, and the tradition of 
esoteric commentary' in A. Laks and G.W. Most (eds), Studies on the Derveni Papyrus. Oxford: 81-90.

- (2005). 'The New Sappho'. ZPE 151:1-9. (2007). 'Phasis and Aia'. $M H$ 64: 193-198.

Williamson, M. (1995). Sappho's Immortal Daughters. Cambridge, MA.

Wilson, L.H. (1996). Sappho's Sweetbitter Songs: Configurations of Female and Male in Ancient Greek Lyric. London.

Winkler, J. (1981). 'Gardens of nymphs: public and private in Sappho's lyrics' in H.P. Foley (ed.), Reflections of Women in Antiquity. New York: 63-90. Repr. in Greene (ed.) (1996): 89-109.

Zusanek, H. (2005). Eos. Untersuchungen zum dio-Begriff 3. Frankfurt a. M. 


\title{
Female Choruses and Gardens of Nymphs: Visualizing Chorality in Sappho*
}

\author{
Katerina Ladianou
}

In light of Romanticism, Sappho's poetry has been read as an expression of the poet's inner feelings. According to this model, Sappho is a soloist, performing her songs and playing her lyre in a private space, a small circle of same-sex companions. ${ }^{1}$ This idea went unchallenged until fairly recently, but the similarity of Sappho's songs to Alcman's Partheneia and the rise of performance studies - especially since the publication of Calame's groundbreaking book ${ }^{2}$ have cleared the way for discussions of Sappho's public persona and the possibility of choral, public performance. Although it is now acknowledged that at least some of Sappho's songs were probably meant to be performed chorally, nevertheless it is true that the extended fragments of Sappho provide us only with descriptions of choral activity, not explicit stage directions that would directly point to their performance.

Adding to this ongoing discussion, this chapter will first focus on the imagery and visualization of chorality. I will show how the visual blends with other senses in Sappho's fragments in an attempt to map out the synaesthetic quality of Sappho's poetry. In the second section of this paper, I will use later references to Sapphic poetry in an attempt to show that synaesthesia was considered

* I would like to thank R. Martin, A. Lardinois and A.E. Peponi for organizing a stimulating conference, the anonymous readers for their detailed and helpful comments, Zacharoula Petraki for reading many drafts and enduring long discussions, Heidi Broome-Raines for meticulous editing. Finally, I am grateful to Anastasia-Erasmia Peponi for my first inspirational look at lyric.

1 Gentili (1988). Winkler (1990); Hallett (1979) discuss Sappho's social context and the coexistence of public and private in the Sapphic corpus. Parker (1993) re-examines testimonia supporting a sympotic performance by older women. Calame (1996), (2001) discusses choral performance within an initiatory context. For Nagy (2007), Alcaeus and Sappho songs were performed by choruses of young men and women in ritual contexts. Lardinois (1994), (1996), (2001) also argues in favor of public choral performance even in the case of so-called 'solo' songs such as frr. 94 and $96 \mathrm{v}$.

2 Calame (2001).

(C) KATERINA LADIANOU, 2016 | DOI: 10.1163/9789004314849_015

This is an open access chapter distributed under the terms of the Creative Commons AttributionNoncommercial 3.0 Unported (CC-BY-NC 3.0) License. 
an inherent characteristic of this poetry. Taking Philostratus Imagines 2.1 as a starting point, I will further refer to Aulus Gellius and an epigram from the Palatine Anthology to show that later authors' reception of Sappho's poetry points both to a plurality of voices and to a blurring of the senses as main characteristics of her poetic art. Furthermore, it will be argued that this blurring of senses is related to these authors' understanding of Sappho's poetry as essentially choral. Finally, I will come back to Sappho's poems to demonstrate how the plurality of voices and multiple sensibilia assumed by the later authors can be found in her poetry. In conclusion, a question will be raised: is it possible to argue that the visual and the blurring of the senses in Sappho could be an added argument for the choral dimension of her poetry?

\section{The Look of Song: Sappho and the Visual}

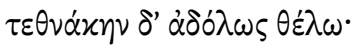

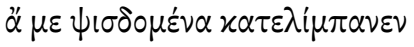

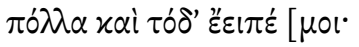

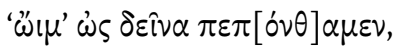

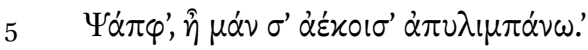

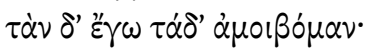

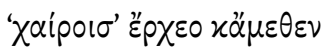

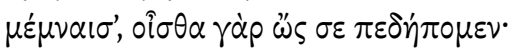

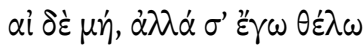

10

$\partial \mu \nu \alpha l \sigma \alpha l[\ldots .] ..[\ldots] . . \alpha l$

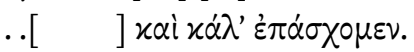

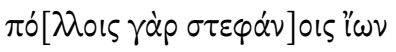

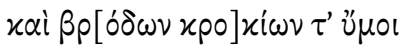

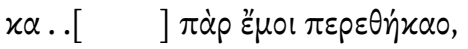

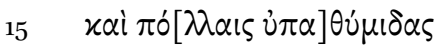

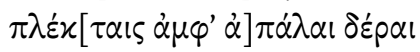

$\dot{\alpha} \nu \theta \dot{\varepsilon} \omega \nu \stackrel{\varepsilon}{\varepsilon}[\beta \alpha \lambda \varepsilon \varsigma] \pi \varepsilon \pi 0 \eta \mu \mu \varepsilon \dot{v} \alpha \alpha \varsigma$,

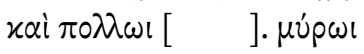

$\beta \rho \varepsilon v \theta \varepsilon i \omega l[\quad] \rho v[..] \nu$

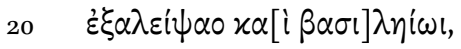

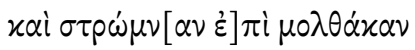

$\dot{\alpha} \pi \dot{\alpha} \lambda \alpha \nu \pi \alpha .[\quad] \ldots \omega \nu$

ह่'ंins $\pi \dot{\theta} \theta 0[\nu] . \nu i \delta \omega \nu$,

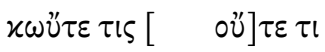

25 îpov oủdv[ 


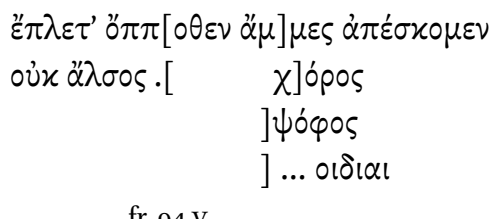

Honestly, I wish I were dead. She was leaving me, shedding many tears, and saying this: 'Alas, what a dreadful thing has happened to us, Sappho, I am leaving you, honestly, not by my own will.'

And I replied to her thus: 'Go, farewell and remember me, for you know how we cherished you. And, if you don't, I wish to remind you ... that beautiful things happened to us. Many garlands of violets and roses and saffron you put around you, lying close to me, and round your tender neck you put woven garlands made from flowers, and much perfume ... made from flowers ... royal ... you anointed yourself, and lying on the soft couch you used to satisfy the desire ... there was neither ... nor a shrine ... from which we were absent ... nor grove ... dance ... sound ... songs. ${ }^{3}$

As the beginning of fr. $94 \mathrm{~V}$. is missing, there is no clear indication either of the identity of the speaking 'I' or of the time of utterance, both of which have been the object of scholarly debate. ${ }^{4}$ I am inclined to think that this fragment evokes various moments in time: the beginning of the fragment stages the lyric self at a present moment of distress ( $\theta \dot{\varepsilon} \lambda \omega$, 'I wish I were dead', 1 ) and this is followed by a shift to the past moment of separation ('she was leaving me, shedding tears', $x \alpha \tau \varepsilon \lambda(\mu \pi \alpha v \varepsilon v, 2)$. There follows a dialogue set in the past: she

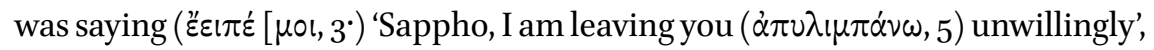

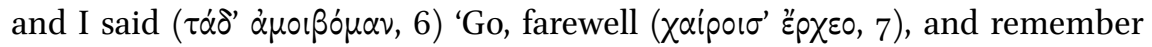
me $\left(\chi \alpha \alpha_{\mu} \mu \varepsilon \varepsilon v / \mu \varepsilon \varepsilon^{\prime} \mu \nu \alpha \sigma \sigma^{\prime}, 8\right)$ '. A second person emerges as an interlocutor who is addressing by name the lyric ' $\mathrm{I}$ ' ( $\Psi^{\prime} \alpha \varphi^{\prime}$ ', 5). Then there is another time shift, as memory helps both the speaking 'I' and the audience to return again to the past, even before the separation: 'remember how we lived together, and if you don't, I wish to remind you ( $(\theta \dot{\varepsilon} \lambda \omega /$ ö $\mu \nu \alpha I \sigma \alpha l, 9-10)$ '. Although this is a

3 For all Sappho's fragments, with the exception of the Tithonus poem, I cite Campbell (1982). Translations, unless otherwise indicated, are mine reflecting the discussion at hand. Words not fully attested in the Greek text are marked with a question mark.

4 For an overview of past scholarship see Burnett (1983) 292-293 and esp. n. 38; Greene (1996). In short, scholars attribute the first line to (a) Sappho's addressee at the time of parting, (b) the female narrator of the parting scene, (c) speaking Sappho at the time of parting. 
narration of the past, there is a sense of the future. ${ }^{5}$ The lyric 'I' will go on to recall the previous experience of their common life, trying to preserve, store, and secure the memory of the past. The self, then, is preserved as past and future combined. Memory is both "what we were" and "what we will have been". What the speaker wants is both to create a memory and to share it to ensure its preservation in the future. Three different voices are then staged in a dialogue which takes place across several spatial as well as temporal positions. ${ }^{6}$

The opening of the fragment, according to this reading, is the space of the here and now, only described via the feelings of despair of the speaking person, that swifty changes into the space of separation, the final dialogue. Here the dialogic 'space' is set between the 'I' and the 'you', with the 'I' named by her interlocutor, a signature Sapphic trick. In at least 19 of its 29 preserved lines, then, the poem focuses on the memory of the past, in a last desperate attempt to preserve through memory a eutopia of togetherness. Furthermore, the construction through memory of the eutopic space focuses on its visualization: the

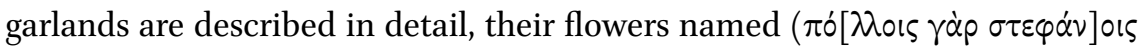

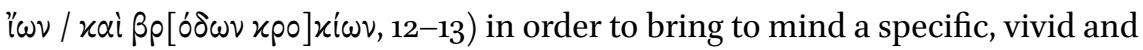
multicolored picture. The description of the performative reality is not only visualized but also described synaesthetically, since all senses are activated and addressed. It is not only the garland but the act of self- and mutual garlanding

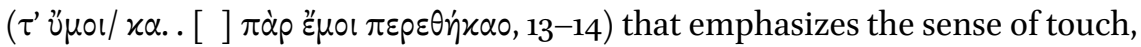
highlighted by the adjectives $\dot{\alpha}] \pi \dot{\alpha} \lambda \alpha \mathrm{l}$ (16), $\dot{\alpha} \pi \dot{\alpha} \lambda \alpha \nu$ (22), $\mu 0 \lambda \theta \dot{\alpha} x \alpha \nu$ (21) in combination with the verbs $\ddot{\varepsilon}[\beta \alpha \lambda \varepsilon \varsigma]$ (17) and $\xi^{\prime} \xi \alpha \lambda \varepsilon$ í $\psi \alpha 0$ (20). Smell is also a part of the description: the adjectives $\beta \rho \varepsilon \dot{v} \theta \varepsilon \varepsilon \omega l$ (19) and $\beta \alpha \sigma l] \lambda \eta^{\prime}(\omega l$ (20) modify the noun $\mu v \dot{p} \omega \mathrm{\omega}(18)$ probably describing a specific smell. Finally the sense of hearing is also described in the last, regrettably fragmentary, lines. Although the lines are broken, the word $\chi$ ]ópos (27) is highly probable, and the more difficult read-

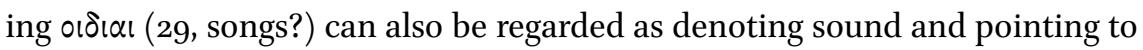
performance. ${ }^{7}$ Finally the term yópos (sound) points not only to the sense of hearing but also to a lyric performance, since it can refer to the sound of musical instruments (usually the flute or lyre). ${ }^{8}$

$5 \Theta \varepsilon \dot{\varepsilon} \omega \partial^{\circ} \mu \nu \alpha \iota \sigma \alpha l$ is not a future per se but a future expression, a wished-for-event situated in the future.

6 For the polyphonic dimensions of the poem see also Yatromanolakis (2003) 55-56. He also speaks of 'dreamlike images deprived of specific time' (57).

7 As Lardinois (1996) 163-164 points out, 'the whole poem ... is concerned with choral performances'.

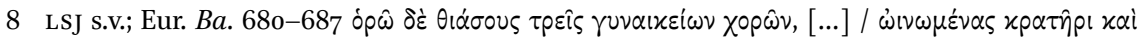


It is evident, then, that Sappho stages a female eutopia through the description of female singing, the sound of multiple female voices, smells, and textures. Almost all the senses come into play and lines 21-23 explicitly describe the inti-

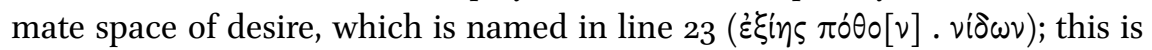
an explicit scene of female homoerotic desire as a marker, I suggest, of female homilia. Sappho's description emphasizes the body and its movements: the soft neck on which the garlands are placed, the bodies anointed with perfumes, the bodies reclining on couches feeling soft to the touch. Female desire is heavily emphasized, as it is also in Alcman's Partheneia. Most importantly, in the broken end of the fragment there is the memory of women singing and probably dancing. ${ }^{9}$

I hope to have shown that fr. $94 \mathrm{~V}$. is set in a fluid time and space that is represented as such through a fusion of voices (by switching grammatical persons) and senses. In fr. $44 \mathrm{~V}$. we find another case of visualized fusion of song and dance. I believe that this fragment can be compared with fr. 94, to throw some light on the ending of the latter. Fragment 44, as we have it today, begins with a vivid description of the wedding procession of Hector and Andromache as narrated by the herald Idaeus:

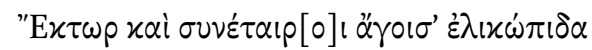

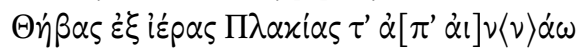

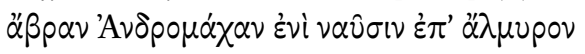

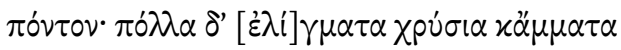

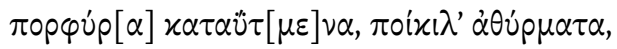

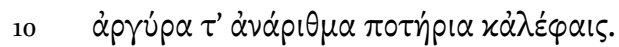

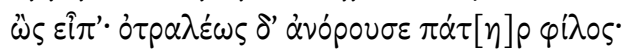

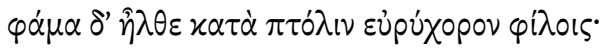

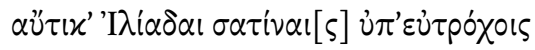

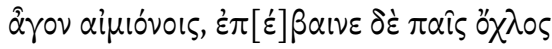

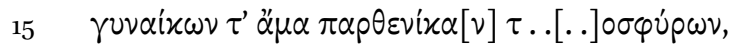

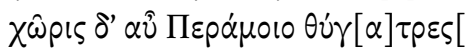

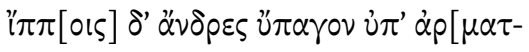

fr. $44.5^{-17} \mathrm{v}$.

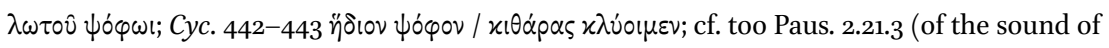
the trumpet).

9 At least according to Lobel-Page who read $\chi$ ]opós where Voigt prints].pós. See Lardinois (1994) 70 and n. 50 . 
... Hector and his companions are bringing the lively-eyed, graceful Andromache from holy Thebe and ever-flowing Placia in their ships over the salt sea. And there are many golden bracelets and perfumed purple robes, ornate trinkets and countless silver drinking cups." So he spoke; and nimbly his dear father leapt up, and the news went to his friends throughout the spacious city. At once the sons of Ilus yoked the mules to the smooth running carriages, and the whole crowd of women and tenderankled maidens climbed on board. Apart drove the daughters of Priam ... and unmarried men yoked horses to chariots ... ${ }^{10}$

The herald's words imply an internal audience: the Trojans, to whom the speech is addressed. Although this is a description spoken out loud by the herald and is therefore directed at the sense of hearing his words create a vivid visual image. First, the long journey from Thebes and Placia to Troy across the sea is conjured up for the audience's eyes. Then Andromache is described; the lively look in her eyes travels with her from line 5 to line 7 , where it meets the noun it qualifies, as the journey is structurally placed between the adjective and the proper name. The emphasis on Andromache's glance creates the impression that the journey is seen through her own eyes. Then the catalogue of the wedding gifts is presented with an emphasis on the costliness of materials. Gold, silver, ivory,

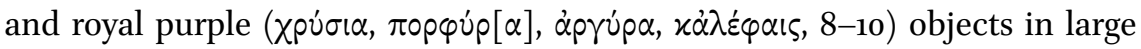
quantities $(\pi \dot{o} \lambda \lambda \alpha, \dot{\alpha} \nu \dot{\alpha} p \mid \theta \mu \alpha, 8,10)$ create an atmosphere of luxury and a colorful and bright visual image. The end of Idaeus' message is immediately followed by the reaction of the Trojan royal family, who with the Trojan people comprise the poem's internal audience, to the news. The message is first conveyed to Priam, who leaps up from his throne, then it travels all over the city. The spaciousness of the city is emphasized both verbally (evंpúxopov) and through the description of the crowd as it prepares to meet the royal couple. The reference to the preparations of the father and friends, then of the children, young women, and daughters of Priam, and finally of the young and grown men, proceeds gradually from the confined space of the palace to the open space of the city streets, aptly showing the engagement of the whole polis both as a space and as a citizen body.

The action of the rest of the fragment takes place in the civic space, and the emphasis rests on the description of various lyric performances as visualized for an external audience: 


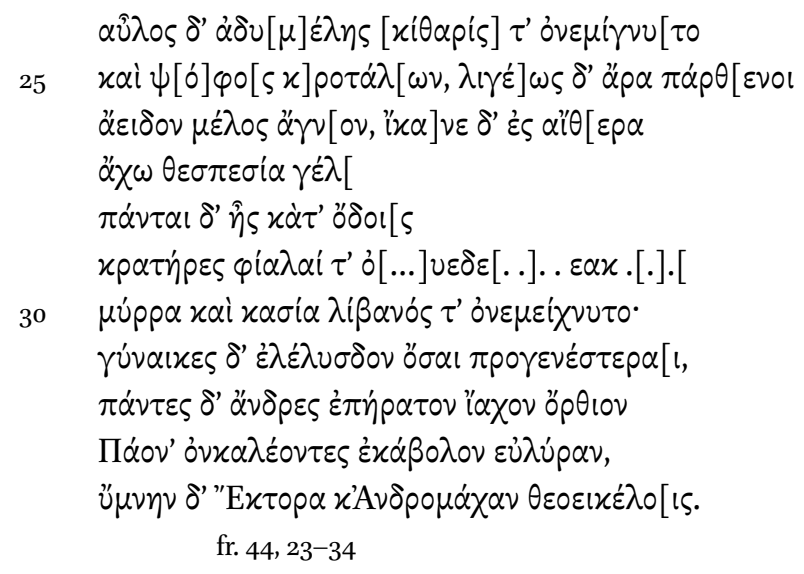

The sweet-sounding pipe mingled with the lyre and the sound of the castanets, and maidens sang clearly a holy song, and the exquisite echo reached the sky ... and everywhere in the streets ... bowls and cups ... and cassia and myrrh and frankincense were mingled. And the older women cried out and all men raised a loud cry calling on Apollo Paean, the Archer, the player of the lyre, praising Hector and Andromache, similar to gods.

The citizen body, previously described on the way to meet the royal couple, is now presented in performance. The choruses are shown in action in the order employed previously to describe the preparations. There are probably

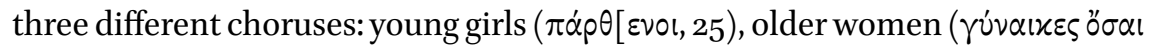

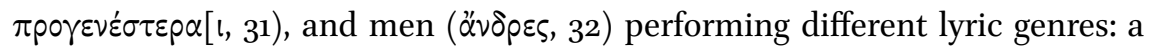

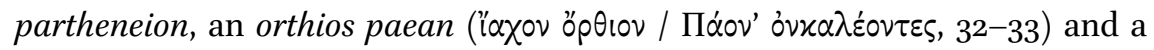

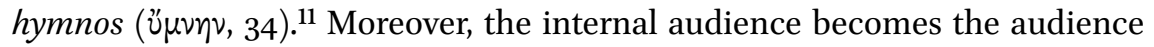
of the festivities, but Hector and Andromache-previously the topic of the herald's message - can be seen as part of the internal audience since they now

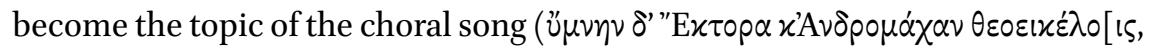
34).

The external audience, for whom the vivid description is intended, is led to perceive the performances through all senses. The fragment describes choral

11 See Carey (2009) for an overview of past scholarship and an excellent introduction to lyric genre categories. With most scholars Carey emphasizes the resistance of lyric genres to rigid categorization, pointing out that 'literary genres are best seen not as categories but as tendencies' (22). Be that as it may, I do not intend here to make any suggestion regarding the content or categorization of specific lyric genres. What I am pointing out is that the text refers explicitly to recognizable lyric genres, such as a hymn and orthios paean. 
performances and, just as in fr. 94, in fr. $44 \mathrm{~V}$. the visual element is combined not only with sound but also with smell. There is the sound of pipes ( $\alpha \hat{i} \lambda \circ s$ $\left.\delta^{\prime} \dot{\alpha} \delta \cup[\mu] \dot{\varepsilon} \lambda \eta \varsigma, 24\right)$, castanets ( $\psi[\dot{o}] \varphi \circ[\varsigma x] \rho \circ \tau \dot{\lambda} \lambda[\omega \nu, 25)$, and songs ( $\alpha^{\prime \prime} \chi \omega \theta \varepsilon \sigma \pi \varepsilon-$

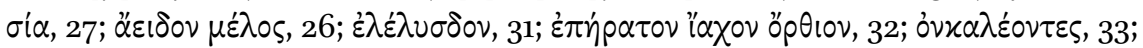
ن $\mu \nu \eta \nu$, 34) performed by men and women. Indeed, the senses seem to be mingled: the description of sound is brought together with the description of scent

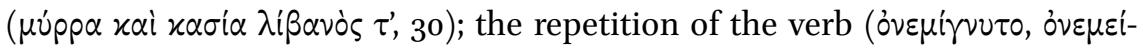
$\chi \vee v \tau 0,24,30)$ emphasizes the fusion, connecting it with choral performance. Finally, when the crowd mingles, women and men sing together and even the wine is mixed in the mixing bowls. Apollo is called in their song by many of his epithets: he is Paean, archer, and lyre-player. Lyric genres are fused. In this ecstatic description of a wedding ceremony, nothing is static, nothing is separate; everything is mobile and fused together literally and metaphorically. The fragment sets up different audiences, viewers and spectacles, but this categorization is fluid as well: the internal audience of the herald's message becomes the audience or the performers of the celebratory choral dances. Andromache, a viewer in the beginning of the poem, becomes a spectacle, the subject of performance and its audience at the same time.

The fusion of the senses is connected to the description of choral performances also in fr. $2 \mathrm{~V}$. Already Hermogenes in his second-century AD treatise On the Kinds of Style noted that the pleasure derived from this fragment has to do with the visualization of the locus amoenus. Quoting fr. 2 he argues that certain things can afford pleasure ( $\dot{\delta} \delta \circ v \eta$ ) not only to the eye when seen but

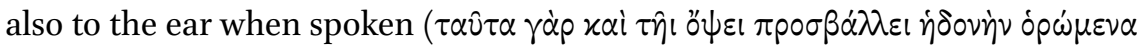

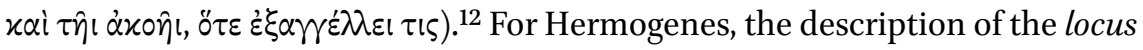
amoenus targets both the eye and the ear: by visualizing the beautiful place, the picture is set before the eyes of the audience while listening to the poem. At the same time the description engages the ear as well, not only because the performance of the poem is intended to be heard but also because the description is not only visual but also acoustic.

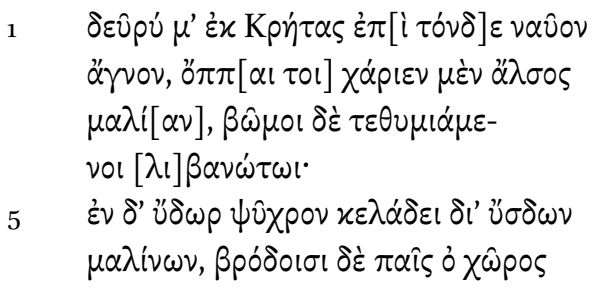




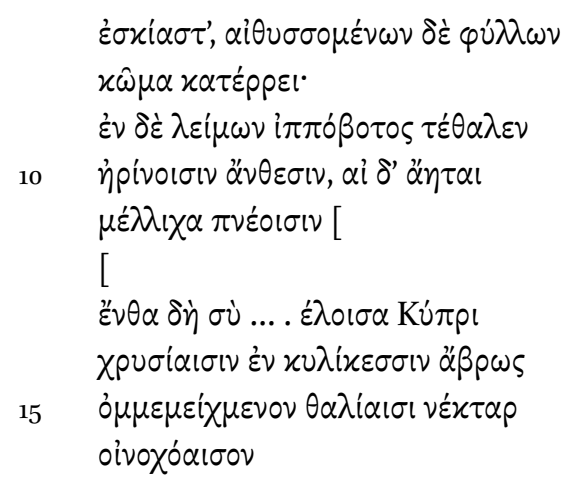

Hither from Crete to this holy temple (?) where is a delightful grove of apple trees and altars smoking with incense. There, your cold water resounds while rushing through the apple branches, and the whole place is shadowed by roses, and from the shimmering leaves sleep ... down (?) There is also a meadow, grazed by horses, blossoms with spring flowers, and the breeze sweetly blows. There you ... taking, Cypris, charmingly pour in golden cups nectar mingled with our festivities.

The space is carefully constructed by the use of deictic markers: the second person invocation to Cypris stages a dialogue between the persona loquens $(\mu \varepsilon, 1)$ and a persona audiens $(\sigma \dot{v})$ that is set in two different spaces. Cypris

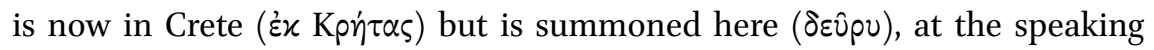
position of the speaking 'I' which is first defined by means of deictic markers

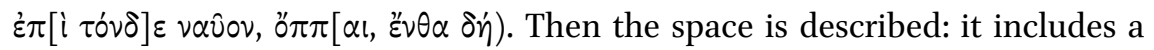

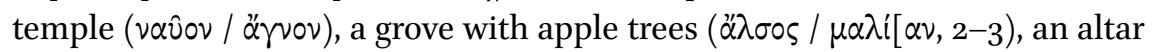

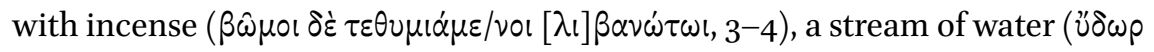

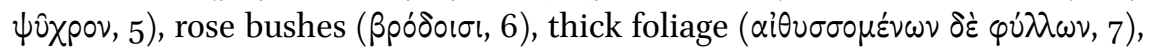

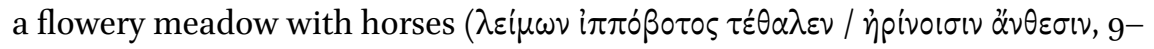
10). ${ }^{13}$

The grove is probably not inhabited since and there is no description of human presence. The smoking altar, however, denotes human activity and the end of the poem suggests a gathering $\left(\theta \alpha \lambda i \alpha \_\sigma l, 15\right)$ where Cypris is invited as a wine bearer (oivoxóal $\sigma 0 v, 16$ ). In addition to the goddess, a second internal, now mortal, audience emerges: the members of the $\theta \alpha \lambda i \alpha$. Although there is no description or invocation to the mortal audience, the grove is described

13 Most editors accept the emendation vavov. Contra Yatromanolakis (2003) 54-55 who reads ह้v $\alpha \cup\langle\lambda\rangle \circ v$ ('dwelling') instead. 
through the totality of human senses creating such a presence. Smell, touch, and hearing are also employed: the smell of the incense, the cold water, the sound of water, the sleep all presuppose a human presence. The description is also mobile: the altar is smoking, the water is running, the breeze is blowing, sleep is coming down. According to Hermogenes, such a setting gives pleasure to both the viewer and the listener; hence it can be suggested that the description constructs an internal audience for the performance by describing how the pleasurable setting impacts their senses.

Although the descriptive context can sometimes be identified with its performative context, I only submit that fragment as good evidence that the fusion of the senses is connected to the description of choral performances. Moreover, it is noteworthy that the representation of a choral performance emphasizes fusion of senses as its indispensable characteristic in the context of Sapphic poetry. In the following section, I will show that this is the case for later contexts as well.

\section{Looking at Sappho's Songs: Philostratus 2.1}

In my discussion of the importance of the element of visualization to Sapphic poetry, I hope to have shown that the visual is often connected with the other senses, creating a synaesthetic, pleasurable, vivid image, one that Hermogenes would call hedonic. It is interesting, then, that such an emphasis on visualization is evident in the later reception of Sappho. In this section, I will first discuss Philostratus Imagines 2.1 and later bring in Aulus Gellius and an epigram from the Palatine Anthology in an attempt to show that visualization and the blurring of the senses was considered by them an indispensable characteristic of Sapphic poetry. Secondly, I will go on to argue that in the mind of later audiences such a synaesthetic visual effect was closely connected with choral performance.

Philostratus' Imagines, a collection of ekphraseis of the paintings thataccording to the narrator-decorated a gallery in Naples, is the obvious place where literature and representational art meet. ${ }^{14}$ One of the paintings

14 The bibliography on ekphrasis is vast and exploring it is not within the scope of this paper. For an introduction and extended bibliography see Leach (1988); Fowler (1991); Goldhill (1994); Bartsch and Elsner (eds) (2007). On ekphraseis in Philostratus' Imagines see Shaffer (1998) and Dubel (2009). Most recently, Whitmarsh (2013) has discussed artwork in erotic contexts, raising questions on gender politics. 
depicts Sappho and a group of young girls in a ritual setting. The passage is worth quoting in full: ${ }^{15}$

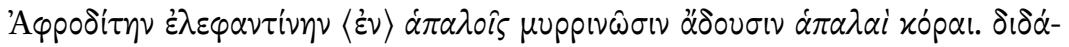

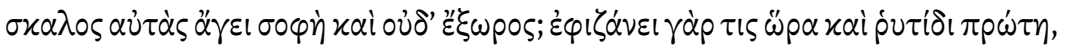

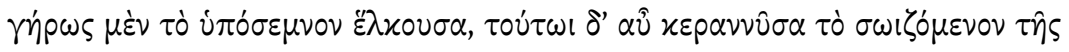

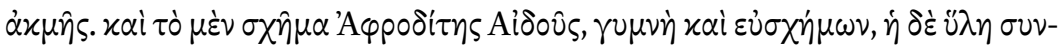

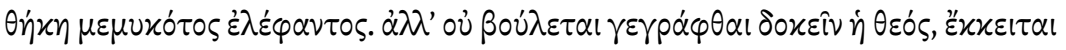

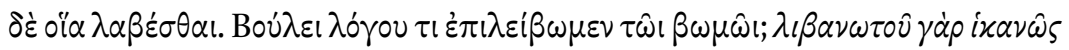

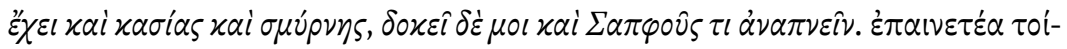

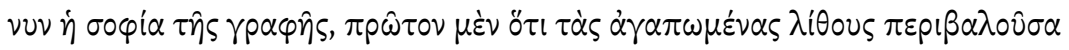

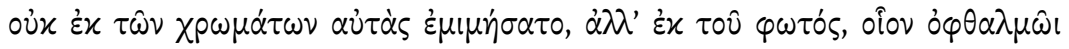

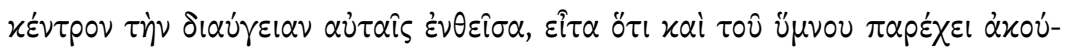

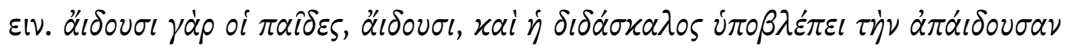

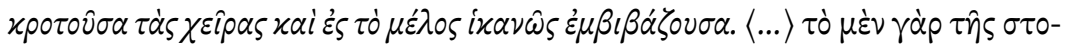

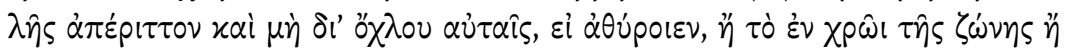

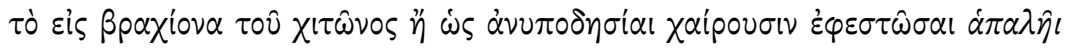

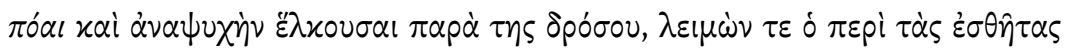

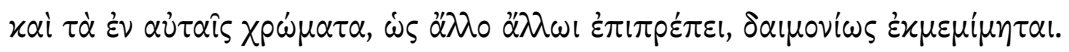

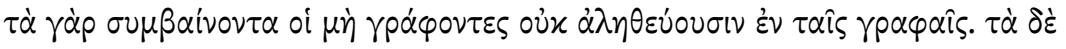

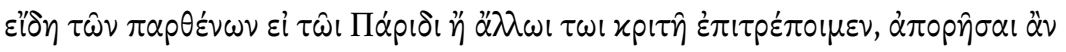

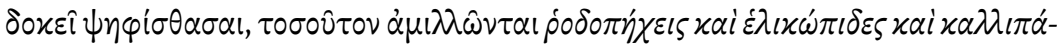

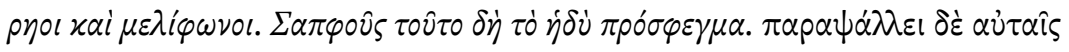

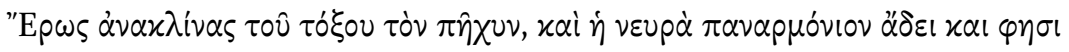

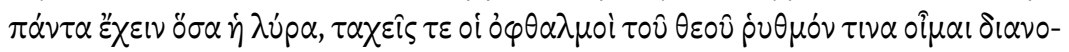

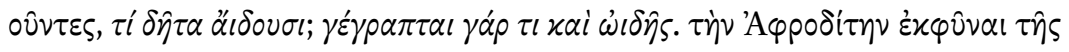

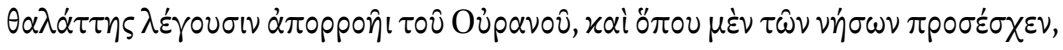

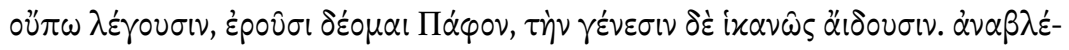

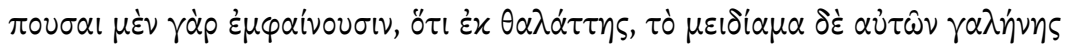

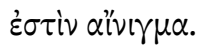

An Aphrodite, made of ivory, tender maidens are hymning in tender myrtle groves. The chorodidaskalos who leads them is skilled in her art, and not yet past her youth; for a certain beauty rests even on her first wrinkle, which, though it brings with it the gravity of age, yet tempers this with what remains of her prime. The type of the goddess is that of 
Aphrodite goddess of Modesty, unclothed and decorous, and the material is ivory, closely joined. However, the goddess is unwilling to seem painted, but she stands out as though one could take hold of her. Do you wish us to pour a libation of discourse on the altar? For of frankincense and cinnamon and myrrh it has enough already, and it seems to me to give out also a fragrance as of Sappho. Accordingly the wisdom of the painting must be praised, first, because the artist, in making the border of precious stones, has used not colors but light to depict them, putting a radiance in them like the pupil in an eye, and, secondly, because he even makes us hear the hymn. For the maidens are singing, are singing, and the chorodidaskalos frowns at one who is off-key, clapping her hands and trying earnestly to bring her into tune ... For as to their garments, they are simple and such as not to impede their movements if they should playfor instance, the close-fitting girdle, the chiton that leaves the arm free, and the way they enjoy treading with naked feet on the tender grass and drawing refreshment from the dew; and the flowered decoration of their garments, and the colors used on them - the way they harmonize the one with the other-are represented with wonderful truth; for painters who fail to make the details consistent with one another do not depict the truth in their paintings. As to the figures of the maidens, if we were to leave the decision regarding them to Paris or any other judge, I believe he would be at a loss how to vote, so close is the rivalry among them in rosy arms and flashing eyes and fair cheeks and in 'honeyed voices', to use the charming expression of Sappho. Eros, tilting up the centre of his bow, lightly strikes the string for them and the bow-string resounds with a full harmony and asserts that it possesses all the notes of a lyre; and swift are the eyes of the god as they recall, I fancy, some particular measure. What, then, is the song they are singing? For indeed something of the subject has been expressed in the painting; they are telling how Aphrodite was born from the sea through an emanation of Uranus. Upon which one of the islands she came ashore they do not yet tell, though doubtless they will name Paphos; but they are singing clearly enough of her birth, for by looking upward they indicate that she is from Heaven (Uranus), and by slightly moving their upturned hands they show that she has come from the sea, and their smile is an intimation of the sea's calm.

The description begins with a double focus: on the ivory statue of Aphrodite and the $\delta 1 \delta \alpha \sigma x \alpha \lambda \circ \varsigma$, leading a chorus of young girls. The description of the statue is an embedded ekphrasis, a description of a work of art within an 
ekphrasis, in this case, the description of a painting. But it is interesting that the description, although constructing an ekphrasis within an ekphrasis, tends to overcome its limits and strives for a realistic effect: the goddess is not

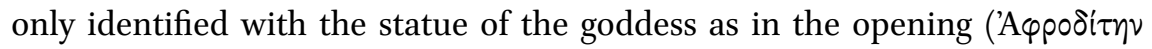
$\dot{\varepsilon} \lambda \varepsilon \varphi \alpha \nu \tau i \nu \eta \nu)$ but also with the painted image of her statue.

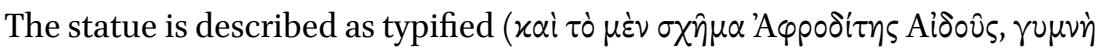

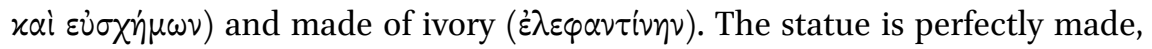

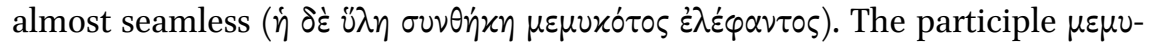
xótos, deriving from the verb $\mu v^{\prime} \omega$ (shut the eyes), introduces a metaphor: the pieces are closely joined together like two eyelids. The metaphor not only emphasizes the closeness and the fact that the two pieces physically belong together but also introduces the importance of eyesight by focusing on the eyes. The intention of the sculptor was to fool the eye, the two pieces appearing like one. But the intention of the sculptor coincides with the intention of the goddess herself whose wish is not to look like a painted image ( $\alpha \lambda \lambda^{\prime} \circ \nu$

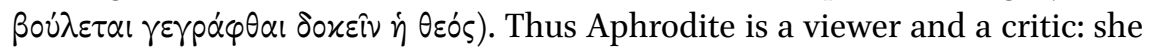
does not want to look as if she were a painting, she wants to look as real-

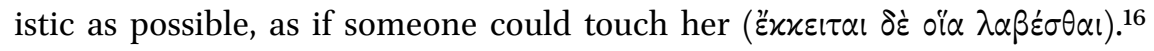
Moreover, the intention of both the goddess and the painter coincides with the one of the writer of the ekphrasis: bringing the scene before the eyes of the reader is the desirable effect of the ekphrasis, as progymnasmata prescribe. ${ }^{17}$

The description of Sappho is the second focus of the ekphrasis. The chorus leader, unlike the dancers, is clearly past her prime although not too old (ovं $\delta^{\prime}$ है $\xi$ (wpos), with the first wrinkles mixed with her past beauty. The description is very precise, visualizing not only the looks but also the overall impression of her stature and physique. The description of her age is also interesting as Sappho has features of both young and old age at the same time, creating a blurring-

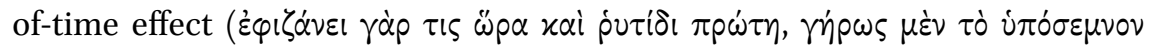

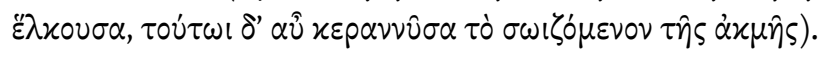

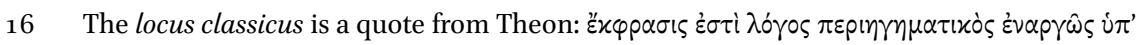

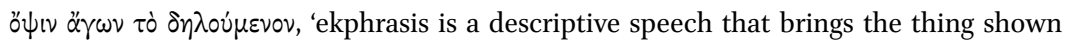
vividly before the eyes' (Prog. p. 118 Spengel = 66 Patillon). For detailed bibliography and discussions on enargeia: Fowler (1991) 26; Goldhill (2007) 3; Bartsch (1989) 9; Webb (2009) Chapter 4. For a theoretical approach on the question of focalization (who sees) see Fowler (1991) 29-31.

17 For rhetorical handbooks on ekphrasis see Webb (2009). For shorter discussions see Bartsch (1989) 7-10; Goldhill (2007) 3-7. 
It is only to be expected that the visual element would be emphasized in the framework of an ekphrasis of a painting. ${ }^{18}$ Moreover, Philostratus describes not only the image but also the act of viewing, the play of light and the effect of the eye capturing this light. ${ }^{19}$ The artist made a frame of precious stones around his painting so that the light reflected in the stones creates a gleaming effect. Referring to the artistry of the painter, Philostratus breaks the realistic effect, reminding his audience that this is really a painting. On the other hand, it highlights its artistry; he is not only a good artist, he is ropós. I suggested earlier that the description of Aphrodite was a case of an embedded ekphrasis. It is my view that Sappho, the second focus of the ekphrasis, is an embedded ekphrasis as well. This time Philostratus describes not a visual artifact, but Sapphic poetry. ${ }^{20}$

In reading the ekphrasis both an act of interpretation and one of emulation become apparent: in order for the $\delta \eta \lambda \circ u \varepsilon \varepsilon v 0 v$ to come before the audience's eyes, a prior knowledge of Sapphic poetry is necessary. Philostratus is describing the grove using Sapphic imagery (frr. 2 and 44 V. in particular) and diction, and he quotes directly from Sappho when calling the chorus girls honey-voiced, 'to use the charming expression of Sappho.'21 The insistence on touch is again

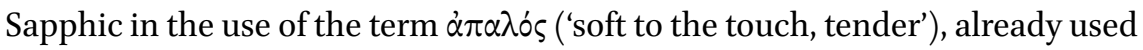
by Sappho in fr. $94 \mathrm{~V}$. His description of a work of art is then two-fold, since he is describing the painting and the poetic work at the same time. It is first the painter himself who tried to imitate Sappho; Philostratus' ekphrasis tries to represent and imitate, or emulate, both. It is noticeable that both Sappho and

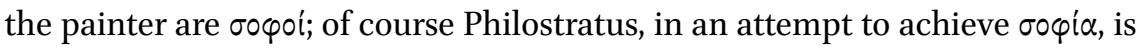
competing with both of them. ${ }^{22}$ Finally, the audience has to be equally wise, a learned audience well versed in visual arts and poetry.

As Shaffer (1998) rightly observes, 'Philostratus' attempt to translate impressions from the pictorial to the literary medium calls attention to the mimetic quality of both and invites the act of interpretation.'23 The wisdom of the paint-

18 See e.g. Webb (2009) 127: 'For what enargeia, and thus ekphrasis, seek to imitate is not so much an object, or scene, or person in itself, but the effect of seeing that thing.'

19 For Goldhill (2007) 2 ekphrasis dramatizes 'the moment of looking as a practice of interpreting, of reading - a way of seeing meaning'.

20 See Shaffer (1998) 313 who discusses Imag. 1.1 (Scamander) and its dialogue with the Homeric poem.

21 Sappho fr. $185 \mathrm{~V}$.

22 For sophos see Goldhill (2007) 2 according to whom ekphrasis 'dramatizes not just an interpretation, but a sophos — an educated wit—interpreting'; and Shaffer (1998) 314.

23 Shaffer $(1998) 304$. 
ing, according to Philostratus, must be praised for two reasons: first, because

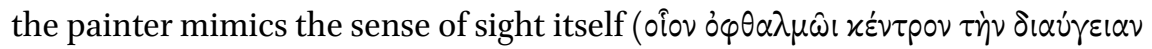

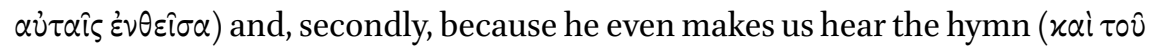
$\left.\ddot{u} \mu \nu \circ v \pi \alpha \rho \dot{\varepsilon} \chi \varepsilon l \dot{\alpha} x \circ v_{\varepsilon} \varepsilon v\right)$. The importance of the visual is then a feature of $\sigma \circ \varphi^{\prime} \alpha$, as is the fusion of all senses, the synaesthetic reception of Sappho. It is evident that Philostratus understands that the painting attempts to engage not only the vision but all other senses as well. ${ }^{24}$ The fact that ekphrasis usually employs all senses is of course well established, since the descriptions of the work of art direct the viewer to perceive them with more senses than sight alone. ${ }^{25}$ As Bartsch rightly observes, interpretation in Philostratus entails seeing and describing more than is actually visible. ${ }^{26}$ What I am suggesting, however, is that Philostratus' appeal to all the senses is also mimicking Sapphic poetry. Apart from the visual, already discussed, there is also an insistence on touch and scent in Philostratus' description: right from the beginning tender girls sing in a tender grove, and later again the emphasis is on the sense of touch when girls feel the soft, moist grass under their bare feet. Scent is again very important: there is an emphasis on the beautiful smell of incense but there are also two interesting points. The first is the idea of discourse as an offering; the ekphrasis is offered to the goddess as incense is:

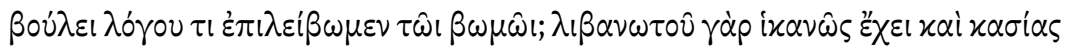

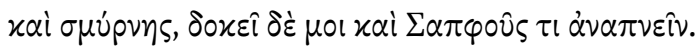

Do you wish us to pour a libation of discourse on the altar? For of frankincense and cinnamon and myrrh it has enough already and it seems to me to give out also a fragrance as of Sappho.

Discourse, usually perceived though hearing, is then fragrant, perceived by smell. Describing Sapphic discourse in synaesthetic terms, Philostratus considers the emphasis on the visual and its combination with other senses, that is,

24 As Shaffer (1998) 308 points out, 'beyond mere visual description, Philostratus attempts to achieve full sensuous reality in the medium of words and even attributes sensations of fragrance and sound to his immediate visual perceptions'.

25 See Webb (2009) 187 who points out that the pictures are meant to elicit a synaesthetic response.

26 Bartsch (1989) 16-17 according to whom 'Philostratus does not restrict himself to a catalogue of details: what he tells his imaginary audience (and us) about the pictures is far from purely descriptive involving both the details actually visible in each picture and those he has brought in from myth, literature, and historiography' (16). 
synaesthesia, as an integral characteristic of Sapphic poetry not only in terms of its perception but also of its reception. Moreover, and most importantly, the fragrance of the ekphrasis, as it were, is nothing but a mimesis of the fragrance of Sapphic discourse. There is then, it seems, a certain scent to a Sapphic song, a scent that the writer of the ekphrasis seems to emulate. Listening to a Sapphic song is, to Philostratus, a synaesthetic experience, where all senses are employed. It is clear, then, I suggest, that Philostratus perceives the fusion of senses as an common feature of Sapphic poetry, one that his audience would recognize as characteristically Sapphic. Hence the interplay of the visual, tactile, and olfactory is recalled to the mind of the audience for the ekphrasis to be closer to its prototype, a more realistic imitation of Sappho's poetry.

I hope to have shown that Philostratus employs a recognizable characteristic of Sapphic poetry as a vehicle for a more realistic ekphrasis. At this point, one more feature of Philostratus' description is worth discussing at some length. At the beginning of the ekphrasis, the portrait of Sappho is clearly that of a chorus teacher leading off a dance of young girls. The network of technical terms refers unmistakably to choral performance. The chorus teacher ( $\dot{\eta} \delta 1 \delta \dot{\alpha} \sigma \kappa \alpha \lambda$ ) $)$ leads

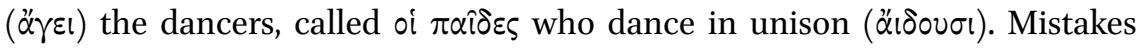
are not tolerated, and the capable leader sets the off-tune girl straight with a 'condescending' look followed by a clap of her hands ( $\dot{v} \pi \circ \beta \lambda \varepsilon \dot{\varepsilon} \pi \varepsilon 1 \tau \eta \dot{\nu} \nu \dot{\alpha} \pi \dot{\alpha} 1 \delta 0 v \sigma \alpha \nu$

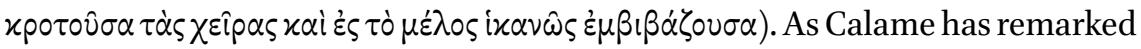
'It is unnecessary to point out the presence of the typically choral semantic features of "leading" and "beginning" in this scene described by Philostratus.' ${ }^{27}$ The harmony of their choreia is represented by 'the way they harmonize the one with the other-are represented with wonderful truth'. In the context of this performance, both steps and voice should be kept in harmony. The harmony of the song is part of Philostratus' visualization, since visual art alone could not have represented such a sequence of motion. Moreover, it is not only the performance but also the content of the song that Philostratus describes: 'what, then, is the song they are singing? For indeed something of the subject has been expressed in the painting.' The subject of the song is represented in both its kinetic and vocal elements. The chorus is singing of the birth of Aphrodite: the painting then is the painting of the performance of a Sapphic song by a chorus of girls in the context of a ritual for Aphrodite. I am not going to suggest that this is a realistic representation of an archaic performance, nor am I using it as evidence to prove that Sappho's songs were composed to be performed. But the testimony of the third-century writer is critical because it indicates that by 
Philostratus' time Sappho's performance is, first, intended to be perceived by all senses and, second, received as choral, in Philostratus' world.

Philostratus is not the only writer who perceives Sappho as a choral poet. In a passage from the Attic Nights, choirs of girls and boys, and lyre players are brought into the dining room to perform songs of Sappho and (pseudo-)Anacreon. ${ }^{28}$

Ac posteaquam introducti pueri puellaeque sunt, iucundum in modum

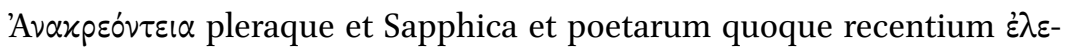
$\gamma \varepsilon \hat{\imath} \alpha$ quaedam erotica dulcia et uenusta cecinerunt.

And when the boys and girls were brought in, they sang in a delightful way several odes of Anacreon and Sappho, as well as some erotic elegies of more recent poets that were sweet and graceful.

The performance itself is not described but it is clear that we are not dealing with a solo performance. I believe that a chorus of girls (puellae) would sing the Sapphic songs and that of the boys (pueri) would then sing Anacreon. Moreover, the fact that the song is sweet is emphasized twice (iucundum, dulcia). Both adjectives can denote taste but are used to describe something perceived with sight and hearing. ${ }^{29}$ The song's perception is, therefore, again described in synaesthetic terms, with both senses blending in. The passage is of course not archaic but it points significantly to the later reception of Anacreontic and Sapphic poetry as choral. The cases of the two poets are very similar, as Dimitrios Yatromanolakis points out. ${ }^{30} \mathrm{He}$ reads the aforementioned passage as reflecting 'the conflation of monodic and choral modes of singing' in second-century AD dinner parties. ${ }^{31}$ I have argued elsewhere in favor of Anacreontic choral performances and I will come back to Anacreon presently, but let me now turn to a last later reference to choral performance of Sappho. ${ }^{32}$

In an epigram in the Palatine Anthology of uncertain date and authorship, Sappho is described as leading a chorus of young girls to the temple of Hera.

28 Aul.Gell. N.A. 19.9.4. Text and translation quoted from Rolf (1968-1978).

29 Iucundus refers to all senses: uerba ad audiendum iucunda, Cic. De Or. 1.49, 213; aqua ... potui iucunda, Plin. Nat. 6.37, 203; iucunde olet, Plin. Nat. 20. 69, 177; conspectus uester est mihi multo iucundissimus, Cic. De Imp. Pomp. 1.1; cantare et psallere iucunde, Suet. Tit. 3 .

30 Yatromanolakis (2007) 213-220.

31 Yatromanolakis $(2007) 84-85$.

32 Ladianou (2005). On Anacreontic performance in sympotic/comastic-ritual setting and its visual representation see Nagy (2007). 
This time their performance is described: the chorus with their soft, whirling footsteps, their sweet voice, their smiling faces, and Sappho as the leader, playing the lyre. Sappho is emphatically described as an $\dot{\xi} \xi \dot{\alpha} p \times 0 v \sigma \alpha$ and as the one who sets up the chorus, most probably the leader, the composer, the lyre player, and the dance teacher: ${ }^{33}$

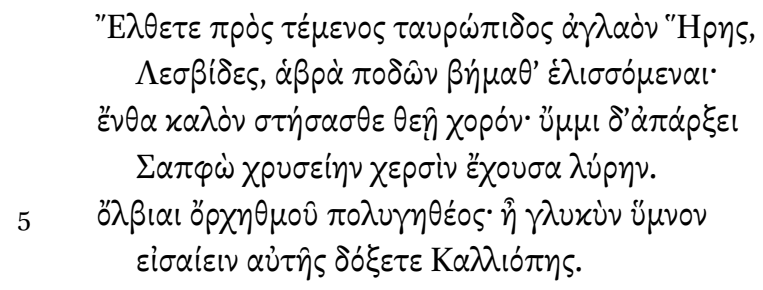

Come to the glorious precinct of bull-faced Hera, women of Lesbos, whirling your delicate footsteps, and set up there the beautiful dance to the goddess; and Sappho will lead you, bearing her golden lyre. Happy you women, in the delightful dancing! Indeed, you will seem to perceive a sweet hymn from Calliope herself.

I am, again, citing the epigram only as an attestation of later Sapphic reception. ${ }^{34}$ The epigram is probably Hellenistic or later but its diction is archaizing, pointing to Sappho and Homeric epic: the performance is therefore presented as archaic. Be that as it may, the poet does describe Sappho as leading a chorus of Lesbian women; we do have the description of footsteps in dance, accompaniment of lyre, and song. Moreover, we have a plethora of terms connected to

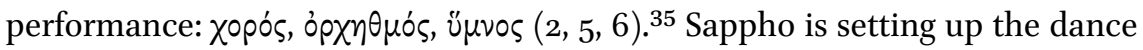
(as a female Stesichoros) and leads in playing the lyre ( $\dot{\alpha} \pi \dot{\alpha} p \xi \varepsilon l, 3)$. The synaesthetic description of a sweet hymn and emphasis on the tenderness ( $\dot{\alpha} \beta \rho \dot{\alpha}, 2)$ of the dancers' footsteps are to be noticed. Moreover, plurality of voices is evident, since not only are Sappho and the chorus probably singing, but the voice of Calliope is also metaphorically joining the dance.

So far, I have suggested that later authors not only perceive the emphasis on the visual and its connection with all other senses as a characteristic of Sapphic poetry but also associate this feature with chorality. Their perception

33 A.P. 9.189. Text and translation quoted from Campbell (1982).

34 For Sappho in Hellenistic epigram see Acosta-Hughes (2010) 82-92. Lardinois (1994) 75 entertains the possibility that the epigram 'reflects an authentic tradition and Sappho sometimes sang her songs in public while her chorus danced'.

For the performative connotations of the term í $\mu v \varepsilon i v$ see Peponi (2009) $5^{6}$. 
of choral song as synaesthetic is not, however, a first. In the Laws, Plato uses the term choreia to describe the combination of song and dance: $\chi \circ p \varepsilon i \alpha \gamma \varepsilon \mu \eta \nu$

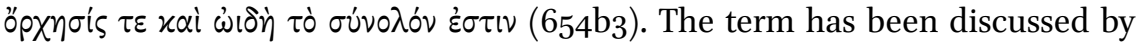
Peponi in the context of the Homeric Hymn to Apollo, with the emphasis on the fact that 'one practicing choreia is principally involved in vocal activity, while kinetic acts visually codify the attitudes and emotions expressed through the uttered words.' ${ }^{36}$ I have also argued elsewhere that, in the context of choreia, hearing and vision are completely fused together. ${ }^{37}$ Moreover, this integration of music, dance, and singing coexist at the levels not only of composition but also of reception. The descriptions of choreia always point not only to hearing and seeing but usually to all senses; the song stages and visualizes its perception not only by hearing but also sight, smell, and touch.

Going back to the epigram, the whirling footsteps ( $\pi \circ \delta \hat{\omega} \nu \beta \eta^{\prime} \mu \alpha \theta^{\prime} \dot{\varepsilon} \lambda \lambda_{l} \sigma \sigma \delta \mu \varepsilon v \alpha l$, 2) of the chorus members are combined with the sound of the lyre and the

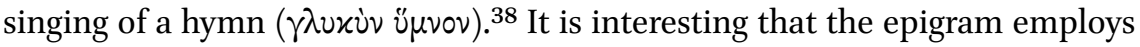

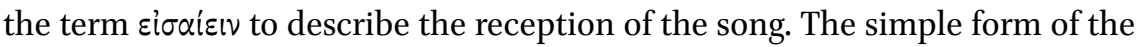
verb is a term that can invariably used to denote both hearing and seeing and I propose that the term is employed here because it carries both meanings. ${ }^{39}$ Using a verb that can reflect both senses, the author exploits a duality already found in Sapphic poetry. ${ }^{40}$ I am therefore proposing that both the Philostratus and the Palatine Anthology passages discussed so far can bear witness to a Sapphic choreia where the kinetic action of the chorus is complementing the Sapphic song.

I have so far suggested that later authors recognized in Sappho's poetry a plurality of voices and blurring of the senses which they associated with chorality. I have also shown that choreia was perceived as a fusion of song and dance already in Plato's time and that fusion of senses was considered to

36 Peponi (2009) 59. Steiner (2011) 319 also points to the 'continued emphasis on the several elements of choreia'.

37 Ladianou (2005) 48.

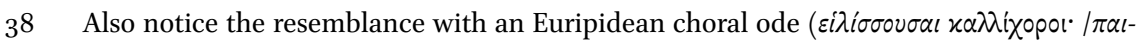

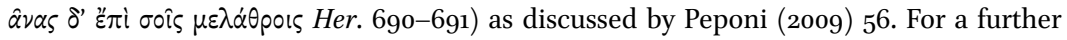
discussion of choreia in dramatic contexts see Steiner (2011).

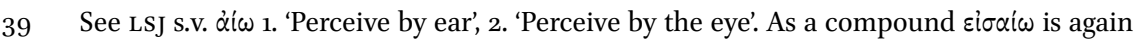
glossed as 1. 'hearing' and 2. 'feeling the effect of'.

40 The term $\alpha \dot{\alpha} \omega$ is used again in the A.P. for the work of a choral poet (Pindar): 7.34.3 $0 \hat{0}$

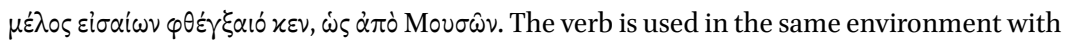

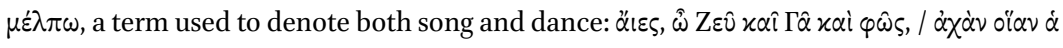

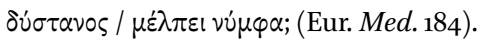


be an integral feature of choreia. In the section which follows I come back to Sappho's fragments, reflecting on the possible interrelation between chorality and synaesthesia.

\section{Looking at the Dance: Sappho and the Chorus}

In the previous section, I discussed later authors' reception of Sappho's poetry, arguing that synaesthesia, the blurring of the senses, is such a primary characteristic of her poetic art that it directly evokes its prototype when imitated. This calls for a final question: if visualization and synaesthesia point to the choral quality of Sappho's poetry, as assumed by the later authors, could theyperhaps-be considered an indication of choral performance? In other words, it will be discussed whether the plurality of voices and multiple sensibilia cannot only be found in her poetry but can also point to a performative reality.

Fragment $2 \mathrm{~V}$. has already been read as choral-performed by a chorus of girls, perhaps in the context of a ritual in honor of a female goddess. ${ }^{41}$ Again the only reference to a chorus ( $\left.\theta \alpha \lambda \lambda^{\prime} \alpha \iota \sigma\right)$ might be found in the problematic end of the fragment, summoning Aphrodite to the festivities. ${ }^{42}$ Although no choral performance is described yet, the emphasis on the fusion of senses points to the performance. ${ }^{43}$ The grove itself is not really inhabited by the chorus and

41 For Sappho's connection to ritual see Nagy (2007). Lardinois (1994), (1996), and (2001) suggests that at least some of Sappho's poetry was composed for choral performance in a ritual setting. See above, n. 19. For fr. 2 V. see especially Lardinois (1994) 78; (1996) 165. Contra Lardinois and others, Yatromanolakis (2003) 53-54 argues that, due to its fragmentary state, fr. 2 cannot be categorized as a cult song or hymn.

42 L.-P. and Campbell print oivoxó $\alpha$ เøov in line 16. Athenaeus (11.9.21) provides a slightly different 'Attic version' reading:

$\dot{\varepsilon} \lambda \theta \dot{\varepsilon}, \mathrm{K} \dot{\pi} \pi \rho \mathrm{l},\langle\ldots\rangle$

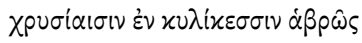

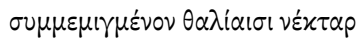

oivoxov̂ $\alpha$

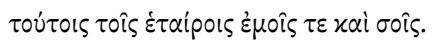

Lardinois (1996) 165 suggests that if this is a part of the poem it can be seen as an indication of the presence of the hetairai. Yatromanolakis (2003) 53 connects the 'Attic version' with the Athenian 'performative transmission of Sappho's songs'. More explicitly, Nagy (2007) 218-219 discusses the two attested closures of the fragment and argues that the 'Attic version' as quoted by Athenaeus points to a sympotic closure and can, therefore, be an indication of its performance by boys or men in Athenian symposia.

In the sense that the relaxation can be followed by a performance. For example see 
still, described through the totality of human senses, it creates human presence and evokes choral performance: apples, altar with incense, murmur of cold water running down the branches, sweet smell of roses, touch, hearing, all fused together as perceived by the senses of the dancers and our own at the same time. It is very probable that the fragment was the model for Philostratus' ekphrasis. Be that as it may, it is safer to point to the fact that Philostratus reconstructs the performance of the Sapphic song through the description she provides in her poetry. In other words, he received the song's reference to the locus amoenus as a reference to the place of the song's performance.

The fragment might have also been in the mind of the rhetor Menander when discussing hymns of invocation $\left(\chi \lambda \eta \tau i x 0^{i}\right){ }^{44}$ Referring to the composition of such hymns by Sappho, Anacreon, and Alcman, he points to the fact that the poets used to describe the places where gods are summoned:45

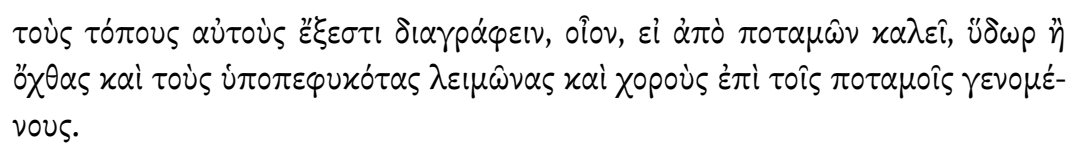

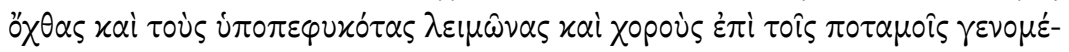
vous.

For they can describe the places themselves: in the case of rivers, the water and banks, the nearby meadows and dances held beside the rivers.

Although there is no positive indication that Menander refers to the fragment at hand, such a description closely resembles the locus amoenus of fr. $2 \mathrm{~V}$., whose beginning points to a cletic hymn. Moreover, the $\theta \alpha \lambda i \alpha i \sigma l$ at the end of the fragment can possibly refer to choral performance, the 'dances' (Xopoús) to which Menander refers. Supposing that the rhetorician had the whole poem at his disposal, it is probable that the final lines of the poem explicitly referred to the performance of a chorus. If that is correct, the external audience of the fragment would also be included in the list of potential audiences, becoming the mirror of the mortal internal audience.

It has already been claimed that both Philostratus and Gellius assume that Sapphic poetry was meant to be chorally performed. Moreover, it is interesting that Gellius brings Sappho and Anacreon together in this passage. His choice

Alcman's second Partheneion (PMGF 3.7-10) where rising from sleep is followed by choral

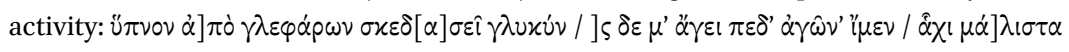

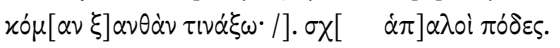

For Menander and ekphrasis see Bartsch (1989) and Webb (2009). For cletic hymns see especially Webb (2009) 156-157, 160-161.

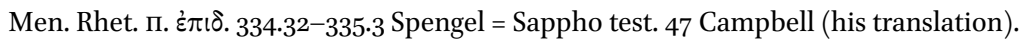


is not accidental, since the two cases are similar: they are both considered monodic poets, but their poetry emphasizes the fusion of song with dance. It is also appealing to consider two very similar fragments in which both poets describe symptoms of their old age followed by a desire to dance. Anacreon himself describes the symptoms of his old age in quite a pessimistic tone, but in the Anacreontic tradition the old poet desires to remove the cloak of his old age and join the choreia of the young dancers. ${ }^{46}$ The Tithonus poem offers a good case for comparison. The now complete version of fr. $58 \mathrm{v}$. goes beyond a catalogue of symptoms of old age, attempting to alleviate the realization of ageing with poetry in performance. ${ }^{47}$

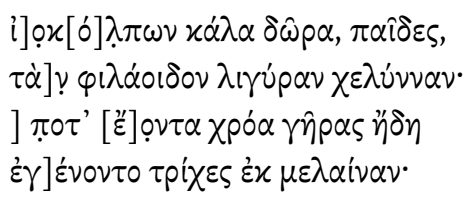

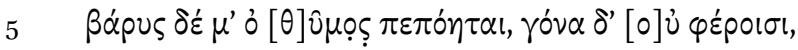

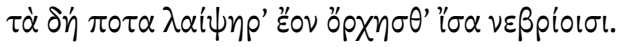

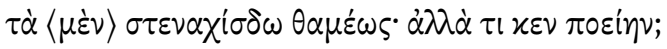

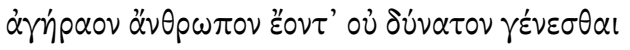

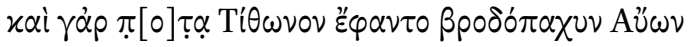

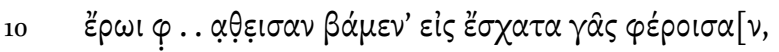

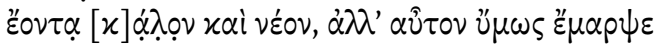

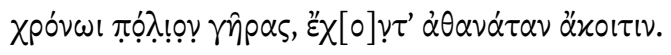

... the violet-rich Muses' fine gifts, children, ... the clear-voiced song-loving lyre. ... skin once was soft is withered now, ... hair has turned white which

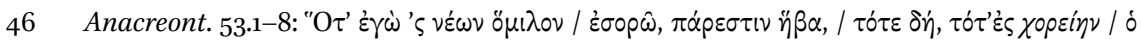

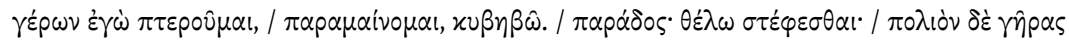

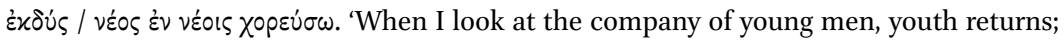
at such times in spite of my age I take wing for the dance. I am totally mad, I am frantic, I want to wear a garland: hand me one! Stripped of my old age, I shall dance, a young among the youths.' (trans. Campbell, with minor adjustments).

47 Text and translation of the 'Tithonus poem' are quoted from Obbink (2009); the translation is also Obbink's. I am sympathetic to the view of those who wish to include 'continuation $2^{\prime}$ as part of the poem or better as a possible version of the poem which survived in a longer and a shorter version, as in Lardinois (2009) 42-45 and 48; Boedeker (2009) 79-81; Nagy (2009) 186 proposes that the longer version would be more appropriate for performance during public events while the shorter for private; Greene (2009) 148, 158-160 aptly demonstrates how the two different endings affect the interpretation of the poem. That said, I choose not to include the continuation since it does not affect my discussion. 
once was black; my heart has been weighted down, my knees which once were swift for dance like young fawns fail me. How often I lament these things. But what can you do? No being that is human can escape old age. For people used to think that Dawn with rosy arms ... Tithonus fine and young to the edges of the earth; yet still grey old age in time did seize him, though he had a deathless wife.

The poetic 'I' addresses a chorus of young girls ( $\pi \alpha \hat{\imath} \delta \varepsilon \varsigma$ ), asking them to fetch a lyre under the tunes of which a performance is going to take place. There is no reference to actual dancing but the reference to the lyre cannot but lead to a performative context. The reference to a past choreia does occur later in the

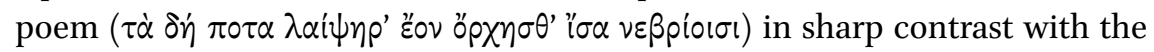
immobile limbs of the old poet. Sappho bemoans the fact that her poetic ability is reduced both because her thymos is now growing heavier but also because she cannot anymore be a part of a performing chorus. In this poem, then, the poet considers dancing to be an integral part of her own poetic performance. ${ }^{48}$

Moreover, the way Sappho stages space and time is very interesting. ${ }^{49}$ In talking about her aging, she does not merely list the symptoms of old age, as Anacreon does in $P M G 395 .{ }^{50}$ In Sappho old and young age are described at the same time, as the poet juxtaposes past and present. The poem is structured on antithesis: soft skin vs. wrinkles, white hair vs. black, light vs. heavy heart, nimble knees vs. stiff ones. The effect is then different from mere symptomatology,

48 Compare also Alcm. PMGF 26

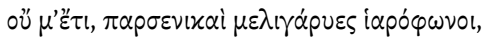

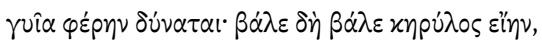

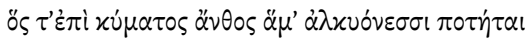

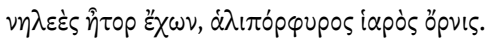

'No longer, honey toned, strong-voiced girls, can my limbs carry me. If only I were a cerylus, who lives along with the halcyons over the flower of the wave with resolute heart, strong, sea-blue bird' (trans. Campbell).

For a connection of the two fragments see also Lardinois (1994) 67 .

For an excellent discussion of temporal markers see Stehle (2009).

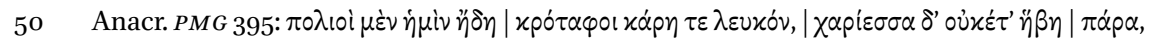

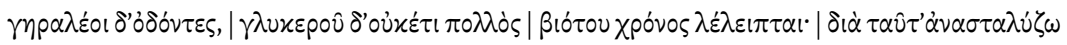

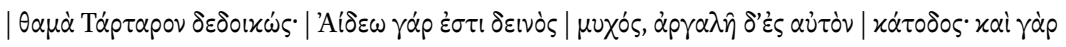

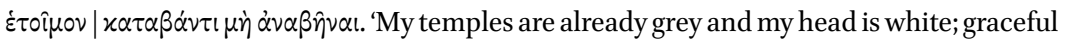
youth is no more with me, my teeth are old, and no long span of sweet life remains now. And so I often weep in fear of Tartarus: for the recess of Hades is grim, and the road down to it grievous; and it is certain that he who goes down does not come up again' (trans. Campbell). 
since her old body and young body are described at the same time, creating a visual —almost cinematic — effect: she is seen as both the old, wrinkly, whitehaired, immobile woman and the young, soft skinned, black-haired dancer. She is, in essence, cheating time. As in fr. $94 \mathrm{~V}$., time is then fluid, an effect visualized in performance. As the chorus of young girls dances, Sappho's past and present are both staged: they can still dance as fawns and by saying these words the 'young' Sappho can, again, dance. Differently from Tithonus' case, then, poetic immortality and eternal youth can be achieved in performance.

Sappho and Anacreon both provide us with poems dealing with old age and choreia. In both cases, literary tradition and testimonia attest to the fact that the two poets are considered to be choral; ${ }^{51}$ I would argue that this has to do with their reception as choral poets and with their highly visual poetic art. In the same context, representations of Sappho in vase paintings such as the red figure hydria from the Archaeological Museum in Athens insist on representing Sappho with a lyre, garlands, and scrolls of poetry flanked with female companions. ${ }^{52}$ It must be noted that no vase painting with a named Sappho leading a chorus has survived; but if in Sappho and Anacreon the idea of chorality is already in the poem itself, the poem creating and recreating its performance, then it is not surprising that artists tried to represent by means of their art that which Sappho represented in hers: the visualization of chorality.

Ruth Webb has argued that 'the rhetorical manuals reveal to the modern reader the rich network of ideas and assumptions that underlay the composition and reception of ancient texts. ${ }^{53}$ Hermogenes, then, emphasizing the pleasure via the senses as an effect of Sapphic poetry and Menander regarding choral dances as the sine qua non of a cletic hymn can shed some light on the assumptions of the ancient reader and the reception of the Sapphic text. On that note, I would further suggest that the insistence of later allusions to choral performances of Sapphic poetry (Gellius, Philostratus) can be taken as a possible indication of actual Sapphic chorality. This insistence, I submit, in using the vocabulary and imagery of choral singing and dancing may lead one to suspect that these were thought as indispensable characteristics of the Sapphic poetic identity. But more importantly, I hope I have shown that in Sapphic poetry imagery and the visualization point to a blurring of boundaries that can be better understood in a performative reality of choreia. In Sappho's poetry

$5^{1} \quad$ Yatromanolakis (2007) 64 and 85 points out that Sappho and Anacreon are the two most popular poets in vase paintings, where they are represented at the time of performance. On vase paintings and Sapphic performance see Yatromanolakis (2001) and (2007). More to the point Nagy (2007) 233-235, 226, 230, 243, who brings Sappho and Anacreon together.

Webb (2009) 4-5. 
the fixity and stability of a 'text' are undone by performance. For every time it is performed, the time and spatial markers of the poem (here-there, now-then) change. ${ }^{54}$ If the poem itself enforces time-, space- and voice-shifts, permitting fluidity and a blurring of boundaries, performance goes one step further. Space and time become even more fluid since 'here' and 'now' change with any given performance and the act of saying the words is not an attempt to fix the moment, but the acceptance of the impossibility of doing so.

\section{Works Cited}

Acosta-Hughes, B. (2010). Arion's Lyre: Archaic Lyric into Hellenistic Poetry. Princeton.

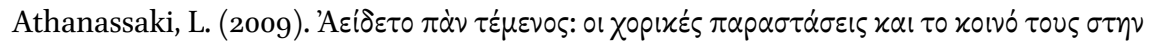

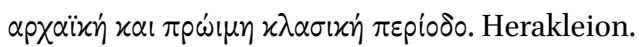

Bakker, E. (2009). 'Homer, Odysseus and the narratology of performance' in J. Grethlein and A. Rengakos (eds), Narratology and Interpretation: The Content of Narrative Form in Ancient Literature. Berlin: 117-136.

Bartsch, S. (1989). Decoding the Ancient Novel: the Reader and the Role of Description in Heliodorus and Achilles Tatius. Princeton.

Bartsch, S. and Elsner, J. (eds) (2007). CPh 102.1: Special Issue on Ekphrasis.

Burnett, A.P. (1983). Three Archaic Poets: Archilochus, Alcaeus, Sappho. London.

Calame, C. (1996). 'Sappho's group: an initiation into womanhood' in Greene (ed.) (1996): 113-124.

(2001). Choruses of Young Women in Ancient Greece: Their Morphology, Religious Role, and Social Function. Trans. D. Collins and J. Orion. Lanham, MD.

Campbell, D.A. (1982). Greek Lyric, I: Sappho and Alcaeus. Cambridge, MA.

Carey, C. (2009). 'Genre, occasion and performance' in F. Budelmann (ed.), The Cambridge Companion to Greek Lyric. Cambridge: $21-38$.

Dubel, S. (2009). 'Colour in Philostratus' Imagines' in E. Bowie and J. Elsner (eds), Philostratus. Cambridge: 309-321.

Fairbanks, A. (1931). Philostratus. Imagines. Cambridge, MA.

Fowler, D.P. (1991). 'Narrate and describe: The problem of ekphrasis'. JRS 81: 25-35.

Gentili, B. (1988). Poetry and its Public in Ancient Greece:From Homer to the Fifth Century. Trans. A.T. Cole. Baltimore.

54 See Bakker (2009) 122-125 who coins the term 'projected indexicality'. According to him, when statements containing deictic references are meant to be performed (and reperformed) their inbuilt 'hereness' or 'nowness' are projected. For the polysemy of deixis in the performance and reperformance of Pindar and Bacchylides see Athanassaki (2009). 
Goldhill, S. (1994). 'The naïve and knowing eye: Ecphrasis and the culture of viewing in the Hellenistic world' in S. Goldhill and R. Osborne (eds), Art and Text in Ancient Greek Culture. Cambridge: 197-223. (2007). 'What is ekphrasis for?' in Bartsch and Elsner (eds) (2007): 1-19.

Greene, E. (2009) 'Sappho 58. Philosophical reflections on death and aging' in Greene and Skinner (eds) (2009): 147-161.

Greene, E. (ed.) (1996). Reading Sappho: Contemporary Approaches. Berkeley.

Greene, E. and Skinner, M.B. (eds) (2009). The New Sappho on Old Age: Textual and Philosophical Issues. Washington, DC.

Hallett, J. (1979). 'Sappho and her social context: Sense and sensuality'. Signs 4:447464.

Ladianou, K. (2005). 'The poetics of choreia: Imitation and dance in the Anacreontea'. QUCC 80: 47-60.

Lardinois, A. (1994). 'Subject and circumstance in Sappho's poetry'. TA PA 124: 57-84.

- (1996). 'Who sang Sappho's songs?' in Greene (ed.) (1996): 150-172.

(2001). 'Keening Sappho' in A. Lardinois and L. McClure (eds), Making Silence Speak: Women's Voices in Greek Literature and Society. Princeton: 75-92.

Leach, E.W. (1988). The Rhetoric of Space: Literary and Artistic Representations of Landscape in Republican and Augustan Rome. Princeton.

Nagy, G. (2007). 'Did Sappho and Alcaeus ever meet?' in A. Bierl, R. Lämmle and K. Wesselmann (eds), Wege zu einer mythisch-rituellen Poetik bei der Grieschen. MythosEikonPoesis 1.1: 211-269.

- (2009). "The "new Sappho" reconsidered in the light of the Athenian reception of Sappho' in Greene and Skinner (eds) (2009): 176-199.

Obbink, D. (2009). 'Sappho fragments $5^{8-59}$. Text, apparatus criticus, and translation' in Greene and Skinner (eds) (2009): 7-16.

Parker, H. (1993). 'Sappho schoolmistress'. TAPA 123: 309-351.

Peponi, A.E. (2009). 'Choreia and aesthetics in the Homeric Hymn to Apollo: The performance of the Delian Maidens (lines 156-164)'. cA 28.1: 39-70.

Rolfe, J.C. (1968-1978). The Attic Nights of Aulus Gellius. Cambridge, MA.

Shaffer, D. (1998). 'Ekphrasis and the rhetoric of viewing in Philostratus' imaginary museum'. Philosophy \& Rhetoric 31.4: 303-316.

Stehle, E. (2009). “'Once” and "now." Temporal markers and Sappho's self-representation' in Greene and Skinner (eds) (2009): 118-130.

Steiner, D. (2011). 'Dancing with the stars: Choreia in the third stasimon of Euripides' Helen'. CPh 106.4: 299-323.

Webb, R. (2009). Ekphrasis, Imagination and Persuasion in Ancient Rhetorical Theory and Practice. Farnham.

Winkler, J. (1990). The Constraints of Desire. The Anthropology of Sex and Gender in Ancient Greece. New York. 
Whitmarsh, T. (2013). Beyond the Second Sophistic: Adventures in Greek Postclassicism. Berkeley.

Yatromanolakis, D. (2001). 'Visualizing poetry: An early representation of Sappho'. CPh 96.2: $159-168$.

(2003). 'Ritual poetics in archaic Lesbos: Contextualizing genre in Sappho' in D. Yatromanolakis and P. Roilos (eds), Towards a Ritual Poetics. Athens: 43-59. (2007). Sappho in the Making: The Early Reception. Cambridge, MA. 


\title{
Imagining Images: Anacreontea 16 and 17
}

\author{
Ippokratis Kantzios
}

\begin{abstract}
Anacreontea 16

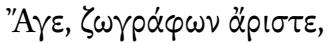
$\{\gamma \rho \alpha \dot{\varphi} \varphi, \zeta \omega \gamma \rho \alpha \dot{\varphi} \omega \nu \alpha а \alpha เ \sigma \tau \varepsilon$,

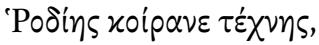
$\alpha \pi \varepsilon \circ \hat{\sigma} \sigma \alpha \nu, \dot{\omega} \varsigma \alpha \ddot{\nu} \varepsilon \| \pi \omega$,

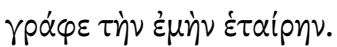

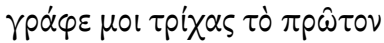

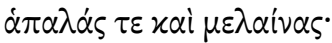

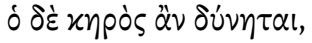

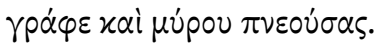

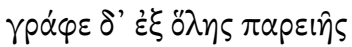
نं

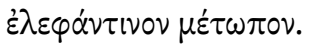

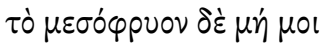
$\delta \dot{\prime}^{\prime} x \circ \pi \tau \varepsilon \mu \eta^{\prime} \tau \varepsilon \mu{ }^{\prime} \sigma \gamma \varepsilon$,

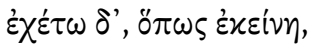

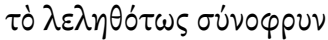

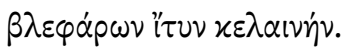

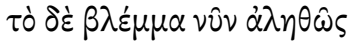

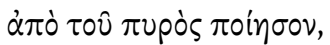

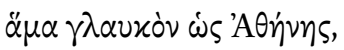

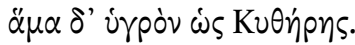

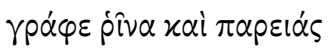

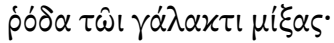

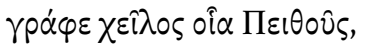
$\pi \rho \circ \kappa \alpha \lambda \circ \cup \dot{\mu \varepsilon v o v} \varphi \hat{i} \lambda \eta \mu \alpha$.

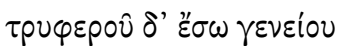

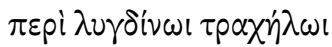

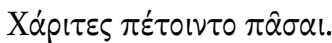

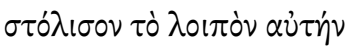

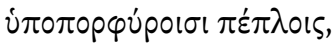

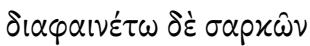

Come, best of painters, \{paint, best of painters\} master of the Rhodian art, paint my absent girlfriend, as I tell you.

First paint her hair soft and black; and if the wax can do it, paint it even perfumed with myrrh.

Paint her entire cheek and beneath the dark hair an ivory forehead. And neither divide nor join the part between her eyebrows, but, just as she has them, let them meet imperceptibly the dark rim of her eyelids. And make her gaze as it truly is, from fire, at once flashing, like Athena's and soft, like the Kytherean's. Paint her nose and cheeks having mingled roses with cream. Paint her lip like Persuasion's calling for a kiss. And under her tender chin may all Graces fly around her neck, white as marble. Adorn the rest of her with light-purple robes, but let a little of her flesh be seen through




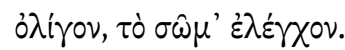

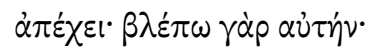

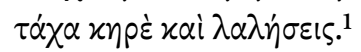

\section{Anacreontea 17}

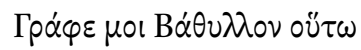

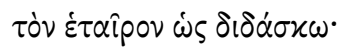

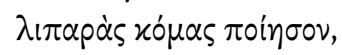
$\tau \dot{\alpha} \mu \varepsilon \dot{v} \nu{ }^{2} \nu \delta 0 \theta \varepsilon v \mu \varepsilon \lambda \alpha i v \alpha \varsigma$,

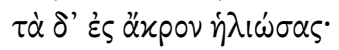

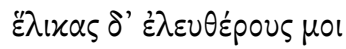

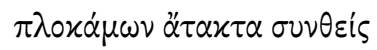

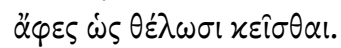
$\dot{\alpha} \pi \alpha \lambda \dot{o} v \delta \dot{\varepsilon} x \alpha \grave{l} \delta \rho \circ \sigma \omega \delta \varepsilon \varsigma$ $\sigma \tau \varepsilon \varphi \varepsilon \dot{\tau} \tau \omega \mu \dot{\varepsilon} \tau \omega \pi \circ \nu$ ò $\varphi \rho \hat{\varsigma} \varsigma$

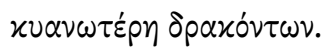

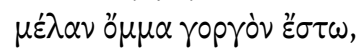

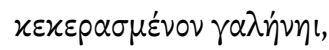

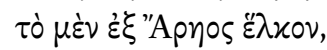

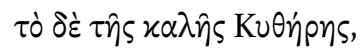

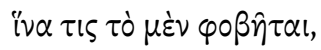

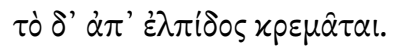

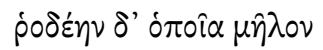

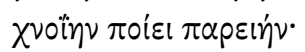

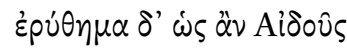

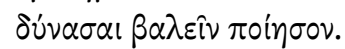

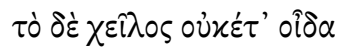

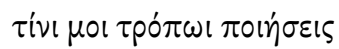
$\dot{\alpha} \pi \alpha \lambda o^{\prime}, \gamma \varepsilon \dot{\mu} \mu \circ \nu \tau \varepsilon \Pi \varepsilon \varepsilon \theta 0 \hat{\varsigma} \varsigma$

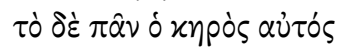
$\dot{\varepsilon} \chi \dot{\varepsilon} \tau \omega \lambda \alpha \lambda \omega \hat{\omega} \nu \sigma \omega \pi \hat{\eta} \iota$.

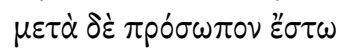

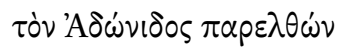

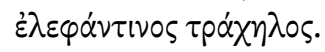

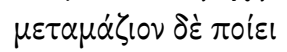

verifying (the beauty of) her body.

Hold! For I see her!

Soon, wax, you will even talk.

Paint for my sake Bathyllos, my beloved, just as I am instructing you: Make his hair shining, the parts beneath dark but the ends brightened by the sun. And having placed unconstrained curling locks, let them lie in disorder, as they wish.

And let his eyebrows, darker than snakes,

10 crown

his soft and dewy forehead.

Let his dark, grim eyes

be blended with calmness, the one deriving from Ares,

15 the other from the beautiful Kytherean so that someone may be in fear but also be suspended in hope. And make his downy cheek rosy like an apple.

20 If you can do it, place some red, like that of Modesty.

I no longer know in what way you will make his lips soft and full of Persuasion.

25 But let the wax itself attend to everything, speaking in silence.

And after his face, let there be an ivory neck superior to that of Adonis.

30 Make his chest

\footnotetext{
1 The text is according to West (1984). All translations are mine unless otherwise specified.
} 


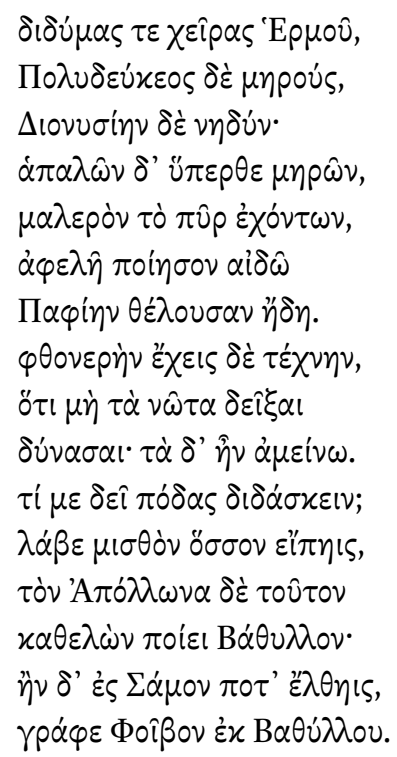

and his two hands like Hermes',

his thighs like Polydeukes' and his belly like Dionysus'.

Above his soft thighs, containing a mighty fire, make a brazen member already desiring the Paphian. But you have a grudging art because you are not able to show his buttocks; that would have been better. Why should I instruct you about his feet? Take your fee, as much as you say. Having removed this Apollo, make Bathyllos. paint Phoebus from Bathyllos.

Despite its name, the Anacreontea, a collection of sixty-two poems, was not written by Anacreon, as its first printed edition (Paris, 1554) led its audience to believe, but by anonymous imitators who lived from around the first century ВСE to the beginning of the Byzantine era. ${ }^{2}$ Not surprisingly, the corpus of Anacreon and that of his imitators have a number of traits in common, from the setting of performance - the symposion - to treatment of similar themes, mainly those of love, youth, old age and wine-drinking, all being expressions of the sympotic motif of carpe diem. ${ }^{3}$ Whereas Anacreon shows little interest in artifacts, the Anacreontea displays a keen interest in them, although not as finished objects of art already in use or display, but as works in progress, the completion of which advances simultaneously with the completion of the poems in which they appear. These artifacts have as their source the imagination of the poet and emerge through his instructions to particular craftsmen. ${ }^{4}$ In the two poems discussed here, the speaker bids a painter depict his beloved: a hetaira in 16 and an eromenos in 17. By fictionalizing the process by which language is transformed into image, the poems invite us to explore the inter-

2 For the dating of particular poems, structure and organization of the collection, see West (1984) xvi-xviii; Campbell (1988) 10-18; Rosenmeyer (1992) 123-146.

3 Cf. West (1990) 272-276; Ladianou (2005) 47-6o, who understands the references to dance (choreia) as the 'linguistic imprint' of an element present in Anacreon but absent in his imitators.

4 Poems 3, 16 and 17 are addressed to a painter; poems 4, 5 and 57, to a silversmith. 
actions between word and sight, not only abstractly but also in the context of their literary and cultural milieu, that is, the Greek East after the first century ВСЕ. I suggest that the speaker's response to the paintings differs from the usual patterns of viewing naturalistic art in that he perceives the depicted figures as reciprocating through their gaze, while, at the same time, he maintains an awareness of their artificiality and avoids being absorbed into their illusionist setting. Moreover, the speaker's narrative creates interplay between different levels of imagined realities and fusion of roles among the characters of the poems (and even between the poet/speaker and the reader), a fusion which generates a range of functional ambivalences and interdependencies.

The two poems, written in the Greek East of the post-Hellenistic period, are products of an environment well known for its interest in the complexities of viewing works of art. This interest is expressed primarily through the prominence of paintings and other artifacts in contemporary literature and also through the exploration of the concept of ekphrasis in the field of rhetoric. The varied modes of viewing, as depicted in one of its major literary genres, the Greek novel, have attracted increasing attention, and the study of subjects such as gaze, image, and description reveals their importance not only as narrative elements but also as metatextual references which shape our understanding of the author's voice in a fundamental way. ${ }^{5}$ But visuality is treated in other literary areas as well, especially in the sub-genre known as 'ekphrastic epigram', typically presenting a setting in which readers are invited to look at a painting and attempt to interpret it. Through such narrative frames and responses to works of art these epigrams generate sophisticated commentary not only on the aesthetics of the painting but also on the relationships between viewer and representation on the one hand, and viewer and cultural reception on the other. ${ }^{6}$ The instances of viewing in literature find their counterpart in the examination of similar ideas in the rhetorical handbooks of the time (Progymnasmata), containing exercises on topics appropriate for 'a descriptive account which brings the indicated event or object vividly before one's eyes. ${ }^{7}$ Such an account generates in the viewer a powerful mental representation, the technical term for which is $\varphi \alpha v \tau \alpha \sigma^{\prime} \alpha$. The ability of words to create the illusion of 'being there' was coveted in rhetorical circles because immediacy and a sense of presence were perceived as heightening emotions and thus facilitating per-

5 Bartsch (1989) 11-35; Whitmarsh (2002) 111-125; Morales (2004) 77-95; Webb (2009) 345-352.

6 See Goldhill (1994) 197-223.

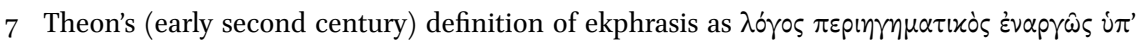

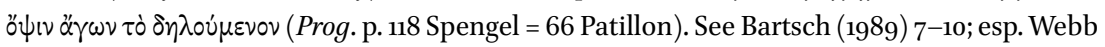
(2009) 39-6o. 
suasion. It is in these handbooks that we first encounter the term 'ekphrasis' and also detailed guidelines regarding the suitability of particular topics for ekphrastic treatment. Physical appearance of persons was one of the appropriate topics. ${ }^{8}$

Poems 16 and 17 reflect this culture of ekphrasis. ${ }^{9}$ Their vividness ('̇váp$\gamma \varepsilon(\alpha)$ is achieved through the effusiveness of the instructions pertaining to colors and shapes of the beloved's body and even to non-visual aspects, such as the softness of his flesh and perfume of his hair, elements which obviously cannot be depicted in a two-dimensional artifact. ${ }^{10}$ In both poems the composition proceeds in an orderly fashion, from top to bottom: the remarks about hair are followed by details about the various parts of the face (cheeks, brow, eyes, lips), then neck and finally torso, which is treated with distinct scopophilic earnestness. The hetaira's body is spared detailed description, but is nevertheless exposed with titillating voyeurism, as the speaker imagines her in essence undressed, her purple $\pi \dot{\varepsilon} \pi \lambda$ o revealing rather than concealing. ${ }^{11}$ Bathyllos receives an even more intrusive gaze, as the focus now turns on the youth's erect genitalia and attractive thighs and buttocks. ${ }^{12}$ These sexually arousing details are the final references to the beloved's body, as in both poems the speaker leaves his instructions unfinished, having already described a satisfying simulacrum.

The prevailing colors of the portraits are three, white, red, and black, indicated either by standard adjectives or nouns, such as $\mu \varepsilon \lambda \alpha i v \alpha \varsigma, \chi \varepsilon \lambda \alpha \iota v \eta^{\prime} \nu, \dot{\varepsilon} p \dot{-}$

$\pi \rho \delta ́ \sigma \omega \pi \alpha$ as an acceptable topic for ekphrasis appears in all surviving handbooks (Theon, ps. Hermogenes, Apthonios and Nikolaos). For a detailed list, see Webb (2009) 64 .

The detailed charts in Campbell (1988) 16-18 indicate that there is general agreement among the editors (Hanssen, Sitzler, Edmonds, Sánchez, West) that both poems are among the oldest of the collection; dialect, prosody and stylistic elements suggest a date in the first century of our era or probably later.

Cf. Philostratos the Elder, who in his work Eixóves brings up not only the literary and historiographical associations of the paintings but also non-visual elements which generate synaesthetic perceptions, see Bartsch (1989) 16; Manieri (1999) 111-121; Webb (2009) 187 on the sounds and scents of the painting as an important aspect of the perceptual world of the gallery.

11 Cf. Olson (2008) 94 on the male gaze as comparable to sexual penetration.

12 Shapiro (1992) 53-72. Sutton (1992) 21 discussing the Greek culture of male nudity notes that its pornographic effect cannot be dismissed, given the high visibility of pederasty and homosexuality: nude athletes and other figures, regardless of what else they stood for, were also understood as a source of sexual pleasure. For the interest of the Palatine Anthology in voyeuristic descriptions, see poems 10.20, 12.3, 12.95, 12.197, 12.207 (penis/male arousal); 12.6, 12.210, 12.222 (anus), all included in Hubbard (2003) 294-304. 
$\theta \eta \mu \alpha$, or by figures of speech: ivory, milk/cream $(\gamma \dot{\alpha} \lambda \alpha)$ and marble stand for

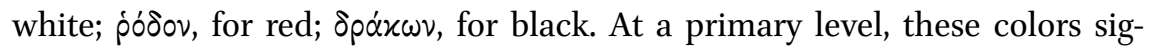
nify physical characteristics which, in turn, may suggest additional personal qualities: delicacy of complexion, for example, implies urbanity with its concomitants of luxury and sophistication; rosy cheeks allude to health and youth. But colors, especially in a figurative context, are also employed in ways which, to use Goldhill's expression, enable us 'to see the character in the image and the image as a mark of character. ${ }^{13}$ The ivory metaphor, for instance, appearing in both poems, has unmistakable cultural and mythological overtones: in the Odyssey (19.564) and the Aeneid (6.895-896) the gates of false dreams are made of this material; in Ovid's Metamorphoses, Narcissus notices the 'ivory' neck of his reflection (3.422), and Hermaphroditus, when he appears in the waters of the lake, is 'like an eburnean figure sealed up in clear glass' (4.353-355). ${ }^{14}$ Thus ivory is soft, warm, luxurious and exotic, alluding to the faraway places of its origin; but it combines these elements with an evocation of deceptiveness, elusiveness and distance. ${ }^{15}$ The póoov simile expresses a similar ambiguity: on the one hand the rose is a symbol of youth, erotic passion, divine beauty and poetic inspiration. On the other, its thorns can turn it into a dangerous possession, as we learn from various mythological tales. ${ }^{16}$ But while the red of the póoov, suggesting delicate freshness and divine allure, is encountered in both poems, another type of red, $\dot{\varepsilon} \rho \dot{\theta} \theta \eta \mu \alpha$, associated with Ai $\delta \dot{\omega} \omega$ (modesty, shame, regard for propriety), significantly appears on the cheeks of the eromenos alone. The beloved of 16 is a hetaira, a female whose profession renders it unlikely or even undesirable that she feel Ai $\delta \dot{\omega} \varsigma$; even when half-clothed she is exposed to the penetrating gaze of the male. On the other hand, because he too becomes the object of the speaker's pitiless voyeurism, the eromenos is expected to display a sense of Ai $\delta \omega \dot{\omega} \varsigma$ and thus preserve his respectability. ${ }^{17}$ Distinctions between the red of desire and the red of Ai $\delta \dot{\omega} \varsigma$ cannot be indicated, of course, by paint

\footnotetext{
13 Goldhill (1994) 213.

14 Skin viewed as ivory appears already in Il. 4.141-142.

15 Cf. Elsner (2007) 126; Salzman-Mitchell (2008) 296; Stoichita (2008) 7, 210 n. 5.

16 In the letters of Philostratos the Elder roses prick Aphrodite's feet; spring from the blood of dead Adonis; are woven by Medea into the crown that causes Glauke's death, see Rosenmeyer (1992) 210-211.

17 Cairns (1996) 79: 'Aidos traditionally is something that conceals, that prevents exposure; this is part of the fundamental association between aidos and the visual.' On blushing,

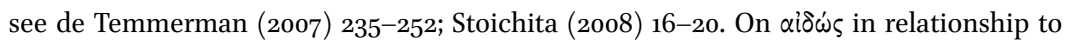
exposure and objectifying gaze, see Hubbard (2003) 10-11; Elsner (2007) 136; Olson (2008) 94-95.
} 
alone; ${ }^{18}$ and thus in his eagerness to portray the beloved in his fullness, the speaker imposes upon the painter an impossible task. Yet when the poet looks at the portrait, he thinks that his instructions have been carried out to perfection. His desire to see the beloved as he imagines him preconditions him to see precisely what he wishes.

Desire grows from absence, we are told, ${ }^{19}$ and both poems are expressions of absence: in 16, the speaker informs us directly that his beloved is $\dot{\alpha} \pi \varepsilon \circ \hat{\sigma} \sigma \alpha$ (4), and in the last lines of 17 he indicates that the setting of the poem is at a place other than Samos, the island associated with Bathyllos (and, of course, Anacreon). To fill the void the speaker commissions a portrait, which gives him the opportunity to transcend the separation by speaking about the beloved. Roland Barthes, discussing a similar subject, notes that absence is always an unsustainable situation because it generates a clash between two time spheres, with the beloved being absent as referent but present as thought or subject of discussion: to talk about the absent is to postpone the sense of abandonment and loss. ${ }^{20}$ The ancients, too, from early on seem to have been aware of the uses of language as a compensation for absence: in Homer, the invocations to the Muses can be seen as mediation between word and sight ${ }^{21}$ and Demodokos' retelling of the war is credited by Odysseus as having the power of an eyewitness' account ( $\alpha \dot{\tau} \tau \dot{\text { jo }} \pi \alpha \rho \varepsilon \omega \dot{\omega} \nu, O d$. 8.491) which revives the

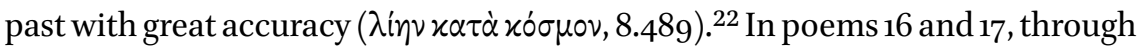
the $\dot{\varepsilon} \dot{\alpha}^{\prime} p \gamma \varepsilon ı \alpha$ (vividness) of his own words and the dexterity of the painter, the poet transfers the mental representation $\left(\varphi \alpha \nu \tau \alpha \sigma^{\prime} \alpha\right)$ of his absent beloved onto an actual canvas in such a way that the eye is fooled into believing that it sees

18 Cf. Philostratos' treatment of colors in Manieri (1999) 111-121 and Dubel (2009) 309-321.

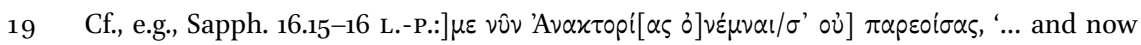
she reminds me of Anaktoria, who is not present'; 94.1-2: $\tau \varepsilon \theta \nu \alpha \dot{\alpha} \eta \nu \nu \delta^{\prime} \dot{\alpha} \delta \dot{\delta} \lambda \omega \varsigma \theta \varepsilon \dot{\varepsilon} \lambda \omega$. / $\ddot{\alpha} \mu \varepsilon$ $\psi(\sigma \delta \circ \mu \varepsilon \dot{v} \alpha \alpha \alpha \tau \varepsilon \lambda i \mu \pi \alpha v \varepsilon v$, 'Honestly I wish I were dead; she, in tears, was leaving me ...'; 96.6-

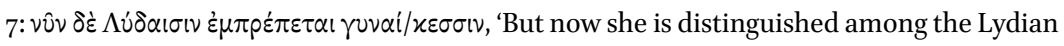
women'.

20 Barthes (1978) 13-17. Socrates seems to allude to the same notion, when he scolds teasingly

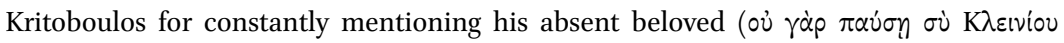
$\mu \varepsilon \mu \nu \eta \mu \varepsilon ́ v o \varsigma ;$ Xen. Symp. 4.21).

21 Cf. Hardie (2002) 4: 'The Muses, present always and everywhere, are called on to be present to the poet at the moment of composition; Muses and poet are in turn conduits of real presence to the reader, transforming memory of the past into an experience of being present at the time.'

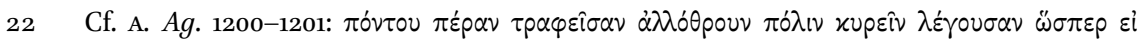
$\pi \alpha \rho \varepsilon \sigma \tau \dot{\alpha} \tau \varepsilon I \zeta$, 'Although you [sc. Kassandra] have been bred across the sea, you speak about a foreign city correctly, as if you had been here'. 
the real person. ${ }^{23}$ Mimesis plays its trick. In commemorating the absent-asreferent the poet and artist together make present the absent-as-thought.

It is precisely this power of naturalism to fool the eye - and the mind - that lies behind familiar tales such as the ones in which a handsome young man is captivated by his own reflection, thinking it is a lover; a sculptor falls in love with his statue of a beautiful woman (and even tries to have intercourse with it); or birds confuse painted grapes for real ones. In the same way, the speaker in the Anacreontea succumbs to the disorienting effects of illusion; for as the image on the canvas becomes increasingly complete, he is overwhelmed by its sight and begins to believe that it responds to him, until he ends his narrative abruptly, as if unable to bear the awakened awareness of the beloved's absence. This tension between the speaker and the image is different, however, from the tension often associated with the viewing of mimetic art in two respects: a) the speaker thinks that he is perceived reciprocally by the depicted beloved, but b) he manages to maintain an awareness of the true nature of the image as a painting.

One of the traps of naturalistic representation is that while it invites the viewer to participate in its illusion, at the same time it makes this participation impossible. It has been noted that mimesis operates independently of the viewer, and thus it produces only implausible yearning and frustrated desire. ${ }^{24}$ Yet in poems 16 and 17 the speaker believes that he interacts with the image through exchanges of gaze. In fact, in both portraits the eyes become a focal point: in 16, the hetaira responds with a fiery and soft look that forbids and at the same time welcomes; while the promise in Bathyllos' eyes is tempered with a shadow of inapproachability, suggestively conveyed by the use of the adjective ropyóv (fierce, grim), which brings to mind the Gorgons of the myth, transforming anyone they looked at into a stone. ${ }^{25}$ His gaze clearly has power

23 Pliny (Nat. 35.43) in fact suggests that the invention of clay portraiture is associated with the solitude of the lover left behind: 'Modeling portraits from clay was first invented by Boutades, a potter of Sicyon, at Corinth. He did this owing to his daughter, who was in love with a young man; and she, when he was going abroad, drew in outline on the wall the shadow of his face thrown by a lamp. Her father pressed clay on this and made a relief.' (Translated by H. Rackham, Loeb Classical Library). I owe this reference to Françoise Letoublon.

24 See Elsner (2007) 24; Lacan (1979) 67-119. Art's inability to substitute for reality is expressed

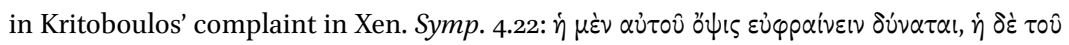

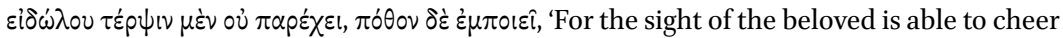
me up, but the sight of the image provides no delight, while it creates desire'. I owe this reference to Anastasia-Erasmia Peponi.

Cf. the nuanced translation of the poem in Hubbard (2003) 306. 
to impact the viewer. But even in their severity the beloved's eyes open a door for the viewer into the image's realm and break the self-containment of naturalistic art, because 'seeing and being seen are means of engaging the world, constituting the self, and fulfilling desires. ${ }^{26}$

Despite this engagement resulting from the imagined establishment of reciprocal gaze, the speaker paradoxically is not absorbed into the illusionist reality. On the contrary, he displays a strong awareness that the painted beloved is just that and nothing more. In fact, one of the salient elements in both poems is the centrality which the artifact achieves precisely as artifact: the intense anaphora of $\gamma p \alpha \dot{\alpha} \varphi \varepsilon$ (seven times in poem 16 alone), verbs of poiesis

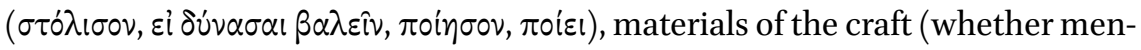
tioned literally—xnpós—or figuratively—

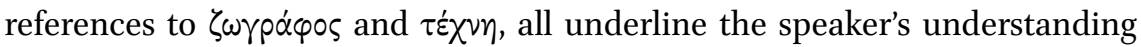
that the painted figure is, in Plato's words, in appearance only like the original object, while, in fact, not real. ${ }^{27}$ The limitations of naturalistic art, however, do not diminish the speaker's enthusiasm for it: while he recognizes that a two-dimensional image cannot reproduce three-dimensionality (and thus the painting cannot render at once Bathyllos' genitalia and also his buttocks), he downplays this limitation by attributing it to $\varphi$ Oóvos (grudge) rather than lack of power on the part of art. ${ }^{28}$ It is significant that both poems end not with a reference to the beloved but to the craftsman's work. ${ }^{29}$

And yet the craftsman's work exists for the memorialization of the beloved. Indeed what an ideal beauty the pictures reveal! The eyes of the hetaira are flashing, like Athena's, and soft ('moist'), like Aphrodite's; the neck of Bathyllos

26 Nelson (2000) 8-9 in his discussion of Lacan; also Quinet (1995) 139-148.

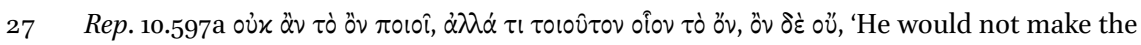
real thing but something similar to the real thing, but in fact not real'. On Plato's notions on art and imitation, see Hyman (2006) 59-72. On the limitations and dangers of replication of reality, see Bryson (1983); Elsner (2007) 1-26; Stoichita (2008).

28 It is an irony that despite the speaker's belief in the supremacy of visual art, his poetry/verbal skill proves more effective: by alluding to (and thus, in a sense, already displaying) the desirability of the beloved's body in its totality he achieves what the painter cannot. Cf. Dubel (2009) 319-320 on the ability of words to give the painting its synaesthetic power; also Stoichita (2008) 6 on the primacy of the text in the artistic process. For the ancients' notions of visual representation as opposed to representation by poetry, see Sharrock (1996) 103-106.

29 Cf. the almost forced emphasis on paintings in the Greco-Roman novels. These paintings, besides their interpretive/metatextual function (Bartsch [1989] 11-35; Morales [2004] 7795), also draw attention to the artifice of the novel per se, see Maeder (1991) 1-33; Webb (2009) $310-35^{2}$. 
is finer than Adonis', while his chest and hands are like Hermes', his thighs like Polydeukes' and his stomach like Dionysus'. Such superlative language points to a truly rare countenance, divine rather than human in its perfection. Upon closer inspection, however, one realizes that the verbal portraits of the two objects of desire are quite clichéd. Martin West's edition, with its generous apparatus, makes it abundantly clear that the images, as projected by the speaker, are hardly the representation of particular individuals, but rather the summation of generic beauty, as depicted in Hellenistic and subsequent literature, especially the Palatine Anthology. The flashing and melting eyes, the rosy and white cheeks, the inviting mouth, the perfumed hair, the revealing purple dress, erotic $\Pi \varepsilon \imath \theta \dot{\omega}$, and so on, all prove to be poetic topoi. In other words, the speaker in 16 and 17 employs signifiers of beauty not unique, as he believes the beauty of his beloved to be, but rather collected from the repository of stock similes and metaphors commonly used in Hellenistic, Greco-Roman and Latin poetry.

Does the poet really believe his beloved is as beautiful as the gods, or is this extravagant description simply lack of originality on his part? Norman Bryson in his discussion of Lacan points out that visuality is a cultural construct, an experience determined by 'a screen of signs consisting of all the multiple discourses on vision built into the social arena. ... Seeing is social, that is, an articulation of our retinal experiences with the codes of recognition that come to us from our social milieu. ${ }^{30}$ More simply, we see beauty the way we have been taught to see it, and we express it with the verbal or visual means which our social environment has handed us. Lacan speaks in broad psychoanalytical, almost sociological, terms, but since visuality is discussed here in a poetic context, it is advisable to narrow the focus and replace 'social milieu' with 'literary milieu', especially since the latter is an aspect of the former. Thus the portraits in 16 and 17 reveal the fantasies of a lover who perceives the beloved as an idealized object of desire and expresses this perception through the medium of a recognized literary discourse. The attribution, then, of divine beauty to the beloved does not necessarily reveal delusion on the part of the speaker, but rather his wish to stay within (or his inability to break from) the well-traveled path with its conventionalized imagery for the expression of erotic desire. ${ }^{31}$

$30 \quad$ Bryson (1987) 91-92.
31 Cf. the propensity of the Greco-Roman novel to depiction of human beauty in divine over-
tones, e.g. Chariton, Khaireas and Kallirhoe: 'Her beauty was not human, but divine ... (like
that) of maiden Aphrodite ...' (1.1.2). 'When she walked in public, wonder possessed the
entire crowd, just as when Artemis appears to hunters in remote places' (1.1.16). Xenophon,
An Ephesian Tale: 'The beauty of his body was surpassing ... and all looked at the boy like 
An examination of the relationships among the characters of the two poems (the poet/speaker, the artist and the beloved) and also between the poet and the reader suggests that there is interplay between different levels of fictionality and also a shifting fusion of roles. To start with the poet in relationship to the painter: in both 16 and 17 , from early on the poet consciously blurs the territories of verbal and visual representation through the repetition of the term $\gamma p \alpha \dot{\alpha} \varphi \omega$, which connotes both pictorial and authorial activity. ${ }^{32}$ The poet acts as if perceiving the artist as an extension of himself, an alter ego of his poetic persona. In fact the speaker seems to produce his instructions with the intent of facilitating the artistic process, by which the drawing of the human figure begins at the head and works its way down. ${ }^{33}$ Moreover, the fact that the poet is here a lover enhances his similarity to a painter, for, to recall Plutarch, he constructs and carries the image of the beloved in his heart. ${ }^{34}$ The affinities of

a god. And there were already some who, when they saw him, prostrated and prayed ...' (1.1.1-3). 'Her body was a flower of beauty ... Often the Ephesians prostrated before her, as if before Artemis ... some saying she is the goddess herself' (1.2.5-7). Heliodorus, An Ethiopian Story: 'A girl was sitting on a rock, her beauty incredible, giving the impression she was a goddess' (1.2.1). The poet of 17 may even have been inspired by Anacreon himself, who, it is said, claimed that he did not write hymns to the gods because his gods were the

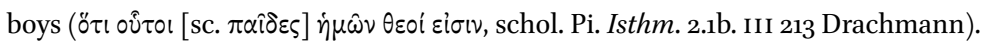

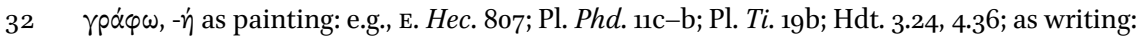
e.g., Pl. Phdr. 274b, 276c; Hdt. 1.125; Pi. O. 10.3; etc. In Longus' prologue to Daphnis and Chloe,

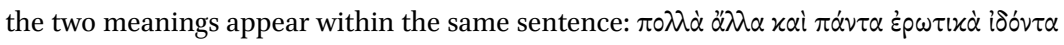

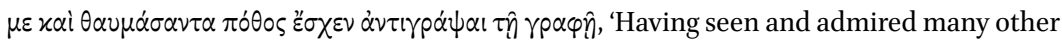
things, all of them related to love, I was seized by desire to write in response to the picture'. The similarities between written word and painting were noticed by Plato, although with

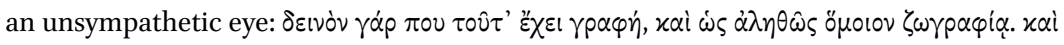

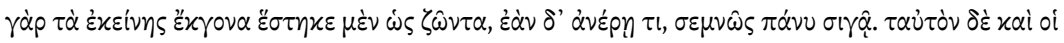
$\lambda \hat{o}^{\prime} \mathrm{ol}$, 'For writing has this strange feature, and it is truly similar to painting: for its offspring stand there as if alive, but if you ask them something, they are solemnly silent altogether. The same applies to [written] words' (Phdr. 275d).

33 See Vermeer's 'The Artist's Studio' (1665), in which the painter is depicted as starting the drawing of his female model from the head, and specifically her hair and flower crown. In manuals on how to draw the human figure, the reader is invariably advised to proceed from top to bottom.

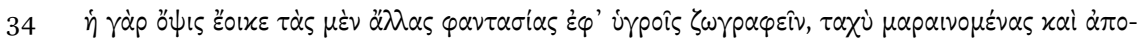

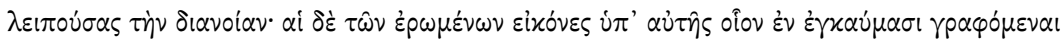

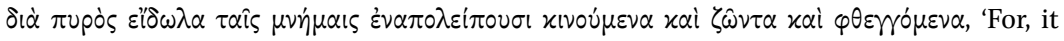
seems, vision paints other representations on wet surfaces, which fade swiftly and become forgotten. But the pictures of lovers, painted by it [vision] with fire, as in encaustic paintings, leave in the memory images which move, are alive and speak' (Plut. Amat. 759c.). In 
poetic and artistic action are underlined even further by the fact that in the two poems the portraits are works in progress. While a completed painting offers itself in wholeness at once, a verbal description of the same image is by necessity fragmented and sequential. ${ }^{35}$ In the two poems, however, there is symmetry between verbal and visual representation in that the image is revealed in both cases only gradually. For the internal viewer (poet, painter) and external one (reader) the figures of the beloved materialize with complete synchronicity, as verses and brushwork advance simultaneously.

As for the poet in relationship to his beloved: in the last decades, there has been extensive discussion (with various degrees of rigidity) of the sociopolitical empowerment of the objectifying gaze, which could inform our approach to the two poems beneficially. ${ }^{36}$ The reader however does not fail to recognize that this empowerment is not unconditional and that the lover, although in control of the visual pleasure, is "in fear" and also 'suspended by hope' (17.1617) at the prospect of winning his beloved. At least in the case of Bathyllos, the poem suggests that he wields considerable leverage over his admirer, which arises perhaps from his civic/social status and certainly his attractive form. For 'simple demographic reckoning tells us that eligible youths in that short-lived, but most desirable, window of efflorescence (from about fourteen to eighteen) were far fewer in numbers than the adult lovers who might pursue them: ${ }^{37}$ Despite his intrusive gaze, the speaker's dominance here is not unequivocal, as the beloved responds with a look resonant with ambiguity. In fact this lack of easy responsiveness, a staple in erotic poetry, ${ }^{38}$ reinforces the notion that the objects of desire are depicted stereotypically, whether this depiction has roots in reality or not; they are fictions of fashionable erotic partners. The hetaira of 16, like the puella of Roman elegy, does not even have a name. 'Bathyllos', we

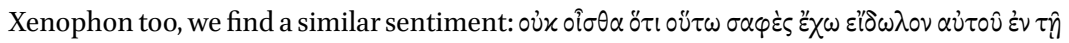

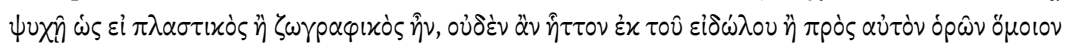
$\alpha \dot{\tau} \tau \hat{\omega} \dot{\alpha} \pi \varepsilon i \rho \gamma \alpha \sigma \dot{\alpha} \mu \eta v$; 'Don't you know that I have such a clear picture of him [the beloved] in my heart that if I were a sculptor or a painter I could produce a likeness of him not less perfect from the picture than from looking directly at him?' (Xen. Symp. 4.21). Cf. Shakespeare's sonnet 24.1-2: 'Mine eye hath played the painter and hath stelled / Thy beauty's form in table of my heart.'

35 Cf. Sharrock (1996) 103-130.

36 For an overview of gender-sensitive studies of scopophilia and especially of the female as an erotic spectacle, see Salzman-Mitchell (2005) 6-21.

37 Hubbard (2003) 10-11.

38 Esp. in Anacreon's poetry, the model for the Anacreontea, lack of fruition in erotic pursuits is a perennial motif, see Kantzios (2010) $577^{-589}$. 
know, was a literary eromenos of Anacreon, ${ }^{39}$ who lived at least five centuries before the poet of 17. Our Bathyllos, then, is the reincarnation of a beloved who sprang out of the verses of the great archaic poet and has now been recast with the idealizing markers de rigueur of the Hellenistic and Greco-Roman period. But Bathyllos as an eromenos requires an Anacreon as a lover. Thus in 17, the poet imagines himself as Anacreon imagining his eromenos being imaginedand portrayed — by a painter.

This painter's role is ambivalent: on the one hand he yields to the authority of the speaker and faithfully transforms his words into visual images. On the other, through the lifelikeness of his images he too becomes a figure of authority, creating poetry like the speaker. For in both portraits the lips of the beloved exude $\pi \varepsilon \theta \theta \dot{\omega}$ (persuasion, seduction) through words which the lover expects to

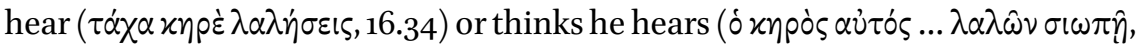
17.25-26). Thus in the two poems poetry turns into image, and conversely image into poetry. Words paint pictures, paintings speak. ${ }^{40}$

As for us the readers, are we not in complicity with the speaker, when, listening to his words, we generate a mental image, a $\varphi \alpha v \tau \alpha \sigma i \alpha$ of the beloved that fits our sensibilities, conforms to our aesthetic predilections and activates our longings? In a sense we are like the painter, following orders, and we too are called upon to transform language into images, although on the canvas of our imagination. But we are called upon to do more than that: theoretical studies in the last decades inform us of the intricacies of the relationship between author and reader. ${ }^{41}$ The latter is also a co-creator, the agent who through his experiences negotiates the text and ultimately controls its meaning. Thus even before we transfer the instructions of the poet into the visual sector of our brain we insert into them the values of the 'interpretive community' to which we belong and adapt them sufficiently to make them our own. There should be

39 A.Pl. 306, 307; A.P. 7.30, 31; Anacr. PMG 402, 471, 503.

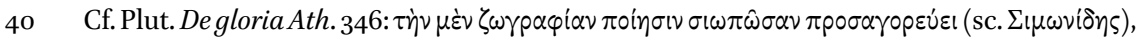

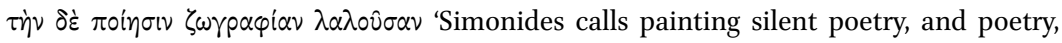
painting that speaks'. See also Olson (2008) 5 on the ability of pictures to impose meaning immediately, without analyzing or diluting it.

41 See especially the reader-response approach, as developed by theorists such as S. Fish, W. Iser, N. Holland and H. Jauss, according to whom reading a text can be seen in many ways as analogous to performing a musical composition. The meaning of the text is determined not by the author but the reader, who is the final arbiter through a negotiable relationship with the written word. Cf. Elsner (2007) 122: 'The theme of Pygmalion as a viewer is itself a metaphor for the reader as creator of his own narrative, his own reality out of the text.' 
no doubt that there are as many distinct mental portraits of the two objects of desire as there are readers of the poems. The reader is both painter and poet along with the characters in the poem.

Anacreontea 16 and 17 differ from the ekphrastic epigrams and even more from the Greek novels (both of which are loaded with metatextual or authorial concerns $)^{42}$ because their narrative framing is minimal and the images themselves bare of editorial commentary. But this editorial absence should not be taken necessarily as a lack of self-awareness on the part of the poet, for he navigates competently not only through the various levels of imagined realities but also through the normative codes of looking at art. Thus the emerging portraits in their fictionalized settings are complex. They function, on the one hand, as a remedy for absence and as a fulfillment of the desire for erotic reciprocity; and, on the other, as agents of visual gratification or objectification through the verbalization of the beloved's beauty. In fact, the beloved's objectification is carried even further in another way: in poem 17 , the speaker, with his suggested replacement of the portrait of Apollo with that of Bathyllos, moves viewing from the private realm of the lover's eye into the public sphere. This movement transforms the beloved into a sight for public consumption and cancels his privileged relationship with one particular lover. It is an irony that for the speaker this act of ultimate alienation is understood as a token of intimacy. In a sense, however, this objectification brings the circle to its completion: through the use of commonplace poetic language, the public domain has provided the poet with the materials for the creation of the Ideal Intimate. Now this Ideal Intimate, through the public display of his portrait, is returned to common view not as an object of private desire, but as a kind of a Universal Beloved, the embodiment of Everyman's fantasies.

In closing, Anacreontea 16 and 17 are part of a cultural milieu which cultivated a keen interest in the complexities of viewing mimetic art. The two verbal portraits, through their vividness and detailed instruction, strive for complete lifelikeness of the absent beloved, at least as the speaker imagines it, a lifelikeness which does not confine itself to form alone but reveals aspects of character as well. The speaker does succumb to the effects of naturalist illusion, in fact he even thinks that the depicted figures respond to him through reciprocal gaze; yet he manages to maintain an awareness of the true nature of the images as paintings. The images themselves become the occasion for fusion of roles and the nexus of interactions among the characters of the two poems and also between the poet and the reader. The instructions to the artist and the speaker's 
response to the images indicate that the poet is cognizant of certain important aspects of the relationships between word and sight, viewer and representation. In fact the poet brings forth these relationships in a spirit of sophisticated playfulness: in the end, poems 16 and 17 discuss mimesis while they themselves are a mimesis of the poetry of Anacreon. ${ }^{43}$

\section{Work Cited}

Barthes, R. (1978). A Lover's Discourse: Fragments. New York.

Bartsch, S. (1989). Decoding the Ancient Novel: the Reader and the Role of Description in Heliodorus and Achilles Tatius. Princeton.

Bryson, N. (1983). Vision and Painting: the Logic of the Gaze. New Haven.

(1987). 'The gaze in the expanded field' in H. Foster (ed.), Vision and Visuality. Seattle: $87-113$.

Cairns, D.L. (1996). “'Off with her AIDOS”: Herodotus 1.8.3-4'. cQ 46: 78-83.

Campbell, D.A. (1988). Greek Lyric, II. Cambridge, MA.

Dubel, S. (2009). 'Colour in the Imagines of Philostratus'. in E. Bowie and J. Elsner (eds), Philostratus. Cambridge: 309-321.

Elsner, J. (2007). Roman Eyes: Visuality and Subjectivity in Art and Text. Princeton.

Goldhill, S. (1994). 'The naive and knowing eye: Ecphrasis and the culture of viewing in the Hellenistic world' in S. Goldhill and R. Osborne (eds), Art and Text in Ancient Greek Culture. Cambridge: $197-223$.

Hardie, P. (2002). Ovid's Poetics of Illusion. Cambridge.

Hubbard, T. (2003). Homosexuality in Greece and Rome: A Sourcebook of Basic Documents. Berkeley.

Hyman, J. (2006). The Objective Eye: Color, Form, and Reality in the Theory of Art. Chicago. Kantzios, I. (2010). 'Marginal voice and erotic discourse in Anacreon'. Mnemosyne 63: $577-589$.

Lacan, J. (1979). The Four Fundamental Concepts of Psycho-Analysis. Harmondsworth.

Ladianou, K. (2005). 'The poetics of choreia: Imitation and dance in the Anacreontea'. QUCC 80: 47-6o.

Maeder, D. (1991). 'Au seuil des romans grecs: Effets de réel et effets de création'. Groningen Colloquia on the Novel 4: 1-33.

Manieri, A. (1999). 'Colori, suoni e profumi nelle Imagines: Principi dell'estetica filostratea'. Qucc 63: 111-121.

43 Many thanks to the anonymous referees and the audience of the conference at Delphi for their helpful suggestions; also to Niki Kantzios for her editorial eye. 
Morales, H. (2004). Vision and Narrative in Achilles Tatius' Leucippe and Clitophon. Cambridge.

Nelson, R.N. (2000). Visuality Before and Beyond the Renaissance. Cambridge.

Olson, K. (2008). Dress and the Roman Woman: Self-Presentation and Society. London.

Quinet, A. (1995). 'The gaze as an object' in R. Feldstein, B. Fink and M. Jaanus (eds), Reading Seminar XI: Lacan's Four Fundamental Concepts of Psychoanalysis. Albany: 139-148.

Rosenmeyer, P.A. (1992). The Poetics of Imitation: Anacreon and the Anacreontic Tradition. Cambridge.

Salzman-Mitchell, P. (2005). A Web of Fantasies: Gaze, Image, and Gender in Ovid's Metamorphoses. Columbus.

(2008). ‘A whole out of pieces: Pygmalion's ivory statue in Ovid's Metamorphoses'. Arethusa 41: 291-311.

Shapiro, H.A. (1992). 'Eros in love: Pederasty and pornography in Greece' in A. Richlin (ed.), Pornography and Representation in Greece and Rome. New York: 53-72.

Sharrock, A. (1996). 'Representing metamorphosis' in J. Elsner (ed.), Art and Text in Roman Culture. Cambridge: 103-130.

Stoichita, V.I. (2008). The Pygmalion Effect: from Ovid to Hitchcock. Chicago.

Sutton, R. (1992). 'Pornography and persuasion in Attic pottery' in A. Richlin (ed.), Pornography and Representation in Greece and Rome. New York: 3-35.

de Temmerman, K. (2007). 'Blushing beauty: Characterizing blushes in Chariton's Callirhoe'. Mnemosyne 6o: 235-252.

Webb, R. (2009). Ekphrasis, Imagination and Persuasion in Ancient Rhetorical Theory and Practice. Surrey.

West, M.L. (1984). Carmina Anacreontea. Leipzig. 1990. 'The Anacreontea' in O. Murray (ed.), Sympotica. Oxford: $272-276$.

Whitmarsh, T. (2002). 'Written on the body: Ekphrasis, perception and deception in Heliodorus' Aethiopica'. Ramus 31: 111-125. 
978-90-04-31484-9

Downloaded from Brill.com $\odot 4 / 26 / 2023$ 12:27:28PM via free access 


\section{Index}

Aeschylus 150, 153

Agamemnon 231-232

Danaids 199-200

Eumenides 22-23

Mysians 55

Seven Against Thebes 217-234

parodos 220-224

$563-566 \quad 230-231$

Suppliants 231-232

Telephus 55

Aesop 118-119, 123-125, 130, 142

Agathon 6

Alcaeus 14, 66, 153, 175, 192, 322

fr. $129115 \mathrm{n} 31$

fr. $140 \quad 204-207,215$

fr. $141 \quad 153$

fr. $249 \quad 166$

fr. 345153,167

fr. $348 \quad 167$

Alcman 13, 195, 271, 363, 343, 347

PMGF

$1 \quad 3,76-77,96,198$ n $35,219-220,257-$ $260,268,272,302$

3 260-262, 297-298, 363n 43

$26 \quad 323-324,365 n 48$

Alexandrian scholarship $\quad 53,61,66,152,292$, 308-309

Anacreon 13, 302, 359, 363, 364, 366, 376, 382

$P M G$

$$
\begin{array}{ll}
413 & 302 \\
459 & 299
\end{array}
$$

Anacreontea 13, 359, 364, 372

$$
\begin{array}{lr}
16 & 370-384 \\
17 & 370-384 \\
53.1-8 & 364
\end{array}
$$

Antiphanes 161

Apollodorus $\quad 5^{2-53}$

Archilochus 6o, 63-64

fr. 1053

fr. $118 \quad 188$

fr. $172 \quad 125$

frr. $185^{-187} \quad 108-142$

fr. $196 \quad 300-301$

'Telephus elegy' 12, 56-58, 60, 66

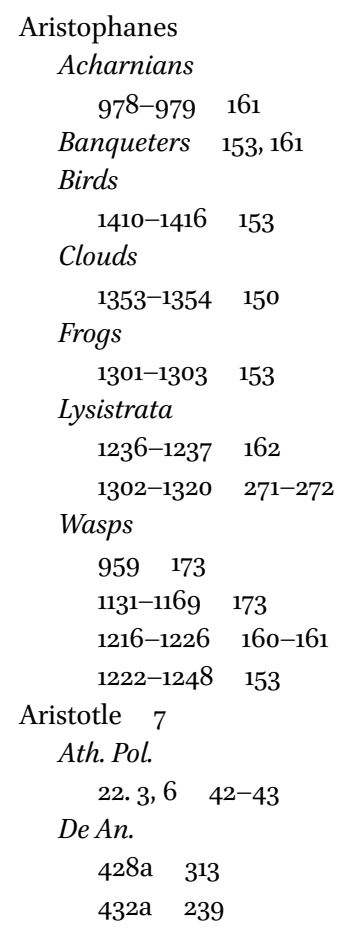

Hist. An.

502a-b 113

Pol.

$1342 \mathrm{~b} \quad 170$

$P M G$

$842 \quad 162-163$

Aristoxenus 154, 157

fr. 99159

fr. $125 \quad 148-149$

Asclepiades

Epigram 3 (Sens) 197n3o

Athenaeus 153-168, 193-194, 206, $362 n 42$

Aulus Gellius 344, 363, 366

Attic Nights

19.9.4 359

Bacchylides $\quad 17$

Ode

$3.17-22 \quad 19$

$5.176-186 \quad 264-265$

$13 \quad 269$ 


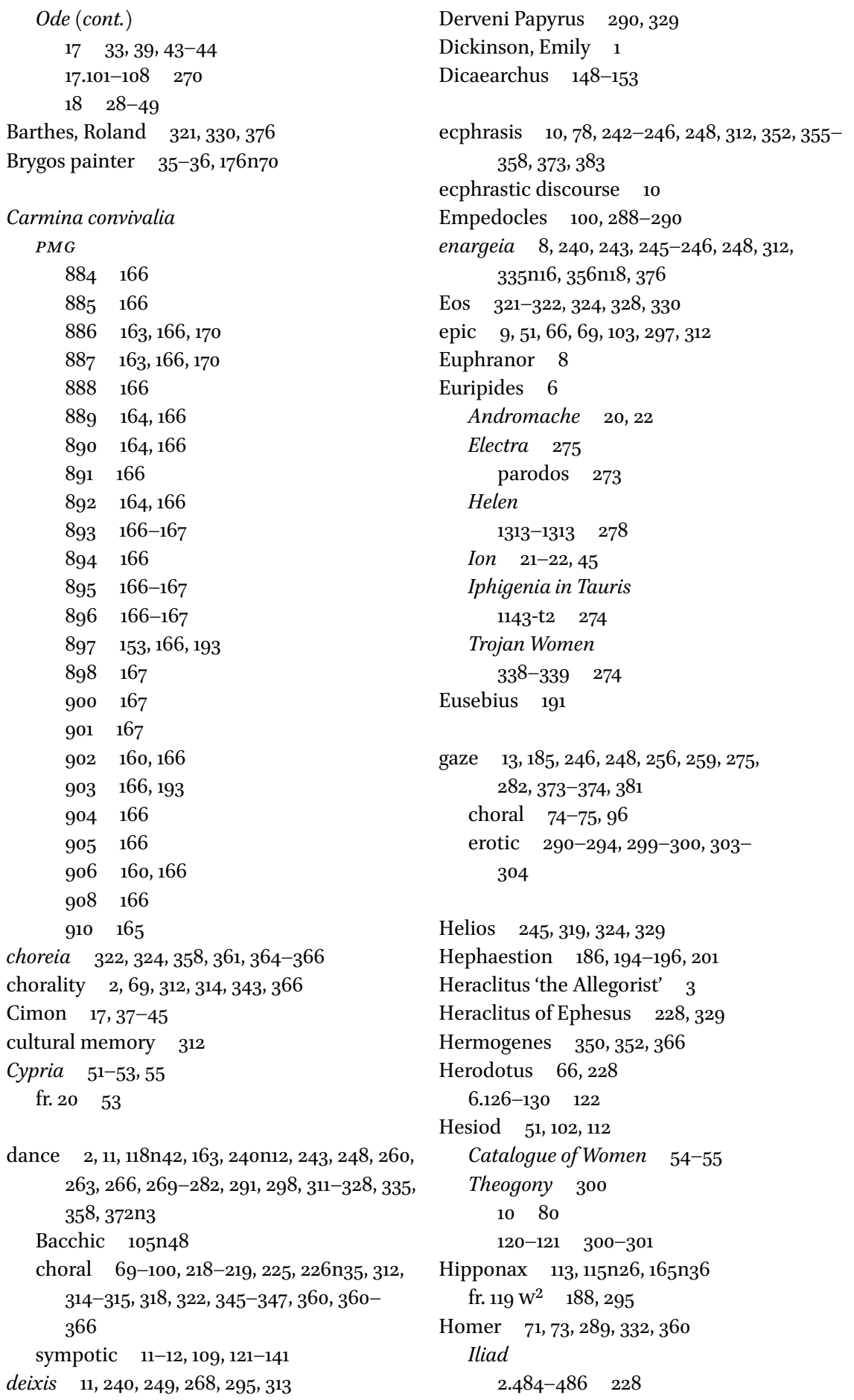




$$
\begin{array}{lc}
14.182-183 & 99 \mathrm{n} 43 \\
14.292-296 & 301 \\
16.181-185 & 277 \\
18.478-608 & 70 \\
21.220 & 58
\end{array}
$$

Odyssey

6.99-109 279-280

6.153-159 280-281

8.248-249 121

$8.260-278 \quad 81$

$8.489 \quad 376$

$8.491 \quad 376$

12.3-3 321

$18.29899 n 43$

Homeric Hymns

to Apollo 80

149-155 74-75

156-176 102

to Aphrodite

117-120 277-278

119-120 79

221-224 320

to Demeter $4-8 \quad 278$

Horace 7

Ibycus 302

PMGF

$287 \quad 299$

initiation $198-201,255^{-283}, 291-296$

ivory $32,353-355,370-371,375$

kinaesthesia $\quad 311,313$

Lacan, Jacques $\quad 377 \mathrm{n} 24,379$

lament $\quad 9-10,166,169,314,323,33^{2-3} 33$

lyric 'I' 265n31, 318, 320-321, 324, 327, 346

Lucian

Piscator

$36 \quad 118$

Macedonia $\quad 5^{-6}$

Melanippides 6

Menander Rhetor 363,366

metaphor $3,77,86,179-180,204,232,238-$ 250, 257, 289-295, 299, 303 313, 324, 355, 375

mimesis 44, 73-74, 77, 82, 102-104, 109, 141, $219,250,35^{6}-35^{8}, 377,384$
Mimnermus

fr. $4 \mathrm{~W} \quad 325$

Muses $80,101,103,115,266,303315^{-316}$, 316 n $35,318,320,323,335,376$

naturalistic representation $\quad 60,90,373,377^{-}$ 378,383

New Music 5

Orpheus / Orphism 290, 314, 322, 328-329, $331,334-335$

Palatine Anthology $\quad 344,359-361,374 n 12,379$ 9.189360

painting $1,4,6-11,39-40,142,35^{2-}-35^{8}, 370-$ 384

Pausanias 51

$1.15 \cdot 3 \quad 39-40$

$1.17 \cdot 2-3 \quad 39$

3.26.9-10 63n27

10.11.5 23

$10.25^{-31} 9$ 9n21

performance $4-5,308-310,313,315,322$, 346

choral $349,35^{8-359,360,362,366}$

Hellenistic 308

solo 2

sympotic (re)performance 192, 331, 372 phantasia 240-241, 247-249, 313, 373, 376, 38on 34,382

Phaon $321,327,329,332$

Philitas of Cos 56

Philodemus

Epigram 14.2 Sider $\quad 187$

De mus. $4.12 \quad 158$

Philostratus $4,12,51,58-59,60,361,363$, 366

Heroicus

$$
\begin{array}{lll}
2.15 & 60 \\
23.24-25 & 5^{8-59}
\end{array}
$$

Imagines

$$
\begin{array}{ll}
1.3 & 142 \\
2.1 & 344,35^{2}-359
\end{array}
$$

Philoxenus $6,168 \mathrm{n} 48$

Pindar 11, 23, 147, 148, 151

Olympian

$$
\begin{array}{ll}
1.1-11 & 247-248 \\
2 & 22 \\
2.1-6 & 263-264
\end{array}
$$




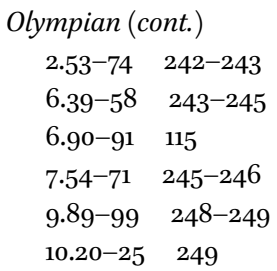

Pythian

$$
\begin{array}{ll}
1.1-4 & 265^{-266} \\
2.72 & 119-120 \\
6 & 22 \\
6.1-17 & 23 \\
7 & 22,45 \\
9 & 73-74
\end{array}
$$

Nemean

$$
\begin{array}{ll}
5 \cdot 1-5 & 23 \\
8.13^{-15} & 179
\end{array}
$$

Isthmian

$$
\begin{array}{ll}
2 & 22 \\
2.1-16 & 264-265 \\
2.43-46 & 23 \\
8.49-50 & 58
\end{array}
$$

Paean

$$
\begin{array}{lr}
2 & 267 \\
2.97 & -102 \\
4.21-24 \\
6 & 268 \\
8 & 22 \\
9 & 233
\end{array}
$$$$
\text { 2.97-102 269 }
$$$$
\text { 4.21-24 } 267
$$

fr. $94 \mathrm{~b} \quad 262-263$

fr. $122 \quad 153,155^{-157}$

fr. $123 \quad 289-290,299$

fr. 124d 158

fr. $125 \quad 159,169$

fr. $126 \quad 159$

fr. $128 \quad 158,267$

fr. 128c $\quad 267$

Plato $7,228 \mathrm{n} 42,328$

Charmides

155c-d 185

Cratylus

420a-b 303

Gorgias

$$
451 \mathrm{e} \quad 162
$$

Laws

$654 \mathrm{~b} \quad 361$

709e $105^{n} 48$

Meno

$$
\text { 76c-d 288nı }
$$

Phaedrus

224-251 303-304

275 d $380 n 32$

Republic

$372 \mathrm{~b} \quad 210$

398d 168

398e-399a $\quad 169-170$

597a $\quad 378$

$620 \mathrm{c} \quad 118$

Symposium 311

Plato Comicus

Spartans (fr. 71 K.-A.) $\quad 161$

poikilia $\quad 70-72,179,240,246,249-250,25^{8}$ 259, 274-275, 347

Polyidus 6

Plutarch 7,380

Amat.

759c $380 n 34$

De glor. Ath.

$346 \quad 1$

Quaest. conv.

$$
\begin{array}{ll}
615^{\mathrm{a}-c} & 149 \\
747-748 & 11 \\
35.8 \quad 39 &
\end{array}
$$

(Ps.-)Plutarch

de musica

$$
114 \text { of } 153
$$

Praxilla 154

$$
P M G
$$

$747 \quad 194,334 n 91$

$748 \quad 194$

749 151ng, 192

$750 \quad 193$

$\begin{array}{ll}751 & 194\end{array}$

$75^{2} \quad 194$

$753 \quad 195$

$754 \quad 13,185^{-203}$

Proclus 51, 118, 268n 40

Pythermos 165,168

Quintus of Smyrna

$$
7.100 \quad 5^{8}
$$

pódov $\quad 245^{-246}, 375,378$

Romanticism 343

Sappho

fr. 1328,331

fr. $2 \quad 350-35^{2}, 362-363$ 

fr. $16295,310,319-320,326-327$
fr. 30201
fr. $31 \quad 297,326$
fr. $44 \quad 347-35^{\circ}$
fr. $58 \quad 364-366$
fr. $94 \quad 344-347$
fr. 110200
fr. 111200
fr. $112 \quad 300-301$
fr. 114200
fr. $130 \quad 300-301$
fr. 154195,316
fr. 168 b. 3 v. 316

'Brothers poem' 201

'Cologne Sappho' 305-336

sculpture $7,12,16-19,23,3^{2}, 41,45,5^{0}, 61-66$, 355,377

shield of Achilles $\quad 70-84,90,96,101$

Simonides $1,6-11,16,39,149,215,382 \mathrm{n} 40$

fr. $22.9-14 \mathrm{~W} \quad 299-300$

$P M G$

$$
\begin{array}{ll}
507 & 15^{0} \\
543 & 9 \\
55^{0} & 16 \mathrm{n} 1
\end{array}
$$

skutalê 111-115, 119, 125n64

Solon
frr. 1-3 117
fr. $4.22 \quad 121$
fr. $5.1 \quad 124$

Sophocles 42

Mysians 55

Captives 193

spectatorship $\quad 1-6,70,75^{-76}, 79,83,87,92$, $102-103,217,248,278$

symposium 109, 121-122, 135, 161-162, 170173, 186-196, 204-215, 290-291, 308, 312

synaesthesia $10,223,239,311,313,328,343$, $346,349-350,352,357,360-362$
Telestes 6

Terpander $\quad 147-148,153,159,168-169,174-180$

Theocritus 195

Idyll

18 198-199, 201

Theognis $14,115 \mathrm{n} 31,164 \mathrm{n} 35$

$467-496 \quad 210-212$

Theophrastus 123

On the Senses $\quad 288-289$

Thucydides $8,111,113$

Timocreon of Rhodes

$P M G$

$731 \quad 153,165,167$

Timotheus 6,66

tragedy $2,4,17,44,51,55^{-5} 5,61,66,151,218-$ 220, 276

transmission $\quad 192-195,307-310,362 \mathrm{n} 42$

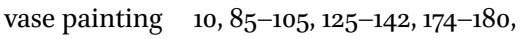
187-190, 314, 322, 328, 366

virtual chorus 311,314

vision $\quad 2-3,218,238,288,295,313,379$

visualization $2-4,86,123,128,204,217-234$, $307,313-314,322,336,343,346-361,366$

weaving $22,71,89,229,331$

wedding songs $13,70,83,148,197-201,274-$ $275,309 n 8$

Xenophanes

fr. $1 \quad 207-210$

Xenophon

Hiero 9n2o

Memorabilia

3.11.10 185

Symposium

$2.22 \quad 122$

$4.21 \quad 381 n 34$ 